ISSN 1028-4427 (Print)

ISSN 2542-131X (Online)

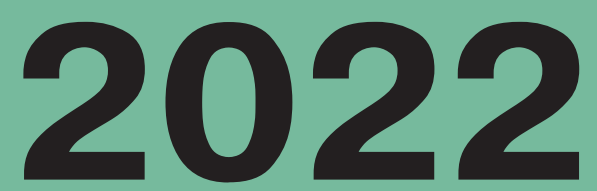

No1 28
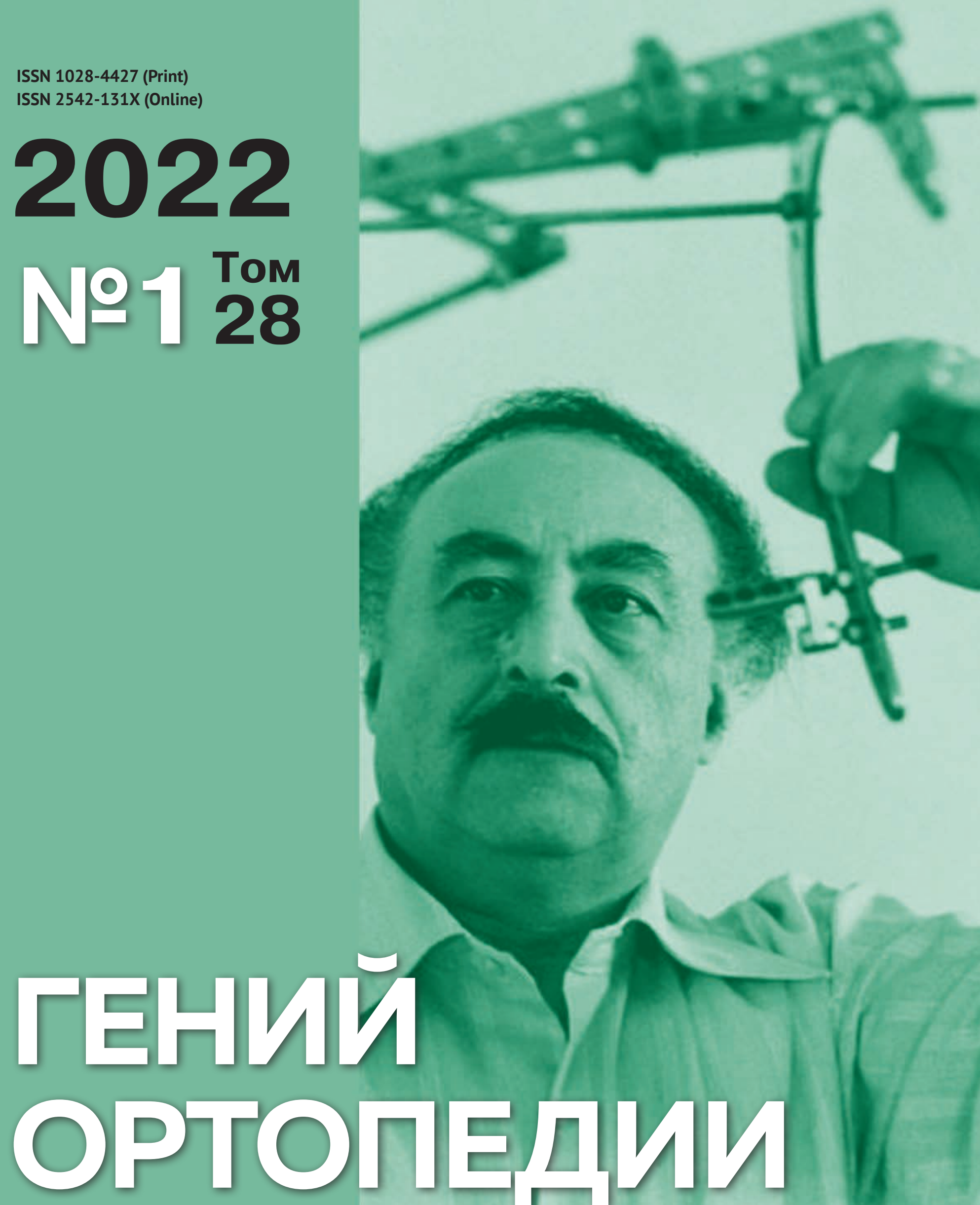

Научно-теоретический и практический журнал 



\title{
Tenuí Орпопедиn
}

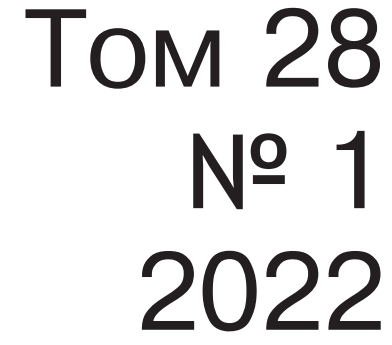

Orthopaedic Senius

\author{
Научно-теоретический и практический журнал \\ Основан в память академика Г.А. Илизарова
}

\section{РЕДАКЦИОННАЯ КОЛЛЕГИЯ}

Бурцев А.В. (Россия, Курган) - главный редактор

Аранович А.М. (Россия, Курган) - заместитель главного редактора

Samchukov M.L. (США) - заместитель главного редактора

Баиндурашвили А.Г. (Россия, Санкт-Петербург)

Борзунов Д.Ю. (Россия, Екатеринбург)

Губин А.В. (Россия, Москва)

Дьячкова Г.В. (Россия, Курган)

Котельников Г.П. (Россия, Самара)

Кутепов С.М. (Россия, Екатеринбург)

Минасов Б.Ш. (Россия, Уфа)

Новиков К.И. (Россия, Курган)

Попков А.В. (Россия, Курган)

Попков Д.А. (Россия, Курган)

Тихилов Р.М. (Россия, Санкт-Петербург)

Щурова Е.Н. (Россия, Курган)

Kirienko А. (Италия)

Paley D. (СШA)

Pinzur M.S. (США)

Catagni M.A. (Италия)

Hosny G.A. (Египет)

Chaudhary M.M. (Индия)

Lascombes P. (Швейцария)

Madan S. (Великобритания)

Weiss H.-R. (Германия)

Dubousset J. F. (Франция)

Birch J.G. (США)

Podeszwa D.A. (США)

Mitković M.В. (Сербия)

Monsell F. (Великобритания)

Glatt V. (США)

Борзунова О.Б. - ответственный секретарь

Беляева М.А. - технический секретарь

Марченкова Л.О. - редактор

\section{THE EDITORS}

Burtsev A.V. (Russia, Kurgan) - Editor in Chief Aranovich A.M. (Russia, Kurgan) - Deputy Editor Samchukov M.L. (USA) - Deputy Editor Baindurashvili A.G. (Russia, St. Petersburg) Borzunov D.Iu. (Russia, Ekaterinburg) Gubin A.V. (Russia, Moscow)

Diachkova G.V. (Russia, Kurgan)

Kotel'nikov G.P. (Russia, Samara) Kutepov S.M. (Russia, Ekaterinburg)

Minasov B.Sh. (Russia, Ufa)

Novikov K.I. (Russia, Kurgan)

Popkov A.V. (Russia, Kurgan)

Popkov D.A. (Russia, Kurgan)

Tikhilov R.M. (Russia, St. Petersburg)

Shchurova E.N. (Russia, Kurgan)

Kirienko A. (Italy)

Paley D. (USA)

Pinzur M.S. (USA)

Catagni M.A. (Italy)

Hosny G.A. (Egypt)

Chaudhary M. M. (India)

Lascombes P. (Switzerland)

Madan S. (UK)

Weiss H.-R. (Germany)

Dubousset J. F. (France)

Birch J.G. (USA)

Podeszwa D.A. (USA)

Mitković M.B. (Serbia)

Monsell F. (UK)

Glatt V. (USA)

Borzunova O.B. - Executive Secretary Beliaeva M.A. - Technical Secretary Marchenkova L.O. - Editor 


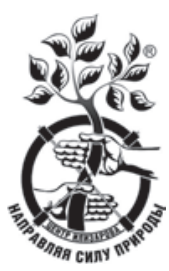

Учредитель журнала:

федеральное государственное бюджетное учреждение «Национальный медицинский исследовательский центр травматологии и ортопедии имени академика Г.А. Илизарова» Министерства здравоохранения Российской Федерации

Издание журнала осуществляется при поддержке Ассоциации по изучению и применению метода Илизарова России (A.S.A.M.I. Россия)

Журнал включен в перечень научных специализированных изданий ВАК, в которых могут публиковаться основные результаты диссертационных работ на соискание кандидатской и докторской степени

(3.1.8 - травматология и ортопедия)

Журнал включен в Реферативный журнал и Базы данных ВИНИТИ Сведения о журнале ежегодно публикуются в международной справочной системе по периодическим и продолжающимся изданиям «Ulrich’s Periodicals Directory»

Журнал включен в библиографические и реферативные базы данных РИНЦ и SCOPUS

Журнал включен в электронные информационные ресурсы базы данных EBSCO

Электронная версия журнала размещена на сайтах

Научной Электронной Библиотеки http://elibrary.ru

Научной Электронной Библиотеки «КИБЕРЛЕНИНКА» http://cyberleninka.ru и НМИЦ ТО имени академика Г.А. Илизарова http://ilizarov-journal.com

Адрес: НМИЦ ТО имени академика Г.А. Илизарова, 6, ул. М. Ульяновой, г. Курган, 640014, Россия Телефоны: (3522) 43-06-94 - ответственный секретарь

(3522) 43-06-94 - технический секретарь

(3522) 23-42-60 - реклама

Интернет: http://lizarov-journal.com/

Email:_genius@ilizarov.ru

Перепечатка материалов разрешается только по согласованию с редакционным советом.

Оригинал-макет изготовлен ОИАиВР ФГБУ «НМИЦ ТО имени академика Г.А. Илизарова» Минздрава России.

Журнал зарегистрирован Федеральной службой по надзору в сфере связи, информационных технологий и массовых коммуникаций ПИ № ФС77-68207 от 30 декабря 2016 года.

Территория распространения: Российская Федерация, зарубежные страны. Язык: русский, английский. Издается 6 раз в год.

Цена свободная.

Индекс для подписки по каталогу Агентства «Книга-Сервис» - E81417.

(c) Федеральное государственное бюджетное учреждение «Национальный медицинский исследовательский центр травматологии и ортопедии имени академика Г.А. Илизарова» Министерства здравоохранения Российской Федерации, 2022. 


\section{Уважаемые читатели!}

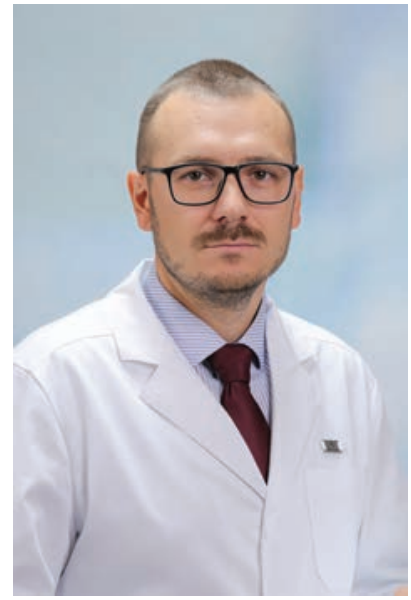

В декабре 2022 года состоится XII Всероссийский съезд травматологовортопедов, крупнейший и наиболее авторитетный научно-образовательный форум специалистов нашего профиля. Особо актуальны для травматологоортопедических служб регионов проблемы травм опорно-двигательной системы и их последствий. Мы символично делаем первый выпуск тематическим, открывая год определенным трендом для травматолого-ортопедического сообщества страны. Номер посвящен обсуждению тактических подходов к лечению травм и повреждений различных сегментов опорно-двигательной системы, а также мягких и покровных тканей, нервов, сосудов.

В разделе "Оригинальные статьи" Н.М. Белокрылов с соавт. (Пермь) делятся опытом лечения детей с повреждениями магистральных сосудов конечностей с полным нарушением кровотока и отмечают, что при повреждениях магистральных артериовенозных образований показано неотложное хирургическое лечение, направленное на сохранение конечности, восстановление кровоснабжения, нервных образований, целости кости. Н.Н. Чирков с соавт. (Чебоксары) предлагают к обсуждению проблему хирургического лечения невосстановимых массивных повреждений вращательной манжеты плечевого сустава и авторскую методику коррекции данной патологии, позволяющую восстановить вертикальный баланс в плечевом суставе, достоверно улучшить клинико-функциональные показатели, сократить число повторных разрывов сухожилий ротаторов в сравнении с методикой частичной реконструкции. А.Ю. Денисова с соавт. (Красноярск) на основании сравнительного анализа доказывают, что анкерная фиксация при Suture Bridge-технике и классический трансоссальный шов показывают сопоставимые отдаленные клинические результаты, а отсутствие неудовлетворительных исходов при использовании экстракортикальных фиксаторов делает перспективным дальнейшее изучение данного метода. В.А. Калантырская с соавт. (Москва) делают заключение, что при выборе тактики лечения тяжелых травм локтевого сустава необходимо учитывать не только тяжесть повреждения, но возраст пациента и качество кости, особенно у лиц пожилого возраста, а отказ от выполнения остеосинтеза в пользу первичного тотального эндопротезирования дает возможность сохранить объем движений, улучшить функциональные результаты и выживаемость эндопротеза. Б.Ш. Минасов с соавторами (Уфа) в работе, касающейся серьезной проблемы аутотрансплантации утраченного первого пальца кисти, показывают, что микрохирургические технологии при реконструкции утраченного большого пальца кисти позволяют в быстрые сроки восстановить первый палец и значительно улучшить функции травмированной кисти как органа. Свободная пересадка второго пальца стопы на микрососудистых анастомозах в позицию отсутствующего первого пальца кисти позволяет восстановить все основные функции захвата кисти и улучшить эстетическую привлекательность травмированной кисти. Ф.Ф. Камолов с соавт. (Томск) представляют доказательства того, что оптимальным вариантом иммобилизации при повреждении сухожилия разгибателей пальцев кисти в первой зоне является физиологическое положение, и демонстрируют отличные и хорошие результаты по J.P. Crawford у всех прооперированных пациентов с подкожным разрывом сухожилия. Л.К. Брижань с соавт. (Москва) доказывают, что индивидуальный подход к выбору метода оперативного лечения при повреждениях медиального мениска в сочетании с варусной деформацией голени в зависимости от величины механического феморотибиального угла позволяет скорректировать положение механической оси нижней конечности и, тем самым, улучшить отдаленные клинико-функциональные и рентгенологические результаты. Е.Н. Гончаров с соавт. (Москва, С.-Петербург) приводят сравнение результатов восстановления передней крестообразной связки коленного сустава с использованием аутотрансплантата из сухожилия длинной малоберцовой мышцы и из связки надколенника с двумя костными блоками и отмечают, что аутотрансплантат из сухожилия длинной малоберцовой мышцы является альтернативным вариантом при первичном восстановлении ПКС. Я.А. Иванов и соавт. (Москва) после проведенной оценки структур коленного сустава пациентов детского возраста с повреждением передней крестообразной связки после консервативного лечения делают вывод о его неудовлетворительных результатах, так как у пациентов были отмечены выраженные признаки нарушения распределения нагрузки в коленном суставе, а также вторичное повреждение мениска вследствие антеромедиальной нестабильности. А.В. Лычагин с соавт. (Москва) отмечают, что пластическое замещение обширных дефектов голени свободным васкуляризированным кожно-мышечным лоскутом с фрагментами ребер и дистракционным остеогенезом по Г.А. Илизарову создает благоприятные условия для одномоментного хирургического вмешательства, позволяющего сохранить конечность, восстановить опороспособность и вернуть пациентов к трудовой деятельности. Г.П. Котельников с соавт. (Самара) приводят экспериментальное обоснование новых способов армирования ахиллова сухожилия и подчеркивают, что методики с использованием ахиллова сухожилия плантарной мышцы и порции сухожилия 
длинной малоберцовой мышцы на дистальном основании позволяют значительно увеличить прочность зоны повреждения.

Большой интерес у читателей, несомненно, вызовет публикация М.Ю. Коростелева и Н.Г. Шихалевой (Москва, Курган), где обсуждаются ошибки и осложнения при лечении больных с обширными отслойками покровных тканей. Авторы отмечают, что большинство осложнений стало результатом допущенных организационных, диагностических, лечебно-тактических и технических ошибок, и предлагают ряд рекомендаций по профилактике возникновения ошибок и осложнений при лечении данной группы пострадавших.

В разделе «Случай из практики» представлено четыре сообщения, касающиеся лечения пациентов с открытым переломом плечевой кости и обширным дефектом костной ткани с использованием костной пластики (Ш.М. Давиров, П.У. Уринбоев, Узбекистан), тяжелой инъекционной травмы кисти высоким давлением (А.М. Аристов с соавт., Краснодар), пересадки культи трехфалангового пальца противоположной кисти на микрососудистых анастомозах у больных с последствиями отморожений кистей и стоп (Н.М. Александров с соавт., Нижний Новгород), использования способа открытой лавсанопластики большеберцовой коллатеральной связки (О.Н. Ямщиков с соавторами, Тамбов).

В обзорных статьях представлены аналитические работы по проблемам оценки современных методов медикаментозной и локальной терапии замедленной консолидации переломов (Р.И. Садыков и И.Ф. Ахтямов, Казань), гетеротопической оссификации как побочного эффекта применения рекомбинантных человеческих костных морфогенетических белков (У.Ф. Мухаметов с соавт., Уфа, Челябинск, Москва, Екатеринбург, Тюмень), выбора хирургической тактики при лечении больных с последствиями внутрисуставных повреждений дистального отдела костей голени (О.А. Кауц с соавт., Саратов), улучшения результатов лечения повреждений дистального межберцового синдесмоза (Д.А. Никифоров с соавт., Москва) и реконструкции мягких тканей при обширных раневых дефектах стопы лоскутами с осевым типом кровоснабжения (Б.Ш. Минасов с соавт., Уфа).

Хочу подчеркнуть особую социальную значимость внедрения новых технологий в лечение и реабилитацию пациентов с травмами опорно-двигательной системы и их последствиями и пригласить травматологов-ортопедов Российской Федерации принять активное участие в работе предстоящего съезда.

Главный редактор журнала "Гений ортопедии" Ә.м.н. Буриев А.В. 


\section{Содержание}

\section{Оригинальные статьи}

Повреждения магистральных сосудов конечностей с полным нарушением кровотока у детей (результаты клинических наблюдений)

Н.М. Белокрылов, А.Н. Белокрылов, И.С. Мухамадеев, А.С. Денисов, В.Н. Киряков, К.И. Горковеч

Хирургическое лечение невосстановимых массивных повреждений вращательной манжеты плечевого сустава

Н.Н. Чирков, В.Н. Яковлев, А.В. Алексеева Е.В. Андронников, В.Ю. Емельянов

Сравнительный анализ клинических результатов применения шва вращательной манжеты плеча в зависимости от способа фиксации сухожилия

А.Ю. Денисова, А.А. Галов, А.В. Данилов, А.Н. Наркевич, E.B. Серова

Тотальное эндопротезирование локтевого сустава при травмах В.А. Калантырская, И.О. Голубев, А.Ю. Заров, К.А. Егиазарян

Результаты аутотрансплантации второго пальца стопы в позицию утраченного первого пальца кисти

Б.Ш. Минасов, И.З. Гарапов, Э.М. Бикташева, М.М. Валеев, Р.Р. Якупов, Т.Б. Минасов, Т.Р. Мавлютов

Оптимизация лечения повреждений сухожилий разгибателей пальцев кисти в первой зоне

Ф.Ф. Камолов, В.Ф. Байтингер, К.В. Селянинов

Индивидуальный подход к лечению пациентов с повреждением медиального мениска в сочетании с варусной деформацией голени

Л.К. Брижань, Д.В. Давыдов, А.А. Керимов, Б.В. Тюлькевич,

Д.А. Найда

Сравнение результатов восстановления передней крестообразной связки коленного сустава с использованием аутотрансплантата из сухожилия длинной малоберцовой мышцы и из связки надколенника с двумя костными блоками

Е.Н. Гончаров, Н.Г. Гончаров, Э.Н. Безуглов, А.А. Ветошкин, И.А. Резуненко, С.Х. Оганесян, О.А. Коваль

Оценка структур коленного сустава пациентов детского возраста с повреждением передней крестообразной связки после консервативного лечения

Я.А. Иванов, А.Г. Ельцин, Д.С. Мининков

Лечение последствий ранений голени: продолжение развития технологии Илизарова

А.В. Льчагин, А.А. Грицюк, В.С. Корытин

Экспериментальное обоснование армирования ахиллова сухожилия новыми способами

Г.П. Котельников, Ю.Д. Ким, Д.С. Шитиков, Н.А. Князев, Н.Э. Лихолатов

Ошибки и осложнения при лечении больных с отслойками покровных тканей М.Ю. Коростелев, Н.Г. Шихалева

\section{Случай из практики}

Лечение пациента с открытым переломом плечевой кости с обширным дефектом костной ткани с использованием костной пластики (случай из практики)

Ш.М. Давиров, П.У. Уринбоев

\section{Contents}

\section{Original Articles}

Damage to the major limb vessels with complete disturbance of blood flow in children

(results of clinical observations)

7 N.M. Belokrylov, A.N. Belokrylov, I.S. Mukhamadeev, A.S. Denisov, V.N. Kiryakov, K.I. Gorkovets

Surgical treatment of irreparable massive injuries of the rotator cuff of the shoulder joint

12 N.N. Chirkov, V.N. Yakovlev, A.V. Alekseeva, E.V. Andronnikov, V.Yu. Emelyanov

Comparative analysis of clinical outcomes of rotator cuff sutures and their dependence on the methods of cuff fixation

18 A.Yu. Denisova, A.A. Galov, A.V. Danilov, A.N. Narkevich, E.V. Serova

Total elbow arthroplasty due to injuries

24 V.A. Kalantyrskaya, I.O. Golubev, A.Yu. Zarov, K.A. Egiazaryan

Results of the second toe autotransplantation for thumb reconstruction

B.Sh. Minasov, I.Z. Garapov, E.M. Biktasheva, M.M. Valeev, R.R. Iakupov, T.B. Minasov, T.R. Mavliutov

Optimization of the treatment of finger extensor tendon injuries in $1^{\text {st }}$ zone

39 F.F. Kamolov, V.F. Baitinger, K.V. Selyaninov

Personalized approach to the treatment of patients with medial meniscus tear combined with varus deformity of the tibia

46 L.K. Brizhan, D.V. Davydov, A.A. Kerimov, B.V. Tyulkevich, D.A. Nayda

Comparison of results of the anterior cruciate ligament reconstruction of the knee joint using peroneus longus tendon autograft or patellar tendon autograft with two bone blocks

53 E.N. Goncharov, N.G. Goncharov, E.N. Bezuglov, A.A. Vetoshkin, I.A. Rezunenko, S.Kh. Oganesyan, O.A. Koval

Evaluation of the knee joint structures of pediatric patients with anterior cruciate ligament injury after conservative treatment

62 Y.A. Ivanov, A.G. Yeltsin, D.S. Mininkov

Treatment of tibial wound consequences: further development of the Ilizarov technology

69 A.V. Lychagin, A.A. Gritsyuk, V.S. Korytin

Experimental validation for the Achilles tendon reinforced with new techniques

76 G.P. Kotelnikov, Yu.D. Kim, D.S. Shitikov, N.A. Knyazev,

N.E. Likholatov

Failures and complications in treatment of patients with degloving injury of integumentary tissues

83 M.Yu. Korostelev, NG. Shikhaleva

\section{Case report}

Repair of open humerus fracture and extensive bone defect using bone grafting (case report)

91 Sh.M. Davirov, P.U. Urinboev 


\section{Содержание Contents}

Восстановительное хирургическое лечение тяжелой инъекционной травмы кисти высоким давлением

А.М. Аристов, С.Б. Богданов, С.Н. Куринный А.В. Каракулев, В.А. Аладьина

Пересадка культи трехфалангового пальца противоположной кисти на микрососудистых анастомозах у больных с последствиями отморожений кистей и стоп (случаи из практики)

Н.М. Александров, И.Д. Вешаев, Д.А. Купцов

Опыт использования способа открытой лавсанопластики большеберцовой коллатеральной связки

О.Н. Ямщииков, С.А. Емельянов, С.А. Мордовин,

Е.А. Колобова

Обзор литературы

Современные методы медикаментозной и локальной терапии замедленной консолидации переломов (обзор литературы)

Р.И. Садыков, И.Ф. Ахтямов

Гетеротопическая оссификация как побочный эффект применения рекомбинантных человеческих костных морфогенетических белков

У.Ф. Мухаметов, С.В. Люлин, Д.Ю. Борзунов, И.Ф. Гареев, О.А. Бейлерли, А.А. Суфианов

Хирургическая тактика при лечении пациентов с последствиями внутрисуставных повреждений дистального отдела костей голени (обзор литературы)

О.А. Кауи, Ю.А. Барабаш, С.И. Киреев, К.А. Гражданов, П.П. Зуев, А.Л. Кесов, И.А. Норкин

Повреждение дистального межберцового синдесмоза, пути улучшения результатов лечения (обзор литературы)

Д.А. Никифоров, М.А. Панин, В.Г. Процко, Р.Д. Боргут, Р.Н. Алиев

Реконструкция мягких тканей при обширных раневых дефектах стопы лоскутами с осевым типом кровоснабжения (обзор литературы)

Б.Ш. Минасов, Э.М. Бикташева, М.М. Валеев, Р.Р. Якупов, Т.Б. Минасов, Т.Р. Мавлютов

Указатель статей научно-теоретического и практического журнала «Гений Ортопедии» за 2021 г., Т. 27, №№ 1-6

Правила для авторов научно-теоретического и практического журнала «Гений Ортопедии»
Surgical reconstruction for high-pressure injection injuries to the hand

97 A.M. Aristov, S.B. Bogdanov, S.N. Kurinniy, A.V. Karakulev, V.A. Aladina

Opposable triphalangeal digital stump transplanted with microvascular anastomoses in patients with frostbitten hands and feet (case report)

104 N.M. Aleksandrov, I.D. Veshaev, D.A. Kuptsov

Experience with open lavsanoplasty of the tibial collateral ligament

111 O.N. Yamshchikov, S.A. Emelyanov, S.A. Mordovin, E.A. Kolobova

\section{Literature review}

Modern methods of medication and local therapy for delayed fracture consolidation (literature review)

116 R.I. Sadykov, I.F. Akhtyamov

Heterotopic ossification as a side effect of the use of recombinant human bone morphogenetic proteins

123 U.F. Mukhametov, S.V. Lyulin, D.Yu. Borzunov, I.F. Gareev O.A. Beylerli, A.A. Sufianov

Surgical approach to the treatment of patients with sequelae of intra-articular fractures of the distal tibia (literature review)

133 O.A. Kauts, Yu.A. Barabash, S.I. Kireev, K.A. Grazhdanov, P.P. Zuev, A.L. Kesov, I.A. Norkin

Injury to the distal tibiofibular syndesmosis, ways to improve treatment results (literature review)

141 D.A. Nikiforov, M.A. Panin, V.G. Protsko, R.D. Borgut, R.N. Aliev

Soft tissues reconstruction in the patients with extensive wound defects of the foot using flaps with axial type of circulation (literature review)

150 B.Sh. Minasov, E.M. Biktasheva, M.M. Valeev, R.R. Yakupov, T.B. Minasov, T.R. Mavlyutov

158 Index of articles from the scientific-theoretical and practical journal "Orthopaedic Genius" 2021, T. 27, no. 1-6

163 Instructions for authors of the scientific-theoretical and practical journal «Orthopaedic Genius» 
Гений ортопедии. 2022. Т. 28, № 1. С. 7-11.

Genij Ortopedii. 2022. Vol. 28, no. 1. P. 7-11.

\title{
Научная статья
}

УДК [617.57/.58+616.13/.14+616.833]-001-089.843-053.2

https://doi.org/10.18019/1028-4427-2022-28-1-7-11

\section{Повреждения магистральных сосудов конечностей с полным нарушением кровотока у детей (результаты клинических наблюдений)}

\section{Н.М. Белокрылов ${ }^{1 \bowtie}$, А.Н. Белокрылов ${ }^{1}$, И.С. Мухамадеев ${ }^{1}$, А.С. Денисов ${ }^{2}$, В.Н. Киряков ${ }^{1}$, К.И. Горковец ${ }^{1}$}

${ }^{1}$ Краевая детская клиническая больница, Пермь, Россия

2 Пермский государственный медицинский университет имени академика Е.А. Вагнера, Пермь, Россия

Автор, ответственный за переписку: Николай Михайлович Белокрылов, belokrylov1958@mail.ru Аннотация

Обоснование. Травма с одновременным повреждением магистральных артерий и вен характерна для взрослых, сообщения о подобных травмах у детей единичны. В организации помощи встречаются трудности в формировании бригад с привлечением ангиохирургов. Вопросы восстановления функции конечности при подобных повреждениях в случаях повреждения мышц, нервных стволов и полной ампутации конечности остаются актуальными и у детей, несмотря на их изначально высокие восстановительные способности. Каждый подобный случай лечения в учреждениях практического здравоохранения имеет свои особенности и сложности, что и явилось поводом для этого сообщения. Цель. Поделиться клиническим опытом и деталями оказания экстренной медицинской помощи пострадавшим детям с полным нарушением магистрального артерио-венозного кровотока. Материалы и методы. Рассмотрено 3 случая с полным повреждением магистральных артерий и вен, в том числе с их дефектами. Описаны детали тактики и особенности хирургических пособий. Всем больным проведено клинико-лабораторное обследование, оказана неотложная помощь силами травматологов-ортопедов, ангиохирургов. Все больные поступили в состоянии геморрагического шока 2-3 ст. Хирургические пособия оказывали при критическом, практически терминальном состоянии больных. Результаты. У 1 -го больного при поступлении через 40 минут после травмы диагностирована глубокая резаная рана задней поверхности правого бедра с повреждением мышц сгибателей голени, бедренной артерии и вены с их дефектом до 3 см, резаная рана правой голени. Комбинированная пластика дефектов сосудов трансплантатами из большой подкожной вены бедра, шов мышц. Отличный результат отмечен уже через 3 месяца. Во 2-м случае было повреждение стеклом в области левой подмышечной ямки с поперечным перерывом всех нервов, плечевой артерии и вены, сухожилий двуглавой и трёхглавой мышц плеча. Через 1,5 года диагностирован отличный результат первичной реконструкции. В 3-ем случае больной поступил с полной травматической ампутацией правого предплечья в нижней трети в результате использования механического дровокола, реплантация начата через 5 часов после отчленения конечности. Реплантация удалась. Потребовалось 4 этапа лечения, 2-й этап после наступившего тромбоза - повторная ревизия и шов сосудов через 16 часов после 1-й операции. Последующие 2 этапа включали комбинированную пластику мышц и сухожилий сначала разгибательной, затем сгибательной поверхности предплечья. Движения появились через 6 месяцев после травмы при восстановлении чувствительности. Получен вполне удовлетворительный результат лечения, больной через 1 год начал пользоваться рукой в быту, писать. Заключение. При повреждениях магистральных артериовенозных образований показано неотложное хирургическое лечение, направленное на сохранение конечности, восстановление кровоснабжения, нервных образований, целости кости. В случае полной ампутации возможно отложить восстановление мышечносухожильных образований на последующие этапы. При оказании первичной помощи следует учитывать необходимость последующей, порою длительной реабилитации, результат которой напрямую зависит от восстановления нейро-трофических и чувствительных функций.

Ключевые слова: повреждение магистральных артерий и вен, нарушения нервных стволов, травматическая ампутация, реплантация конечности, глубокая резаная рана, геморрагический шок

Для цитирования: Повреждения магистральных сосудов конечностей с полным нарушением кровотока у детей (результаты клинических наблюдений) / Н.М. Белокрылов, А.Н. Белокрылов, И.С. Мухамадеев, А.С. Денисов, В.Н. Киряков, К.И. Горковец // Гений ортопедии. 2022. T. 28, № 1. C. 7-11. https://doi.org/10.18019/1028-4427-2022-28-1-7-11

\section{Original article}

\section{Damage to the major limb vessels with complete disturbance of blood flow in children (results of clinical observations)}

\section{N.M. Belokrylov ${ }^{1 凶}$, A.N. Belokrylov ${ }^{1}$, I.S. Mukhamadeev ${ }^{1}$, A.S. Denisov², V.N. Kiryakov ${ }^{1}$, K.I. Gorkovets ${ }^{1}$}

\author{
${ }^{1}$ Regional Children's Clinical Hospital, Perm, Russian Federation \\ ${ }^{2}$ Academician Ye.A. Vagner Perm State Medical University, Perm, Russian Federation
}

Corresponding author: Nikolay M. Belokrylov, belokrylov1958@mail.ru

Abstract

Background Trauma with associated damage to major arteries and veins typically occurs in adults; reports on such injuries in children are rare. In the organization of their treatment, difficulties are encountered such as formation of teams that must include angiosurgeons. The issues of restoring limb function after injuries with damage to muscle, nerve trunks or complete amputation of the limb remain relevant in children, despite their high abilities to recover. Each particular case in health care institutions has its own characteristics and difficulties for treatment, which was the reason for this communication. Purpose To share our clinical experience and details of providing urgent medical care to injured children with complete impairment of the main arteriovenous blood flow. Materials and methods Three cases with complete damage to major arteries and veins, including their defects, were studied. We describe the details of tactics and features of their surgical management. All patients underwent clinical and laboratory examination; emergency assistance was provided by orthopedic traumatologists and angiosurgeons. All patients were admitted in a state of hemorrhagic shock in stage 2 or 3. Surgical aid was provided in patients with a critical, almost terminal condition. Results On admission 40 minutes after the injury, one patient was diagnosed with a deep cut wound on the posterior surface of the right thigh with damage to the flexor muscles of the leg, femoral artery and vein with their defects up to $3 \mathrm{~cm}$, and a cut wound on the right lower leg. Combined plasty of vascular defects with grafts from the great saphenous vein of the thigh and muscle suture were performed. An excellent result was noted after 3 months. In the second patient, there was an injury with glass in the area of the left axillary fossa with a transverse cut of all nerves, brachial artery and vein, tendons of the biceps and triceps muscles of the shoulder. An excellent result of primary reconstruction was diagnosed 1.5 years later. In the third case, the patient was admitted with a complete traumatic amputation of the right forearm in the lower third due to the use of a mechanical wood splitter; replantation began 5 hours after the cut off. Replantation was successful. It included 4 stages of treatment; the 2nd one was repeated revision and suture of the vessels 16 hours after the onset of thrombosis following the $1 \mathrm{st}$ operation. The next two stages included combined plastic surgery of muscles and tendons, first on the extensor and then of the flexor surface of the forearm. Movements appeared 6 months after the injury during the restoration of sensitivity. A completely satisfactory result of treatment was obtained; the patient began to use his hand in everyday life and to write after one year. Conclusion Damage to the main arteriovenous formations requires urgent surgical treatment, aimed at preserving the limb, restoring blood supply, nerve formations, and bone integrity. In complete amputation, restoration of 
muscle-tendon formations may be postponed for subsequent stages. In primary care, one should consider the need for subsequent, sometimes long-term rehabilitation, the result of which directly depends on the restoration of neurotrophic and sensitive functions.

Keywords: damage to the main arteries and veins, disorders of the nerve trunks, traumatic amputation, limb replantation, deep cut wound, hemorrhagic shock

For citation: Belokrylov N.M., Belokrylov A.N., Mukhamadeev I.S., Denisov A.S., Kiryakov V.N., Gorkovets K.I. Damage to the major limb vessels with complete disturbance of blood flow in children (results of clinical observations). Genij Ortopedii, 2022, vol. 28, no 1, pp. 7-11. https://doi. org/10.18019/1028-4427-2022-28-1-7-11

\section{ВВЕДЕНИЕ}

Травма магистральных сосудов конечностей является крайне опасным повреждением, так как представляет угрозу для жизни пострадавшего и часто исключает возможность сохранения анатомических образований и адекватных функциональных характеристик дистальных отделов сегмента или конечности в целом. Общая летальность при сосудистой травме конечностей, по данным разных авторов, составляет от 8,7 до 18 \% среди пострадавших мирного времени, частота первичных ампутаций колеблется от 8 до 10,8 \% [1]. Успех зависит от множества факторов, среди которых огромную роль играет возможность экстренной организации совместной помощи сосудистых хирургов и травматологов-ортопедов, иногда хирургов или нейрохирургов [2, 3]. Установлено, что наиболее критичной ситуация становится при одновременном повреждении магистральных артерий и вен, что требует их одновременного восстановления $[4,5,6]$. Ситуация усугубляется при полном отрыве сегмента конечности, что предполагает сомнительный результат приживления, и, тем более, функционального восстановления. Сообщения о реплантации крупного участка конечности при её полном отрыве или полном нарушении кровоснабжения встречаются редко, и результаты подобных реконструктивных вмешательств не всегда бывают удовлетворительными [7]. Тоталь-

ное повреждение сосудов, чаще верхней конечности, является прерогативой взрослого возраста [8]. Главные осложняющие обстоятельства в восстановлении кровоснабжения в виде повреждений нервных стволов или костной травмы требуют дополнительного проведения сложных хирургических пособий, правильной и достаточно эффективной интра- и послеоперационной терапии, длительной последующей реабилитации: это распространяется в равной мере и на пациентов детского возраста $[9,10,11]$. Проблемой является организация хирургической помощи при повреждениях магистральных сосудов конечностей в условиях больниц, не имеющих собственного сосудистого отделения: а эта ситуация существует почти во всех региональных детских учреждениях даже самого высокого уровня. В практическом здравоохранении сообщения об успешной работе с такими больными единичны, когда дело касается полного нарушения непрерывности магистральных вен и артерий, и особенно среди пострадавших детского возраста $[12,13]$. Поэтому каждый из подобных случаев заслуживает внимания: это и явилось предпосылкой для подготовки данного сообщения.

Цель. Поделиться клиническим опытом и деталями оказания экстренной медицинской помощи пострадавшим детям с полным нарушением магистрального артериовенозного кровотока.

\section{МАТЕРИАЛЫ И МЕТОДЫ}

Рассмотрены три случая оказания экстренной помощи больным с полным повреждением магистральных вен и артерий с полным нарушением кровоснабжения дистальных отделов конечности. Всем больным проведено клинико-лабораторное обследование, оказана экстренная помощь силами травматологов-ортопедов, ангиохирургов, проведено переливание крови по жизненным показаниям, клинически установлена кровопотеря 1/2 объёма циркулирующей крови и более. Все больные поступили в состоянии геморрагического шока 2-3 ст.

При повреждении магистральных артерий и вен, больших мышечных групп без повреждения нервных стволов происходит наиболее быстрое восстановление. Методом выбора является пластика сосудов. При резано-рваном повреждении бедра эффективным оказывается пластика дефектов бедренной артерии и глубокой вены аутотрансплантатом из v. saphena magna, первичный шов мышц, гипсовая иммобилизация.

Родители пациентов дали согласие на проведение исследования и публикацию данных по лечению пациентов и полученных результатов.

\section{РЕЗУЛЬТАТЫ}

Клиническое наблюдение 1. Больной К., 9 лет. Травма стеклом межкомнатной двери - разбил дверь ногой и сел на массив разбитого стекла. У больного при поступлении через 40 минут после травмы диагностирована глубокая резаная рана задней поверхности правого бедра с повреждением мышц, сгибателей голени, бедренной артерии и вены с их дефектом до 3 см, полное повреждение большой подкожной вены бедра, резаная рана правой голени, массивная кровопотеря. Геморрагический шок 2 ст. По экстренным показаниям под наркозом проведена ревизия раны с клипированием сосудов. Оказались повреждены полумембранозная, полусухожильная, двуглавая мышцы бедра, икроножная мышца, седалищный нерв интактен. Комбинированной бригадой с участием ангиохирурга больному проведено восстановление бедренной артерии и вены с пластикой их дефектов сосудистыми трансплантатами из повреждённой большой подкожной вены (рис. 1), шов мышц бедра. Сосудистый этап операции: имелся дефект бедренной артерии и вены до 3,0 см. Взяты два трансплантата из большой подкожной вены до 2,5 см и 4,0 см. Взятая из первого трансплантата вена развёрнута и использована для замещения дефекта артерии, второй трансплантат применён для пластики глубокой бедренной вены, перевязана большая подкожная вена (источник трансплантатов). Второй трансплантат малого диаметра по отношению к общей бедренной вене взят из 2-х частей, получившиеся прямоугольные венозные лоскуты продольно сшиты в цилиндрический трансплантат на шаблоне (инсулиновом шприце). После прекращения гипсовой иммобилизации через 6 недель начата разработка коленного сустава. Достигнуто полное восстановление функции конечности через 3 месяца после травмы. 


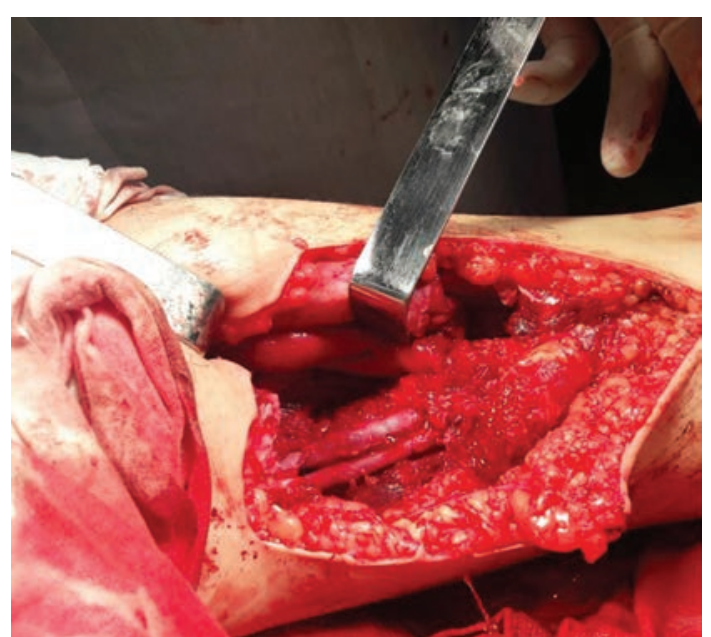

Рис. 1. Фото раны поврежденной нижней конечности больного К., 9 лет. Момент хирургического вмешательства: после пластического восстановления бедренной артерии и вены

Результат восстановления при тотальном повреждении сосудов в анатомически неблагоприятной зоне совместно с нервными стволами и мышцами становится сомнительным, но далеко не безнадёжным при качественном оказании хирургической и длительной реабилитационной помощи.

Клиническое наблюдение 2. Больная В., 7 лет. Поступила 26.10.2018 г. с ранением стеклом из разбитой межкомнатной двери в области левой подмышечной впадины длиной 10 см через 1 час после травмы. Практически ребёнка транспортировали в состоянии пальцевого прижатия сосудов, тампонады, что не предотвратило большой кровопотери. Геморрагический шок 3 степени. Состояние при поступлении терминальное. При поступлении

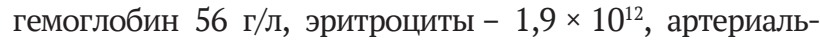
ное давление - 97/62 мм рт. ст., пульс - 132 уд. в мин. Больная взята в операционную. Диагностировано полное поперечное повреждение плечевой артерии и вены, стволов лучевого, локтевого, срединного, мышечно-кожного нервов, повреждение сухожилий m. biceps и m. triceps, дистальный отдел конечности висит на мягких тканях, холодный, нежизнеспособный. Противошоковые мероприятия проведены одновременно с восстановлением всех указанных образований. В течение операции перелито 1005 мл эритроцитарной массы, 480 мл плазмы, 2200 мл физраствора. Особенности операции: диаметр артерии 2,5 мм, диаметр вены 3,5 мм. Выполнен скошенный анастомоз плечевой артерии конец в конец (пропилен 6.0). Проксимальнее анастомоза артерии имелся краевой поперечный дефект стенки 1,5 мм, выполнено ушивание краевого дефекта артерии, проведён анастомоз конец в конец между 2 концами плечевой вены. Последовательный эпиневральный шов всех нервных стволов в пределах этой же операции. После длительных реабилитационных мероприятий восстановление чувствительности всех нервных стволов произошло через 14 месяцев. Осмотрена через 1,5 года после травмы. Функция конечности полностью восстановлена, достигнута полная амплитуда движений во всех суставах конечности: остаётся незначительное $\left(10^{\circ}\right)$ ограничение разгибания пальцев по сравнению с правой рукой (рис. 2, 3, 4). Нарушений иннервации нет. Больная и врачи полностью удовлетворены результатом лечения. Пациентка ведёт обычный для ребёнка образ жизни.

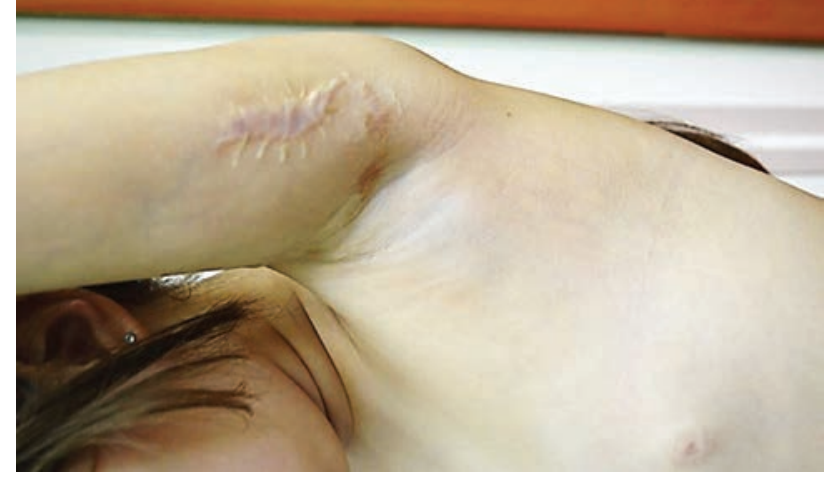

Рис. 2. Фото больной В., 8,5 лет (на момент осмотра). Рубец после операции при полном отведении плеча

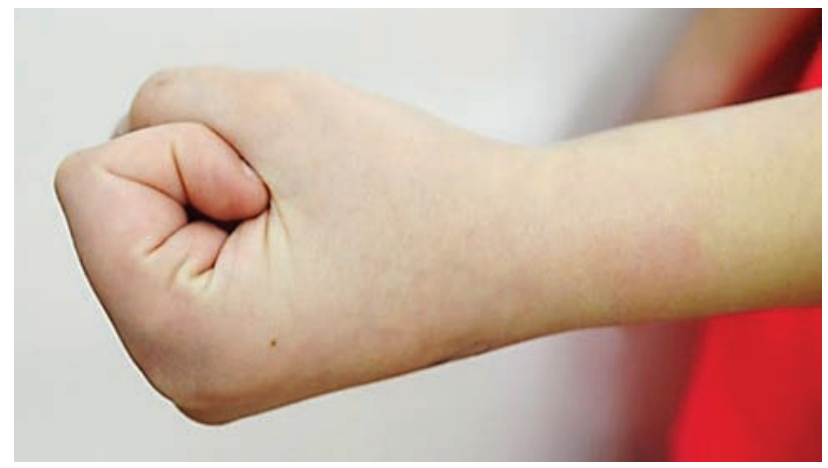

Рис. 3. Фото больной В., 8,5 лет (на момент осмотра). Результат. Сгибание пальцев кисти

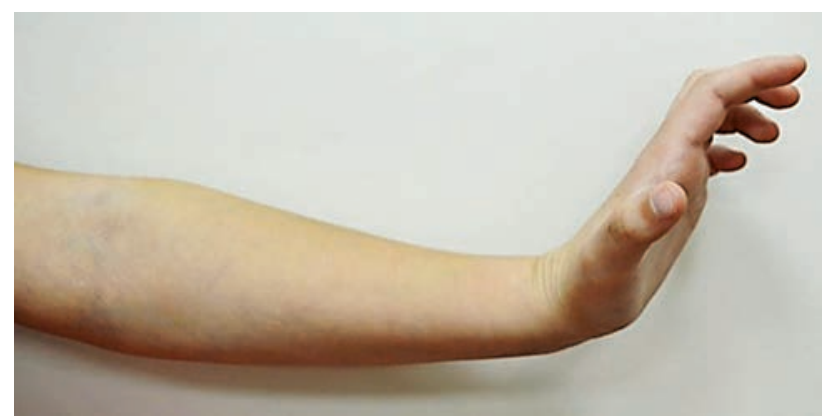

Рис. 4. Фото больной В., 8,5 лет (на момент осмотра). Результат. Разгибание пальцев кисти

Самая критичная ситуация возникает при полной ампутации конечности. Механизм нанесения раны рубящего характера с размозжением тканей делает результат лечения крайне сомнительным. Отдалённость пострадавшего от клиники усугубляет последствия. Однако и в таких ситуациях реплантация может привести к удовлетворительному результату лечения: такое страшное происшествие было и в нашей практике.

Клиническое наблюдение 3. Больной Л., 14 лет. Поступил 21.07.2019 г. из района Пермского края через 5 часов после травмы, доставлен санавиацией. При использовании механического дровокола отрубил себе правое предплечье в нижней трети. Больному на месте проведена обработка раны, наложены повязки, жгут. Пострадавший и ампутированный отдел конечности в охлаждённом виде доставлены в хирургический стационар краевой детской клинической больницы (рис. 5). 


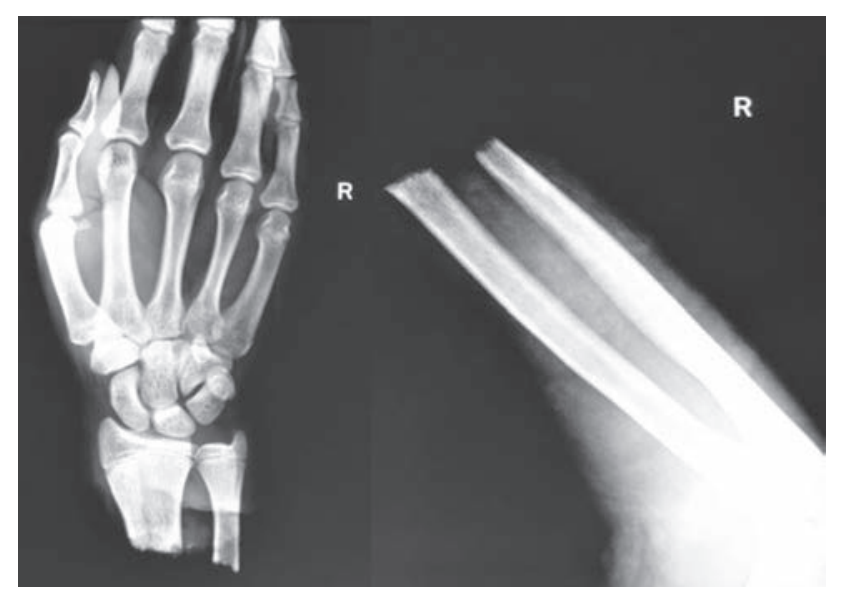

Рис. 5. Рентгенограммы отчленённых фрагментов конечности больного Л., 14 лет. Ампутация предплечья

Одновременно с оказанием реанимационной помощи создана комбинированная бригада травматологов и сосудистых хирургов. Больному выполнена реплантация правого предплечья и кисти, остеосинтез костей правого предплечья пластинами с предварительной резекцией повреждённых костных концов суммарно до 2,5 cм, аутовенозное протезирование правой лучевой, локтевой артерии, медиальной и латеральной подкожных вен правого предплечья, эпиневральный шов локтевого, срединного и поверхностной ветви лучевого нервов правого предплечья. Мышцы и сухожилия первично сшивали единым пучком. Длительность операции 8 часов. Через 8 часов после окончания первого хирургического вмешательства наступил тромбоз сосудов, больной экстренно взят в операционную. Выполнена ревизия и повторная пластика сосудов, декомпрессия с иссечением части сухожилий вследствие отёка и их частичного гофрирования. Первично сухожилия не восстанавливали из-за критического состояния конечности. В течение 3-х недель проводилась сосудистая терапия высокими дозами гепарина под контролем свёртываемости. Реплантация оказалась успешной. Больному 20.08.2019 г. проведена ревизия, пластическая реконструкция разгибательного и 6.09.2019 г. сгибательного мышечно-сухожильного аппарата правого предплечья и кисти. Проблема состояла в том, что предварительные хирургические вмешательства потребовали резекции сухожилий и мышечной части, что дополнительно выполнено и при повторной ревизии через 16 часов после первичной обработки во избежание сдавления сосудов, находящихся в критическом состоянии. Восстановление нервной проводимости произошло концу декабря 2019 года, стабильная фиксация привела к консолидации, однако вопрос об удалении пластин не ставился (рис. 6). Восстановление функции захвата пальцами, изолированных движений пальцами в ограниченном объёме наступило к концу февраля 2020 года. Через 1 год больной начал активно пользоваться кистью (рис. 7-9). Продолжает реабилитационные мероприятия, начал писать этой рукой и выполнять необходимые бытовые действия.

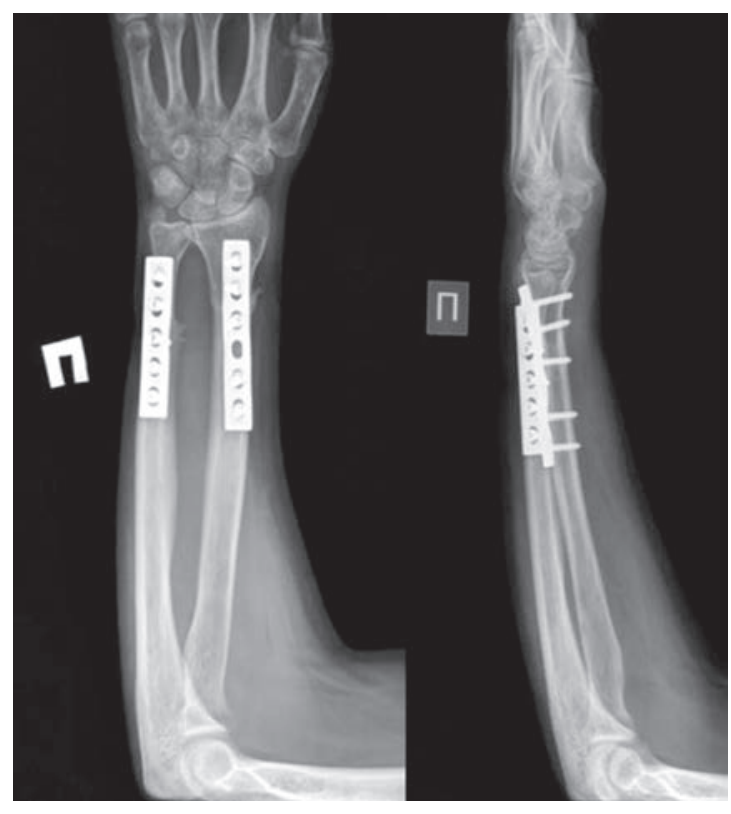

Рис. 6. Рентгенограммы предплечья больного Л. через 7 месяцев после ампутации, консолидация лучевой и локтевой костей

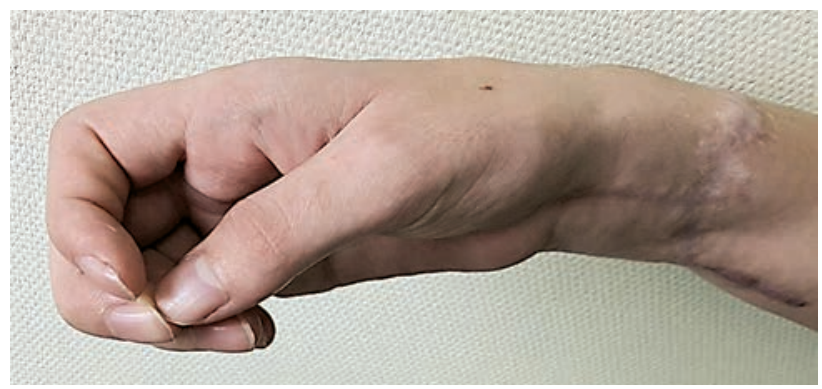

Рис. 7. Фото кисти больного Л., результат через 1 год после травмы

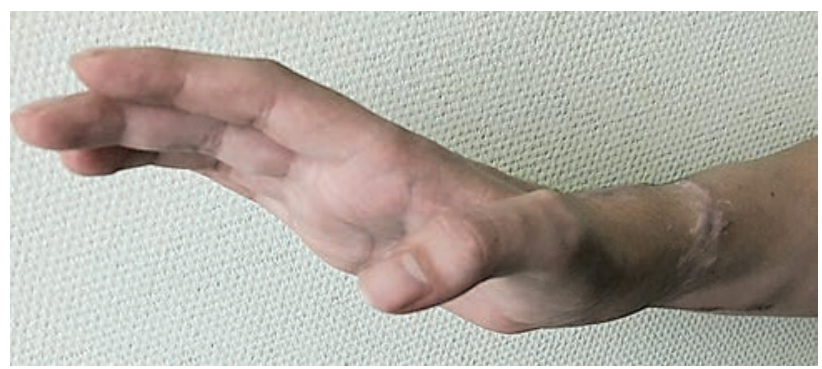

Рис. 8. Фото кисти больного Л., функция разгибания через 1 год

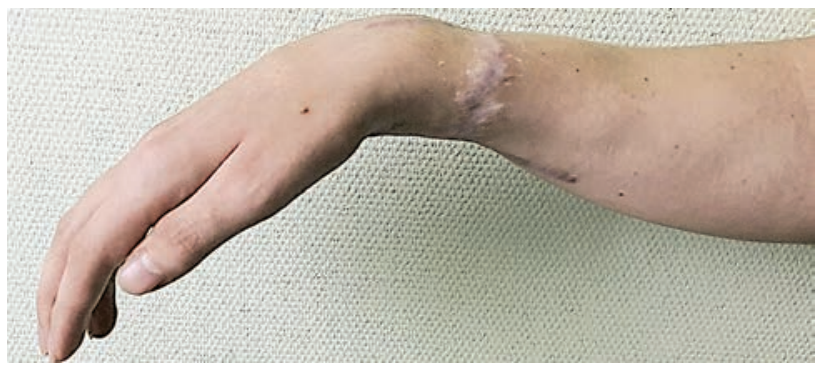

Рис. 9. Фото кисти больного Л., функция сгибания через год после полной ампутации

\section{ОБСУЖДЕНИЕ}

В случаях повреждения крупных магистральных сосудов единственной возможностью сохранения конечно- сти и жизни больного является привлечение сосудистых хирургов, создание комбинированных бригад, длитель- 
ное лечение в условиях реанимации и продолжительная реабилитация. Хирургические вмешательства проводятся одновременно с реанимационными мероприятиями. В наших наблюдениях нам удалось сохранить жизнеспособность конечностей. В одном из них была техническая необходимость отсрочить хирургические вмешательства по реконструкции сухожильного аппарата в случае полной ампутации предплечья с отсроченной реплантацией. В двух случаях получен отличный, в одном хороший результат с продолжающейся реабилитацией, сохранена ампутированная конечность на уровне предплечья, достигнута удовлетворительная функция руки.

Мы полагаем, что возможность успешного оказания помощи таким больным в городских и областных детских медицинских учреждениях напрямую связана, прежде всего, с небольшими временными сроками от момента травмы до поступления больного в стационар и возможностью быстрой организации комбинированных бригад специалистов, на что особо указывают практически все авторы $[1,6,7,9,12,13]$. Во всех этих случаях борьба за жизнь больного при повреждении магистральных сосудов проводится одновременно с реконструктивными вмешательствами по восстановлению кровотока, целости кости, нервных образований, мышц и их сухожильной части $[2,4,8]$. Возможность восстановления кровотока в крупных магистральных сосудах, а в представленных случаях при повреждениях артерий и вен одновременно с дефектами в области ранений, в детском возрасте всегда существует, даже в особо осложнённых условиях при полном отчленении конечности с размозжёнными сегментами кости. Для сохранения конечности в этих случаях необходима резекция повреждённых концов костей (кости) с их по возможности минимальным укорочением, обеспечение первичной консолидации, что обеспечивается стабильной фиксацией. Всегда остаётся риск сосудистых осложнений в виде тромбозов, поэтому требуется длительное консервативное лечение с динамическим клинико-лабораторным контролем $[1,2,6,11]$. Подобные клинические наблюдения у детей встречаются не часто, поэтому детали лечения и результаты подобных наблюдений мы сочли достаточно интересными для специалистов.

\section{ЗАКЛЮЧЕНИЕ}

Во всех случаях повреждения крупных магистральных артерий и вен, нервных образований требуется незамедлительное восстановление указанных структур одновременно с реанимационными мероприятиями. Шов нервов следует проводить одновременно с восстанов-

лением целостности сосудов. Реплантация отчленённой конечности должна быть проведена с учётом характера повреждения мягких тканей и кости, с целью качественной адаптации может оказаться необходимой резекция костных образований с укорочением конечности.

\section{СПИСОК ИСТОчнИКОВ}

1. Миначенко В.К., Бландинский В.Ф., Семишин В.Н. Лечение повреждений магистральных сосудов у детей и подростков // Вестник хирургии. 1988. № 3. С. 81-85.

2. Королёв М.П., Уракчеев Ш.К. Хирургическое лечение крупных сосудов // Вестник хирургии. 2011. № 6. С. 56-58.

3. Организация оказания медицинской помощи пострадавшим при дорожно-транспортных происшествиях в травмоцентрах СанктПетербурга / А.Н. Тулупов, В.Ю. Афончиков, А.Е. Чикин, С.Ш. Тания, А.С. Ганин // Вестник хирургии. 2014. № 1. С. 98-103.

4. Леменёв В.Л., Михайлов И.П., Исаев Г.А. Лечение больных с травмой магистральных артерий нижних конечностей // Ангиология и сосудистая хирургия. 2005. Т.11, № 3. С. 108-114.

5. Васютков В.Я., Евстифеев Л.К., Васютков А.В. Ятрогенная травма кровеносных сосудов // Грудная и сердечно-сосудистая хирургия. 1994. № 4. С. $45-48$.

6. Диагностика и лечение повреждений магистральных сосудов конечностей : монография / Ю.И. Казаков, В.Я. Киселев, Л.К. Евстифеев, А.Ю. Казаков. Тверь : ГЕРС, 2013. 136 с.

7. Replantation and revascularization of large segments of the hand and forearm / A. Caroli, R. Adani, C. Castagnetti, P B. Squarzina, G. Pancaldi, G. Cristiani // Ital. J. Orthop. Traumatol. 1991. Vol. 17, No 4. P. 443-447.

8. Hunt C.A., Kingsley J.R. Vascular injuries of upper extremity // South Med. J. 2000. Vol. 93, No 5. P. 466-468.

9. Franga D.L., Hawkins M.L., Mondy J.S. Management of subclavian and axillary artery injuries: spanning the range of current therapy // Am. Surg. 2005. Vol. 71, No 4. P. 303-307.

10. Хирургическое лечение повреждений сосудов конечностей / А.К. Жигунов, А.Д. Асламов, И.С. Абазова, О.Е. Логвина // Вестник хирургии. 2006. Т. 165 , № 2. С. 45-47.

11. Харузина О.В. Опыт ведения пациентов с ранениями магистральных сосудов шеи, верхних и нижних конечностей в многопрофильном госпитале // Здоровье семьи - 21 век. 2012. № 4. С. 19-25.

12. Опыт лечения сочетанных костно-сосудистых повреждений конечностей у детей / А.Б. Хакимов, А.А. Юлдашев, Р.А. Ахмедов, Ф.А. Машарипов, О.Н. Низов // Ангиология и сосудистая хирургия. 2015. Т. 21, № 2. С. 159-165.

13. Фомин В.Н. Лечение повреждений магистральных сосудов конечностей в условиях центральной районной больницы (наблюдения из практики) // Вестник хирургии. 2008. Т. 167, № 6. С. 127-128.

Статья поступила в редакцию 22.09.2021; одобрена после рецензирования 09.11.2021; принята к публикации 23.12.2021.

The article was submitted 22.09.2021; approved after reviewing 09.11.2021; accepted for publication 23.12.2021.

\section{Информация об авторах:}

1. Николай Михайлович Белокрылов - доктор медицинских наук, заслуженный врач РФ, член A.S.A.M.I., belokrylov1958@mail.ru;

2. Алексей Николаевич Белокрылов - кандидат медицинских наук, член A.S.A.M.I., leksab@mail.ru;

3. Ильдус Султанович Мухамадеев - доктор медицинских наук, ildus60@mail.ru;

4. Александр Сергеевич Денисов - доктор медицинских наук, профессор, заслуженный врач РФ, лауреат Государственной премии;

5. Василий Николаевич Киряков - sudozavodnet@mail.ru;

6. Константин Ильич Горковец - kogorkovets@gmail.ru.

\section{Information about the authors:}

1. Nikolay M. Belokrylov - Doctor of Medical Sciences, Honored Doctor of the Russian Federation, member of A.S.A.M.I., belokrylov1958@mail.ru;

2. Alexey N. Belokrylov - Candidate of Medical Sciences, member of A.S.A.M.I., leksab@mail.ru;

3. Ildus S. Mukhamadeev - Doctor of Medical Sciences, ildus_60@mail.ru;

4. Alexander S. Denisov - Doctor of Medical Sciences, Professor, Honored Doctor of the Russian Federation, State Prize Laureate;

5. Vasily N. Kiryakov - M.D., sudozavodnet@mail.ru;

6. Konstantin I. Gorkovets - M.D., kogorkovets@gmail.ru.

Источники финансирования. Работа не имела специального финансирования

Конфликт интересов. Авторы декларируют отсутствие явных и потенциальных конфликтов интересов, связанных с публикацией настоящей статьи. 
Гений ортопедии. 2022. Т. 28, № 1. С. 12-17.

Genij Ortopedii. 2022. Vol. 28, no. 1. P. 12-17.

\section{Научная статья}

УДК 616.727.2-072.1:616.747.2-018.38-001.5-089.844

https://doi.org/10.18019/1028-4427-2022-28-1-12-17

\section{Хирургическое лечение невосстановимых массивных повреждений вращательной манжеты плечевого сустава}

\section{Н.Н. Чирков ${ }^{1,2 \bowtie}$, В.Н. Яковлев ${ }^{1}$, А.В. Алексеева ${ }^{1}$, Е.В. Андронников ${ }^{1}$, В.Ю. Емельянов ${ }^{1,2}$}

1 Федеральный центр травматологии, ортопедии и эндопротезирования, Чебоксары, Россия

2 Чувашский государственный университет им. И.Н. Ульянова, Чебоксары, Россия

Автор, ответственный за переписку: Николай Николаевич Чирков, surgenik@gmail.com

\section{Аннотация}

Введение. Хирургическое лечение массивных невосстановимых повреждений вращательной манжеты плеча (ВМП) сопряжено с множеством трудностей для травматологов-ортопедов. Неэффективность стандартной рефиксации, отсутствие общепринятой методики лечения данной когорты пациентов обусловливают актуальность поиска альтернативных способов реконструкции. Цель. Разработка новой методики реконструкции невосстановимых разрывов ВМП, сравнение ее клинической эффективности с методикой частичной реконструкции. Материалы и методы. В исследование включены 58 пациентов с массивными невосстановимыми повреждениями ВМП, которым была выполнена артроскопическая реконструкция, из них 30 пациентам (I группа, контрольная) проведена частичная реконструкция манжеты, а 28 (II группа, основная) - реконструкция по разработанной методике. Суть данной методики заключается в дополнительной пластике ротаторов при помощи аутосухожилия длинной малоберцовой мышцы и проксимального отдела бицепса. Средний срок наблюдения составил $30,7 \pm 5,6$ месяца. Результаты оценивали по шкалам BAШ, ASES, UCLA, CSS, рентгенографии и данным МРT. Результаты. Достижение хороших и отличных результатов по показателям шкал UCLA-ASES-CS у пациентов II группы составило 53,6 \% против 26,7 \% у пациентов I группы (p = 0,036), ВАШ: I группа - 2,1 $\pm 1,8$, II группа - 1,0 $\pm 1,1$ (p = 0,02). При применении модифицированной методики реконструкции ВМП средняя величина акромиоплечевого интервала составила 6,7 $\pm 2,7$ мм, против 3,6 $\pm 2,1$ мм у пациентов контрольной группы (р < 0,0001). По данным МРТ частота полнослойных повторных разрывов сухожилий ВМП после реконструкции с использованием модифицированной методики была достоверно ниже - 17,9 \%, против 56,7 \% при использовании методики частичной реконструкции (p = 0,002). Ревизионная операция потребовалась четырем пациентам из I группы, причем двум из них был установлен реверсивный эндопротез в связи с прогрессированием артрозных изменений в плечевом суставе. Заключение. Разработанная методика реконструкции "невосстановимых" массивных повреждений ВМП позволяет восстановить вертикальный баланс в плечевом суставе, достоверно улучшить клинико-функциональные показатели, сократить число повторных разрывов сухожилий ротаторов в сравнении с методикой частичной реконструкции.

Ключевые слова: плечевой сустав, вращательная манжета плеча, массивное невосстановимое повреждение, артроскопическая реконструкция, аутосухожильная пластика

Для цитирования: Хирургическое лечение невосстановимых массивных повреждений вращательной манжеты плечевого сустава / Н.Н. Чирков, В.Н. Яковлев, А.В. Алексеева, Е.В. Андронников, В.Ю. Емельянов // Гений ортопедии. 2022. Т. 28, № 1. С. 12-17. httрs://doi. org/10.18019/1028-4427-2022-28-1-12-17

\section{Original article}

\section{Surgical treatment of irreparable massive injuries of the rotator cuff of the shoulder joint N.N. Chirkov ${ }^{1,2}$, V.N. Yakovlev ${ }^{1}$, A.V. Alekseeva ${ }^{1}$, E.V. Andronnikov ${ }^{1}$, V.Yu. Emelyanov ${ }^{1,2}$}

${ }^{1}$ Federal Center for Traumatology, Orthopedics and Arthroplasty, Cheboksary, Russia

2 I.N. Ulyanov Chuvash State University, Cheboksary, Russia

Corresponding author: Nikolai N. Chirkov, surgenik@gmail.com

Abstracts

Introduction Surgical treatment of massive non-repaired injuries of the rotator cuff of the shoulder (RCS) is associated with many difficulties for orthopedic traumatologists. Standard refixation is ineffective in these patients and there no any generally accepted treatment strategies. Therefore, there is a need to look for alternative methods of reconstruction. The aim of the study was to develop a new technique for the reconstruction of irreparable ruptures of the RCS, comparing its clinical effectiveness with the technique of partial reconstruction. Materials and methods The study included 58 patients with massive irreparable injuries of the RCS, who underwent arthroscopic reconstruction of the RCS in the time period from 2017 to 2020 at the FSBI "FCTA" of the Ministry of Health of Russia (Cheboksary). Thirty patients of group I (control group) underwent partial reconstruction of the cuff, and 28 patients of group II had reconstruction according to the technique developed by us. The essence is additional plasty of the rotators using tendon autograft from the long fibular muscle and the proximal biceps. The average follow-up period was $30.7 \pm 5.6$ months. The results were evaluated using the VAS, ASES, UCLA, CSS scales, X-ray and MRI data. Results Good and excellent results according to the UCLA-ASES-CSS scales were achieved in $53.6 \%$ in patients of group II versus $26.7 \%$ in patients of group I ( $p=0.036$ ). In group I, VAS was $2.1 \pm 1.8$ and in group II $-1.0 \pm 1.1(\mathrm{p}=0.02)$. The average value of the acromiohumeral interval was $6.7 \pm 2.7 \mathrm{~mm}$ after using the modified RCS reconstruction technique, versus $3.6 \pm 2.1 \mathrm{~mm}$ in the control group of patients $(\mathrm{p}<0.0001)$. According to MRI data, the rate of full-layer repeated ruptures of the RCS tendons after reconstruction using the modified technique was significantly lower, $17.9 \%$ versus $56.7 \%$ in the group of partial reconstruction technique $(\mathrm{p}=0.002)$. Four patients from group I underwent revision surgery, and two of them required arthroplasty with a reversible endoprosthesis due to the progression of arthritic changes in the shoulder joint. Conclusion The developed technique for reconstruction of "irreparable" massive injuries of the RCS allows restoring vertical balance in the shoulder joint, significantly improves clinical and functional indicators, reduces the number of repeated ruptures of the rotator tendons in comparison with the method of partial reconstruction.

Keywords: shoulder joint, rotator cuff, massive irreparable injury, arthroscopic reconstruction, autograft plastic surgery

For citation: Chirkov N.N., Yakovlev V.N., Alekseeva A.V., Andronnikov E.V., Emelyanov V.Yu. Surgical treatment of irreparable massive injuries of the rotator cuff of the shoulder joint. Genij Ortopedii, 2022, vol. 28, no 1, pp. 12-17. https://doi.org/10.18019/1028-4427-2022-28-1-12-17

\section{ВВЕДЕНИЕ}

По литературным данным, разрыв вращательной манжеты плечевого сустава (ВМПС) с дефектом площадью более 5 см по данным МРТ или затрагивающим два или более сухожилий относится к массивным повреждениям вращательной манжеты. В случаях, когда хирургическим путем технически не удается произве- 
сти полную рефиксацию сухожилий ВМПС из-за ретракции сухожилий, жировой мышечной инфильтрации или атрофии мышц, состояние определяется как невосстановимый массивный разрыв вращательной манжеты [1]. У пациентов с невосстановимыми массивными разрывами ВМПС определяется значительная дисфункция плечевого сустава [2].

Методики лечения невосстановимых разрывов ВМПС вариабельны, включают как консервативное, так и хирургическое лечение: тенотомия сухожилия длинной головки двуглавой мышцы плеча, частичное восстановление вращательной манжеты, баллонная пластика, реконструкция верхней капсулы сустава, мышечные трансферы и реверсивное эндопротезирование плечевого сустава [3].

Наибольшее распространение получила методика реконструкции верхней капсулы сустава путем уста- новки трансплантата от верхнего полюса гленоида до большого бугорка плечевой кости. В качестве трансплантата предложены различные варианты: широкая фасция бедра, сухожилие длинной головки двуглавой мышцы, бесклеточный дермальный аллотрансплантат, ксенотрансплантат или синтетический трансплантат [4].

Несмотря на большое количество методик лечения, процент неудовлетворительных исходов лечения невосстановимых разрывов ВМПС по-прежнему остается высоким. Так, Ok H.S. et al. сообщают о частоте повторного разрыва с несостоятельностью реконструкции в пределах от 17,6 до 94 \% [5].

Цель исследования - разработка новой методики реконструкции невосстановимых разрывов ВМПС, сравнение ее клинической эффективности с традиционной методикой частичной реконструкции.

\section{МАТЕРИАЛЫ И МЕТОДЫ}

Для достижения цели потребовалось решить ряд взаимосвязанных задач, которые были объединены в два основных этапа работы: анализ результатов пролеченных пациентов по традиционной методике (ретроспективный) и экспериментально-клинический (проспективный) анализ результатов лечения по модифицированной методике. Из 71 пациента, проходивших амбулаторный отбор и последующее хирургическое лечение в ФГБУ «Федеральный центр травматологии, ортопедии и эндопротезирования» Минздрава России (г. Чебоксары) с 2017 по 2020 год по поводу невосстановимого массивного повреждения ВМПС, в первичную когорту клинического исследования были включены 58 пациентов согласно дополнительно установленным критериям.

Критерии включения: в исследование включали всех последовательных пациентов с невосстановимым массивным повреждением ВМПС, подтвержденным данными магнитно-резонансной томографии (МРТ), за которыми осуществлялось этапное наблюдение на протяжении послеоперационного периода с наличием заполненных стандартных опросников и шкал.

Критерии исключения: грубая неврологическая симптоматика верхней конечности и деформирующий артроз плечевого сустава II или III стадии, полный отрыв сухожилия подлопаточной мышцы.

Исследование выполнено в соответствии с этическими принципами Хельсинской декларации (World Medical Association Declaration of Helsinki - Ethical Principlesfor Medical Research Involving Human Subjects, 2013) и «Правилами клинической практики в Российской Федерации» (Приказ Минздрава РФ от 19 июня 2003 года № 266). Все пациенты выразили добровольное информированное согласие на участие в исследовании.

Срок давности травмы варьировал от одного до 4,7 года. Возраст пациентов составил от 41 до 72 лет, большинство пациентов $(71,8$ \%) были мужского пола.

При поступлении все пациенты предъявляли жалобы на ноющие боли в области травмированного плечевого сустава с усилением их после физических нагрузок и в ночные часы, трудности самообслуживания, ограничения в выполнении трудовых обязанностей, занятиях спортом.

Хирургическое вмешательство

Всем пациентам была выполнена артроскопическая реконструкция вращательной манжеты плечевого сустава. Во время хирургического вмешательства всем пациентам выполняли артроскопическую диагностику с оценкой ригидности сухожилий, осуществляли релиз поврежденных сухожилий, бурсэктомию, коррекцию сопутствующей патологии.

Пациенты были разделены на две группы. Пациентам I группы (контрольная, $\mathrm{n}=30 ; 51,7$ \% выборки) выполняли вынужденное частичное восстановление вращательной манжеты плеча для создания баланса пар сил действия наружных и внутренних ротаторов.

Пациентам II группы (основная, $\mathrm{n}=28 ; 48,3$ \%) выполняли реконструкцию повреждения ВМПС по разработанной авторской методике. Для этого в положении пациента полусидя с боковой тракцией верхней конечности выполняли стандартный артроскопический доступ в плечевой сустав. Производили релиз и анкерную рефиксацию сухожилий по технике однорядного шва, где это было технически возможно. Верхнюю часть вращательной манжеты укрепляли вовлечением сухожилия длинной головки двуглавой мышцы плеча, которое дистально фиксировали в области большого бугорка. Выполняли продольный разрез кожи 2,0 см в области наружной лодыжки, производили забор сухожилия длинной малоберцовой мышцы для аутотрансплантации. Сформированный аутотрансплантат пропускали через мягкие ткани вращательной манжеты с помощью хирургических щипцов. Аутосухожилие натягивали, а его концы фиксировали в области большого бугорка при помощи двух якорных фиксаторов. Таким образом формировалась дополнительная петля из аутосухожилия, страхующая вращательную манжету от повторного разрыва после реконструкции. Вовлеченное сухожилие длинной головки двуглавой мышцы плеча и сухожильный аутотрансплантат совместно заполняли дефект верхней части вращательной манжеты и формировали подобие верхней капсулы сустава (рис. 1). 

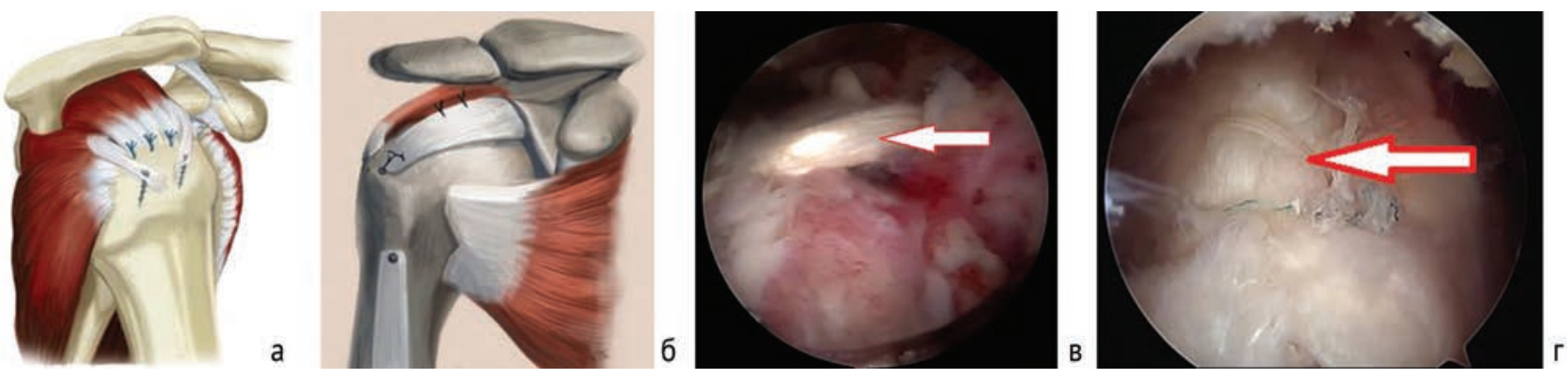

Рис. 1.: а - схема укрепления реконструкции при помощи аутосухожилия длинной малоберцовой мышцы; б - схема формирования верхней капсулы сустава из сухожилия длинной головки двуглавой мышцы плеча; в - артроскопическая картина части установленного аутосухожилия длинной малоберцовой мышцы (стрелка); г - артроскопическая картина вовлеченного в реконструкцию проксимального отдела сухожилия бицепса

\section{Оиенка результатов}

Оценку клинических результатов осуществляли с помощью функциональных измерений, тестов и шкал. Для измерения углов отведения, сгибания и ротационных движений в плечевом суставе использовали стандартный угломер. Силу отведения и сгибания в плечевом суставе измеряли путем попеременного поднятия тарированых в килограммах грузов. Степень проявления болевого синдрома оценивали по визуально-аналоговой шкале (ВАШ). Результат лечения плечевого сустава оценивали при помощи валидизированных шкал:

1) оценка плеча Калифорнийского университета в Лос-Анджелесе (UCLA, University of California, Los Angeles);

2) американских хирургов плечевого и локтевого суставов (ASES, American Shoulder and Elbow Surgeons Assessment);

3) оценка плеча Константа (CSS, Constant Shoulder Score). За итоговый показатель бралась оценка, по которой совпадали результаты 2 из 3 шкал.

Проводили полипозиционную рентгенографию плечевого сустава, где оценивали центрацию головки плечевой кости отностительно гленоида. Для этого определяли величину акромиоплечевого интервала: при расстоянии 8-12 мм отмечали нормальную центрацию плеча, 6-7 мм соответствовало умеренной децен- трации плеча, и при сужении акромиоплечевого интервала менее 6 мм отмечали верхний подвывих плеча с несостоятельностью реконструкции [6].

МРТ-оценку состоятельности реконструкции сухожилий ВМПС после операции производили при помощи упрощенной классификации Sugaya [7]. При I и II типах интеграции сухожилия с костью реконструкцию считали состоятельной. III тип определяли как частичный отрыв восстановленного сухожилия с состоятельностью поверхностного либо глубокого слоя ВМПС в области якорных фиксаторов. IV и V типы соответствовали полному повторному разрыву сухожилий ротаторов после операции.

Статистический анализ

Обработка данных выполнена на персональном компьютере с использованием разработанных статистических программ в среде Excel 2010 и GraphPad Prism 8.0 for Windows 10.0 (GraphPad Software, США) [61]. При обработке данных рассчитывали среднее и стандартное отклонения (M \pm SD). Статистическая значимость различий между данными при отсутствии нормального распределения оценивали по непараметрическому критерию Манна-Уитни - U тест. Для качественных данных оценку различий проводили по критерию хи-квадрат $\left(\chi^{2}\right)$. Данные считали достоверными при вероятности ошибки (р) менее 0,05.

\section{РЕЗУЛЬТАТЫ}

Результаты предоперационного обследования

Результаты дооперационного обследования пациентов обеих групп были сопоставимы, без статистически значимых различий. При клиническом осмотре лопаточной области пациентов с массивным повреждением ВМПС на стороне поражения отмечали гипотрофию надостной и подостной мышц в виде западения тканей в области надостной и подостной ямок (рис. 2).

У всех пациентов определяли крепитацию в пораженном плечевом суставе. Крепитация проявлялась в момент трения оголенной площадки большого бугорка плечевой кости после отрыва сухожилия надостной мышцы о нижнюю поверхность акромиального отростка лопатки (при отведении плеча на 45-60²). Таким образом, выявление крепитации у пациентов с разрывами ВМПС позволяет считать последнюю ценным диагностическим признаком, по которому предварительно можно заподозрить полнослойный разрыв сухожилия надостной мышцы.

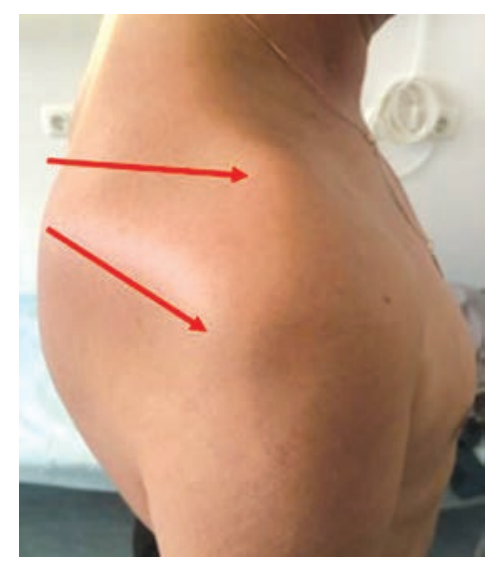

Рис. 2. Клиническое проявление гипотрофии надостной и подостной мышц, вид справа

При вовлечении в разрыв сухожилия подостной мышцы у пациента значительно снижалась сила наружной ротации плеча. Данный симптом выявлен у 68 наших пациентов до операции (95,8 \%). Снижение 
силы внутренней ротации плеча относительно здорового выявлено у 8 пациентов (11,3 \%), что свидельствовало о повреждении сухожилия подлопаточной мышцы.

Средний показатель по шкале ВАШ до операции составил 6,6 $\pm 1,03$. Средний показатель сгибания $98,2 \pm 38,7^{\circ}$, отведения - 78,7 $\pm 36,5^{\circ}$, наружной ротации $-6,2 \pm 8,5^{\circ}$. Средняя величина акромиальноплечевого интервала по данным рентгенографии составила 2,0 \pm 1,4 мм, что свидетельствует о верхнем подвывихе плеча и нарушении стабильности плечевого суставав вертикальной плоскости.

По данным дооперационных МРТ у всех пациентов выявлены признаки застарелого отрыва сухожилий надостной и подостной мышц с ретракцией 3 стадии, мышечной жировой дегенерацией и атрофией 3 и 4 стадии. У 9 пациентов дополнительно определяли признаки частичного повреждения верхней трети сухожилия подлопаточной мышцы (5 пациентов I группы, 4 пациента II группы), которым была произведена рефиксация данного сухожилия по стандартной технике.

Функциональные результаты после операции

Результаты лечения оценены у 30 пациентов I группы и у 28 пациентов II группы на среднем сроке $30,7 \pm 5,6$ мес. Проведенное хирургическое лечение позволило улучшить клинико-функциональные показатели в обеих группах $(\mathrm{p}<0,05)$, однако у пациентов II группы они были статистически значимо лучше по сравнению с первой группой (табл. 1). Так, достижение хороших и отличных результатов по шкалам UCLA-ASES-CS у пациентов II группы составило $53,6$ \% против 26,7 \% у пациентов I группы ( $=0,036)$. Большинство пациентов были довольны проведенным лечением, отмечали купирование болевого синдрома, улучшение функции сустава.

Результаты лучевых методов исследований

Рентгенография и МРТ плечевого сустава после операции проведена всем пациентам исследуемого профиля. У пациентов II группы с применением модифицированной методики реконструкции ВМПС средняя величина акромиоплечевого интервала составила

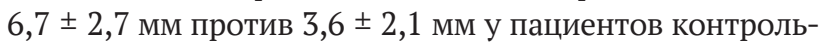
ной I группы ( $<<0,0001)$.

По данным МРТ частота полнослойных повторных разрывов сухожилий ВМПС после реконструкции при использовании модифицированной методики была достоверно ниже, чем при использовании методики частичной реконструкции - 17,9 \% против 56,7 \% $(\mathrm{p}=0,002)$. Ревизионные операции были проведены четырем пациентам I группы, причем двум из них потребовалась установка реверсивного эндопротеза в связи с прогрессированием артрозных изменений в плечевом суставе. Центрация головки плеча в горизонтальной плоскости после операции была равнозначно достигнута у пациентов обеих групп при условии состоятельности реконструкции.

Послеоперационных осложнений у пациентов обеих групп не наблюдалось.

Таблица 1

Клинико-функциональные показатели после реконструкции вращательной манжеты плечевого сустава

\begin{tabular}{|c|c|c|c|}
\hline \multirow{2}{*}{ Показатель, шкала } & I группа (контрольная) & II группа (основная) & \multirow{2}{*}{$\mathrm{p}^{*}$} \\
\hline & $\mathrm{M}(\mathrm{SD})$ & $\mathrm{M}(\mathrm{SD})$ & \\
\hline Количество пациентов & 30 & 28 & \\
\hline ВАШ, баллы & $2,1(1,8)$ & $1,0(1,1)$ & 0,0201 \\
\hline Сгибание, град. ${ }^{1}$ & $133,7(40,5)$ & $161,4(16,9)$ & 0,0022 \\
\hline Отведение, град. ${ }^{1}$ & $120,3(43,2)$ & $152,5(27)$ & 0,0007 \\
\hline Наружная ротация, град. ${ }^{1}$ & $17,83(16,8)$ & $29,82(15,2)$ & 0,0061 \\
\hline UCLA, баллы ${ }^{1}$ & $22,00(5,8)$ & $25,86(5)$ & 0,0106 \\
\hline ASES, баллы ${ }^{1}$ & $57,97(20,1)$ & $72,46(14,2)$ & 0,0211 \\
\hline CSS, баллы1 & $69,73(14,4)$ & $80,21(10,8)$ & 0,0222 \\
\hline Удовлетворенность, \% ${ }^{2}$ & 57,1 & 82,1 & \\
\hline
\end{tabular}

Манна-Уитни, значения $\mathrm{p} \leqslant 0,05$ принимались как достоверные; ${ }^{2}-$ проценты.

\section{ДиСКУССия}

Полнослойные повреждения вращательной манжеты плеча встречаются примерно у 10 \% людей старше 60 лет и являются одной из наиболее распространенных причин боли и дисфункции в плечевом комплексе [8]. Пациенты с массивными разрывами вращательной манжеты могут испытывать сильную боль, снижение объема движений в суставе и нарушение повседневной активности. Артроскопическое восстановление массивного поражения ВМПС имеет неопределенный прогноз, так как показатели частоты повторного разрыва выше, чем при реконструкции повреждений малых размеров [9].

С течением времени было разработано множество методик для улучшения результатов лечения массивных повреждений ВМПС, включая применение техники двухрядного наложения швов, реконструкций верхней капсулы плечевого сустава, методик мышечно-сухожильных трансферов, а также технология реверсивного эндопротезирования. B PubMed за последние 5 лет проиндексировано более 100 статей, упоминающих «массивный разрыв вращательной манжеты плеча» в заголовке или аннотации. Если рассматривать описанные в литературе методики, то наиболее распространена реконструкция верхней капсулы сустава. Однако в отечественной практике в настоящий момент применение данной методики встречает серьезные препятствия, связанные с доступностью трансплантата для замещения дефекта ВМПС. Они сопряжены либо с юридическими ограничениями, либо с отсутствием регистрации на территории РФ. По сути, единственным доступным вариантом для формирова- 
ния верхней капсулы является использование аутосухожилия из широкой фасции бедра. Однако для забора данного аутотрансплантата необходим дополнительный большой разрез в области бедра, что мы считаем излишней агрессией. К тому же, сама техника установки верхней капсулы сустава технически сложна и требует большого количества расходного материала, что ограничивает ее широкое применение.

Забор аутосухожилия длинной малоберцовой мышцы технически прост и не требует больших разрезов. Аутосухожилие обладает большей механической прочностью по сравнению с аллографтом и имеет больший потенциал биологического приращения. Преимуществом предлагаемой методики является то, что, в отличие от классического формирования верхней капсулы, данная конструкция является динамической структурой, так как один конец фиксирован к сухожилию манжеты.

Для замещения невосстановимой части ВМПС предложена методика установки биоразлагаемого субакромиального спейсера (InSpace), которая позволяет расширить субакромиальное пространство, восстановить соосность головки плеча во впадине [10]. Однако данная методика, как и методика реконструкции верхней капсулы, имеет низкую эффективность при сочетанных повреждениях сухожилий надостной и подостной мышц [11].

Для замещения поврежденных наружных ротаторов плеча описаны различные методики миотранспозиций. Наиболее распространенным является вариант с транспозицией широчайшей мышцы спины, который является травматичным и сложным хирургическим вмешательством со сложной кривой обучения [3]. Поэтому данный вариант лечения невосстановимых повреждений ВМПС не получил широкого распространения. Анализируя собственный хирургический опыт, можем отметить, что нам всегда удавалось артроскопически восстановить поврежденные наружные ротаторы плеча (сухожилия подостной и малой круглой мышц). Для этого мы осуществляли тракцию за сухожилие и использовали циркулярный релиз данных структур - рассечение фиброзных спаек, капсулы и рубцов электроинструментом для придания мобильности. Фиксацию к большому бугорку осуществляли при помощи 3-4 якорных фиксаторов.

Вариантом выбора хирургического лечения застарелых массивных повреждений ВМПС является эндопротезирование с использованием реверсивной конструкции эндопротеза. Данная конструкция эндопротеза низводит и медиализирует центр вращения в суставе, что позволяет отводить конечность за счет дельтовидной мышцы без участия коротких ротаторов плеча. Однако это травматичное вмешательство и оно сопряжено с риском значительных осложнений, к наиболее частым из которых относятся вывихи в эндопротезе, инфекция, осложнения механического характера [12]. Поэтому мы считаем неоправданным применение эндопротезирования при наличии неповрежденного хрящевого покрытия плечевого сустава.

По нашим наблюдениям, как и по литературным данным, восстановление сухожилия надостной мышцы при массивных повреждениях ВМПС не представляется возможным из-за её выраженной ретракции. В таких случаях допустим вариант частичного восстановления поврежденных сухожилий для создания баланса пар сил и стабилизации сустава в горизонтальной плоскости. Данный вариант в клинической практике применяется наиболее часто, так как он технически прост и не требует применения дополнительных материалов. Анализ собственного клинического материала показал, что у пациентов I группы, которым была выполнена частичная реконструкция ВМПС, величина акромиоплечевого интервала после операции составила 3,6 \pm 2,1 мм, что соответствует остаточному верхнему подвывиху плеча. Таким образом, по нашим данным, операция частичной реконструкции ВМПС не обеспечивает баланс плечевого сустава в вертикальной плоскости. Напротив, применение модифицированной методики с использованием аутосухожилия длинной малоберцовой мышцы вкупе с аугментацией бицепсом, позволяет одновременно укрепить реконструированные сухожилия наружных ротаторов плеча, а также получить эффект верхней капсулы сустава. Об этом свидетельствует наличие субакромиального пространства толщиной 6,7 $\pm 2,7$ мм, наблюдаемое у пациентов в послеоперационном периоде после выполнения данной методики. Данная конструкция обеспечивает правильную центрацию головки плечевой кости в суставной впадине лопатки. Безусловно, суждение об эффективности предлагаемой методики требует уточнения по мере увеличения клинических наблюдений. Однако полученные результаты исследований позволяют судить об ее большей эффективности в сравнении с парциальным восстановлением вращательной манжеты.

Предложенная нами методика может быть рекомендована для дополнительного укрепления рефиксированных сухожилий ротаторов, поскольку вовлечение в реконструкцию аутосухожилия позволяет шунтировать нагрузку на фиксирующие швы. Подтверждением тому служит меньшая частота повторных разрывов ВМПС после реконструкции по разработанной методике по сравнению с частичным восстановлением.

\section{ЗАКЛЮЧЕНИЕ}

Разработанная методика реконструкции невосстановимых массивных повреждений вращательной манжеты плеча позволяет восстановить вертикальный баланс в плечевом суставе, достоверно улучшить клинико-функциональные показатели, сократить число повторных разрывов сухожилий ротаторов по сравнению с методикой частичной реконструкции.

\section{СПИСОК ИСТОЧнИКОВ}

1. Irreparable rotator cuff tears: Current treatment options / T. Juhan, M. Stone, O. Jalali, W. Curtis, J. Prodromo, A.E. Weber, G.F. Hatch III, R. Omid // Orthop. Rev. (Pavia). 2019. Vol. 11, No 3. P. 8146. DOI: 10.4081/or.2019.8146. 
2. The Rotator Cuff and the Superior Capsule: Why We Need Both / C.R. Adams, A.M. DeMartino, G. Rego, P.J. Denard, S.S. Burkhart// Arthroscopy. 2016. Vol. 32, No 12. P. 2628-2637. DOI: 10.1016/j.arthro.2016.08.011.

3. Management of the Irreparable Rotator Cuff Tear / G.L. Cvetanovich, B.R. Waterman, N.N. Verma, A.A. Romeo // J. Am. Acad. Orthop. Surg. 2019. Vol. 27, No 24. P. 909-917. DOI: 10.5435/JAAOS-D-18-00199.

4. Arthroscopic Single-Row Superior Capsular Reconstruction for Irreparable Rotator Cuff Tears / T.S. Roth, M.L. Welsh, D.C. Osbahr, A. Varma // Arthrosc. Tech. 2020. Vol. 9, No 5. P. e675-e681. DOI: 10.1016/j.eats.2020.01.024.

5. Clinical Relevance of Classifying Massive Rotator Cuff Tears: Results Based on Functional and Radiological Findings after Arthroscopic Repair / H.S. Ok, B.G. Kim, W.C. Choi, C.G. Hong, J.W. Kim, J.H. Kim // Am. J. Sports. Med. 2017. Vol. 45, No 1. P. 157-166. DOI: $10.1177 / 0363546516667498$.

6. Knipe H., Baba Y. Acromiohumeral interval. Reference article // Radiopaedia.org. DOI: 10.53347/rID-30619.

7. Intra- and inter-observer agreement in MRI assessment of rotator cuff healing using the Sugaya classification 10 years after surgery / L. Niglis, P. Collin, J.C. Dosch, N. Meyer, J.F. Kempf; SoFCOT // Orthop. Traumatol. Surg. Res. 2017. Vol. 103, No 6. P. 835-839. DOI: 10.1016/j. otsr.2017.06.006.

8. Shepet K.H., Liechti D.J., Kuhn J.E. Nonoperative treatment of chronic, massive irreparable rotator cuff tears: a systematic review with synthesis of a standardized rehabilitation protocol // J. Shoulder Elbow Surg. 2021. Vol. 30, No 6. P. 1431-1444. DOI: 10.1016/j.jse.2020.11.002.

9. Defining massive rotator cuff tears: a Delphi consensus study / A. Schumaier, D. Kovacevic, C. Schmidt, A. Green, A. Rokito, C. Jobin, E. Yian, F. Cuomo, J. Koh, M. Gilotra, M. Ramirez, M. Williams, R. Burks, R. Stanley, S. Hasan, S. Paxton, S. Hasan, W. Nottage, W. Levine, U. Srikumaran, B. Grawe // J. Shoulder Elbow Surg. 2020. Vol. 29, No 4. P. 674-680. DOI: 10.1016/i.jse.2019.10.024.

10. Wright M.A., Abboud J.A., Murthi A.M. Subacromial Balloon Spacer Implantation // Curr. Rev. Musculoskelet. Med. 2020. Vol. 13, No 5. P. 584591. DOI: 10.1007/s12178-020-09661-9.

11. Outcomes of Subacromial Balloon Spacer Implantation for Massive and Irreparable Rotator Cuff Tears: A Systematic Review / R.K. Stewart, L. Kaplin, S.A. Parada, B.R. Graves, N.N. Verma, B.R. Waterman // Orthop. J. Sports Med. 2019. Vol. 7, No 10. P. 2325967119875717. DOI: $10.1177 / 2325967119875717$.

12. Comparison of complication types and rates associated with anatomic and reverse total shoulder arthroplasty / S.A. Parada, P.H. Flurin, T.W. Wright, J.D. Zuckerman, J.A. Elwell, C.P. Roche, R.J. Friedman // J. Shoulder Elbow Surg. 2021. Vol. 30, No 4. P. 811-818. DOI: 10.1016/j. jse.2020.07.028.

Статья поступила в редакцию 20.12.2021; одобрена после рецензирования 24.12.2021; принята к публикации 23.12.2021.

The article was submitted 20.12.2021; approved after reviewing 24.12.2021; accepted for publication 23.12.2021.

\section{Информация об авторах:}

1. Николай Николаевич Чирков - кандидат медицинских наук, surgenik@gmail.com, https://orcid.org/0000-0001-7099-2672;

2. Владимир Николаевич Яковлев - vnyakovlev@orthoscheb.com, https://orcid.org/0000-0003-4958-8215;

3. Алена Вячеславовна Алексеева - alexeeva.shokolad@yandex.ru;

4. Евгений Александрович Андронников - andronnikovevgenij@mail.ru, https://orcid.org/0000-0002-3151-4368;

5. Владимир Юрьевич Емельянов - кандидат медицинских наук, vemelianov@mail.ru, https://orcid.org/0000-0003-1720-1741.

\section{Information about the authors:}

1. Nikolay N. Chirkov - Candidate of Medical Sciences, surgenik@gmail.com, https://orcid.org/0000-0001-7099-2672;

2. Vladimir N. Yakovlev - M.D., vnyakovlev@orthoscheb.com, https://orcid.org/0000-0003-4958-8215;

3. Alena V. Alekseeva - M.D., alexeeva.shokolad@yandex.ru;

4. Evgeniy A. Andronnikov - M.D., andronnikovevgenij@mail.ru, https://orcid.org/0000-0002-3151-4368;

5. Vladimir Yu. Emelyanov - Candidate of Medical Sciences, vemelianov@mail.ru, https://orcid.org/0000-0003-1720-1741.

Авторы заявляют об отсутствии конфликта интересов.

The authors declare no conflicts of interests. 
Гений ортопедии. 2022. Т. 28, № 1. С. 18-23.

Genij Ortopedii. 2022. Vol. 28, no. 1. P. 18-23.

Научная статья

УДК 616.727.2:616.74-018.38-001.5-089.84

https://doi.org/10.18019/1028-4427-2022-28-1-18-23

\title{
Сравнительный анализ клинических результатов применения шва вращательной манжеты плеча в зависимости от способа фиксации сухожилия
}

\section{А.Ю. Денисова ${ }^{1 凶}$, А.А. Галов ${ }^{2}$, А.В. Данилов ${ }^{3}$, А.Н. Наркевич${ }^{1}$, Е.В. Серова ${ }^{1}$}

\author{
${ }^{1}$ Красноярский государственный медицинский университет имени профессора В.Ф. Войно-Ясенецкого, Красноярск, Россия \\ 2 Краевая клиническая больница, Красноярск, Россия \\ ${ }^{3}$ Клиника Медистар, Красноярск, Россия
}

Автор, ответственный за переписку: Анастасия Юрьевна Денисова, а.j.denisova@gmail.com

\section{Аннотация}

Введение. Частичный или полный разрыв вращательной манжеты занимает в настоящее время одно из первых мест среди причин боли и дисфункции в плечевом суставе. Несмотря на разнообразие существующих хирургических техник, частота повторных разрывов после оперативного лечения по данным МРТ-исследований составляет от 20 до 39 \%. Цель. Оценка и сравнение клинических результатов оперативного лечения полнослойных разрывов вращательной манжеты плеча с применением различных способов фиксации сухожилия. Материалы и методы. Проведен ретроспективный анализ историй болезни, протоколов операций и опрос пациентов, проходивших оперативное лечение с диагнозом «разрыв вращательной манжеты плеча» на базе Красноярской краевой клинической больницы за период 6 лет. Выборка составила 120 человек. Все исследуемые были разделены на три группы в зависимости от способа фиксации сухожилия: 1 ) Suture Bridge - техника с использованием анкеров (A); 2) классический двурядный трансоссальный шов (ТОШ); 3) двурядный трансоссальный шов с использованием экстракортикальных фиксаторов (Endobutton, Flipptack) (ТОШ+). Также проводился анализ зависимости исхода лечения от времени ожидания оперативного вмешательства и прохождения курса реабилитации после. Результаты. При оценке влияния длительности ожидания операции на исход получены сопоставимые распределения как отрицательных, так и положительных результатов, независимо от давности травмы. Лучшие клинические результаты получены в группе пациентов, проходивших в послеоперационном периоде реабилитационную программу. В группе А отличный и хороший результат получен в 72,9 \%, удовлетворительный - в 8,6 \%, неудовлетворительный - в 18,6 \%. В группе ТОШ отличный и хороший результат составил 66,7 \% случаев, удовлетворительный - в 15,2 \%, неудовлетворительный - 18,2 \%. В группе ТОШ+ показатель отличного и хорошего результата составил 76,5 \%, удовлетворительного $23,5 \%$, ни одного неудовлетворительного результата получено не было. При анализе группы ТОШ+ получены близкие к статистически значимым результаты, и, возможно, при увеличении выборки удастся доказать достоверность полученного на практике отличного результата. Выводы. Анкерная фиксация при Suture Bridge-технике и классический трансоссальный шов показывают сопоставимые отдаленные клинические результаты. Отсутствие неудовлетворительных исходов в группе с использованием экстракортикальных фиксаторов делает перспективным дальнейшее изучение данного метода на большей выборке.

Ключевые слова: вращательная манжета плеча, разрыв, трансоссальный шов, костно-сухожильный шов, анкерный шов

Для иитирования: Сравнительный анализ клинических результатов применения шва вращательной манжеты плеча в зависимости от способа фиксации сухожилия / А.Ю. Денисова, А.А. Галов, А.В. Данилов, А.Н. Наркевич, Е.В. Серова // Гений ортопедии. 2022 . Т. 28 , № 1. C. 18-23. https://doi.org/10.18019/1028-4427-2022-28-1-18-23

\section{Original article}

\section{Comparative analysis of clinical outcomes of rotator cuff sutures and their dependence on the methods of cuff fixation}

\author{
A.Yu. Denisova ${ }^{1}$, A.A. Galov², A.V. Danilov³, A.N. Narkevich ${ }^{1}$, E.V. Serova ${ }^{1}$ \\ ${ }^{1}$ Krasnoyarsk State Medical University named after Professor V.F. Voino-Yasenetsky, Krasnoyarsk, Russian Federation \\ ${ }^{2}$ Krasnoyarsk Regional Clinical Hospital, Krasnoyarsk, Russian Federation \\ ${ }^{3}$ Medistar private clinic, Krasnoyarsk, Russian Federation
}

Corresponding author: Anastasia Yu. Denisova, a.j.denisova@gmail.com

Abstract

Partial or full-thickness rotator cuff tear is one of the leading causes of pain and dysfunction in the shoulder joint. Despite the variety of existing surgical techniques, the incidence of re-ruptures after surgical treatment, according to MRI studies, varies from $20 \%$ to $39 \%$. Purpose To evaluate and compare the clinical results of full-thickness rotator cuff tears surgical treatment using various methods of tendon fixation. Materials and methods A retrospective analysis of case histories, surgery protocols and interviews of patients who underwent surgical treatment for rotator cuff tears at the Krasnoyarsk Regional Clinical Hospital within a period of 6 years was carried out. The sample consisted of 120 patients. All patients were divided into three groups depending on the method of fixation: 1) SutureBridge technique using anchors, 2) classic double-row transosseous suture, 3) double-row transosseous suture using extracortical fixators (Endobutton, Fliptack). Results In the first group, excellent and good results were obtained in $72.86 \%$ and poor results were observed in $18.57 \%$. In the second group, excellent and good results were obtained in $66.66 \%$ of cases, unsatisfactory results in $18.18 \%$. In the third group, excellent and good results were obtained in $76.47 \%$, there were no poor outcomes. The best clinical results were obtained in the group of patients who underwent postoperative rehabilitation. Conclusion Anchor SutureBridge technique and classical transosseous suture technique demonstrate comparable long-term outcomes. The absence of poor outcomes in the group of extracortical fixators makes further study of this method promising and should be shown in a larger sample. Keywords: rotator cuff, rotator cuff tear, transosseous suture, bone-tendon suture, anchor suture

For citation: Denisova A.Yu., Galov A.A., Danilov A.V., Narkevich A.N., Serova E.V. Comparative analysis of clinical outcomes of rotator cuff sutures and their dependence on the methods of cuff fixation. Genij Ortopedii, 2022, vol. 28, no 1, pp. 18-23. https://doi.org/10.18019/1028-44272022-28-1-18-23

() Денисова А.Ю., Галов А.А., Данилов А.В., Наркевич А.Н., Серова Е.В., 2022 


\section{ВВЕДЕНИЕ}

Среди всех причин, вызывающих боль и дисфункцию в плечевом суставе, частичный или полный разрыв вращательной манжеты (ВМП) в настоящее время стоит на одном из первых мест [1-5]. Биомеханическая роль вращательной манжеты заключается в поддержании конгруэнтности суставных поверхностей плечевого сустава. В случае разрыва одного из четырех сухожилий нарушается стабилизация головки в суставной впадине лопатки, что обусловливает развитие болевого синдрома, плече-лопаточного остеоартроза и прогрессирующей потери функции верхней конечности [6]. Причиной разрыва чаще всего является травма или повторяющаяся микротравма в совокупности с длительно существующим импинджмент-синдромом, приводящие к дегенеративному перерождению сухожилий [7, 8]. По данным британского исследования 2014 года, заболеваемость составляет 87 человек на 100000 в год, наиболее часто данная патология встречается у женщин в возрастной группе 55-59 лет [9]. Среди анатомических находок разрыв ВМП составляет, по разным данным, от 5 до $40 \%$ [8, 10]. Характерно множество факторов риска, начиная от генетической и анатомической предрасположенности, заканчивая курением и злоупотреблением алкоголем [7, 9, 11-13]. Наиболее значимая корреляция отмечается с возрастом: начиная с 4 \% бессимптомных разрывов в возрастной группе младше 40 лет, до 54 \% старше 60 [11, 14, 15].

В настоящее время хирургия ВМП насчитывает 110 лет: с 1911 года, когда E.A. Codman впервые описал шов сухожилия надостной мышцы «конец в конец» [16], пройден путь до полностью артроскопической техники фиксации. Длительное время, начиная с 40-х годов 20-го века, благодаря работам H.L. McLaughlin «30лотым стандартом» хирургической техники считался трансоссальный шов, проводившийся в совокупности с акромиопластикой по C.S. Neer [17-20]. В 1986 году в США хирург Е.M. Goble и инженер W.K. Somers paзpaбатывают и патентуют первый анкер [21, 22], несколькими годами ранее M. Wiley и M. Older разрабатывают артроскопическую технику для исследования плечевого сустава [23], что в совокупности позволило после почти 10-ти лет исследований и наблюдений предложить полностью артроскопический способ восстановления целостности сухожилий ВМП. Для того, чтобы обеспечить эквивалентную трансоссальному шву прочность фиксации, артроскопическая хирургическая техника прошла эволюцию от простого однорядного анкерного шва до Arthroscopic Transosseous-Equivalent (TOE) или Suture Bridge repair. Одно- и двурядный анкерный шов, согласно многочисленным исследованиям, проигрывает простому трансоссальному шву в прочности фиксации [24-29], а ТОЕ-техника, предложенная в 2006 г. Maxwell C. Park, показывает сопоставимые прочностные характеристики [26, 27, 30, 31]. Однако специфические осложнения, возникающие при использовании анкеров, такие как реакция на имплантат, его миграция, нестабильность в порозной кости, остеолизис в области установки анкера, сложности при ревизионном вмешательстве, в совокупности с дороговизной расходных материалов привели к возобновлению интереса к классическому трансоссальному шву в последние 15 лет и попыткам найти решение для его артроскопической реализации [32-37]. В настоящее время для этих целей представлены ArthroTunneler (Tornier, Edina, MN, USA) и OmniCuff (MinInvasive Ltd, Magal, Israel), показывающие хорошие клинические результаты [1, 38-40]. Тем не менее, несмотря на разнообразие существующих хирургических техник, частота повторных разрывов после шва ВМП по данным МРТ-исследований составляет от 20 до $39 \%$, в случае массивных разрывов 41-94 \% [14], а противоречивые результаты исследований различных способов фиксации сухожилия не позволяют прийти к единому стандарту хирургической тактики. Поэтому выбор оперативного пособия всегда индивидуализирован и обусловлен как техническими, так и, зачастую, экономическими факторами [41, 42].

Цель работы - оценка и сравнение клинических результатов оперативного лечения полнослойных разрывов вращательной манжеты плеча с применением различных способов фиксации сухожилия к кости.

\section{МАТЕРИАЛЫ И МЕТОДЫ}

В рамках исследования проведен ретроспективный анализ историй болезни, протоколов операций и опрос пациентов, прооперированных с диагнозом «разрыв вращательной манжеты плеча» на базе Красноярской краевой клинической больницы (г. Красноярск). Исследуемый период составил 6 лет (2014-2019 гг.). Выборка составлена из базы данных программы qMS: параметр запроса - код диагноза по МКБ-10 S46.0 «Травма сухожилия вращательной манжеты плеча». Критерии исключения: неполнослойные разрывы, массивные невосстановимые разрывы, разрывы, ассоциированные с отрывным переломом большого бугорка плечевой кости, разрывы на фоне калькулезного тендинита надостной мышцы.

За исследуемый период шов ВМП выполнялся одной хирургической бригадой тремя хирургическими техниками: 1) Suture Bridge-техника с использованием анкеров (далее - A), 2) двурядный трансоссальный шов

лавсановой нитью с дистальной фиксацией на анкере (далее - ТОШ), 3) двурядный трансоссальный шов с укреплением первого ряда швов на экстракортикальных фиксаторах (Endobutton, Flipptack) (далее - ТОШ+). Так как целью исследования была оценка надежности фиксации сухожилия за счет различных хирургических техник, способ выполнения оперативного вмешательства - артротомно или артроскопически, не брался в расчет, однако подавляющее большинство операций выполнено в открытой технике (96,6 \%). При наличии показаний шов ВМП дополнялся субакромиальной декомпрессией и тенодезом длинной головки бицепса. В послеоперационном периоде всем пациентам рекомендовался стандартный протокол ведения: жесткая иммобилизация оперированной конечности в гипсовой повязке Дезо или Вайнштейна в течение 4-х недель, последующая реабилитация в условиях реабилитационного центра, включающая занятия ЛФК, механотерапию, массаж. 
Подходящими под параметры исследования за рассматриваемый период оказалось 120 пациентов, которые были разделены на 3 группы в зависимости от хирургической техники: А - 70 человек (58,3 \%); ТОШ - 33 человека (27,5 \%); ТОШ+ - 17 человек (14,2 \%). Из них мужчины составили 59,2 \% (71 человек), женщины 40,8 \% (49 человек), медиана возраста пациентов на момент операции составила 59,0 [52,8; 64,0] лет. Учитывая территориальную распространенность обслуживаемого региона (Красноярский край), явка пациентов на очный осмотр затруднена, в связи с чем в рамках данного исследования было принято решение о взаимодействии в телефонном режиме. Все опрашиваемые ставились в известность о целях опроса, давали согласие на участие в нем. Пациентам задавались стандартные вопросы:

1) Была ли травма в анамнезе?

2) Время, прошедшее от момента травмы до операции?

3) Прохождение реабилитации в послеоперационном периоде?

4) Субъективная оценка результата операции в настоящее время?

Исходя из ответов, произведена градация результатов по следующим группам:

а) отличный результат - пациент не испытывает никаких затруднений при повседневной активности, справляется со спортивными нагрузками, ограничения объема движения или боли в плечевом суставе нет; б) хороший - ограничения движений нет, не испытывает затруднений при повседневной активности, эпизодически беспокоят боли во время/после физических нагрузок, «на погоду», не требующие медикаментозного купирования;

в) удовлетворительный - не справляется с интенсивными физическими нагрузками, но не испытывает затруднений на бытовом уровне;

г) неудовлетворительный - испытывает затруднения при самообслуживании или рецидив разрыва ВМП, потребовавший повторного оперативного вмешательства.

Статистический анализ полученных данных осуществлялся с применением статистического пакета IBM SPSS Statistics v.19. Нормальность распределения количественных данных оценивалась с помощью критерия Шапиро-Уилка. В связи с тем, что все количественные данные не подчинялись закону нормального распределения, они представлены в виде медианы, первого и третьего квартилей (Me [Q1; Q3]). Качественные признаки представлены в виде относительных частот, выраженных в процентах (\%). Сравнение качественных признаков между группами пациентов осуществлялось с помощью критериев Хи-квадрат, Хи-квадрат с поправкой Йейтса и точного критерия Фишера в зависимости от значения ожидаемых частот при построении таблиц сопряженности. Различия между группами считались статистически значимыми при уровне значимости $\mathrm{p}<0,05$.

РЕЗУЛЬТАТЫ

Медиана времени, прошедшего от момента травмы до операции, составила 7,0 [4,0; 11,0] месяцев. По данному показателю было выделено три группы: 1 - до полугода, 2 - от 6 месяцев до года, 3 - год и более. В первой группе показатель неудовлетворительных результатов составил 11,8 \%, отличных - 49,0 \%. Во второй группе неудовлетворительный результат получен в 15,8 \%, отличный - в 42,1 \%. В третьей группе неудовлетворительный результат составил 14,3 \%, отличный - 42,9 \% (рис. 1). В отношении распределения результатов оперативного вмешательства в данных группах статистически значимых различий не установлено (p > 0,05).

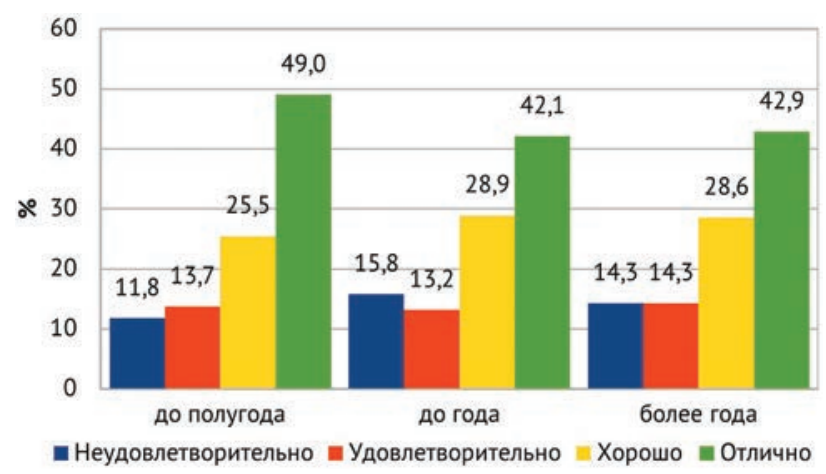

Рис. 1. Отдаленные результаты в зависимости от времени, прошедшего с момента травмы до операции

Всего реабилитацию в послеоперационном периоде прошло 48,3 \% опрошенных (58 человек). Из них хороший и отличный результат получен у 77,8 \% (44 человека), неудовлетворительный - у 13,3 \% (6 человек). В группе не проходивших реабилитацию
(62 человека) хороший и отличный результат получен в 68,0 \% (44 человека; p = 0,545), неудовлетворительный - в 17,3 \% случаев (13 человек; р = 0,179) (рис. 2).

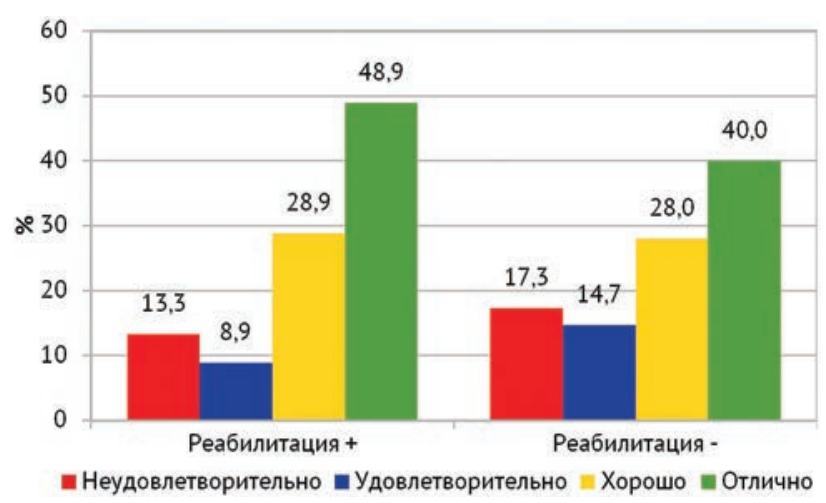

Рис. 2. Результаты в зависимости от наличия реабилитационного этапа в послеоперационном периоде

Медиана возраста на момент операции в группе А составила 59,0 [52,0; 66,5] лет $\left(\mathrm{p}_{\text {тош-А }}=0,885\right.$; $\left.\mathrm{p}_{\text {тош+-A }}=0,810\right)$. Реабилитацию прошло 41,4 \% (29 человек) пролеченных пациентов. Отличный и хороший результат получен в 72,9 \% ( рош-А $_{\text {тош }}=0,519$; $\left.\mathrm{p}_{\text {тош+-A }}=1,000\right)$, удовлетворительный - в 8,6 \%, неудовлетворительный - в 18,6 \% (13 человек; $\mathrm{p}_{\text {тош-А }}=0,962$; $\left.\mathrm{p}_{\text {тош+-А }}=0,063\right)$ случаев.

Медиана возраста на момент операции в группе ТОШ составила также 59,0 [52,0; 64,0] лет. Реабилитация пройдена 42,4 \% (14 человек) пациентов. Отличный и хороший результат среди пациентов группы ТОШ получен в 66,7 \% случаев, удовлетвори- 
тельный - в 15,2 \%, неудовлетворительный - в 18,2 \% (6 случаев).

Медиана возраста на момент операции в группе ТОШ+ составила $61,0[55,0 ; 64,0]$ год $\left(\mathrm{p}_{\text {тош-тош+ }}=0,637\right)$. Из них реабилитация пройдена двумя больными
(11,8 \%). Показатель отличных и хороших результатов составил 76,5\% ( тош-тош+ $=0,540)$, удовлетворительных - 23,5 \%, ни одного неудовлетворительного результата не было $\left(\mathrm{p}_{\text {тош-тош+ }}=0,083\right)$.

Общий результат представлен на рисунке 3.

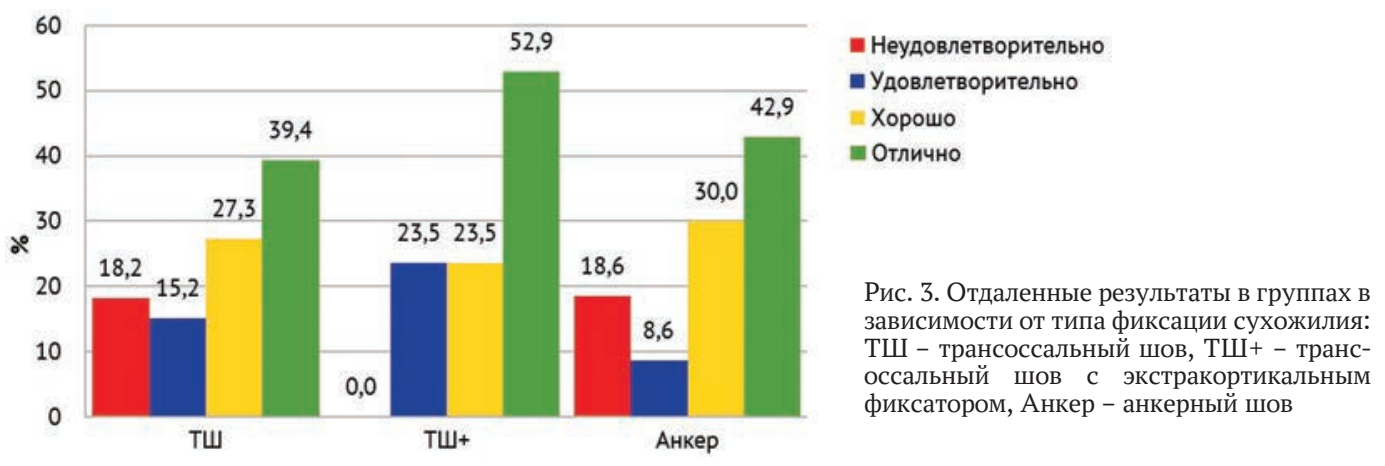

ОБСУЖДЕНИЕ

При анализе влияния на отдаленный клинический результат длительности ожидания операции после травмы статически значимой разницы получено не было. Во всех группах наблюдалось практически сопоставимое процентное распределение как положительных, так и отрицательных результатов.

Оценка наличия или отсутствия реабилитационных мероприятий в послеоперационном периоде не дала статистически значимого результата $(\mathrm{p}>0,05)$. Однако в группе прошедших реабилитацию отмечается меньший процент неудовлетворительных исходов, а процент отличных результатов в большем числе случаев.

Согласно полученным данным, анкерная фиксация в Suture Bridge-технике и классический трансоссальный шов показали сопоставимые результаты, что соответствует результатам известных исследований. Учитывая, что выполнение трансоссального шва экономически значительно менее затратно, а при наличии должного опыта не представляет больших технических сложностей, помощь пациентам с разрывами ВМП может быть в большей степени расширена географически, что сократит сроки ожидания операции, а для пациентов трудоспособного возраста - длительность нетрудоспособности.

Неожиданным оказался результат в группе ТОШ+, где не получено ни одного неудовлетворительного результата. Упоминаний о подобной модификации костно-сухожильного шва за счет дополнения его экстракортикальными фиксаторами в качестве опорной площадки нами в литературе не найдено. Изначально данная методика появилась в процессе выполнения трансоссального шва на порозной кости, когда в ходе операции была отмечена тенденция к прорезыванию кости лавсановыми нитями. Для предотвращения возможных осложнений проксимальный ряд швов был выполнен с использованием экстракортикального фиксатора ENDOBUTTON с тем, чтобы равномерно распределить нагрузку на поверхности кости. При анализе группы ТОШ+ получены близкие к статистически значимым результаты, и, возможно, при увеличении выборки удастся доказать достоверность полученного на практике отличного результата. Данный метод не имеет каких-либо противопоказаний к применению, отличных от стандартных противопоказа- ний к выполнению трансоссального шва и применению экстракортикальных фиксаторов. К относительным недостаткам метода можно отнести возможные сложности с проведением МРТ-контроля в послеоперационном периоде, обусловленные артефактами от металлических деталей. Также использование шовных пуговиц значительно повышает стоимость трансоссального шва, тем не менее оставляя его более дешевым, чем анкерная фиксация. Использование данного метода предполагается в ситуациях, когда качество кости не исключает возможности прорезывания нитей после выполнения лавсанового шва и делает невозможным введение анкеров в связи с перспективой их дальнейшей нестабильности.

При анализе историй болезни мы столкнулись с практикой упрощенной формулировки диагноза при данной патологии, который в большинстве случаев звучал как «разрыв вращательной манжеты плеча». В настоящее время нет единого требования к формулировке диагноза при разрыве ВМП, однако мы, со своей стороны, считаем целесообразным введение практики формулирования развернутого диагноза, основанного на современных классификациях. Это позволяет проводить в последующем ретроспективный анализ собственной работы, составлять план оперативного вмешательства на подготовительных этапах, а также анализировать послеоперационные осложнения. Особенно это актуально для ситуаций, когда направляющий на оперативное лечение врач, оперирующий хирург и специалист, занимающийся послеоперационным ведением пациента, не являются одним лицом. Кроме того, данная практика позволит интегрировать результаты собственной работы и результаты современных отечественных и зарубежных исследований. В таблицах 1-6 представлены основные характеристики повреждения ВМП, указания на которые, по нашему мнению, должны присутствовать в окончательном послеоперационном диагнозе.

Для оценки сопутствующего плече-лопаточного остеоартроза необходимо использовать классификацию K. Hamada (1990 г.) [43], в основе которой лежит акромиогумеральный интервал (АНI).

Для оценки послеоперационных результатов шва ВМП в настоящее время предложено 5 типов костносухожильной интеграции по Н. Sugaya (2005 г.) [44]. 
Таблица 1

Классификации H. Ellman и Gartsman

(1993 г.) по форме разрыва

\begin{tabular}{|c|l|}
\hline 1 & Серповидный \\
\hline 2 & Реверсивный L-образный \\
\hline 3 & L-образный \\
\hline 4 & Трапециевидный \\
\hline 5 & Массивный \\
\hline
\end{tabular}

Степень жировой дегенерации мышц ВМП по классификации Goutallier (1994 г.)

\begin{tabular}{|l|l|}
\hline 0 степень & Нормальное сухожилие \\
\hline 1 степень & Имеются жировые включения \\
\hline 2 степень & Менее 50 \% мышечной атрофии \\
\hline 3 степень & $50 \%$ мышечной атрофии \\
\hline 4 степень & Жировая дистрофия более $50 \%$ \\
\hline
\end{tabular}

Типы костно-сухожильной интеграции по Н. Sugaya (2005 г.) [44]

Таблица 2

Классификация R.H. Cofield

(1982 г.) по площади разрыва

\begin{tabular}{|l|l|}
\hline 1 & Малые - менее 1 см \\
\hline 2 & Средние - 1-3 см \\
\hline 3 & Большие - 3-5 см \\
\hline 4 & Массивные - более 5 см \\
\hline
\end{tabular}

Таблица 4

\begin{tabular}{|l|l|}
\hline I стадия & АНI > 6 мм \\
\hline II стадия & АНI < 5 мм \\
\hline III стадия & $\begin{array}{l}\text { Вогнутая деформация акромиона (ацетабулизация } \\
\text { акромиона) }\end{array}$ \\
\hline IV стадия & Сужение суставной щели \\
\hline V стадия & Коллапс головки плечевой кости \\
\hline
\end{tabular}

Таблица 6

Таблица 3

Степень ретракции края сухожилия классификация D. Patte (1990 г.)

\begin{tabular}{|l|l|}
\hline 1 степень & $\begin{array}{l}\text { Край сухожилия на уровне места } \\
\text { инсерции }\end{array}$ \\
\hline 2 степень & $\begin{array}{l}\text { Край сухожилия на уровне головки } \\
\text { плеча }\end{array}$ \\
\hline 3 степень & Ретракция до гленоида и дальше \\
\hline
\end{tabular}

Таблица 5

Классификация К. Hamada (1990 г.)

\section{ВЫВоды}

Лучшие клинические результаты отмечаются на фоне реабилитационных мероприятий в послеоперационном периоде.

Анкерная фиксация в Suture Bridge-технике и классический трансоссальный шов показывают сопоставимые отдаленные клинические результаты.

Дешевизна и относительная техническая простота трансоссального шва дают возможность более широко оказывать помощь пациентам с разрывами вращательной манжеты плеча.

Хорошие и отличные результаты, полученные при применении трансоссального шва, укрепленного экстракортикальным фиксатором, а также отсутствие не- удовлетворительных исходов в данной группе делают перспективным дальнейшее исследование метода.

Необходима развернутая формулировка диагноза с использованием современных классификаций для грамотного планирования оперативного вмешательства, прогнозирования послеоперационного результата, ретроспективного анализа проведенной работы и возможности соотносить результаты собственной работы с результатами отечественных и зарубежных исследований.

Для получения статистически значимых результатов требуется дальнейшее исследование с большей выборкой пациентов.

\section{СПИСОК ИСТОЧнИКОВ}

1. Atoun E., Kane L.T., Abboud J.A. Arthroscopic, Needle-Based, Transosseous Rotator Cuff Repair // Arthrosc. Tech. 2020. Vol. 9, No 1. P. e57-e63. DOI: 10.1016/j.eats.2019.09.004.

2. All-Suture Transosseous Repair for Rotator Cuff Tear Fixation Using Medial Calcar Fixation / M. Aramberri-Gutiérrez, A. Martínez-Menduiña, M. Valencia-Mora, S. Boyle // Arthrosc. Tech. 2015. Vol. 4, No 2. P. e169-e173. DOI: 10.1016/i.eats.2015.01.001.

3. Современные представления о дифференциальной диагностике и лечении пациентов с болью в области плеча / И.Н. Самарцев, С.А. Живолупов, А.Ю. Емелин, Н.А. Рашидов, С.Н. Бардаков // Русский медицинский журнал (РМЖ). 2017. № 9. Р. 564-571.

4. Оперативное лечение повреждений вращательной манжеты плечевого сустава / К.А. Егиазарян, Г.Д. Лазишвили, А.П. Ратьев, М.А. Данилов, Д.И.. Ответчикова // Кафедра травматологии и ортопедии. 2017. № 2 (28). Р. 15-18.

5. Азизов М.Ж., Ирисметов М.Э., Ражабов Х.С. Хирургические вмешательства при повреждении вращательной манжеты плеча // Ортопедия, травматология и протезирование. 2011. № 4 (585). Р. 38-41.

6. Фоменко С.М., Алекперов А.А. Симагаев Р.О. Повреждения ротаторной манжеты // Современные проблемы науки и образования. 2017. № 6. URL: https://science-education.ru/ru/article/view?id=27114 (дата обращения: 17.05.2020).

7. A Cross-Sectional Study on Novel-Risk Factors Associated with Supraspinatus Tendon Tear / S. Haveri, K.S. Patil, R.B. Uppin, S. Patil, B.B. Putti // Indian J. Orthop. 2020. Vol. 55, No 2. P. 457-463. DOI: 10.1007/s43465-020-00222-3.

8. Dead men and radiologists don't lie: a review of cadaveric and radiological studies of rotator cuff tear prevalence / P. Reilly, I. Macleod, R. Macfarlane, J. Windley, R.J. Emery // Ann. R. Coll. Surg. Engl. 2006. Vol. 88, No 2. P. 116-121. DOI: 10.1308/003588406X94968.

9. An epidemiological study of rotator cuff pathology using The Health Improvement Network database / J.J. White, A.G. Titchener, A. Fakis, A.A. Tambe, R.B. Hubbard, D.I. Clark // Bone Joint J. 2014. Vol. 96-B, No 3. P. 350-353. DOI: 10.1302/0301-620X.96B3.32336.

10. Barr K.P. Rotator cuff disease // Phys. Med. Rehabil. Clin. N. Am. 2004. Vol. 15, No 2. P. 475-491. DOI: 10.1016/j.pmr.2004.03.002.

11. Tashjian R.Z. Epidemiology, natural history, and indications for treatment of rotator cuff tears // Clin. Sports Med. 2012. Vol. 31, No 4. P. $589-604$. DOI: 10.1016/.j.csm.2012.07.001.

12. Massive rotator cuff tears: Diagnosis and management. Ed. 1. Gulotta L.V., Craig E.V., editors. Springer US. 2015. P. 163-171. 
13. Factors affecting the onset and progression of rotator cuff tears in the general population / T. Ichinose, H. Shitara, T. Tajika, T. Kobayashi, A. Yamamoto, N. Hamano, T. Sasaki, D. Shimoyama, M. Kamiyama, R. Miyamoto, K. Takagishi, H. Chikuda // Sci. Rep. 2021. Vol. 11, No 1. P. 1858. DOI: 10.1038/s41598-020-79867-x.

14. Clement N.D., Nie Y.X., McBirnie J.M. Management of degenerative rotator cuff tears: a review and treatment strategy // Sports Med. Arthrosc. Rehabil. Ther. Technol. 2012. Vol. 4, No 1. P. 48. DOI: 10.1186/1758-2555-4-48.

15. Biomechanical Comparison of Transosseous Knotless Rotator Cuff Repair versus Transosseous Equivalent Repair: Half the Anchors with Equivalent Biomechanics? / R.Z. Tashjian, R.W. Hoy, J.R. Helgerson, A.D. Guss, H.B. Henninger, R.T. Burks // Arthroscopy. 2018. Vol. 34, No 1. P. 58-63. DOI: 10.1016/j.arthro.2017.08.253.

16. Codman E.A. Complete rupture of the supraspinatus tendon. Operative treatment with report of two successful cases. $1911 / /$ J. Shoulder Elbow Surg. 2011. Vol. 20, No 3. P. 347-349. DOI: 10.1016/j.jse.2010.10.031.

17. McLaughlin H.L. Lesions of the musculotendinous cuff of the shoulder. The exposure and treatment of tears with retraction. $1944 / /$ Clin. Orthop. Relat. Res. 1994. No 304. P. 3-9.

18. McLaughlin H.L. Repair of Major Cuff Ruptures // Surg. Clin. North Am. 1963. Vol. 43. P. 1535-1540. DOI: 10.1016/s0039-6109(16)37141-9.

19. Neer C.S. 2nd. Impingement lesions // Clin. Orthop. Relat. Res. 1983. No 173. P. 70-77.

20. A history of shoulder surgery / S. Iqbal, U. Jacobs, A. Akhtar, R. J. Macfarlane, M. Waseem // Open. Orthop. J. 2013. Vol. 7. P. 305-309. DOI: $10.2174 / 1874325001307010305$.

21. Goble E.M., Somers W.K. Suture anchor assembly. USA Patent no. 4632100, A 61 B 17/56; A 61 B 17/04; A 61 B 17/16; A 61 B 19/00; A 61 F 2/08; A 61 B 17/88; A 61 F 5/04; 1986. № 19. URL: https://www.freepatentsonline.com/4632100.html.

22. The development of suture anchors for use in soft tissue fixation to bone / M.E. Goble, K.W. Somers, R. Clark, R.E. Olsen // Am. J. Sports Med. 1994. Vol. 22, No 2. P. 236-239. DOI: 10.1177/036354659402200214.

23. Wiley A.M., Older M.W. Shoulder arthroscopy. Investigations with a fibreoptic instrument // Am. J. Sports Med. 1980. Vol. 8, No 1. P. 31-38. DOI: $10.1177 / 036354658000800106$.

24. Functional and structural outcomes of single-row versus double-row versus combined double-row and suture-bridge repair for rotator cuff tears / T. Mihata, C. Watanabe, K. Fukunishi, M. Ohue, T. Tsujimura, K. Fujiwara, M. Kinoshita // Am. J. Sports Med. 2011. Vol. 39, No 10. P. 2091-2098. DOI: $10.1177 / 0363546511415660$.

25. Tendon-to-bone pressure distributions at a repaired rotator cuff footprint using transosseous suture and suture anchor fixation techniques / M.C. Park, E.R. Cadet, W.N. Levine, L.U. Bigliani, C.S. Ahmad // Am. J. Sports Med. 2005. Vol. 33, No 8. P. 1154-1159. DOI: 10.1177/0363546504273053.

26. Fixation of soft tissue to bone: Techniques and fundamentals / B.J. Cole, E.T. Sayegh, A.B. Yanke, P.N. Chalmers, R.M. Frank // J. Am. Acad. Orthop. Surg. 2016. Vol. 24, No 2. P. 83-95. DOI: 10.5435/JAAOS-D-14-00081.

27. Anchored Transosseous-Equivalent versus Anchorless Transosseous Rotator Cuff Repair: A Biomechanical Analysis in a Cadaveric Model / K.G. Kilcoyne, S.G. Guillaume, C.V. Hannan, E.R. Langdale, S.M. Belkoff, U. Srikumaran // Am. J. Sports Med. 2017. Vol. 45, No 10. P. 23642371. DOI: 10.1177/0363546517706136.

28. Cole B.J., ElAttrache N.S., Anbari A. Arthroscopic rotator cuff repairs: an anatomic and biomechanical rationale for different suture-anchor repair configurations // Arthroscopy. 2007. Vol. 23, No 6. P. 662-669. DOI: 10.1016/j.arthro.2007.02.018.

29. Difference in vascular patterns between transosseous-equivalent and transosseous rotator cuff repair / A. Urita, T. Funakoshi, T. Horie, M. Nishida, N. Iwasaki // J. Shoulder Elbow Surg. 2017. Vol. 26, No 1. P. 149-156. DOI: 10.1016/j.jse.2016.06.010.

30. “Transosseous-equivalent” rotator cuff repair technique / M.C. Park, N.S. Elattrache, C.S. Ahmad, J.E. Tibone // Arthroscopy. 2006. Vol. 22, No 12. P. 1360.e1-5. DOI: 10.1016/j.arthro.2006.07.017.

31. Biomechanical evaluation of transosseous rotator cuff repair: do anchors really matter? / M.J. Salata, S.L. Sherman, E.C. Lin, R.A. Sershon, A. Gupta, E. Shewman, V.M. Wang, B.J. Cole, A.A. Romeo, N.N. Verma// Am. J. Sports Med. 2013. Vol. 41, No 2. P. 283-290. DOI: 10.1177/0363546512469092.

32. Complications associated with arthroscopic rotator cuff repair: a literature review / P. Randelli, P. Spennacchio, V. Ragone, P. Arrigoni, A. Casella, P. Cabitza // Musculoskelet. Surg. 2012. Vol. 96, No 1. P. 9-16. DOI: 10.1007/s12306-011-0175-y.

33. Arthroscopic Transosseous Anchorless Rotator Cuff Repair using the X-Box Technique / A. Steinitz, P. Buxbaumer, M. Hackl, E. Buess // Arthrosc. Tech. 2019. Vol. 8, No 2. P. e175-e181. DOI: 10.1016/j.eats.2018.10.004.

34. Biomechanical study comparing 3 fixation methods for rotator cuff massive tear: Transosseous No. 2 suture, transosseous braided tape, and doublerow / S. Hinse, J. Ménard, D.M. Rouleau, F. Canet, M. Beauchamp// J. Orthop. Sci. 2016. Vol. 21, No 6. P. 732-738. DOI: 10.1016/j.jos.2016.07.001.

35. Midterm clinical outcomes following arthroscopic transosseous rotator cuff repair / B.A. Flanagin, R. Garofalo, E.Y. Lo, L. Feher, A. Castagna, H. Qin, S.G. Krishnan // Int. J. Shoulder Surg. 2016. Vol. 10, No 1. P. 3-9. DOI: 10.4103/0973-6042.174511.

36. Jang S.H. Editorial Commentary: Perianchor Cysts - We Need More Worries after Rotator Cuff Repair Like We Need Holes in the Head // Arthroscopy. 2019. Vol. 35, No 8. P. 2293-2294. DOI: 10.1016/j.arthro.2019.05.017.

37. Perianchor Cyst Formation after Arthroscopic Rotator Cuff Repair using All-Suture-Type, Bioabsorbable-Type, and PEEK-Type Anchors / K. Ro, S. Pancholi, H.S. Son, Y.G. Rhee // Arthroscopy. 2019. Vol. 35, No 8. P. 2284-2292. DOI: 10.1016/j.arthro.2019.03.032.

38. Arthroscopic transosseous (anchorless) rotator cuff repair / R. Garofalo, A. Castagna, M. Borroni, S.G. Krishnan // Knee Surg. Sports Traumatol. Arthrosc. 2012. Vol. 20, No 6. P. 1031-1035. DOI: 10.1007/s00167-011-1725-4.

39. Is there a difference in clinical outcomes and repair integrity between arthroscopic single-row versus transosseous (anchorless) fixation? A retrospective comparative study / R. Garofalo, R. Calbi, A. Castagna, E. Cesari, A. Budeyri, S.G. Krishnan // J. Orthop. Sci. 2018. Vol. 23, No 5. P. 770-776. DOI: 10.1016/j.jos.2018.05.011.

40. A laboratory comparison of a new arthroscopic transosseous rotator cuff repair to a double row transosseous equivalent rotator cuff repair using suture anchors / F.J. Kummer, M. Hahn, M. Day, R.J. Meislin, L.M. Jazrawi // Bull. Hosp. Jt. Dis. (2013). 2013. Vol. 71, No 2. P. 128-131.

41. Fixation strength of rotator cuff repairs with suture anchors and the transosseous suture technique / D.V. Craft, J.B. Moseley, P.W. Cawley, P.C. Noble // J. Shoulder Elbow. Surg. 1996. Vol. 5, No 1. P. 32-40. DOI: 10.1016/s1058-2746(96)80028-0.

42. Footprint contact characteristics for a transosseous-equivalent rotator cuff repair technique compared with a double-row repair technique. Part I / M.C. Park, N.S. ElAttrache, J.E. Tibone, C.S. Ahmad, B.J. Jun, T.Q. Lee// J. Shoulder Elbow Surg. 2007. Vol. 16, No 4. P. 461-468. DOI: 10.1016/j. jse.2006.09.010.

43. A radiographic classification of massive rotator cuff tear arthritis / K. Hamada, K. Yamanaka, Y. Uchiyama, T. Mikasa, M. Mikasa // Clin. Orthop. Relat. Res. 2011. Vol. 469, No 9. P. 2452-2460. DOI: 10.1007/s11999-011-1896-9.

44. Functional and structural outcome after arthroscopic full-thickness rotator cuff repair: single-row versus dual-row fixation / H. Sugaya, K. Maeda, K. Matsuki, J. Moriishi // Arthroscopy. 2005. Vol. 21, No 11. P. 1307-1316. DOI: 10.1016/j.arthro.2005.08.011.

Статья поступила в редакцию 17.06.2021; одобрена после рецензирования 21.10.2021; принята к публикации 23.12.2021.

The article was submitted 17.06.2021; approved after reviewing 21.10.2021; accepted for publication 23.12.2021.

\section{Информация об авторах:}

1. Анастасия Юрьевна Денисова - a.j.denisova@gmail.com;

2. Александр Александрович Галов - gal_alex2@mail.ru;

3. Алексей Витальевич Данилов - alexey.vitalievich.danilov@gmail.com;

4. Артем Николаевич Наркевич - доктор медицинских наук, narcevichart@gmail.com;

5. Екатерина Валерьевна Серова - доктор медицинских наук.

\section{Information about the authors:}

1. Anastasia Yu. Denisova - a.j.denisova@gmail.com;

2. Alexander A. Galov - M.D., gal_alex2@mail.ru;

3. Alexey V. Danilov - M.D., alexey.vitalievich.danilov@gmail.com;

4. Artem N. Narkevich - Doctor of Medical Sciences, narcevichart@gmail.com;

5. Ekaterina V. Serova - Doctor of Medical Sciences. 
Гений ортопедии. 2022. Т. 28, № 1. С. 24-33.

Genij Ortopedii. 2022. Vol. 28, no. 1. P. 24-33.

Научная статья

уДК 616.727.3-001-089.843-77

https://doi.org/10.18019/1028-4427-2022-28-1-24-33

\section{Тотальное эндопротезирование локтевого сустава при травмах \\ В.А. Калантырская ${ }^{1,3}$, И.О. Голубев², А.Ю. Заров ${ }^{1}$, К.А. Егиазарян ${ }^{3}$}

${ }^{1}$ Центральная клиническая больница Святителя Алексия Митрополита Московского Московской Епархии Русской Православной Церкви, Москва, Россия

2 Национальный медицинский исследовательский центр травматологии и ортопедии имени Н.Н. Приорова, Москва, Россия

3 Российский национальный исследовательский медицинский университет имени Н.И. Пирогова, Москва, Россия

Автор, ответственный за переписку: Валентина Анатольевна Калантырская, kalan.v@mail.ru

Аннотация

Цель. Выявление особенностей тотального эндопротезирования локтевого сустава при травмах и их последствиях у пациентов различных возрастных групп и проведение сравнительного ретроспективного анализа дифференцированной тактики лечения. Материалы и методы. Проведен ретроспективный анализ результатов тотального эндопротезирования локтевого сустава (ТЭЛС) в период с 2009 по 2019 г. у 101 пациента с травмами и выраженными последствиями травм локтевого сустава (ЛС), 56 (55,4 \%) мужчин и 45 (44,5 \%) женщин, средний возраст 48,5 $\pm 12,5$ лет. Три группы пациентов: группа I - 29 (28,7 \%) человек, которым до эндопротезирования проводили консервативное лечение переломов; вторая группа (II) - 52 (51,5 \%) пациента, которым было выполнено ТЭЛС после остеосинтеза, третья группа (III) пациенты, которым было выполнено первичное ТЭЛС - 20 (19,8). Исследовали болевой синдром (ВАШ), объем движений, проводили тестирование по шкалам DASH и MEPS, определяли силу кисти. Результаты. При анализе результатов через год была отмечена статистическая разница в результатах (p = 0,0213) между группой III (первичное ТЭЛC, DASH = 7,3 $\pm 2,1)$ по сравнению с группами I (DASH = 20,6 $\pm 3,3)$ и II $($ DASH $=18,4 \pm 4,2)$; в группе III $($ MEPS = 90,7 \pm 8,4) - отлично, в группах I $($ MEPS = 83,8 $\pm 7,4)$ и II $($ MEPS = 84,2 $\pm 5,6)-$ хорошо $(p=0,0344)$, при динамометрии силы кисти и показателях боли различий не было. Обсуждение. Лечение переломов области локтевого сустава является актуальной проблемой и имеет несколько аспектов: при консервативном лечении наблюдается высокая частота образования выраженных контрактур, что влияет на объем движений в локтевом суставе после ТЭЛС; при тяжелых повреждениях кости и хряща необходимо оценивать множество факторов, чтобы сделать правильный выбор между остеосинтезом и первичным ТЭЛС; для обеспечения хорошего длительного функционирования протеза локтевого сустава, особенно у молодых пациентов, необходимы новые технологии изготовления протезов. Выводы. При выборе тактики лечения тяжелых травм локтевого сустава необходимо учитывать не только тяжесть повреждения, но возраст пациента и качество кости, особенно у пациентов пожилого возраста, отказ от выполнения остеосинтеза в пользу первичного тотального эндопротезирования дает возможность сохранить объем движений, улучшить функциональные результаты и выживаемость эндопротеза.

Ключевые слова: локтевой сустав, травмы, эндопротезирование, первичная тотальная артропластика

Для цитирования: Тотальное эндопротезирование локтевого сустава при травмах / В.А. Калантырская, И.О. Голубев, А.Ю. Заров, К.А. Егиазарян // Гений ортопедии. 2022. Т. 28, № 1. С. 24-33. https://doi.org/10.18019/1028-4427-2022-28-1-24-33

Original article

\section{Total elbow arthroplasty due to injuries}

\section{V.A. Kalantyrskaya ${ }^{1,3 凶}$, I.O. Golubev ${ }^{2}$, A.Yu. Zarov ${ }^{1}$, K.A. Egiazaryan ${ }^{3}$}

${ }^{1}$ Autonomous non-profit organization Central Clinical Hospital of St. Alexy Metropolitan of the Moscow, Moscow Diocese of the Russian Orthodox Church, Moscow, Russian Federation

${ }^{2}$ N.N. Priorov National Medical Research Center of Traumatology and Orthopaedics, Moscow, Russian Federation

${ }^{3}$ Pirogov Russian National Research Medical University, Moscow, Russian Federation

Corresponding author: Valentina A. Kalantyrskaya, kalan.v@mail.ru

Abstract

The aim of the study was to identify the features of total elbow arthroplasty in traumatic cases and their consequences in patients of different age groups and to conduct a comparative retrospective analysis of differentiated treatment tactics. Materials and Methods A retrospective analysis of the results of total elbow arthroplasty (TEA) in the period from 2009 to 2019 was carried out in 101 patients with injuries and severe consequences of elbow joint injuries, 56 (55.4\%) men and 45 (44.5\%) women among them in the average age of $48.5 \pm 12.5$ years. Three groups of patients were formed. Group I were $29(28.7 \%)$ subjects who underwent conservative treatment of fractures before TEA; the second group (II) of 52 (51.5 \%) patients underwent TEA after ORIF, the third group of 20 (19.8) individuals (III) were patients who had primary TEA. We investigated pain (VAS), range of motion, tests with the DASH and MEPS scales, hand strength. Results One year later, there was a statistical difference in the results $(\mathrm{p}=0.0213)$ between group III DASH $=7.3 \pm 2.1)$ compared with groups I (DASH $=20.6 \pm 3.3$ ) and II (DASH $=18.4 \pm 4.2)$; in group III, MEPS was excellent $(90.7 \pm 8.4)$, and in groups I $(\mathrm{MEPS}=83.8$ $\pm 7.4)$ and II (MEPS $=84.2 \pm 5.6)$ good $(\mathrm{p}=0.0344)$. There were no differences in the dynamometry of hand strength and pain. Discussion Treatment of fractures of the elbow joint is a challenge that has several aspects. Conservative treatment results in high incidence of pronounced contractures, which affect the range of motion in the elbow joint after TEA; in severe damage to bone and cartilage, it is necessary to evaluate many factors in order to make the right choice between ORIF and primary TEA. New prosthetic technologies are needed to ensure good long-term functioning of the elbow prosthesis, especially in young patients. Conclusion To choose the treatment tactics in severe injuries of the elbow joint, it is necessary to consider not only the severity of the injury, but also the age of the patient and the quality of the bone, especially in elderly patients. Rejection to perform osteosynthesis in favor of primary total arthroplasty is aimed at maintaining the range of motion, improving the functional results and survival of the endoprosthesis.

Keywords: injuries of the elbow, primary total elbow arthroplasty

For citation: Kalantyrskaya V.A., Golubev I.O., Zarov A.Yu., Egiazaryan K.A. Total elbow arthroplasty due to injuries. Genij Ortopedii, 2022, vol. 28, no 1, pp. 24-33. https://doi.org/10.18019/1028-4427-2022-28-1-24-33

\section{ВВЕДЕНИЕ}

Тотальное эндопротезирование локтевого сустава (ТЭЛС) является эффективным хирургическим вмеша- тельством, которое позволяет восстановить объем движений в локтевом суставе (ЛС), силу и функцию верх- 
ней конечности, избавить пациента от боли [1]. Травмы и переломы костей, образующих ЛС, стоят на втором месте по частоте эндопротезирования между лидером - ревматоидным артритом и первичным остеоартритом. Показаниями к ТЭЛС являются так называемый «не фиксируемый» внутрисуставной оскольчатый перелом дистальной части плечевой кости и проксимальных отделов костей предплечья, остеоартрит (OА) и посттравматический артрит [2-10].

Если вопрос лечения переломов дистального отдела плечевой кости и проксимального отдела предплечья у пожилых пациентов практически решен, и все большее количество хирургов в настоящее время выбирают ТЭЛС [5, 7-9, 11-13], то вопрос в отношении молодых пациентов остается открытым, так как не хватает работ по анализу отдаленных результатов $[14,15]$.

Rajaee et al. (2016) сравнили результаты ТЭЛС с открытой репозицией и внутренней фиксацией (ОРВФ, англ. «ORIF») с использованием данных, полученных из Общенациональной выборки стационарных пациентов за 2002-2012 годы, с ранее опубликованными результатами McKee MD et al., 2009 г. Сравнительный анализ показал, что частота ТЭЛС у пожилых пациентов с переломами дистального отдела плечевой кости, не поддающихся стабильной фиксации, увеличилась в 2,6 раза, и по функциональным результатам ТЭЛС предпочтительнее, чем ОРВФ $[9,16]$.

Barco et al. (2017) сообщили, что средняя оценка боли по визуальной аналоговой шкале (ВАШ) составила 0,6 ; среднее сгибание - $123^{\circ}$, а средняя потеря разгибания составила $24^{\circ}$. Среднее значение MEPS составило 90,5 балла, однако по функциональному результату и выживанию протезов локтевого сустава у молодых пациентов отчетливых данных пока нет [17].

Однако многими авторами показано, что лечение выраженного посттравматического остеоартрита методом ТЭЛС возможно, но при этом функциональные результаты значительно хуже, чем при ревматоидном артрите и первичном эндопротезировании при переломах [9, 18-22]. Если пациенты с остеоартритом после остеосинтеза (плюс удаления металлофиксаторов) имели грубые рубцы и контрактуру локтевого сустава, то оперативное вмешательство было намного более сложным и травматичным, а результаты эндопротезирования значительно ухудшались и сопровождались тяжелыми ограничениями объема движений из-за сокращения мягких тканей [23]. Но еще хуже результаты были у пациентов, у которых при лечении перелома имели место явления воспалительного артрита [24, 25].

Более ранние данные, опубликованные Hildebrand K.A. et al. (2000), подтверждают худшие функциональные исходы ТЭЛС в группе пациентов с воспалительным артритом (MEPS $=78 \pm 18$ баллов), чем в группе с травматическим или посттравматическим остеоартритом (90 \pm 11 баллов) [26]. Несмотря на то, что Celli A. и Morrey B.F. (2009) сообщили о серии из 55 ТЭЛС, выполненных пациентам в возрасте менее 40 лет со средним сроком наблюдения 7,5 лет, у 36 пациентов (65 \%) результат был «отличным», а у 15 (27 \%) - «хорошим» [27]. Park J.G. et al. (2015) сообщили о серии из 23 ТЭЛС (пациенты моложе 40 лет, средний период наблюдения 10 лет) и также получили благоприятные исходы, но в 25 \% случаев развились осложнения, потребовавшие ревизионной операции [28].

В отечественной литературе мы не нашли статей, посвященных данной проблеме, за исключением результатов одноцентрового исследования, где группой сравнения была резекционная артропластика, и работ, посвященных микрохирургической пластике мягких тканей при эндопротезировании локтевого сустава и проблеме лечения огнестрельных ранений локтевого сустава [29, 30, 31].

Учитывая актуальность проблемы и разноречивость литературных данных, мы поставили целью исследования выявление особенностей тотального эндопротезирования локтевого сустава при травмах и их последствиях у пациентов различных возрастных групп и проведение сравнительного ретроспективного анализа дифференцированной тактики лечения.

\section{МАТЕРИАЛЫ И МЕТОДЫ}

Проведен ретроспективный анализ результатов тотального эндопротезирования локтевого сустава (ТЭЛС) в период с 2009 по 2019 г. у 101 пациента с тяжелыми травмами и их последствиями - посттравматическими деформациями, контрактурами и остеоартрозом локтевого сустава (ЛС). За этот период времени в больнице прошло стационарное лечение 1653 пациента с травмами области локтевого сустава, эндопротезирование выполнено в 6,11 \% случаев.

ТЭЛС выполнено 56 мужчинам $(55,4 \%)$ и 45 женщинам (44,6 \%), из которых 79 пациентов (78,2 \%) были работоспособного возраста от 18 до 65 лет, ведущие активный образ жизни, старше 65 лет - 22 пациента (21,8 \%), средний возраст составил 48,5 $\pm 12,5$ (мин. 23 года, макс. 76 лет) лет. Распределение пациентов по полу и возрасту предоставлено в таблице 1.

Из 101 пациента у 53 (52,5 \%) имела место закрытая травма области локтевого сустава, у 48 (47,5 \%) - открытые повреждения. Переломы дистального отдела плечевой кости были диагностированы у 51 пациента (50,5 \%), проксимальной части костей предплечья - у 33 пациентов (32,7 \%) и ассоциированные переломы области локтевого сустава (дистального метафиза плечевой кости и проксимального метафиза костей предплечья) - у 17 пациентов (16,8 \%).

Таблица 1

Распределение больных по возрасту и полу

\begin{tabular}{|l|c|c|c|c|c|c|}
\hline \multirow{2}{*}{ Возраст } & \multicolumn{3}{|c|}{ Количество больных } & \multicolumn{2}{c|}{ Итого } \\
\cline { 2 - 6 } & \multicolumn{2}{|c|}{ мужчины } & \multicolumn{2}{|c|}{ женщины } & \multicolumn{2}{c|}{} \\
\cline { 2 - 6 } & абс. & $\%$ & абс. & $\%$ & абс. & $\%$ \\
\hline От 18 до 45 лет & 33 & 32,7 & 22 & 21,8 & 55 & 54,5 \\
\hline От 46 до 65 лет & 13 & 12,8 & 11 & 10,8 & 24 & 23,7 \\
\hline От 66 до 75 лет & 10 & 9,9 & 8 & 7,9 & 18 & 17,8 \\
\hline Старше 75 лет & - & - & 4 & 4,0 & 4 & 4,0 \\
\hline Всего & 56 & 55,4 & 45 & 44,6 & 101 & 100 \\
\hline
\end{tabular}

Основными причинами повреждений были дорожно-транспортные происшествия (ДТП) - 46,6 \%, 
кататравма - 32,7 \%, огнестрельные ранения - 10,8 \% и бытовая травма - 9,9 \%. Закрытые переломы у пострадавших были только типа В и С по классификации АО, открытые переломы (по классификации Gustilo R.B. и Anderson J.T., 1976) типа I-II-IIIA были у 40 пациентов (39,6 \%), у 6 пациентов (5,9 \%) - IIIB, а в 2-х случаях - IIIC. Данным пациентам были выполнены экстренные реваскуляризирующие операции шунтирования плечевой артерии (аутовеной), без тяжелых ишемических последствий. Необратимые повреждения мышц предплечья и кисти в результате ишемии или травмы нервов мы считали противопоказанием к эндопротезированию локтевого сустава. Распределение пациентов по характеру травмы представлено в таблице 2 .

При лечении переломов области локтевого сустава (без смещения отломков) в 28,7 \% случаев была применена консервативная тактика - гипсовая иммобилизация конечности, при наличии смещения отломков 29 пациентам (28,7 \%) выполнили открытую репозицию и накостный остеосинтез пластинами. У пациентов старше 60 лет при закрытых внутрисуставных переломах области локтевого сустава со значительным повреждением хряща и признаками выраженного остеопороза в 20 случаях (19,8 \%) первично выполнили ТЭЛС. При открытых переломах области локтевого сустава со смещением отломков выполняли внеочаговый остеосинтез аппаратами внешней фиксации в 16 случаях (15,8 \%), а у 10 пациентов (9,9 \%) применили комбинированный остеосинтез: первично внеочаговую фиксацию аппаратом и после заживления раны открытую репозицию и накостный остеосинтез пластиной. При вторично открытых переломах или открытых переломах без сме- щения отломков в 22 случаях (21,7 \%) была выполнена первичная хирургическая обработка (ПХО) раны и гипсовая иммобилизация. Остеосинтез выполняли при закрытом переломе в среднем на 3,2 \pm 1,4 суток (мин. 1 и макс. 6-е сутки), при открытых переломах наложение АВФ выполняли при ПХО раны, комбинированный остеосинтез на 19,6 \pm 5,3 сутки (мин. 12 и макс. 26 сутки). Распределение пациентов по методу лечения перелома представлено в таблице 3.

Показаниями к ТЭЛС у пациентов после травмы считали:

1) контрактуры с выраженным болевым синдромом и нарушением функции верхней конечности;

2) болтающиеся суставы при асептическом некрозе или дефекте костей локтевого сустава;

3) деформации дистального метаэпифиза плечевой кости и проксимального метаэпифиза костей предплечья в результате неправильно сросшихся переломов и повреждения суставных поверхностей.

Исследование было одобрено ЛЭК (№ 3266, от 24.05.2011 г.), все пациенты были информированы о предстоящем лечении и подписали информированное согласие на операцию, анестезию и публикацию материалов исследования.

Пациентов разделили на три группы: группа I 29 пациентов (28,7%), которым до операции проводили консервативное лечение переломов области локтевого сустава; группа II - 52 пациента (51,5%), которым было выполнено ТЭЛС после оперативного лечения перелома костей области локтевого сустава; группа III - 20 пациентов (19,8 \%), которым было выполнено первичное ТЭЛС. Демографическое описание групп приведено в таблице 4 .

Таблица 2

Распределение пациентов по характеру повреждения

\begin{tabular}{|c|c|c|c|c|c|c|c|c|c|c|c|c|c|c|}
\hline \multirow{3}{*}{ Механизм повреждения } & \multicolumn{6}{|c|}{ Закрытая травма (АО) } & \multicolumn{6}{|c|}{ Открытая травма (Gustilo and Anderson) } & \multirow{2}{*}{\multicolumn{2}{|c|}{ Всего }} \\
\hline & \multicolumn{2}{|c|}{ ДЧПК } & \multicolumn{2}{|c|}{ ПЧП } & \multicolumn{2}{|c|}{ ДЧПиПЧКП } & \multicolumn{2}{|c|}{ ДЧПК } & \multicolumn{2}{|c|}{ ПЧП } & \multicolumn{2}{|c|}{ ДЧПиПЧКП } & & \\
\hline & абс. & $\%$ & абс. & $\%$ & абс. & $\%$ & абс. & $\%$ & абс. & $\%$ & абс. & $\%$ & абс. & $\%$ \\
\hline ДТП & 12 & 11,9 & 8 & 7,9 & 3 & 3,0 & 16 & 15,9 & 4 & 4,0 & 4 & 3,9 & 47 & 46,6 \\
\hline Кататравма & 7 & 6,9 & 9 & 8,9 & 4 & 4,0 & 4 & 4,0 & 7 & 6,9 & 2 & 2,0 & 33 & 32,7 \\
\hline Огнестрельное ранение & - & - & - & - & - & - & 6 & 5,9 & 2 & 2,0 & 3 & 2,9 & 11 & 10,8 \\
\hline Бытовая травма & 6 & 5,9 & 3 & 3,0 & 1 & 1,0 & - & - & - & - & - & - & 10 & 9,9 \\
\hline Итого & 25 & 24,7 & 20 & 19,8 & 8 & 7,9 & 26 & 25,8 & 13 & 12,9 & 9 & 8,9 & 101 & 100 \\
\hline
\end{tabular}

Обозначения: ДЧПК - дистальная часть плечевой кости; ПЧП - проксимальная часть предплечья; ДЧПиПЧКП - дистальная часть плечевой и проксимальная часть костей предплечья.

Таблица 3

Распределение пациентов по методу лечения перелома

\begin{tabular}{|c|c|c|c|c|c|c|c|c|c|c|c|c|c|c|}
\hline \multirow{3}{*}{$\begin{array}{l}\text { Метод лечения } \\
\text { перелома }\end{array}$} & \multicolumn{6}{|c|}{ Закрытая травма (АО) } & \multicolumn{6}{|c|}{ Открытая травма (Gustilo and Anderson) } & \multirow{2}{*}{\multicolumn{2}{|c|}{ Всего }} \\
\hline & \multicolumn{2}{|c|}{ ДЧПК } & \multicolumn{2}{|c|}{ ПЧП } & \multicolumn{2}{|c|}{ ДЧПиПЧКП } & \multicolumn{2}{|c|}{ ДЧПК } & \multicolumn{2}{|c|}{ ПЧП } & \multicolumn{2}{|c|}{ ДЧПиПЧКП } & & \\
\hline & абс. & $\%$ & абс. & $\%$ & абс. & $\%$ & абс. & $\%$ & абс. & $\%$ & абс. & $\%$ & абс. & $\%$ \\
\hline Консервативное (гипс) & 4 & 3,9 & 3 & 3,0 & - & - & 16 & 15,8 & 3 & 3,0 & 3 & 3,0 & 29 & 28,7 \\
\hline Остеосинтез накостный & 15 & 14,9 & 10 & 9,9 & 4 & 3,9 & - & - & - & - & - & - & 29 & 28,7 \\
\hline $\begin{array}{l}\text { Остеосинтез } \\
\text { внеочаговый }\end{array}$ & - & - & - & - & - & - & 6 & 5,9 & 5 & 4,9 & 5 & 4,9 & 16 & 15,8 \\
\hline $\begin{array}{l}\text { Комбинированный } \\
\text { остеосинтез* }\end{array}$ & - & - & - & - & - & - & 3 & 3,0 & 3 & 3,0 & 1 & 1,0 & 7 & 7,0 \\
\hline Первичное ТЭЛС & 6 & 5,9 & 7 & 6,9 & 4 & 3,9 & 1 & 0,9 & 2 & 2,0 & - & - & 20 & 19,8 \\
\hline Итого & 25 & 24,7 & 20 & 19,8 & 8 & 7,9 & 26 & 25,8 & 13 & 12,9 & 9 & 8,9 & 101 & 100 \\
\hline
\end{tabular}

Обозначения: ДЧПК - дистальная часть плечевой кости; ПЧП - проксимальная часть предплечья; ДЧПиПЧКП - дистальная часть плечевой и проксимальная часть костей предплечья; * - комбинированный остеосинтез: применение АВФ и после заживления раны накостный остеосинтез пластиной. 
Демографические данные пациентов

\begin{tabular}{|c|c|c|c|c|c|}
\hline \multirow{2}{*}{\multicolumn{2}{|c|}{ Демографические показатели }} & \multicolumn{3}{|c|}{ Группа } & \multirow{2}{*}{ P value } \\
\hline & & I & II & III & \\
\hline \multicolumn{2}{|c|}{ Количество, n (\%) } & $29(28,7)$ & $52(51,5)$ & $20(19,8)$ & 0,572 \\
\hline \multicolumn{2}{|c|}{ Возраст* (лет) } & $52,3 \pm 3,2$ & $46,0 \pm 1,9$ & $68,2 \pm 1,3$ & 0,0098 \\
\hline \multicolumn{2}{|c|}{ ИМТ $^{*}\left(\mathrm{\kappa г} / \mathrm{M}^{2}\right)$} & $32,9 \pm 2,5$ & $31,8 \pm 1,2$ & $34,2 \pm 1,1$ & 0,512 \\
\hline \multicolumn{2}{|c|}{ Пол\#: мужчины/женщины } & $15 / 14$ & $33 / 19$ & $8 / 12$ & 0,977 \\
\hline \multirow{3}{*}{$\mathrm{AO} \#$} & $\mathrm{~A}\left(\mathrm{n}_{1}=30\right) * *$ & 18 & 12 & 0 & \multirow{3}{*}{0,0862} \\
\hline & $\mathrm{B}\left(\mathrm{n}_{1} / \mathrm{n}_{2}=43 / 5\right)$ & 11 & $27 / 3$ & $5 / 2$ & \\
\hline & $\mathrm{C}\left(\mathrm{n}_{1} / \mathrm{n}_{2}=28 / 12\right)$ & 0 & $13 / 3$ & $15 / 9$ & \\
\hline \multirow{3}{*}{ ASA\# (n/\%) } & $\mathrm{I}$ & $14 / 13,9$ & $34 / 33,7$ & $0 / 0$ & \multirow{3}{*}{0,0094} \\
\hline & II & $13 / 12,9$ & $8 / 7,9$ & $1 / 0,9$ & \\
\hline & III & $2 / 1,9$ & $10 / 9,8$ & $19 / 18,8$ & \\
\hline \multicolumn{2}{|c|}{ Время от момента травмы до ТЭЛС (месяцев) ${ }^{* * *}$} & $19,9 \pm 2,1$ & $29,0 \pm 1,4$ & $1,9 \pm 1,7$ & 0,00634 \\
\hline
\end{tabular}

ИМТ - индекс массы тела, ASA - Американское общество анестезиологов (шкала); * - анализируется односторонним дисперсионным анализом ANOVA; ** - в скобках значения: $\mathrm{n}_{1}$ - количество пациентов с переломами по классификации АО; $\mathrm{n}_{2}-$ количество пациентов с ассоциированными переломами, при этом при наличии переломов типа В и С, пациент относился в группу более тяжелого перелома типа С; \# - анализируется с помощью хи-квадрата Пирсона или точного критерия Фишера; *** - в третьей группе в сутках после травмы.

Имеет место неравномерное распределение пациентов по группам, группа с остеосинтезом в анамнезе наиболее многочисленная, и по возрасту первые две группы также значительно различались, однако распределение по другим показателям позволяет их сравнивать между собой.

В послеоперационном периоде проводили стандартную реабилитационную программу, рентгенографию локтевого сустава выполняли после операции. Болевой синдром перед и после операции регистрировали по десятибалльной шкале ВАШ. Функциональные результаты определяли ежегодно измерением объема движений в градусах (сгибание-разгибание, наружная и внутренняя ротация) и тестированием по шкалам DASH и MEPS. Шкала DASH (The Disabilities of the Arm, Shoulder and Hand Score, 2006), согласно которой отличным считали результаты в диапазоне от 0 до 8 баллов, хорошим - от 9 до 20, удовлетворительным - от 21 до 35 и неудовлетворительным - > 35 баллов (макс. 100). Шкала MEPS (Mayo Elbow Performance Score, 1986), согласно которой отлично 90-100, хорошо 75-89, удовлетворительно 60-74, плохо менее 60 баллов. Силу кисти измеряли медицинским динамометром ДМК-100 (кг, диапазон измерений 10-100 кг).

Статистический анализ проводили односторонним дисперсионным анализом ANOVA, с помощью хиквадрата Пирсона или точного критерия Фишера.

\section{РЕЗУЛЬТАТЫ}

После предоперационного обследования всем пациентам было выполнено ТЭЛС цементным полусвязанным протезом Coonrad-Morrey (Zimmer, Warsaw, IN, USA), под общей анестезией, задним срединным продольным линейным доступом длиной около 15 см, с мобилизацией локтевого нерва, без остеотомии локтевого отростка. Пациентам второй группы в 29 случаях из 52 (55,8 \%) выполняли операцию одновременно с удалением металлоконструкции, у другой части (23 пациента - 44,2 \%) металлические фиксаторы были удалены на предыдущих этапах. При подготовке к эндопротезированию мы ни в одном случае специально имплантаты не удаляли.

В раннем послеоперационном периоде имели место осложнения со стороны раны (гематомы, серомы) у 3 пациентов (2,97 \%) II и III групп (2 и 1 случаев соответственно), которые потребовали санации раны без вмешательства на протезе, у пациентов I группы проблем с заживлением раны не было. Однако у одного пациента первой группы имела место глубокая перипротезная инфекция через 8 месяцев после операции, потребовавшая удаления протеза. Наиболее частым осложнением при эндопротезировании локтевого сустава были послеоперационные невриты локтевого нерва, мобилизация которого во время операции была обязательна во всех случаях, что связано с выраженным руб- цово-спаечным процессом в области локтевого сустава и предшествовавшими операциями. Данные осложнения были у 6 пациентов (5,94 \%), при этом одинаково во всех группах (по 2 пациента), потребовали длительного консервативного лечения, и только в одном случае у пациента III группы наблюдалась остаточная анестезия 5 пальца кисти без снижения двигательной функции кисти. Других осложнений в нашей выборке пациентов не было.

После операции с первых суток начинали пассивную двигательную терапию (аппаратную) в течение 3-х суток, после чего начинали активные движения и раннюю реабилитацию. Швы снимали на 12-14 сутки. Рентгенологические исследования проводили вместе с контрольными осмотрами через 3-12 месяцев после операции, далее ежегодно.

При анализе результатов функции верхней конечности после тотального эндопротезирования локтевого сустава мы видим улучшение функции, которая набирает максимум к одному году после операции, после чего отмечается отчетливое плато на протяжении всего периода наблюдения. Начиная со срока в один год была отмечена статистическая разница в результатах $(p=0,0213)$ между группой III (первичное ТЭЛC, DASH $=7,3 \pm 2,1)$ по сравнению с группами I $(\mathrm{DASH}=20,6 \pm 3,3)$ и II (DASH $=18,4 \pm 4,2)$ (рис. 1$)$. 


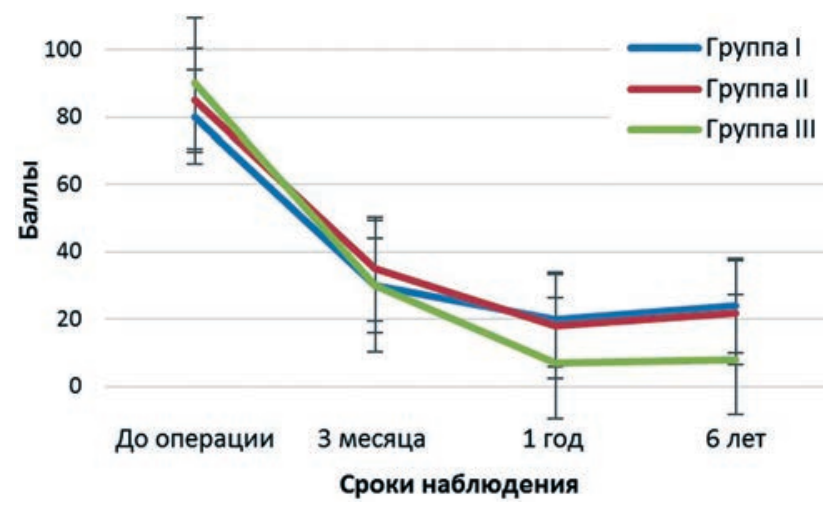

Рис. 1. Динамика изменения функции верхней конечности по шкале DASH

Сходная динамика была и при анализе результатов по шкале MEPS, в срок наблюдения один год после операции результаты в группе пациентов III (MEPS $=90,7 \pm 8,4$ ) можно было оценить как отличные, в группах I $($ MEPS $=83,8 \pm 7,4)$ и II $($ MEPS $=84,2 \pm 5,6)$ как хорошие, с достоверной статистической разницей в результатах ( $\mathrm{p}=0,0344)$, что представлено на рисунке 2 .

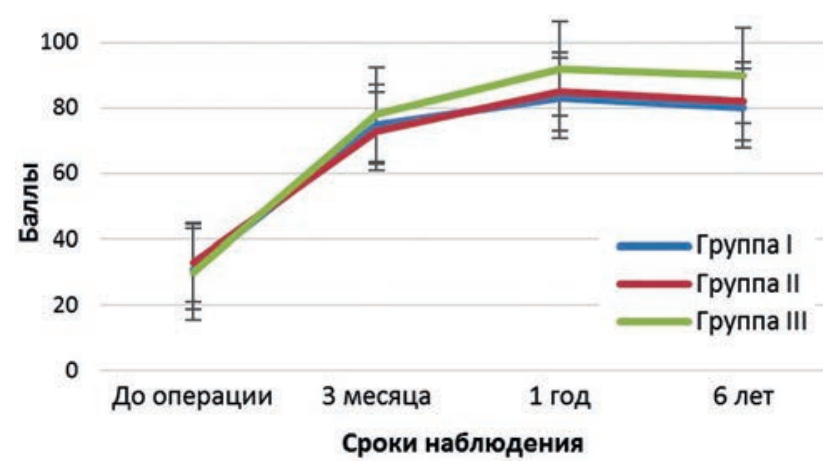

Рис. 2. Динамика изменения функции верхней конечности по шкале MEPS

При анализе динамики изменения силы кисти также отмечена отчетливая динамика улучшения результатов после операции в сравнении с предоперационными во всех группах, однако статистически значимой разницы между группами выявлено не было (рис. 3).

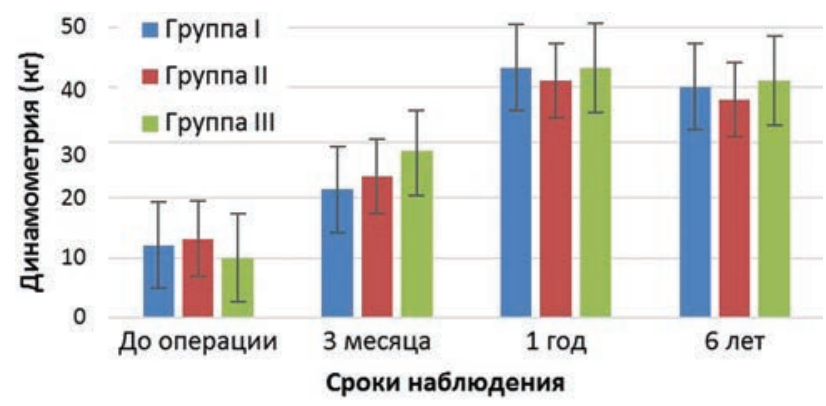

Рис. 3. Динамика изменения силы кисти (динамометрия)

При исследовании объема движений в локтевом суставе после операции по сравнению с дооперационными показателями при первичном ТЭЛС мы принимали за точку отсчета объем движений в здоровой руке, что может быть не совсем корректно, но в группах консервативного лечения перелома и после остеосинтеза до операции объем движений был значительно отграничен, и восстановить у них объем движений идентичный здо- ровой руке мы не смогли, поэтому абсолютные результаты улучшения объема движений были разнородными. Однако, субъективно, мы отметили тенденцию в первых двух группах: при полном отсутствии, например, ротационных движений в течение длительного периода (более 1,5 лет в нашем исследовании) восстановить хороший объем ротации не удается, но статистически достоверных различий мы не обнаружили.

Клинический случай из первой группы. Пациент Н., 69 лет, около трех лет назад, со слов пострадавшего, получил «внутрисуставной оскольчатый перелом правого локтевого сустава» (медицинской документации и первичных рентгенограмм нет), при осмотре - выраженная комбинированная контрактура локтевого сустава (сгибание $50^{\circ}$, разгибание $160^{\circ}$, ротационные движения отсутствуют), значительный болевой синдром при движениях и в покое (ВАШ = 5). Показатели $\mathrm{DASH}=90$ и $\mathrm{MEPS}=20$, ДМК $=14$ кг (рис. 4).
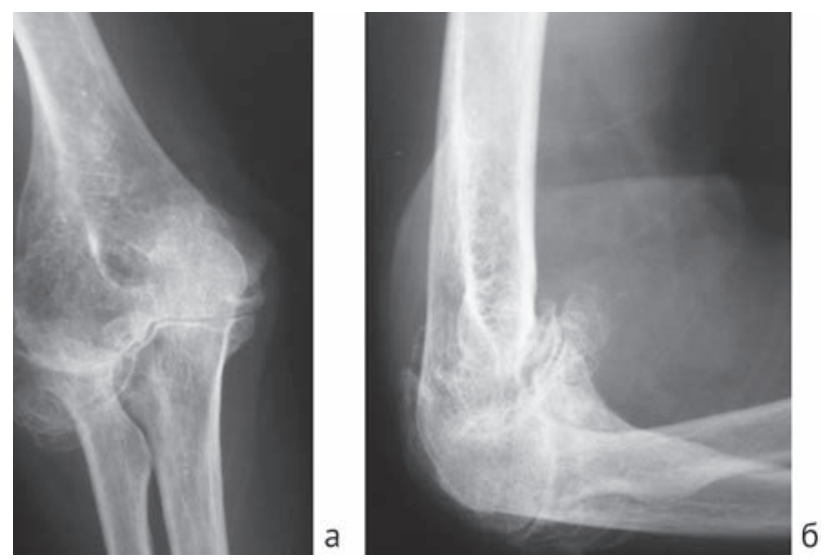

Рис. 4. Пациент Н. Рентгенограммы области локтевого сустава перед операцией: a - передне-задняя проекция; б - боковая проекция

Выполнено тотальное эндопротезирование правого локтевого сустава цементным полусвязанным протезом Coonrad-Morrey (Zimmer, Warsaw, IN, USA) (рис. 5).

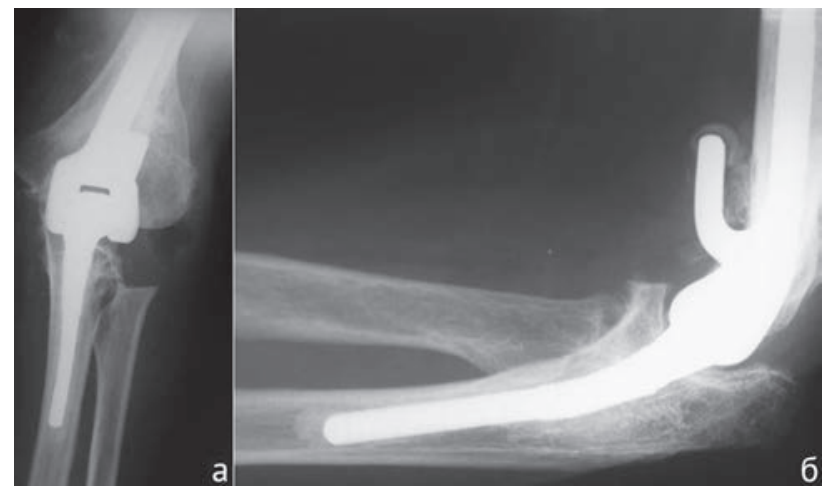

Рис. 5. Пациент Н. Рентгенограммы области локтевого сустава через год после ТЭЛС: а - передне-задняя проекция, б - боковая проекция

Интраоперационно: движения в локтевом суставе в полном объеме. После заживления раны проведен курс стандартного реабилитационного лечения, пациент доволен функциональным результатом, при осмотре через год болевой синдром купирован (ВАШ = 1), показатели $\mathrm{DASH}=20$ и MEPS $=78$, ДМК = 29 кг, объем движений в локтевом суставе: сгибание $30^{\circ}$, разгибание $165^{\circ}$, но ротационные движения отсутствуют (рис. 6). 

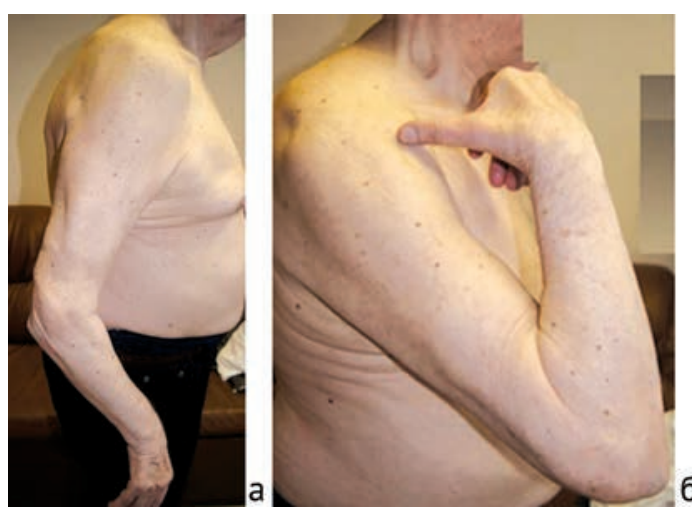

Клинический пример (группа II) эндопротезирования ЛС после остеосинтеза дистального метаэпифиза плеча. Пациентка С., 52 лет, получила травму за 1,5 года до обращения в нашу клинику. Диагноз - закрытый внутрисуставной перелом дистального метаэпифиза левого плеча (13С2) (рис. 7).
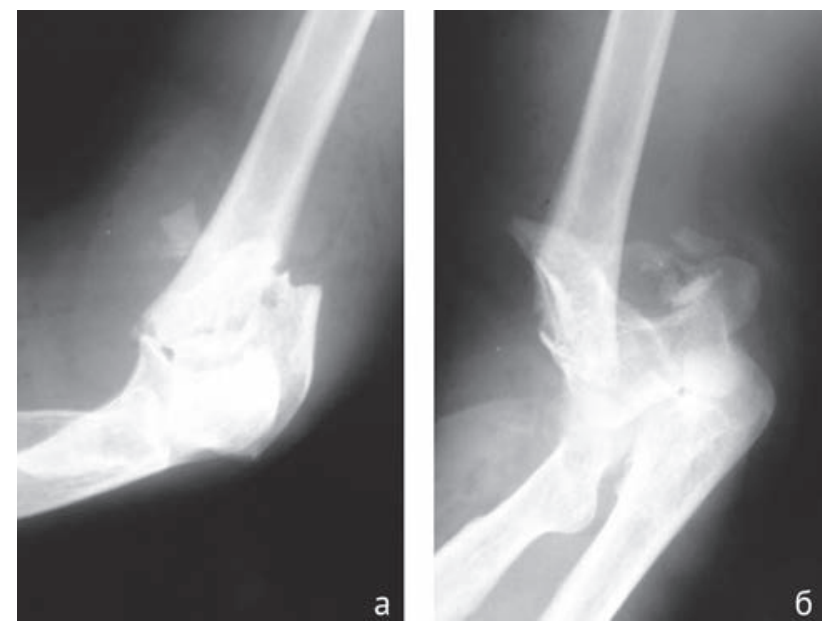

Рис. 7. Пациентка С. Рентгенограммы левого ЛС после травмы: а - боковая проекция; б - прямая проекция

По месту жительства выполнена остеотомия локтевого отростка, открытая репозиция, остеосинтез блокируемой реконструкционной пластиной и губчатым винтом (рис. 8).

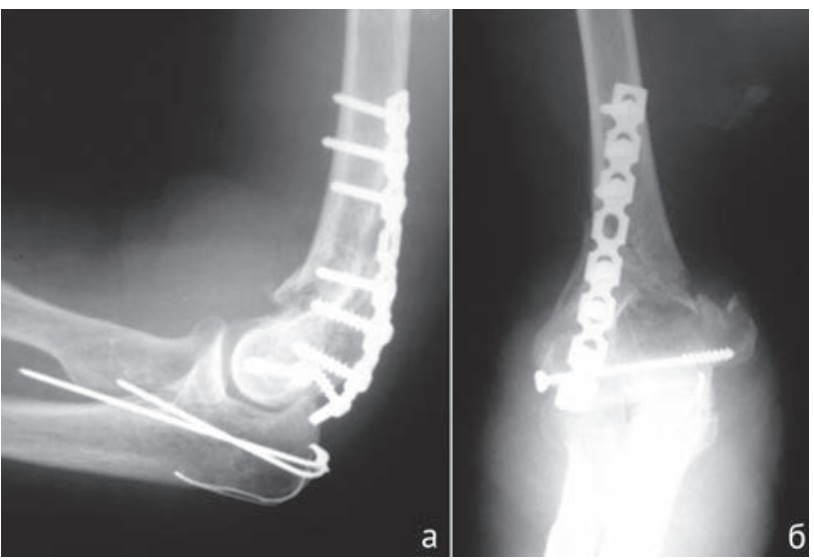

Рис. 8. Пациентка С. Рентгенограммы ЛС после операции остеосинтеза: a - боковая проекция; б - прямая проекция

В послеоперационном периоде при выполнении движений появились боли и резкое ограничение дви- жений, на рентгенограммах через 12 месяцев после остеосинтеза отмечалась миграция конструкции, ложный сустав плечевой кости и выраженная деформация в области ЛС (рис. 9).

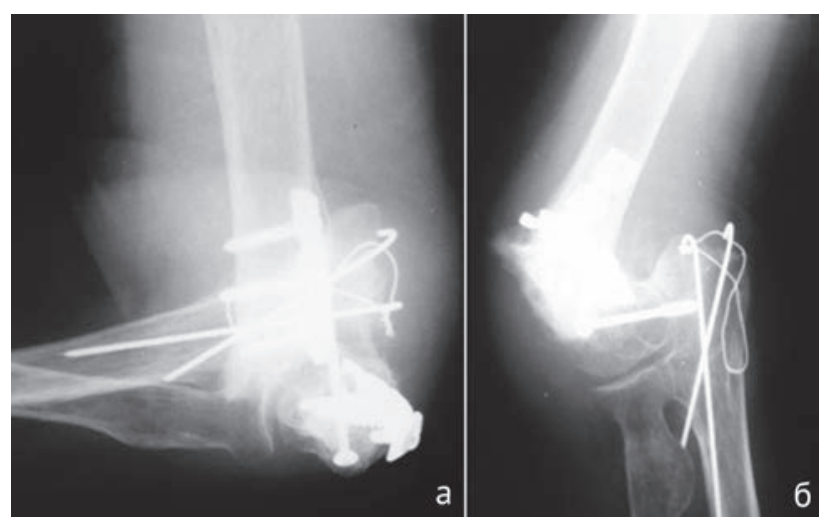

Рис. 9. Пациентка С. Рентгенограммы ЛС через 12 месяцев после операции (миграция и перелом пластины): а - боковая проекция; б - прямая проекция

В представленном случае выполнить реконструкцию (реостеосинтез) не представлялось возможным, поэтому пациентке было выполнено ТЭЛС цементным полусвязанным протезом Coonrad-Morrey (Zimmer, Warsaw, IN, USA) (рис. 10). На осмотре через год после эндопротезирования. Жалоб нет. Объем движений в ЛС: сгибание $-45^{\circ}$, разгибание $-175^{\circ}$, пронация $-55^{\circ}$, супинация $-85^{\circ}$, показатели DASH $=16$ и $\mathrm{MEPS}=88$, ДМК = 32 кг (рис. 11).

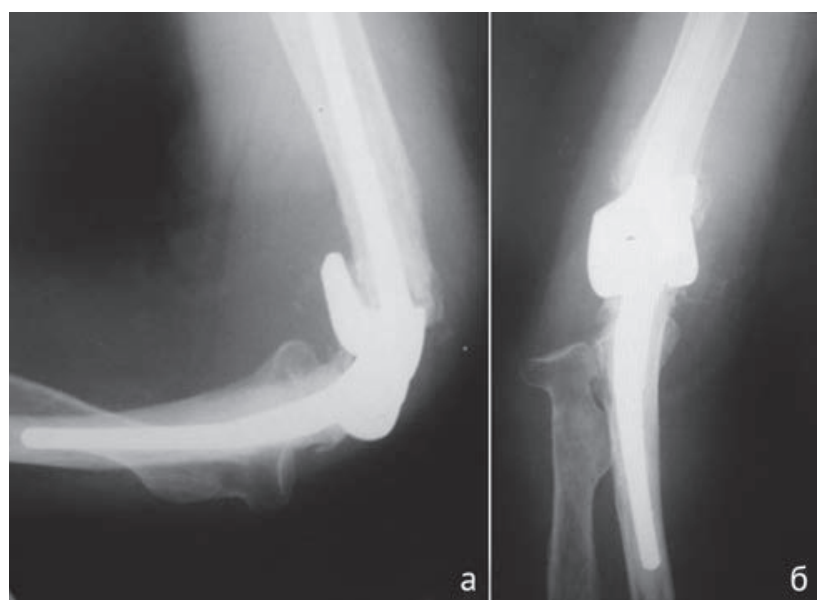

Рис. 10. Пациентка С. Рентгенограммы ЛС через 12 месяцев после эндопротезирования 


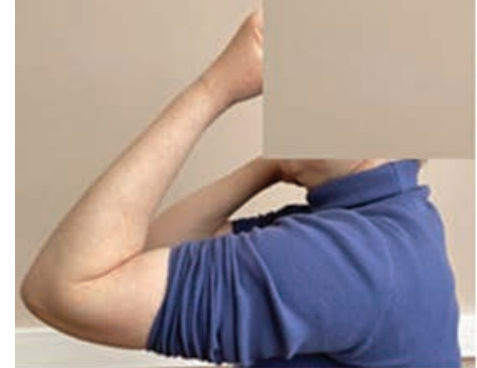

a

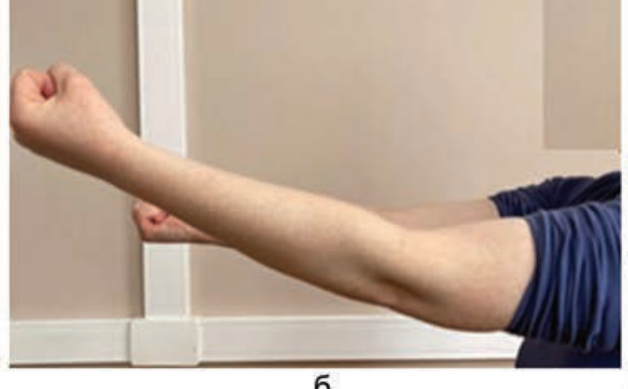

6
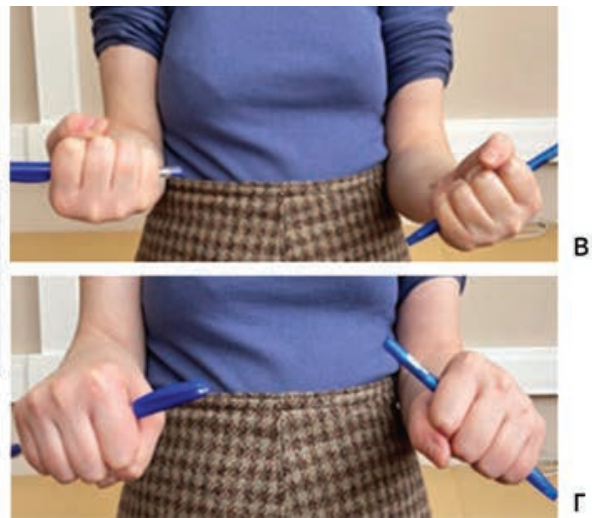

Рис. 11. Функциональный результат через год после операции: а - сгибание; б - разгибание; в - супинация; г - пронация

При анализе данного клинического случая нужно отметить, что полные внутрисуставные переломы дистального метаэпифиза плеча (13 тип С) необходимо фиксировать двумя пластинами с угловой стабильностью. В данном случае можно предположить, что фиксация была недостаточной. Перед эндопротезированием имело место выраженное нарушение функции и силы кисти, однако оперативное лечение позволило восстановить функцию верхней конечности.

Опыт применения первичного ТЭЛС при тяжелом раздробленном переломе суставных концов плечевой, лучевой и локтевой костей у пациентов старше 65 лет (группа III). Пациентка К., 68 лет, получила бытовую травму: закрытый внутрисуставной многооскольчатый перелом дистального конца плечевой кости, перелом головки лучевой кости и локтевого отростка со смещением отломков (рис. 12). При поступлении выполнена попытка закрытой репозиции, которая не улучшила положение отломков, выполнена иммобилизация гипсовой лонгетной повязкой. Учитывая характер перелома и возраст пациентки, принято решение выполнить эндопротезирование локтевого сустава.
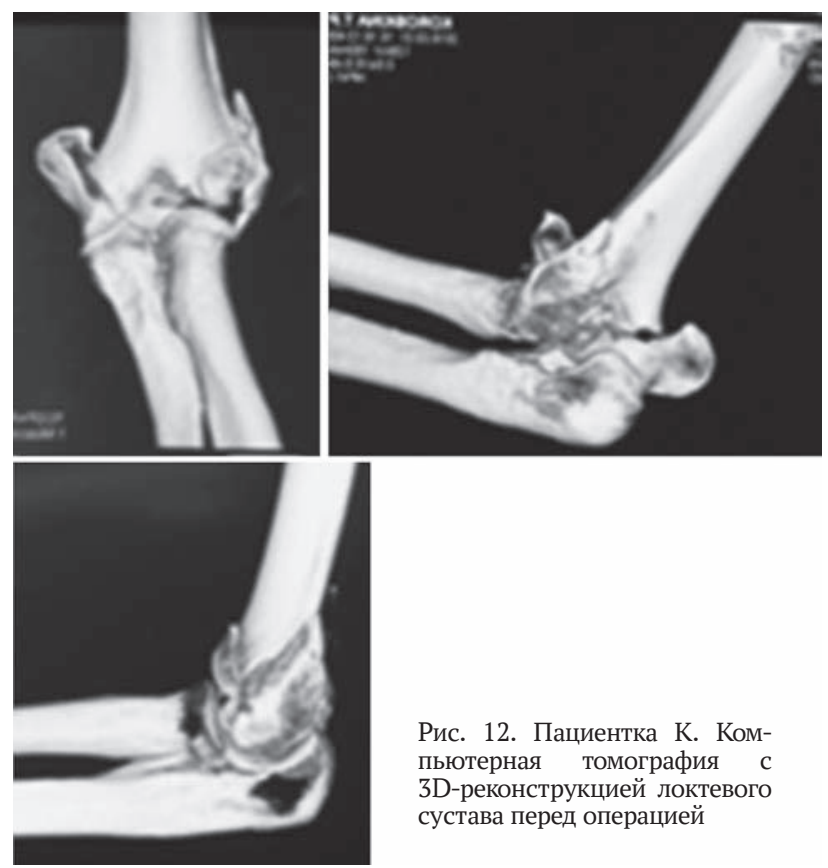

Рис. 12. Пациентка К. Компьютерная томография с 3D-реконструкцией локтевого сустава перед операцией

Интраоперационно выявлено большое количество мелких, свободных костных отломков, перелом головки лучевой кости, головчатого возвышения и блока плечевой кости, которые решено удалить (рис. 13, а).
Выполнена резекция костных фрагментов плечевой и локтевой костей, обработка костномозговых каналов рашпилями. Определение размеров и объема движений на примерочном протезе и цементная фиксация протеза (рис 13, б), на послеоперационных рентгенограммах стояние компонентов протеза удовлетворительное (рис. 14).

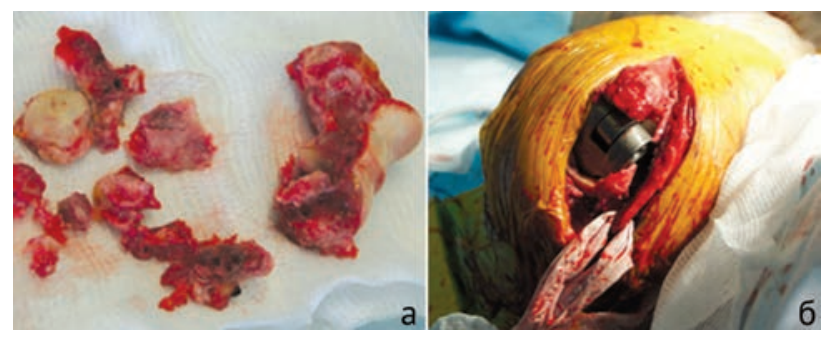

Рис. 13. Пациентка К. Интраоперационная картина: а фрагменты костей локтевого сустава; б - вид протеза

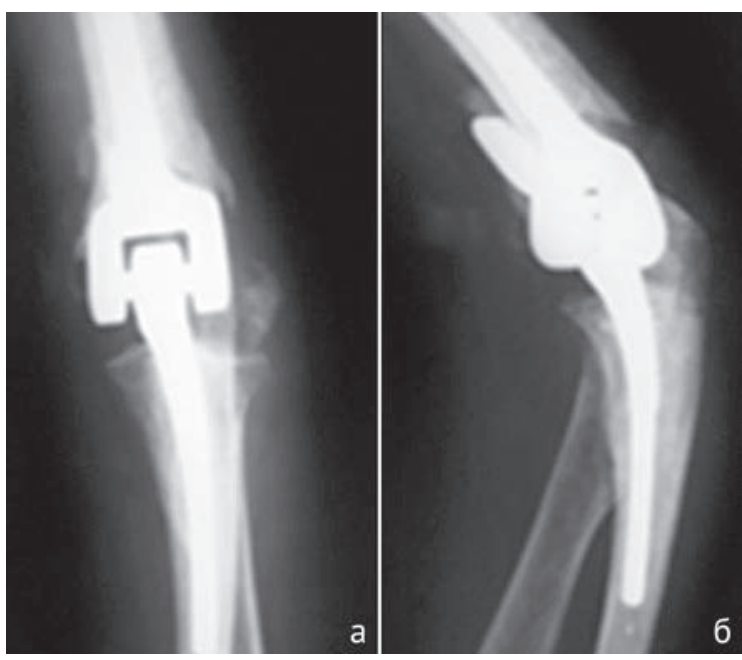

Рис. 14. Пациентка К. Рентгенограммы локтевого сустава после операции: а - передне-задняя проекция; б - боковая проекция

После проведенного реабилитационного периода больная выписана, функция конечности восстановилась.

Пациентка К. находилась под наблюдением в течение 10 лет, довольна объемом движений в локтевом суставе, силой и функциональными возможностями конечности (рис. 15). На рентгенограммах стояние компонентов протеза удовлетворительное, незначительная эктопическая оссификация, состояние цементной мантии удовлетворительное (рис. 16). 

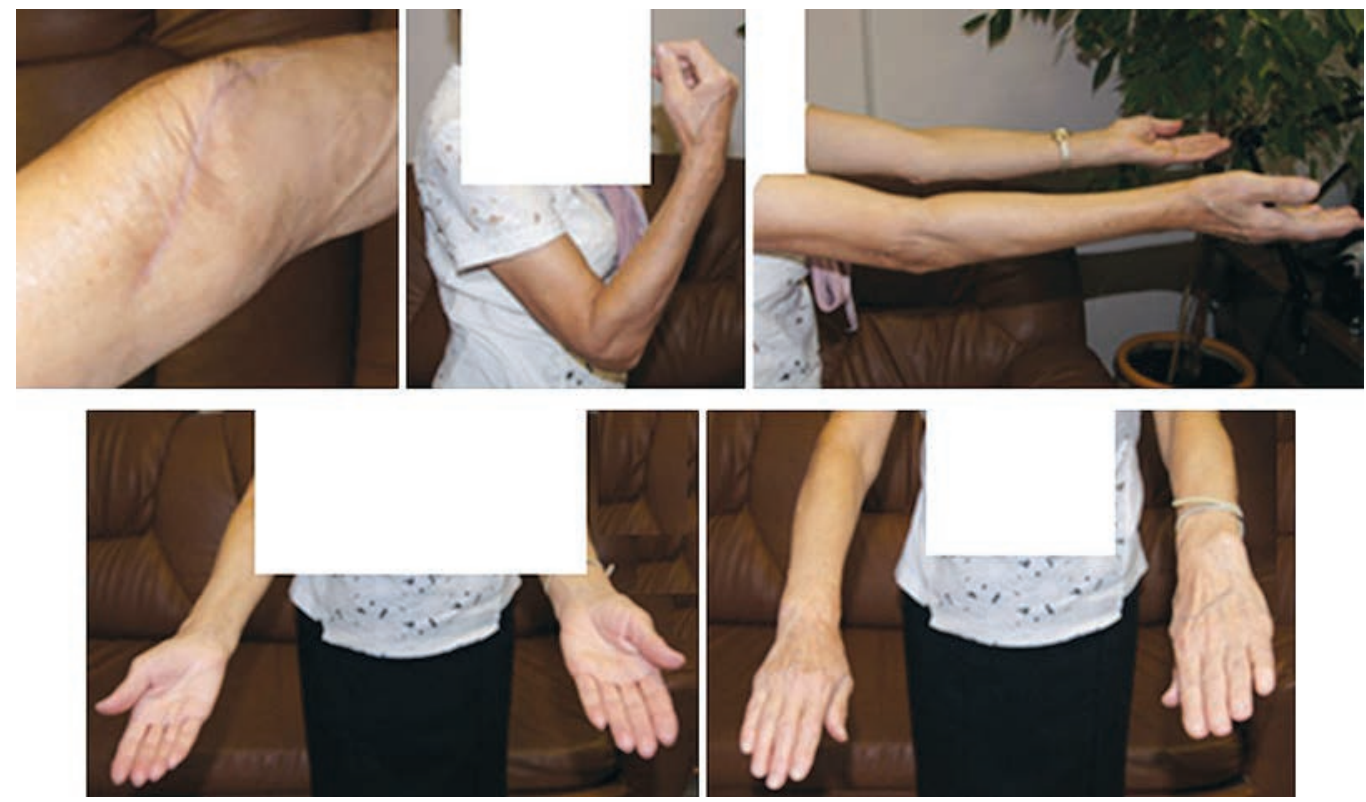

Рис. 15. Пациентка К. Вид послеоперационного рубца и функция правой верхней конечности через 10 лет после операции
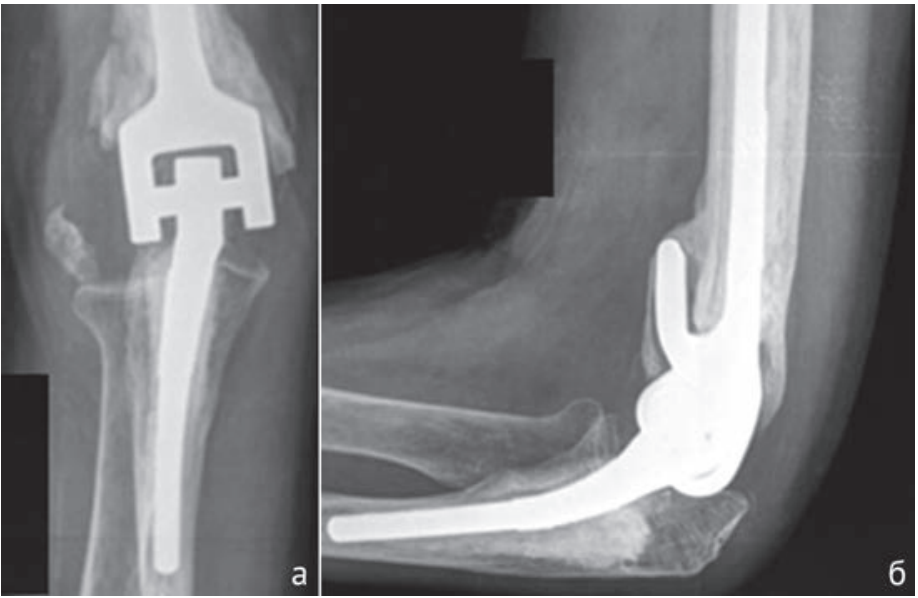

Рис. 16. Пациентка К. Рентгенография локтевого сустава через 10 лет после операции: а - передне-задняя проекция, б - боковая проекция

\section{ОБСУЖДЕНИЕ}

Лечение переломов дистального метаэпифиза плечевой кости и проксимальных метаэпифизов костей предплечья является актуальной проблемой как по частоте, достигая 1-2 \% всех переломов [32, 33], так и по неудовлетворительным результатам. При детальном рассмотрении имеем несколько проблем.

1. Достаточно распространенная тактика консервативного лечения гипсовой повязкой при лечении внутрисуставных переломов области ЛС приводит к выраженным контрактурам, что не удовлетворяет врача и пациента, это было в нашей работе и подчеркивается в работах других авторов [34]. Мы не проводили детального анализа результатов и ошибок консервативного лечения и реабилитации, но с точки зрения последующего тотального эндопротезирования и восстановления объема движений необходимо на это обращать внимание и помнить, что даже при гипсовой иммобилизации и консервативной тактике, выполненной по максимальной программе, необходимо попытаться сохранить объем движений в локтевом суставе, который является ключом дальнейшего реконструктивного лечения и ТЭЛС.
2. Другой проблемой является то, что, несмотря на все более широкое применение активной хирургической тактики открытой репозиции и внутренней фиксации внутрисуставных переломов дистального метаэпифиза плечевой кости и проксимальных метаэпифизов костей предплечья, количество результатов, требующих впоследствии коррекции методом эндопротезирования, постоянно растет, проблема не нова и обсуждается более двух десятилетий $[16,36]$. Здесь явно прослеживается необходимость разработки тактического подхода к решению вопросов качества кости, степени повреждения кости и суставного хряща, возможностей современных металлоконструкций фиксировать и обеспечить оптимальные условия для сращения переломов с восстановлением функции сустава и всей верхней конечности. Эти вопросы далеки от своего решения сегодня, но многие авторы видят его в развитии хирургических методов лечения травм области локтевого сустава [37].

Первичное тотальное эндопротезирование локтевого сустава при травмах и их последствиях у пожилых пациентов на фоне остеопороза с «плохим качеством 
кости» - вопрос на сегодняшний день решенный, но у молодых пациентов также бывают переломы, при которых перспектив восстановления хорошей функции конечности немного. Необходимость изучения данного вопроса высока, однако современные методы диагностики не позволяют перед операцией объективно оценить качество кости, и во время операции не всегда можно точно определить перспективу восстановления функции конечности. При этом отдаленные результаты эндопротезирования в 7 и 10 лет немногочисленные и не очень хорошие, что не дает возможности широко рекомендовать отказ от остеосинтеза в пользу эндопро- тезирования, поэтому данный вопрос требует дальнейших исследований и внедрения новых конструкций и материалов [17, 38, 39, 40].

Мы понимаем, что наше исследование имеет много недостатков, таких как малая выборка, одноцентровое исследование, основанное на использовании одной модели эндопротеза. Однако оно подтвердило основные тенденции в лечении переломов области локтевого сустава и эндопротезировании, показало актуальность и перспективы дальнейших исследований, увеличение выборки путем отработки протоколов лечения травм локтевого сустава и создания регистра эндопротезирования.

\section{ВЫВоды}

При выборе тактики лечения тяжелых травм локтевого сустава необходимо учитывать не только тяжесть повреждения, но и возраст пациента, а также качество кости, особенно у пациентов пожилого возраста. От- каз от выполнения остеосинтеза в пользу первичного тотального эндопротезирования дает возможность сохранить объем движений, улучшить функциональные результаты и выживаемость эндопротеза.

\section{СПИСОК ИСТОЧНИКОВ}

1. Kwak J.M., Koh K.H., Jeon I.H. Total Elbow Arthroplasty: Clinical Outcomes, Complications, and Revision Surgery // Clin. Orthop. Surg. 2019. Vol. 11, No 4. P. 369-379. DOI: 10.4055/cios.2019.11.4.369.

2. Broberg M.A., Morrey B.F. Results of delayed excision of the radial head after fracture // J. Bone Joint Surg. Am. 1986 . Vol. 68, No 5. P. 669-674.

3. Radial head, radiocapitellar and total elbow arthroplasties: a review of recent literature / G. Giannicola, F.M. Sacchetti, G. Antonietti, A. Piccioli, R. Postacchini, G. Cinotti // Injury. 2014. Vol. 45, No 2. P. 428-436. DOI: 10.1016/j.injury.2013.09.019.

4. Ellenbogentotalendoprothetik bei traumatischen und posttraumatischen Knochendefekten / M. Hackl, L.P. Müller, T. Leschinger, K. Wegmann // Orthopade. 2017. Vol. 46, No 12. P. 990-1000. DOI: 10.1007/s00132-017-3493-4.

5. First-line management of distal humerus fracture by total elbow arthroplasty in geriatric traumatology: Results in a 21-patient series at a minimum 2 years' follow-up / D. Lami, M. Chivot, A. Caubere, A. Galland, J.N. Argenson // Orthop. Traumatol. Surg. Res. 2017. Vol. 103, No 6. P. 891-897. DOI: 10.1016/j.otsr.2017.06.009.

6. The role of total elbow arthroplasty in traumatology / P. Mansat, N. Bonnevialle, M. Rongieres,P. Bonnevialle; Bone, Joint Trauma Study Group (GETRAUM) // Orthop. Traumatol. Surg. Res. 2014. Vol. 100, No 6 Suppl. P. S293-S298. DOI: 10.1016/i.otsr.2014.06.008.

7. Total elbow arthroplasty following complex fractures of the distal humerus: results in patients over 65 years of age / F. Pogliacomi, P. Schiavi, M. Defilippo, M. Corradi, E. Vaienti, F. Ceccarelli, R. Rotini, F. Calderazzi // Acta Biomed. 2016. Vol. 87, No 2. P. $148-155$.

8. Pooley J., Salvador Carreno J. Total elbow joint replacement for fractures in the elderly - Functional and radiological outcomes // Injury. 2015. Vol. 46, No Suppl. 5. P. S37-S42. DOI: 10.1016/j.injury.2015.08.011.

9. Rajaee S.S., Lin C.A., Moon C.N. Primary total elbow arthroplasty for distal humeral fractures in elderly patients: a nationwide analysis // J. Shoulder Elbow Surg. 2016. Vol. 25, No 11. P. 1854-1860. DOI: 10.1016/j.jse.2016.05.030.

10. Total elbow arthroplasty for primary osteoarthritis / B.S. Schoch, J.D. Werthel, J. Sánchez-Sotelo, B.F. Morrey, M. Morrey // J. Shoulder Elbow Surg. 2017. Vol. 26, No 8. P. 1355-1359. DOI: 10.1016/j.jse.2017.04.003.

11. Rangarajan R., Papandrea R.F., Cil A. Distal Humeral Hemiarthroplasty versus Total Elbow Arthroplasty for Acute Distal Humeral Fractures // Orthopedics. 2017. Vol. 40, No 1. P. 13-23. DOI: 10.3928/01477447-20161227-02.

12. Short-Term Complications of Distal Humerus Fractures in Elderly Patients: Open Reduction Internal Fixation versus Total Elbow Arthroplasty / A.J. Lovy, A. Keswani, S.M. Koehler, J. Kim, M. Hausman // Geriatr. Orthop. Surg. Rehabil. 2016. Vol. 7, No 1. P. 39-44. DOI: $10.1177 / 2151458516630030$.

13. Lapner M., King G.J. Elbow arthroplasty for distal humeral fractures // Instr. Course Lect. 2014. Vol. 63. P. 15-26.

14. Zhang D., Chen N. Total elbow arthroplasty // J. Hand Surg. Am. 2019. Vol. 44, No 6. P. 487-495. DOI: 10.1016/j.jhsa.2018.11.005.

15. Results of Total Elbow Arthroplasty in Patients Less Than 50 Years Old / B. Schoch, J. Wong, J. Abboud, M. Lazarus, C. Getz, M. Ramsey // J. Hand Surg. Am. 2017. Vol. 42, No 10. P. 797-802. DOI: 10.1016/j.jhsa.2017.06.101.

16. A multicenter, prospective, randomized, controlled trial of open reduction - internal fixation versus total elbow arthroplasty for displaced intraarticular distal humeral fractures in elderly patients / M.D. McKee, C.J.H. Veillette, J.A. Hall, E.H. Schemitsch, L.M. Wild, R. Mccormack, B. Perey, T. Goetz, M. Zomar, K. Moon, S. Mandel, S. Petit, P. Guy, I. Leung // J. Shoulder Elbow Surg. 2009. Vol. 18, No 1. P. 3-12. DOI: 10.1016/j. jse.2008.06.005

17. Total Elbow Arthroplasty for Distal Humeral Fractures: A Ten-Year-Minimum Follow-up Study / R. Barco, P.N. Streubel, B.F. Morrey, J. SanchezSotelo // J. Bone Joint Surg. Am. 2017. Vol. 99, No 18. P. 1524-1531. DOI: 10.2106/JBJS.16.01222.

18. Total Elbow Arthroplasty: A Systematic Review / C.L. Welsink, K.T.A. Lambers, D.F.P. van Deurzen, D. Eygendaal, M.P.J. van den Bekerom // JBJS Rev. 2017. Vol. 5, No 7. P. e4. DOI: 10.2106/JBJS.RVW.16.00089.

19. Is total elbow arthroplasty indicated in the treatment of traumatic sequelae? 19 Cases of Coonrad-Morrey( $\left.{ }^{\circledR}\right)$ reviewed at a mean follow-up of 5.2 years / P.Y. Barthel, P. Mansat, F. Sirveaux, F. Dap, D. Mole, G. Dautel // Orthop. Traumatol. Surg. Res. 2014. Vol. 100, No 1. P. 113-118. DOI: $10.1016 /$ j.otsr.2013.10.012.

20. Total elbow replacement: outcome of 1,146 arthroplasties from the Scottish Arthroplasty Project / P.J. Jenkins, A.C. Watts, T. Norwood, A.D. Duckworth, L.A. Rymaszewski, J.E. McEachan // Acta Orthop. 2013. Vol. 84, No 2. P. 119-123. DOI: 10.3109/17453674.2013.784658.

21. Results after 562 total elbow replacements: a report from the Norwegian Arthroplasty Register / B.T. Fevang, S.A. Lie, L.I. Havelin, A. Skredderstuen, O. Furnes // J. Shoulder Elbow Surg. 2009. Vol. 18, No 3. P. 449-456. DOI: 10.1016/j.jse.2009.02.020.

22. Amirfeyz R., Blewitt N. Mid-term outcome of GSB-III total elbow arthroplasty in patients with rheumatoid arthritis and patients with post-traumatic arthritis // Arch. Orthop. Trauma Surg. 2009. Vol. 129, No 11. P. 1505-1510. DOI: 10.1007/s00402-009-0876-y.

23. A survivorship study of 838 total elbow replacements: a report from the Norwegian Arthroplasty Register 1994-2016 / Y. Krukhaug, G. Hallan, E. Dybvik, S.A. Lie, O.N. Furnes // J. Shoulder Elbow Surg. 2018. Vol. 27, No 2. P. 260-269. DOI: 10.1016/j.jse.2017.10.018.

24. Discovery elbow system: 2- to 5-year results in distal humerus fractures and posttraumatic conditions: a prospective study on 24 patients / G. Giannicola, M. Scacchi, D. Polimanti, G. Cinotti // J. Hand Surg. Am. 2014. Vol. 39, No 9. P. 1746-1756. DOI. 10.1016/j.jhsa.2014.05.027.

25. Lenich A., Imhoff A.B., Siebenlist S. Sekundäre Arthrose des Ellenbogengelenkes : Endoprothetische Möglichkeiten beim jungen Patienten // Orthopade. 2016. Vol. 45, No 10. P. 844-852. DOI: 10.1007/s00132-016-3328-8. 
26. Functional outcome of semiconstrained total elbow arthroplasty / K.A. Hildebrand, S.D. Patterson, W.D. Regan, J.C. MacDermid, G.J. King // J. Bone Joint Surg. Am. 2000. Vol. 82, No 10. P. 1379-1386. DOI: 10.2106/00004623-200010000-00003.

27. Celli A., Morrey B.F. Total elbow arthroplasty in patients forty years of age or less // J. Bone Joint Surg. Am. 2009. Vol. 91, No 6. P. $1414-1418$. DOI: 10.2106/JBJS.G.00329.

28. Clinical Outcomes of Semiconstrained Total Elbow Arthroplasty in Patients Who Were Forty Years of Age or Younger / J.G. Park, N.S. Cho, J.H. Song, D.S. Lee, Y.G. Rhee // J. Bone Joint Surg. Am. 2015. Vol. 97, No 21. P. 1781-1791. DOI: 10.2106/JBJS.N.01325.

29. Амбросенков А.В. Артропластика локтевого сустава (резекционная и эндопротезирование различными конструкциями) при его повреждениях и заболеваниях : дис. ... канд. мед. наук. СПб., 2008. 173 с.

30. Родоманова Л.А., Кутянов Д.И., Рябов В.А. Использование технологий реконструктивно-пластической микрохирургии в системе лечения больных с патологией локтевого сустава // Травматология и ортопедия России. 2011. № 3 (61). С. 24-31.

31. Особенности протезирования локтевого сустава при ранениях и травмах: отдаленные результаты / А.А Грицюк., А.В. Лычагин, Е.В. Крюков, Л.К. Брижань, Д.В. Давыдов // Военно-медицинский журнал. 2017. Т. 338, № 12. С. 37-44.

32. Varecka T.F., Myeroff C. Distal Humerus Fractures in the Elderly Population // J. Am. Acad. Orthop. Surg. 2017. Vol. 25 , No 10. P. $673-683$. DOI: $10.5435 /$ JAAOS-D-15-00683.

33. Epidemiology of distal humerus fractures in the elderly / J.L. Charissoux, G. Vergnenegre, M. Pelissier, T. Fabre, P. Mansat ; SOFCOT // Orthop. Traumatol. Surg. Res. 2013. Vol. 99, No 7. P. 765-769. DOI: 10.1016/j.otsr.2013.08.002.

34. Aitken S.A., Jenkins P.J., Rymaszewski L. Revisiting the 'bag of bones': functional outcome after the conservative management of a fracture of the distal humerus // Bone Joint J. 2015. Vol. 97-B, No 8. P. 1132-1138. DOI: 10.1302/0301-620X.97B8.35410.

35. Adult distal humeral metaphyseal fractures: epidemiology and results of treatment / C.M. Robinson, R.M. Hill, N. Jacobs, G. Dall, C.M. CourtBrown // J. Orthop. Trauma. 2003. Vol. 17, No 1. P. 38-47. DOI: 10.1097/00005131-200301000-00006.

36. Galano G.J., Ahmad C.S., Levine W.N. Current treatment strategies for bicolumnar distal humerus fractures // J. Am. Acad. Orthop. Surg. 2010. Vol. 18, No 1. P. 20-30. DOI: 10.5435/00124635-201001000-00004.

37. Distal humeral fractures in adults / A. Nauth, M.D. McKee, B. Ristevski, J. Hall, E.H. Schemitsch // J. Bone Joint Surg. Am. 2011. Vol. 93 , No 7. P. 686-700. DOI: 10.2106/JBJS.J.00845.

38. Cobb T.K., Morrey B.F. Total elbow arthroplasty as primary treatment for distal humeral fractures in elderly patients // J. Bone Joint Surg. Am. 1997. Vol. 79, No 6. P. 826-832. DOI: 10.2106/00004623-199706000-00004.

39. Garcia J.A., Mykula R., Stanley D. Complex fractures of the distal humerus in the elderly. The role of total elbow replacement as primary treatment // J. Bone Joint Surg. Br. 2002. Vol. 84, No 6. P. 812-816. DOI: 10.1302/0301-620x.84b6.12911.

40. Kamineni S., Morrey B.F. Distal humeral fractures treated with noncustom total elbow replacement // J. Bone Joint Surg. Am. 2004 . Vol. 86 , No 5. P. 940-947. DOI: 10.2106/00004623-200405000-00009.

Статья поступила в редакцию 17.08.2021; одобрена после рецензирования 10.11.2021; принята к публикации 23.12.2021.

The article was submitted 17.08.2021; approved after reviewing 10.11.2021; accepted for publication 23.12.2021.

\section{Информация об авторах:}

1. Валентина Анатольевна Калантырская - кандидат медицинских наук, kalan.v@mail.ru;

2. Игорь Олегович Голубев - доктор медицинских наук;

3. Алексей Юрьевич Заров - secretary@ckbsva.ru;

4. Карен Альбертович Егиазарян - доктор медицинских наук, профессор.

\section{Information about the authors:}

1. Valentina A. Kalantyrskaya - Candidate of Medical Sciences, kalan.v@mail.ru;

2. Igor O. Golubev - Doctor of Medical Sciences;

3. Alexey Yu. Zarov - M.D., secretary@ckbsva.ru;

4. Karen A. Egiazaryan - Doctor of Medical Sciences, Professor. 
Гений ортопедии. 2022. Т. 28, № 1. С. 34-38.

Genij Ortopedii. 2022. Vol. 28, no. 1. P. 34-38.

\author{
Научная статья \\ УДК 617.577-089.844 \\ https://doi.org/10.18019/1028-4427-2022-28-1-34-38

\section{Результаты аутотрансплантации второго пальца стопы в позицию утраченного первого пальца кисти}

\title{
Б.Ш. Минасов, И.З. Гарапов, Э.М. Бикташева, М.М. Валеев ${ }^{\bowtie}$ Р.Р. Якупов, Т.Б. Минасов, Т.Р. Мавлютов
}

Башкирский государственный медицинский университет, Уфа, Россия

Автор, ответственный за переписку: Марат Мазгарович Валеев, valeevmm@rambler.ru

\section{Аннотация}

Помимо физического увечья, дефекты первого пальца кисти негативно влияют на психологическое состояние пострадавших, приводят к депрессивным настроениям пациентов, ощущению личной неполноценности и бесперспективности в будущем. Цель. Изучение отдаленных результатов реконструкции утраченного первого пальца кисти путем аутотрансплантации второго пальца стопы с применением микрососудистых анастомозов. Материалы и методы. Пересадку второго пальца стопы в позицию первого пальца кисти выполнили у 54 пациентов. Из общего количество оперированных больных мужчин было 48 человек, женщин - 6, в возрасте от 12 до 55 лет. При анализе отдаленных результатов учитывали анатомическое состояние пальца и степень восстановления функции травмированной кисти: объем движений в суставах пальца; мышечную силу кисти; наличие основных видов захвата кистью. Результаты. Полное приживление аутотрансплантата с восстановлением оппозиции вновь сформированного пальца к остальным пальцам кисти наступило у 51 пациента. Аутотрансплантат не прижился в трех случаях. У этих пациентов первый палец сформирован другими, менее функциональными методами. Заключение. Микрохирургические технологии при реконструкции утраченного большого пальца кисти позволяют в быстрые сроки восстановить первый палец и значительно улучшить функции травмированной кисти как органа. Свободная пересадка второго пальца стопь на микрососудистых анастомозах в позицию отсутствующего первого пальца кисти позволяет восстановить все основные функции захвата кисти и улучшить эстетическую привлекательность травмированной кисти.

Ключевые слова: микрохирургия, пластическая хирургия, реконструкция, пересадка пальца, первый палец, дефект

Для иитирования: Результаты аутотрансплантации второго пальца стопы в позицию утраченногот первого пальца кисти / Б.Ш. Минасов И.3. Гарапов, Э.М. Бикташева, М.М. Валеев, Р.Р. Якупов, Т.Б. Минасов, Т.Р. Мавлютов // Гений ортопедии. 2022. Т. 28, № 1. С. 34-38. httрs://doi. org/10.18019/1028-4427-2022-28-1-34-38

\section{Original article}

\section{Results of the second toe autotransplantation for thumb reconstruction}

\section{B.Sh. Minasov, I.Z. Garapov, E.M. Biktasheva, M.M. Valeev ${ }^{\bowtie}$, R.R. lakupov, T.B. Minasov, T.R. Mavliutov}

Bashkir State Medical University, Ufa, Russia

Corresponding author: Marat M. Valeev, valeevmm@rambler.ru

\section{Abstract}

Defects of the thumb negatively impact physical and mental health, lead to depression, inferiority complex and hopelessness in the future. The aim of the study was to explore long-term results of thumb reconstruction using autologous transplantation of the second toe with microvascular anastomoses. Material and methods Second toe transplantation for thumb reconstruction was performed for 54 patients. There were 48 male and 6 female patients aged from 12 to 55 years. When analyzing the long-term results of surgical treatment of patients. The anatomy and functionality of the repaired finger was evaluated at a long term measuring the range of motion in the joints, muscle strength of the hand and major types of hand grips. Results The autograft completely healed with opposition of the reconstructed thumb and the rest fingers restored in 51 patients. The autograft failed in three cases treated with less functional methods. Conclusion Microsurgical reconstruction technologies used for a lost thumb facilitated rapid recovery of the finger and significantly improved functions of the injured hand as an entity. Free second toe transplantation using microvascular anastomoses for the thumb reconstruction allowed the patient regain basic gripping functions and improve cosmesis of the injured hand. Keywords: microsurgery, plastic surgery, reconstruction, toe transplantation, thumb, defect

For citation: Minasov B.Sh., Garapov I.Z., Biktasheva E.M., Valeev M.M., lakupov R.R., Minasov T.B., Mavliutov T.R. Results of the second toe autotransplantation for thumb reconstruction. Genij Ortopedii, 2022, vol. 28, no 1, pp. 34-38. https://doi.org/10.18019/1028-4427-2022-28-134-38

\section{ВВЕДЕНИЕ}

Травматические отчленения и ампутации пальцев кисти в результате некроза мягких тканей приводят в 70-80 \% к стойкому нарушению функции кисти. Отсутствие большого пальца кисти является причиной снижения трудоспособности на 50 \%, в связи с чем актуальность реконструкции этого пальца обостряет данную проблему в травматологии и ортопедии [1-12].

Реконструированный палец должен быть эстетически приемлемым; иметь достаточную длину и полноценную чувствительность; обеспечивать кистевые схваты. Для большого пальца основным считается способность противопоставляться к остальным четырем для выполнения тонких кинематических движений. Выбор метода реконструкции первого пальца и, соответственно, максимальное восстановление эстетической привлекательности и функциональной способности травмированной кисти зависит от длины культи и состояния мышц тенара [2, 3, 7, 9, 13-23].

Учитывая, что травматическому отчленению первого пальца кисти подвергаются пациенты молодого, трудоспособного возраста, утрачивающие способность к выполнению профессиональных, бытовых и социальных обязанностей, актуальность реконструкции утраченного первого пальца кисти подталкивает хирургов к поиску оптимальных путей решения этой проблемы [24-39]. 


\section{МАТЕРИАЛЫ И МЕТОДЫ}

Пересадку второго пальца стопы в позицию первого пальца кисти выполнили у 54 пациентов. У всех оперированных, наряду с высокой степенью нарушения функции захвата травмированной кисти, имелись отклонения и в психоэмоциональной сфере жизнедеятельности вследствие утраты стереотипных двигательных актов кистью: от немотивированной раздражительности до нелюдимости в целом, особенно у женщин.

Наличие у пациентов в возрасте от 12 до 55 лет ампутационной культи первого пальца кисти в подостром и отдаленном периодах после травмы являлось критерием включения в исследование. Критериями исключения были декомпенсированная соматическая патология; инфекционные процессы в травмированной кисти; психические, неврологические и сосудистые заболевания в стадии декомпенсации; холодовые травмы, приведшие к некрозу пальцев кисти и стопы.

Причинами утраты первого пальца кисти были травматические отчленения, обширное разрушение мягких тканей на производстве или в быту. Из общего количество оперированных больных мужчин было 48 человек, женщин - 6 .

Перед оперативным вмешательством выполняли общеклиническое обследование, включая рентгено- графию травмированной кисти и УЗДГ магистральных артерий проблемной конечности и донорской нижней конечности; учитывали возраст (не более 55 лет), давность травмы и доминантную кисть, профессию и наличие сопутствующих заболеваний. При клиническом осмотре оценивали состояние кожных покровов, рубцов и подвижность суставов, пульсацию магистральных артерий конечностей, степень функционирования апокриновых желез донорской стопы.

Перед оперативным вмешательством проводилась оценка функционального состояния верхней конечности и кисти, а также активности пациента по опроснику шкалы DASH (Disability of the arm, shoulder and hand outcome measure), включающему 30 вопросов. Расчет производился по формуле: (сумма по ответам / n-1) × 25, при этом $\mathrm{n}$ - количество заполненных ответов. У всех пациентов до операции показатели составляли от 75 до 100 баллов. Для оценки объема движений первого пальца кисти использовалась шкала Капанджи А.И. (1986). Функциональное состояние верхней конечности по шкалам DASH и Капанджи до операции было оценено в $53,9 \pm 8,22$ балла и $54,72 \pm 8,04$ балла после операции и в 2,3 \pm 0,34 балла до операции и 2,35 \pm 0,36 после операции соответственно.

\section{РЕЗУЛЬТАТЫ}

Положительный результат в отдаленном послеоперационном периоде получен у 51 пациента. Неприживление аутотрансплантата отмечалось у трех пациентов, у которых улучшение функциональных возможностей проблемной кисти осуществлялось другими, менее функциональными методами. При анализе отдаленных результатов хирургического лечения учитывали анатомичность реконструкции пальца и степень восстановления функциональных способностей травмированной кисти, амплитуду движений в суставах пальца, мышечную силу кисти, наличие основных видов захвата кистью (шкала DASH, шкала А.И. Капанджи, оценка качества жизни по шкале SF-36). Проведенный статистический анализ полученных исходов позволил определить достоверность результатов проведенного исследования. По результатам анализа работы выявлено статистически значимое восстановление показателей травмированной кисти после операции по сравнению с ее дооперационным состоянием: достоверно увеличилась амплитуда движений, повысилась эффективность основных типов захвата и показатели силовых тестовых нагрузок.

Оценка восстановления анатомии, амплитуды движений в первом пальце (сгибание и разгибание) и улучшение основных видов захвата кисти выявила значимое улучшение данных показателей в послеоперационном периоде $(\mathrm{p}<0,01)$ (табл. 1$)$.

Показатели динамометрии статистически значимо улучшились в послеоперационном периоде ( $<<0,01)$. Функциональное состояние верхней конечности в отдаленном периоде после операции - показатели по шкале Капанджи достоверно улучшились ( $<$ 0,01), объем движений составил 7,17 $\pm 1,42$. Сравнительная оценка исходов реконструкции первого пальца кисти по шкале DASH также выявила статистически значи- мую разницу между значениями «до операции» и «после операции» $(\mathrm{p}=0,019)-2,3 \pm 0,34$.

Таблица 1

Показатели захвата кисти до и после операции

\begin{tabular}{|c|c|}
\hline До операции & После операции \\
\hline \multicolumn{2}{|c|}{$\begin{array}{c}\text { Сферический захват } \\
\left(\chi^{2} \text { Макнамара (A/D) } 0,1, \mathrm{p}=0,75 ;(\mathrm{B} / \mathrm{C}) 24,04, \mathrm{p}<0,001\right)\end{array}$} \\
\hline отсутствие захвата & наличие захвата \\
\hline \multicolumn{2}{|c|}{$\begin{array}{c}\text { Крючкообразный захват } \\
\left(\chi^{2} \text { Макнамара (A/D) } 4,08, \mathrm{p}=0,043 ;(\mathrm{B} / \mathrm{C}) 22,04, \mathrm{p}<0,001\right)\end{array}$} \\
\hline ограничение захвата & наличие захвата \\
\hline \multicolumn{2}{|c|}{$\begin{array}{c}\text { Плоскостной захват } \\
\left(\chi^{2} \text { Макнамара (A/D) } 1,45, \mathrm{p}=0,23 ;(\mathrm{B} / \mathrm{C}) 23,04, \mathrm{p}<0,001\right)\end{array}$} \\
\hline отсутствие захвата & наличие захвата \\
\hline \multicolumn{2}{|c|}{$\begin{array}{c}\text { Цилиндрический захват } \\
\left(\chi^{2} \text { Макнамара (A/D) } 0,8, \mathrm{p}=0,37 ;(\mathrm{B} / \mathrm{C}) 29,03, \mathrm{p}<0,001\right)\end{array}$} \\
\hline отсутствие захвата & наличие захвата \\
\hline \multicolumn{2}{|c|}{$\begin{array}{c}\text { Противопоставление } \\
\left(\chi^{2} \text { Макнамара (A/D) } 0,25, \mathrm{p}=0,62 ;(\mathrm{B} / \mathrm{C}) 30,03, \mathrm{p}<0,001\right)\end{array}$} \\
\hline отсутствие захвата & наличие захвата \\
\hline \multicolumn{2}{|c|}{$\begin{array}{c}\text { Щипковый захват ( } \chi^{2} \text { Макнамара (A/D) } 1,50, p=0,220 ;(B / C) \\
29,03, p<0,001)\end{array}$} \\
\hline отсутствие захвата & наличие захвата \\
\hline
\end{tabular}

Оценка качества жизни по шкале SF-36 выявила достоверное преимущество после операции: физическое функционирование, ролевое функционирование, обусловленное физическим состоянием, психическое здоровье, жизненная активность и ролевое функционирование, обусловленное эмоциональным состоянием ( $<<0,05)$. До операции по тесту Спилбергера-Ханина отмечались высокие уровни личностной (46,6 балла) и реактивной тревожности (34,5 баллов). После операции уровень личностной тревожности составил 18 баллов, личностной - 37,8 балла. После операции повысились показатели общего здоровья и физического функционирования. По 
шкалам ролевого, социального, эмоционального функционирования, шкале жизнеспособности, психического здоровья и боли наблюдалось незначительное увеличение показателей, что говорит об улучшении качества жизни у всех пациентов после лечения.

Клинический пример. Пациент В., 45 лет, госпитализирован через 3 недели после получения производственной травмы с жалобами на отсутствие первого пальца правой кисти (рис. 1).

Пациенту произведена операция - свободная пересадка второго пальца левой стопы на место отсутствующего большого пальца кисти на микрососудистых анастомозах (рис. 2).

В послеоперационном периоде осложнений не наблюдалось, аутотрансплантат полностью прижился. Через 10 лет после операции при осмотре с участием первого пальца выполняются все основные виды захвата кистью. Чувствительность вновь сформированного пальца полностью восставлена (рис. 3).
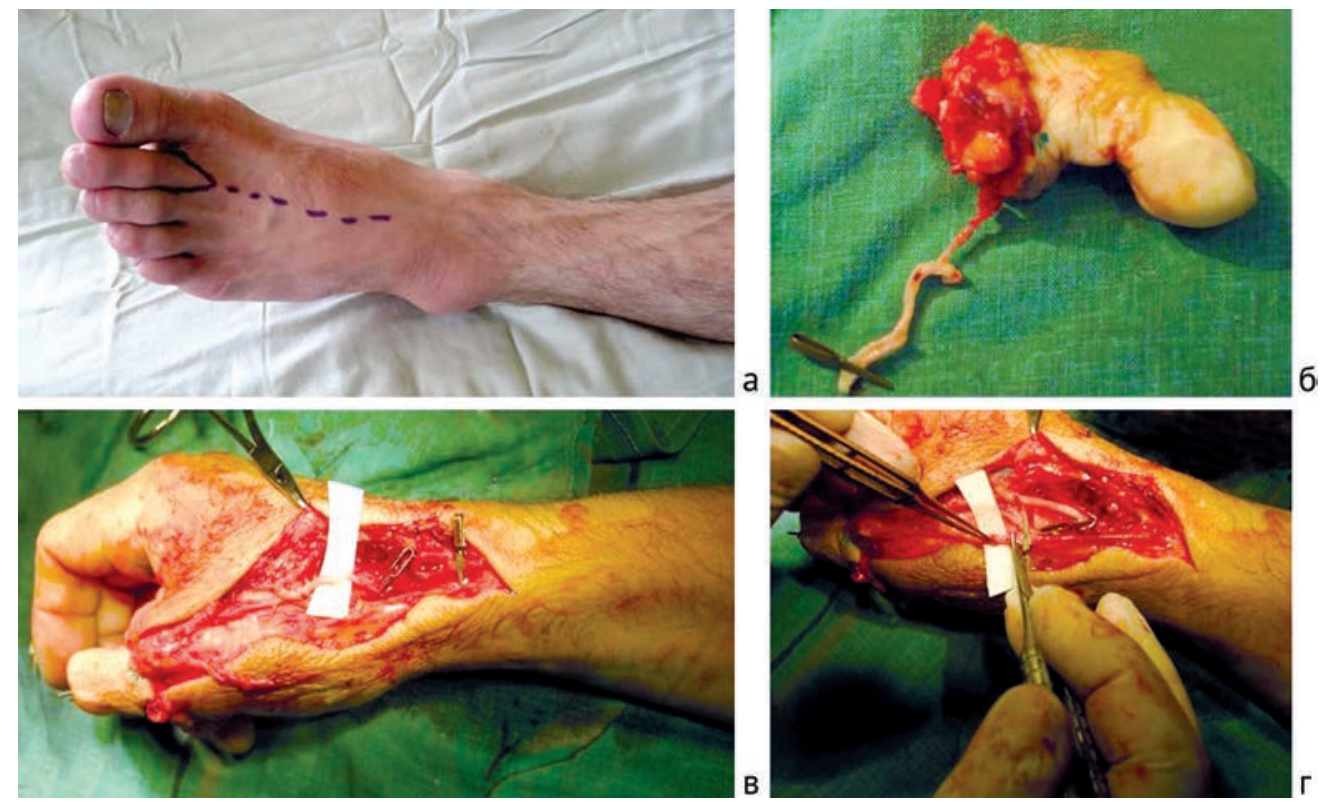

Рис. 1. Внешний вид (а) и рентгенограмма правой кисти (б) пациента В., 45 лет, диагноз: ампутационная культя 1 пальца правой кисти на кисть».

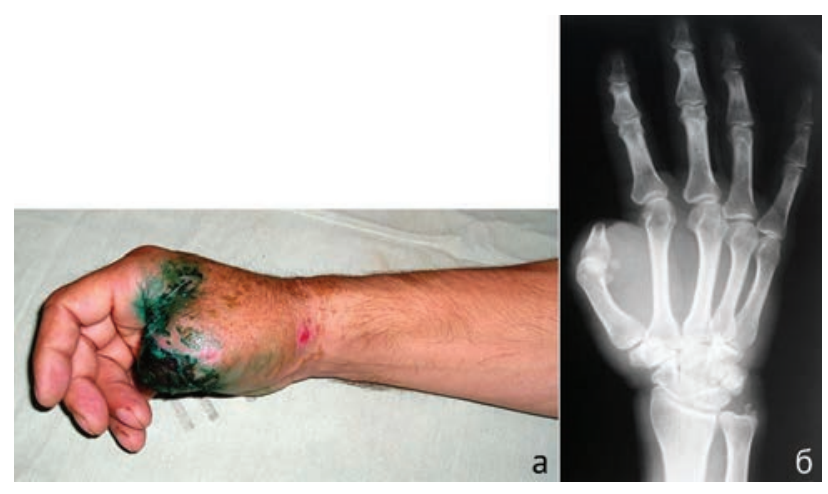

Рис. 2. Этапы операции: а - планирование хирургического доступа на донорской стопе; б - аутотрансплантат на питающих сосудах; в - этап наложения артериального анастомоза; г - этап наложения венозного анастомоза
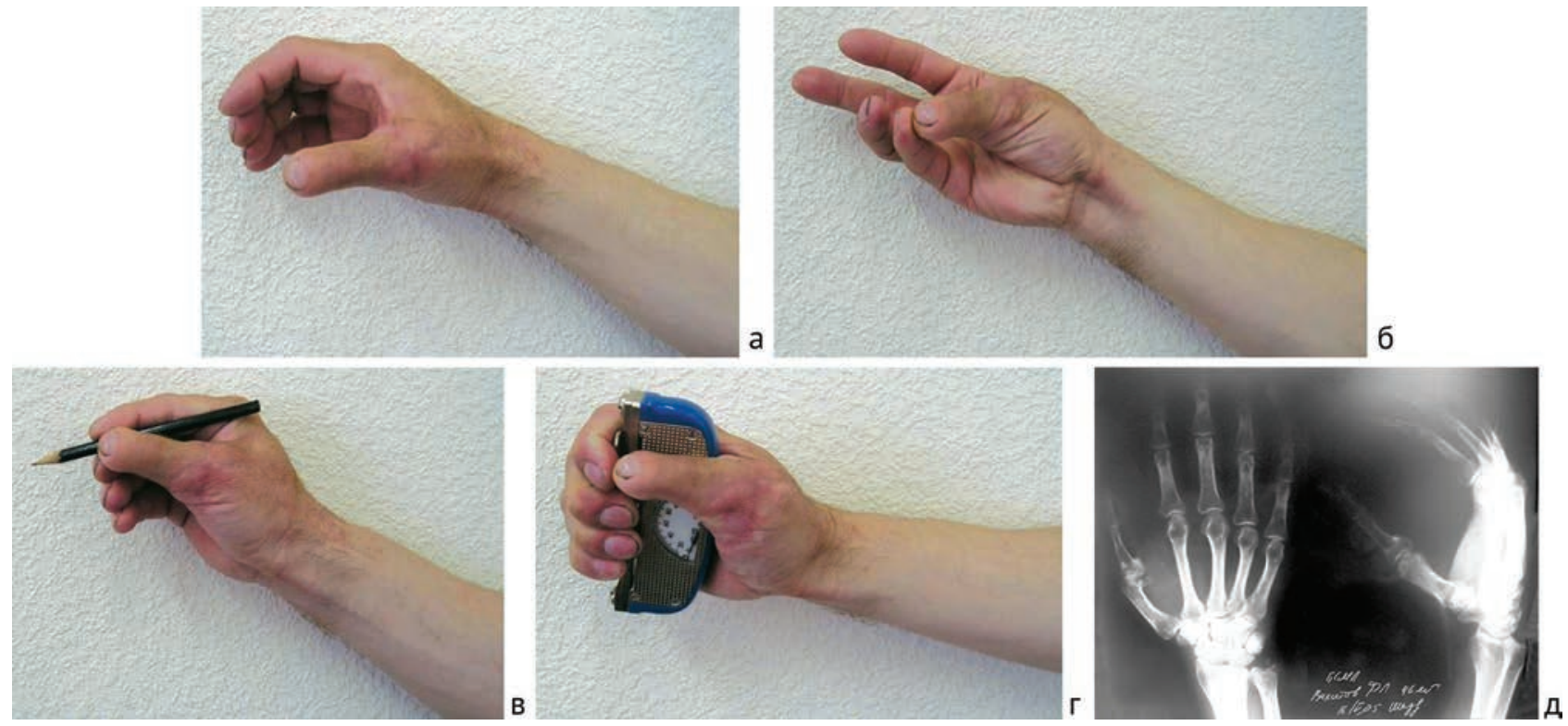

Рис. 3. Внешний вид (а-г) и рентгенограмма правой кисти (д) в отдаленном периоде после операции 


\section{ОБСУЖДЕНИЕ}

Планирование лечебных мероприятий у пациентов с посттравматическими дефектами первого пальца кисти должно основываться на раннем проведении реконструктивных вмешательств на поврежденных структурах, реализующих оптимизацию адаптации пациента в социальной среде, восстановление профессиональных навыков и функциональных возможностей в рамках бытовой адаптации [5, 6, 7, 9, 15, 16, 21, 23].

При реконструкции первого пальца кисти многими авторами предпочтение отдается методикам пластики кожно-костными лоскутами, причем восстановление мягкотканного компонента вновь сформированного пальца производится путем выкраивания стебля Филатова, сдвоенного лоскута Конверса-Блохина, несвободного пахового лоскута на трубчатой ножке. Костный остов пальца формируют фрагментом гребня подвздошной кости или лучевой кости. Подобные методики отличаются многоэтапностью лечения, что доставляет пациентам много неудобств в виде длительного порочного положения конечности и влечет за собой развитие тугоподвижности суставов, образования участков мацерации и частичного некроза кожных покровов. Эстетическая привлекательность травмированной кисти при реконструкции первого пальца вышеперечисленными лоскутами отставляет желать лучшего. Самым главным недостатком использования подобных лоскутов, по нашему мнению, является отсутствие у вновь образованных пальцев суставов, необходимых для выполнения различных захватов кисти. Также существенным недостатком реконструкции первого пальца кисти методом кожно-костной пластики является невозможность восстановления чувствительности лоскута [2, 8, 11, 12, 14, 22, 24].

Вышеперечисленных недостатков можно избежать при использовании для реконструкции первого пальца кисти метода свободной пересадки второго пальца стопы на микрохирургических анастомозах. Данная мето- дика позволяет в один этап выполнить реконструкцию первого пальца кисти с полным восстановлением всех анатомических структур, необходимых для полноценного функционирования, и значительно улучшить внешний вид травмированной кисти. Существенным недостатком реконструкции первого пальца кисти на основе использования свободной пересадки второго пальца стопы с наложением микрохирургических анастомозов является некроз аутотрансплантата. По сути, используется принцип «или все, или ничего». Данная проблема решается наличием опытной хирургической бригады [1, 4, 5, 6, 7, 9, 16, 17, 21, 33, 37].

При интерпретации отдаленных исходов лечения на основе доказательной медицины на современном этапе развития реконструктивной хирургии пальцев кисти главенствующим является восстановление функции вновь сформированного пальца и внешнего вида травмированной кисти [1, 3, 5, 6, 9, 10, 16, 17, 20, 21, 23, 27, 32, 36].

Таким образом, сложность выполнения реконструктивных операций на первом пальце кисти зачастую подталкивает специалистов к принятию более простого решения и использованию методов кожно-костной реконструкции, не предполагающих восстановление суставов вновь образованного пальца и, соответственно, исключающих реконструкцию захватов травмированной кисти, что негативно сказывается на функциональных перспективах кисти данного пациента. При оказании хирургической помощи пациентам с утратой первого пальца кисти следует придерживаться следующей доктрины - анатомическая реконструкция первого пальца и восстановление кинематики движений травмированной кисти с профессиональной, бытовой и социальной реинтеграцией пациентов. Оптимизация лечения пациентов с посттравматическими дефектами большого пальца кисти на основе использования пересадки второго пальца стопы, как органа, имеет важное научное и прикладное значение и является перспективным направлением.

\section{ЗАКЛЮЧЕНИЕ}

Анализ доступной современной литературы демонстрирует, что выбор вида и сроков хирургического лечения пациентов с утраченным первым пальцем кисти на сегодняшний день является не совсем решенной проблемой и предметом обсуждения в травматологии и ортопедии. При изучении отдаленных результатов реконструкции первого пальца кисти необходимо учитывать несколько факторов: воссоз- дание анатомии и эстетической привлекательности; восстановление необходимой амплитуды движений в суставах вновь образованного пальца и основных видов захвата; достижения необходимой силы травмированной кисти. Пересадка второго пальца стопы в позицию отсутствующего первого пальца кисти позволяет в быстрые сроки восстановить первый палец травмированной кисти.

\section{СПИСОК ИСТОчНИКОВ}

1. Адани Р., Морандини Э. Микрохирургическая реконструкция травмированного большого пальца кисти // Вопросы реконструктивной и пластической хирургии. 2013. Т. 16, № 1 (44). С. 6-19.

2. Способ полицизации кисти с травматическим дефектом первого луча : заявка 2001100634 Рос. Федерация : МПК А61В / 17/56 / Валеев М.М., Большаков Р.Е. ; заявитель Башкирский государственный медицинский университет. № 2001100634/14; заявл. 09.01.2001 ; опубл. 20.11.2002.

3. Способ восстановления утраченного первого пальца кисти : пат. Рос. Федерация : МПК А61В 17/00 / Губочкин Н.Г., Гайдуков В.М., Микитюк С.И., Лукичёва Н.П. ; патентообладатель Федеральное государственное бюджетное военное образовательное учреждение высшего профессионального образования Военно-медицинская академия им. С.М. Кирова Министерства обороны Российской федерации. № 2013156907/14 ; заявл. 20.12.2013 ; опубл. 20.05.2015, Бюл. № 14.

4. Versatility of Free Cutaneous Flaps for Upper Extremity Soft Tissue Reconstruction / H.D. Wang, J.C. Alonso-Escalante, B.H. Cho, R. DeJesus // J. Hand Microsurg. 2017. Vol. 9, No 2. P. 58-66. DOI: 10.1055/s-0037-1603918.

5. Минасов Б.Ш., Валеев М.М. Восстановление и формирование структурно-функциональных стереотипов у больных с дефектом I пальца кисти // Травматология и ортопедия России. 2005. № 3 (36). С. 21-25.

6. Реплантация и трансплантация как методы восстановления отчлененной конечности или ее сегментов / Ю.В. Новиков, В.В. Ключевский, К.П. Пшениснов, 3.С. Ходжабагян // Вопросы реконструктивной и пластической хирургии. 2016. № 2 (57). С. 63-73.

7. Хирургическое лечение пациентов с посттравматическими дефектами первого пальца кисти / Б.Ш. Минасов, И.З. Гарапов, М.М. Валеев, Э.М. Бикташева, Р.Р. Якупов, Т.Б. Минасов, Т.Р. Мавлютов // Уральский медицинский журнал. 2020. № 4 (187). С. 150-155.

8. Roger de Oña I., Garcia Villanueva A., Studer de Oуa A. An Alternative Thumb Reconstruction by Double Microsurgical Transfer from the Great and Second Toe for a Carpometacarpal Amputation // J. Hand Surg. Am. 2018. Vol. 43, No 10. P. 955.e1-955.e9. DOI: 10.1016/j.jhsa.2018.03.022. 
9. Валеев М.М., Гарапов И.З., Бикташева Э.М. Микрохирургические технологии при травматическом дефекте первого пальца кисти // Креативная хирургия и онкология. 2019. Т. 9, № 1. С. 44-49.

10. Новые подходы к реконструкции пальцев кисти / В.В. Азолов, Н.М. Александров, С.В. Петров, Е.В. Ручкина // Медицинский альманах. 2010. № 2 (11). С. 194-198.

11. Александров Н.М., Киселев Д.В., Углев О.И. Восстановление пальцев с использованием кровоснабжаемых кожно-костных комплексов у больных с тяжелыми посттравматическими деформациями кисти // Acta Medica Eurasica. 2015. № 4. С. 1-9.

12. Александров Н.М., Петров С.В. Кожно-костная реконструкция пальцев кисти с использованием кровоснабжаемых трансплантатов // Современные технологии в медицине. 2011. № 4. С. 22-27.

13. Reconstruction of post-traumatic upper extremity soft tissue defects with pedicled flaps: An algorithmic approach to clinical decision making / R. Naalla, S. Chauhan, A. Dave, M. Singhal // Chin. J. Traumatol. 2018. Vol. 21, No 6. P. 338-351. DOI: 10.1016/j.cjtee.2018.04.005.

14. Александров Н.М., Петров С.В. Реконструкция пальцев кисти с использованием традиционных и микрохирургических методик // Травматология и ортопедия России. 2010. Т. 16, № 3 (57). С. 111-117.

15. Posterior interosseous flap versus reverse adipofascial radial forearm flap for soft tissue reconstruction of dorsal hand defects / O. Akdağ, G. Yıldıran, M. Sütsü, M. Karameşe // Ulus. Trauma Acil. Cerrahi. Derg. 2018. Vol. 24, No 1. P. 43-48. DOI: 10.5505/tjtes.2017.41196.

16. Валеев М.М., Бикташева Э.М. Формирование первого пальца кисти путем свободной пересадки второго пальца стопы : материалы конф. «Проблемные вопросы травматологии и ортопедии» // Здравоохранение Башкортостана. 2006. № S2. C. 139-142.

17. Микрохирургическая аутотрансплантация пальцев стопы на кисть у детей / С.И. Голяна, Н.В. Авдейчик, Д.Ю. Гранкин, А.В. Сафонов // Современные проблемы науки и образования. 2019. № 6. С. 150.

18. Шведовченко И.В. Врожденные пороки развития кисти. Общие положения микрохирургических реконструкций // Вопросы реконструктивной и пластической хирургии. 2017. Т. 20, № 1 (60). С. 28-35. DOI: 10.17223/1814147/60/03.

19. Стабильный функциональный остеосинтез переломов костей кисти : материалы 2 Всерос. съезда кистевых хирургов / М.М. Валеев, Д.В. Моисеев, С.А. Чистиченко, А.О. Фаизов, С.С. Прасад, Э.М. Валеева // Травматология и ортопедия России. 2008 . № S2 (Приложение). С. 15-16.

20. Сравнительный анализ эстетических и функциональных результатов закрытия обширных дефектов покровных тканей первого пальца кисти / И.З. Гарапов, Б.Ш. Минасов, М.М. Валеев, Э.М. Бикташева // Медицинский вестник Башкортостана. 2017. Т. 12, № 1 (67). С. 36-42.

21. Шведовченко И.В., Кольцов А.А. Пересадка пальцев стопы на кисть у детей с врожденной и приобретенной патологией - основные проблемы и пути их решения // Анналы пластической, реконструктивной и эстетической хирургии. 2017. № 1. С. 163-164.

22. Реконструкция пальцев кисти с использованием кожно-костных трансплантатов на микрососудистых анастомозах / Н.М. Александров, С.В. Петров, Д.А. Купцов, M.S. Petrov // Современные технологии в медицине. 2020. Т. 12, № 1. С. 16-24.

23. Курбанов У.А., Давлатов А.А., Джанобилова С.М. Особенности реплантации и реконструкции большого пальца кисти // Вестник Авиценны. 2012. № 2 (51). С. 7-20.

24. Валеев М.М., Гарапов И.З., Бикташева Э.М. Способ поллицизации кисти // Илизаровские чтения : науч.-практ. конф. с междунар. участием «Костная патология: от теории до практики», посвящ. 95-летию со дня рождения Г.А. Илизарова, 65-летию метода Илизарова, 45-летию Центра Илизарова : материалы. Курган, 2016. С. 87-88.

25. Segu S.S., Athavale S.N., Manjunath P. Osteoplastic Reconstruction for Post Traumatic Thumb Amputations around Metacarpophalangeal Joint // J. Clin. Diagn. Res. 2015. Vol. 9, No 8. P. PC11-13. DOI: 10.7860/JCDR/2015/14334.6404.

26. Устранение посттравматических дефектов покровных тканей верхних конечностей / М.Х. Маликов, К.П. Артыков, Г.Д. Карим-Заде, Д.Д. Джононов, Н.А. Махмадкулова, М.А. Хасанов // Пластическая хирургия и эстетическая медицина. 2020. № 1. С. 54-62.

27. Кутянов Д.И., Родоманова Л.А. Современные принципы и тенденции использования осевых кровоснабжаемых лоскутов в реконструктивной хирургии конечностей // Травматология и ортопедия России. 2015. № 1 (75). С. 106-115.

28. Валеев М.М. Медицинская реабилитация больных с последствиями повреждений верхней конечности на основе хирургических технологий : автореф. дис. ... д-ра мед. наук. Уфа, 2006. 41 с.

29. Коррекция мягкотканных дефектов и последствий повреждения сосудисто-нервных пучков верхних конечностей / Г.Д. Карим-Заде, М.Х. Маликов, Э.К. Ибрагимов, Х. Нарзилло, Х.Ф. Мирзобеков, Н.А. Махмадкулова // Вестник Авиценны. 2018. Т. 20, № 4. С. 395-401.

30. Способ двухэтапной пересадки пальца стопы на кисть : пат. 2345726 С1 Рос. Федерация : МПК А61В 17/56 / Родоманова Л.А., Кочиш А.Ю., Полькин А.Г., Наконечный Д.Г., Аксюк Е.Ф. ; патентообладатель ФГУ «Российский научно-исследовательский институт травматологии и ортопедии им. Р.P. Вредена Федерального агентства по высокотехнологичной медицинской помощи». № 2007126442/14 ; заявл. 11.07.2007 ; опубл. 10.02.2009, Бюл. № 4 .

31. Березуцкий С.Н., Чечурин А.С., Воловик В.Е. Артериализированные венозные лоскуты в реконструктивной хирургии кисти и пальцев (обзор иностранной литературы) // Здравоохранение Дальнего Востока. 2018. № 4 (78). С. 64-68.

32. Yoon W.Y., Lee B.I. Fingertip reconstruction using free toe tissue transfer without venous anastomosis // Arch. Plast. Surg. 2012 . Vol. 39 , No 5. P. 546-550. DOI: 10.5999/aps.2012.39.5.546.

33. Валеев М.М. Использование аутовитальных лоскутов у больных с дефектом мягких тканей конечностей // Здравоохранение Башкортостана. 2004. № 6. С. 67-80.

34. Андрусон М.В. Кожная пластика при открытых повреждениях кисти и пальцев // Ортопедия, травматология и протезирование. 2015 . № 4 (601). С. 85-90.

35. Голяна С.И., Гранкин Д.Ю. Ангиоархитектоника сосудов, питающих аутотрансплантат второго пальца стопы, и варианты их «подключения» к реципиентным сосудам при пересадке на кисть у детей // Современные проблемы науки и образования. 2018. № 6. С. 107.

36. Тактика лечения посттравматических дефектов мягких тканей конечностей / Е.Ю. Шибаев, П.А. Иванов, А.В. Неведров, М.П. Лазарев, А.П. Власов, Л.Л. Цоглин, А.Л. Рыбинская // Журнал им. Н.В. Склифосовского Неотложная медицинская помощь. 2018. Т. 7, № 1. С. 37-43.

37. Александров Н.М., Купцов Д.А., Вешаев И.Д. Атипичное перемещение сегментов кисти при последствиях травмы // Современные проблемы науки и образования. 2020. № 5. С. 137.

38. Социальная, бытовая и профессиональная реинтеграция больных с дефектами мягких тканей на основе функциональной и эстетической реабилитации / Б.Ш. Минасов, М.М. Валеев, И.Э. Нигамедзянов, А.Ю. Жуков. Уфа : Здравоохранение Башкортостана, 2005. 188 с.

39. Toe Tissue Transfer for Reconstruction of Damaged Digits due to Electrical Burns / H. D. Kim, S.M. Hwang, K.R. Lim, Y.H. Jung, S.M. Ahn, J.K. Song // Arch. Plast. Surg. 2012. Vol. 39, No 2. P. 138-142. DOI: 10.5999/aps.2012.39.2.138.

Статья поступила в редакцию 12.05.2020; одобрена после рецензирования 25.02.2021; принята к публикации 23.12.2021.

The article was submitted 12.05.2020; approved after reviewing 25.02.2021; accepted for publication 23.12.2021.

\section{Информация об авторах:}

1. Булат Шамильевич Минасов - доктор медицинских наук, професcop, B.minasov@ya.ru;

2. Ильнур Зиннурович Гарапов - garap1@mail.ru;

3. Элина Маратовна Бикташева - кандидат медицинских наук, dr.elinabiktasheva@yandex.ru;

4. Марат Мазгарович Валеев - доктор медицинских наук, valeevmm@rambler.ru;

5. Расуль Радикович Якупов - доктор медицинских наук, rasulr@mail.ru;

6. Тимур Булатович Минасов - доктор медицинских наук, m004@yandex.ru;

7. Тагир Рыфатович Мавлютов - доктор медицинских наук, mavlutovtagir@mail.ru.

\section{Information about authors:}

1. Bulat Sh. Minasov - Doctor of Medical Sciences, Professor, B.minasov@ya.ru;

2. Ilnur Z. Garapov - M.D., dr.elinabiktasheva@yandex.ru;

3. Elina M. Biktasheva - Candidate of Medical Sciences, dr.elinabiktasheva@yandex.ru;

4. Marat M. Valeev - Doctor of Medical Sciences, valeevmm@rambler.ru;

5. Rasul R. Iakupov - Doctor of Medical Sciences, rasulr@mail.ru;

6. Timur B. Minasov - Doctor of Medical Sciences, m004@yandex.ru;

7. Tagir R. Mavliutov - Doctor of Medicine, mavlutovtagir@mail.ru. 
Гений ортопедии. 2022. Т. 28, № 1. С. 39-45.

Genij Ortopedii. 2022. Vol. 28, no. 1. P. 39-45.

\section{Научная статья}

УДК 616.747.65-001-089.168-073

https://doi.org/10.18019/1028-4427-2022-28-1-39-45

\section{Оптимизация лечения повреждений сухожилий разгибателей пальцев кисти в первой зоне Фируз Фарходович Камолов ${ }^{\bowtie}$, Владимир Федорович Байтингер, Константин Владимирович Селянинов}

Научно-исследовательский институт микрохирургии, Томск, Россия

Автор, ответственный за переписку: Фируз Фарходович Камолов, shurab56@yandex.ru

\section{Аннотация}

Несмотря на значительный прогресс в хирургии кисти, результаты лечения повреждений сухожилий разгибателей пальцев кисти в 1-й зоне совершенно не устраивают ни пациентов, ни врачей. Сложность анатомического строения и функции разгибательного аппарата пальцев кисти, а также значительное количество $(15,7 \%)$ неудовлетворительных исходов лечения этих травм [1, 2, 3] придают данной проблеме особую актуальность. Цель. Улучшить результаты диагностического исследования и хирургического лечения пациентов с повреждением сухожилий разгибателей пальцев кисти в 1-й зоне. Материалы и методы. В исследование были включены две группы пациентов: 1-я (контрольная) группа - пациенты с отрывом сухожилия разгибателя от основания ногтевой фаланги и подкожным разрывом в 1-й зоне, лечившихся амбулаторно без операции в различных поликлиниках г. Томска (n = 149); 2-я (основная) группа (n = 163) - пациенты с подкожным разрывом сухожилия в 1-й зоне, которым проведено хирургическое лечение. Пациентам обеих групп выполняли рентгенологическое и ультразвуковое исследование области повреждения. Оценку результатов проводили при помощи субъективной шкалы DASH и объективной оценки по шкале J.P. Crawford. Результаты и обсуждение. По критерию J.P. Crawford у 132 из 149 пациентов контрольной группы наблюдали дефицит разгибания ногтевой фаланги различной степени, всего у 17 пациентов получен отличный результат, тогда как по шкале DASH только 45 из 149 пациентов не смогли полноценно выполнить указанные задачи в соответствии с тестом. У всех 163 пациентов основной группы, подвергнутых хирургическому восстановлению сухожилия, на диагностическом этапе выявили положение в суставах пальцев кисти, обеспечивающее максимальное сближение концов поврежденного сухожилия разгибателя пальцев кисти в 1-й зоне в физиологическом положении. Оценка результатов хирургического лечения у данной группы пациентов по J.P. Crawford показала отличные и хорошие результаты у всех 163 прооперированных пациентов, а по шкале DASH все пациенты смогли выполнить указанные действия.

Ключевые слова: сухожилия разгибателей кисти, подкожное повреждение, молоткообразный палец, блокирующий шов

Для цитирования: Камолов Ф.Ф., Байтингер В.Ф., Селянинов К.В. Оптимизация лечения повреждений сухожилий разгибателей пальцев кисти в 1-й зоне // Гений ортопедии. 2022. Т. 28, № 1. С. 39-45. https://doi.org/10.18019/1028-4427-2022-28-1-39-45

\section{Original article}

\section{Optimization of the treatment of finger extensor tendon injuries in $1^{\text {st }}$ zone Firuz F. Kamolov ${ }^{凶}$, Vladimir F. Baitinger, Konstantin V. Selyaninov}

Scientific Research Institute of Microsurgery, Tomsk, Russian Federation

Corresponding author: Firuz F. Kamolov, shurab56@yandex.ru

Abstract

Despite the apparent simplicity of diagnosis and treatment of injuries of the finger extensor tendons, the number of unsatisfactory outcomes reaches 10-15.7\%, and $61.2 \%$ in combined injuries. The small volume of extensor excursions (a small lever to the joint), unlike the flexors, requires a special attitude to the surgical restoration of the extensors. The accuracy of extensor length recovery is an essential factor in successful treatment. Purpose of the study was to develop diagnostic and surgical algorithms for the treatment and rehabilitation of hammer-like deformity of the fingers. Material and methods The study included two groups of patients with dropped distal phalanx of the fingers. The control group consisted of patients $(n=149)$ with a separation of the extensor tendon from the tuberosity of the nail phalanx. The main group $(n=163)$ were patients with tendon rupture at the level of the joint space. Patients in both groups underwent radiographic and ultrasound examination. Evaluation of the results was carried out using the subjective DASH criterion and objective assessment according to J.P. Crawford. Results Most patients in the control group were diagnosed with a tendon separation from the tuberosity of the nail phalanx. These patients were treated with a diagnosis of damage to the extensor tendons of the fingers in the 1st zone. Thus, the treatment tactics did not correspond to the diagnosis and is the reason for the deficiency of extension of the distal phalanx of the fingers of the hand after conservative therapy. According to the evaluation criterion (J.P. Crawford), the distal phalanx was observed in the majority of patients $(n=132)$, and according to the subjective assessment of DASH, only 45 could not fully perform these tests. In the patients of the main group at the diagnostic (ultrasound) stage, the position in the joints of the fingers of the hand was revealed, where the diastasis approached maximally between the damaged ends of the extensor tendon of the fingers of the hand in the 1st zone. Assessment of treatment results in this group of patients according to J.P. Crawford received excellent and good results, and according to DASH, all patients were able to perform these actions. Conclusions For the diagnosis of drooping distal phalanges of the fingers, it is necessary to apply x-ray and ultrasound examinations. Patients with an extensor tendon separation from the tuberosity of the nail phalanges should undergo surgical treatment using the blocking suture method. After surgical treatment of patients with subcutaneous rupture of the extensor tendons of the fingers in the 1st zone, immobilize the hand in the physiological position. Keywords: extensor tendons, subcutaneous tendon rupture, mallet finger

For citation: Kamolov F.F., Baitinger V.F., Selyaninov K.V. Optimization of the treatment of finger extensor tendon injuries in $1^{\text {st }}$ zone. Genij Ortopedii, 2022, vol. 28, no 1, pp. 39-45. https://doi.org/10.18019/1028-4427-2022-28-1-39-45

\section{ВВЕДЕНИЕ}

«Mallet finger» - молоткообразная деформация дистальной фаланги пальцев кисти. Частота закрытых повреждений сухожилий разгибателей пальцев кисти, приводящая к свисанию (провисанию) дистальной фаланги, составляет 1,5-3,0 \% от всех травм кисти [1-3]. Механизм закрытого повреждения сухожилия разгибателя на уровне дистальной фаланги пальца связан с неожи- данно резким ее сгибанием, когда палец встречает препятствие при быстром движении [4-8]. При этом происходит поперечный разрыв сухожилия дистальнее места слияния боковых пучков, на уровне его прикрепления $\mathrm{k}$ дистальной фаланге $[6,9,10]$, вследствие чего последняя принимает положение сгибания в дистальном межфаланговом суставе (дМФС). Это объясняется превали-

(c) Камолов Ф.Ф., Байтингер В.Ф., Селянинов К.В., 2022 
рованием тонуса глубокого сгибателя, фиксирующегося к ладонной поверхности дистальной фаланги [5, 11-13]. В некоторых случаях при mallet finger сухожилие разгибателя пальца остается интактным. Происходит отрыв сухожилия от основания ногтевой фаланги вместе с фрагментом кости [4, 7, 14, 15]. Переломы ногтевой фаланги в месте прикрепления сухожилия разгибателя пальца кисти составляют 17 \% [6, 9, 14, 16] от всех внутрисуставных переломов фаланг пальцев кисти. В обоих случаях молоткообразную деформацию лечат в амбулаторных условиях в объеме иммобилизации дистальной фаланги в разогнутом в дМФС положении различными видами шин, предполагая, что такое положение обеспечит четкое сближение поврежденных концов сухожилия и фиксацию костного отломка [5, 12, 15, 17-19]. Результаты консервативного лечения редко кем анализируются. Лишь некоторые пациенты, для которых функция дистальной фаланги важна (музыканты, парикмахеры,

\section{МАТЕРИАЛЫ И МЕТОДЫ}

На базе клиники АНО «НИИ микрохирургии» (г. Томск) были обследованы две группы пациентов в период 2014-2020 гг.

Клинически оба повреждения приводили к «mallet finger» дистальной фаланги пальцев кисти.

В первую группу (контрольную) были включены 149 человек, которым ранее проведено консервативное лечение. Всех пациентов контрольной группы лечили методом иммобилизации дистальной фаланги различными фиксирующими материалами в положении переразгибания.

Половозрастная характеристика пациентов контрольной группы была следующей: мужчин в группе было 84 (56,4 \%), женщин - 65 (43,6 \%). Возраст пациентов варьировал от 18 до 74 лет, средний возраст составил 41,30 \pm 13,36 года. Структура повреждений сухожилий разгибателей пальцев у пациентов контрольной группы в зависимости от того, какая именно (правая или левая) кисть вовлечена в патологический процесс, представлена в таблице 1 .

Основную группу составили 163 пациента с закрытыми повреждениями сухожилий разгибателей пальцев кисти в 1-й зоне (167 пальцев), прооперированных в Институте микрохирургии (г. Томск) за период
IT-инженеры), обращаются в стационары для восстановления полной подвижности дистального межфалангового сустава пальцев кисти. Однако в оперативном лечении остаются нерешенными вопросы, касающиеся технологии дифференцированного лечения обеих форм «mallet finger», адекватной послеоперационной иммобилизации, реабилитации и оценки результатов лечения.

Цель работы: улучшить результаты диагностического исследования и хирургического лечения пациентов с повреждением сухожилий разгибателей пальцев кисти в 1-й зоне.

\section{Задачи:}

1) оценить результаты консервативного лечения пациентов с молоткообразной деформацией пальцев кисти;

2) определить тактику хирургического лечения при повреждении сухожилий разгибателей пальцев кисти в 1-й зоне.

с 2014 по 2020 г. Возраст пациентов варьировал от 19 до 72 лет, средний возраст составил 44,90 \pm 11,67 года, по половому признаку группа состояла из 95 (58,2 \%) мужчин и 68 (41,8 \%) женщин.

Структура повреждений сухожилий разгибателей пальцев у пациентов основной группы в зависимости от того, какая именно (правая или левая) кисть вовлечена в патологический процесс, представлена в таблице 2.

С целью отбора пациентов для участия в обследовании были разработаны критерии включения и исключения:

1-я группа (контрольная):

- критерий включения: отрыв сухожилия разгибателя от основания ногтевой фаланги по классификации J.R. Doyle (1-й тип повреждения);

- критерий исключения: открытые повреждения сухожилий разгибателей в 1-й зоне.

2-я группа:

- критерий включения: подкожный разрыв сухожилия разгибателя в 1-й зоне (I-V палец);

- критерии исключения: открытые повреждения дистальной фаланги;

- застарелое повреждение сухожилий разгибателей в 1-й зоне.

Таблица 1

Локализация повреждений пальцев кисти в контрольной группе пациентов ( $\mathrm{n}=149)$

\begin{tabular}{|c|c|c|c|c|c|c|c|c|c|c|c|c|}
\hline \multirow{3}{*}{ Кисть } & \multicolumn{10}{|c|}{ Палец } & \multirow{2}{*}{\multicolumn{2}{|c|}{ Итого }} \\
\hline & \multicolumn{2}{|c|}{ I } & \multicolumn{2}{|c|}{ II } & \multicolumn{2}{|c|}{ III } & \multicolumn{2}{|c|}{ IV } & \multicolumn{2}{|c|}{ V } & & \\
\hline & $\mathrm{n}$ & $\%$ & $\mathrm{n}$ & $\%$ & $\mathrm{n}$ & $\%$ & $\mathrm{n}$ & $\%$ & $\mathrm{n}$ & $\%$ & $\mathrm{n}$ & $\%$ \\
\hline Левая & 4 & 4,3 & 11 & 11,8 & 28 & 30,1 & 23 & 24,7 & 27 & 29,0 & 93 & 62,4 \\
\hline Правая & 1 & 1,8 & 8 & 14,3 & 15 & 26,8 & 15 & 26,8 & 17 & 30,4 & 56 & 37,6 \\
\hline Всего & 5 & 3,4 & 19 & 12,8 & 43 & 28,9 & 38 & 25,5 & 44 & 29,5 & 149 & 100 \\
\hline
\end{tabular}

Таблица 2

Локализация повреждений пальцев кисти в основной группе пациентов (n = 163)

\begin{tabular}{|c|c|c|c|c|c|c|c|c|c|c|c|c|}
\hline \multirow{3}{*}{ Кисть } & \multicolumn{10}{|c|}{ Палец } & \multirow{2}{*}{\multicolumn{2}{|c|}{ Итого }} \\
\hline & \multicolumn{2}{|c|}{ I } & \multicolumn{2}{|c|}{ II } & \multicolumn{2}{|c|}{ III } & \multicolumn{2}{|c|}{ IV } & \multicolumn{2}{|c|}{ V } & & \\
\hline & $\mathrm{n}$ & $\%$ & $\mathrm{n}$ & $\%$ & $\mathrm{n}$ & $\%$ & $\mathrm{n}$ & $\%$ & $\mathrm{n}$ & $\%$ & $\mathrm{n}$ & $\%$ \\
\hline Правая & 3 & 4,9 & 1 & 1,6 & 30 & 49,2 & 17 & 27,9 & 10 & 16,4 & 61 & 37,4 \\
\hline Левая & 4 & 3,9 & 11 & 10,8 & 29 & 28,4 & 36 & 35,3 & 22 & 21,6 & 102 & 62,6 \\
\hline Всего & 7 & 4,3 & 12 & 7,4 & 59 & 36,2 & 53 & 32,5 & 32 & 19,6 & 163 & 100 \\
\hline
\end{tabular}


Всем пациентам с молоткообразной деформацией ногтевой фаланги пальцев кисти проводили рентгенологическое и ультразвуковое исследование для верификации диагноза и распределения по группам (рис. 1).

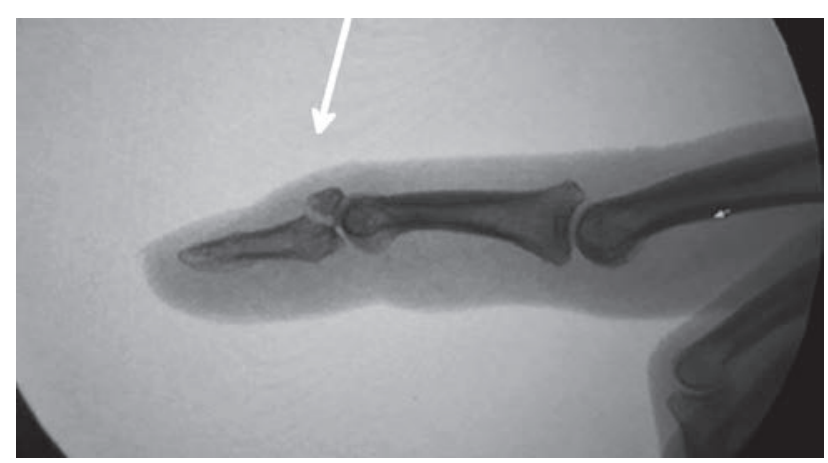

Рис. 1. Рентгенограмма III пальца кисти, пациент контрольной группы. Перелом основания ногтевой фаланги (mallet finger) Стрелкой показана зона перелома

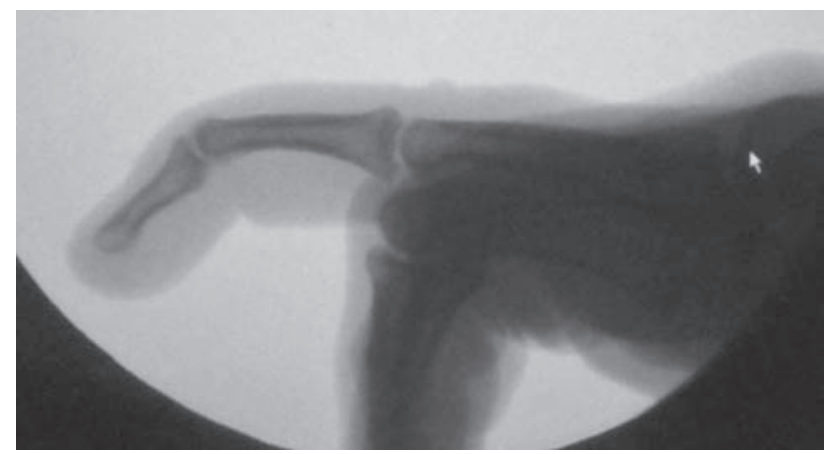

Рис. 2. Рентгенограмма III пальца кисти, пациент основной группы. Структура костей III пальца не нарушена (mallet finger)

Для определения эффективности представленной методики нами использовались критерии субъективной оценки DASH и объективной оценки по G.P. Crawford. Через 6 недель после лечения пациенты исследовались на предмет наличия/отсутствия дефицита разгибания дистальной фаланги пальцев кисти (рис. 3 а, б). Исследование данного параметра проводили с учетом критериев G.P. Crawford (табл. 3) с помощью угломера (рис. 3, в) [20].
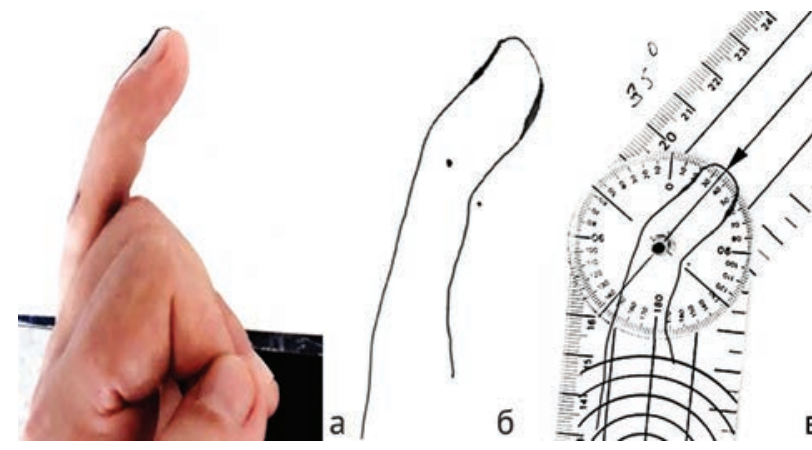

Рис. 3. Определение дефицита разгибания дистальной фаланги с помощью угломера
Критерии оценки функции дистальных фаланг пальцев кисти по G.P. Crawford

\begin{tabular}{|l|l|}
\hline Результат & Описание \\
\hline Отличный & $\begin{array}{l}\text { Полное сгибание-разгибание, отсутствие } \\
\text { боли }\end{array}$ \\
\hline Хороший & $\begin{array}{l}\text { дефицит разгибания 0-10, полное } \\
\text { сгибание, отсутствие боли }\end{array}$ \\
\hline Удовлетворительный & $\begin{array}{l}\text { дефицит разгибания 10-25ㅇ, } \\
\text { незначительный дефицит сгибания, } \\
\text { отсутствие боли }\end{array}$ \\
\hline Неудовлетворительный & $\begin{array}{l}\text { Дефицит разгибания более } 25^{\circ}, \\
\text { постоянные боли }\end{array}$ \\
\hline
\end{tabular}

Пациентов основной группы исследовали по субъективным данным анкеты DASH до и после оперативного лечения, они самостоятельно в течение двух недель оценивали функцию своей кисти. Сумму баллов в анкете рассчитывали по формуле:

$\mathrm{DASH}=($ сумма $\mathrm{n}$ ответов $/ \mathrm{n}-1) \times 25$,

где $\mathrm{n}$ - количество заполненных ответов.

Методы статистической обработки материала

Сравнение групп по количественным показателям было проведено при помощи непараметрических критериев. Величины уровней значимости указаны в виде абсолютных значений либо (в случае экспоненциальных величин) как $\mathrm{p}<0,0001$.

Анализ количественных шкал на нормальность распределения проводили по D-критерию КолмогороваСмирнова и W-критерию Шапиро-Уилка.

Статистический анализ был проведен с использованием пакета программ IBM SPSS Statistics (версия 25.0).

Основная конечная точка исследования была сформулирована следующим образом: доля ответов по результатам лечения, выраженная в частоте успешных исходов по шкале Крауфорда через 6 месяцев после лечения.

Данный показатель является частотным и представляет собой свернутый до следующего вида вариант шкалы Крауфорда: «неудовлетворительный» и «удовлетворительный» виды исходов расценивают как «неприемлемый» исход, а «отличный» и «хороший» виды исходов - как «успешный» исход. Оценка этого показателя была проведена при помощи точного критерия Фишера для всех пациентов, завершивших исследование согласно предусмотренного плана.

Вторичные конечные точки исследования:

1. Величина баллов по шкале DASH, измеренная спустя 3 месяца после лечения.

Данный показатель является количественной переменной. Сравнение было проведено при помощи непараметрического критерия Манна-Уитни (для межгруппового сравнения), а также методом Вилкоксона (для внутригруппового анализа).

2. Дефицит разгибания дистальных фаланг пальцев кисти, измеренный в градусах, спустя 3 месяца после консервативной терапии.

Данный показатель является количественной переменной. Сравнение было проведено при помощи непараметрического критерия Манна-Уитни.

\section{РЕЗУЛЬТАТЫ}

Из 149 пациентов контрольной группы у 132 человек имелся различной величины дефицит разгибания дистальной фаланги. 45 человек (34,1 \%) испытывали затруднение в повседневной жизни, поскольку этот де- фицит доставлял им дискомфорт в профессиональной деятельности. Из них у 11 пациентов с повреждением III пальца правой (ведущей) руки, несмотря на достигнутый хороший результат по J.P. Crawford, имелось 
функциональное ограничение в деятельности. 15 пациентов с удовлетворительными результатами (двое из них с ведущей левой рукой) имели дефицит разгибания II пальца 12-16. У 21 пациента с повреждением IV и $\mathrm{V}$ пальцев правой кисти (все пациенты с ведущей правой рукой) выявлен плохой результат по Crawford, и дефицит разгибания дистальной фаланги превышал $25^{\circ}$.

Таким образом, результаты консервативного лечения повреждений сухожилия разгибателя I-V пальцев (1-я зона), проведенного у пациентов контрольной группы, оцененные по J.P. Crawford и согласно опросника DASH, оказались неоднозначными: по объективному показателю дефицита разгибания дистальной фаланги самые плохие результаты были получены после восстановления сухожилия $\mathrm{V}$ пальца рабочей правой кисти, где дефицит разгибания в среднем превышал $25^{\circ}$. По мере уменьшения дефицита разгибания пальцы располагались в следующем порядке: V, IV, III, II, I, дефицит разгибания дистальных фаланг составил 7-20․ Субъективные данные, оцененные с помощью опросника DASH, показали, что у 87 пациентов, имеющих различный дефицит разгибания дистальной фаланги, последний не вызывал никакого дискомфорта - ни в части самообслуживания, ни в части профессиональной деятельности пациентов. И только 45 из 132 пациентов отмечали неудовлетворенность полученным результатом лечения. Это были лица, для которых восстановление функции дистального МФС имело принципиальное значение (музыканты, парикмахеры, офисные работники).

Клинические примеры результатов после консервативной терапии пациентов контрольной группы представлены на рисунке 4.

Результаты оценки по критерию дефицита разгибания дистальных фаланг пальцев кисти по J.P. Crawford приведены на рисунке 5.

Результаты УЗИ поврежденного пальца пациентов основной группы, проведенного для определения диастаза между поврежденными концами сухожилия разгибателя в 1-й зоне, показали, что сближение/расхождение концов зависит от положения суставов пальцев кисти. При полном разгибании в суставах пальца кисти диастаз между поврежденными концами увеличивался (рис. 6).
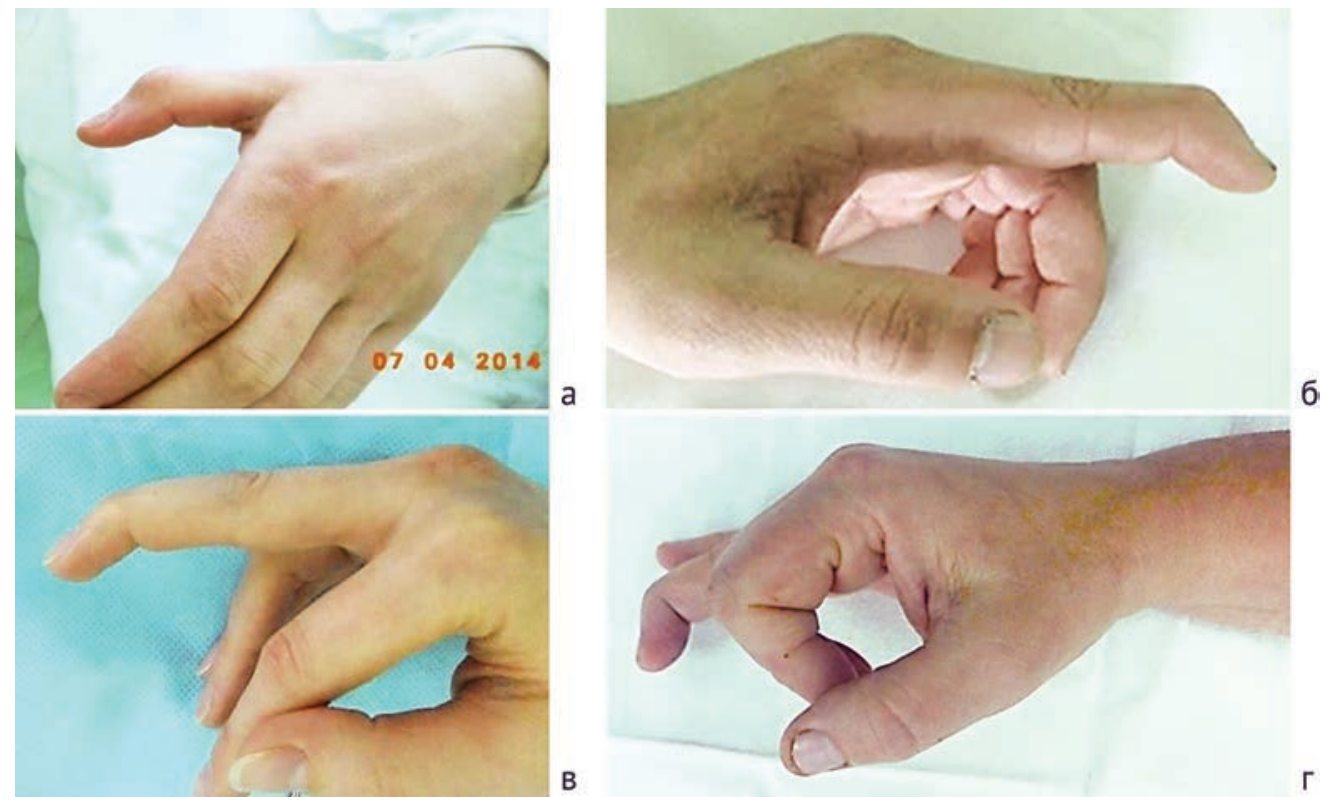

Рис. 4. Клинические примеры. Фото кисти: а - больной Л., 25 лет, отрыв сухожилия разгибателя I пальца левой кисти в 1-й зоне; б - больной Ш., 47 лет, отрыв сухожилия разгибателя II пальца левой кисти в 1-й зоне; в - больной Б., 47 лет, отрыв сухожилия разгибателя III пальца правой кисти в 1-й зоне; г - больной О., 71 год, отрыв сухожилия разгибателя IV пальца правой кисти в 1-й зоне

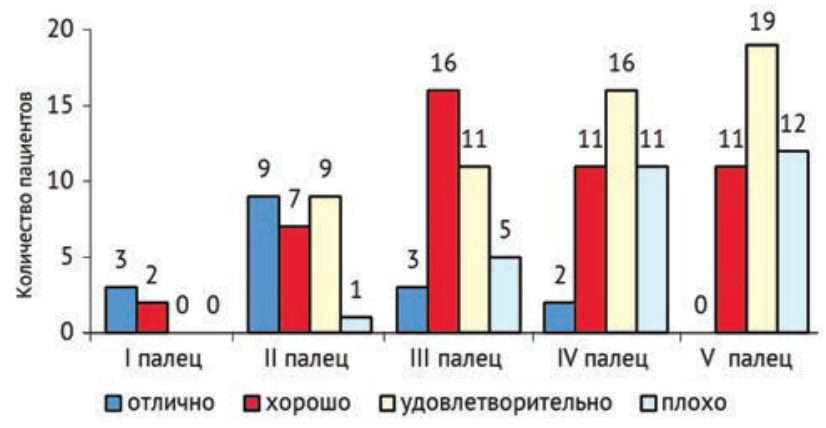

Рис. 5. Распределение пациентов контрольной группы по дефициту разгибания дистальных фаланг пальцев кисти (J.P. Crawford)
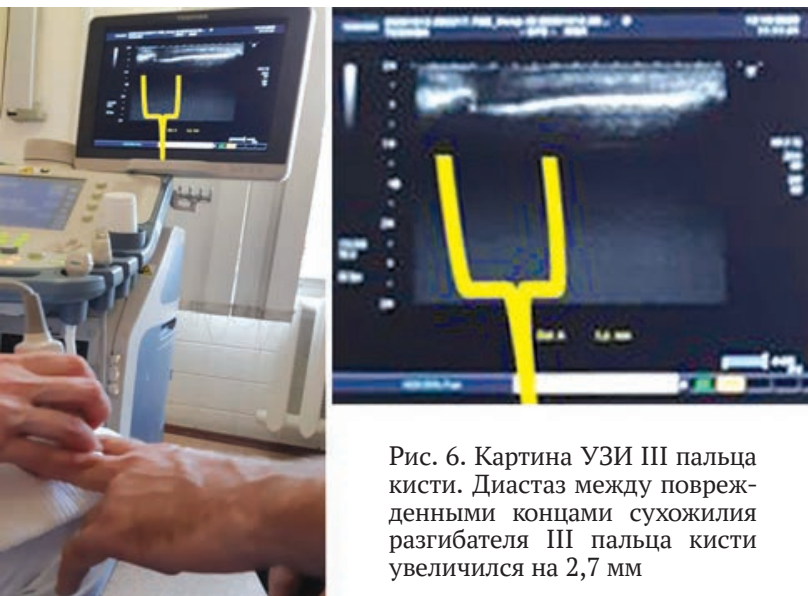

Рис. 6. Картина УЗИ III пальца кисти. Диастаз между поврежденными концами сухожилия разгибателя III пальца кисти увеличился на 2,7 мм 
После придания пальцу физиологического положения (рис. 7, а): сгибание в пястно-фаланговом суставе $60^{\circ}$, проксимальном МФС - $40^{\circ}$ и дистальном МФС - $0^{\circ}$ привело к максимальному сближению поврежденных концов сухожилия разгибателя в 1-й зоне (рис. 7, б).
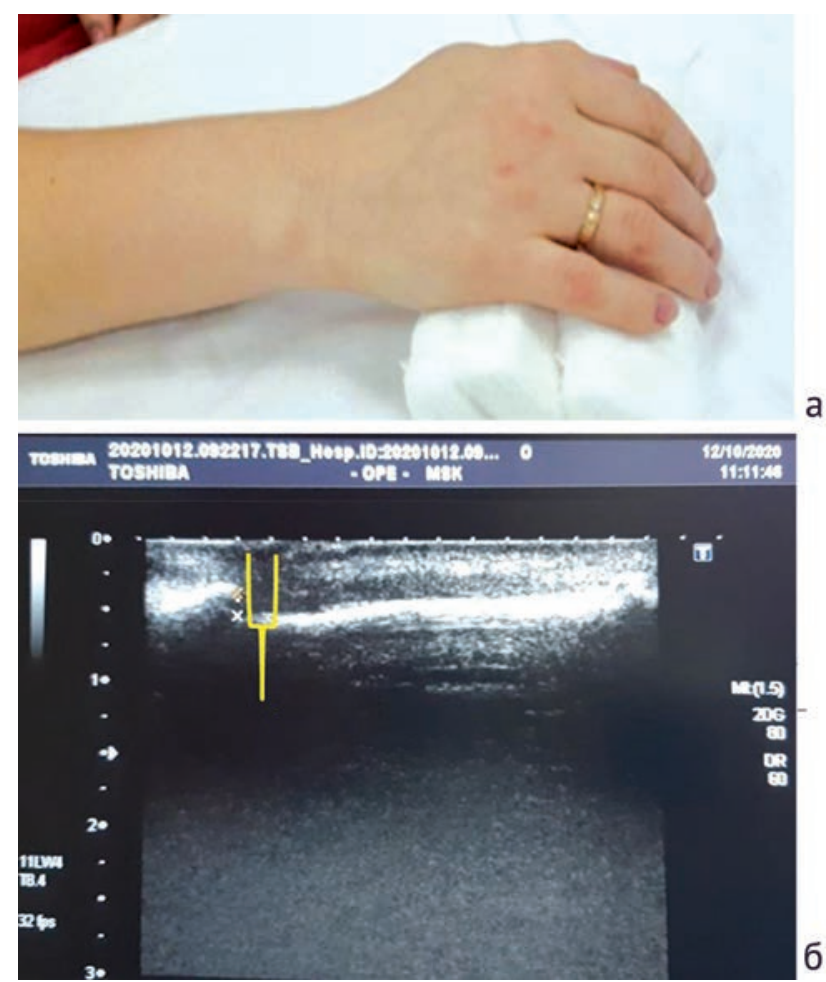

Рис. 7. Пациент Л.: а - физиологическое положение кисти; б-ультразвуковое исследование поврежденного пальца правой кисти, максимальное сближение поврежденных концов сухожилия на $1,4 \mathrm{~mm}$

Следующим этапом проводили оперативное лечение. После обескровливания пальца выполняли регионарную анестезию 1 \%-м раствором Лидокаина (5 мл). Разрез кожи в виде буквы «П» производили над дистальным МФС для доступа к зоне повреждения сухожилия (рис. 8 a). После приведения пальцев кисти в физиологическое положение поврежденные концы сухожилия максимально сблизились (рис. 8,6 ).
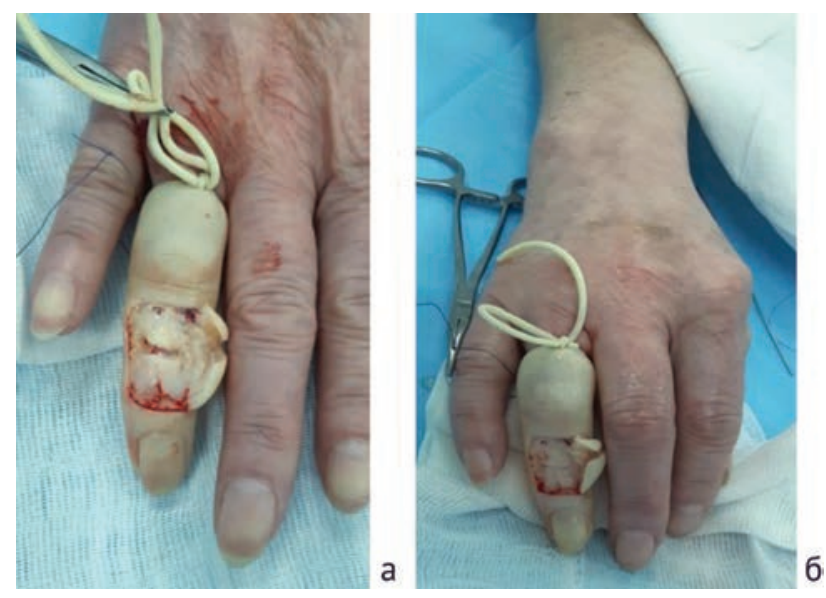

Рис. 8. Интраоперационное определение диастаза между поврежденными концами сухожилия разгибателя IV пальца правой кисти пациентки С.: a - поврежденные концы сухожилия расходятся; б - в физиологическом положении пальца поврежденные концы максимально сблизились
После получения максимального сближения концов приступали к восстановлению непрерывности сухожилия разгибателя пальцев кисти в 1-й зоне П-образным швом нитью викрил 4.0. На кожу накладывали узловые швы нитью монофил 4.0., асептическую повязку. Обязательно проводили гипсовую иммобилизацию суставов пальцев кисти в физиологическом положении. Иммобилизация длилась в течение 6 недель. После истечения срока иммобилизации проводили УЗИ для определения зрелости сухожильного регенерата. Пациенты основной группы также самостоятельно разрабатывали движения в суставах пальцев кисти. Оценку результатов исследования у пациентов основной группы проводили не ранее чем через 3 месяца.

Таким образом, интраоперационное исследование подтвердило данные УЗИ: сближение поврежденных концов сухожилия разгибателя в 1-й зоне происходит в физиологическом положении пальцев кисти. Расхождение поврежденных концов сухожилия разгибателя пальцев кисти в 1-й зоне происходило при фиксации дистального МФС в положении разгибания и при каждом движении (сгибание/разгибание) в ПФС и проксимальном МФС.

\section{Результаты статистических исследований}

По основной конечной точке исследования нами была зарегистрирована статистически значимая разница между группами пациентов по частоте успешных (суммированных «отличных» и «хороших») исходов лечения на основе оценок по свернутой шкале Crawford. В основной группе доля таких исходов практически в 2,36 раза превышала таковую в группе контроля и составила 151 случай против 64 ( $\mathrm{p}<0,00001$ для точного критерия Фишера) соответственно (рис. 10).

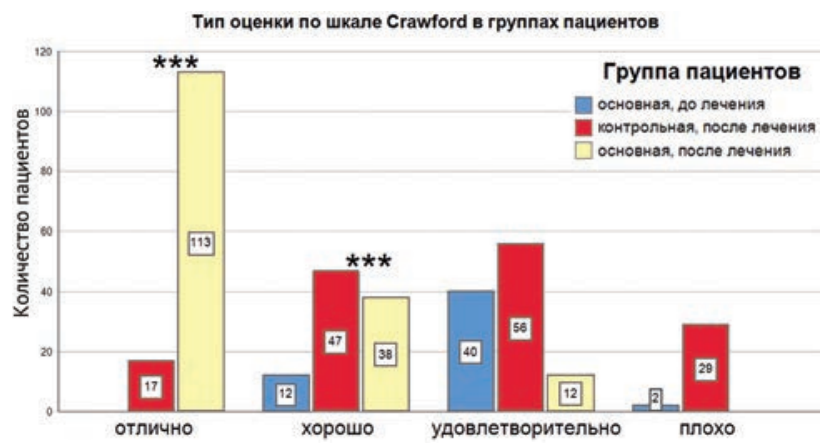

Рис. 10. Диаграмма результатов оценки по шкале Crawford в исследованных группах пациентов; *** - p < 0,00001 для точного критерия Фишера

В основной группе сумма баллов по данной шкале была более чем в 5,7 раза меньше таковой в контрольной группе $(Z=-9,029 ; \mathrm{p}<0,00001)$ и стремилась к околонулевым значениям, которые характеризуются как наиболее благоприятный вид результата согласно принципам интерпретации данной шкалы (рис. 11).

В основной группе сумма баллов по данной шкале была более чем в 5,7 раза меньше таковой в контрольной группе $(Z=-9,029 ; \mathrm{p}<0,00001)$ и стремилась к околонулевым значениям, которые характеризуются как наиболее благоприятный вид результата согласно принципам интерпретации данной шкалы (DASH) (рис. 12). 


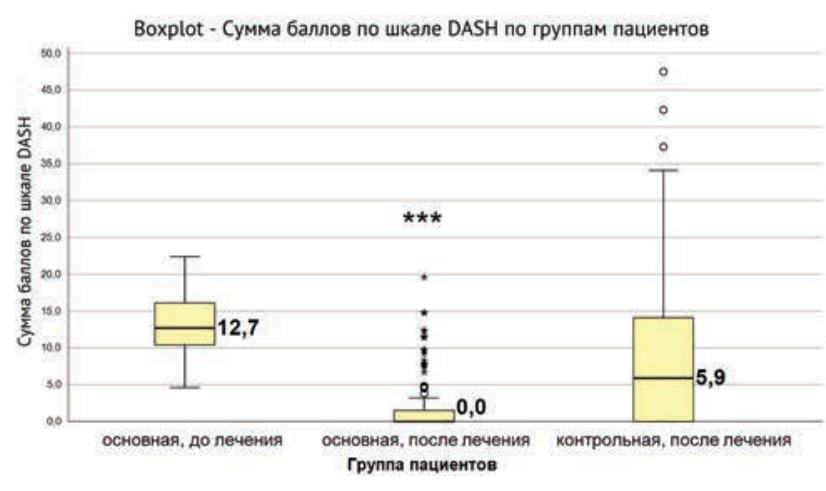

Рис. 11. Диаграмма результатов оценки по сумме баллов по шкале DASH; *** - p < 0,00001 для U-критерия Манна-Уитни

Проверка зависимости значений по шкале DASH от шкалы Крауфорда в группах пациентов по критерию Краскела-Уоллиса показала наличие в обеих группах статистически значимых отличий суммы баллов по шкале DASH в зависимости от присвоенной пациенту оценки по шкале Крауфорда (Н-критерий Краскела-

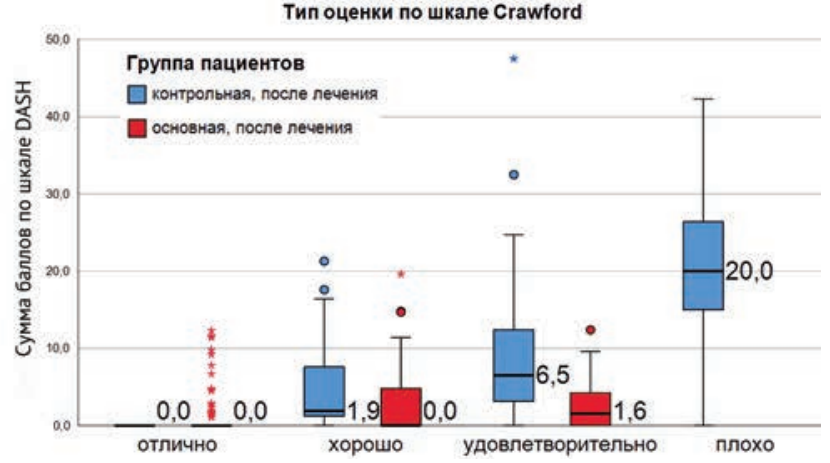

Рис. 12. Диаграмма оценки различий между группами по шкале DASH и шкале Crawford

Уоллиса $=16,140 ; \mathrm{p}=0,000313$ для основной группы и Н-критерий Краскела-Уоллиса = 70,736; $\mathrm{p}<0,0001$ для контрольной группы) - то есть результат по шкале DASH менялся в ту или иную сторону пропорционально результату оценки конкретного пациента по шкале Крауфорда.

\section{ОБСУЖДЕНИЕ}

В мировом сообществе кистевой хирургии до настоящего времени применяют методику фиксации дистального МФС после оперативного лечения или консервативной терапии в разогнутом положении. Предполагается, что такое положение приводит к сближению поврежденных концов сухожилия разгибателей пальцев кисти в 1-й зоне. В своей работе мы использовали результаты хирургического лечения пациентов с подкожными разрывами сухожилий разгибателей пальцев кисти в 1-й зоне, проанализировав исходы лечения пациентов контрольной и основной групп. На основе проведенных исследований в контрольной группе пациентов мы выявили дефицит разгибания дистальной фаланги разных степеней у 132 (88,6 \%) пациентов. При этом 45 (30,2 \%) пациентов испытывали затруднение в повседневной жизни, поскольку дефицит разгибания доставлял им дискомфорт в их профессиональной деятельности.

Возможно, из-за оценки только субъективных данных после различного рода лечения пациентов с подкожными повреждениями сухожилий разгибателей пальцев кисти в 1-й зоне, полученных хороших и отличных результатов, многие исследователи не стали искать причину дефицита разгибания дистальных фа- ланг пальцев кисти. В литературных источниках мы не нашли информации об отдаленных результатах лечения повреждений сухожилий разгибателей пальцев кисти в 1-й зоне. С разрывом сухожильного механизма на уровне дистальной фаланги сила разгибания концентрируется на проксимальном межфаланговом суставе. Со временем, особенно, если растягивается ладонная фиброзная пластина, это приводит к его переразгибанию и возникновению деформации по типу «лебединая шея» [3, 12, 21-23]. Поэтому даже небольшая деформация дистальной фаланги, связанная с травмой сухожилия разгибателя в 1-й зоне, требует обязательного лечения с целью дальнейшего предупреждения деформации и нарушений функции проксимальных фаланг пальцев кисти.

Таким образом, пациентам с отрывом сухожилия разгибателя с костным отломком от основания дистальной фаланги целесообразно проведение хирургического лечения с фиксацией костного отломка вместе с сухожилием к месту отрыва. При консервативном лечении и после хирургического лечения пациентов с подкожным разрывом сухожилий разгибателей пальцев кисти в 1-й зоне необходимо добиваться надежного тесного сопоставления поврежденных концов сухожилия.

\section{ВЫВОды}

1. Анализ результатов лечения пациентов контрольной группы по опроснику DASH показал, что субъективная оценка функциональности дистальных фаланг пальцев кисти оказалась выше в связи с малой значимостью мелкой моторики кисти для большинства пациентов.

2. С учетом биомеханики движения пальцев кисти иммобилизация должна обеспечить сближение поврежденных концов сухожилия разгибателей пальцев кисти в 1-й зоне и снять натяжение с сухожильного шва. Оптимальным вариантом иммобилизации при повреждении сухожилия разгибателей пальцев кисти в 1-й зоне является физиологическое положение: (II$\mathrm{V}$ пальцев кисти) сгибание в ПФС на 50-65, проксимальном МФС - на 30-40 и дистальном МФС - $0^{\circ}$, а для первого пальца: сгибание и локтевая девиация лучезапястного сустава на $10^{\circ}$, сгибание в ПФС на $20^{\circ}$, дистальном МФС - на $10^{\circ}$. 


\section{СПИСОК ИСТОЧнИКОВ}

1. Байтингер В.Ф., Голубев И. О. Очерки клинической анатомии кисти. Томск : Дельтаплан, 2012. С. 78-83.

2. Geyman J.P., Fink K., Sullivan S.D. Conservative versus surgical treatment of mallet finger: a pooled quantitative literature evaluation // J. Am. Board Fam. Pract. 1998. Vol. 11, No 5. P. 382-390. DOI: 10.3122/15572625-11-5-382.

3. Alla S.R., Deal N.D., Dempsey I.J. Current concepts: mallet finger // Hand (N Y). 2014. Vol. 9, No 2. P. 138-144. DOI: 10.1007/s11552-014-9609-y.

4. Leinberry C. Mallet finger injuries // J. Hand Surg. Am. 2009. Vol. 34, No 9. P. 1715-1717. DOI: 10.1016/j.jhsa.2009.06.018.

5. Байтингер В.Ф., Камолов Ф.Ф. Опыт хирургического лечения подкожного повреждения сухожилия длинного разгибателя I пальца кисти // Вопросы реконструктивной и пластической хирургии. 2015. № 3 (54). С. 12-17.

6. Lamaris G.A., Matthew M.K. The Diagnosis and Management of Mallet Finger Injuries // Hand (N Y). 2017. Vol. 12, No 3. P. $223-228$. DOI: $10.1177 / 1558944716642763$.

7. Delayed Extension Block Pinning in 27 Patients with Mallet Fracture / T.J.M. Kootstra, J. Keizer, M. van Heijl, S. Ferree, M . Houwert, D. van der Velde // Hand (N Y). 2021. Vol. 16, No 1. P. 61-66. DOI: 10.1177/1558944719840749.

8. Неттов Г.Г. Опыт лечения свежих повреждений разгибателей пальцев кисти // Практическая медицина. 2013. Т. 2, № 1-2 (69). С. $112-113$.

9. Капанджи А.И. Физиология суставов. Верхняя конечность : схемы биомеханики человека с комментариями / пер. с англ. Г.М. Абелевой, Е.В. Кишиневского). 6-е изд. М. : ЭКСМО, 2009. Т. 1. С. 278-284.

10. Mallet finger - diagnosis, classification and treatment / P. Rosinsky, O. Sarig, Y. David, A. Oron // Harefuah. 2018. Vol. 157, No 2. P. $104-107$.

11. Коршунов В.Ф., Москвин А.Д., Магдиев Д.А. Лечение закрытых повреждений сухожильно-апоневротического растяжения пальцев на уровне дистального межфалангового сустава // Ортопедия, травматология и протезирование. 1988. № 8. С. $12-14$.

12. Байтингер В.Ф., Камолов Ф.Ф. Отдаленные результаты хирургического лечения закрытых повреждений сухожилия разгибателя II-V пальцев кисти в I зоне // Вопросы реконструктивной и пластической хирургии. 2014. Т. 17, № 2 (49). С. 61-66.

13. Bachoura A., Ferikes A.J., Lubahn J.D. A review of mallet finger and jersey finger injuries in the athlete // Curr. Rev. Musculoskelet. Med. 2017. Vol. 10, No 1. P. 1-9. DOI: 10.1007/s12178-017-9395-6.

14. Rocchi L., Genitiempo M., Fanfani F. Percutaneous fixation of mallet fractures by the "umbrella handle" technique // J. Hand Surg. Br. 2006. Vol. 31, No 4. P. 407-412. DOI: 10.1016/j.jhsb.2006.04.014.

15. Open reduction and compression with double Kirschner wires for the treatment of old bony mallet finger / J. Tang, K. Wu, J. Wang, J. Zhang // J. Orthop. Surg. Res. 2019. Vol. 14, No 1. P. 459. DOI: 10.1186/s13018-019-1513-2.

16. Valdes K., Naughton N., Algar L. ICF components of outcome measures for mallet finger: A systematic review // J. Hand Ther. 2016. Vol. 29 , No 4. P. 388-395. DOI: 10.1016/j.jht.2016.06.005.

17. Review of Acute Traumatic Closed Mallet Finger Injuries in Adults / S. Salazar Botero, J.J. Hidalgo Diaz, A. Benaïda, S. Collon, S. Facca, P.A. Liverneaux // Arch. Plast. Surg. 2016. Vol. 43, No 2. P. 134-144. DOI: 10.5999/aps.2016.43.2.134.

18. Modification of the Internal Suture Technique for Mallet Finger / B. Jiang, P. Wang, Y. Zhang, J. Zhao, Q. Dong // Medicine (Baltimore). 2015. Vol. 94, No 6. P. e536. DOI: 10.1097/MD.0000000000000536.

19. Georgescu A.V., Capota I.M., Matei I.R. A new surgical treatment for mallet finger deformity: Deepithelialised pedicled skin flap technique // Injury. 2013. Vol. 44, No 3. P. 351-355. DOI: 10.1016/j.injury.2013.01.013.

20. Crawford G.P. The molded polythene splint for mallet finger deformities // J. Hand Surg. Am. 1984. Vol. 9, No 2. P. 231-237. DOI: 10.1016/s03635023(84)80148-3.

21. Clinical results of tension band fixation of avulsion fractures of the hand / R. Bischoff, U. Buechler, R. De Roche, J. Jupiter // J. Hand Surg. Am. 1994. Vol. 19, No 6. P. 1019-1026. DOI: 10.1016/0363-5023(94)90109-0.

22. Stern P.J., Kastrup J.J. Complications and prognosis of treatment of mallet finger // J. Hand Surg. Am. 1988. Vol. 13, No 3. P. 329-334. DOI: 10.1016/ s0363-5023(88)80002-9.

23. Gruber J.S., Bot A.G., Ring D. A prospective randomized controlled trial comparing night splinting with no splinting after treatment of mallet finger // Hand (N Y). 2014. Vol. 9, No 2. P. 145-150. DOI: 10.1007/s11552-013-9600-z.

Статья поступила в редакцию 09.10.2020; одобрена после рецензирования 23.11.2020; принята к публикации 23.12.2021.

The article was submitted 09.10.2020; approved after reviewing 23.11.2020; accepted for publication 23.12.2021.

\section{Информация об авторах:}

1. Фируз Фарходович Камолов - shurab56@yandex.ru;

2. Владимир Федорович Байтингер - доктор медицинских наук, професcop, заслуженный врач РФ, baitinger@mail.tomsknet.ru;

3. Константин Владимирович Селянинов - доктор медицинских наук.

\section{Information about the authors:}

1. Firuz F. Kamolov - M.D., shurab56@yandex.ru;

2. Vladimir F. Baitinger - Doctor of Medical Sciences, Professor, Honored Doctor of the Russian Federation, baitinger@mail.tomsknet.ru;

3. Konstantin V. Selyaninov - Doctor of Medical Sciences.

Этика публикации: пациенты дали добровольное информированное согласие на участие в исследовании.

Конфликт интересов: не заявлен.

Источник финансирования: АНО НИИ «микрохирургии». 
Гений ортопедии. 2022. Т. 28, № 1. С. 46-52.

Genij Ortopedii. 2022. Vol. 28, no. 1. P. 46-52.

\section{Научная статья \\ удК 616.728.3-018.3-001.5+616.728.3-007.55]-089 \\ https://doi.org/10.18019/1028-4427-2022-28-1-46-52 \\ Индивидуальный подход к лечению пациентов с повреждением медиального мениска в сочетании с варусной деформацией голени}

\section{Л.К. Брижань, Д.В. Давыдов, А.А. Керимов, Б.В. Тюлькевич $₫$, Д.А. Найда}

Главный военный клинический госпиталь имени академика Н.Н. Бурденко, Москва, Россия

Автор, ответственный за переписку: Борис Владимирович Тюлькевич, 1983loki@mail.ru

\section{Аннотация}

Введение. Разрыв мениска является одним из самых распространенных повреждений коленного сустава, на долю разрывов медиального мениска приходится 23-31 \% от всех травм коленного сустава. Основным методом лечения разрыва мениска является его парциальная резекция. 13,5 \% больным в течение 15 лет после резекции мениска выполняется эндопротезирование, что расценивается как неудовлетворительный результат. Цель. Оценить и сравнить отдаленные клинико-функциональные и рентгенологические результаты оперативного лечения пациентов с повреждением медиального мениска в сочетании с варусной деформацией голени и без нее. Материалы и методы. С 2013 по 2020 г. было прооперировано 245 пациентов по поводу повреждения медиального мениска. Больные были разделены на 4 группы. В группу 1 вошли больные с механическим феморотибиальным углом (МФТУ) от $0^{\circ}$ до $3^{\circ}$, которым выполнена артроскопическая резекция мениска (AРМ). В группе 2 всем больным также выполнялась АРМ, а МФТУ был больше $3^{\circ}$. В группе 3 больным с МФТУ от $3^{\circ}$ до $5^{\circ}$ выполнялась симультанно АРМ и проксимальная остеотомия малоберцовой кости (ПОМК) с формированием её дефекта. В группу 4 вошли больные с МФТУ более $5^{\circ}$, которым выполнена высокая вальгизирующая остеотомия большеберцовой кости (ВВОБК) с АРМ. Оценка изменения основных референтных линий и углов проводилась на телерентгенограммах. Оценка функциональных результатов проводилась до и после операции по шкалам Lysholm Knee Scoring Scale, 2000 IKDC, KOOS. Результаты. Изолированная резекция мениска у пациентов с МФТУ более $3^{\circ}$ без его коррекции приводит к постепенному увеличению деформации, в течение первого года после операции на $1,07 \pm 0,5^{\circ}$, а к пятому году - на $2,2 \pm 0,7^{\circ}$. В группах 1,3 и 4 статистически значимого увеличения МФТУ за все время наблюдения не выявлено. Клинические результаты лечения больных четырех групп в первые три года после операции статистически не различались, однако в сроки от 3 до 5 лет у больных с МФТУ больше $3^{\circ}$, которым выполнялась только АРМ, результаты лечения были хуже, чем в остальных группах ( $<$ < 001). Выводы. Индивидуальный подход к методу оперативного лечения при повреждениях медиального мениска, в зависимости от МФТУ, позволяет скорректировать положение механической оси нижней конечности и МФТУ, тем самым улучшить отдаленные клиникофункциональные и рентгенологические результаты оперативного лечения.

Ключевые слова: разрыв мениска, варусная деформация голени, высокая вальгизирующая остеотомия, проксимальная остеотомия малоберцовой кости

Для цитирования: Индивидуальный подход к лечению пациентов с повреждением медиального мениска в сочетании с варусной деформацией голени / Л.К. Брижань, Д.В. Давыдов, А.А. Керимов, Б.В. Тюлькевич, Д.А. Найда // Гений ортопедии. 2022. Т. 28 , № 1. С. 46-52. https://doi.org/10.18019/1028-4427-2022-28-1-46-52

\section{Original article}

\section{Personalized approach to the treatment of patients with medial meniscus tear combined with varus deformity of the tibia \\ L.K. Brizhan, D.V. Davydov, A.A. Kerimov, B.V. Tyulkevich $₫$, D.A. Nayda}

N.N. Burdenko Main Military Clinical Hospital, Moscow, Russian Federation

Corresponding author: Boris V.Tyulkevich,1983loki@mail.ru

Abstract

Introduction Meniscus tear is one of the most common injuries of the knee joint. Medial meniscus tear accounts for 23-31 \% of knee joint injuries. The main method of treatment is partial resection. As reported, $13.5 \%$ of patients undergo arthroplasty within 15 years after meniscus resection, what is regarded as an unsatisfactory result. Purpose To evaluate and compare the long-term clinical, functional and radiological results of surgical treatment in patients with medial meniscus tear combined with varus deformity of the tibia and without it. Materials and methods From 2013 to 2020 , medial meniscus tear was treated in 245 patients. The patients were divided into 4 groups. Group 1 included patients with a mechanical femorotibial angle (MFTA) from $0^{\circ}$ to $3^{\circ}$ who had arthroscopic meniscus resection (AMR). In the $2^{\text {nd }}$ group, all patients also underwent AMR, but their MFTA was more than $3^{\circ}$. In group 3, patients with MFTA from $3^{\circ}$ to $5^{\circ}$ underwent simultaneous AMR and proximal fibular osteotomy (PFO) with the formation of a defect. Group 4 included patients with MFTA more than $5^{\circ}$, who underwent high tibial osteotomy (HTO) and AMR. Changes in the main lines and angles were assessed with telemetry radiography of the lower extremities. Functional results were evaluated before and after surgery using the Lysholm Knee Scoring Scale, 2000 IKDC, KOOS. Results Isolated meniscus resection in patients with MFTA more than $3^{\circ}$ without axial correction leads to a gradual increase in the deformity by $1,070 \pm 0.50^{\circ}$ during the first year after surgery, and by $2.20 \pm 0.70^{\circ}$ to the fifth year. In groups 1,3 and 4 , there was no statistically significant increase in MFTA during the entire observation period. The clinical treatment results of patients of the four groups in the first three years after surgery did not differ statistically. However, within the period from 3 to 5 years, patients with MFTA greater than $3^{\circ}$ who underwent only AMR had poorer clinical results than in the other groups $(\mathrm{p}<0.001)$. Conclusions A personalized approach to the method of surgical treatment for medial meniscus tear based on the MFTA enables to correct the mechanical axis of the lower extremities and MFTA, and thus improve the long-term clinical, functional and radiological results of surgical treatment.

Keywords: meniscus tear, varus tibial deformity, high tibial osteotomy, proximal fibular osteotomy

For citation: Brizhan L.K., Davydov D.V., Kerimov A.A., Tyulkevich B.V., Nayda D.A. Personalized approach to the treatment of patients with medial meniscus tear combined with varus deformity of the tibia. Genij Ortopedii, 2022, vol. 28, no 1, pp. 46-52. https://doi.org/10.18019/1028-44272022-28-1-46-52

\section{ВВЕДЕНИЕ}

Разрывы менисков являются одной из самых распространенных травм коленного сустава, и по данным отечественных и зарубежных авторов, показатель коле- блется от 0,61 до 0,70 на 1000 человек в год, достигая 8,27 среди молодых пациентов с высоким уровнем физической активности [1-3]. Учитывая то, что сотруд- 
ники силовых структур подвергаются повышенным физическим нагрузкам, ввиду особенности и характера условий службы, частота повреждений менисков у них выше на 15-20 \%, чем среди гражданского населения. Также отмечается высокая частота повреждений менисков среди спортсменов различных игровых видов спорта, особенно у футболистов, баскетболистов и борцов [4].

Одним из основных методов лечения разрывов мениска является его парциальная или субтотальная резекция. Однако при оценке результатов лечения больных через 15 лет после менискэктомии получены неутешительные данные. 13,5 \% больным в течение 15 лет после операции было выполнено эндопротезирование, причем женщинам оно выполнялось в два раза чаще, чем мужчинам [5]. Таким образом, эндопротезирование после резекции мениска выполнялось в 10 раз чаще чем в среднем в популяции, особенно плачевная ситуация в группе молодых пациентов в возрасте до 40 лет, где частота выполнения эндопротезирования увеличивается в 40 раз [5]. В первую очередь это связано с тем, что функция мениска долгое время недооценивалась. При его резекции происходит нарушение биомеханических взаимоотношений в коленном суставе, которое приводит к необратимому повреждению хряща, покрывающего суставные поверхности костей. Одним из основных факторов риска, приводящим к прогрессированию деформирующего артроза коленного сустава, является нарушение механической оси нижней конечности в виде варусной деформации голени [6]. В своем исследовании Yoon К.Н. с соавторами показали, что резекция медиального мениска ведет к прогрессированию варсуной деформации на $1,7 \pm 1,5^{\circ}$ [7]. Changwan Kim с соавторами произвели оценку прогрессирования стадии деформирующего артроза по Kellgren-Lawrence и изменение высоты суставной щели у пациентов, которым была выполнена резекция медиального мениска. Пациенты были разделены на две группы, в первую вошли больные с нормальной дооперационной осью нижних конечностей, а во вторую - больные с варусной деформацией более $3^{\circ}$. По результатам исследования у больных первой группы различия в стадии деформирующего артроза и высоты суставной щели до и после операции были статистически не значимы, а во второй отмечено значимое прогрессирование деформирующего артроза и снижение высоты суставной щели [8]. Таким образом, угол варусной деформации влияет на результаты лечения больных с разрывом медиального мениска.

Для коррекции варусной деформации голени в настоящее время в клинической практике в основном применяется ВВОБК $[9,10]$, однако при небольшой деформации применение ВВОБК остается спорным. В таких случаях для разгрузки медиального отдела коленного сустава может применятся ПОМК [11, 12]. Эти операции можно рассматривать как профилактические вмешательства, направленные на предотвращение развития гонартроза [13-15].

В настоящее время не существует алгоритма и показаний для проведения оперативного лечения у пациентов с повреждением медиального мениска в сочетании с варусной деформацией голени.

Цель исследования - оценить среднесрочные клинико-функциональные и рентгенологические результаты оперативного лечения пациентов с повреждением медиального мениска в сочетании с варусной деформацией голени. На основании сравнительного анализа данных определить показания к выполнению как изолированной артроскопической резекции мениска, так и симультанно с различными методиками остеотомии.

\section{МАТЕРИАЛЫ И МЕТОДЫ}

В исследование включены 245 пациентов, находившихся на лечении в Центре травматологии и ортопедии ФГБУ «Главный военный клинический госпиталь им. Н.Н. Бурденко» Минобороны России по поводу повреждения медиального мениска в период с 2013 по 2020 г. Возраст пациентов составил от 21 до 41 года (средний возраст 31,5 \pm 5,7 года).

Исследование проводилось в соответствии с этическими и юридическими нормами и стандартами, изложенными в Хельсинской декларации. Получено информированное согласие лиц, включенных в исследование.

В предоперационном периоде оценивали жалобы больных, функцию коленного сустава по шкалам Lysholm Knee Scoring Scale, 2000 IKDC, KOOS. Проводилось стандартное клиническое обследование коленного сустава и лучевая диагностика (рентгенография коленного сустава в прямой и боковой проекциях, телерентгенометрия нижних конечностей, магнитно-резонансная томография (МРТ)). При этом оценивались механическая ось нижних конечностей, проходящая от центра головки бедренной кости до центра блока таранной кости; точка прохождения её через коленный сустав (в процентах от ширины плато большеберцовой кости); механический феморотибиальный угол (МФТУ) - угол между механической осью бедра и голени; медиальный проксимальный угол большеберцовой кости (mMPTA - medial proximal tibial angle) - угол наклона плато большеберцовой кости; динамика развития остеоартроза (стадия по Kellgren-Lawrence).

Критериями включения являлось изолированное повреждение медиального мениска коленного сустава, наличие данных МРТ и рентгенограмм на всех этапах наблюдения. В зависимости от угла варусной деформации и выбранной тактики оперативного лечения больные были разделены на четыре группы. В группу 1 вошли больные с МФТУ от $0^{\circ}$ до $3^{\circ}$, которым выполнена АРМ. В группе 2 всем больным также выполнялась АРM, а МФТУ до операции был больше $3^{\circ}$. В группе 3 больным с варусной деформацией от $3^{\circ}$ до $5^{\circ}$ выполнялась симультанно АРМ и проксимальная остеотомия малоберцовой кости (ПОМК) с формированием её дефекта. В группу 4 (60 пациентов, 24,5 \%) вошли больные с МФТУ более $5^{\circ}$, которым выполнена высокая вальгизирующая остеотомия большеберцовой кости (ВВОБК) по типу «открытый клин» с резекцией медиального мениска.

Критериями исключения являлись различные виды нестабильности коленного сустава, дегенеративные или посттравматические изменениями в наружных отделах коленного сустава, сопровождающиеся повреждением наружного мениска, остеоходропатия, вальгусная деформация, а также пателлофеморальный артроз, различные аутоиммунные заболевания.

Всем больным выполнялась стандартная артроскопия коленного сустава с оценкой внутренних структур и 
парциальной или субтотальной резекцией медиального мениска в зависимости от степени его повреждения.

Больным группы 3 артроскопическая менискэтомия дополнялась ПОМК с формированием её дефекта. Остеотомию малоберцовой кости осуществляли на 5 см дистальнее шейки малоберцовой кости, для исключения повреждения общего малоберцового нерва. Выполнялся разрез кожи и подкожно-жировой клетчатки над малоберцовой костью длиной 4-5 см. После чего вскрывалась поверхностная фасция голени, тупо разводились мышцы, и обнажался диафиз малоберцовой кости. При помощи осциллирующей пилы выполнялась остеотомия малоберцовой кости с формированием дефекта от 0,5 до 1,0 см, костный фрагмент удалялся. Этапы операции представлены на рисунке 1.
Пациентам группы 4 симультанно выполнялась ВВОБК по типу «открытый клин» с костной пластикой сформированного дефекта большеберцовой кости аутотрансплантатом из гребня подвздошной кости. Остеотомия проводилась с использованием системы Hinge Pin, которая позволяет снизить риск перелома наружной кортикальной пластинки большеберцовой кости. Большеберцовая кость фиксировалась специальной пластиной, имеющей 4 отверстия для винтов (2 дистально и 2 проксимально) и блок между ними, соответствующий размеру клина и удерживающий его высоту, блок на пластине выбирался в зависимости от необходимого угла коррекции в соответствии с предоперационным планированием. Этапы операции представлены на рисунке 2 .

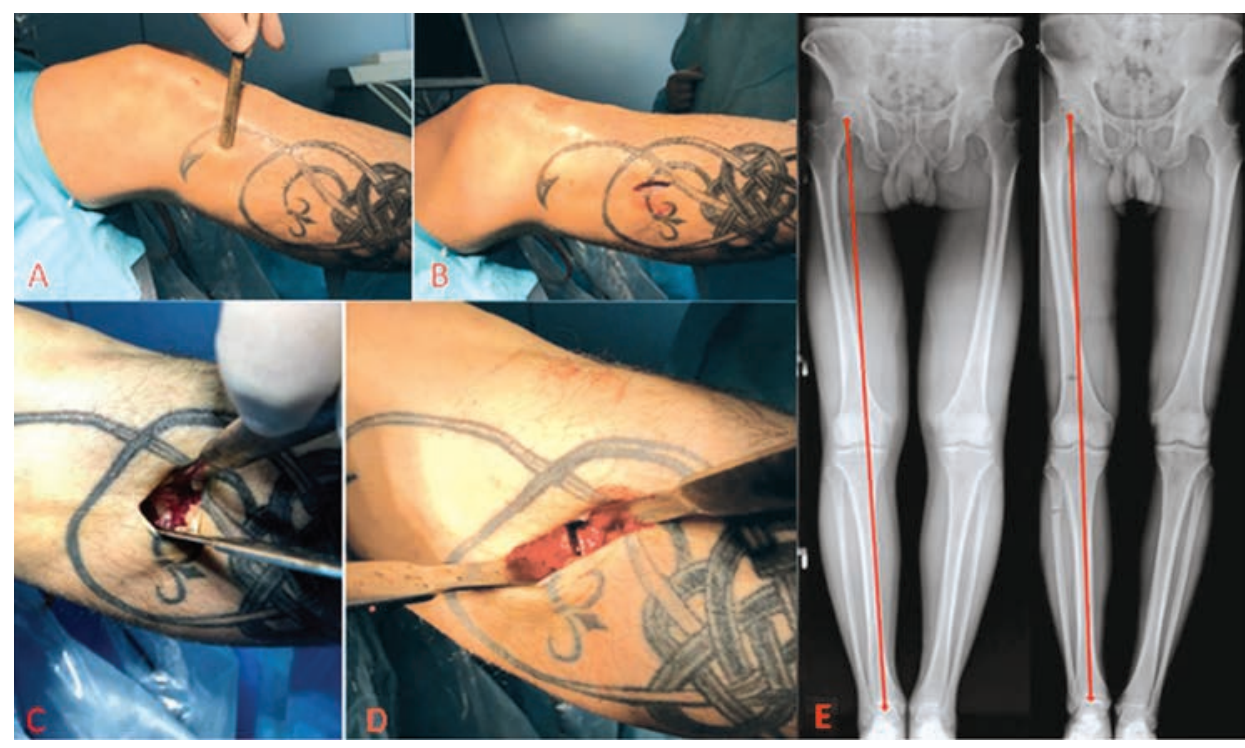

Рис. 1. Этапы операции при выполнении проксимальной остеотомии малоберцовой кости: А - пальпаторное определение головки и шейки малоберцовой кости; В - выполнение операционного доступа на 5 см дистальнее шейки малоберцовой кости; С - выделение малоберцовой кости; D - остеотомия малоберцовой кости с формированием дефекта; Е - предоперационные и послеоперационные телерентгенограммы нижних конечностей

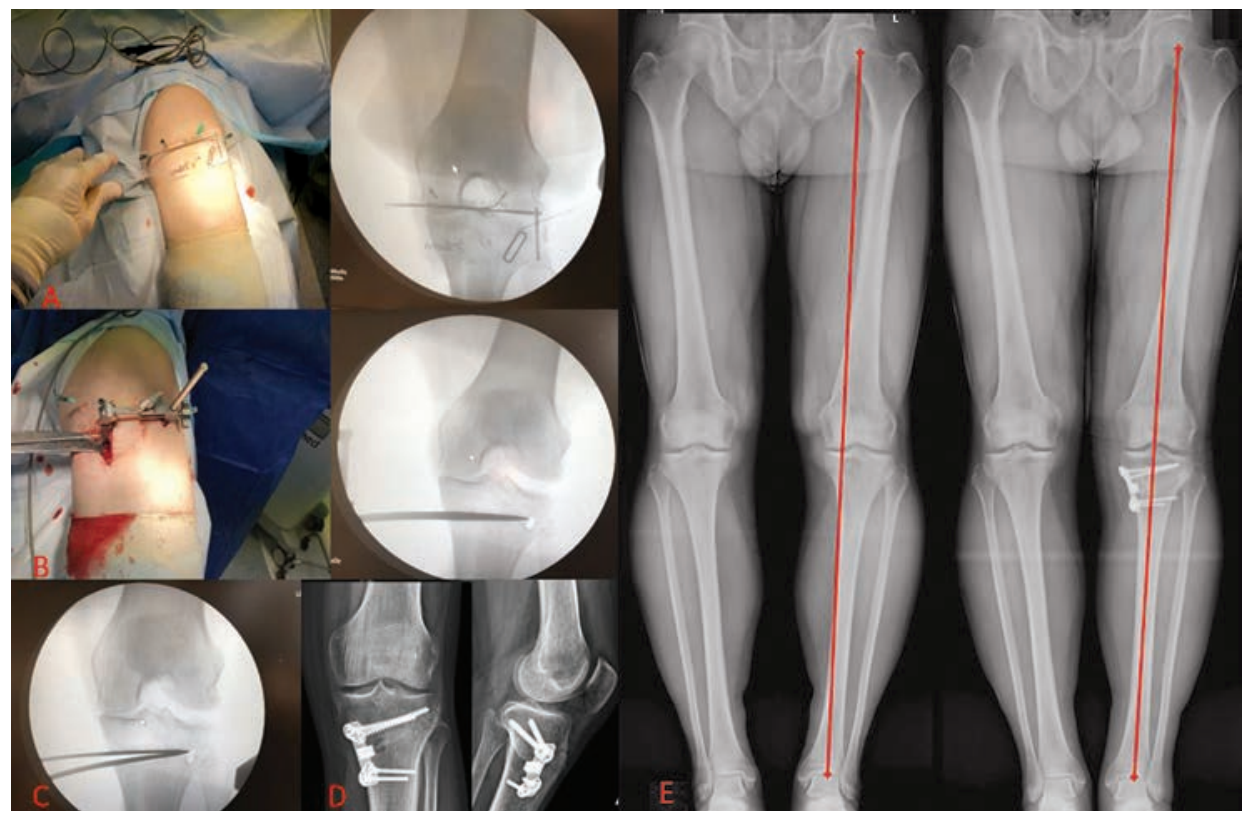

Рис. 2. Этапы операции при выполнении высокой вальгизирующей остеотомии большеберцовой кости по типу «открытый клин». A - использование специального рентгеновского направителя для выбора точки установки Hinge Pin; В - установка блока для опила на Hinge Pin и выбор угла опила большеберцовой кости; C - расклинивание большеберцовой кости на необходимый угол коррекции; D - фиксация фрагментов большеберцовой кости пластиной на 4 отверстия с блоком; Е - предоперационные и послеоперационные телерентгенограммы нижних конечностей 
Сравнение и оценка результатов лечения в группах осуществлялась через 1,3 и 5 лет после операции. Статистическую обработку полученных данных проводили на персональном компьютере с использованием приложения Microsoft Excel и пакета статистического анализа данных IBM SPSS Statistics. Для проверки нормальности распределения использовали тест Колмогорова-Смирнова. При нормальном распределении количественные данные представлены в виде средней \pm стандартное отклонение, при распределении, отличном от нормального, количе- ственные данные представлены в виде медианы и интерквартильного размаха (25-го и 75-го процентилей). Сравнение двух групп при нормальном распределении количественных данных в них производилось при помощи критерия Стьюдента, трех и более групп - при помощи однофакторного дисперсионного анализа. При сравнении двух и более групп, данные которых не соответствуют нормальному распределению, применялся критерий Краскела-Уоллиса. Различия считали статистически значимыми при уровне ошибки $\mathrm{p}<0,05$.

\section{РЕЗУЛЬТАТЫ}

При оценке рентгенологических результатов лечения (табл. 1) у пациентов группы 1 на всех сроках наблюдения не было отмечено достоверного изменения угла mMPTA (p1 = 0,8; p2 =0,8; p3 = 0,5) (табл. 2). Отмечается достоверное ( $<<0,001)$ увеличение угла деформации на $0,26 \pm 0,07^{\circ}$ и изменение положения механической оси $(0,33 \pm 0,09 \%)$. Но, учитывая незначительное изменение показателей, а также маленькую выборку больных, эти значения расценивались как статистически незначимые. В группе 2 выявлено увеличение угла варусной деформации, по сравнению с предоперационным значением, и постепенное его увеличение со временем: в течение первого года после операции на $1,07 \pm 0,5^{\circ}$, а к пятому году - на $2,2 \pm 0,7^{\circ}$ ( $\mathrm{p}<0,001)$. Помимо этого отмечается медиальное смещение механической оси на 9,76 $\pm 1,2$ \% к 5-му году наблюдения. Достоверного изменения угла mMPTA в группе 2 не отмечено (p1 = 0,058; p2 = 0,058; p3 = 0,058). В группе 3 зарегистрировано уменьшение угла варусной деформации через год после операции в среднем на $2,84 \pm 0,7^{\circ}(\mathrm{p}<0,001)$, последующее наблюдение не выявило значимого изменения. В группе 4 определено значимое уменьшение угла варусной деформации на $7,07 \pm 2,3^{\circ}$ и латеральное смещение механической оси нижней конечности ( $<<0,001)$, таким образом МФТУ был скорректирован до $0,8 \pm 1,23^{\circ}$, а механическая ось проходила через $49,32 \pm 1,43 \%$ от площади плато большеберцовой кости, что фактически соответствует центру коленного сустава. Изменение угла mМРТА отмечено только в группе 4, что связано с выполненной остеотомией большеберцовой кости, в среднем угол увеличился на $7,19 \pm 1,4^{\circ}(\mathrm{p}<0,001)$ через год после операции (табл. 1 и 2, рис. 3).

Функциональные результаты лечения пациентов во всех группах на всех сроках наблюдения были достоверно выше, чем перед операцией ( $<$ <,001) (табл. 4). Однако в группе 2 при сравнении результатов через год с результатами через три и пять лет отмечается выраженное снижение клинико-функциональных показателей по всем использованным шкалам (табл. 3). В остальных группах значимого снижения функциональных результатов лечения отмечено не было (табл. 3 и 4, рис. 4).

Таблица 1

Рентгенологические результаты лечения пациентов

\begin{tabular}{|c|c|c|c|c|c|}
\hline & \multirow{2}{*}{ Группа } & \multirow{2}{*}{ До операции } & \multicolumn{3}{|c|}{ После операции } \\
\hline & & & 1 год & 3 года & 5 лет \\
\hline \multirow{4}{*}{ МФТУ, гр. } & 1 & $1,50 \pm 1,13$ & $1,68 \pm 1,15$ & $1,70 \pm 1,15$ & $1,76 \pm 1,14$ \\
\hline & 2 & $6,63 \pm 1,91$ & $7,70 \pm 1,94$ & $8,73 \pm 2,07$ & $9,83 \pm 1,97$ \\
\hline & 3 & $4,05 \pm 0,89$ & $1,21 \pm 0,89$ & $1,36 \pm 0,87$ & $1,43 \pm 0,77$ \\
\hline & 4 & $7,87 \pm 1,85$ & $0,80 \pm 1,23$ & $0,71 \pm 1,16$ & $0,79 \pm 1,12$ \\
\hline \multirow{4}{*}{ Механическая ось, \% } & 1 & $47,55 \pm 1,93$ & $47,37 \pm 1,88$ & $47,31 \pm 1,89$ & $47,22 \pm 1,89$ \\
\hline & 2 & $33,57 \pm 7,85$ & $31,11 \pm 7,63$ & $27,68 \pm 8,65$ & $23,81 \pm 8,81$ \\
\hline & 3 & $43,69 \pm 2,46$ & $48,85 \pm 0,93$ & $48,72 \pm 0,94$ & $48,67 \pm 0,88$ \\
\hline & 4 & $29,28 \pm 8,17$ & $49,32 \pm 1,43$ & $49,44 \pm 1,27$ & $49,36 \pm 1,28$ \\
\hline \multirow{4}{*}{ mMPTA, гр. } & 1 & $86,72 \pm 1,38$ & $86,70 \pm 1,38$ & $86,67 \pm 1,39$ & $86,66 \pm 1,42$ \\
\hline & 2 & $81,76 \pm 1,43$ & $81,69 \pm 1,40$ & $81,63 \pm 1,44$ & $81,55 \pm 1,48$ \\
\hline & 3 & $84,21 \pm 1,00$ & $84,64 \pm 1,04$ & $84,75 \pm 1,13$ & $84,90 \pm 1,06$ \\
\hline & 4 & $80,98 \pm 1,40$ & $87,30 \pm 0,83$ & $87,23 \pm 0,85$ & $87,17 \pm 0,85$ \\
\hline
\end{tabular}

Таблица 2

Доверительная вероятность различий рентгенологических результатов лечения

\begin{tabular}{|c|c|c|c|c|c|c|c|c|c|}
\hline & \multicolumn{9}{|c|}{ Внутригрупповая доверительная вероятность, p } \\
\hline & \multicolumn{3}{|c|}{ МФТУ } & \multicolumn{3}{|c|}{ Механическая ось } & \multicolumn{3}{|c|}{ mMPTA } \\
\hline & p1 & $\mathrm{p} 2$ & p3 & p1 & $\mathrm{p} 2$ & p3 & p1 & $\mathrm{p} 2$ & p3 \\
\hline Группа 1 & $<0,001$ & $<0,001$ & $<0,001$ & $<0,001$ & $<0,001$ & $<0,001$ & 0,8 & 0,8 & 0,5 \\
\hline Группа 2 & $<0,001$ & $<0,001$ & $<0,001$ & $<0,001$ & $<0,001$ & $<0,001$ & 0,058 & 0,058 & 0,058 \\
\hline Группа 3 & $<0,001$ & $<0,001$ & $<0,001$ & $<0,001$ & $<0,001$ & $<0,001$ & $<0,001$ & $<0,001$ & $<0,001$ \\
\hline Группа 4 & $<0,001$ & $<0,001$ & $<0,001$ & $<0,001$ & $<0,001$ & $<0,001$ & $<0,001$ & $<0,001$ & $<0,001$ \\
\hline
\end{tabular}

p1 - доверительная вероятность различий между дооперационными значениями и через 1 год после операции; р2 - доверительная вероятность различий между дооперационными значениями и через 3 года после операции; р3 - доверительная вероятность различий между дооперационными значениями и через 5 лет после операции. 


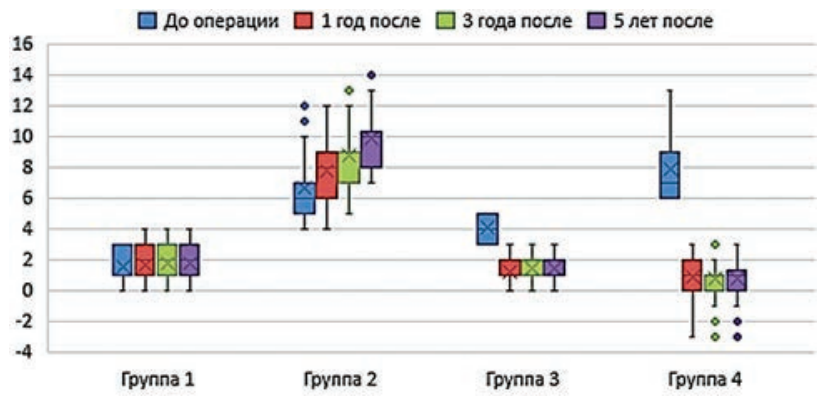

Рис. 3. Изменение механического феморотибиального угла

Таблица 3

Функциональные результаты лечения пациентов

\begin{tabular}{|c|c|c|c|c|c|}
\hline & \multirow{2}{*}{ Группа } & \multirow{2}{*}{ До операции } & \multicolumn{3}{|c|}{ После операции } \\
\hline & & & 1 год & 3 года & 5 лет \\
\hline \multirow{4}{*}{ Lysholm Knee Scoring Scale, баллы } & 1 & $53,64 \pm 3,80$ & $91,93 \pm 3,59$ & $91,64 \pm 3,53$ & $90,91 \pm 2,99$ \\
\hline & 2 & $53,83 \pm 3,63$ & $91,27 \pm 3,60$ & $80,10 \pm 4,39$ & $71,19 \pm 2,86$ \\
\hline & 3 & $53,28 \pm 3,85$ & $93,46 \pm 2,72$ & $93,14 \pm 2,28$ & $93(91,25 ; 94)$ \\
\hline & 4 & $53,22 \pm 3,65$ & $92,75 \pm 2,79$ & $92,27 \pm 2,75$ & $91,98 \pm 2,87$ \\
\hline \multirow{4}{*}{ Шкала 2000 IKDC, \% } & 1 & $21,24 \pm 2,31$ & $71,03 \pm 2,56$ & $70,90 \pm 2,59$ & $71(70 ; 73)$ \\
\hline & 2 & $21,70 \pm 2,48$ & $70,57 \pm 2,88$ & $51,02 \pm 2,32$ & $51,33 \pm 2,40$ \\
\hline & 3 & $22,21 \pm 2,53$ & $72,03 \pm 1,66$ & $72,17 \pm 1,54$ & $71,77 \pm 1,36$ \\
\hline & 4 & $21,60 \pm 2,53$ & $71,68 \pm 1,67$ & $71,63 \pm 1,75$ & $71,71 \pm 1,76$ \\
\hline \multirow{4}{*}{ Шкала KOOS, баллы } & 1 & $144,74 \pm 6,44$ & $38,71 \pm 3,92$ & $40,56 \pm 3,30$ & $41,93 \pm 3,44$ \\
\hline & 2 & $145,13 \pm 7,27$ & $39,60 \pm 4,22$ & $81,93 \pm 4,81$ & $111(108 ; 113)$ \\
\hline & 3 & $144,92 \pm 7,23$ & $37,49 \pm 3,60$ & $37,44 \pm 3,43$ & $38(36 ; 39)$ \\
\hline & 4 & $146,72 \pm 7,74$ & $38,60 \pm 3,89$ & $38,96 \pm 3,91$ & $38,74 \pm 4,15$ \\
\hline
\end{tabular}

Таблица 4

Доверительная вероятность различий функциональных результатов лечения

\begin{tabular}{|c|c|c|c|c|c|c|c|c|c|}
\hline & \multicolumn{9}{|c|}{ Внутригрупповая доверительная вероятность, p } \\
\hline & \multicolumn{3}{|c|}{ Lysholm Knee Scoring Scale } & \multicolumn{3}{|c|}{ Шкала 2000 IKDC } & \multicolumn{3}{|c|}{ Шкала KOOS } \\
\hline & p1 & $\mathrm{p} 2$ & p3 & $\mathrm{p} 1$ & $\mathrm{p} 2$ & p3 & p1 & p2 & p3 \\
\hline Группа 1 & $<0,001$ & $<0,001$ & $<0,001$ & $<0,001$ & $<0,001$ & $<0,001$ & $<0,001$ & $<0,001$ & $<0,001$ \\
\hline Группа 2 & $<0,001$ & $<0,001$ & $<0,001$ & $<0,001$ & $<0,001$ & $<0,001$ & $<0,001$ & $<0,001$ & $<0,001$ \\
\hline Группа 3 & $<0,001$ & $<0,001$ & $<0,001$ & $<0,001$ & $<0,001$ & $<0,001$ & $<0,001$ & $<0,001$ & $<0,001$ \\
\hline Группа 4 & $<0,001$ & $<0,001$ & $<0,001$ & $<0,001$ & $<0,001$ & $<0,001$ & $<0,001$ & $<0,001$ & $<0,001$ \\
\hline
\end{tabular}

p1 - доверительная вероятность различий между дооперационными значениями и через 1 год после операции; р2 - доверительная вероятность различий между дооперационными значениями и через 3 года после операции; р3 - доверительная вероятность различий между дооперационными значениями и через 5 лет после операции.

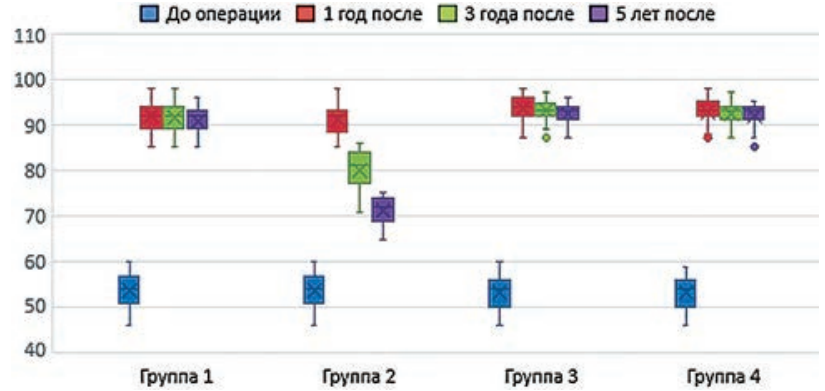

Шести больным группы 2 (8,5 \%) в течение 5 лет после операции выполнено эндопротезирование коленного суста-
Рис. 4. Изменение результатов опроса по шкале Lysholm Knee Scoring Scale

\section{дискУССИя}

В отечественной и мировой литературе появляется все больше статей, в которых авторы отмечают прогрессирование деформирующего артроза коленного сустава после резекции медиального мениска, что при хороших результатах в раннем послеоперационном периоде, приводит к большому количеству неудовлетворительных исходов в отдаленном $[16,17,18]$. В этих работах учитыва- ва, в остальных группах эндопротезирование исследованным больным за весь срок наблюдения не выполнялось. ются различные факторы (индекс массы тела, пол, стадия деформирующего артроза), влияющие на прогрессирование остеоартроза. Однако стоит отметить, что не у всех больных, даже при наличии отягощающих факторов, происходит прогрессирование деформирующего артроза, и в отдаленном периоде у части больных сохраняется хороший функциональный результат лечения $[19,20]$. 
По нашему мнению, это связано с тем, что в этих исследованиях недооценивалось влияние варусной деформации голени на отдаленные клинические результаты лечения больных с повреждением медиального мениска.

По результатам нашего исследования установлено, что при выполнении резекции медиального мениска у больных без варусной деформации голени в послеоперационном периоде не происходит прогрессирование МФТУ и медиального смещения механической оси нижней конечности, и при этом хороший функциональный результат отмечается у этой группы больных на всех сроках наблюдения.

При варусной деформации (МФТУ до операции больше $3^{\circ}$ ) после резекции медиального мениска значимо увеличивается МФТУ и происходит медиальное смещение механической оси нижней конечности, что является одним из основных факторов, способствующих прогрессированию деформирующего артроза. Это, в первую очередь, связано с увеличением контактного давления между мыщелком бедренной и плато большеберцовой кости $[21,22]$. Это приводит к нарастанию болевого синдрома и снижению функциональных результатов лечения к 3-ему и 5-ому годам после операции, хотя через год после операции результаты были сопоставимы с другими группами.

Таким образом, оперативное лечение больных с разрывом медиального мениска, у которых МФТУ больше $3^{\circ}$, не должно ограничиваться только АРМ. Необходимо выполнять операции, направленные на коррекцию оси нижней конечности. Мы оценили эффективность двух методов оперативного лечения, на- правленных на коррекцию механической оси нижней конечности. Первый - это ПОМК - легко воспроизводимая операция, не требующая специализированного инструментария и дополнительных фиксирующих устройств. ПОМК - операция, рекомендованная при начальных стадиях деформирующего артроза с варусной деформацией голени, так как она позволяет снизить контактное давление в медиальном отделе коленного сустава [23, 24].

У больных с МФТУ до операции от 3 до $5^{\circ}$ в дополнение к АРМ выполняли ПОМК, что позволило скорректировать механическую ось на 2,2 $\pm 0,7^{\circ}$. ПОМК, благодаря своей простоте и отсутствию дополнительных расходов на импланты, очень популярна в КНР и Индии. Ряд авторов описывает хороший функциональный результат после ПОМК у больных с выраженной варусной деформацией голени на поздних стадиях деформирующего артроза $[25,26]$. Этот вопрос требует дальнейшего изучения.

Вторым методом коррекции варусной деформации голени являлась ВВОБК по типу «открытый клин», которая показана больным с МФТУ более $5^{\circ}$ [27]. Эта операция технически сложнее, требует наличия дополнительного хирургического инструментария, электронно-оптического преобразователя, а также тщательного предоперационного планирования [9, 28]. В ряде случаев она рассматривается как альтернатива одномыщелковому эндопротезированию при медиальном гонатрозе [14, 29]. Данная методика, при правильном выполнении и грамотной коррекции угла, позволяет достичь хороших функциональных результатов как в раннем, так и отдаленном периоде. [30].

\section{ВЫВоды}

Артроскопическая резекция мениска, на данный момент, является технически простой операцией, позволяющей быстро и с хорошим функциональным результатом вернуть больных к прежнему образу жизни. Однако недооценка угла варусной деформации коленного сустава при выполнении данной операции приводит к прогрессированию деформирующего артроза и, как следствие этого, к большому проценту неудовлетворительных результатов в отдаленном периоде. В связи с чем, выполнение телерентгенометрии нижних конечностей с оценкой МФТУ на предоперационном этапе очень важно и должно рутинно выполняться всем больным с повреждением медиального мениска.
При наличии варусной деформации (МФТУ > $3^{\circ}$ ) резекция медиального мениска должна дополняться либо проксимальной остеотомией малоберцовой кости с формированием её дефекта при МФТУ от 3 до $5^{\circ}$, либо высокой вальгизирующей остеотомией большеберцовой кости по типу «открытый клин» при МФТУ $>5^{\circ}$. Такой индивидуальный подход к лечению пациентов с повреждением медиального мениска в сочетании с варусной деформацией голени позволяет скорректировать положение механической оси нижней конечности и МФТУ, тем самым снизить вероятность прогрессирования деформирующего артроза коленного сустава.

\section{СПИСОК ИСТОЧНИКОВ}

1. Дейкало В.П., Болобошко К.Б. Структура травм и заболеваний коленного сустава // Новости хирургии. 2007. Т. 15, № 1. С. 26-31.

2. Epidemiology of meniscal lesions in the knee. 1,215 open operations in Copenhagen 1982-84 / A. Hede, D.B. Jensen, P. Blyme, S. Sonne-Holm // Acta Orthop. Scand. 1990. Vol. 61, No 5. P. 435-437. DOI: 10.3109/17453679008993557.

3. Incidence and risk factors associated with meniscal injuries among active-duty US military service members / J.C. Jones, R. Burks, B.D. Owens, R.X. Sturdivant, S.J. Svoboda, K.L. Cameron // J. Athl. Train. 2012. Vol. 47, No 1. P. 67-73. DOI: 10.4085/1062-6050-47.1.67.

4. Epidemiology of meniscal injuries in US high school athletes between 2007 and 2013 / J. Mitchell, W. Graham, T.M. Best, C. Collins, D.W. Currie, R.D. Comstock, D.C. Flanigan // Knee Surg. Sports Traumatol. Arthrosc. 2016. Vol. 24, No 3. P. 715-722. DOI: 10.1007/s00167-015-3814-2.

5. Long-term rates of knee arthroplasty in a cohort of 834393 patients with a history of arthroscopic partial meniscectomy / S.G.F. Abram, A. Judge, D.J. Beard, A.J. Carr, A.J. Price // Bone Joint J. 2019. Vol. 101-B, No 9. P. 1071-1080. DOI: 10.1302/0301-620X.101B9.BJJ-2019-0335.R1.

6. What are the Prognostic Factors for Radiographic Progression of Knee Osteoarthritis? A Meta-analysis / A.N. Bastick, J.N. Belo, J. Runhaar, S.M. Bierma-Zeinstra // Clin. Orthop. Relat. Res. 2015. Vol. 473, No 9. P. 2969-2989. DOI: 10.1007/s11999-015-4349-z.

7. Does varus alignment increase after medial meniscectomy? / K.H. Yoon, S.H. Lee, D.K. Bae, S.Y. Park, H. Oh // Knee Surg. Sports Traumatol. Arthrosc. 2013. Vol. 21, No 9. P. 2131-2136. DOI: 10.1007/s00167-012-2261-6.

8. Progression of radiographic osteoarthritis after partial meniscectomy in degenerative medial meniscal posterior root tears was greater in varus- than in neutral-aligned knees: a minimum 5-year follow-up / C. Kim, S.I. Bin, J.M. Kim, B.S. Lee, T.H. Kim // Knee Surg. Sports Traumatol. Arthrosc. 
2020. Vol. 28, No 11. P. 3443-3449. DOI: 10.1007/s00167-020-05905-w.

9. Rossi R., Bonasia D.E., Amendola A. The role of high tibial osteotomy in the varus knee // J. Am. Acad. Orthop. Surg. 2011. Vol. 19, No 10. P. 590599. DOI: $10.5435 / 00124635-201110000-00003$.

10. High tibial osteotomy in varus knees: indications and limits / M.C. Loia, S. Vanni, F. Rosso, D.E. Bonasia, M. Bruzzone, F. Dettoni, R. Rossi // Joints. 2016. Vol. 4, No 2. P. 98-110. DOI: 10.11138/ jts/2016.4.2.098.

11. Upper partial fibulectomy improves knee biomechanics and function and decreases knee pain of osteoarthritis: A pilot and biomechanical study / Y. Nie, J. Ma, Z. Huang, B. Xu, S. Tang, B. Shen, V.B. Kraus, F. Pei // J. Biomech. 2018. Vol. 71. P. 22-29. DOI: 10.1016/j.jbiomech.2017.12.004.

12. Comparison of Clinical and Biomechanical Outcomes between Partial Fibulectomy and Drug Conservative Treatment for Medial Knee Osteoarthritis / G. Chen, B. Xu, J. Xie, Y. Nie, S. Tang, J. Ma, Q. Huang, Z. Zhou, B. Shen, X. Li, H. Shen, F. Pei // Biomed. Res. Int. 2019. Vol. 2019. 4575424. DOI: $10.1155 / 2019 / 4575424$.

13. Место эстетической хирургии нижних конечностей в современной ортопедии / А.А. Артемьев, Л.К. Брижань, Д.В. Давыдов, 3.М. Бытдаев, А.М. Кашуб, А.А. Шипулин, Г.Г. Гулулян // Гений ортопедии. 2021. Т. 27. № 1. С. 59-67. DOI: 10.18019/1028-4427-2021-27-1-59-67.

14. Высокая открытоугольная подмыщелковая остеотомия в комплексном лечении гонартроза / А.А. Городянский, Л.Ю. Слиняков, С.В. Донченко, М.Ю. Блоков // Кафедра травматологии и ортопедии. 2018. № 2 (32). С. 14-19. DOI 10.17238/issn2226-2016.2018.2.14-19.

15. Osteotomy for treating knee osteoarthritis / R.W. Brouwer, T.M. van Raaij, S.M. Bierma-Zeinstra, A.P. Verhagen, T.S. Jakma, J.A. Verhaar // Cochrane Database Syst. Rev. 2007. No 3. CD004019. DOI: 10.1002/14651858.CD004019.

16. Knee Osteoarthritis after Arthroscopic Partial Meniscectomy: Prevalence and Progression of Radiographic Changes after 5 to 12 Years Compared with Contralateral Knee / U.G. Longo, M. Ciuffreda, V. Candela, G. Rizzello, V. D'Andrea, N. Mannering, A. Berton, G. Salvatore, V. Denaro // J. Knee Surg. 2019. Vol. 32, No 5. P. 407-413. DOI: 10.1055/s-0038-1646926.

17. Osteoarthritis progression after exercise therapy or meniscectomy in patients with degenerative meniscal tears / Y. Yu, S. Lu, J. Sun, J. Xu // Osteoarthritis Cartilage. 2020. Vol. 28, No 8. P. 1147. DOI: 10.1016/j.joca.2020.04.018.

18. Горевич И.И., Сибгатуллин Р.Р., Уткин В.А. Анализ развития гонартроза в отдаленном периоде после резекции и шва мениска у спортсменов // II Международный конгресс ассоциации ревмоортопедов : тез. докл. конгр., Москва, 21-22 сентября 2018 г. М. : Научная книга, 2018. C. $45-46$.

19. Arthroscopic partial meniscectomy for meniscal tears of the knee: a systematic review and meta-analysis / S.G.F. Abram, S. Hopewell, A.P. Monk, L.E. Bayliss, D.J. Beard, A.J. Price // Br. J. Sports Med. 2020. Vol. 54, No 11. P. 652-663. DOI: 10.1136/bjsports-2018-100223.

20. Arthroscopic partial meniscectomy for a degenerative meniscus tear: a 5 year follow-up of the placebo-surgery controlled FIDELITY (Finnish Degenerative Meniscus Lesion Study) trial / R. Sihvonen, M. Paavola, A. Malmivaara, A. Itälä, A. Joukainen, J. Kalske, H. Nurmi, J. Kumm, N. Sillanpää, T. Kiekara, A. Turkiewicz, P. Toivonen, M. Englund, S. Taimela, T.L.N. Järvinen; FIDELITY (Finnish Degenerative Meniscus Lesion Study) Investigators // Br. J. Sports Med. 2020. Vol. 54, No 22. P. 1332-1339. DOI: 10.1136/bjsports-2020-102813.

21. Varus alignment aggravates tibiofemoral contact pressure rise after sequential medial meniscus resection / L. Willinger, J.J. Lang, D. Berthold, L.N. Muench, A. Achtnich, P. Forkel, A.B. Imhoff, R. Burgkart, C. von Deimling // Knee Surg. Sports Traumatol. Arthrosc. 2020. Vol. 28 , No 4. P. 1055-1063. DOI: 10.1007/s00167-019-05654-5.

22. Changes in tibiofemoral contact mechanics following radial split and vertical tears of the medial meniscus an in vitro investigation of the efficacy of arthroscopic repair / M.G. Muriuki, D.A. Tuason, B.G. Tucker, C.D. Harner // J. Bone Joint Surg. Am. 2011. Vol. 93, No 12. P. $1089-1095$. DOI: 10.2106/JBJS.I.01241.

23. Effects of proximal fibular osteotomy on stress changes in mild knee osteoarthritis with varus deformity: a finite element analysis / D. Pan, L. TianYe, Y. Peng, X. JingLi, L. HongZhu, Z. HeRan, Z. QingWen, C. LeiLei, C. ZhenQiu, W. QiuShi, H. Wei // J. Orthop. Surg. Res. 2020. Vol. 15, No 1. P. 375. DOI: 10.1186/s13018-020-01894-1.

24. Proximal fibular osteotomy for the management of medial compartment knee osteoarthritis: A systematic review and meta-analysis / J.A. Sugianto, T. Hadipranata, G. Lazarus, A.H. Amrullah // Knee. 2021. Vol. 28. P. 169-185. DOI: 10.1016/j.knee.2020.11.020.

25. Vaish A., Kumar Kathiriya Y., Vaishya R. A Critical Review of Proximal Fibular Osteotomy for Knee Osteoarthritis // Arch. Bone Jt. Surg. 2019. Vol. 7, No 5. P. 453-462.

26. Comparison of Clinical and Biomechanical Outcomes between Partial Fibulectomy and Drug Conservative Treatment for Medial Knee Osteoarthritis / G. Chen, B. Xu, J. Xie, Y. Nie, S. Tang, J. Ma, Q. Huang, Z. Zhou, B. Shen, X. Li, H. Shen, F. Pei // Biomed. Res. Int. 2019. Vol. 2019. P. 4575424. DOI: $10.1155 / 2019 / 4575424$.

27. Degenerative Meniscal Tears and High Tibial Osteotomy: Do Current Treatment Algorithms Need to be Realigned? /C.A. Primeau, T.B. Birmingham, K.M. Leitch, C.T. Appleton, J.R. Giffin // Clin. Sports Med. 2019. Vol. 38, No 3. P. 471-482. DOI: 10.1016/j.csm.2019.02.010.

28. Medial opening wedge high-tibial osteotomy using a kinematic navigation system versus a conventional method: a 1-year retrospective, comparative study / S.J. Kim, Y.G. Koh, Y.M. Chun, Y.C. Kim, Y.S. Park, C.H. Sung // Knee Surg. Sports Traumatol. Arthrosc. 2009. Vol. 17, No 2. P. 128-134. DOI: $10.1007 / \mathrm{s} 00167-008-0630-y$.

29. Santoso M.B., Wu L. Unicompartmental knee arthroplasty, is it superior to high tibial osteotomy in treating unicompartmental osteoarthritis? A metaanalysis and systemic review // J. Orthop. Surg. Res. 2017. Vol. 12, No 1. P. 50. DOI: 10.1186/s13018-017-0552-9.

30. Progress in the treatment of knee osteoarthritis with high tibial osteotomy: a systematic review / M. He, X. Zhong, Z. Li, K. Shen, W. Zeng // Syst. Rev. 2021. Vol. 10, No 1. P. 56. DOI: 10.1186/s13643-021-01601-z.

Статья поступила в редакцию 28.09.2021; одобрена после рецензирования 09.11.2021; принята к публикации 23.12.2021.

The article was submitted 28.09.2021; approved after reviewing 09.11.2021; accepted for publication 23.12.2021.

\section{Информация об авторах:}

1. Леонид Карлович Брижань - доктор медицинских наук, brizhan.leonid@mail.ru;

2. Денис Владимирович Давыдов - доктор медицинских наук, dvdavydov@yandex.ru;

3. Артур Асланович Керимов - кандидат медицинских наук, kerartur@yandex.ru;

4. Борис Владимирович Тюлькевич - 1983loki@mail.ru;

5. Дарья Александровна Найда - dariaanayda@gmail.com.

\section{Information about the authors:}

1. Leonid K. Brizhan - Doctor of Medical Sciences, brizhan.leonid@mail.ru;

2. Denis V. Davydov - Doctor of Medical Sciences, dvdavydov@yandex.ru;

3. Artur A. Kerimov - Candidate of Medical Sciences, kerartur@yandex.ru;

4. Boris V. Tyulkevich - M.D., 1983loki@mail.ru;

5. Daria A. Nayda - M.D., dariaanayda@gmail.com. 
Гений ортопедии. 2022. Т. 28, № 1. С. 53-61.

Genij Ortopedii. 2022. Vol. 28, no. 1. P. 53-61.

Научная статья

УДК 616.728.38-089.844

https://doi.org/10.18019/1028-4427-2022-28-1-53-61

\section{Сравнение результатов восстановления передней крестообразной связки коленного сустава с использованием аутотрансплантата из сухожилия длинной малоберцовой мышцы и из связки надколенника с двумя костными блоками}

\section{Е.Н. Гончаров ${ }^{1,2}$, Н.Г. Гончаров ${ }^{1,2}$, Э.Н. Безуглов ${ }^{3}$, А.А. Ветошкин ${ }^{4}$, И.А. Резуненко ${ }^{2}$, С.Х. Оганесян ${ }^{5}$, О.А. Коваль $^{2}$}

${ }^{1}$ Российская медицинская академия непрерывного профессионального образования, Москва, Россия

2 Центральная клиническая больница Российской академии наук, Москва, Россия

3 Первый Московский государственный медицинский университет им. И.М. Сеченова, Москва, Россия

${ }^{4}$ Всероссийский центр экстренной и радиационной медицины им. А.М. Никифорова, Санкт-Петербург, Россия

5 Городская клиническая больница № 17 Департамента здравоохранения города Москвы, Москва, Россия

Автор, ответственный за переписку: Евгений Николаевич Гончаров, goncharoven@gmail.com

Аннотация

Введение. Растущие знания и понимание биомеханики и кинематики коленного сустава побуждают к поиску новых хирургических техник и новых трансплантатов ПКС. Цель. Оценка среднесрочных результатов первичного артроскопического восстановления передней крестообразной связки коленного сустава с использованием аутотрансплантата из сухожилия длинной малоберцовой мышцы и сравнение результатов с контрольной группой пациентов, получивших первичное артроскопическое восстановление передней крестообразной связки с использованием аутотрансплантата из связки надколенника с двумя костными блоками. Материалы и методы. В период $2017-2018$ гг. было прооперировано 108 пациентов, из которых сформировано две группы: 55 пациентов - артроскопическое восстановление ПКС с использованием аутотрансплантата из сухожилия длинной малоберцовой мышцы; 53 пациента - артроскопическое восстановление ПКС с трансплантатом из связки надколенника с двумя костными блоками. Оценка функции коленного сустава в двух группах основывалась на клиническом осмотре, сборе анамнеза, результатах функциональных тестов, результатах MPT, на данных инструментальных методов диагностики (КТ-1000) после оперативного лечения, ответах пациентов при заполнении шкал до операции и через два года после операции (Tegner Lysholm, IKDC). Дополнительно пациентам исследуемой группы перед оперативным вмешательством и через 24 месяца после него производили исследование на плантографе. Также проводили оценку после оперативного вмешательства по шкале AOFAS. Результаты. B группе 1 средний показатель по шкале Tegner Lysholm до операции составил 69,2 $\pm 10,7$ балла, после операции - 92,2 $\pm 10,4$ балла; по шкале IKDC до операции $68,2 \pm 10,6 \%$, после операции - 90,1 $\pm 9,5 \%$. KT-1000 - 3,7 $\pm 1,4$ мM, AOSAF - 95,3 \pm 7,5 \%. Разрыв аутотрансплантата в течение 2-х лет после операции выявлен у 4 из 50 пациентов, что составило 8 \%. Измерения на плантографе ПКС-01 через 24 месяца после операции не выявили изменений в своде стопы. В группе 2 средний показатель по шкале Tegner Lysholm до операции составил 70,2 $\pm 11,6$ балла, после операции $94,3 \pm 8,7$ балла. Среднее значение по шкале IKDC до операции - 68,6 $\pm 8,7 \%$, после операции - 91,5 $\pm 8,2 \%$. КT-1000 - 3,4 $\pm 1,2$ мм. Разрыв аутотрансплантата в течение 2-х лет после операции выявлен у 3 из 50 пациентов, что составило $6 \%$. Заключение. Результаты выполненных операций в двух группах можно оценить как хорошие, статистически значимых различий не выявлено, что указывает на то, что аутотрансплантат из сухожилия длинной малоберцовой мышцы является альтернативным вариантом при первичном восстановлении ПКС. Ключевые слова: передняя крестообразная связка, пластика, сухожилие длинной малоберцовой мышцы, связка надколенника, коленный сустав, нестабильность

Для цитирования: Сравнение результатов восстановления передней крестообразной связки коленного сустава с использованием аутотрансплантата из сухожилия длинной малоберцовой мышцы голени и из связки надколенника с двумя костными блоками / Е.Н. Гончаров, Н.Г. Гончаров, Э.Н. Безуглов, А.А. Ветошкин, И.А. Резуненко, С.Х. Оганесян, О.А. Коваль // Гений ортопедии. 2022. Т. 28, № 1. С. 53-61. httрs:// doi.org/10.18019/1028-4427-2022-28-1-53-61

Original article

\section{Comparison of results of the anterior cruciate ligament reconstruction of the knee joint using peroneus longus tendon autograft or patellar tendon autograft with two bone blocks}

\section{E.N. Goncharov ${ }^{1,2}$, N.G. Goncharov ${ }^{1,2}$, E.N. Bezuglov ${ }^{3}$, A.A. Vetoshkin ${ }^{4}$, I.A. Rezunenko², S.Kh. Oganesyan ${ }^{5}$, O.A. Koval ${ }^{2}$}

${ }^{1}$ Russian Medical Academy of Continuous Professional Education, Moscow, Russia

${ }^{2}$ Central Clinical Hospital of the Russian Academy of Sciences, Moscow, Russia

3 Sechenov First Moscow State Medical University, Moscow, Russian Federation

${ }^{4}$ The Nikiforov Russian Center of Emergency and Radiation Medicine, St. Petersburg, Russia

${ }^{5}$ City Clinical Hospital № 17, Moscow, Russian Federation

Corresponding author: Evgeniy N.Goncharov, goncharoven@gmail.com

Abstract

Introduction Growing knowledge and understanding of the biomechanics and kinematics of the knee are prompting the search for new surgical techniques and new ACL grafts. Purpose Evaluation of the medium-term results of primary arthroscopic reconstruction of the anterior cruciate ligament of the knee using peroneus longus tendon autograft and comparing the results with the control group of patients who underwent primary arthroscopic reconstruction of the anterior cruciate ligament using patellar tendon autograft with two bone blocks. Materials and methods 108 patients were operated on in 2017-2018. They were divided into two groups. 55 patients underwent reconstruction of ACL using peroneus longus ligament autograft group 1 (study group). 53 patients underwent reconstruction of ACL using patella tendon autograft - group 2 (control group). Evaluation of the knee joint function was based on clinical examination, medical history, results of functional tests, MRI results, on the data of instrumental diagnostic methods (CT-1000) after the surgical treatment, patient responses when filling out scales before surgery and two years after the surgery (Tegner Lysholm, IKDC). Additionally, the patients of the study group underwent a study on a plantograph before surgery and 24 months after it. Postoperative evaluation was also performed using the AOFAS scale. Results In group 1, the average score on the Tegner Lysholm scale before surgery was $69.2 \pm 10.7$ points, after surgery $-92.2 \pm 10.4$ points; on the IKDC scale before surgery $-68.2 \pm 10.6 \%$, after surgery $-90.1 \pm 9.5 \%$. KT-1000 - 3.7 \pm 1.4 mm, AOSAF $95.3 \pm 7.5 \%$. An autograft rupture within 2 years after the surgery was detected in 4 out of 50 patients, which amounted to $8 \%$. Measurements on the PKS-01 plantograph 24 months after the operation did not reveal changes in the arch of the foot. In group 2, the average score on the Tegner Lysholm scale before surgery was $70.2 \pm 11.6$ points, after surgery it was $94.3 \pm 8.7$ points. The mean value on the IKDC scale before surgery was $68.6 \pm 8.7 \%$, after surgery it was $91.5 \pm 8.2 \%$ KT-1000-3.4 $\pm 1.2 \mathrm{~mm}$. Autograft rupture within 2 years after the surgery was detected in 3 out of 50 patients, which 
amounted to $6 \%$. Conclusion The results of the operations performed in the two groups can be assessed as good, no statistically significant differences were found, which indicates that the peroneus longus tendon autograft is an alternative option for primary ACL repair.

Keywords: anterior cruciate ligament, plasty, peroneus longus tendon, patellar tendon, knee joint, instability

For citation: Goncharov E.N., Goncharov N.G., Bezuglov E.N., Vetoshkin A.A., Rezunenko I.A., Oganesyan S.Kh., Koval O.A. Comparison of results of the anterior cruciate ligament reconstruction of the knee joint using peroneus longus tendon autograft or patellar tendon autograft with two bone blocks. Genij Ortopedii, 2022, vol. 28, no 1, pp. 53-61. https://doi.org/10.18019/1028-4427-2022-28-1-53-61

Разрыв передней крестообразной связки (ПКС) одна из самых часто встречающихся травм коленного сустава у физически активных людей [1], а история артроскопического восстановления ПКС насчитывает более 30 лет [2, 3]. В современной хирургической практике существует большое количество хирургических техник, используемых трансплантатов и методов их фиксации в костных каналах. Считается, что трансплантатами выбора при первичном восстановлении ПКС являются аутотрансплантаты из сухожилий нежной и полусухожильной мышц и связки надколенника с двумя костными блоками (ВТВ) [4, 5]. Однако, как и при использовании любого аутотрансплантата, наравне с плюсами, существуют и минусы, к примеру, использование трансплантата ВТВ имеет высокие показатели боли в переднем отделе коленного сустава, в месте забора трансплантата (в 60 \% случаев), риск развития остеоартроза и разрыва ПКС контралатеральной конечности [6]. Использование аутотрансплантата из сухожилий нежной и полусухожильной мышц бедра может вызывать мышечный дисбаланс между мышцами-сгибателями и мышцамиразгибателями голени, что увеличивает риск разрыва аутотрансплантата $[7,8]$.

Ксено- и аллотрансплантаты ПКС, ввиду различных причин, таких, к примеру, как повышенный риск разрыва трансплантата, сохранение остаточного Lachman и pivot-shift в отсроченном послеоперационном периоде, высокая цена, используются в практике реже [9-14]. Растущие знания и понимание биомеханики и кинематики коленного сустава мотивируют на поиск новых хирургических техник, направленных на сохранение динамических стабилизаторов коленного сустава. Одним из перспективных вариантов аутотрансплантата ПКС является сухожилие длинной малоберцовой мышцы голени (СДММГ). Данный трансплантат имеет ряд преимуществ, например, скорость забора, толщина трансплантата, отсутствие влияния на динамические стабилизаторы коленного сустава - эти свойства помогают избежать осложнений, связанных с забором вышеописанных аутотрансплантатов, позволяя его использовать при артроскопическом восстановлении ПКС $[15,16]$. Однако на сегодняшний день в мире и в России недостаточно изучены возможности использования данного аутотрансплантата при артроскопическом восстановлении ПКС и влияние забора последнего на функцию стопы, в связи с чем данная тема требует освещения.

Цель исследования - оценка среднесрочных результатов первичного артроскопического восстановления передней крестообразной связки коленного сустава с использованием аутотрансплантата из сухожилия длинной малоберцовой мышцы голени и сравнение результатов с контрольной группой пациентов, получивших первичное артроскопическое восстановление передней крестообразной связки с использованием аутотрансплантата из связки надколенника с двумя костными блоками.

\section{МАТЕРИАЛЫ И МЕТОДЫ}

Тип исследования: моноцентровое проспективное продлённое рандомизированное сравнительное контролируемое исследование.

В период с 2017 по 2018 год было прооперировано 108 пациентов, соответствующих критериям включения в исследование:

55 пациентов, получивших лечение в объеме артроскопического восстановления ПКС с использованием аутотрансплантата из сухожилия длинной малоберцовой мышцы голени - группа 1 (исследуемая);

53 пациента, получившие лечение в объёме артроскопического восстановления ПКС с трансплантатом из связки надколенника с двумя костными блоками группа 2 (контрольная).

Выбор типа аутотрансплантата осуществлялся случайным образом. Поочерёдно были прооперированы обе группы пациентов с использованием обозначенных аутотрансплантатов без привязки к каким-либо критериям.

Хирургическое лечение проводилось с использованием единой техники, инструментов и расходного материала.

Критерии включения пациентов в исследование:

- занятия спортом не менее трех раз в неделю;
- отсутствие травм в анамнезе, нестабильности голеностопного сустава (группа 1);

- возраст от 18 до 50 лет;

- отсутствие каких-либо хирургических вмешательств на оперируемом коленном суставе;

- согласие на проведение МРТ коленного сустава до выполнения хирургического лечения;

- отсутствие неврологических и психических расстройств;

- согласие на заполнение анкет и участие в исследовании.

Критерии исключения пациентов из исследования:

- плоскостопие двустороннее 3-4 ст. (группа 1);

- мультилигаментарные повреждения;

- полнослойные дефекты суставного хряща коленного сустава.

Оценка функции коленного сустава в двух группах основывалась на клиническом осмотре, сборе анамнеза жизни и заболевания, результатах клинических тестов, оценке результатов МРТ, на данных инструментальных методов диагностики (КТ-1000) после оперативного лечения, ответах пациентов при заполнении шкал до операции и через два года после операции (Lysholm Knee 
Questionnaire, IKDC-2000). Дополнительно пациентам исследуемой группы перед оперативным вмешательством и через 24 месяца после него производили исследование на плантографе компьютерном (ПКС-01) с расчетом индекса Чижина и Шритера с целью оценки возможного влияния забора аутотрансплантата из сухожилия длинной малоберцовой мышцы на свод стопы формирование плоскостопия. Также проводили оценку после оперативного вмешательства по шкале AOFAS.

\section{Статистический анализ}

Задачи данной работы предусматривали расчет средних значений с доверительными интервалами таких показателей как Lysholm Knee Questionnaire, IKDC-2000, KT-1000 (после операции) для обеих групп пациентов (основные показатели указаны в таблице 1 ).
Нормальность распределения проверялась с помощью одновыборочного критерия Колмогорова-Смирнова (табл. 2).

В данном случае на уровне доверительней вероятности 95 \% только данные по LKQ до операции имеют нормальное распределение. Так как остальные показатели распределены не нормально, то проверка различий будет проводиться посредством непараметрических методов сравнения. В данном случае воспользуемся критерием Манна-Уитни. Непараметрическим сравнением для независимых выборок (табл. 3).

Средние ранги по группам в контрольной группе по выборке превышают исследуемую. Посмотрим на значимость данных различий (табл. 4).

Таблица 1

Результаты опросников

\begin{tabular}{|c|c|c|c|c|c|}
\hline \multirow{2}{*}{\multicolumn{2}{|c|}{ Статистика }} & \multicolumn{4}{|c|}{ Показатели } \\
\hline & & \multirow{2}{*}{$\begin{array}{c}\text { LKQ до операции } \\
100\end{array}$} & \multirow{2}{*}{$\begin{array}{c}\text { LKQ после операции } \\
100\end{array}$} & \multirow{2}{*}{$\begin{array}{c}\text { IKDC-2000 до операции } \\
100\end{array}$} & \multirow{2}{*}{$\begin{array}{c}\text { IKDC-2000 после операции } \\
100\end{array}$} \\
\hline $\mathrm{N}$ & допустимо & & & & \\
\hline iv & пропущенные & 1 & 1 & 1 & 1 \\
\hline \multicolumn{2}{|c|}{ Среднее значение } & 69,739 & 93,24 & 65,661 & 89,89 \\
\hline \multicolumn{2}{|c|}{ Стандартная ошибка среднего значения } & 1,0878 & 0,9642 & 1,7108 & 1,2665 \\
\hline \multicolumn{2}{|l|}{ Медиана } & 70 & 97 & 69,55 & 93,1 \\
\hline \multicolumn{2}{|l|}{ Мода } & 63 & 100 & $67,8^{a}$ & 97,7 \\
\hline \multicolumn{2}{|c|}{ Стандартное отклонение } & 10,8779 & 9,6422 & 17,1084 & 12,6649 \\
\hline \multicolumn{2}{|l|}{ Минимум } & 41 & 54 & 0 & 0 \\
\hline \multicolumn{2}{|l|}{ Максимум } & 94 & 100 & 87,4 & 100 \\
\hline \multirow{3}{*}{ Процентили } & 25 & 63 & 90 & 59 & 88,5 \\
\hline & 50 & 70 & 97 & 69,55 & 93,1 \\
\hline & 75 & 78 & 100 & 76,725 & 96,6 \\
\hline
\end{tabular}

Примечание: LKQ - Lysholm Knee Questionnaire; ${ }^{\text {a }}$ с существует несколько модальных значений, показано наименьшее значение.

Таблица 2

Одновыборочный критерий Колмогорова-Смирнова

\begin{tabular}{|c|c|c|c|c|c|}
\hline & \multirow{2}{*}{$\mathrm{N}$} & LKQ до операции & LKQ после операции & IKDC-2000 до операции & IKDC-2000 после операции \\
\hline & & 100 & 100 & 100 & 100 \\
\hline Параметры & среднее значение & 69,739 & 93,24 & 65,661 & 89,89 \\
\hline $\begin{array}{l}\text { нормального } \\
\text { распределения а, b }\end{array}$ & $\begin{array}{l}\text { среднеквадратичное } \\
\text { отклонение }\end{array}$ & 10,8779 & 9,6422 & 17,1084 & 12,6649 \\
\hline Наибольшие & абсолютная & 0,088 & 0,242 & 0,151 & 0,232 \\
\hline экстремальные & положительные & 0,074 & 0,242 & 0,108 & 0,212 \\
\hline & отрицательные & $-0,088$ & $-0,185$ & $-0,151$ & $-0,232$ \\
\hline Статистика критег & & 0,088 & 0,242 & 0,151 & 0,232 \\
\hline $\begin{array}{l}\text { Асимптотическая } \\
\text { (двусторонняя) }\end{array}$ & начимость & $0,055^{c}$ & $0,000^{c}$ & $0,000^{c}$ & $0,000^{c}$ \\
\hline
\end{tabular}

Примечание: LKQ - Lysholm Knee Questionnaire; ${ }^{\mathrm{a}}$ - проверяемое распределение является нормальным; ${ }^{\mathrm{b}}$ - вычислено из данных; ${ }^{\mathrm{c}}$ - коррекция значимости Лильефорса.

Таблица 3

Критерий Манна-Уитни

\begin{tabular}{|c|c|c|c|c|}
\hline & Группа & $\mathrm{N}$ & Средний ранг & Сумма рангов \\
\hline \multirow{3}{*}{ LKQ до операции } & контрольная & 50 & 51,63 & 2581,5 \\
\hline & исследуемая & 50 & 49,37 & 2468,5 \\
\hline & Всего & 100 & & \\
\hline \multirow{3}{*}{ LKQ после операции } & контрольная & 50 & 54,58 & 2729 \\
\hline & исследуемая & 50 & 46,42 & 2321 \\
\hline & Всего & 100 & & \\
\hline \multirow{3}{*}{ IKDC-2000 до операции } & контрольная & 50 & 53,12 & 2656 \\
\hline & исследуемая & 50 & 47,88 & 2394 \\
\hline & Всего & 100 & & \\
\hline \multirow{3}{*}{ IKDC-2000 после операции } & контрольная & 50 & 51,35 & 2567,5 \\
\hline & исследуемая & 50 & 49,65 & 2482,5 \\
\hline & Всего & 100 & & \\
\hline
\end{tabular}

Примечание: LKQ - Lysholm Knee Questionnaire 
Статистические критерии

\begin{tabular}{|c|c|c|c|c|}
\hline & LKQ до операции & LKQ после операции & IKDC-2000 до операции & IKDC-2000 после операции \\
\hline U Манна-Уитни & 1193,5 & 1046 & 1119 & 1207,5 \\
\hline W Вилкоксона & 2468,5 & 2321 & 2394 & 2482,5 \\
\hline $\mathrm{Z}$ & $-0,39$ & $-1,429$ & $-0,904$ & $-0,294$ \\
\hline $\begin{array}{l}\text { Асимптотическая значимость } \\
\text { (двусторонняя) }\end{array}$ & 0,696 & 0,153 & 0,366 & 0,769 \\
\hline
\end{tabular}

Примечание: LKQ - Lysholm Knee Questionnaire

Как мы видим, при 95 \% доверительной вероятности между исследуемой и контрольной группой значимые различия отсутствуют (для подтверждения значимых различий показатели асимптотической значимости не должны превышать 0,05 при уровне доверительной вероятности 95 \%).

Произвели проверку различий в долях пациентов, имеющих повторный разрыв, в исследуемой и контрольных группах посредствам Z-критерия. Выполнили изучение связи диаметра костного канала в исследуемой группе с такими антропометрическими показателями как вес, рост и возраст пациента, что осуществили посредствам вычисления коэффициента корреляции Пирсона. Статистическую обработку производили в программах Excel и SPSS. Порог статистической значимости $-\mathrm{p}<0,05$. В статистическую обработку были включены все пациенты, в том числе и пациенты с осложнениями в послеоперационном периоде (разрыв аутотрансплантата ПКС, развитие нестабильности голеностопного сустава (для исследуемой группы), повреждение ветви икроножного нерва (для исследуемой группы)).

В данном случае, на уровне доверительней вероятности 95 \% только данные по значению «Lysholm Knee Questionnaire до операции» имеют нормальное распределение. Так как остальные показатели распределены не нормально, проверку различий провели посредством непараметрических методов сравнения - в данном случае использовали критерий Манна-Уитни. Средние ранги в контрольной группе по выборке превышали исследуемую. При 95 \% доверительной вероятности между исследуемой и контрольной группами значимые различия отсутствуют. Касательно статистики случаев повторного разрыва трансплантата - для данных выборок z-критерий является незначимым.

\section{Хирургическая техника}

Перед восстановлением передней крестообразной связки у пациентов обеих групп проводили диагностическую артроскопию, выполняли необходимые лечебные мероприятия (резекция/шов менисков, иссечение гипертрофированных складок и гипертрофированной синовиальной выстилки сустава, подготовка к формированию костных каналов). По окончании лечебнодиагностической артроскопии переходили к забору аутотрансплантата и основному хирургическому этапу.

Оперативное лечение пациентов в группе 1 (исследуемая) осуществляли с использованием однопучковой техники с формированием анатомических каналов через передне-медиальный порт. Для восстановления ПКС использовали аутотрансплантат из сухожилия длинной малоберцовой мышцы ипсилатеральной нижней конеч- ности. Диаметр костных каналов зависел от диаметра полученного трансплантата. Фиксацию трансплантата осуществляли при помощи биодеградируемых интерферентных винтов (состав композитный - «полимолочная кислота - гидроксиапатит»): диаметр винта соответствовал диаметру канала, длина 25 мм - для бедренного канала и 30 мм для большеберцового канала.

Для забора трансплантата определяли ход сухожилия длинной малоберцовой мышцы путём инверсии стопы, после чего выполняли разрез кожи по ходу сухожилия по заднему краю латеральной лодыжки длиной около 2 см (рис. 1).

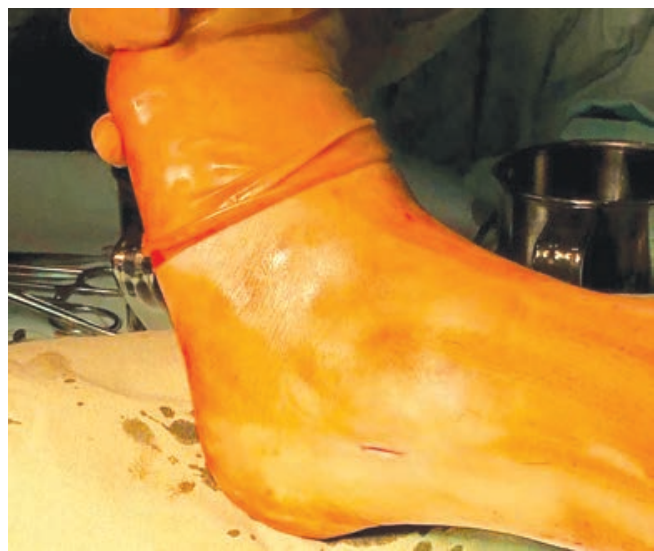

Рис. 1. Разрез кожи в проекции СДМБМ (сухожилие длинной малоберцовой мышцы) левой голени

При помощи сосудистых ножниц производили мобилизацию кожи в проксимальном и дистальном направлениях по ходу сухожилия. Производили рассечение фасции, после чего при помощи зажима (диссектор, зажим Бильрота) производили выделение СДМБМ (рис. 2).

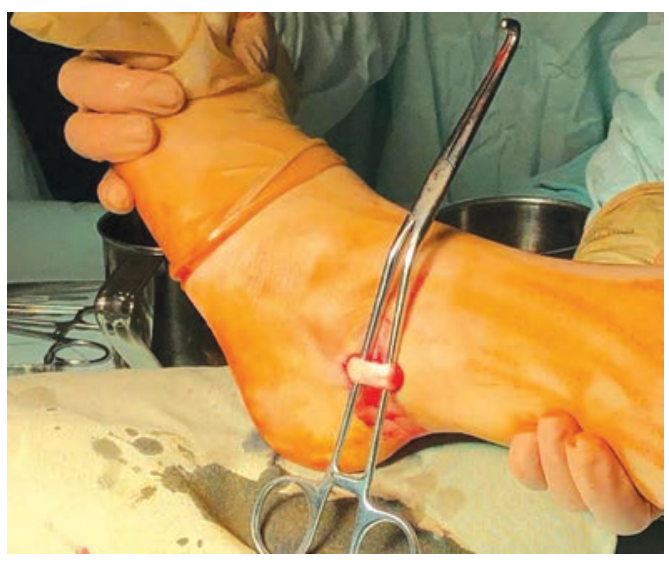

Рис. 2. Выделение инструментом СДМБМ (сухожилие длинной малоберцовой мышцы) левой голени 
Следует обратить внимание, что забор осуществляли инструментом с тупыми браншами в вентральном направлении с целью профилактики травмы прилежащих анатомических структур, в особенности n. suralis. Сухожилие длинной малоберцовой мышцы (СДМБМ) лежит поверхностно относительно сухожилия короткой малоберцовой мышцы. Отличительной особенностью сухожилия короткой малоберцовой мышцы является короткая и более тонкая сухожильная часть и наличие мышечных волокон на уровне забора, что позволяет провести дифференциальную оценку с целью предотвращения ошибки до прошивания трансплантата (рис. 3).

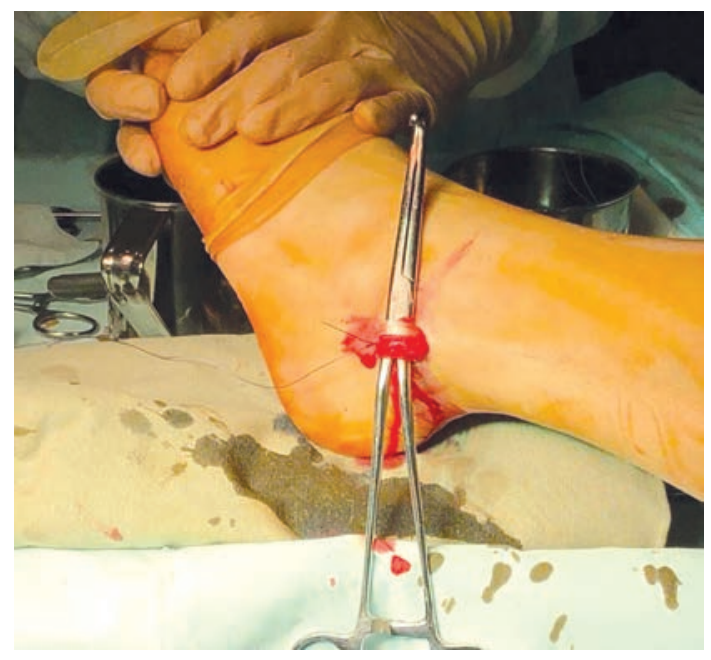

Рис. 3. Сравнение СДМБМ (сухожилие длинной малоберцовой мышцы) и сухожилия короткой малоберцовой мышцы левой голени

После выделения СДМБМ осуществляли прошивание проксимальной части швом по Кракову - 25 мм, дистальную часть прошивали биодеградируемой нитью, после чего сухожилие пересекали между прошитыми фрагментами. Дистальную часть СДМБМ подшивали к сухожильной порции сухожилия короткой малоберцовой мышцы. При помощи стриппера проксимальную часть сухожилия отделяли от мышцы и забирали трансплантат (рис. 4).

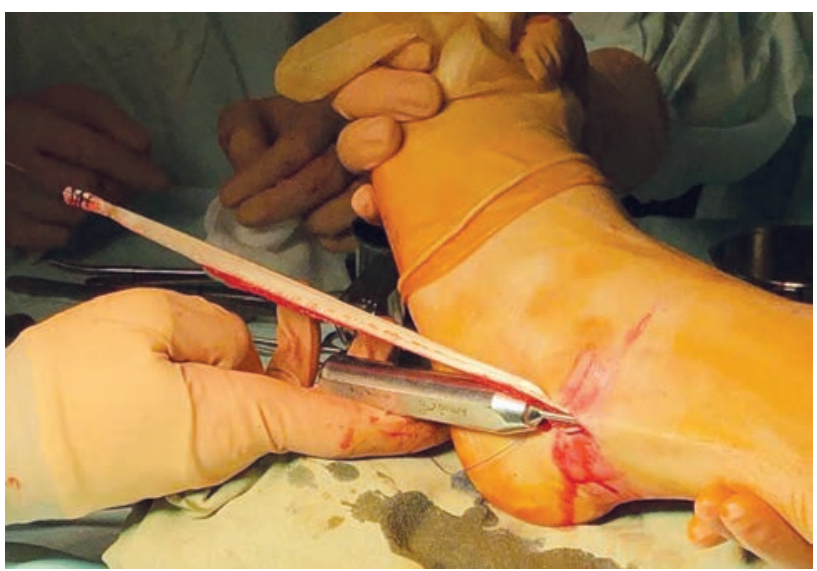

Рис. 4. Забор аутотрансплантата из СДМБМ (сухожилие длинной малоберцовой мышцы) левой голени

При помощи рассасывающегося шовного материала выполняли шов фасции, после чего нерассасывающимся материалом производили шов кожи.
По окончании процедуры забора трансплантата ассистент производил подготовку трансплантата к имплантации следующим образом: отделяли мышечные волокна от сухожилия, трансплантат складывали вдвое, проксимальный и два дистальных конца трансплантата фиксированы на станции подготовки трансплантата. Нитью производили шов по Кракову непрошитой дистальной порции на протяжении 25 мм, после чего проксимальный отдел прошивали на протяжении 25 мм биодеградируемой нитью 2/0 (рис. 5). После, на калибраторе, определяли диаметр трансплантата.

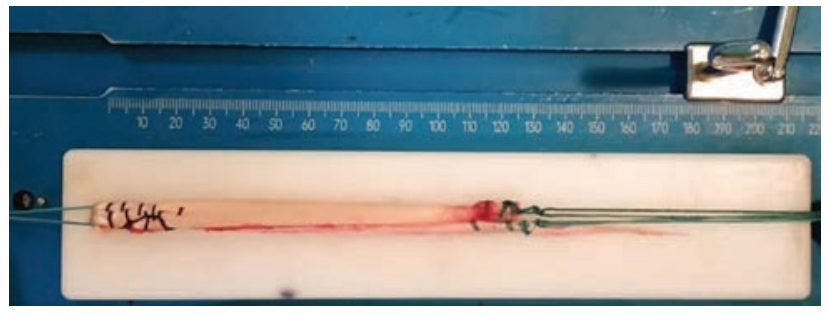

Рис. 5. Готовый аутотрансплантат

Параллельно оперирующий хирург формировал костные каналы, согласно вышеописанной технике. По готовности трансплантат проводили через сформированные каналы с последующей фиксацией биодеградируемыми винтами.

Оперативное лечение пациентов в группе 2 (контрольная) осуществляли с использованием такой же техники как в группе 1. Для восстановления ПКС использовали аутотрансплантат из связки надколенника с двумя костными блоками. Во всех случаях диаметр костных каналов - 10 мм. Фиксация трансплантата по классической методике с использованием биодеградируемых интерферентных винтов (состав композитный - «полимолочная кислота - гидроксиапатит») различной длины: $8 \times 25$ мм - бедренный канал, 8 × 30 мм - большеберцовый канал.

\section{Послеоперационное ведение}

Протокол послеоперационного ведения был одинаковым в обеих группах пациентов. Ортез в раннем послеоперационном периоде не использовали. Разрешали передвижение с полной опорой на оперированную конечность и сгибание-разгибание в оперированном суставе в безболевой амплитуде на следующий день после операции. В течение 3-х недель пациентам рекомендовали домашний режим. К 6-й неделе после операции пациенты обеих групп имели угол сгибания в коленном суставе не менее 90о. С 3-го месяца разрешали бег по ровной поверхности, по прямой, без резкого изменения направления движения, занятия в тренажерном зале. Возврат к спортивным нагрузкам рекомендовали после восстановления мышечного корсета бедра и голени, в среднем, через 8 месяцев. Пациенты являлись на контрольные осмотры через 14, 30 дней, затем через 3, 6, 12 и 24 месяца после операции. 


\section{РЕЗУЛЬТАТЫ}

Групna 1

Из 55 пациентов, вошедших в эту группу, в раннем и отсроченном послеоперационном периодах для наблюдения и контрольных осмотров было доступно 50 пациентов. Средний возраст пациентов составил $33,4 \pm 8,9$ года; распределение по половому признаку в группе составило: 72 \% мужчин, 28 \% женщин. Три пациента были недоступны для связи и контрольных встреч в послеоперационном периоде. Через 24 месяца после операции 7 из 50 пациентов отмечали появление отека в месте забора трансплантата при физических нагрузках. На следующий день после нагрузок отёк разрешался. Также у 2-х пациентов выявлено повреждение порции икроножного нерва при заборе трансплантата, что вызвало нарушение тактильной чувствительности и парестезии в области 5-ой плюсневой кости. Через 24 месяца с момента операции отмечен регресс неврологической симптоматики, тем не менее, пациенты отмечали снижение тактильной чувствительности перманентно по сравнению с аналогичным участком контралатеральной конечности. Через 24 месяца после операции 6 из 50 пациентов испытывали незначительную боль и дискомфорт (1-2 балла по ВАШ боли) в оперированном коленном суставе при физических нагрузках.

Средний показатель по шкале Lysholm Knee Questionnaire до операции составил 69,2 $\pm 10,7$ балла, после операции - 92,2 $\pm 10,4$ балла. Среднее значение по шкале IKDC-2000 до операции - 68,2 \pm 10,6 балла, после операции - 90,1 \pm 9,5 баллов. КТ-1000 по результатам оперативного лечения - 3,7 $\pm 1,4$ мм, AOFAS по результатам оперативного лечения - 95,3 \pm 7,5 \%.

Разрыв аутотрансплантата в течение 2-х лет после операции выявили у 4 из 50 пациентов, что составило 8 \%. Для пациентов обеих групп, у которых был диагностирован разрыв аутотрансплантата ПКС, диагноз ставили на контрольных встречах с пациентами, исходя из данных объективного и инструментального (по данным КТ-1000 смещение голени более 5 мм) осмотров, анамнеза, с обязательным последующим МРТисследованием и подтверждением диагноза.

По результатам предоперационной плантографии у 12 пациентов выявили двустороннее продольно-поперечное плоскостопие 1 и 2 степени, у 12 пациентов высокий свод стоп, у 26 пациентов были нормальные стопы. Измерения на плантографе ПКС-01 через 24 месяца после операции не выявили изменений в своде стопы, что указывало на отсутствие влияния забора аутотрансплантата из сухожилия длинной малоберцовой мышцы на развитие плоскостопия.

Также в данной работе просчитан коэффициент корреляции Пирсона между диаметром костного канала в зависимости от диаметра трансплантата и такими показателями как рост, вес и возраст пациента (показатель корреляции возраста, роста, веса и диаметра трансплантата в исследуемой группе указаны в таблице 5).

Таблица 5

Показатель корреляции возраста, роста, веса и диаметра трансплантата в исследуемой группе

\begin{tabular}{|l|c|}
\hline \multicolumn{1}{|c|}{$\begin{array}{c}\text { Показатель связи с диаметром } \\
\text { аутотрансплантата }\end{array}$} & Коэффициент корреляции \\
\hline Корреляция с возрастом & 0,174 \\
\hline Корреляция с ростом & 0,234 \\
\hline Корреляция с весом & $-0,001$ \\
\hline
\end{tabular}

Как видно, все коэффициенты не превышают 0,3, из чего мы можем сделать вывод, что убедительная связь между такими антропометрическими показателями как рост, вес и возраст пациента и диаметром аутотрансплантата в данной работе отсутствует, в связи с чем, предоперационное планирование диаметра трансплантата и костных каналов, основывающееся на вышеуказанных параметрах, затруднительно.

Групnа 2

Из 53 пациентов, вошедших в эту группу, в раннем и отсроченном послеоперационном периодах для наблюдения и контрольных осмотров было доступно 50 пациентов. Средний возраст пациентов составил 27,9 \pm 7,4 года; распределение по половому признаку в группе составило: 78 \% мужчин, 22 \% женщин. Пять пациентов были недоступны для связи и контрольных встреч в послеоперационном периоде. Через 24 месяца после операции 14 из 50 пациентов испытывали незначительную боль и дискомфорт (1-2 балла по ВАШ боли) в переднем отделе коленного сустава при физических нагрузках.

Оценку показателей по шкалам Lysholm Knee Questionnaire и IKDC-2000 осуществляли до и после оперативного лечения, также через 24 месяца с момента операции, пациентам производили замер остаточного показателя Лахмана с помощью КТ-1000.

Средний показатель по шкале Lysholm Knee Questionnaire до операции составил 70,2 \pm 11,6 балла, после операции - 94,3 \pm 8,7 балла. Среднее значение по шкале IKDC-2000 до операции - 68,6 \pm 8,7 балла, после операции - 91,5 \pm 8,2 балла. КТ-1000 по результатам оперативного лечения - 3,4 $\pm 1,2$ мм.

Разрыв аутотрансплантата в течение 2-х лет после операции выявлен у 3 из 50 пациентов, что составило $6 \%$.

Оиенка

Подводя итоги, результаты выполненных операций в двух группах можно оценить как хорошие, статистически значимых различий не выявлено, что указывает на то, что аутотрансплантат из сухожилия длинной малоберцовой мышцы является альтернативным вариантом при первичном восстановлении ПКС, позволяющим сохранить динамические стабилизаторы коленного сустава. Тенденции к формированию плоскостопия отмечено не было.

\section{ОБСУЖДЕНИЕ}

Хирургическая техника, механические особенности, отдалённые результаты при использовании аутотрансплантатов из сухожилий нежной и полусухожильной мышц и из связки надколенника с двумя костными блоками хорошо изучены, отчего использование этих ви- дов трансплантатов прогнозируемо и даёт хорошие послеоперационные результаты [5, 17-20]. Тем не менее, остаётся открытым вопрос о биомеханике коленного сустава после оперативного вмешательства. К примеру, забор аутотрансплантата с использованием стабилизато- 
ров коленного сустава может в дальнейшем негативно влиять на его функцию и нижней конечности в целом: ослабление силы сгибателей и разгибателей голени может привести к снижению функциональных показателей коленного сустава в послеоперационном периоде, не исключены и риски повреждения трансплантата [21]. Безусловно, анатомическое формирование костных каналов, полноценная реабилитация снижают риски, но поиск и использование альтернативных аутотрансплантатов, возможно, могло бы некоторым образом оказать влияние на уменьшение послеоперационных рисков, связанных с биомеханикой непосредственно коленного сустава. Одним из альтернативных и, некоторым образом, недооценённых трансплантатов, на наш взгляд, является сухожилие длиной малоберцовой мышцы голени. История использования данного трансплантата насчитывает уже более 10 лет, но «популярности» данный трансплантат в практике хирургов не получил. Работ, посвящённых исследованию и использованию данного трансплантата, не так много. Так, в некоторых исследованиях проведена оценка среднесрочных результатов после артроскопического восстановления ПКС с использованием аутотрансплантата из сухожилия длинной малоберцовой мышцы в группах пациентов [15, 16, 22]. Результаты оценены как хорошие и отличные, получен высокий рейтинг удовлетворённости пациентов результатами операции. Отрицательного влияния на функцию стопы и голеностопного сустава в послеоперационном периоде не выявлено. Авторы исследований рекомендуют данный трансплантат к использованию при первичном восстановлении ПКС. Напротив, в исследовании Angthong C. et al. авторы указывают на изменения функции голеностопного сустава и стопы в послеоперационном периоде, что влияет на качество жизни пациентов, в результате чего, авторы рекомендуют использование данного аутотрансплантата как альтернативны, например, при ревизионном восстановлении ПКС [23]. По нашим наблюдениям, изменения функции голеностопного сустава и стопы (развития нестабильности голеностопного сустава или формирования плоскостопия) у пациентов исследуемой группы выявлено не было, наиболее частой жалобой после операции был отёк в области забора трансплантата, который в подавляющем большинстве случаев разрешался по истечении года с момента оперативного лечения. Примечательно, что, по нашим наблюдениям (наблюдения не включены в работу), разрешение отёчности происходило быстрее при активной реабилитационной программе под контролем врача-реабилитолога и инструктора ЛФК. Считается, что забор сухожилия длинной малоберцовой мышцы не приводит к формированию нестабильности голеностопного сустава, так как данная структура не является стабилизатором сустава, возможно, частично функция сухожилия сохраняется при подшивании дистального фрагмента к сухожилию короткой малоберцовой мышцы. В исследовании коллег, использующих данный трансплантат с 1997 года, при проведении контрольного МРТ-исследования голеностопных суставов и голеней для сравнения регенераторного потенциала забранного сухожилия указали на частичную регенерацию сухожилия длинной малоберцовой мышцы в позднем послеоперационном периоде [24]. B paботе Song X. et al. дана оценка толщине трансплантата, где средние показатели вдвое сложенного сухожи- лия колебались в пределах 8,3 мм, в сочетании с длиной трансплантата данные показатели позволяют провести предоперационное планирование с высокой «гарантией» получения трансплантата с хорошими качествами [25]. В другой работе средний диаметр трансплантата составил 8,56 мм, и по предложенной авторами методике можно определить примерный диаметр трансплантата на стадии предоперационного планирования [26]. По нашим наблюдениям, толщина вдвое сложенного трансплантата в среднем колебалась в диапазоне 7,9 мм, но корреляции между такими антропометрическими показателями как рост, вес и возраст пациента мы не выявили, что не даёт возможности проведения предоперационного планирования. Однако, вероятно, что диаметр трансплантата может зависеть от физической активности (чем спортивнее человек, тем толще трансплантат). Также требует внимания простота и скорость забора трансплантата, что влияет на продолжительность оперативного вмешательства. Хотя в нашей практике, несмотря на единую технику и использование анатомических ориентиров, дважды было выявлено неврологическое осложнение, вероятно вызванное анатомическими особенностями n. suralis: пациенты в течение года отмечали парестезию и нарушение тактильной и температурной чувствительности в области латеральной поверхности 5-ой плюсневой кости стопы с тенденцией к постепенному, но неполноценному регрессу симптоматики. Данные осложнения были связаны нами с индивидуальными топографическими особенностями n. suralis. Для профилактики подобных осложнений, по нашему мнению, следует строго следовать анатомическим ориентирам, придерживаясь хирургической техники, минимизировать использование острых зажимов и проявлять бдительность при наложении швов на фасцию и кожу. В исследовании Bi M. et al. авторы используют переднюю порцию сухожилия длинной малоберцовой мышцы, сложенной вчетверо, тем самым сохраняя порцию сухожилия, избегая полного забора сухожилия. Послеоперационные результаты оценены как отличные, с хорошими функциональными показателями как коленного, так и голеностопного сустава в послеоперационном периоде [16]. В нашей практике данной методики мы не придерживались, в качестве сохранения частичной функции сухожилия длинной малоберцовой мышцы выполняли подшивание дистального фрагмента биодеградируемой нитью к сухожилию короткой малоберцовой мышцы. В работе Кожевникова Е.В. и коллег [27] было выполнено артроскопическое восстановление ПКС в группе из 50 пациентов, для послеоперационного наблюдения было доступно 17 пациентов, авторы получили отличные послеоперационные результаты, в проведенном анатомическом эксперименте выявлено, что прочностные показатели вдвое сложенного аутотрансплантата из сухожилия длинной малоберцовой мышцы соответствуют вчетверо сложенному аутотрансплантату из сухожилий нежной и полусухожильной мышц. Авторы указывают на преимущество данного аутотрансплантата в виде сохранения интактными динамических стабилизаторов коленного сустава. Однако в данном исследовании отсутствует группа сравнения, группа пациентов негомогенна по сопутствующей внутрисуставной патологии, что могло бы так же как в нашем исследовании повлиять на конечный результат. 


\section{ЗАКЛЮЧЕНИЕ}

По результатам проведённого исследования мы не выявили значимых различий в результатах лечения пациентов исследуемой и контрольной групп, что указывает на возможность применения аутотрансплантата из сухожилия длинной малоберцовой мышцы при первичном артроскопическом восстановлении передней крестообразной связки коленного сустава. Отрицательного влияния забора данного трансплантата на функцию голеностопного сустава, а также развития продольно-поперечного плоскостопия через 24 месяца после операции в данном исследовании не выявили.

Ограничение исследования. В данном исследовании изучили негомогенные группы пациентов по возрасту, полу, антропометрическим данным, сопутствующим поражениям структур коленного сустава. Например, действия относительно патологии мениска - шов или резекция - могут влиять на конечный показатель «остаточный Lachman». Аутотрансплантаты, используемые в двух группах пациентов, также имеют различия (тип трансплантата, особенности лигаментизации, механические свойства), которые могли повлиять на результаты и ход исследования. Требуется дальнейшее исследование в гомогенных по менискальной патологии, гипермобильности и другим показателям группах пациентов.

\section{СПИСОК ИСТОЧнИКОВ}

1. Incidence of anterior cruciate ligament tears and reconstruction: a 21-year population-based study / T.L. Sanders, H.M. Kremers, A.J. Bryan, D.R. Larson, D.L. Dahm, B.A. Levy, M.J. Stuart,A.J. Krych//Am. J. Sports. Med. 2016. Vol.44, No6.P.1502-1507. DOI: 10.1177/0363546516629944.

2. The evolution of ACL reconstruction over the last fifty years / P. Chambat, C. Guier, B. Sonnery-Cottet, J.M. Fayard, M. Thaunat// Int. Orthop. 2013. Vol. 37, No 2. P. 181-186. DOI: 10.1007/s00264-012-1759-3.

3. Schindler O.S. Surgery for anterior cruciate ligament deficiency: a historical perspective // Knee Surg. Sports. Traumatol. Arthrosc. 2012. Vol. 20, No 1. P. 5-47. DOI: 10.1007/s00167-011-1756-x.

4. Hamstring Autograft versus Patellar Tendon Autograft for ACL reconstruction: Is there a difference in graft failure rate? A meta-analysis of 47,613 patients / B.T. Samuelsen, K.E. Webster, N.R. Johnson, T.E. Hewett, A.J. Krych // Clin. Orthop. Relat. Res. 2017. Vol. 475, No 10. P. 2459-2468. DOI: $10.1007 / \mathrm{s} 11999-017-5278-9$.

5. A meta-analysis of bone-patellar tendon-bone autograft versus four-strand hamstring tendon autograft for anterior cruciate ligament reconstruction / X. Xie, X. Liu, Z. Chen, Y. Yu, S. Peng, Q. Li // Knee. 2015. Vol. 22, No 2. P. 100-110. DOI: 10.1016/j.knee.2014.11.014.

6. Twenty-Year Outcome of a Longitudinal Prospective Evaluation of Isolated Endoscopic Anterior Cruciate Ligament Reconstruction with Patellar Tendon or Hamstring Autograft / S.M. Thompson, L.J. Salmon, A. Waller, J. Linklater, J.P. Roe, L.A. Pinczewski // Am. J. Sports. Med. 2016. Vol. 44, No 12. P. 3083-3094. DOI: 10.1177/0363546516658041.

7. Likelihood of ACL graft rupture: not meeting six clinical discharge criteria before return to sport is associated with a four times greater risk of rupture / P. Kyritsis, R. Bahr, P. Landreau, R. Miladi, E. Witvrouw // Br. J. Sports. Med. 2016. Vol. 50, No 15. P. 946-951. DOI: 10.1136/ bjsports-2015-095908.

8. Failure risks in anatomic single-bundle anterior cruciate ligament reconstruction via the outside-in tunnel technique using a hamstring autograft / Y. Yamanashi, H. Mutsuzaki, K. Iwai, K. Ikeda, T. Kinugasa // J. Orthop. 2019. Vol. 16, No 6. P. 504-507. DOI: 10.1016/j.jor.2019.04.015.

9. Mulford J.S., Chen D. Anterior cruciate ligament reconstruction: a systematic review of polyethylene terephthalate grafts // ANZ. J. Surg. 2011. Vol. 81, No 11. P. 785-789. DOI: 10.1111/j.1445-2197.2011.05884.x.

10. Autograft or allograft for reconstruction of anterior cruciate ligament: a health economics perspective / H. Mistry, A. Metcalfe, J. Colquitt, E. Loveman, N.A. Smith, P. Royle, N. Waugh // Knee Surg. Sports Traumatol. Arthrosc. 2019. Vol. 27, No 6. P. 1782-1790. DOI: 10.1007/s00167019-05436-z.

11. Autograft versus Allograft Anterior Cruciate Ligament Reconstruction: A prospective, randomized clinical study with a minimum 10-year followup / C.R. Bottoni, E.L. Smith, J. Shaha, S.S. Shaha, S.G. Raybin, J.M. Tokish, D.J. Rowles // Am. J. Sports Med. 2015. Vol. 43, No 10. P. 2501-2509. DOI: $10.1177 / 0363546515596406$.

12. Comparison of clinical outcomes after anterior cruciate ligament reconstruction with hamstring tendon autograft versus soft-tissue allograft: A metaanalysis of randomised controlled trials / H.D. Wang, H. Zhang, T.R. Wang, W.F. Zhang, F.S. Wang, Y.Z. Zhang // Int. J. Surg. 2018. Vol. 56. P. 174183. DOI:10.1016/j.ijsu.2018.06.030.

13. Irradiated allograft versus autograft for anterior cruciate ligament reconstruction: A meta-analysis and systematic review of prospective studies / H.D. Wang, Y.B. Zhu, T.R. Wang, W.F. Zhang, Y.Z. Zhang // Int. J. Surg. 2018. Vol. 49. P. 45-55. DOI: 10.1016/j.ijsu.2017.12.007.

14. Autograft versus allograft in anterior cruciate ligament reconstruction: A meta-analysis with trial sequential analysis / S.L. Kan, Z.F. Yuan, G.Z. Ning, B. Yang, H.L. Li, J.C. Sun, S.Q. Feng // Medicine (Baltimore). 2016. Vol. 95, No 38. P. e4936. DOI: 10.1097/MD.0000000000004936.

15. Peroneus longus autograft can be recommended as a superior graft to hamstring tendon in single-bundle ACL reconstruction / S. Rhatomy, A.I.Z. Asikin, A.E. Wardani, T. Rukmoyo, I. Lumban-Gaol, N.C. Budhiparama // Knee Surg. Sports Traumatol. Arthrosc. 2019. Vol. 27, No 11. P. 3552-3559. DOI: 10.1007/s00167-019-05455-w.

16. All-Inside Single-Bundle Reconstruction of the Anterior Cruciate Ligament with the Anterior Half of the Peroneus Longus Tendon Compared to the Semitendinosus Tendon: A two-year follow-up study / M. Bi, C. Zhao, S. Zhang, B. Yao, Z. Hong, Q. Bi // J. Knee Surg. 2018. Vol. 31, No 10. P. 1022-1030. DOI: 10.1055/s-0038-1627466.

17. Tan S.H.S., Lau B.P.H., Krishna L. Outcomes of Anterior Cruciate Ligament Reconstruction in Females Using Patellar-Tendon-Bone versus Hamstring Autografts: A systematic review and meta-analysis // J. Knee Surg. 2019. Vol. 32, No 8. P. 770-787. DOI: 10.1055/s-0038-1669916.

18. Anatomic Anterior Cruciate Ligament Reconstruction via independent tunnel drilling: A systematic review of randomized controlled trials comparing Patellar Tendon and Hamstring Autografts / M.C. Ciccotti, E. Secrist, F. Tjoumakaris, M.G. Ciccotti, K.B. Freedman // Arthroscopy. 2017. Vol. 33, No 5. P. 1062-1071.e5. DOI: 10.1016/j.arthro.2017.01.033.

19. Исходы восстановления передней крестообразной связки / М.Э. Ирисметов, Ф.М. Усмонов, Д.Ф. Шамшиметов, А.М. Холиков, К.Н. Ражабов, М.Б. Таджиназаров // Гений ортопедии. 2019. Т. 25, № 3. C. 285-289. DOI: 10.18019/1028-4427-2019-25-3-285-289.

20. Модификация способа подготовки и установки четырехпучкового аутотрансплантата из сухожилия полусухожильной мышцы при пластике передней крестообразной связки / В.В. Сластинин, Н.В. Ярыгин, М.В. Паршиков, М.В. Сычевский, А.М. Файн // Гений ортопедии. 2019. T. 25, № 3. C. 277-284. DOI 10.18019/1028-4427-2019-25-3-277-284.

21. The effect of targeted exercise on knee-muscle function in patients with persistent hamstring deficiency following ACL reconstruction - study protocol for a randomized controlled trial / B. Bregenhof, U. Jørgensen, P. Aagaard, N. Nissen, M.W. Creaby, J.B. Thorlund, C. Jensen, T. Torfing, A. Holsgaard-Larsen // Trials. 2018. Vol. 19, No 1. P. 75. DOI: 10.1186/s13063-018-2448-3.

22. Eversion and First Ray Plantarflexion Muscle Strength in Anterior Cruciate Ligament Reconstruction Using a Peroneus Longus Tendon Graft / S. Rhatomy, F.H. Wicaksono, N.R. Soekarno, R. Setyawan, S. Primasara, N.C. Budhiparama // Orthop. J. Sports Med. 2019. Vol. 7, No 9. 2325967119872462. DOI: 10.1177/2325967119872462. 
23. The Anterior Cruciate Ligament Reconstruction with the Peroneus Longus Tendon: A Biomechanical and Clinical Evaluation of the Donor Ankle Morbidity / C. Angthong, B. Chernchujit, A. Apivatgaroon, K. Chaijenkit, P. Nualon, K. Suchao-in // J. Med. Assoc. Thai. 2015. Vol. 98 , No 6. P. $555-560$.

24. Magnetic resonance imagination of the peroneus longus tendon after anterior cruciate ligament reconstruction/S. Kerimoğlu, P. Koşucu, M. Livaoğlu, I. Yükünç, A.U. Turhan // Knee Surg. Sports Traumatol. Arthrosc. 2009. Vol. 17, No 1. P. 35-39. DOI: 10.1007/s00167-008-0626-7.

25. Predicting the graft diameter of the peroneus longus tendon for anterior cruciate ligament reconstruction / X. Song, Q. Li, Z. Wu, Q. Xu, D. Chen, Q. Jiang // Medicine (Baltimore). 2018. Vol. 97, No 44. P. e12672. DOI: 10.1097/MD.0000000000012672.

26. Influence of anthropometric features on peroneus longus graft diameter in Anterior Cruciate Ligament reconstruction: A cohort study / S. Rhatomy, H. Tanzil, R. Setyawan, C. Amanda, K.Y. Phatama, J. Andrianus, T. Rukmoyo, B. Kisworo // Ann. Med. Surg. (Lond). 2019. Vol. 48. P. 77-80. DOI: 10.1016/j.amsu.2019.10.023.

27. Кожевников Е.В., Баженов П.А. Пластическое восстановление передней крестообразной связки свободным аутотрансплантатом из сухожилия длинной малоберцовой мышцы // Политравма. 2011. № 1. С. 76-81.

Статья поступила в редакцию 18.08.2020; одобрена после рецензирования 15.02.2021; принята к публикации 23.12.2021.

The article was submitted 18.08.2020; approved after reviewing 15.02.2021; accepted for publication 23.12.2021.

Информация об авторах:

1. Евгений Николаевич Гончаров - кандидат медицинских наук, goncharoven@gmail.com;

2. Николай Гавриилович Гончаров- доктор медицинских наук, професcop, goncharovng57@gmail.com;

3. Эдуард Николаевич Безуглов - e.n.bezuglov@gmail.com;

4. Александр Александрович Ветошкин - кандидат медицинских наук, totoalex5@gmail.com;

5. Иван Александрович Резуненко - dr.rezunenko81@gmail.com;

6. Сергей Хачатурович Оганесян - o.s.x1@mail.ru;

7. Олег Александрович Коваль - drkovaloa@gmail.com.

\section{Information about the authors:}

1. Evgeniy N. Goncharov - Candidate of Medical Sciences, goncharovng57@gmail.com;

2. Nikolay G. Goncharov - Doctor of Medical Sciences,, Professor, goncharovng57@gmail.com;

3. Eduard N. Bezuglov - M.D., e.n.bezuglov@gmail.com;

4. Aleksandr A. Vetoshkin - Candidate of Medical Sciences, totoalex5@gmail.com;

5. Ivan A. Rezunenko - M.D., dr.rezunenko81@gmail.com;

6. Sergey Kh. Oganesyan - M.D., o.s.x1@mail.ru;

7. Oleg A. Koval - M.D., drkovaloa@gmail.com. 
Гений ортопедии. 2022. Т. 28, № 1. С. 62-68.

Genij Ortopedii. 2022. Vol. 28, no. 1. P. 62-68.

\section{Научная статья}

удК 616.728.3-07:616.758.3-001-039.73-053.2

https://doi.org/10.18019/1028-4427-2022-28-1-62-68

\section{Оценка структур коленного сустава пациентов детского возраста с повреждением передней крестообразной связки после консервативного лечения}

\section{Ярослав Александрович Иванов ${ }^{\bowtie}$, Александр Геннадьевич Ельцин, Дмитрий Сергеевич Мининков}

Национальный медицинский исследовательский центр травматологии и ортопедии имени Н.Н. Приорова, Москва, Россия

Автор, ответственный за переписку: Ярослав Александрович Иванов, docyaroslav@gmail.com

\section{Аннотация}

Обоснование. Вопрос консервативного лечения пациентов детского возраста с антеромедиальной нестабильностью после разрыва ПКС весьма актуален и вызывает дискуссии в научном сообществе. Весьма неоднозначными являются результаты такого лечения у пациентов как с открытыми зонами роста, так и у взрослых пациентов, достигших костной зрелости. Также вызывает интерес влияние антеромедиальной нестабильности на повреждение таких структур коленного сустава как мениски и суставной хрящ. Цель. Оценить результаты консервативного лечения у молодых спортсменов, используя методы клинического осмотра, анкетирования и МРТ-диагностики. Материалы и методы. В исследовании принимало участие 20 пациентов с антеромедиальной нестабильностью в возрасте от 13 до 20 лет. Срок наблюдения составил до 2,7 года (33 месяца). Пациенты анкетировались по опросникам KOOS-Child и Pedi-IKDC. Tакже выполнялось как минимум два МРТ-исследования. Пациентам назначалась консервативная терапия. Результаты и обсуждение. По данным МРТ-исследования у 9 (45 \%) из 20 пациентов отмечались остеохондральные изменения мыщелков обеих костей. У 14 пациентов отмечено истончение хрящевого покрытия коленного сустава на $\geqslant 0,7$ см. Восемнадцать человек имели клинически подтвержденную нестабильность коленного сустава. Восьми (40 \%) пациентам впоследствии выполнялось оперативное лечение. Заключение. По результатам исследования мы делаем вывод о неудовлетворительных результатах консервативного лечения. Только 2 пациента вернулись к прежним нагрузкам, и клинически нестабильность коленного сустава не отмечалась. В остальных случаях пациенты не удовлетворены результатами лечения. На основании данных МРТ-исследований и данных статистического анализа у пациентов отмечались выраженные признаки нарушения распределения нагрузки в коленном суставе, а также вторичное повреждение мениска вследствие антеромедиальной нестабильности.

Ключевые слова: дети, коленный сустав, повреждение, вторичные изменения, повреждение менисков, антеромедиальная нестабильность, повреждение ПКС, KOOS-Child, Pedi-IKDC, консервативное лечение, оценка результатов лечения

Благодарности: авторы выражают благодарность Сергею Игоревичу Моисееву за большой вклад в анализ данных.

Для цитирования: Иванов Я.А., Ельцин А.Г., Мининков Д.С. Оценка структур коленного сустава пациентов детского возраста с повреждением передней крестообразной связки после консервативного лечения // Гений ортопедии. 2022. T. 28, № 1. С. 62-68. https://doi. org/10.18019/1028-4427-2022-28-1-62-68

\section{Original article}

\section{Evaluation of the knee joint structures of pediatric patients with anterior cruciate ligament injury after conservative treatment}

\section{Yaroslav A. Ivanov ${ }^{\bowtie}$, Alexander G. Yeltsin, Dmitry S. Mininkov}

National Medical Research Center of Traumatology and Orthopedics named after N.N. Priorov, Moscow, Russian Federation

Corresponding author: Yaroslav A. Ivanov, docyaroslav@gmail.com

\section{Abstract}

Background Conservative treatment of pediatric patients with anteromedial instability after ACL rupture is a very topical subject and raises many debates in the scientific community. Results of this treatment are rather controversial both in patients with open physis and in adult patients who reached skeletal maturity. Influence of anteromedial instability on damaging such structures of the knee joint and meniscus and articular cartilage also generates interest. Purpose The purpose is to evaluate results of conservative treatment in young athletes using methods of clinical examination, questionnaires and MRI-diagnostics. Material and methods The study included 20 patients with anteromedial instability aged 13-20 years. Duration of observation was up to 2.7 years (33 months). The patients filled out KOOS-Child and Pedi-IKDC questionnaires. At least two MRI-examinations were done also. The patients were treated conservatively. Results and discussion MRI data indicated that 9 (45\%) patients had osteochondral changes in condyles of the both bones. Thinning of the knee cartilage by $\geqslant 0.7 \mathrm{~cm}$ was observed in 14 patients. Eighteen patients has the clinically confirmed knee joint instability. Eight (40\%) patients underwent operative treatment later. Conclusion Our study results allowed us to make a conclusion about poor results of the conservative treatment. Only 2 patients returned to previous activities and the knee instability was not observed clinically. The rest of the patients were not satisfied with the treatment results. MRI data and statistical analysis data indicated that the patients had signs of significant weight distribution disorders in the knee joint and also secondary damage of meniscus due to anteromedial instability.

Keywords: children, knee joint, injury, secondary changes, meniscus damage, anteromedial instability, ACL injury, KOOS-Child; Pedi-IKDC; conservative treatment; evaluation of treatment results

Acknowledgments: The authors are grateful to Sergei Igorevich Moiseev for his great contribution to data analysis.

For citation: Ivanov Ya.A., Yeltsin A.G., Mininkov D.S. Evaluation of the knee joint structures of pediatric patients with anterior cruciate ligament injury after conservative treatment. Genij Ortopedii, 2022, vol. 28, no 1, pp. 62-68. https://doi.org/10.18019/1028-4427-2022-28-1-62-68

\section{ВВЕДЕНИЕ}

При антеромедиальной нестабильности коленного сустава, связанной с разрывом ПКС, значительно увеличивается риск развития вторичных повреждений менисков [1-4], дегенеративных изменений [5, 6] и, как следствие, вероятность не вернуться к прежним физическим нагрузкам [7-11], а также снижается качество жизни $[12,13]$. Все вышеперечисленные проблемы являются важными аргументами в пользу оперативного лечения, которое признано стандартом у пациентов взрослой возрастной группы. Однако у пациентов детского возраста в связи с активной зоной роста возникает ряд проблем с выбором в пользу оперативного 
лечения [14]. В первую очередь, в связи с риском повреждения зон роста, что может привести к укорочению конечности и деформации коленного сустава [15-17]. Также существует ряд трудностей, связанных с техникой выполнения пластики ПКС у пациентов с активны- ми темпами роста. Оценка результатов консервативного лечения в форме клинического осмотра, анкетирования, а также при помощи МРТ-исследований структур коленного сустава дает возможность, взглянув на проблему под более широким углом, улучшить ее понимание.

\section{МАТЕРИАЛЫ И МЕТОДЫ}

Все пациенты и добровольцы, участвовавшие в клиническом исследовании, дали на это письменное согласие. Исследование выполнено в соответствии с требованиями Хельсинской декларации Всемирной медицинской ассоциации (в ред. 2013 г.). Исследование одобрено этическим комитетом.

Были выделены следующие критерии включения в исследование: разрыв ПКС у пациентов в возрасте от 13 до 20 лет. Пациенты анкетировались опросниками KOOS-Child и Pedi-IKDC. Проводился клинический осмотр (Pivot-shift, Lachman тесты). Также выполнялось как минимум два МРТ-исследования (первые недели после травмы и в различные сроки после первого исследования) на аппарате мощностью не менее 1,5 Тесла. Средний срок между выполнением 1-ой и 2-ой МРТ составил 13 месяцев, минимальный - 2 месяца, максимальный 33 месяца. У 14 человек МРТ была выполнена на одном и том же аппарате. Режимы исследования: T1, T2, PD, PD SW, T1 FSE. Пациентам также назначалась консервативная терапия в объеме иммобилизации в ортезе в течение 4-х недель, курс НПВП (нестероидные противовоспалительные средства) и последующая реабилитация.

Исследование одноцентровое. В исследование не вошли пациенты, у которых помимо разрыва ПКС на- блюдались переломы межмыщелкового возвышения и повреждение боковых связок, ЗКС.

Для исследования было отобрано 20 пациентов, которым в период с 2020 по 2021 год проводилось консервативное лечение в связи с разрывом ПКС. Из них 12 мужского и 8 женского пола. Срок наблюдения составил до 2,7 года (33 месяца).

Для выявления взаимосвязей между критериями, определяющими качество результатов лечения пациентов, использовались методы статистического анализа, включающие в себя теорию параметрического и непараметрического корреляционного анализа. Ставилась задача выявления взаимосвязей между показателями, критериями и измерительными инструментами (MPT), которые используются для оценки качества лечения пациентов. Были решены следующие задачи: обоснован выбор измерительного инструмента для оценки качества лечения; оценена адекватность методов измерения, показателей и критериев, применяющихся для измерения результатов лечения; получены количественные зависимости между критериями оценки качества лечения; определена структура взаимозаменяемости и взаимодополняемости методов обследования пациентов и другие задачи.

\section{РЕЗУЛЬТАТЫ}

По данным МРТ у 10 (50 \%) из 20 пациентов отмечались остеохондральные изменения мыщелков обеих костей, из них у 8 (40 \%) человек на наружном мыщелке бедренной кости, у 1-го на обоих мыщелках бедренной кости и у 1-го пациента на латеральных мыщелках большеберцовой и бедренной костей.

В приведенном случае показан пример склеротического поражения костного мозга. Данное «утолщение» костной структуры возникает вследствие неправильно распределенной нагрузки в коленном суставе. Пациент отмечал нестабильность в коленном суставе, что было подтверждено клиническим осмотром и данными МРТ-исследования, диагностирующего разрыв ПКС. На зону склеротического изменения идет постоянная локальная ударная нагрузка, вследствие чего возникает ответная компенсаторная реакция организма в виде утолщения. На рисунке 1 представлены изображения МРТ-исследований с разницей в 2 месяца.

Впоследствии в описываемой зоне возрастает риск возникновения трансхондрального перелома, и возможно образование кисты [18]. На рисунке 2 представлены МРТ-изображения коленного сустава с разницей в 16 месяцев.

Пациента также беспокоила нестабильность в коленном суставе, что было подтверждено клинически. На изображении (В) видно повреждение заднего рога наружного мениска (Stoller IIIb) вследствие возникшей антеромедиальной нестабильности коленного сустава после разрыва ПКС. Также у пациента, как и в первом случае (рис. 1), отмечается склеротическое изменение костной структуры наружного мыщелка бедренной кости, являющееся подтверждением неправильно распределяемой нагрузки в коленном суставе [19].

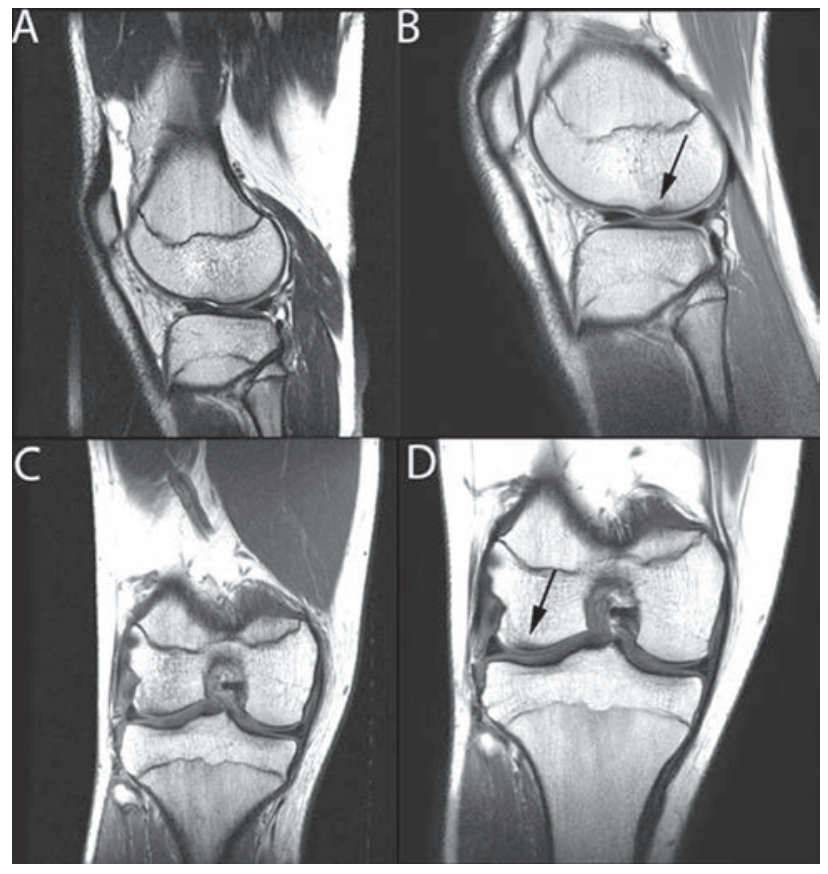

Рис. 1. Наружный отдел коленного сустава пациента в первые недели после травмы (A, C). Через 2 месяца на повторной MPT (режим PD TSE) в том же отделе отмечается (B, D) уплотнение костной ткани вследствие неправильного распределения нагрузки (черная стрелка) 


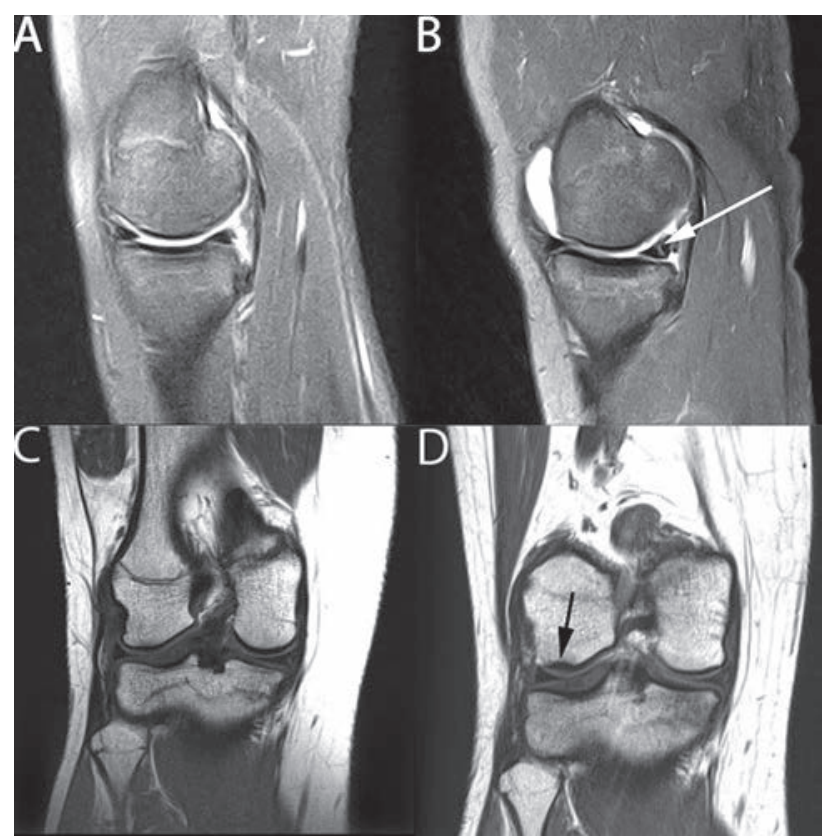

Рис. 2. Наружный отдел коленного сустава в сагиттальной (А) и коронарной проекции (С). Исследование сделано в первую неделю после травмы. Спустя 16 месяцев после первого МРТ-исследования (режим PD TSE FS (A, B) и режим T1 SE (C, D)) отмечается повреждение (белая стрелка) заднего рога наружного мениска (Stoller III) (B), а также уплотнение костной ткани (черная стрелка) вследствие неправильно распределенной нагрузки в коленном суставе изза антеромедиальной нестабильности

На рисунке 3 представлены МРТ-изображения с разницей в 13 месяцев между исследованиями. Черной стрелкой указана зона начинающейся деструкции костной структуры. Данное нарушение является следствием образовавшегося трансхондрального перелома, подвергшегося литическому воздействию синовиальной жидкости.
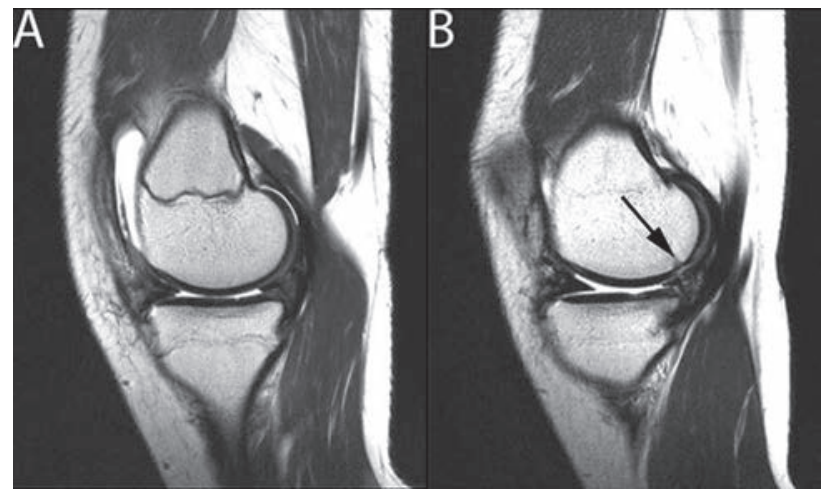

Рис. 3. МРТ-изображение (режим Т1 SE) медиального отдела коленного сустава в сагиттальной проекции (А) в первые недели с момента травмы. Тот же отдел коленного сустава через 13 месяцев с момента выполнения первой МРТ (B). На изображении видна начинающаяся деструкции костной ткани в результате возникновения перелома (черная стрелка)

На рисунке 4 представлены данные MPTисследования коленного сустава пациента с разрывом ПКС. На изображении (В) видно вторичное повреждение заднего рога наружного мениска (Stoller IIIb) вследствие антеромедиальной нестабильности. В нашем исследовании у 9 (45 \%) пациентов обнаружено повреждение мениска: у 5 человек выявлен разрыв внутреннего мениска, а у 4-х человек - наружного.

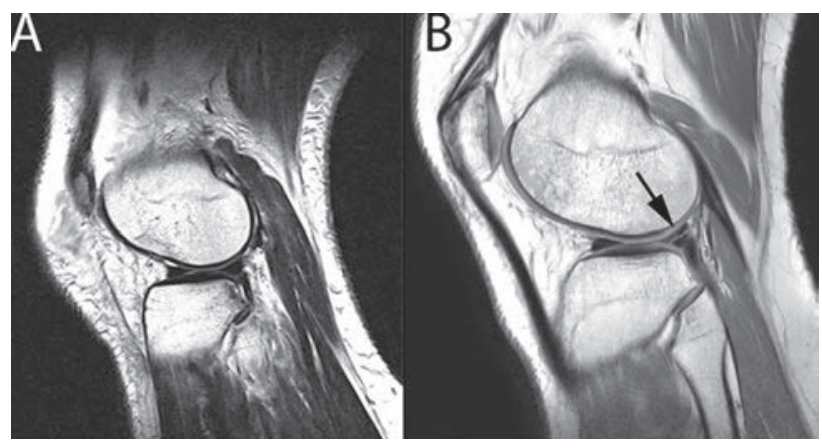

Рис. 4. МРТ (режим T1 SE) коленного сустава в сагиттальной проекции (А) в первые недели после травмы. MPT (режим T1 SE) спустя 5 месяцев после выполнения первого исследования (В). Визуализируется повреждение заднего рога наружного мениска (черная стрелка)

На рисунке 5 показана схема измерения толщины хряща. Измерение производится в 2-х проекциях: сагиттальной и коронарной. На каждом мыщелке большеберцовой и бедренной костей устанавливается по три точки, в которых измеряется толщина хряща. Всего точек измерения 24 , после чего проводится аналогичная процедура на вторых МРТ-снимках пациента, выполненных спустя время. Измерение проводилось с использованием программы RadiAnt в режимах T1, PDW, T2. В настоящий момент наиболее точным методом измерения толщины хряща является картирование. В нашем исследовании измерение при помощи данного метода не проводилось. В связи с высокой вероятностью неточности обычного измерения при помощи инструмента линейки в специализированном программном обеспечении была учтена погрешность, равная 0,7 см. По данным исследования у 4 (20\%) человек отмечается истончение хрящевого покрытия латерального мыщелка бедренной кости $\geqslant 0,7$ см, у 2-х (10 \%) отмечается истончение как на латеральном, так и медиальном мыщелке бедренной кости $\geqslant 0,7$ см, у 3-х (15 \%) отмечается истончение хрящевого покрытия только на медиальном мыщелке бедренной кости $\geqslant 0,7$ см. На наружном мыщелке большеберцовой кости истончение $\geqslant 0,7$ см отмечается у 3 (15 \%) человек, на обоих мыщелках $\geqslant 0,7$ см отмечается у 6 (30 \%) человек.

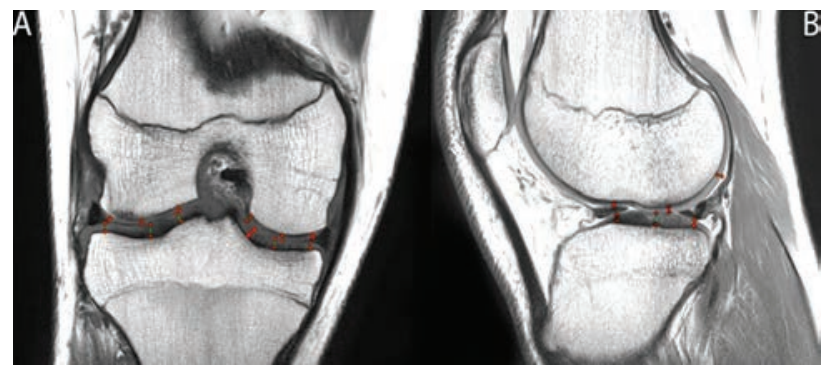

Рис. 5. На МРТ-изображении (режим T1 SE) в коронарной проекции (A) показан метод измерения толщины хряща в трех точках на каждом мыщелке большеберцовой и бедренной костей. В сагиттальной проекции (В) показан пример измерения толщины хряща в трех точках на медиальных мыщелках большеберцовой и бедренной костей

В исследовании применялись опросники KOOSChild и Pedi-IKDC у пациентов младше 18 лет, а опросники KOOS и IKDC у пациентов более старшего возраста. Пациенты с жалобами на неустойчи- 
вость в коленном суставе осматривались клинически. У 18 человек при выполнении тестов ПВЯ, Lachman и pivot-shift отмечалась нестабильность. Помимо указанных жалоб, пациентам пришлось значительно снизить уровень активности либо отказаться от спорта совсем. Только 2 пациента из 20 остались удовлетворены результатами консервативного лечения и вернулись к прежним нагрузкам. Восьми (40 \%) пациентам выполнено впоследствии оперативное лечение. В объеме пластики ПКС 6-ти (30 \%) и 2-м (10 \%) - в объеме резекции поврежденной части мениска.

Выявление взаимосвязей между критериями, определяющими качество результатов лечения пациентов. Статистический анализ

В данном разделе ставится задача выявления взаимосвязей между показателями, критериями или измерительными инструментами, которые используются для оценки качества лечения пациентов с антеромедиальной нестабильностью. Определение таких связей позволит решить несколько задач: обосновать выбор «измерительного инструмента» для оценки качества лечения; судить об адекватности методов измерения, показателей и критериев; получить количественные зависимости между критериями оценки качества лечения; определить структуру взаимозаменяемости и взаимодополняемости методов обследования пациентов.

Критерии оценки представлены в таблице 1. Там же указано их условное обозначение, которое будет использоваться далее, а также шкалы оценки по критериям.

На первом этапе для выбора модели оценивания взаимосвязей между критериями необходимо определиться с методами вычисления корреляции между ними. Для этого необходимо статистически определить возможный закон распределения измерений по каждому критерию. Проверка закона распределения измерений для всех критериев, проводимая на основании критерия согласия Пирсона [20-23], показала, что оценки по количественным критериям распределены по закону, близкому к нормальному, на уровне значимости, не превышающем 0,05. В то же время, оценка результатов измерений по дихотомическим критериям показала отличие распределения от нормального.

На основании этого было принято решение брать за основу непараметрические методы корреляционного анализа (ранговый коэффициент корреляции Спирмена), которые не зависят от закона распределения оцениваемых параметров, но для уточнения результатов для количественных критериев сравнить их с расчетами по параметрическим методам, построенным для нормального закона распределения.

Проведя расчеты при объеме выборки $\mathrm{N}=20$, можно рассчитать граничные коэффициенты корреляции для каждой градации связей.

- значение корреляции $\left|r_{m n}\right|$ от 0,378 до 0,515 - связь умеренная;

- значение корреляции $\left|r_{m n}\right|$ от 0,515 до 0,609 - связь сильная;

- значение корреляции $\left|r_{m n}\right|$ от 0,609 до 1 - связь очень сильная.

На рисунке 6 схематично показаны связи между критериями. Исчезновение связей на диаграмме (В) говорит о том, что более мощный критерий Пирсона не выявил значимой корреляции между указанными критериями, поэтому данные связи, возможно, существуют, но к их учету нужно относиться с осторожностью. С другой стороны, корреляция Пирсона выявила дополнительные зависимости, которые не определил ранговый критерий Спирмена, а именно, возникли новые связи между критериями К4-K11, K6-K12, K13-K14. C учетом того, что связи К4-K11 и К13-К14 показывают взаимосвязи между числовыми критериями, которые с большой вероятностью распределены по нормальному закону, есть основания считать, что более мощный метод оценки корреляции Пирсона выявил дополнительную связь между указанными критериями, что следует учесть при анализе взаимосвязей.

Таблица 1

Данные критериев

\begin{tabular}{|c|c|c|}
\hline Обозначение & Описание & Шкала измерений \\
\hline K1 & Толщина хряща наружного мыщелка бедренной кости (мм) & Числовая \\
\hline $\mathrm{K} 2$ & Толщина хряща внутреннего мыщелка бедренной кости (мм) & Числовая \\
\hline K3 & Толщина хряща наружного мыщелка большеберцовой кости (мм) & Числовая \\
\hline K4 & Толщина хряща внутреннего мыщелка большеберцовой кости (мм) & Числовая \\
\hline K5 & Латеральный мениск & Дихотомическая \\
\hline K6 & Медиальный мениск & Дихотомическая \\
\hline K7 & Остеохондральные изменения: наружный мыщелок бедренной кости & Дихотомическая \\
\hline K8 & Остеохондральные изменения: внутренний мыщелок бедренной кости & Дихотомическая \\
\hline K9 & Остеохондральные изменения: наружный мыщелок большеберцовой кости & Дихотомическая \\
\hline K10 & Выполнение МРТ на одном и том же аппарате & Дихотомическая \\
\hline K11 & Кол-во мес. между МРТ-исследованиями & Числовая \\
\hline K12 & Возраст пациента & Числовая \\
\hline K13 & KOOS-Child Pain & Числовая \\
\hline K14 & KOOS-Child Symptom & Числовая \\
\hline K15 & KOOS-Child ADL & Числовая \\
\hline K16 & KOOS-Child Sport/Rec & Числовая \\
\hline K17 & KOOS-Child QOL & Числовая \\
\hline K18 & Pedi-IKDC & Числовая \\
\hline K19 & Клинические тесты на нестабильность коленного сустава & Дихотомическая \\
\hline
\end{tabular}



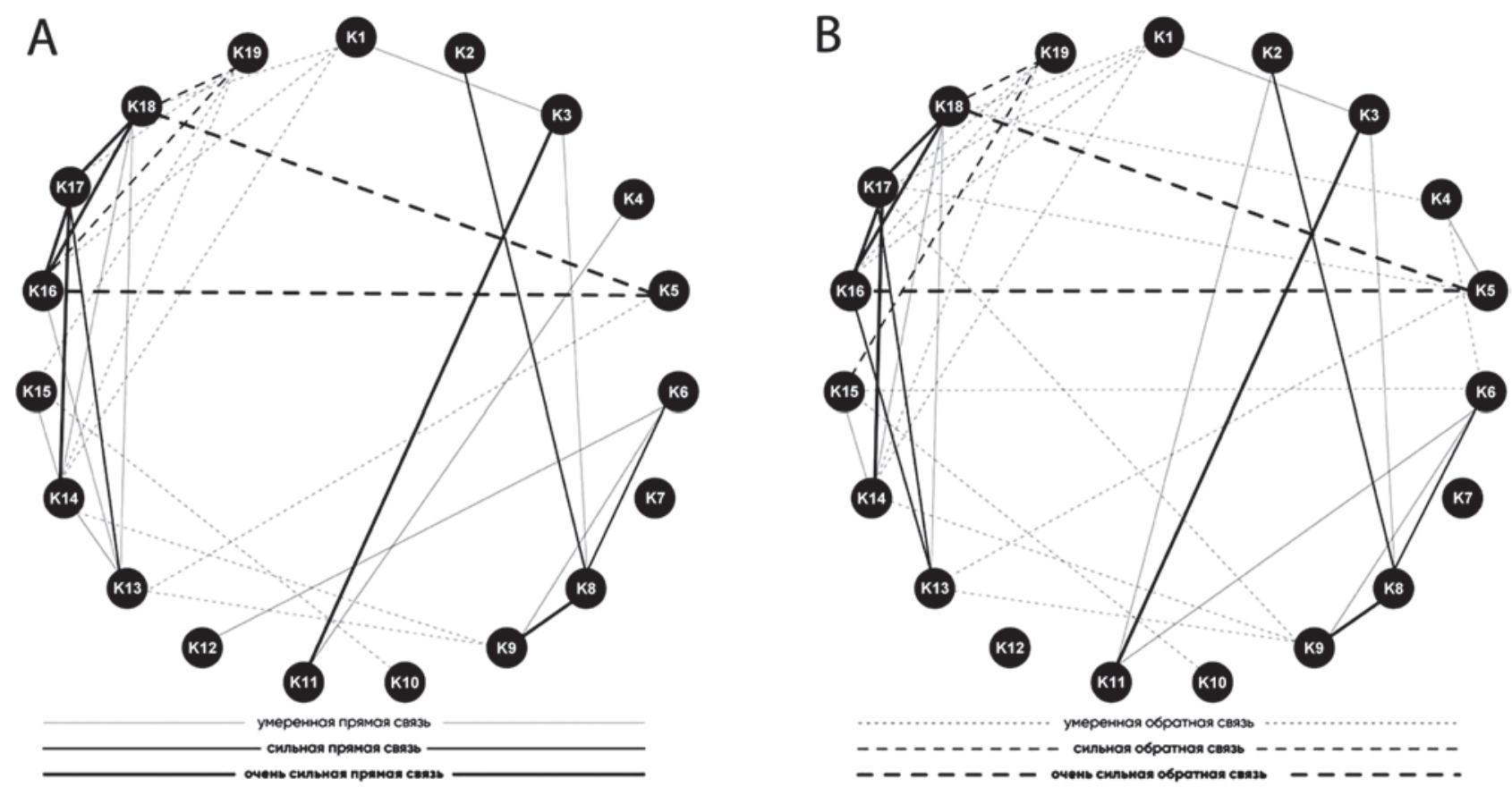

Рис. 6. Граф связей между критериями на основании ранговой корреляции Спирмена (А). Граф связей между критериями на основании параметрической корреляции Пирсона (В)

В результате проведенного статистического анализа выявлены следующие связи:

- очень сильные прямые связи найдены между толщиной хрящевого покрытия медиального мыщелка большеберцовой кости и количеством месяцев между выполнением МРТ; остехондральными изменениями внутреннего мыщелка бедренной кости и наружного мыщелка большеберцовой кости; результатами опросников KOOS-Child и Pedi-IKDC;

- сильные прямые связи найдены между толщи- ной хряща медиального мыщелка бедренной кости и остеохондральными изменениями того же мыщелка; медиальным мениском и остеохондральными изменениями внутреннего мыщелка бедренной кости;

- очень сильная обратная связь найдена между результатами тестов KOOS-Child, Pedi-IKDC и латеральным мениском;

- сильная обратная связь найдена между результатами тестов KOOS-Child, Pedi-IKDC и результатами клинического осмотра.

\section{ОБСУЖДЕНИЕ}

Оценка результатов консервативного лечения пациентов детского возраста с открытыми зонами роста имеет важное значение. Также вызывает интерес влияние антеромедиальной нестабильности на структуры коленного сустава. Похожие исследования проводились и за рубежом. Ekås G.R. et al. [24] исследовали структуру коленного сустава на наличие патологий, связанных с антромедиальной нестабильностью после разрыва ПКС. В исследовании принимало участие 47 пациентов со сроком наблюдения 9,5 лет. Возраст пациентов до 13 лет. Исследование включало в себя выполнение МРТ обоих коленных суставов на аппарате мощностью 3 Тесла через 1,2 и 9,5 лет с момента травмы. Консервативное лечение назначалось 43-м пациентам, 4-м проводилось оперативное лечение. По результатам исследования 16 пациентов имели повреждения менисков, 13 пациентов имели повреждения суставного хряща, 2 пациента имели разницу в длине конечностей > 15 мм. По итогу, 27-ми пациентам (57 \%) впоследствии выполнялась пластика ПКС. В заключении авторы делают вывод о том, что в некоторых случаях консервативное лечение (57 \% пациентов без вторичных изменений в коленном суставе и без признаков начального остеоартроза) может являться вариантом выбора.
Fabricant P.D. et al. [25] проводили обзор литературы с целью сравнения результатов консервативного и оперативного лечения у спортсменов моложе 18 лет. В своем обзоре Mizuta H. et al. представили исследование [26], где $94 \%$ из 18 человек не вернулись к прежним физическим нагрузкам, а 22 \% вовсе перестали заниматься спортом после травмы ПКС. Похожие результаты отмечаются и в исследовании McCarroll [27].

В нашем исследовании проводилась оценка изменений остеохондральных структур вследствие антеромедиальной нестабильности и неправильного распределения нагрузки в коленном суставе: склеротическое поражение костного мозга, начинающаяся деструкция костной структуры и признаки трансхондрального перелома. Помимо этого выявлены случаи повреждения менисков. Также проводились измерения толщины хряща, истончение которого может указывать на формирование деформирующего артроза в будущем. В нашем исследовании была взята высокая погрешность измерения толщины хряща ( $\geqslant 0,7$ см), так как слабой стороной в отношении измерения является отсутствие выполнения картирования у пациентов. Помимо этого, даже при условии выполнения исследования на одном аппарате, срезы выставляются лучевым диагностом в 
момент исследования, что также может приводить к неточностям при измерении толщины хрящевого покрытия. В связи с этим, в нашем исследовании следует считать более весомым критерием оценки остеохондральные изменения вследствие антеромедиальной нестабильности в силу их объективности. Также важно учитывать вторичное повреждение мениска вследствие вышеупомянутой причины.

Помимо использования данных МРТ-диагностики пациенты анкетировались, и проводился клинический осмотр. Жалобы на нестабильность, клинически подтверждённые положительные тесты Lachman и ПВЯ, а также низкие баллы опросников KOOS-Child и PediIKDC имеют решающее значение в оценке отдаленных результатов лечения, а также выбора в пользу оперативной стабилизации коленного сустава.

Похожие результаты отмечаются и в других исследованиях. Mizuta H. et al. [26] оценивали результаты консервативного лечения у детей с полным разрывом ПКС. В исследовании принимало участие 18 человек со сроком наблюдения не менее 36 месяцев. Все пациенты анкетировались по шкале Lysholm, где только у одного пациента, который смог вернуться к прежним физическим нагрузкам, результат оценивался как хороший. Повторное повреждение менисков отмечалось у 6 пациентов. Радиологические доказательства дегенеративных изменений в суставе отмечались у 11-ти пациентов. В заключении автор делает вывод о том, что результаты консервативного лечения являются неудовлетворительными.

Moksnes H. et al. [28] проводили исследование peзультатов консервативного лечения пациентов младше 12 лет. В качестве метода консервативного лечения авторы использовали свой алгоритм. По результатам исследования из 46 человек 34 не были прооперированы, а 38 \% снизили свой уровень активности. Срок наблюдения составил 2 года. Вторичные повреждения мениска наблюдались у 8 человек (17 \%).

Также вызывает интерес работа Raad M. et al. [29]. Авторы отметили положительную связь между индексом массы тела (ИМТ) и вторичным повреждением мениска у пациентов детского возраста. Из 160 пациентов 143 были прооперированы впоследствии, а 17 велись консервативно. Возможно, данный показатель может учитываться в будущих отечественных работах на данную тему.

\section{ЗАКЛЮЧЕНИЕ}

По результатам исследования мы делаем вывод о неудовлетворительных результатах консервативного лечения у молодых спортсменов. Только 2 пациента вернулись к прежним физическим нагрузкам, и при осмотре у них отсутствовали признаки нестабильности. В остальных случаях пациенты были не удовлетворены результатами лечения. На основании данных МРТ-исследований и данных статистического анализа у пациентов отмечаются выраженные признаки нарушения распределения нагрузки в коленном суставе, а также вторичное повреждение мениска вследствие антеромедиальной нестабильности коленного сустава. Также найдена связь между данными клинического осмотра и баллами опросников
KOOS-Child и Pedi-IKDC, что свидетельствует об их информативности. Мы рекомендуем при оценке результатов лечения использовать не только данные клинического осмотра, но и проводить анкетирование, а также выполнять МРТ-исследования с целью поиска признаков, указывающих на проявление неблагополучия в коленном суставе, что даст наиболее полное представление о его состоянии. Однако наше исследование не лишено недостатков, которые могут быть учтены в будущих работах: участие в исследовании большего количества пациентов; использование метода картирования суставного хряща с целью получения более точных данных и уменьшения погрешности измерения.

\section{СПИСОК ИСТОЧНИКОВ}

1. Meniscal tears associated with anterior cruciate ligament injury / T. Hagino, S. Ochiai, S. Senga, T. Yamashita, M. Wako, T. Ando, H. Haro // Arch. Orthop. Trauma Surg. 2015. Vol. 135, No 12. P. 1701-1706. DOI: 10.1007/s00402-015-2309-4.

2. Secondary meniscal tears in patients with anterior cruciate ligament injury: relationship among operative management, osteoarthritis, and arthroplasty at 18-year mean follow-up / M.H. Hagmeijer, M. Hevesi, V.S. Desai, T.L. Sanders, C.L. Camp, T.E. Hewett, M.J. Stuart, D.B.F. Saris, A.J. Krych // Am. J. Sports. Med. 2019. Vol. 47, No 7. P. 1583-1590. DOI: 10.1177/0363546519844481.

3. Meniscal tears in the ACL-deficient knee: correlation between meniscal tears and the timing of ACL reconstruction / S.G. Papastergiou, N.E. Koukoulias, P. Mikalef, E. Ziogas, H. Voulgaropoulos // Knee Surg. Sports. Traumatol. Arthrosc. 2007. Vol. 15, No 12. P. 1438-1444. DOI: 10.1007/s00167-007-0414-9.

4. Long-term follow-up of isolated ACL tears treated without ligament reconstruction / T.L. Sanders, A. Pareek, H.M. Kremers, A.J. Bryan, B.A. Levy, M.J. Stuart, D.L. Dahm, A.J. Krych // Knee Surg. Sports. Traumatol. Arthrosc. 2017. Vol. 25, No 2. P. 493-500. DOI: 10.1007/s00167-016-4172-4.

5. Das zeitabhängige Arthroserisiko nach vorderer Kreuzbandverletzung. Ergebnisse einer systematischen Literaturrecherche/G. Spahn, M. Schiltenwolf, B. Hartmann, J. Grifka, G.O. Hofmann, H.T. Klemm // Orthopade. 2016. Vol. 45, No 1. P. 81-90. DOI: 10.1007/s00132-015-3170-4.

6. Post-traumatic osteoarthritis following ACL injury / L.J. Wang, N. Zeng, Z.P. Yan, J.T. Li, G.X. Ni // Arthritis Res. Ther. 2020. Vol. 22 , No 1. P. 57. DOI: 10.1186/s13075-020-02156-5.

7. Fomin S., Gauffin H., Kvist J. Short-term recovery of physical activity and knee function after an acute knee injury // BMJ Open. Sport. Exerc. Med. 2020. Vol. 6, No 1. P. e000950. DOI: 10.1136/bmjsem-2020-000950.

8. Return to sport and re-tears after anterior cruciate ligament reconstruction in children and adolescents / L. Geffroy, N. Lefevre, C. TheveninLemoine, A. Peyronnet, W. Lakhal, J.M. Fayard, F. Chotel; French Arthroscopy Society // Orthop. Traumatol. Surg. Res. 2018. Vol. 104, No 8S. P. S183-S188. DOI: 10.1016/j.otsr.2018.09.006.

9. ACL tears in school-aged children and adolescents over 20 years / N.A. Beck, J.T.R. Lawrence, J.D. Nordin, T.A. DeFor, M. Tompkins // Pediatrics. 2017. Vol. 139, No 3. P. e20161877. DOI: 10.1542/peds.2016-1877.

10. Over $90 \%$ of children and adolescents return to sport after anterior cruciate ligament reconstruction: a systematic review and meta-analysis / J. Kay, M. Memon, R.G. Marx, D. Peterson, N. Simunovic, O.R. Ayeni // Knee Surg. Sports. Traumatol. Arthrosc. 2018. Vol. 26, No 4. P. 1019-1036. DOI: $10.1007 / \mathrm{s} 00167-018-4830-9$.

11. Return to sport after pediatric anterior cruciate ligament reconstruction and its effect on subsequent anterior cruciate ligament injury / T.J. Dekker, J.A. Godin, K.M. Dale, W.E. Garrett, D.C. Taylor, J.C. Riboh// J. Bone Joint. Surg. Am. 2017. Vol. 99, No 11. P. 897-904. DOI: 10.2106/JBJS.16.00758. 
12. Filbay S.R. Early ACL reconstruction is required to prevent additional knee injury: a misconception not supported by high-quality evidence // Br. J. Sports Med. 2019. Vol. 53, No 8. P. 459-461. DOI: 10.1136/bjsports-2018-099842.

13. Клиническая эффективность анатомической пластики передней крестообразной связки коленного сустава / В.В. Заяц, А.К. Дулаев, А.В. Дыдыкин, И.Н. Ульянченко // Гений ортопедии. 2021. Т. 27, № 1. C. 48-54. DOI: 10.18019/1028-4427-2021-27-1-48-54.

14. Садыков Р.Ш., Богатов В.Б., Понамарев И.Р. Пластика передней крестообразной связки коленного сустава у детей с открытыми зонами роста // Классика и инновации в травматологии и ортопедии: сборник материалов Всероссийской научно-практической конференции, посвященной 75-летию профессора А.П. Барабаша. Саратов: Амирит, 2016. С. 301-302. DOI: 10.17816/PTORS4326-31.

15. Anatomical and technical considerations for pediatric ACL reconstruction / R. Seil, F. Weitz, J. Menetrey, F. Chotel // Controversies in the technical aspects of ACL reconstruction. Ed. by N. Nakamura, S. Zaffagnini, R. Marx, V. Musahl. Berlin; Heidelberg: Springer, 2017. Ch. 48. P. 61-71. DOI: $10.1007 / 978-3-662-52742-9$ 8.

16. Growth disturbances without growth arrest after ACL reconstruction in children / F. Chotel, J. Henry, R. Seil, J. Chouteau, B. Moyen, J. Bérard // Knee Surg. Sports Traumatol. Arthrosc. 2010. Vol. 18, No 11. P. 1496-1500. DOI: 10.1007/s00167-010-1069-5.

17. Lawrence J.T., West R.L., Garrett W.E. Growth disturbance following ACL reconstruction with use of an epiphyseal femoral tunnel: a case report // J. Bone Joint. Surg. Am. 2011. Vol. 93, No 8. P. e39. DOI: 10.2106/JBJS.J.00569.

18. Meniscal pathology on MRI increases the risk for both incident and enlarging subchondral bone marrow lesions of the knee: the MOST Study / M. Englund, A. Guermazi, F.W. Roemer, M. Yang, Y. Zhang, M.C. Nevitt, J.A. Lynch, C.E. Lewis, J. Torner, D.T. Felson // Ann. Rheum. Dis. 2010. Vol. 69, No 10. P. 1796-1802. DOI: 10.1136/ard.2009.121681.

19. MRI-detected subchondral bone marrow signal alterations of the knee joint: terminology, imaging appearance, relevance and radiological differential diagnosis / F.W. Roemer, R. Frobell, D. J. Hunter, M.D. Crema, W. Fischer, K. Bohndorf, A. Guermazi // Osteoarthritis Cartilage. 2009. Vol. 17, No 9. P. 1115-1131. DOI: 10.1016/j.joca.2009.03.012.

20. Боровков А.А. Математическая статистика: учебник. СПб.: Лань, 2010. 704 с.

21. Геворкян П.С., Потемкин А.В., Эйсымонт И.М. Теория вероятностей и математическая статистика. М.: Физматлит, 2016.176 с.

22. Гмурман В.Е. Теория вероятностей и математическая статистика: учебник для прикладного бакалавриата. Люберцы: Юрайт, 2016. 479 с.

23. Справочник по прикладной статистике : в 2 т. / ред.: Э. Ллойд, У. Ледерман. М.: Финансы и статистика, 1990.

24. Knee pathology in young adults after pediatric anterior cruciate ligament injury: a prospective case series of 47 patients with a mean 9.5 -year follow-up / G.R. Ekås, M.M. Laane, A. Larmo, H. Moksnes, H. Grindem, M.A. Risberg, L. Engebretsen // Am. J. Sports Med. 2019. Vol. 47 , No 7. P. 1557-1566. DOI: 10.1177/0363546519837935.

25. ACL reconstruction in youth athletes results in an improved rate of return to athletic activity when compared with non-operative treatment: a systematic review of the literature / P.D. Fabricant, N. Lakomkin, A.I. Cruz, E. Spitzer, R.G. Marx // Journal of JISAKOS Joint Disorders \& Orthopaedic Sports Medicine. 2016. Vol. 1, P. 62-69. DOI: 10.1136/jisakos-2015-000013.

26. The conservative treatment of complete tears of the anterior cruciate ligament in skeletally immature patients / H. Mizuta, K. Kubota, M. Shiraishi, Y. Otsuka, N. Nagamoto, K. Takagi // J. Bone Joint. Surg. Br. 1995. Vol. 77, No 6. P. 890-894. DOI: 10.1302/0301-620X.77B6.7593101.

27. McCarroll J.R., Rettig A.C., Shelbourne K.D. Anterior cruciate ligament injuries in the young athlete with open physes // Am. J. Sports Med. 1988. Vol. 16, No 1. P. 44-47. DOI: 10.1177/036354658801600107.

28. Functional outcomes following a non-operative treatment algorithm for anterior cruciate ligament injuries in skeletally immature children 12 years and younger. A prospective cohort with 2 years follow-up / H. Moksnes, L. Engebretsen, I. Eitzen, M.A. Risberg // Br. J. Sports Med. 2013. Vol. 47, No 8. P. 488-494. DOI: 10.1136/bjsports-2012-092066.

29. Delayed reconstruction and high BMI z score increase the risk of meniscal tear in paediatric and adolescent anterior cruciate ligament injury / M. Raad, C.Thevenin Lemoine, E. Bérard, P. Laumonerie, J. Sales de Gauzy, F. Accadbled // Knee Surg. Sports Traumatol. Arthrosc. 2019. Vol. 27, No 3. P. 905-911. DOI: 10.1007/s00167-018-5201-2.

Статья поступила в редакцию 19.04.2021; одобрена после рецензирования 20.05.2021; принята к публикации 23.12.2021.

The article was submitted 19.04.2021; approved after reviewing 20.05.2021; accepted for publication 23.12.2021.

\section{Информация об авторах}

1. Ярослав Александрович Иванов - ORCID: 0000-0002-6352-2784, docyaroslav@gmail.com;

2. Александр Геннадьевич Ельцин - кандидат медицинских наук, ORCID: 0000-0002-7736-9493, agyeltsin@gmail.com;

3. Дмитрий Сергеевич Мининков - кандидат медицинских наук, ORCID: 0000-0002-9490-6932, 45040311@mail.ru.

\section{Information about the authors:}

1. Yaroslav A. Ivanov - ORCID: 0000-0002-6352-2784, docyaroslav@gmail.com;

2. Alexander G. Yeltsin - Candidate of Medical Sciences, ORCID: 0000-0002-7736-9493, agyeltsin@gmail.com;

3. Dmitrii S. Mininkov - Candidate of Medical Sciences, ORCID: 0000-0002-9490-6932, 45040311@mail.ru.

Источник финансирования. Финансирование работы не проводилось.

Конфликт интересов. Авторы декларируют отсутствие явных и потенциальных конфликтов интересов, связанных с публикацией настоящей статьи.

Этическая экспертиза. Все пациенты и их законные представители дали согласие на участие в исследовании. 
Гений ортопедии. 2022. Т. 28, № 1. С. 69-75.

Genij Ortopedii. 2022. Vol. 28, no. 1. P. 69-75.

\title{
Научная статья
}

УДК 616.718.5-001.514-089.227.844

https://doi.org/10.18019/1028-4427-2022-28-1-69-75

\section{Лечение последствий ранений голени: продолжение развития технологии Илизарова Алексей Владимирович Лычагин ${ }^{1}$, Андрей Анатольевич Грицюк ${ }^{1 \bowtie}$, Вадим Сергеевич Корытин ${ }^{1,2}$}

\author{
1 Первый Московский государственный медицинский университет имени И.М. Сеченова (Сеченовский Университет), Москва, Россия
} 23 Центральный военный клинический госпиталь имени А.А. Вишневского, Московская область, Красногорск, п. Новый, Россия

Автор, ответственный за переписку: Андрей Анатольевич Грицюк, drgaamma@gmail.com

\section{Аннотация}

Введение. Тяжелые открытые повреждения и ранения голени являются проблемой травматологии в связи с трудностями функционального восстановления сегмента при наличии дефекта кости и мягких тканей. Материалы и методы. Проведен анализ лечения 11 пациентов с дефектами мягких тканей и большеберцовой кости. На момент реконструкции пациенты мужского пола были по возрасту от 20 до 52 лет (средний возраст $34,2 \pm 3,2$ года). Огнестрельные ранения голени имели место у 7 раненных и травмы голени - у 4 пострадавших. Сегментарные дефекты большеберцовой кости от 6 см до 18 см, в среднем 12,6 $\pm 4,4$ см, кожно-мышечные дефекты по площади составляли от 20 см$^{2}$ до 112 см², в среднем $74,4 \pm 22,4 \mathrm{~cm}^{2}$. Результаты. В семи случаях раны зажили первичным натяжением, признаки воспаления и краевые некрозы мягкотканного компонента лоскута встретились в $4(36,4$ \%) случаях, лечили консервативно (перевязки, санация), в одном случае некроз иссечен (на 21 сутки) и выполнена аутодермопластика расщепленным кожным трансплантатом. Проблем с перемещением (дистракцией) костных регенератов мы не имели, так как реберный каркас лоскутов предохранял мягкие ткани и сосудистую ножку лоскута, несмотря на ранние сроки начала дистракции (средний срок $7,3 \pm 2,1$ суток), продолжительность лечения составила в среднем $163,2 \pm 8,7$ суток. Опороспособность была восстановлена у всех пациентов, функциональные результаты удовлетворительные. Обсуждение. Сочетание дистракционного остеогенеза по Илизарову и реконструкции мягких тканей путем пересадки свободного васкуляризированного лоскута позволяет нивелировать недостатки обоих: облегчить трансфер кости, избежать повреждения рубцово измененной кожи переднемедиальной поверхности голени, сохранить осевое кровообращение трансплантата. Включение фрагмента ребра обеспечивало необходимые условия для применения дистракционного метода Илизарова. Ребро, не являясь опорной костной тканью, защищало мягкотканный компонент лоскута и его сосудистую ножку от деформации и участвовало в формировании костной мозоли. Выводы. Пластическое замещение обширных дефектов голени свободным васкуляризированным кожно-мышечным лоскутом с фрагментами ребер и дистракционным остеогенезом по Г.А. Илизарову создает благоприятные условия для одномоментного хирургического вмешательства, позволяющего сохранить конечность, восстановить опороспособность и вернуть пациентов к трудовой деятельности.

Ключевые слова: голень, ранения и травмы, пластика мягких тканей, реконструктивные операции

Для иитирования: Лычагин А.В., Грицюк А.А., Корытин В.С. Лечение последствий ранений голени: продолжение развития технологии Илизарова // Гений ортопедии. 2022. Т. 28, № 1. С. 69-75. https://doi.org/10.18019/1028-4427-2022-28-1-69-75

\section{Original article}

\section{Treatment of tibial wound consequences: further development of the llizarov technology Alexey V. Lychagin ${ }^{1}$, Andrey A. Gritsyuk ${ }^{1 \bowtie}$, Vadim S. Korytin $^{1,2}$}

1 I.M. Sechenov First Moscow State Medical University (Sechenov University), Moscow, Russian Federation

23 Central Military Clinical Hospital named after A.A. Vishnevsky, Moscow region, Krasnogorsk, p. Novy, Russian Federation

Corresponding author: Andrey A. Gritsyuk,drgaamma@gmail.com

Abstract

Introduction Severe open injuries and wounds of the tibia refer to the topical problem of traumatology due to the difficulties in the functional restoration of the segment when there is a bone and soft tissues defect. Material and method The treatment of 11 patients with soft tissue and tibial defects was analyzed. At the time of reconstruction, the age of male patients ranged from 20 to 52 years (mean age $34.2 \pm 3.2$ years). Gunshot wounds of tibia occurred in 7 injured and tibial injury was observed in 4 cases. Segmental defects of the tibia ranged from $6 \mathrm{~cm}$ to $18 \mathrm{~cm}$, mean $12.6 \pm 4.4 \mathrm{~cm}$, myocutaneous defects ranged from $20 \mathrm{~cm}^{2}$ to $112 \mathrm{~cm}^{2}$, mean $74.4 \pm 22.4 \mathrm{~cm}^{2}$. Results In seven cases, the wounds healed by primary intention, the signs of infection and marginal necrosis of the soft tissue component of the flap were observed in 4 (36.4\%) cases and were addressed conservatively (dressings and debridement), but in one case, necrosis was excised (on day 21) and autodermoplasty was performed using split skin graft. We had no problems with the transport (distraction) of bone regenerates, since the rib cage of the flaps protected the soft tissues and the vascular pedicle of the flap, despite the early start of distraction (mean period $7.3 \pm 2.1$ days) and the length of treatment, when averaged, was $163.2 \pm 8.7$ days. Support function was restored in all patients and the functional results were satisfactory. Discussion The combination of Ilizarov distraction osteogenesisand soft tissue reconstruction using free vascularized flap grafting makes it possible to invalidate the short-comings of both, i.e. to lighten up the bone transfer, to avoid damage to the scarred skin of the anterio-medial surface of tibia and to preserve the axial circulation of the graft. The inclusion of a rib fragment provided the required conditions for application the Ilizarov distraction method. The rib, not being a supportive bone tissue, protected the soft tissue component of the flap and its vascular pedicle from deformity and participated in the formation of callus. Conclusions Plastic filling in the extensive tibial defects using free vascularized myocutaneous flap with rib fragments and Ilizarov distraction osteogenesis provides favorable conditions for acute surgical intervention allowing to save the limb, restore the support ability and return the patients to work.

Keywords: tibia, wounds and injuries, soft tissues plastics, reconstructive operations

For citation: Lychagin A.V., Gritsyuk A.A., Korytin V.S. Treatment of tibial wound consequences: further development of the Ilizarov technology. Genij Ortopedii, 2022, vol. 28, no 1, pp. 69-75. https://doi.org/10.18019/1028-4427-2022-28-1-69-75

\section{ВВЕДЕНИЕ}

Тяжелые открытые повреждения и ранения голени являются проблемой травматологии по нескольким параметрам. Первоначально в процессе лечения достаточно часто приходится решать вопрос жизнеспособности конечности, в последующем при значительном по протяженности по- вреждении мягких тканей и большеберцовой кости на первый план выходят вопросы реконструкции повреждённых структур в свете полноценного функционального восстановления сегмента. Наибольшие трудности имеют место при костно-мягкотканном дефекте голени [1-5]. 
Восстановление мягкотканных структур методами свободной реваскуляризированной аутотрансплантации на сегодняшний день основательно проработаны, и микрососудистая пластика комплекса тканей любого размера и состава при наличии реципиентного сосудистого пучка не представляет трудностей [6]. Однако васкуляризированные костные аутотрансплантаты либо не являются опорными (ребро, край лопатки или подвздошной кости), либо имеют проблемы с консолидацией или с донорской зоной (малоберцовый трансплантат) [7].

«Золотым стандартом» в удлинении и замещении циркулярных дефектов костей конечностей является метод дистракционного остеогенеза Г.А. Илизарова. Однако при наличии мягкотканного дефекта данной области применение его затрудняется $[8,9]$, что снова ставит вопрос о целесообразности реконструкции сегмента конечности [10, 11].

Данные ситуации встречаются в клинической практике достаточно редко [12-14], какого-либо четкого алгоритма в научной литературе мы не нашли, так же как и единого мнения о решении данного вопроса. Мы разработали и запатентовали эффективную методику пластики, данная работа посвящена анализу отдаленных (более 10 лет) результатов нашей работы [15].

Цель исследования - изучить ближайшие и отдаленные результаты лечения тяжелых повреждений голени с дефектами мягких тканей и костей путем сочетания методов дистракционного остеогенеза по Илизарову с микрохирургической пластикой.

\section{МАТЕРИАЛЫ И МЕТОДЫ}

Проведено ретроспективное исследование, одобренное этическим комитетом. Все пациенты подписали информированное согласие. Оперировано по предложенному способу 11 пациентов, у которых имело место сочетание костных и кожно-мягкотканных дефектов голени [16]. На момент реконструкции пациенты мужского пола были по возрасту от 20 до 52 лет (средний возраст 34,2 $\pm 3,2$ года), средний срок наблюдения (на момент написания статьи) составил $14,5 \pm 5,5$ лет. Огнестрельные ранения голени имели место у 7 раненных и травмы голени - у 4 пострадавших. Дефекты большеберцовой кости (циркулярные) по протяженности составляли от $6 \mathrm{~cm}$ до $18 \mathrm{~cm}$, в среднем 12,6 $\pm 4,4 \mathrm{~cm}$, кожно-мышечные раны (дефекты мягких тканей) проецировались в области дефекта кости и по площади составляли от $20 \mathrm{~cm}^{2}$ до $112 \mathrm{~cm}^{2}$, в среднем 74,4 $\pm 22,4 \mathrm{~cm}^{2}$. Необходимо отметить, что все пациенты уже лечились от 3 до 24 мес. (в среднем 6,3 \pm 3,3 мес.) и им было выполнено от 3 до 12 оперативных вмешательств.

В качестве кожно-мышечного компонента лоскута использовали часть широчайшей мышцы спины у 7 (63,6 \%) пациентов, часть передней зубчатой мышцы использовали у 4 (36,4 \%) пациентов. Костный фрагмент трансплантата состоял из фрагмента VII (18,2 \%), VIII (90,9 \%) или IX ребра (45,5 \%), в 6 (54,5 \%) случаях использовали фрагменты двух ребер. В 9 (81,8 \%) случаях лоскут был кожно-мышечно-костным, в 2 (18,2 \%) случаях - костно-мышечным с аутодермопластикой расщепленным трансплантатом. Дистракционный остеогенез был выполнен путем проксимальной монолокальной кортикотомии у 5 (45,5 \%) пациентов, дистальной монолокальной - у 3 (27,3 \%) пациентов, билокальная кортикотомия выполнена у 3 (27,3 \%) пострадавших.

Статистический анализ проводился с использованием критерия Вилкоксона для непараметрических данных (значение $\mathrm{p}<0,05$ считалось статистически значимым).

\section{Техника хирургического вмешательства}

Хирургическое вмешательство включало два этапа: первый одномоментный, на котором выполняли замещение дефекта мягких тканей и остеотомию большеберцовой кости (рис. 1, а-д); второй динамический - производили дистракционный остеогенез большеберцовой кости (рис. 1, е, ж).
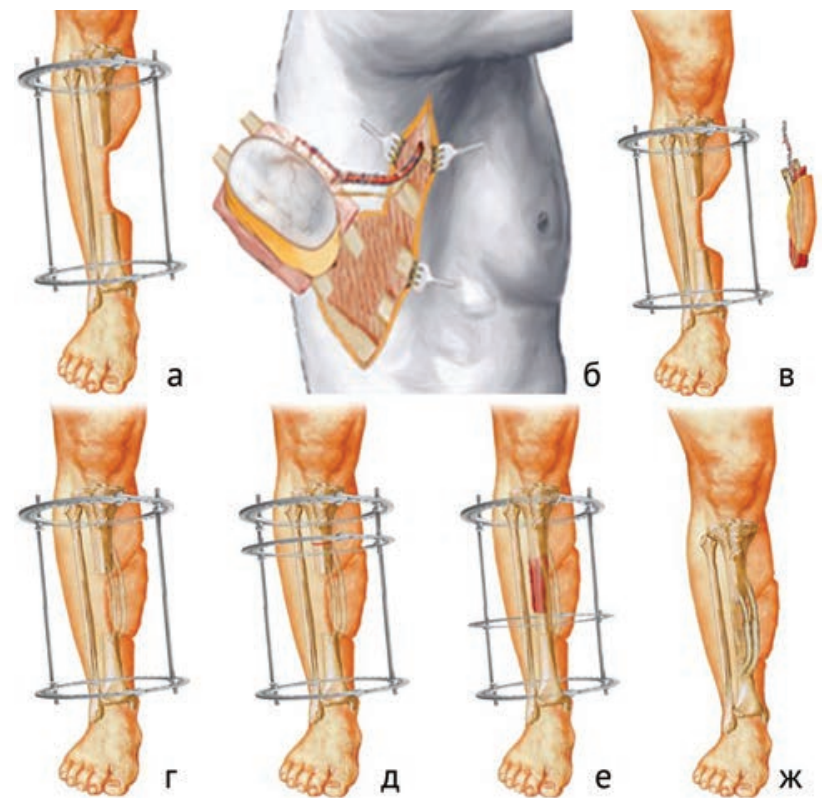

Рис. 1. Схема первого этапа операции: а - голень с сочетанным костно-мягкотканным дефектом фиксирована аппаратом; б - формирование костно-мышечно-кожного передне-зубчатого лоскута; в - микрохирургическая пересадка лоскута в реципиентную зону. Второй этап операции: г, д - проксимальная монолокальная кортикотомия; е - дистракционный остеогенез - перемещение костного фрагмента большеберцовой кости; ж - демонтаж аппарата внешней фиксации после консолидации фрагментов ребер и регенерата большеберцовой кости

В качестве клинического примера представляем раненного военнослужащего С., 24 лет, который получил тяжелое сочетанное минно-взрывное ранение, осколочное ранение головы, груди, живота, конечностей; огнестрельное осколочное слепое проникающее ранение черепа и головного мозга, осколочное слепое ранение мягких тканей грудной клетки и живота, огнестрельный оскольчатый перелом обеих костей левой голени в средней трети со смещением отломков; отрыв правой нижней конечности на уровне нижней трети правого бедра; травматический шок 3 ст. Проводилось многоэтапное лечение, ПХО ран и наложение аппарата Илизарова на левую голень (рис. 2, а). Раневой процесс осложнился остеомиелитом, после многочисленных повторных и вторичных хирургических обработок 
ран выполнена резекция 18 см большеберцовой кости в средней трети (рис. 2, б), за счет чего удалось дефект мягких тканей ушить и купировать очаг воспаления.
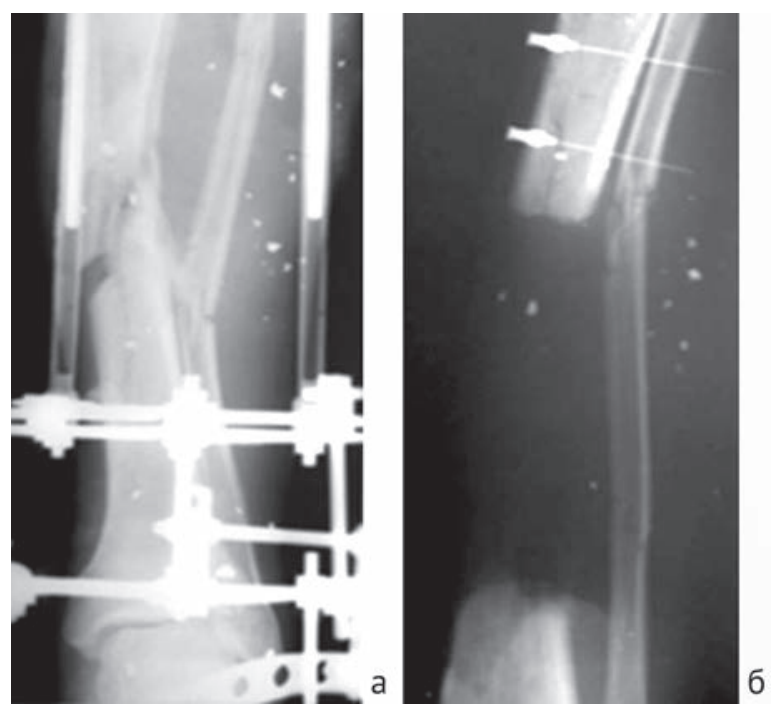

Рис. 2. Рентгенограммы голени: раненый С.: а - огнестрельный многооскольчатый перелом обеих костей голени в средней трети, осложненный остеомиелитом; б - дефект большеберцовой кости после резекции на протяжении 18 см
Раненый категорически отказался от предложенной ампутации левой голени либо ее укорочения, несмотря на отсутствие противоположной конечности, и настаивал на реконструктивном лечении. С целью восстановления тканей голени выполнили перемонтаж КДА левой голени в связи с его нестабильностью и остеотомию дистального отломка для выполнения дистракционного остеогенеза большеберцовой кости по Илизарову с темпом дистракции 1 мм в сутки. Послеоперационное течение осложнилось некрозом кожи в области торца удлиняемой кости, в результате чего дистракцию несколько раз прекращали (рис. 3), однако рубцы и дефицит мягких тканей передней поверхности голени не давали возможности заместить дефект большеберцовой кости.

В связи с этим была выполнена свободная васкуляризированная пластика передне-зубчатым лоскутом с фрагментом VIII ребра в виде мостовидного лоскута, этапы операции представлены на рисунке 4. В дальнейшем, после заживления ран голени (рис. 5, а, б), был продолжен дистракционный остеогенез большеберцовой кости, костные фрагменты закрытым способом состыкованы, и перелом консолидировался (рис. 5, в, г).
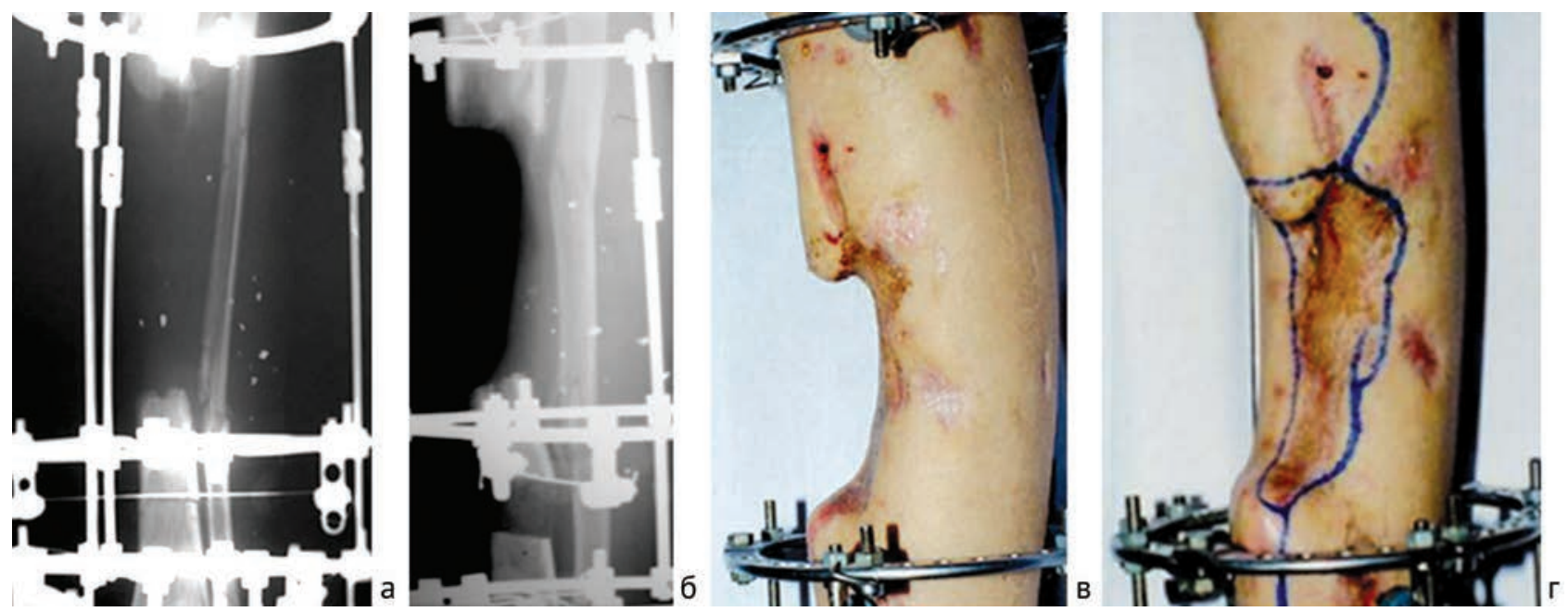

Рис. 3. Раненый С.: а, б - рентгенограммы голени, выполнена остеотомия и дистракция дистального фрагмента большеберцовой кости; в, г - вид голени при дистракции дистального фрагмента большеберцовой кости, перфорация кожи

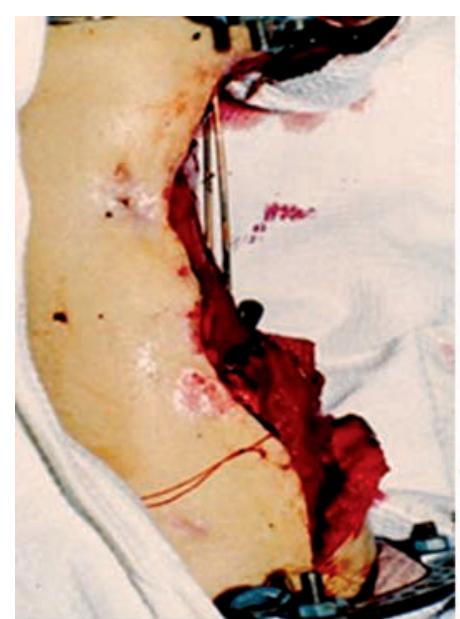

a

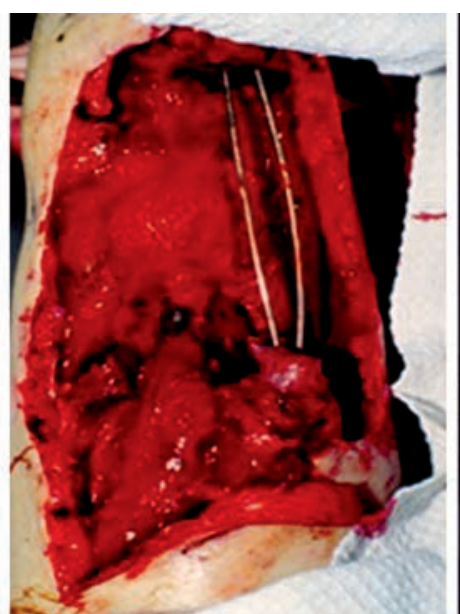

6

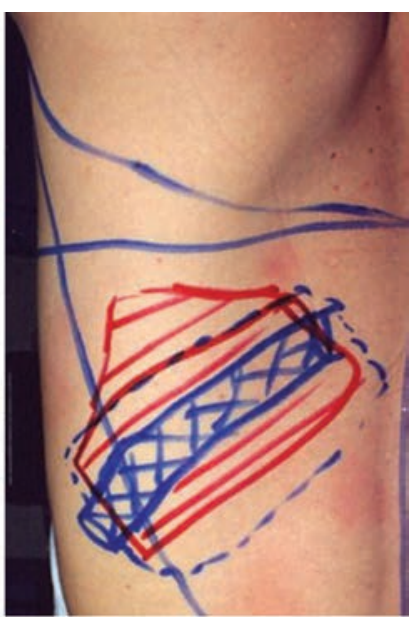

B
Рис. 4. Раненый С. Интраоперационная картина: а, б - выполнено иссечение рубцов передней поверхности голени; в - планирование передне-зубчатого лоскута с фрагментом VIII ребра 

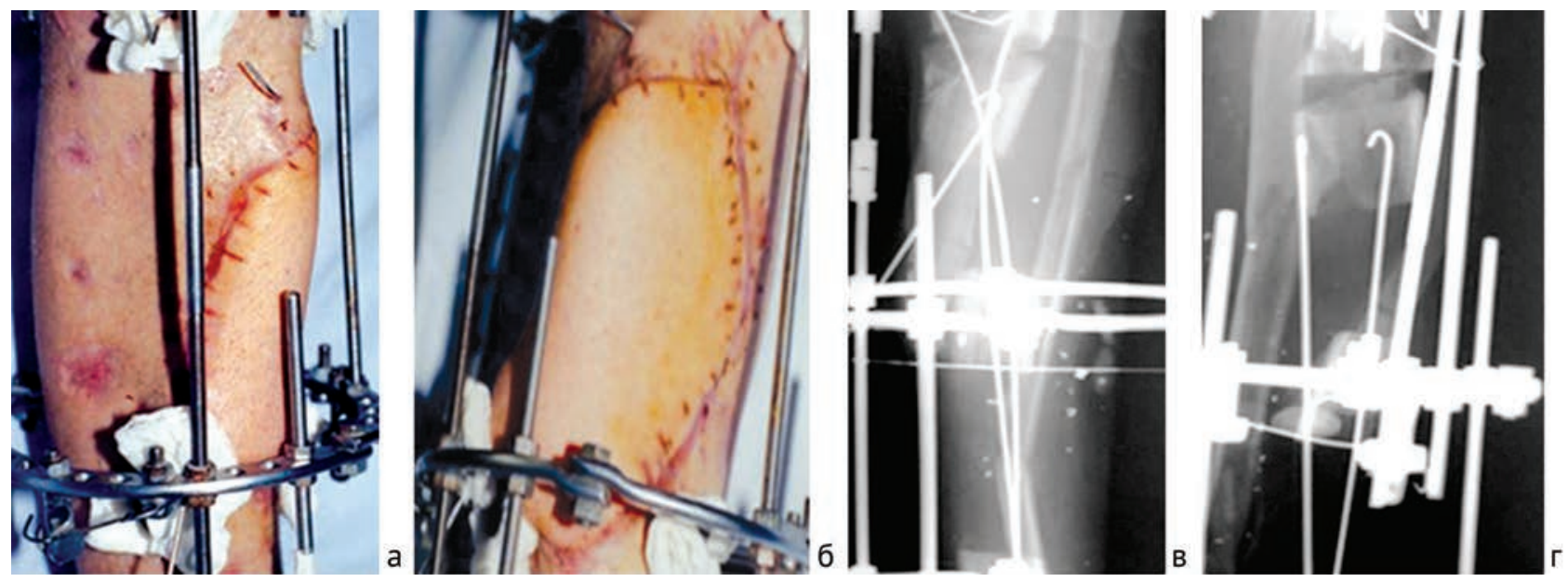

Рис. 5. Раненый С.: а, б - вид голени после реконструкции мягких тканей передне-зубчатым лоскутом с фрагментом VIII ребра; в, г - рентгенограммы левой голени после билокальной остеотомии большеберцовой кости, ребро выполняет функцию «моста», под которым перемещали фрагменты большеберцовой кости после остеотомии

Реконструкция мягких тканей и большеберцовой кости была состоятельной, перелом малоберцовой кости был консолидирован (рис. 6). После проведенного курса реабилитационной терапии и изготовления экзопротеза для правой нижней конечности, раненый выписан в воинскую часть и продолжает военную службу

\section{на нестроевой должности.}

На протяжении 10 лет наблюдается амбулаторно (рис. 7), имеет место контрактура голеностопного сустава, по поводу чего периодически проходит курсы восстановительного лечения, каких-либо повторных хирургических вмешательств не требовалось.
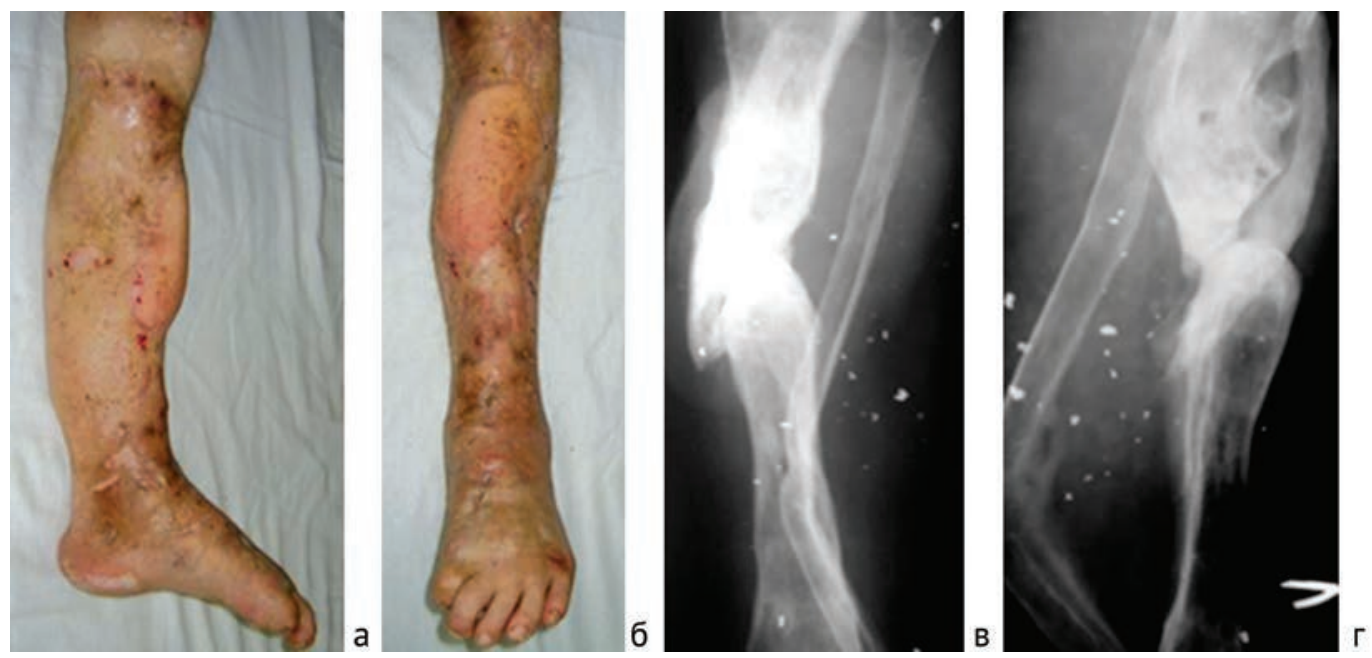

Рис. 6. Раненый С. Результат лечения через 6 месяцев после демонтажа АВФ: а, б - вид конечности, в, г - рентгенограммы левой голени
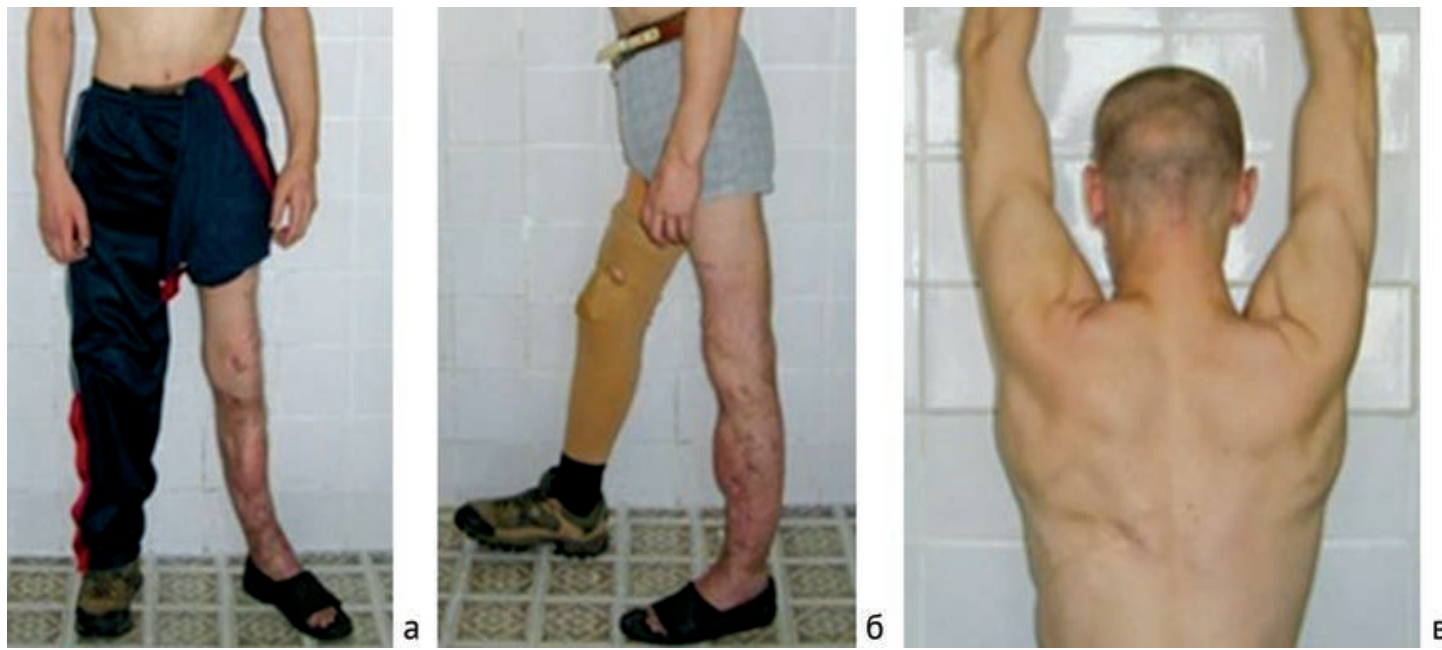

Рис. 7. Раненый С. Функциональный результат через 10 лет 


\section{РЕЗУЛЬТАТЫ}

В семи случаях раны зажили первичным натяжением, признаки воспаления и краевые некрозы мягкотканного компонента лоскута встретились в 4 (36,4 \%) случаях, в трех из них применялось консервативное лечение (перевязки, санация), а в одном случае, при котором площадь некроза была около $17 \mathrm{~cm}^{2}$, некроз иссечен (на 21 сутки) и выполнена аутодермопластика расщепленным кожным трансплантатом.

Проблем с перемещением (дистракцией) костных регенератов мы не имели, так как реберный каркас лоскутов предохранял мягкие ткани и сосудистую ножку лоскута, несмотря на ранние сроки начала дистракции (средний срок начала дистракции составил $7,3 \pm 2,1$ суток). Принимая во внимание, что дистракцию иногда приходилось прекращать и возобновлять снова, использовали механическое раздражение для укрепления регенерата, мы учитывали сроки демонтажа аппарата внешней фиксации, который в среднем снимали через $163,2 \pm 8,7$ суток, но продолжительность фиксации напрямую зависела от протяженности дефекта большеберцовой кости. При минимальном размере (6 см) данный показатель составил 98 суток, при максимальном (18 см) был более чем в 3 раза больше (376 суток).
Термины «замедленная консолидация» или «несращение» в области стыковки не совсем подходят для данных наблюдений (учитывая их временную привязку). Подобная ситуация наблюдалась в двух случаях. В одном случае продолжили фиксацию голени АВФ, и консолидация наступила через 175 суток после операции (примерно на 3 месяца позднее планируемого срока). Во втором случае потребовалась открытая стыковка, микроперфорация области контакта отломков и свободная костная аутопластика (фрагментом гребня подвздошной кости) через 70 суток после стыковки, и еще через 175 суток перелом консолидировался, аппарат был демонтирован (всего 345 суток после операции).

Среди «больших» осложнений был один случай тотального некроза лоскута, что потребовало перекрестной пластики суральным лоскутом. «Малые» осложнения, такие как воспаление мягких тканей вокруг спиц и спицевой остеомиелит были у трех пациентов (27,3%), что потребовало их удаления.

При анализе отдалённых (более 5 лет) результатов выявлено, что 5 пострадавших работали по прежней профессии, 5 раненых имели инвалидность (1 - первой группы, 3 - второй группы и 1 - третьей группы), один проходил учебу.

\section{ОБСУЖДЕНИЕ}

Клиническая практика показала высокую эффективность лечения протяженных (более 5 см) сегментарных дефектов костей голени методом дистракционного остеогенеза по Г.А. Илизарову, но единственным недостатком или, правильнее сказать, условием применения данного способа является сохранность кожного покрова и его васкуляризации [17]. Однако наш опыт показал, что встречаются клинические случаи, когда эти условия отсутствуют, что диктует необходимость двухэтапной тактики. На первом этапе восстанавливали дефект мягких тканей и после этого занимались замещением дефекта большеберцовой кости, что занимало значительно больше времени и сил, нередко пациенты отказывались продолжать многоэтапное лечение.

Альтернативной тактикой, в том числе одномоментной, являлась свободная васкуляризированная костная пластика. Малоберцовый лоскут, лоскут гребня подвздошной кости не позволяют получить необходимое количество костной массы, соответствующего размеру дефекта большеберцовой кости, или дефект мягких тканей превышал возможности данных лоскутов. Что снова заставляет либо прибегать к последовательному лечению сначала дефекта мягких тканей, а затем - кости, либо комбинировать костно-мягкотканные пересадки с другими костно-пластическим операциями [18-20].

Мы считаем, что возможно одноэтапное сочетание дистракционного остеогенеза по Илизарову и реконструкции мягких тканей путем пересадки свободного васкуляризированного лоскута, что подтверждают работы других авторов [21-23]. Несколько попыток реализации такой тактики имели большие трудности в процессе трансфера кости, мягкотканный лоскут деформировался, и осевое кровообращение наруша- лось, что угрожало тотальным некрозом мягких тканей трансплантата [24, 25]. Включение фрагмента ребра, которое мы укладывали поверх костного дефекта в виде «моста», обеспечивало необходимые условия для применения дистракционного метода Илизарова. Ребро, не являясь опорной костной тканью, защищало мягкотканный компонент лоскута и его сосудистую ножку от деформации и участвовало в формировании костной мозоли - своеобразного «консолидата» на месте костного дефекта [26-28].

Проведенное исследование, в ходе которого была разработана и внедрена в клиническую практику тактика и техника замещения сочетанных дефектов голени с использованием свободного васкуляризированного лоскута с фрагментом ребра и дистракционным остеогенезом по Илизарову, показало ее эффективность, безопасность и преимущества $[16,17]$.

В данной группе пациентов со сложными дефектами большеберцовой кости в 100 \% случаев удалось сохранить конечность от ампутации, купировать воспаление, восстановить опороспособность и возвратить пострадавших к профессиональной деятельности. Показатели боли уменьшились до уровня, который, по самооценке, был клинически значимым, хотя численно не был статистически значимым. Все пациенты остались довольны выбором восстановительного лечения вместо ампутации.

Наши результаты следует рассматривать в контексте присущей каждому ретроспективному исследованию систематической ошибки отбора пациентов малой выборки. Важно помнить о потребностях каждого пациента, так как их необходимо индивидуализировать, чтобы справиться со сложными дефектами большеберцовой 
кости. Наконец, мы признаем этот метод как один из многих, позволяющих достичь успешного спасения конечностей при больших дефектах большеберцовой кости, что подтверждают исследования Zierenberg G.C. et al. (2016) и Masquelet A.C. et al. (2019) [19, 29], но мы надеемся, что обсуждение нашего опыта даст возможность оценить предложенную технику в общем стремлении поиска идеального метода восстановления этих пациентов.

\section{ВЫВОдЫ}

Пластическое замещение обширных дефектов голени свободным васкуляризированным кожно-мышечным лоскутом с фрагментами ребер и дистракционным остеогенезом по Г.А. Илизарову создает благоприят- ные условия для одномоментного хирургического вмешательства, позволяющего сохранить конечность, восстановить опороспособность и вернуть пострадавших к трудовой деятельности.

\section{СПИСОК ИСТОЧНИКОВ}

1. Gustilo R.B., Mendoza R.M., Williams D.N. Problems in management of type III (severe) open fractures: a new classification of type III open fractures // J. Trauma. 1984. Vol. 24, No 8. P. 742-746. DOI: 10.1097/00005373-198408000-00009.

2. The nature and incidence of musculoskeletal combat wounds in Iraq and Afghanistan (2005-2009) / P.J. Belmont Jr., B.J. McCriskin, M.S. Hsiao, R. Burks, K.J. Nelson, A.J. Schoenfeld // J. Orthop. Trauma. 2013. Vol. 27, No 5. P. e107-e113. DOI: 10.1097/BOT.0b013e3182703188.

3. Combat wounds in operation Iraqi Freedom and operation Enduring Freedom / B.D. Owens, J.F. Kragh Jr., J.C. Wenke, J. Macaitis, C.E. Wade, J.B. Holcomb // J. Trauma. 2008. Vol. 64, No 2. P. 295-299. DOI: 10.1097/TA.0b013e318163b875.

4. Acute Treatment Patterns for Lower Extremity Trauma in the United States: Flaps versus Amputation / L.R. Mundy, T. Truong, R.L. Shammas, M.J. Gage, G.M. Pomann, S.T. Hollenbeck // J. Reconstr. Microsurg. 2017. Vol. 33, No 8. P. 563-570. DOI: 10.1055/s-0037-1603332.

5. Free flaps for reconstruction of soft tissue defects in lower extremity: A meta-analysis on microsurgical outcome and safety / L. Xiong, E. Gazyakan, T. Kremer, F.J. Hernekamp, L. Harhaus, M. Saint-Cyr, U. Kneser, C. Hirche // Microsurgery. 2016. Vol. 36, No 6. P. 511-524. DOI: 10.1002/ micr.30020.

6. Single-stage orthoplastic reconstruction of Gustilo-Anderson Grade III open tibial fractures greatly reduces infection rates / J.A. Mathews, J. Ward, T.W. Chapman, U.M. Khan, M.B. Kelly // Injury. 2015. Vol. 46, No 11. P. 2263-2266. DOI: 10.1016/j.injury.2015.08.027.

7. Singh J., Dhillon M.S., Dhatt S.S. Single-stage "Fix and Flap" gives Good Outcomes in Grade 3B/C Open Tibial Fractures: A Prospective Study // Malays. Orthop. J. 2020. Vol 14, No 1. P. 61-73. DOI: https://doi.org/10.5704/MOJ.2003.010.

8. Илизаров Г.А. Некоторые вопросы теории и практики компрессионного и дистракционного остеосинтеза // Чрескостный компрессионный и дистракционный остеосинтез : сб. науч. работ. Курган, 1972. Вып. I. С. 5-34.

9. Шевцов В.И., Швед С.И., Сысенко Ю.М. Чрескостный остеосинтез при лечении оскольчатых переломов. Курган, 2002.332 с.

10. Rüedi T. AO principles of fracture management. Vol. 1: Principles, Vol. 2: Specific fractures. 2nd Ed. / Buckley R.E., Moran C.G., editors. Davos: AO Publishing. 2007. 1112 p. Vol. 2. P. 256-285.

11. Бондаренко А.В., Плотников И.А., Гусейнов Р.Г. Лечение посттравматических дефектов диафиза большеберцовой кости методом комбинированного последовательного билокального и блокирующего остеосинтеза // Политравма. 2019. № 4. C. 23-30. DOI: 10.24411/1819-1495-2020-10004.

12. Effects of a formalized collaboration between plastic and orthopedic surgeons in severe extremity trauma patients; a retrospective study / P. Sommar, Y. Granberg, M. Halle, A.C. Skogh, K.T. Lundgren, K.Å. Jansson // J. Trauma Manag. Outcomes. 2015. Vol. 9. P. 3. DOI: 10.1186/s13032-015-0023-4.

13. Orthoplastic surgical collaboration is required to optimise the treatment of severe limb injuries: A multi-centre, prospective cohort study / F. Boriani, A.Ul Haq, T. Baldini, R. Urso, D. Granchi, N. Baldini, D. Tigani, M. Tarar, U. Khan // J. Plast. Reconstr. Aesthet. Surg. 2017. Vol. 70, No 6. P. 715722. DOI: 10.1016/j.bjps.2017.02.017.

14. Song Y., Qi X., Shen J. Free flap combined with external fixator in the treatment of open fractures of the calf // Cell. Biochem. Biophys. 2014. Vol. 70, No 1. P. 549-552. DOI: 10.1007/s12013-014-9954-z.

15. Ханин М.Ю., Дубров В.Э., Кобрицов Г.П. Особенности восстановления опорной функции конечности в зависимости от вида хирургического лечения при открытых переломах костей голени с обширным повреждением мягких тканей // Московский хирургический журнал. 2012. № 1. С. $37-43$.

16. Способ хирургической коррекции сложных комбинированных сочетанных дефектов кости и мягких тканей голени : пат. 2318461 Рос. Федерация МПК А 61 В 17/56 / Николенко В.К., Грицюк А.А., Брижань Л.К., Кострица А.Н., Червяков А.В. ; заявитель и патентообладатель Николенко В.К., Грицюк А.А. № 2006119372/14 ; заявл. 05.06.2006 ; опубл. 10.03.2008.

17. Способ лечения открытых оскольчатых диафизарных переломов костей голени с дефектом костной ткани : пат. 2681114 Рос. Федерация МПК А 61 В 17/56 / Бондаренко А.В., Плотников И.А., Гусейнов Р.Г. ; заявитель и патентообладатель Алтайский гос. мед. ун-т. № 2018104935 ; заявл.08.02.18; опубл. 04.03.19, Бюл. № 7.

18. Оприщенко А.А., Бодаченко К.А., Штутин А.А. Тактика специализрованной помощи раненым с огнестрельными переломами костей голени // Университетская клиника. 2018. № 4. C. 17-21. DOI: https://doi.org/10.26435/uc.v0i4(29).257

19. Acute shortening and re-lengthening in the management of open tibia fractures with severe bone of 14 CMS or more and extensive soft tissue loss / G.C. Zierenberg, C.D. Beaton, J.C. Pérez-López, D.A. Lamela, O.G. Rivera, H.M. González Montalvo, P.J. Reyes-Martínez // Bol. Asoc. Med. P R. 2016. Vol. 108, No 1. P. 91-94.

20. Free vascularized fibular grafts in type 3 open tibia fractures / K. Özaksar, T.S. Sügün, T. Toros, Y. Gürbüz, M. Kayalar, F. Özerkan // Acta Orthop. Traumatol. Turc. 2012. Vol. 46, No 6. P. 430-437. DOI: 10.3944/aott.2012.2876.

21. A simple and effective method to optimize limb position after complex lower limb free flap reconstruction with concurrent external fixation / P. Ciudad, R. Vijayan, G. Pafitanis, B. Kaya, L. Parra Pont, M. Agko, O.J. Manrique, K. Kiranantawat, W.L. Chang, H.C. Chen // Microsurgery. 2019. Vol. 39, No 1. P. 98-99. DOI: 10.1002/micr.30301.

22. Combined Iliazarov and free flap for severe recurrent flexion-contracture release / E. Bar-Meir, B. Yaffe, E. Winkler, N. Sher, M. Berenstein, A. Schindler // J. Burn Care Res. 2006. Vol. 27, No 4. P. 529-534. DOI: 10.1097/01.BCR.0000226033.45478.2D.

23. Transverse debridement and acute shortening followed by distraction histogenesis in the treatment of open tibial fractures with bone and soft tissue loss / S. Salih, E. Mills, J. McGregor-Riley, M. Dennison, S. Royston // Strategies Trauma. Limb. Reconstr. 2018. Vol. 13, No 3. P. 129-135. DOI: $10.1007 / \mathrm{s} 11751-018-0316-z$.

24. Soft Tissue Coverage in Distal Lower Extremity Open Fractures: Comparison of Free Anterolateral Thigh and Free Latissimus Dorsi Flaps / C. Philandrianos, P. Moullot, A.M. Gay, B. Bertrand, R. Legré, N. Kerfant, D. Casanova // J. Reconstr. Microsurg. 2018. Vol. 34, No 2. P. 121-129. DOI: $10.1055 / \mathrm{s}-0037-1607323$.

25. Suprafascial versus traditional harvesting technique for free anterolateral thigh flap: A case-control study to assess the best functional and aesthetic result in extremity reconstruction / M. Maruccia, N. Fallico, E. Cigna, P. Ciudad, F. Nicoli, E. Trignano, E. Nacchiero, G. Giudice, D. Ribuffo, H.C. Chen // Microsurgery. 2017. Vol. 37, No 8. P. 851-857. DOI: 10.1002/micr.30248.

26. Seth A.K., Iorio M.L. Super-Thin and Suprafascial Anterolateral Thigh Perforator Flaps for Extremity Reconstruction // J. Reconstr. Microsurg. 2017. Vol. 33, No 7. P. 466-473. DOI: 10.1055/s-0037-1601422. 
27. Bone transport versus acute shortening for the management of infected tibial non-unions with bone defects / K. Tetsworth, D. Paley, C. Sen, M. Jaffe, D.C. Maar, V. Glatt, E. Hohmann, J.E. Herzenberg // Injury. 2017. Vol. 48, No 10. P. 2276-2284. DOI: 10.1016/j.injury.2017.07.018.

28. Results of the induced membrane technique in the management of traumatic bone loss in the lower limb: a cohort study / D. Giotikas, N. Tarazi, L. Spalding, M. Nabergoj, M. Krkovic // J. Orthop. Trauma. 2019. Vol. 33, No 3. P. 131-136. DOI: 10.1097/BOT.0000000000001384.

29. Masquelet A.C., Kishi T., Benko P.E. Very long-term results of post-traumatic bone defect reconstruction by the induced membrane technique // Orthop. Traumatol. Surg. Res. 2019. Vol. 105, No 1. P. 159-166. DOI: 10.1016/j.otsr.2018.11.012.

Статья поступила в редакцию 28.07.2021; одобрена после рецензирования 09.08.2021; принята к публикации 23.12.2021.

The article was submitted 28.07.2021; approved after reviewing 09.08.2021; accepted for publication 23.12.2021.

\section{Информация об авторах:}

1. Алексей Владимирович Лычагин - доктор медицинских наук, dr.lychagin@mail.ru;

2. Андрей Анатольевич Грицюк - доктор медицинских наук, професcop, drgaamma@gmail.com;

3. Вадим Сергеевич Корытин - msk.dr.vadimsergeevich@gmail.com.

\section{Information about the authors:}

1. Alexey V. Lychagin - Doctor of Medical Sciences, Professor, dr.lychagin@mail.ru;

2. Andrey A. Gritsyuk - Doctor of Medical Sciences, Professor;

3. Vadim Sergeevich Korytin - M.D., msk.dr.vadimsergeevich@gmail.com. 
Гений ортопедии. 2022. Т. 28, № 1. С. 76-82.

Genij Ortopedii. 2022. Vol. 28, no. 1. P. 76-82.

Научная статья

УДК 616-001.5.004.14-616.748.54-018.38

https://doi.org/10.18019/1028-4427-2022-22-1-76-82

\section{Экспериментальное обоснование армирования ахиллова сухожилия новыми способами Г.П. Котельников, Ю.Д. Ким ${ }^{\varpi}$, Д.С. Шитиков, Н.А. Князев, Н.Э. Лихолатов}

Самарский государственный медицинский университет, Самара, Россия

Автор, ответственный за переписку: Юрий Дмитриевич Ким, drkim@mail.ru

\section{Аннотация}

Повреждения ахиллова сухожилия - самые частые травмы среди всех разрывов (подкожных) сухожилий, их доля достигает 47 \%. Цель. Подтверждение эффективности новых способов армирования ахиллова сухожилия в эксперименте. Материалы и методы. Экспериментальная часть работы проводилась на 60 биоманекенах с интактным ахилловым сухожилием в 3 этапа. На 1 этапе производилось измерение группы из 20 сухожилий, сшитых швом по Кракову. На 2 этапе осуществляли армирование с использованием плантарного сухожилия (оформлено рационализаторское предложение СамГМУ) и последующее измерение силы, необходимой для появления признаков разрыва. На 3 этапе производили армирование с использованием порции длинного малоберцового сухожилия (получен патент РФ № 2616767) и последующее измерение силы, необходимой для появления признаков разрыва. Результаты. На первом этапе среднее значение силы, необходимой для разрыва сухожильного шва по Кракову, составило 11,5 кг. На втором - значение силы, необходимой для разрыва шва, армированного плантарным сухожилием, составило 33,4 кг. На третьем этапе значение силы, необходимой для разрыва шва, армированного порцией длинного малоберцового сухожилия, составило 37,3 кг. Заключение. Предложенные новые способы армирования ахиллова сухожилия сухожилием плантарной мышцы и порцией сухожилия длинной малоберцовой мышцы на дистальном основании позволяют увеличить прочность зоны повреждения на 195,6 и 214,4 \% соответственно.

Ключевые слова: ахиллово сухожилие, эксперимент, армирование

Для иитирования: Экспериментальное обоснование армирования ахиллова сухожилия новыми способами / Г.П. Котельников, Ю.Д. Ким Д.С. Шитиков, Н.А. Князев, Н.Э. Лихолатов // Гений ортопедии. 2022. Т. 28, № 1. С. 76-82. https://doi.org/10.18019/1028-4427-2022-28-1-76-82

\section{Original article}

\section{Experimental validation for the Achilles tendon reinforced with new techniques G.P. Kotelnikov, Yu.D. Kim ${ }^{\bowtie}$, D.S. Shitikov, N.A. Knyazev, N.E. Likholatov}

Samara State Medical University, Samara, Russian Federation

Corresponding author: Yuriy D. Kim, drkim@mail.ru

Abstract

An Achilles tendon injury is most common among subcutaneous tendon ruptures and accounts for $47 \%$. The purpose was to experimentally evaluate the effectiveness of new methods of the Achilles tendon reinforcement. Material and methods The experimental part of the work was performed in 3 stages using 60 biomannikins with intact Achilles tendon. A Krakow suture was used at stage 1 for a group of 20 tendons and a force that would result in rupture of the tendon was measured. Reinforcement was performed using the plantaris tendon (technical innovation offered at the Samara State Medical University) at the 2nd stage and the force required for the appearance of signs of rupture was subsequently measured. A portion of the peroneus longus tendon (RF patent No. 2616767) was used for reinforcement at the $3^{\text {rd }}$ stage and the force measurement produced. Results The mean force required to rupture the Krakow suture applied to the tendon at the first stage was $11.5 \mathrm{~kg}$., The force required to rupture the suture reinforced with the plantaris tendon at the second stage measured $33.4 \mathrm{~kg}$. The force required to rupture the suture reinforced with a portion of the peroneus longus tendon at the third stage was $37.3 \mathrm{~kg}$. Conclusion The new techniques offered to reinforce the Achilles tendon with the plantaris tendon and a portion of the peroneus longus tendon at the distal base facilitated increase in the strength of the injury site by $195.6 \%$ and $214.4 \%$, respectively.

Keywords: Achilles tendon, experiment, reinforcement

For citation: Kotelnikov G.P., Kim Yu.D., Shitikov D.S., Knyazev N.A., Likholatov N.E. Experimental validation for the Achilles tendon reinforced with new techniques. Genij Ortopedii, 2022, vol. 28, no 1, pp. 76-82. https://doi.org/10.18019/1028-4427-2022-28-1-76-82

\section{ВВЕДЕНИЕ}

Среди всех подкожных разрывов повреждения ахиллова сухожилия - самые частые и составляют до 47 \% [1-3]. Реруптуры после проведенного лечения являются одним из частых осложнений хирургии ахиллова сухожилия, наряду с инфекционными, и требуют повторных вмешательств $[4,5]$. Анализ литературных данных не позволяет выработать единого мнения о профилактике данных осложнений [6-9]. Есть работы, посвященные изучению последствий длительной иммобилизации голеностопного сустава, приводящих к выраженной гипотрофии трехглавой мышцы голени и, как следствие, длительному реабилитационному периоду $[10,11]$.

Также актуален вопрос ранней активизации голеностопного сустава, но при этом важно не получить элонга- цию ахиллова сухожилия, что ведет к снижению плантарной флексии стопы.

Повышение прочности шва ахиллова сухожилия возможно за счет применения современного шовного материала, но также важно минимизировать риски инфекционных осложнений в связи с подкожным расположением сухожилия, таких как лигатурные свищи, глубокие и поверхностные некрозы, сохранить скользящий аппарат этой зоны. Армирование зоны разрыва по показаниям позволяет повысить прочность шва ахиллова сухожилия. Некоторые авторы предлагают усиливать зону разрыва синтетическими материалами, что повышает риск инфекционных осложнений [12], другие совсем не видят смысла в первичном армировании ахиллова сухожилия известными способами. 
Цель исследования: подтверждение эффективности (прочности) новых способов армирования ахиллова сухожилия в эксперименте.

\section{Задачи исследования:}

1) провести оценку прочности шва ахиллова сухожилия по Кракову, новых способов армирования ахиллова сухожилия в эксперименте и сравнить полученные результаты;

2) выявить показания к первичному армированию ахиллова сухожилия новыми способами в клинической практике.

\section{МАТЕРИАЛЫ И МЕТОДЫ}

Экспериментальная часть работы проводилась на 60 сухожилиях биоманекенов с интактным ахилловым сухожилием. Было выделено 3 экспериментальные группы исследований. Общим в этапах было формирование линейного или Z-образного доступа по задней поверхности голени, а также последующее пересечение ахиллова сухожилия в «классической» зоне разрыва (20-50 мм от энтезиса) и выполнение сухожильного шва по Кракову. В первой группе (20 сухожилий) производилось измерение прочности восстановленного экспериментального разрыва ахиллова сухожилия, сшитого по Кракову. Во второй группе (20 сухожилий) дополнительно к сухожильному шву по Кракову производили армирование зоны повреждения с использованием плантарного сухожилия (оформлено рационализаторское предложение СамГМУ) и последующее измерение силы, необходимой для появления признаков разрыва. В третьей группе (20 сухожилий) дополнительно к сухожильному шву по Кракову производили армирование с использованием порции длинного малоберцового сухожилия (получен патент РФ № 2616767) [13] и последующее измерение силы, необходимой для появления признаков разрыва.

При помощи электронного безмена фирмы Garin (точность измерения 10 гр.) производили измерение веса, необходимого для появления признаков разрыва, во всех группах исследований (60 сухожилий).

Материалы статьи были рассмотрены Комитетом по биоэтике СамГМУ на соответствие этическим нормам.

С позиции доказательной медицины проводилась статистическая обработка полученных результатов при помощи программы Statistica 6.0. Проверка нулевой гипотезы об отсутствии эффекта армирования осуществлялась тремя способами. Доверительные интервалы средних, рассчитанных для выборок каждого этапа исследования, не пересекались между собой и выстраивались в строгой последовательности от третьего этапа к первому.

Первая группа (20 экспериментов): шов ахиллова сухожилия по Кракову.
Для шва использовали нить VICRIL 1. Затем накладывали шов по Кракову на дистальный и проксимальный конец ахиллова сухожилия. Нити связывали между собой с последующим наложением адаптационных швов в области сформированного разрыва (рис. 1, а).

После этого проводили отсечение дистального конца ахиллова сухожилия с частью пяточной кости, за которую фиксировали нить диаметром 5 мм. При помощи электронного безмена фирмы Garin (точность измерения 0,1 гр.) производили измерение веса, необходимого для появления признаков разрыва проведенного шва по Кракову (рис. 1, б).

Среднее значение прочности в 20 экспериментах составило 11,5 кг (112,78 Н).

Вторая группа (20 экспериментов) - армирование ахиллова сухожилия плантарным сухожилием. На этот способ армирования нами оформлено рационализаторское предложение СамГМУ. Для шва использовали нить VICRIL 1. Затем накладывали шов по Кракову на дистальный и проксимальный конец ахиллова сухожилия. Нити связывали между собой с последующим наложением адаптационных швов в области сформированного разрыва. Затем выделяли плантарное сухожилие на дистальном основании с целью сохранения питания последнего. В среднем длина плантарного сухожилия составляла 340 мм. Толщина - 2 мм. Такой длины было достаточно, чтобы произвести армирование зоны разрыва. Плантарное сухожилие проводили П-образно и $\mathrm{X}$-образно в толще ахиллова сухожилия, отступив 5 см от зоны разрыва. Места прохождения плантарного сухожилия в ахилловом сухожилии дополнительно фиксировали противоскользящими швами (рис. 2, а).

После этого проводили отсечение дистального конца ахиллова сухожилия с частью пяточной кости, за которую фиксировали нить диаметром 5 мм. При помощи электронного безмена фирмы Garin (точность измерения 10 гр.) производили измерение веса, необходимого для появления признаков разрыва проведенного шва по Кракову (рис. 2, б). Среднее значение прочности в 20 экспериментах составило 33,4 кг (327,54 Н).
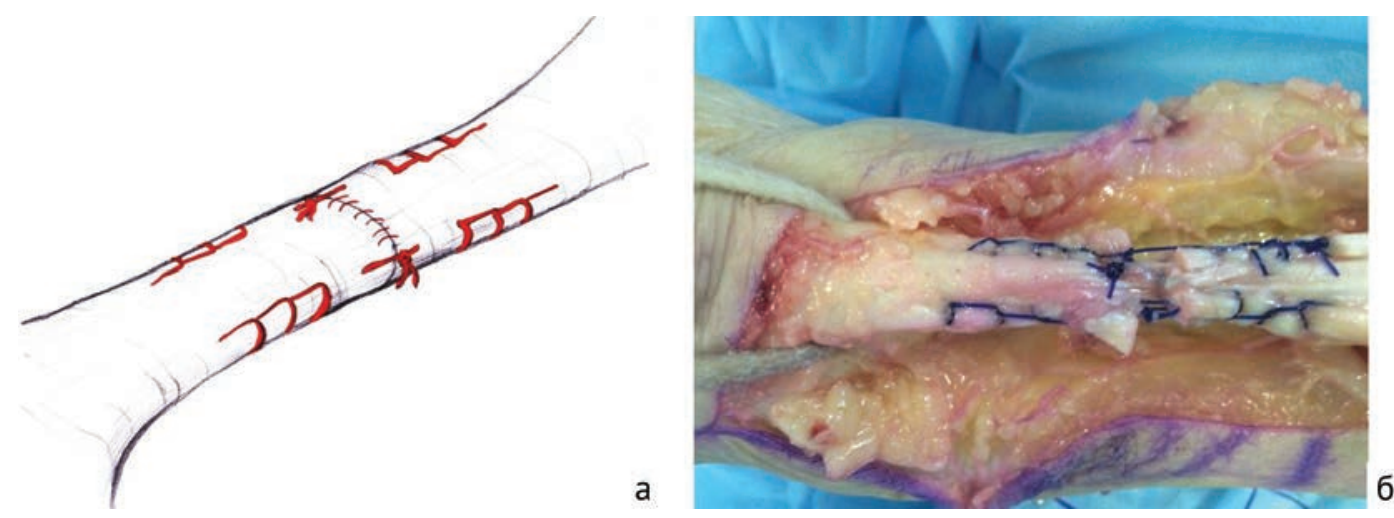

Рис. 1. Схема сухожильного шва по Кракову (а) и признаки разрыва сухожильного шва в эксперименте (б) 

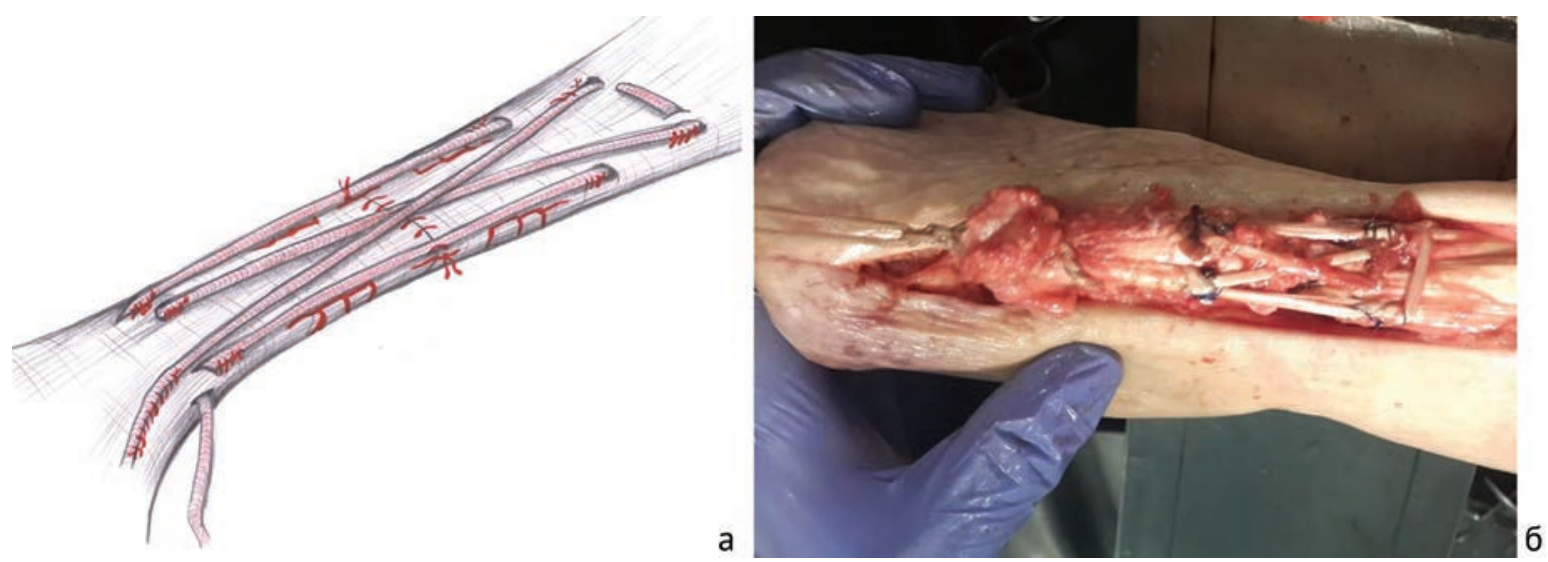

Рис. 2. Схема шва, армированного плантарным сухожилием (а), появление признаков разрыва (б)

Третья группа (20 экспериментов) - армирование ахиллова сухожилия порцией сухожилия длинной малоберцовой мышцы. На этот способ армирования ахиллова сухожилия нами получен патент на изобретение № 2616767 [13]. Для шва использовали нить VICRIL 1. Затем накладывали шов по Кракову на дистальный и проксимальный конец ахиллова сухожилия. Нити связывали между собой с последующим наложением адаптационных швов в области сформированного разрыва. Затем выделяли порцию сухожилия длинной малоберцовой мышцы на дистальном основании для сохранения питания. В среднем длина порции сухожилия длинной малоберцовой мышцы составляла 190 мм, толщина - 5 мм. Такой длины было достаточно, чтобы произвести армирование зоны разрыва. Порцию сухожилия малоберцовой мышцы проводили П-образно в толще ахиллова сухожилия, отступив 5 см от зоны разрыва, и подшивали с медиальной стороны. Места прохождения порции сухожилия малоберцовой мышцы в ахилловом сухожилии дополнительно фиксировали противоскользящими швами (рис. 3, а).

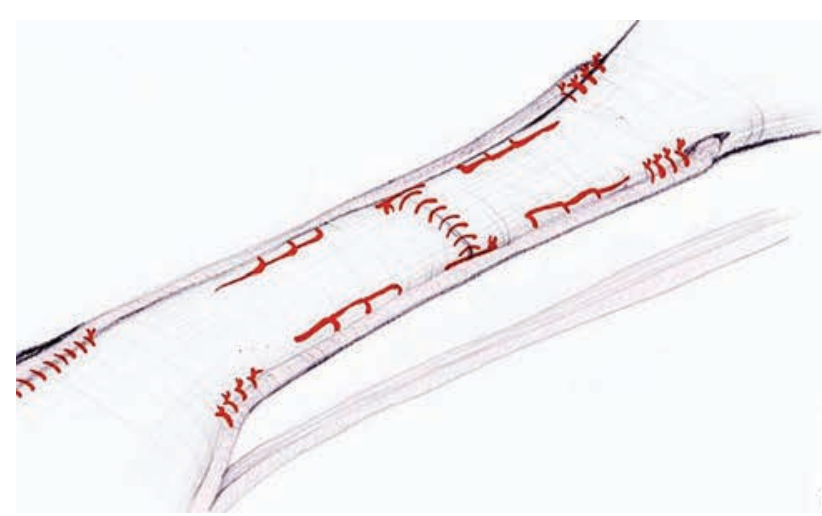

После этого проводили отсечение дистального конца ахиллова сухожилия с частью пяточной кости, за которую фиксировали нить диаметром 5 мм. При помощи электронного безмена фирмы Garin (точность измерения 10 гр.) производили измерение веса, необходимого для появления признаков разрыва проведенного шва по Кракову (рис. 3, б).

Проверка нулевой гипотезы эффекта армирования осуществлялась в три этапа. Первый этап - исходные данные и описательные статистики. Второй этап - проверка однородности стандартных отклонений. Третий этап - поверка однородности матожиданий. Построенная линейная модель зависимости усилия на разрыв от метода армирования имела высокий уровень значимости (коэффициент детерминации R2 = 0,99, критерий Фишеpa $\mathrm{F}=3079, \mathrm{p}$ » 0). Множественные сравнения групповых средних, выполненные методом рандомизации и с использованием поправки Бонферрони, показали высокую значимость эффекта армирования как плантарным сухожилием (критерий Стьюдента $\mathrm{t}=19,5, \mathrm{p}$ » 0), так и сухожилием длинной малоберцовой мышцы ( $\mathrm{t}=23, \mathrm{p}$ » 0$)$.

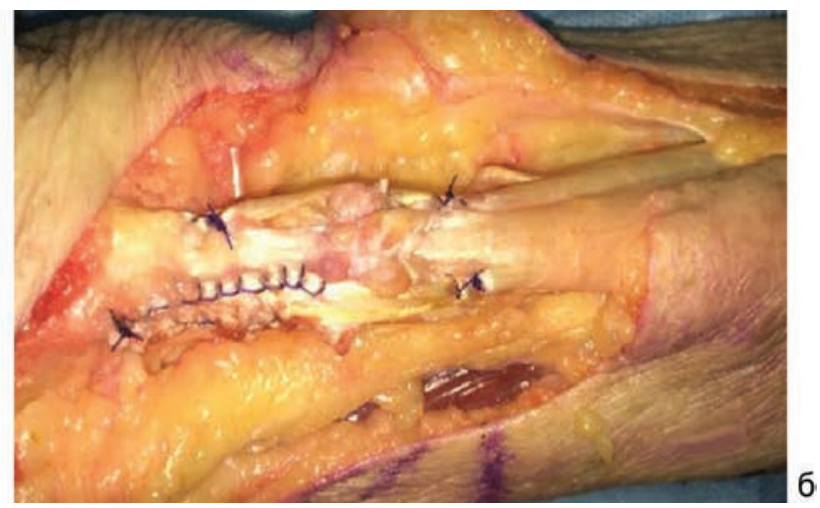

Рис. 3. Схема шва, армированного порцией длинного малоберцового сухожилия (а), и появление признаков разрыва (б)

\section{РЕЗУЛЬТАТЫ}

Среднее значение прочности в 20 экспериментах первой группы составило 11,5 кг $(112,78 \mathrm{H})$ (табл. 1). Среднее время операции 45 мин.

Среднее значение прочности в 20 экспериментах во второй группе составило 33,4 кг $(327,54 \mathrm{H})$ (табл. 2). Среднее время операции 55 мин.
Среднее значение прочности в 20 экспериментах в третьей группе составило 37,3 кг $(365,79$ Н) (табл. 3). Среднее время операции 60 мин.

После полученных цифровых значений мы провели статистическую обработку данных в 3 этапа. 
Таблица 1

Сравнение величины сил, затраченных на разрыв шва по Кракову

\begin{tabular}{|c|c|c|}
\hline Номер эксперимента & Результат в кг & Сила (Н) \\
\hline 1 & 12,36 & 121,21 \\
\hline 2 & 11,58 & 113,56 \\
\hline 3 & 9,74 & 95,52 \\
\hline 4 & 11,87 & 116,40 \\
\hline 5 & 10,42 & 102,19 \\
\hline 6 & 13,06 & 128,07 \\
\hline 7 & 12,50 & 122,58 \\
\hline 8 & 12,16 & 119,25 \\
\hline 9 & 11,79 & 115,62 \\
\hline 10 & 10,88 & 106,70 \\
\hline 11 & 12,24 & 120,03 \\
\hline 12 & 10,73 & 105,23 \\
\hline 13 & 11,62 & 113,95 \\
\hline 14 & 12,07 & 118,37 \\
\hline 15 & 9,85 & 96,60 \\
\hline 16 & 11,71 & 114,84 \\
\hline 17 & 10,56 & 103,56 \\
\hline 18 & 13,02 & 127,68 \\
\hline 19 & 9,91 & 97,18 \\
\hline 20 & 12,47 & 122,29 \\
\hline
\end{tabular}

Таблица 2

Сравнение величины сил, затраченных на разрыв шва ахиллова сухожилия, армированного плантарным сухожилием

\begin{tabular}{|c|c|c|}
\hline Номер эксперимента & Результат в кг & Сила (Н) \\
\hline 1 & 30,41 & 298,22 \\
\hline 2 & 32,76 & 321,27 \\
\hline 3 & 33,58 & 329,31 \\
\hline 4 & 33,91 & 332,54 \\
\hline 5 & 35,01 & 343,33 \\
\hline 6 & 34,89 & 342,15 \\
\hline 7 & 34,82 & 341,47 \\
\hline 8 & 34,61 & 339,41 \\
\hline 9 & 34,75 & 340,78 \\
\hline 10 & 35,00 & 343,23 \\
\hline 11 & 32,84 & 322,05 \\
\hline 12 & 30,67 & 300,77 \\
\hline 13 & 33,21 & 325,68 \\
\hline 14 & 34,14 & 334,79 \\
\hline 15 & 33,78 & 331,27 \\
\hline 16 & 30,93 & 303,32 \\
\hline 17 & 31,97 & 313,52 \\
\hline 18 & 32,69 & 320,58 \\
\hline 19 & 33,82 & 331,66 \\
\hline & 34,96 & 342,84 \\
\hline
\end{tabular}

Таблица 3

Сравнение величины сил, затраченных на разрыв шва ахиллова сухожилия, армированного порцией длинного малоберцового сухожилия

\begin{tabular}{|c|c|c|}
\hline Номер эксперимента & Результат в кг & Сила (Н) \\
\hline 1 & 37,53 & 368,04 \\
\hline 2 & 38,30 & 375,59 \\
\hline 3 & 35,89 & 351,96 \\
\hline 4 & 36,90 & 361,86 \\
\hline 5 & 37,61 & 368,83 \\
\hline 6 & 38,02 & 372,85 \\
\hline 7 & 36,85 & 361,37 \\
\hline 8 & 37,22 & 365,00 \\
\hline 9 & 38,27 & 375,30 \\
\hline 10 & 37,12 & 364,02 \\
\hline 11 & 35,92 & 352,25 \\
\hline 12 & 36,78 & 360,69 \\
\hline 13 & 38,19 & 374,52 \\
\hline 14 & 37,36 & 366,38 \\
\hline 15 & 37,41 & 366,87 \\
\hline 16 & 36,89 & 361,77 \\
\hline 17 & 37,57 & 368,44 \\
\hline 18 & 38,17 & 374,32 \\
\hline 19 & 36,93 & 362,16 \\
\hline 20 & 37,65 & 369,22 \\
\hline
\end{tabular}

\section{1. Исходные данные и описательные статистики}

Зависимая переменная: усилие на разрыв, $\boldsymbol{H}$ Независимый фактор: методы армирования Общее число измерений: 60

Количество градаций фактора: 3

Равный объем групп: $\partial a$

\section{1 Статистики для разных градаций фактора}

\begin{tabular}{|l|c|c|c|}
\hline \multirow{2}{*}{} & \multicolumn{3}{|c|}{ Фактор } \\
\cline { 2 - 4 } & АмбС & АплC & Крак \\
\hline Среднее & 366,1 & 327,9 & 113,0 \\
\hline Медиана & 366,625 & 331,465 & 115,230 \\
\hline Ni & 6,833 & 14,590 & 10,150 \\
\hline Ошибка среднего & 20 & 20 & 20 \\
\hline Min & 1,528 & 3,262 & 2,271 \\
\hline Мах & 351,96 & 298,22 & 95,52 \\
\hline & 375,59 & 343,33 & 128,07 \\
\hline
\end{tabular}

1.2 График распределения наблюдений по группам

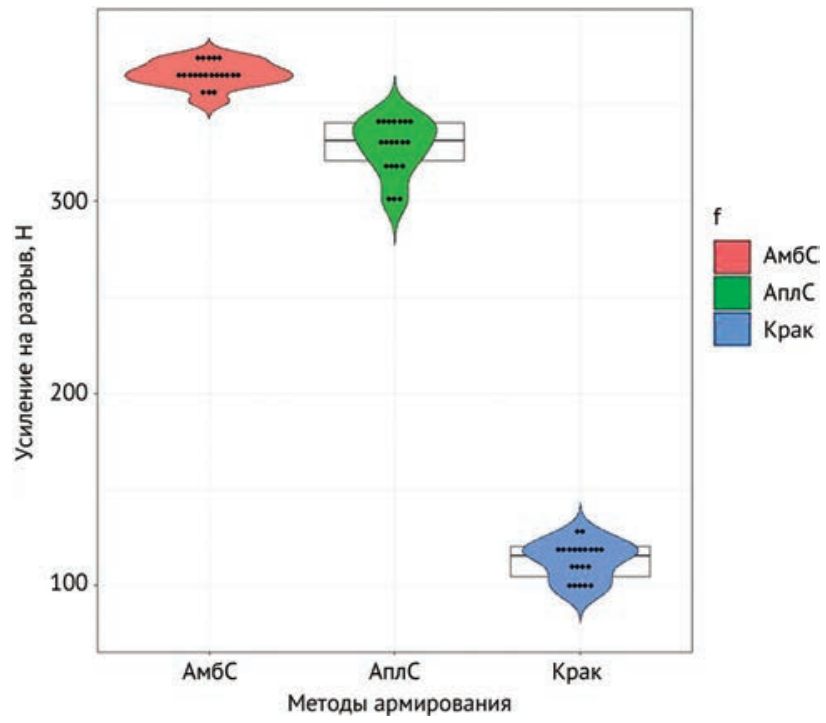

Эта «скрипичная диаграмма» показывает сглаженную функцию плотности распределения данных в каждой группе. Границами ящиков служат первый и третий квартили (25-й и 75-й процентили соответственно), линия в середине ящика - медиана (50-й процентиль).

Использовали анализ с поправкой Бонферрони на множественные сравнения. Т.е. уровень значимости 0,05 принимался для нулевой гипотезы, когда все пары методов лечения не отличаются друг от друга. Следовательно, при сравнении каждой конкретной пары методов использовался уровень значимости 0,017.

1.3 Значения критических и доверительных вероятностей

\begin{tabular}{|c|c|}
\hline alpha & alphaM \\
\hline 0,05 & 0,017 \\
\hline
\end{tabular}

\section{2. Проверка однородности стандартных отклонений}

2.1 Доверительные интервалы стандартных отклонений при alpha $=0,017$

\begin{tabular}{|l|c|c|c|}
\hline \multirow{2}{*}{} & \multicolumn{3}{|c|}{ Фактор } \\
\cline { 2 - 4 } & АмбС & АплС & Крак \\
\hline Стандартное отклонение & 6,833 & 14,590 & 10,150 \\
\hline Ni & 20 & 20 & 20 \\
\hline ДИ_нижн & 4,912 & 10,490 & 7,297 \\
\hline ДИ_верх & 10,92 & 23,32 & 16,22 \\
\hline
\end{tabular}


2.2 График доверительных интервалов стан-

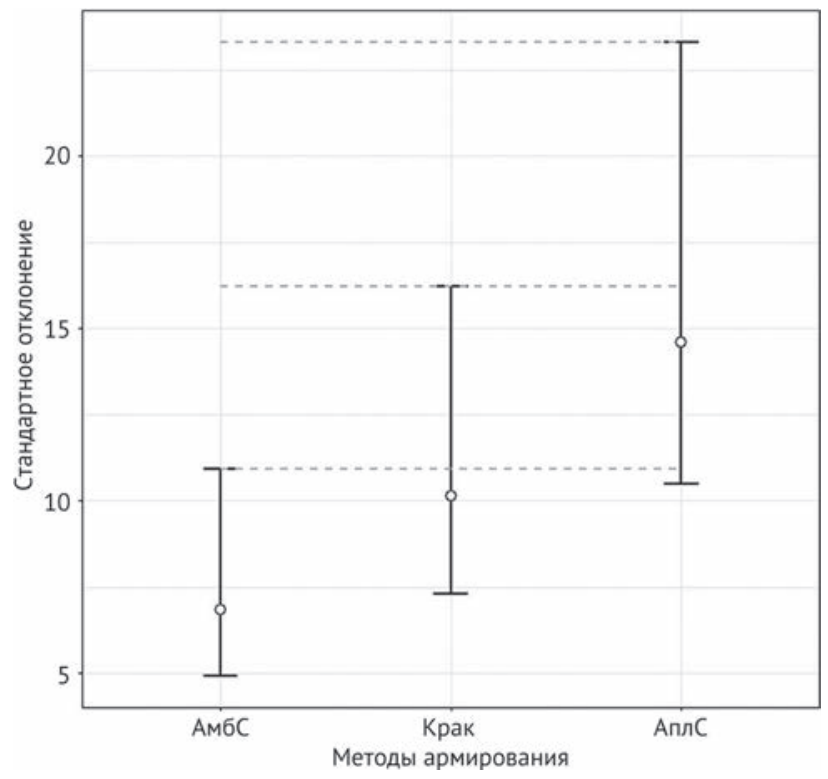

Для сравнения различных методов по t-критерию нужно предварительно убедиться в том, что разброс (дисперсия) в каждой группе примерно одинаков. Для проверки этого мы использовали метод доверительных интервалов. На графике выше доверительные интервалы для стандартных отклонений пересекаются (накладываются друг на друга), следовательно, можно предположить, что дисперсии однородны (примечание: использовалась процедура коррекции р-значений Бонферрони). Можно проверять гипотезу о равенстве средних.

3. Проверка однородности математических ожиданий

3.1 Доверительные интервалы групповых средних при alpha $=0,017$

\begin{tabular}{|l|c|c|c|}
\hline \multirow{2}{*}{} & \multicolumn{3}{|c|}{ Фактор } \\
\cline { 2 - 4 } & АмбС & АплC & Крак \\
\hline Среднее & 366,1 & 327,9 & 113,0 \\
\hline ДИ_нижн & 20 & 20 & 20 \\
\hline ДИ_верх & 361,8 & 323,6 & 108,7 \\
\hline
\end{tabular}
дартных отклонений

3.2 График доверительных интервалов математических ожиданий

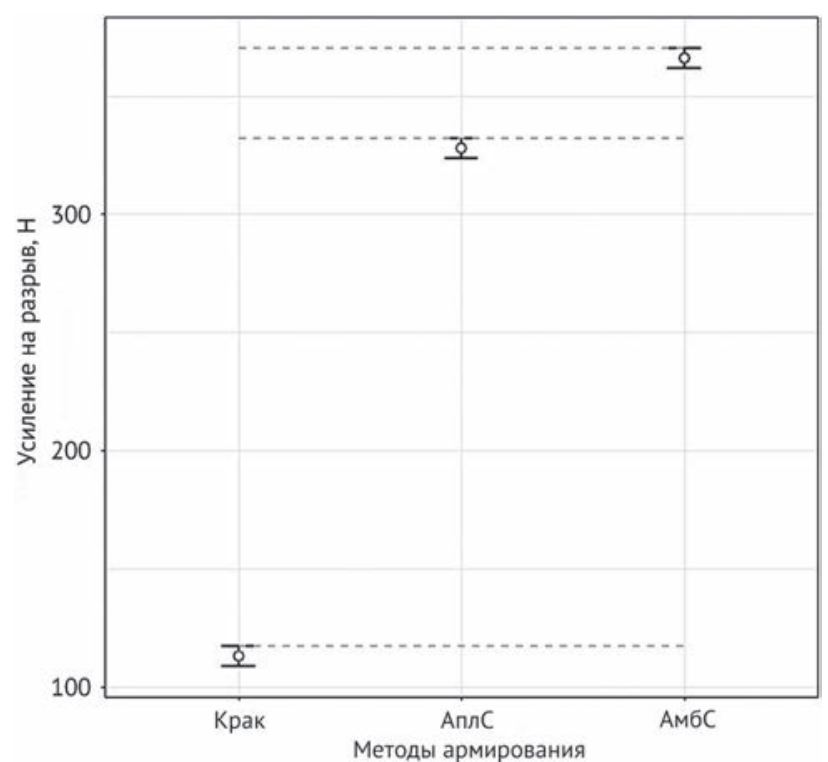

3.3 Тесты парных сравнений групповых средних

3.3.1 Параметрический тест статистики Стьюдента $t$

\begin{tabular}{|l|c|c|c|}
\hline \multirow{2}{*}{ Factor } & АмбС & АплC & Крак \\
\cline { 2 - 4 } & \multicolumn{3}{|c|}{ t-statistics } \\
\hline АмбС & & 3,4700 & 23,0000 \\
\hline АплС & $\mathbf{0 , 0 0 7 6}$ & & 19,5000 \\
\hline Крак & $<\mathbf{0 , 0 0 1}$ & $<\mathbf{0 , 0 0 1}$ & \multicolumn{3}{|c|}{ Parametric p-value } \\
\hline \multicolumn{3}{|c|}{} \\
\hline
\end{tabular}

Примечание: использована процедура коррекции р-значений Бонферрони

3.3.2 Пермутационный тест статистики Стьюдента $t$

\begin{tabular}{|c|c|c|}
\hline & АмбС & АплС \\
\hline АплС & $\mathbf{0 , 0 0 6}$ & \\
\hline Крак & $\mathbf{0 , 0 0 6}$ & $\mathbf{0 , 0 0 6}$ \\
\hline
\end{tabular}

Примечание: использована процедура коррекции р-значений Бонферрони

Тест парных сравнений проводился с использованием как обычного параметрического метода, так и на основе перестановочного алгоритма, не связанного с характером распределения данных. Оба теста показали, что нулевую гипотезу о равенстве усилий на разрыв следует отклонить для всех пар методов.

\section{ОБСУЖДЕНИЕ}

Впервые армирование ахиллова сухожилия при ранних разрывах применил Т.A. Lynn в 1966 году. Для армирования он предложил распластывать плантарное сухожилие и покрывать им область шва ахиллова сухожилия. Затем в 2004 году E.M. Bluman предложил армировать зону повреждения плантарным сухожилием Z-образно. Рандомизированные работы сравнения первичного армирования (методы Lindholm - армирование боковыми лоскутами ахиллова сухожилия, Lynn - армирование распластанным плантарным сухожилием) над швом по типу «конец в конец» проводили S. Aktas и T. Nyyssonen. Группы пациентов не различались по частоте реруптур, функциональным результатам. N. Maffulli с соавторами рекомендуют проводить первичное армирование только при застарелых и повторных разрывах $[14,15]$.
Из отечественных ученых мы встретились с работой А.А. Панова, который предлагает выполнять армирование ахиллова сухожилия сетчатым имплантатом из никелида титана. В результате проведенной работы А.А. Панов с соавторами отмечают значимое снижение сроков восстановления трудоспособности в сравнении с первичным сухожильным швом «конец в конец» [16].

Результаты работ, посвященных сравнению прочности сухожильных швов, достаточно сложно суммировать. Один и тот же шов в руках разных исследователей может показать разные результаты и в большей степени зависит от состояния сухожильной ткани и прочности самой нити. Поэтому в своей работе мы выбрали нить VICRIL 1 в связи с ее техническими характеристиками (период полупрочности 30 дней и полное рассасывание через 56-70 дней), которые, на наш взгляд, опти- 
мальны для выполнения сухожильного шва. При выборе шва мы учитывали работу отечественных ученых А.А. Грицюка и А.П. Середы, которые в эксперименте доказали наибольшую прочность шва Кракова [14].

Проанализировав литературу по армированию ахиллова сухожилия, мы решили провести экспериментальную работу для понимания эффективности армирования этой области аутологичными тканями.

Армирование ахиллова сухожилия аутологичными тканями, такими как плантарное сухожилие и порция сухожилия длинной малоберцовой мышцы на дистальном основании, позволяет повысить прочность блокируемого шва в 3 раза. Использование аутологичных тканей на дистальном питающем основании предположительно позволит снизить количество инфекционных осложнений в сравнении с синтетическими материалами. Недостатком способа армирования плантарным сухожилием является вариабельное дистальное расположение сухожилия подошвенной мышцы [17], в связи с чем забор данного аутотрансплантата и его использование для армирования не всегда является возможным. Целью разработки нового способа армирования ахиллова сухожилия являлось сохранение повышенной прочности армирования ахиллова сухожилия; предсказуемый забор аутосухожилия на дистальном основании.

В первую очередь мы постарались определить показания к армированию ахиллова сухожилия, так как не каждый разрыв требует этой манипуляции. Так, например, при травматическом открытом пересечении ахиллова сухожилия нет необходимости применения армирования в связи с нормальной морфологической структурой сухожилия в области повреждения [18-21]. Но при выраженном дистрофическом процессе в ахилловом сухожилии, например, после применения кортикостероидов при лечении ахиллобурсита, когда разволокнение концов более $3 \mathrm{~cm}$, армирование шва ахиллова сухожилия будет выполнено по показаниям.

Вторым показанием к армированию являются длительные тенопатии ахиллова сухожилия, не поддающиеся консервативному лечению. Пациентов, как правило, беспокоят боли в области ахиллова сухожилия, усиливающиеся после физической нагрузки [22-25]. При осмотре выявляется утолщение в средней трети ахиллова сухожилия и болезненность при пальпации в этой зоне. Целью оперативного лечения пациентов с этой патологией является удаление измененного паратенона и резекция измененной сухожильной ткани в области асептического воспаления. Для профилактики разрыва в области иссечения ахиллова сухожилия армирование этой зоны будет выполнено по показанию. Подробно клиническая часть работы по армированию будет представлена в следующей статье.

\section{ВЫВОДЫ}

1. Предложенные способы армирования ахиллова сухожилия сухожилием плантарной мышцы и порцией сухожилия длинной малоберцовой мышцы на дистальном основании позволяют увеличить прочность зоны повреждения на 195,6 и 214,4 \% соответственно, в сравнении с блокирующим швом Кракова.
2. При выраженном разволокнении концов в зоне разрыва и тенопатии ахиллова сухожилия вероятность реруптуры повышается, что подтверждают данные литературы. Возможно, минимизировать риски реруптуры позволит армирование ахиллова сухожилия новыми способами, что будет изучено в клинической части работы.

\section{СПИСОК ИСТОЧНИКОВ}

1. Миронов С.П. Ортопедия: национальное руководство / под ред. С.П. Миронова, Г.П. Котельникова. М. : ГЕОТАР-Медиа, 2013. 944 с.

2. Ahmad J., Jones K., Raikin S.M. Treatment of Chronic Achilles Tendon Ruptures with Large Defects // Foot Ankle Spec. 2016. Vol. 9, No 5. P. 400408. DOI: $10.1177 / 1938640016640895$.

3. The influence of early weight-bearing compared with non-weight-bearing after surgical repair of the Achilles tendon / A.A. Suchak, G.P. Bostick, L.A. Beaupré, D.C. Durand, N.M. Jomha // J. Bone Joint Surg. Am. 2008. Vol. 90, No 9. P. 1876-1883. DOI: 10.2106/JBJS.G.01242.

4. Minimally Invasive Achilles Tendon Stripping for the Management of Tendinopathy of the Main Body of the Achilles Tendon / N. Maffulli, F. Oliva, G.D. Maffulli, A.G. Via, N. Gougoulias // J. Foot Ankle Surg. 2017. Vol. 56, No 5. P. 938-942. DOI: 10.1053/j.jfas.2017.05.019.

5. Achilles Tendon Load is Progressively Increased with Reductions in Walking Speed / T. Brauner, P. Pourcelot, N. Crevier-Denoix, T. Horstmann, S.C. Wearing // Med. Sci. Sports Exerc. 2017. Vol. 49, No 10. P. 2001-2008. DOI:10.1249/MSS.0000000000001322.

6. Chan J.Y., Elliott A.J., Ellis S.J. Reconstruction of Achilles rerupture with peroneus longus tendon transfer // Foot Ankle Int. 2013. Vol. 34 , No 6. P. 898-903. DOI: 10.1177/1071100712473273.

7. Lohrer H., Nauck T. Results of operative treatment for recalcitrant retrocalcaneal bursitis and midportion Achilles tendinopathy in athletes // Arch. Orthop. Trauma Surg. 2014. Vol. 134, No 8. P. 1073-1081. DOI: 10.1007/s00402-014-2030-8.

8. Achilles tendon rupture rehabilitation: a mixed methods investigation of current practice among orthopaedic surgeons in the United Kingdom / R.S. Kearney, N. Parsons, M. Underwood, M.L. Costa // Bone Joint Res. 2015. Vol. 4, No 4. P. 65-69. DOI: 10.1302/2046-3758.44.2000400.

9. McCormack R., Bovard J. Early functional rehabilitation or cast immobilisation for the postoperative management of acute Achilles tendon rupture? A systematic review and meta-analysis of randomised controlled trials // Br. J. Sports Med. 2015. Vol. 49, No 20. P. 1329-1335. DOI: 10.1136/ bjsports-2015-094935.

10. Anatomic study suggests that the morphology of the plantaris tendon may be related to Achilles tendonitis / Ł. Olewnik, G. Wysiadecki, M. Polguj, M. Topol // Surg. Radiol. Anat. 2017. Vol. 39, No 1. P. 69-75. DOI: 10.1007/s00276-016-1682-1.

11. Performance of the Achilles Tendon Total Rupture Score Over Time in a Large National Database: Development of an Instruction Manual for Accurate Use / M.S. Hansen, K. Nilsson Helander, J. Karlsson, K.W. Barfod // Am. J. Sports Med. 2020. Vol. 48, No 6. P. 1423-1429. DOI:10.1177/0363546520912222.

12. Fell D., Enocson A., Lapidus L.J. Surgical repair of acute Achilles tendon ruptures: a follow-up of 639 consecutive cases // Eur. J. Orthop. Surg. Traumatol. 2020. Vol. 30, No 5. P. 895-899. DOI: 10.1007/s00590-020-02650-1.

13. Способ армирования ахиллова сухожилия : пат. 2616767 Рос. Федерация : МПК А61В 17/00 / Котельников Г.П., Чернов А.П., Лосев И.И., Ким Ю.Д., Шитиков Д.С., Зимин Д.В., Князев Н.А. ; патентообладатель ФГБОУ ВО «Самарский государственный медицинский университет» Министерства здравоохранения Российской Федерации. № 2016113022 ; заявл. 05.04.2016 ; опубл. 18.04.2017. Бюл. № 11.

14. Грицюк А.А., Середа А.П. Ахиллово сухожилие. М. : РАЕН, 2010. 313 с.

15. Plaster cast versus functional bracing for Achilles tendon rupture: the UKSTAR RCT / M.L. Costa, J. Achten, S. Wagland, I.R. Marian, M. Maredza, 
M.M. Schlüssel, A.S. Liew, N.R. Parsons, S.J. Dutton, R.S. Kearney, S.E. Lamb, B. Ollivere, S. Petrou // Health Technol. Assess. 2020. Vol. 24, No 8. P. 1-86. DOI: $10.3310 /$ hta24080.

16. Исследование результатов применения сверхэластичных имплантатов из никелида титана в лечении разрывов ахиллова сухожилия / А.А. Панов, В.И. Подолужный, В.А. Ланшаков, В.Э. Гюнтер, А.Х. Баховудинов // Сибирский медицинский журнал. 2009. Т. 24 , № 3-1. C. $42-44$.

17. Functional anatomy, histology and biomechanics of the human Achilles tendon - A comprehensive review / K. Winnicki, A. Ochała-Kłos, B. Rutowicz, P.A. Pękala, K.A. Tomaszewski // Ann. Anat. 2020. Vol. 229. 151461. DOI: 10.1016/i.aanat.2020.151461.

18. Maffulli N., Via A.G., Oliva F. Chronic Achilles tendon rupture // Open Orthop. J. 2017. Vol. 11. P. 660-669. DOI: 10.2174/1874325001711010660.

19. The risk of Achilles tendon rupture in the patients with Achilles Tendinopathy: Healthcare Database analisis in the United States / Y. Yasui, I. Tonogai, A.J. Rosenbaum, Y. Shimozono, H. Kawano, J.G. Kennedy // Biomed. Res. Int. 2017. Vol. 2017. ID 7021862. DOI: 10.1155/2017/7021862.

20. Outcomes and complications of percutaneous versus open repair of acute Achilles tendon rupture: A meta-analysis / B. Yang, Y. Liu, S. Kan, D. Zhang, H. Xu, F. Liu, G. Ning, S. Feng // Int. J. Surg. 2017. Vol. 40. P. 178-186. DOI: 10.1016/j.ijsu.2017.03.021.

21. Achillon versus open surgery in acute Achilles tendon repair/I. Alcelik, Z.M. Saeed, B.A. Haughton, R. Shahid, J.C. Alcelik, C. Brogden, A. Budgen // Foot Ankle Surg. 2018. Vol. 24, No 5. P. 427-434. DOI: 10.1016/j.fas.2017.04.016.

22. Patel M.S., Kadakia A.R. Minimally Invasive Treatments of Acute Achilles Tendon Ruptures // Foot Ankle Clin. 2019. Vol. 24, No 3. P. 399-424. DOI: 10.1016/j.fcl.2019.05.002.

23. Krueger H., David S. The Effectiveness of Open Repair versus Percutaneous Repair for an Acute Achilles Tendon Rupture // J. Sport Rehabil. 2016. Vol. 25, No 4. P. 404-410. DOI: 10.1123/jsr.2015-0024.

24. Clinical failure after Dresden repair of mid-substance Achilles tendon rupture: human cadaveric testing / C. de la Fuente, G. Carreño, M. Soto, H. Marambio, H. Henríquez // Knee Surg. Sports Traumatol. Arthrosc. 2017. Vol. 25, No 6. P. 1849-1856. DOI: 10.1007/s00167-016-4182-2.

25. Surgical Treatment versus Conservative Management for Acute Achilles Tendon Rupture: A Systematic Review and Meta-Analysis of Randomized Controlled Trials / S. Deng, Z. Sun, C. Zhang, G. Chen, J. Li // J. Foot Ankle Surg. 2017. Vol. 56, No 6. P. 1236-1243. DOI: 10.1053/j.jfas.2017.05.036.

Статья поступила в редакцию 16.07.2021; одобрена после рецензирования 16.09.2021; принята к публикации 23.12.2021.

The article was submitted 16.07.2021; approved after reviewing 16.09.2021; accepted for publication 23.12.2021.

Информация об авторах:

1. Геннадий Петрович Котельников - доктор медицинских наук, профессор, академик РАН;

2. Юрий Дмитриевич Ким - кандидат медицинских наук, drkim@mail.ru;

3. Дмитрий Сергеевич Шитиков - кандидат медицинских наук;

4. Никита Алексеевич Князев;

5. Никита Эдуардович Лихолатов.

\section{Information about the authors:}

1. Gennadii P. Kotelnikov - Doctor of Medical Sciences, Professor, Academician of RAS;

2. Yuriy D. Kim - Candidate of Medical Sciences, drkim@mail.ru;

3. Dmitriy S. Shitikov - Candidate of Medical Sciences;

4. Nikita A. Knyazev - M.D.;

6. Nikita E. Likholatov - M.D. 
Гений ортопедии. 2022. Т. 28, № 1. С. 83-90.

Genij Ortopedii. 2022. Vol. 28, no. 1. P. 83-90.

\title{
Научная статья
}

удК 616.5-001.48-089.844

https://doi.org/10.18019/1028-4427-2022-28-1-83-90

\section{Ошибки и осложнения при лечении больных с отслойками покровных тканей Михаил Юрьевич Коростелев ${ }^{1}$, Наталья Геннадьевна Шихалева ${ }^{2 凶}$}

${ }^{1}$ СМ-Клиник, Москва, Россия

2 Национальный медицинский исследовательский центр травматологии и ортопедии имени академика Г.А. Илизарова, Курган, Россия

Автор, ответственный за переписку: Наталья Геннадьевна Шихалева, nshihaleva@mail.ru

\section{Аннотация}

Введение. Сложность патологии, отсутствие четкой маршрутизации больных с отслойками покровных тканей, неполноценная и несвоевременная диагностика, отсутствие клинических рекомендаций и недостаточное отражение проблемы в литературе приводит к ошибкам и осложнениям в лечении пациентов с данной патологией. Цель. Проанализировать встретившиеся ошибки и осложнения при лечении больных с отслойками покровных тканей, определить пути профилактики. Материалы и методы. Проведен ретроспективный анализ медицинских карт 40 пострадавших с отслойками покровных тканей. Пациенты были пролечены в период с 2008 по 2014 год на базе травматологических отделений и ожогового Центра г. Челябинска. Больные по времени поступления в ожоговый центр были разделены на две группы. Первая группа пострадавших госпитализировалась в сроки 6 суток и более после травмы. Пациенты из второй группы доставлены в комбустиологическое отделение в течение первых 5-ти суток. Результаты. Ошибки диагностики и лечения встречались у большинства больных, поступивших на лечение позднее 5-х суток после травмы. К наиболее частым осложнениям относят некрозы отслоенных тканей, нагноение ран, некрозы кожных аутотрансплантатов. Обсуждение. Большинство осложнений у больных с обширными отслойками покровных тканей стали результатом допущенных организационных, диагностических, лечебно-тактических и технических ошибок, часть осложнений связана с тяжестью и обширностью повреждений тканей. Заключение. Предложен ряд рекомендаций по профилактике возникновения ошибок и осложнений лечения данной группы пострадавших.

Ключевые слова: отслойки покровных тканей, обширные раны, ошибки при лечении ран, кожная пластика, пластическая хирургия, маршрутизация

Для цитирования: Коростелев М.Ю., Шихалева Н.Г. Ошибки и осложнения при лечении больных с отслойками покровных тканей // Гений ортопедии. 2022. Т. 28, № 1. С. 83-90. https://doi.org/10.18019/1028-4427-2022-28-1-83-90

\section{Original article}

\section{Failures and complications in treatment of patients with degloving injury of integumentary tissues}

\section{Mikhail Yu. Korostelev ${ }^{1}$, Natalia G. Shikhaleva ${ }^{2 \varpi}$}

\author{
${ }^{1}$ SM-Clinik, Moscow, Russian Federation \\ 2 Ilizarov National Medical Research Centre for Traumatology and Orthopedics, Kurgan, Russian Federation \\ Corresponding author: Natalia G. Shikhaleva, nshihaleva@mail.ru
}

\section{Annotation}

The complexity of the condition, lack of clear routes for patients with degloving injury of integumentary tissues, inadequate and untimely diagnosis, lack of clinical guidelines and a paucity of literature lead to a great number of failures and complications in treatment of the cohort of patients. The objective of the study was to analyze failures and complications encountered in treatment of patients with degloving injury of integumentary tissues, and identify ways for the prevention. Material and methods Medical records of 40 patients with degloving injury of integumentary tissues were retrospectively reviewed. The patients treated in trauma departments and the Burn Center in Chelyabinsk between 2008 and 2014 were divided into two groups according to the time of admission to the burn center. The first group of patients was hospitalized within 6 days of injury and over. The second group of patients was admitted to the combustiology department in the first 5 days of injury. Results Failures in diagnosis and treatment were mostly observed in patients who were admitted for treatment after 5 days of injury. Most common complications included necrosis of integumentary tissues, infected wounds, necrosis of skin autografts. Discussion Most of the complications seen in patients with extensive degloving injury of integumentary tissues resulted from organizational, diagnostic, therapeutic, strategical and technical failures, and several adverse events were associated with the severity and extent of the involved tissues. Conclusion A number of recommendations have been offered for prevention of failures and complications in treatment of the cohort of patients.

Keywords: degloving injury of integumentary tissues, extensive wound, failure of wound treatment, skin plastic surgery, plastic surgery, patient route

For citation: Korostelev M.Yu., Shikhaleva N.G. Failures and complications in treatment of patients with degloving injury of integumentary tissues. Genij Ortopedii, 2022, vol. 28, no 1, pp. 83-90. https://doi.org/10.18019/1028-4427-2022-28-1-83-90

\section{ВВЕДЕНИЕ}

Отслойки покровных тканей являются результатом приложения к поверхности кожи силы высокой интенсивности с тангенциальными векторами, которые вызывают сжатие, растяжение, скручивание и трение. Эта сила вызывает отслоение кожи и подкожной клетчатки от поверхностной фасции с повреждением в ряде случаев мышц, костей, сосудисто-нервных образований [1-7]. При поступлении в приемный покой стационара пациентов с множественной, сочетанной или комбинированной травмой повреждениям покровных тканей уделяется недостаточное внимание. Травмирование кожных покровов не приводит к жизнеугрожающим состояниям в раннем периоде. В настоящее время предложено множество методик в лечении пострадавших данной группы [8-15]. Однако недооценка некротических изменений отслоенных тканей либо неверно выбранная хирургическая тактика чревата развитием эндогенной интоксикации и фатальных гнойно-септических осложнений, приводящих к летальным исходам. 
В ряде зарубежных литературных источников указывается, что помимо травматолога и реаниматолога в курации этих пациентов необходимо участие пластического хирурга - при оценке жизнеспособности покровных тканей, определении этапности реконструктивного лечения при дефектах кожных покровов, выборе вида пластики и выполнении её в оптимальные максимально ранние сроки [16-18]. На территории Российской Федерации соответствующие навыки входят в профессиональный стандарт врачей нескольких специальностей: травматолог-ортопед, хирург, пластический хирург [19-21]. Пластические хирурги в бюджетных лечебных учреждениях крайне редко участвуют в лечении больных с отслойкой покровных тканей, чаще всего лечение осуществляют хирурги-комбустиологи как специалисты по закрытию обширных раневых дефектов [22]. Сложность патологии, отсутствие четкой маршрутизации больных с данным диагнозом приводит к большому количеству ошибок и осложнений $[1,2,23]$, что определяет актуальность цели работы.

Цель исследования: проанализировать ошибки и осложнения при лечении больных с отслойками покровных тканей, определить пути и меры профилактики.

\section{МАТЕРИАЛЫ И МЕТОДЫ}

Работа выполнена на опыте лечения больных в период с 2008 по 2014 год на базе травматологических отделений ОКБ, ОДКБ г. Челябинска, городских больниц г. Челябинска (в основном ожоговый центр ГБ № 6) и Челябинской области.

Под наблюдением находились 40 пациентов, 21 женщина (52,5 \%) и 19 мужчин $(47,5$ \%) с различными механизмами травмы (табл. 1).

На основе предложенной нами классификации [24] мы провели градацию пациентов, основываясь на глубине повреждения тканей (табл. 2).

Таблица 1

Распределение пациентов по механизму травмы

\begin{tabular}{|l|c|c|}
\hline \multirow{2}{*}{ Механизм травмы } & \multicolumn{2}{|c|}{ Количество пациентов } \\
\cline { 2 - 3 } & абс. & $\%$ \\
\hline Наезд колесом автомобиля & 17 & 42,5 \\
\hline $\begin{array}{l}\text { Попадание конечности в движущийся } \\
\text { механизм (тестомешалка, вальцы, } \\
\text { транспортерная лента) }\end{array}$ & 13 & 32,5 \\
\hline Волочение по асфальту & 2 & 5 \\
\hline $\begin{array}{l}\text { Сдавление конечности и последующая } \\
\text { тракция }\end{array}$ & 3 & 7,5 \\
\hline ДтП со столкновением автомобилей & 3 & 7,5 \\
\hline Ушиб & 1 & 2,5 \\
\hline Укус собаки & 1 & 2,5 \\
\hline Итого & 40 & 100 \\
\hline
\end{tabular}

Таблица 2

Распределение пациентов по глубине повреждения тканей

\begin{tabular}{|l|c|c|}
\hline \multirow{2}{*}{ Виды повреждений } & \multicolumn{2}{|c|}{ Количество пациентов } \\
\cline { 2 - 3 } & абс. & $\%$ \\
\hline $\begin{array}{l}\text { Повреждение на уровне кожи и } \\
\text { подкожно-жировой клетчатки }\end{array}$ & 4 & 10 \\
\hline $\begin{array}{l}\text { Повреждение на уровне кожи, подкожно- } \\
\text { жировой клетчатки и поверхностной } \\
\text { фасции }\end{array}$ & 8 & 20 \\
\hline $\begin{array}{l}\text { Повреждение на уровне покровных } \\
\text { тканей и размозжение мышц }\end{array}$ & 7 & 17,5 \\
\hline $\begin{array}{l}\text { Отслойка покровных тканей, } \\
\text { сочетающаяся с повреждением } \\
\text { сосудисто-нервных образований, } \\
\text { костной ткани (перелом, дефект кости) }\end{array}$ & 21 & 52,5 \\
\hline Итого & 40 & 100 \\
\hline
\end{tabular}

По срокам поступления в ожоговый Центр г. Челябинска все больные были распределены на две основные группы.

Пациенты первой группы (20 человек) после полученной травмы сначала поступали в травматологические отделения ближайших многопрофильных боль- ниц. После стабилизации состояния и консультации комбустиолога на сроках позднее 6-ти суток больного переводили в ожоговый центр г. Челябинска. Сроки госпитализации больных первой группы в ожоговый Центр варьировали от 6 до 30 суток после травмы.

Пациенты второй группы (20 человек) попадали в ожоговый центр в первые 5 суток после травмы. Часть из них доставлена бригадами скорой медицинской помощи с места получения травмы в приемное отделение многопрофильной городской больницы № 6 г. Челябинска, где кроме травматологического отделения имеется и ожоговый Центр. Остальные больные поступали из других лечебных учреждений после осмотра или заочной консультации комбустиолога.

Среди ретроспективно анализируемых историй болезни пациентов первой группы было два летальных случая. Эти больные первично поступили в травматологические отделения городских больниц г. Челябинска, длительное время там лечились. На фоне развития гнойно-септических осложнений пациенты были переведены из травматологических отделений в гнойные и затем в отделения реанимации и интенсивной терапии внутри тех же больниц. К одной пациентке специалиста-комбустиолога пригласили через 1,5 месяца после получения травмы. Ко второй пострадавшей комбустиолог был приглашен за несколько часов до ее смерти (на 18-е сутки после травмы). Летальный исход в обоих случаях наступил на фоне полиорганной недостаточности и септического состояния. Никаких операций в обоих случаях комбустиолог не проводил из-за крайне тяжелого состояния пациентов.

Из второй группы в состоянии шока поступили 6 пациентов. Тяжелое состояние было обусловлено получением травмы, сопутствующими повреждениями, наличием посттравматического и геморрагического шока. С момента поступления они находились в отделении реанимации и интенсивной терапии под совместной курацией травматологов и комбустиологов.

Пациенты первой группы после травмы и проведенного лечения в других лечебных учреждениях при поступлении в ожоговый центр имели некротические раны, относящиеся ко второй и третей стадии инфекционно-воспалительного процесса. Поэтому проводилась санация ран различными методами, повторная хирургическая обработка и последующее оперативное закрытие раневых дефектов различными методами аутодермопластик. 
Во второй группе пациентов реализация лечебного процесса проходила более интенсивно, что позволило избежать развития инфекционного процесса в поврежденных тканях.

Результатом лечения больных в обеих группах было полное восстановление покровных тканей. Мы анализировали сроки окончательного восстановления заживления ран, количество операций и перевязок, длительность стационарного лечения.

Работа была выполнена в соответствии с этическими нормами Хельсинкской декларации Всемирной медицинской ассоциации «Этические принципы проведения научных медицинских исследований с участием человека» с поправками 2013 г. и «Правилами клинической практики в Российской Федерации», утвержденными приказом Минздрава РФ от 19.06.2003 г. № 266. Пациенты подписали информированное согласие на проᄀведение хирургического вмешательства и публикацию полученных данных без идентификации личности.

Статистическую обработку количественных данных провели в электронных таблицах Microsoft Excel с использованием программы Attestat (версия 9.3.1, разработчик Гайдышев И.П., Сертификат Роспатента № 2002611109). Учитывая малый объём выборок (n < 30), для проверки гипотезы о различии сравниваемых групп использовали критерий Манна-Уитни.

\section{РЕЗУЛЬТАТЫ}

После анализа медицинских карт пострадавших выявлено, что ошибки диагностики и лечения встречались у большинства больных первой группы (табл. 3). Лечебно-тактические ошибки наблюдались у всех пациентов первой группы, при этом у 11 пациентов отмечено наличие одновременно нескольких ошибок лечения во время нахождения в травматологическом стационаре.

Все вышеперечисленные ошибки способствовали возникновению осложнений в послеоперационном периоде у всех пациентов первой группы (табл. 4).

Во второй группе организационных, диагностических и лечебных ошибок не было. Несмотря на это, у пяти больных в процессе лечения отмечались краевые некрозы реплантированных утильных кожных трансплантатов. Нагноения не было. Данное осложнение не повлияло на получение хорошего результата лечения.

Таблица 3

Распределение пациентов первой группы по категориям ошибок ( $\mathrm{n}=20)$

\begin{tabular}{|c|c|c|}
\hline \multirow{2}{*}{ Виды ошибок } & \multicolumn{2}{|c|}{ Количество пациентов } \\
\hline & абс. & $\%$ \\
\hline Диагностические ошибки & 11 & 55 \\
\hline Неправильное определение площади отслоенных тканей & 4 & 20 \\
\hline Неправильная (необъективная) оценка жизнеспособности поврежденных покровных тканей & 5 & 25 \\
\hline Недиагностированная закрытая отслойка покровных тканей в случае наличия у больного открытых ран & 2 & 10 \\
\hline Лечебно-тактические ошибки & 20 & 100 \\
\hline $\begin{array}{l}\text { Стремление первичного ушивания имеющейся раны с натяжением ее краев, что на фоне травматическо- } \\
\text { го отека привело к усугублению ишемии тканей и некрозу кожи }\end{array}$ & 5 & 25 \\
\hline $\begin{array}{l}\text { Отсутствие адекватного динамического контроля локального процесса, приведшее к развитию некроти- } \\
\text { ческих и инфекционных осложнений }\end{array}$ & 6 & 30 \\
\hline $\begin{array}{l}\text { Отсутствие активного и/или пассивного дренирования ран (приводило к скоплению раневого отделяе- } \\
\text { мого и его инфицированию) }\end{array}$ & 2 & 10 \\
\hline Укладка отслоенных тканей с критически нарушенным кровоснабжением на прежнее место & 2 & 10 \\
\hline $\begin{array}{l}\text { Укрытие жизнеспособными покровными тканями размозженных мышц и лишенных кровообращения } \\
\text { фасций }\end{array}$ & 3 & 15 \\
\hline Нерациональное выполнение операции по замещению дефекта кожных покровов (выбор метода) & 3 & 15 \\
\hline $\begin{array}{l}\text { Нерациональное выполнение операции по замещению дефекта кожных покровов по времени (сроку) } \\
\text { выполнения операции }\end{array}$ & 11 & 55 \\
\hline Нерациональное использование вакуумной системы для лечения ран & 2 & 10 \\
\hline Технические ошибки & 6 & 30 \\
\hline $\begin{array}{l}\text { Наложение послабляющих разрезов на отслоенную кожу, что приводило к дополнительному наруше- } \\
\text { нию интрадермального кровообращения (отмечены некрозы значительной части лоскутов) }\end{array}$ & 2 & 10 \\
\hline $\begin{array}{l}\text { Оставление в ране нежизнеспособных фасций и мышц, закрытых натянутыми покровными тканями } \\
\text { приводило к развитию гнойно-септических осложнений }\end{array}$ & 3 & 15 \\
\hline Нестабильно выполненный остеосинтез при переломах костей & 1 & 5 \\
\hline
\end{tabular}

Осложнения и неблагоприятные исходы лечения пациентов

\begin{tabular}{|l|c|c|c|}
\hline \multirow{2}{*}{ Виды осложнений и неблагоприятных исходов } & \multicolumn{2}{|c|}{ Группа 1 } & \multicolumn{2}{|c|}{ Группа 2* } \\
\cline { 2 - 4 } & абс. & 100 & 0 \\
\hline Длительный раневой процесс & 20 & 0 & 0 \\
\hline Краевой некроз кожных трансплантатов & 0 & 25 & 0 \\
\hline Распространённый ишемический некроз & 5 & 30 & 0 \\
\hline Глубокое нагноение & 6 & 15 & 0 \\
\hline Лизис трансплантата & 3 & 10 & 0 \\
\hline Летальный исход & 2 & 0 \\
\hline
\end{tabular}

* $-\mathrm{p}^{1-2}=0,05$ по критерию Манна-Уитни. 
Приводим демонстрацию клинического примера пациентки с несколькими «классическими» лечебнотактическими ошибками. Пациентка Б., 54 лет, была зажата во время автодорожной аварии между автобусом и автомобилем. Основной удар пришелся на правую ягодичную область и правое бедро. Бригадой скорой медицинской помощи была доставлена в Областную клиническую больницу г. Челябинска. Выполнено обследование (клиническое, рентгенологическое). Установлен диагноз: отслойка покровных тканей правого бедра (площадь отслойки 9 \%). После этого в экстренном порядке выполнена первичная хирургическая обработка ран правой нижней конечности. Во время операции были нанесены множественные послабляющие и дренирующие насечки на кожу правого бедра и ушивание раны с натяжением тканей. В послеоперационном периоде, несмотря на проводимое лечение, на фоне приема антибиотиков, дезагрегантов стал развиваться некроз отслоенных тканей. Через 2 недели после травмы для консультации был приглашен комбустиолог из ожогового центра г. Челябинска. На момент осмотра на 16 день после травмы у больной было состояние средней степени тяжести, обусловленное полученной травмой, осложненным течением раневого процесса, наличием гной- но-резорбтивной лихорадки. Результатом консультации стал перевод больной в ожоговый Центр и дальнейшее лечение. После перевода была проведена вторичная хирургическая обработка раны. Выявлено, что площадь отслойки покровных тканей составила $9 \%$ - правое бедро (циркулярное повреждение) и 6 \% - правая ягодичная и поясничная область. Видны травмированные покровные ткани с некрозом кожи, некротические раны на месте выполненных разрезов на отслоенных лоскутах (рис. 1, 2, 3). На рисунке 4 (18-е сутки с момента травмы) виден мозаичный характер развития ишемии и некрозов кожи, участки мумифицированной кожи, участки выраженного венозного застоя и ишемических фликтен. Все это в сочетании с инфекционным процессом сделало невозможным реплантацию поврежденной кожи в виде полнослойного или расщепленного аутодермотрансплантата. Удаленная кожа была утилизирована. Если бы вторичная ревизия раны была произведена раньше (хотя бы на 4-6 сутки), то потери пластического материала можно было избежать. Для закрытия ран использовали расщепленные кожные аутотрансплантаты с других участков тела пострадавшей. На рисунке 5 представлен результат лечения пациентки Б. через 12 месяцев после выписки из стационара.
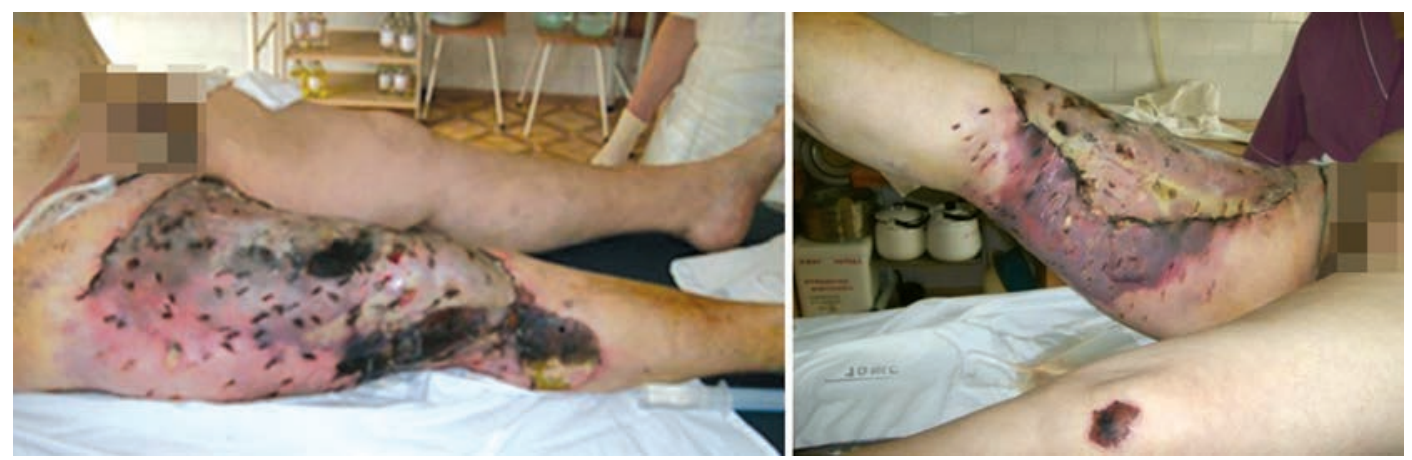

Рис. 1. Фото нижних конечностей больной Б., 54 лет, через 17 суток с момента травмы. Видны травмированные покровные ткани с некрозом кожи, некротические раны на месте выполненных разрезов на отслоенных лоскутах
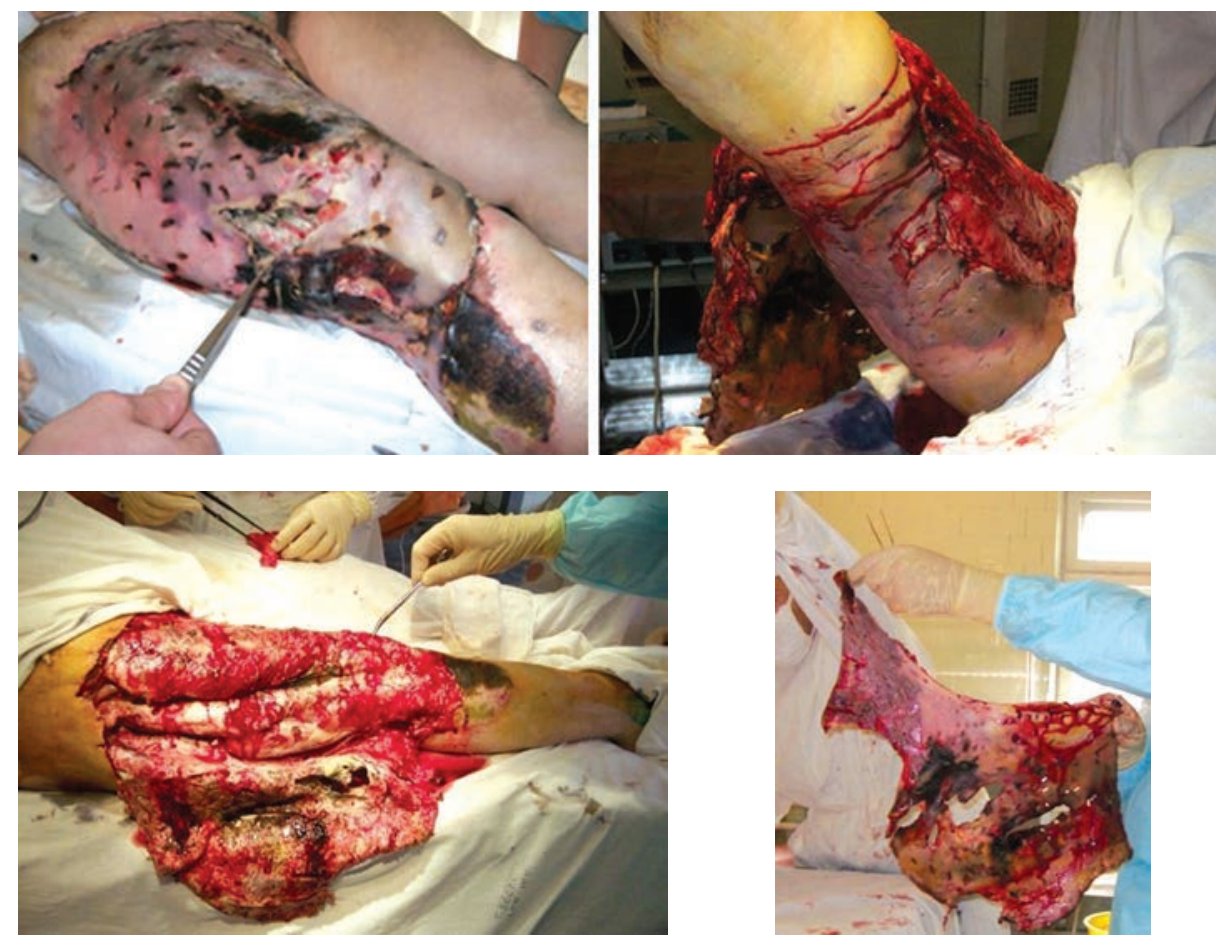

Рис. 3. Фото правого бедра больной Б. Видно, что после снятия отслоенных тканей под ними имеется разволокнение мышц, участки некроза

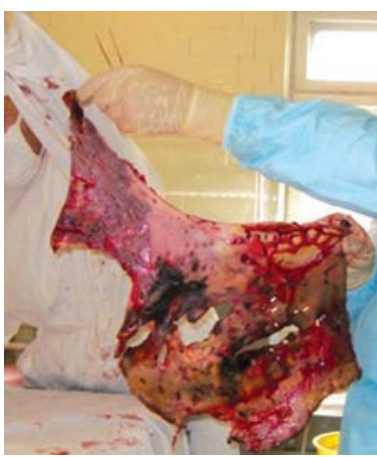

Рис. 4. Внешний вид отслоенной и частично некротизированной кожи
Рис. 2. Фото нижних конечностей больной Б., 54 лет, через 17 суток с момента травмы. При выполнении повторной хирургической обработки видны обширные участки некроза тканей в глубине бедра, циркулярный характер повреждения покровных тканей правого бедра

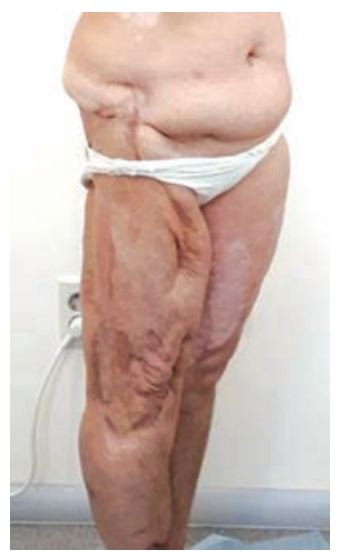

Рис. 5. Фото нижних конечностей больной Б. Результат лечения 


\section{ОБСУЖДЕНИЕ}

Большинство осложнений у больных с отслойками покровных тканей стали результатом допущенных организационных, диагностических, лечебно-тактических и технических ошибок, часть осложнений связана с тяжестью и обширностью повреждений.

Отслойка покровных тканей как диагноз отсутствует в списке нозологических форм МКБ-10 [25]. В настоящее время в перечне нозологий ФОМС по травматологии отдельно данный вид травмы также не выделяется. Соответственно, медицинские карты этих больных учитываются по другим кодам. В лучшем случае диагноз кодируется как политравма (тогда пострадавший осматривается несколькими специалистами). В худшем - как рана или ушиб (в этом случае диагноз не настраивает на серьезность проблемы). Иногда кодировка идет как перелом, повреждение сосудов или нервов, что также не отражает всей полноты необходимого обследования и лечения. Нет утвержденного объема обследования мягких тканей, необходимых методов лечения, критериев выполнения стандарта для данной патологии. Нет клинических рекомендаций лечения пациентов с данной патологией, утвержденных Министерством здравоохранения РФ.

К организационной ошибке, которая существовала ранее и существует в настоящее время, необходимо отнести отсутствие планов маршрутизации пострадавших. Больные получают лечение в хирургических, травматологических, комбустиологических отделениях, в отделениях гнойной хирургии. Такое положение дел говорит об отсутствии единого оптимального подхода в диагностике и лечении, обеспечивающих максимально положительный результат.

В связи с отсутствием приказа о маршрутизации больных нельзя говорить о его нарушении. На наш взгляд, оптимальным вариантом госпитализации пациента с отслойками покровных тканей считаем экстренную госпитализацию в многопрофильные медицинские организации с наличием травмоцентров 1-го или 2-го уровней. Эти организации оказывают весь спектр медицинской помощи на госпитальном этапе пострадавшим с сочетанными, множественными и изолированными травмами, сопровождающимися шоками, их осложнениями и последствиями. В их состав входят противошоковая операционная; специализированное реанимационное отделение; травматологическое отделение (сочетанной травмы); специализированные отделения (травматология-ортопедия, нейрохирургия, хирургия) [26]. Особым условием считаем возможность привлечения к диагностике и лечению в течение 1-2 часов сосудистого хирурга, пластического хирурга или комбустиолога (имеется в виду не столько наличие соответствующего сертификата, сколько умение работать с покровными тканями и навыки закрытия раневых дефектов и использования аутодермотрансплантатов). Наличие обширного повреждения тканей, их инфицирование, проблема длительно существующих раневых поверхностей таят предпосылки для развития множества осложнений. Тем не менее, в отечественной и зарубежной литературе их анализ носит отрывочный характер.
Португальские врачи Milcheski D.A. и другие (2010) [15] ретроспективно оценивали результаты лечения 21 пациента с отслаивающими повреждениями нижних конечностей. Отмечено 11 осложнений: 3 случая ампутаций, что было связано с тяжестью травмы; тромбоз артерии (1 случай); остеомиелит (1 случай); тетраплегия и обнажение костей (по 1 случаю). Два летальных исхода возникли в процессе лечения и были обусловлены сепсисом и острой почечной недостаточностью (по 1 случаю).

Группой авторов во главе с Yan H. [27] за 9 лет были пролечены 102 пациента (129 травмированных конечностей). Средний возраст пострадавших составлял 32,5 года (от 6 до 75 лет), 87 мужчин и 15 женщин. Среди них 94 случая наезда автомобиля, 8 больных стали жертвами несчастных случаев на производстве из-за роликовых устройств. Девяносто семь человек наблюдались в среднем 3,1 года после травмы (от 1 до 8 лет). В результате лечения большинство пострадавших остались довольны косметическим видом их травмированной конечности, тогда как трое предъявляли жалобы на деформированный контур конечностей из-за переноса комплекса тканей. Сгибательная контрактура в области голеностопного и коленного суставов с минимальным ограничением амплитуды движений была зарегистрирована у шести пациентов. Восемь человек периодически отмечали появление эрозий в подколенной ямке, лечение которых проводилось консервативно.

Другой автор - Kudsk K.A. [28] - описывает, что из 21 пациента с отслойками покровных тканей два человека умерли на 2-е и 7-е сутки, выполнены ампутации в пяти случаях, в трех случаях имелись некрозы пересаженных полнослойных кожных аутотрансплантатов.

Олейник Г.А. [29] из Харьковской медицинской академии последипломного образования представил результаты анализа эффективности лечения 427 больных со скальпированными ранами и обширными раневыми дефектами верхних и нижних конечностей за период 2009-2013 годы. В его работе были две группы. Первая - 314 пострадавших, которые лечились по традиционным методикам - визуальное субъективное определение жизнеспособности скальпированных тканей, ПХО раны, реплантация лоскутов, превентивная сосудистая и антибактериальная терапия. Вторая группа (основная) - 113 больных, которые пролечены по разработанной в клинике схеме. При оценке эффективности разработанной схемы оказания помощи больным со скальпированными ранами и обширными раневыми дефектами отмечается уменьшение количества больных с некрозами реплантированных лоскутов на 9 \%, с краевыми некрозами на 11 \%, с полным отторжением реплантированных трансплантатов на $6 \%$.

Белорусские авторы Бордаков В.Н., Елин И.А., Бордаков П.В., Доронин М.В., Сухарев А.А., Савицкий Д.С., Езерский К.Ф. [2] представили обзорную статью, посвященную диагностике и лечебной тактике при лечении пострадавших с травматической отслойкой мягких тканей. Авторы, к сожалению, не указали в работе, сколько пациентов было пролечено ими. Соответственно, отсутствуют данные о процентном 
выражении ошибок и осложнений, с которыми они встретились. Однако описание ошибок и осложнений типично для данной патологии. Авторы выделяют ошибки в диагностике продолжающегося кровотечения в полость отслойки, указывают на возможность неадекватной оценки жизнеспособности отслоенных тканей, что приводит к неправильно выбранной лечебной тактике. Лечебные ошибки авторы описывают следующие: неполноценная хирургическая обработка обширной отслойки кожи: ограничение только дренированием полости отслойки; применение подшивания кожи узловыми швами; перфорирование кожи отдельными разрезами; выполненная первичная хирургическая обработка с наложением первичных («глухих») швов; примитивное длительное бинтование области отслойки.

Daniel Francisco Mello с соавторами [17] поделились опытом лечения 47 пациентов. В статье указывается, что осложнения наблюдались у 29 (62 \%) пострадавших. В 12 случаях отмечалось развитие инфекции, некроза в области отслойки, из которых семь были оценены поздно, а пять - своевременно. У 5-ти пациентов возникли проблемы с фиксацией сопутствующих переломов костей. Также у 5 больных возникли осложнения в виде пневмоний. Осложнения при переливании крови и коагулопатии встретились в 7-ми случаях, стрессовые язвы в 3-х случаях. Два пациента (4,2 \%) умерли на 15 и 25 сутки госпитализации.

Hakim с соавторами [30] представили опыт лечения 178 больных. Обладая современным диагностическим оборудованием, владея методами лечения больных с дефектами кожи, авторы сообщают о следующих осложнениях при общем числе больных с открытыми и закрытыми отслойками кожи: инфекция кожи в 3,9 \% случаях, некрозы кожи в 1,1 \%, летальность - в 9,0 \%.

Китайские коллеги Chen Y. и Liu L. [18] описывают результаты лечения 54 пациентов с отслойками кожи нижних конечностей. Средний возраст 35,7 года (диапазон от 16 до 65 лет). Механизм травмы: ДТП в 44 случаях, удары тяжелыми предметами в 8 случаях и падение с высоты в 2 случаях. Было зарегистрировано поражение 31 бедра, 19 голеней и 4-х стоп. Размеры рваных ран колебались от 10-15 см² до 30-50 см². Геморрагический шок встретился в 16 случаях, 5 пациентов были с переломами бедренной кости и 7 - с переломами большеберцовой кости. Результаты: все 54 пациента выжили и выздоровели и были выписаны без ампутаций. Авторы отмечают о наличии инфекционных осложнений до 54 \% при наличии ран на бедре.

Lekuya H.M. с соавторами (Уганда) [31] пролечили 46 пациентов за 5 месяцев (51 отслойка).Средний возраст пострадавших составил 28,8 года; в 84 \% травмы были вызваны дорожно-транспортными происшествиями и привели к развитию шока при поступлении в 29 \%. В 33 случаях отслойка сочеталась с наличием переломов, в 18 - переломов не было. Летальный исход развился у 6 пострадавших (13,04 \%). Осложнения наблюдались у 15 пациентов (33 \%): локальная инфекция - 8 случаев, хронические язвы - 4, остеомиелит 4 , сепсис - 3, ампутации сегментов - 3, потеря кожных лоскутов - 3, некротический фасциит - 1 .
Выполнено проспективное исследование 48 пациентов, поступивших с отслойками покровных тканей в одну из больниц Кении в период с 1 декабря 2016 г. по 30 ноября 2017 г. [14]. Средний возраст пострадавших составлял 26 лет с соотношением мужчин и женщин 1,5:1. Большинство (75 \%) травм возникли в результате дорожно-транспортных происшествий, чаще всего (n = 23) с поражением нижних конечностей. При лечении применяли либо однократную ( $\mathrm{n}=29)$, либо серийную хирургическую обработку ран $(\mathrm{n}=15)$. Наиболее часто окончательным лечением было первичные закрытие раны (n = 22). Закрытые отслаивающие травмы лечились консервативно. В 31,2 \% случаев развились осложнения. Эти ранние осложнения включали развитие локальной раневой инфекции (40 \%), кровотечение (26,7 \%), несостоятельность трансплантата (20 \%) и первичный некроз лоскута у 13,3 \%.

Обобщая результаты собственного исследования и анализ литературных источников, предлагаем следующие меры профилактики возникновения ошибок и осложнений:

1) на наш взгляд, больные с отслойками покровных тканей должны доставляться после получения травмы в травматологические центры первого уровня в течение первых суток. Современный уровень развития медицины позволяет транспортировать пациентов в состоянии шока с проведением всех необходимых противошоковых мероприятий;

2) в травмоцентре первого уровня пациент с высокоэнергетической травмой должен лечиться мультидисциплинарной бригадой специалистов с участием врача-специалиста по лечению ран и раневых дефектов (в идеале - пластический хирург);

3) использование современных диагностических процедур (УЗИ, КТ с контрастированием сосудов, MPТ, тепловизор, полярография) должно проводиться в ближайшие сутки после травмы. Это позволяет точно и своевременно установить диагноз до развития осложнений, определить тяжесть повреждения тканей и выбрать более правильную хирургическую тактику лечения;

4) оптимальные приёмы первичной хирургической обработки и дренирования раны:

а) ревизия тканей производится после стабилизации состояния больного, а в случае продолжающегося кровотечения - по экстренным показаниям. При проведении ПХО необходимо оценивать жизнеспособность покровных тканей, мышц, фасций. Иссечение травмированных тканей должно быть щадящим;

б) растворы для промывания ран должны быть изотоническими (физиологический раствор);

в) все раневые карманы должны быть задренированы толстыми силиконовыми трубками, большие загрязненные раны после ПХО целесообразно рыхло тампонировать с изотоническим раствором натрия хлорида;

г) недопустимо ушивание ран с натяжением покровных тканей;

д) необходимо исключить выполнение мелких надрезов на отслоенных тканях с целью попытки сведения краев ран; 
5) обработка кожных покровов раствором бриллиантового зеленого (или иными красящими антисептиками) затрудняет визуальную оценку состояния покровных тканей (гиперемию, цианоз, сосудистую реакцию) и должна быть исключена из арсенала лечебных мероприятий;

6) контроль состояния тканей должен проводиться не реже чем один раз в 4-6 часов, перевязки необходимо выполнять под обезболиванием;
7) вакуумные повязки в первые 5 суток накладываются с минимальным разряжением с целью предотвращения кровотечения.

Ограничение выполненного нами сравнительного анализа исходов лечения травматических отслоек кожи в зависимости от сроков поступления в комбустиологическое отделение - малые выборки пациентов, однако разница в количестве неблагоприятных исходов в этих случайных выборках оказалась статистически значимой.

\section{ЗАКЛЮЧЕНИЕ}

Среди осложнений, возникших во время лечения больных с обширными отслойками покровных тканей, первое место принадлежит образованию некрозов тканей (44,4 \% случаев среди всех осложнений), которые отражают тяжесть травмы и в большинстве случаев требуют дополнительных восстановительных и пластических операций. Инфекционные осложнения, подтвержденные микробиологическими данными, составили
9,6 \%. Основные меры профилактики ошибок и осложнений при травматических отслойках кожи включают транспортировку пострадавших в травматологические центры первого уровня в течение первых суток, организацию мультидисциплинарных бригад, использование современных высокоинформативных диагностических процедур, оптимальные приёмы первичной хирургической обработки, раннее вакуумное дренирование.

\section{СПИСОК ИСТОЧНИКОВ}

1. Закрытая травматическая отслойка кожи: принципы диагностики и лечения / И.Г. Беленький, А.Ю. Спесивцев, О.В. Имшенник, У.А. Рамаде // Амбулаторная хирургия. 2004. № 1. С. 38-40.

2. Травматическая отслойка мягких тканей: диагностика и лечебная тактика / В.Н. Бордаков, И.А. Елин, П.В. Бордаков, М.В. Доронин, А.А. Сухарев, Д.С. Савицкий, К.Ф. Езерский // Военная медицина. 2015. № 4. С. 116-119.

3. Коростелев М.Ю., Шихалева Н.Г. Современное состояние проблемы лечения пациентов с обширными отслойками покровных мягких тканей (обзор литературы) // Гений ортопедии. 2017. Т. 23, № 1. С. 88-94. DOI 10.18019/1028-4427-2017-23-1-88-94.

4. Красовитов В.К. Первичная пластика отторгнутыми лоскутами кожи : (С добавлением литературного обзора аутопластики). Краснодар : Краснодарское краевое книгоиздательство, 1947. 239 с.

5. Локтионов П.В., Гудзь Ю.В. Опыт лечения ран нижних конечностей с обширной травматической отслойкой кожи и подкожной клетчатки // Медико-биологические и социально-психологические проблемы безопасности в чрезвычайных ситуациях. 2015 . № 1 . С. $22-28$. DOI: $10.25016 / 2541-7487-2015-0-1-22-28$.

6. Микусев И.Е., Микусев Г.И., Хабибуллин Р.Ф. Травматическая отслойка кожи: вопросы диагностики и лечения // Практическая медицина. 2013. № 1-2 (69). C. 104-107.

7. Degloving Injury / D. Antoniou, A. Kyriakidis, A. Zaharopoulos, S. Moskoklaidis // Eur. J. Trauma. 2005. Vol. 31. P. 593-596. DOI: 10.1007/s00068005-1059-3.

8. Management of soft tissue extremity degloving injuries with full-thickness grafts obtained from the avulsed flap / O. Pilanci, F. Aköz Saydam, K. Başaran, A. Dath, E. Güven // Ulus Travma Acil Cerrahi Derg. 2013. Vol. 19, No 6. P. 516-520. DOI: 10.5505/tjtes.2013.64928.

9. The therapeutic challenges of degloving soft-tissue injuries / R. Latifi, H. El-Hennawy, A. El-Menyar, R. Peralta, M. Asim, R. Consunji, H. Al-Thani // J. Emerg. Trauma Shock. 2014. Vol. 7, No 3. P. 228-232. DOI: 10.4103/0974-2700.136870.

10. Vacuum-Assisted Closure in the Management of Degloving Soft Tissue Injury: A Case Report / T. Andres, F. von Lübken, B. Friemert, G. Achatz // J. Foot Ankle Surg. 2016. Vol. 55, No 4. P. 852-856. DOI: 10.1053/j.jfas.2015.12.002.

11. Severe degloving injury of the sole and heel treated by a reverse flow sural artery neurofasciocutaneous flap and a modified off-loading external fixation device / T. Zgonis, D. T. Cromack, T.S. Roukis, J. Orphanos, V.D. Polyzois // Injury Extra. 2007. Vol. 38, No 5. P. 187-192. DOI: 10.1016/j. injury.2006.08.067.

12. Wójcicki P., Wojtkiewicz W., Drozdowski P. Severe lower extremities degloving injuries - medical problems and treatment results // Pol. Przegl. Chir. 2011. Vol. 83, No 5. P. 276-282. DOI: 10.2478/v10035-011-0043-3.

13. Лечение пострадавшей с политравмой и обширной травматической отслойкой кожи нижней конечности / Я.В. Гаврищук, С.И. Микитюк, А.Е. Демко, И.В. Кажанов, А.В. Никитин // Вестник хирургии им. И.И. Грекова. 2018. Т. 177, № 4. С. 83-85. DOI: 10.24884/0042-4625-2018177-4-83-85.

14. Degloving injuries: Patterns, treatment and early complications among patients at a Teaching Hospital in Western Kenya / D.M. Mutiso, N. Maoga, B.R. Ayumba, E.M. Ashraf // East African Orthopaedic Journal. 2021. Vol. 15, No 2. P. 84-90.

15. Tratamento cirúrgico de ferimentos descolantes nos membros inferiores: proposta de protocolo de atendimento / D.A. Milcheski, M.C. Ferreira, H.A. Nakamoto, P. Tuma Jr., R. Gemperli // Rev. Col. Bras. Cir. 2010. Vol. 37, No 3. P. 199-203. DOI: 10.1590/s0100-69912010000300007.

16. Degloving injuries of trunk and limbs: comparison of outcomes of early versus delayed assessment by the plastic surgery team / D.F. Mello, J.C. Assef, S.C. Soldá, A. Helene Jr. // Rev. Col. Bras. Cir. 2015. Vol. 42, No 3. P. 143-148. (in English, Portuguese) DOI: 10.1590/0100-69912015003003.

17. Chen Y., Liu L. Clinical analysis of 54 cases of large area soft tissue avulsion in the lower limb // Chin. J. Traumatol. 2016. Vol. 19, No 6. P. 337-341. DOI: $10.1016 /$ j.cjtee.2016.09.003.

18. Об утверждении профессионального стандарта "Врач-травматолог-ортопед" : Приказ Министерства труда и социальной защиты РФ от 12 ноября 2018 г. N 698н // Гарант.ру : [сайт]. URL: https:/www.garant.ru/products/ipo/prime/doc/72019308/ (дата обращения: 05.04.2021).

19. Об утверждении профессионального стандарта "Врач-хирург" : Приказ Министерства труда и социальной защиты Российской Федерации от 26.11.2018 N 743н // Официальный интернет-портал правовой информации : [сайт]. URL: http://publication.pravo.gov.ru/Document/ View/0001201812120018 (дата обращения: 05.04.2021).

20. Об утверждении профессионального стандарта "Врач - пластический хирург" : Приказ Министерства труда и социальной защиты Российской Федерации от 31.07.2020 N 482н // Официальный интернет-портал правовой информации : [caйт]. URL: http://publication.pravo.gov.ru/ Document/View/0001202008170011 (дата обращения: 05.04.2021).

21. Особенности пластики полнослойным кожным аутотрансплантатом у пострадавших с травматической отслойкой кожи в зависимости от оценки тяжести состояния и разрушения мягких тканей / С.Н. Куринный, А.Н. Блаженко, С.Б. Богданов, Д.Н. Марченко, В.А. Аладьина, Н.С. Дейниченко // Пластическая хирургия и эстетическая медицина. 2020. № 3. C. 45-52. DOI: 10.17116/plast.hirurgia202003145.

22. Клиническое наблюдение успешного лечения пострадавшего с политравмой и обширной травматической отслойкой кожи левой голени / А.Н. Блаженко, С.Н. Куринный, М.Л. Муханов, А.А. Блаженко, А.А. Афаунов // Политравма. 2019. № 3. С. 71-76.

23. Актуальные аспекты оказания медицинской помощи детям с обширными повреждениями мягких тканей (описание трех клинических 
наблюдений с разбором допущенных при лечении ошибок) / С.Б. Богданов, А.Н. Блаженко, С.Н. Куринный, М.Л. Муханов, А.А. Бойко, А.В. Каракулев, В.А. Аладьина // Ортопедия, травматология и восстановительная хирургия дет-ского возраста. 2021. Т. 9, № 1. С. 107-114. DOI: $10.17816 /$ PTORS48471.

24. Коростелев М.Ю., Шихалева Н.Г., Климов О.В. К вопросу о классификации травматических отслоек покровных тканей // Гений ортопедии. 2021. Т. 27, № 2. C. 169-174. DOI 10.18019/1028-4427-2021-27-2-169-174.

25. International Statistical Classification of Diseases and Related Health Problems / World Health Organization. Vol. 3. An alphabetical index to diseases and nature of injury, external causes of injury, table of drugs and chemicals. Instruction manual. 2010 Edition. ICD-10.

26. Поройский С.В., Ярмолич В.А., Михно В.А. Анализ реализации программы этапной медицинской помощи пострадавшим в ДтП на трассе M6 // Современные проблемы безопасности жизнедеятельности: настоящее и будущее : материалы III Меж-дународной научно-практической конференции в рамках форума «Безопасность и связь». Казань, 2014. Ч. II.

27. The management of degloving injury of lower extremities: technical refinement and classification / H. Yan, W. Gao, Z. Li, C. Wang, S. Liu, F. Zhang, C. Fan // J. Trauma Acute Care Surg. 2013. Vol. 74, No 2. P. 604-610. DOI: 10.1097/TA.0b013e31827d5e00.

28. Kudsk K.A., Sheldon G.F., Walton R.L. Degloving injuries of the extremities and torso // J. Trauma. 1981. Vol. 21, No 10. P. 835-839. DOI: 10.1097/00005373-198110000-00002.

29. Олейник Г.А. Современная тактика диагностики и лечения скальпированных ран конечностей // Харківська хірургічна школа. 2014 . № 5. C. 37-43.

30. Patterns and management of degloving injuries: a single national level 1 trauma center experience / S. Hakim, K. Ahmed, A. El-Menyar, G. Jabbour, R. Peralta, S. Nabir, A. Mekkodathil, H. Abdelrahman, A. Al-Hassani, H. Al-Thani // World J. Emerg. Surg. 2016. Vol. 11. P. 35. DOI 10.1186/ s13017-016-0093-2.

31. Degloving injuries with versus without underlying fracture in a sub-Saharan African tertiary hospital: a prospective observational study/H.M. Lekuya, R. Alenyo, I. Kajja, A. Bangirana, R. Mbiine, A.N. Deng, M. Galukande // J. Orthop. Surg. Res. 2018. Vol. 13, No 1. P. 2. DOI: 10.1186/s13018017-0706-9.

Статья поступила в редакцию 16.07.2021; одобрена после рецензирования 16.09.2021; принята к публикации 23.12.2021.

The article was submitted 16.07.2021; approved after reviewing 16.09.2021; accepted for publication 23.12.2021.

Информация об авторах.

1. Коростелев Михаил Юрьевич - 2351724@mail.ru, https://orcid.org/0000-0002-4963-5467;

2. Шихалева Наталья Геннадьевна - доктор медицинских наук, nshihaleva@mail.ru, https://orcid.org/0000-0003-4889-9783.

\section{Information about the authors:}

1. Mikhail Yu. Korostelev - M.D., 2351724@mail.ru, https://orcid.org/0000-0002-4963-5467;

2. Natalia G. Shikhaleva - Doctor of Medical Sciences, nshihaleva@mail.ru, https://orcid.org/0000-0003-4889-9783.

Информация о финансировании и конфликте интересов. Авторы данной работы заявляют об отсутствии явных и потенциальных конфликтов интересов, связанных с публикацией статьи. Исследование не имело спонсорской поддержки. 
Гений ортопедии. 2022. Т. 28, № 1. С. 91-96.

Genij Ortopedii. 2022. Vol. 28, no. 1. P. 91-96.

\section{Научная статья \\ УДК 616.717.4-001.514-089.227.844 \\ https://doi.org/10.18019/1028-4427-2022-28-1-91-96 \\ Лечение пациента с открытым переломом плечевой кости с обширным дефектом костной ткани с использованием костной пластики (случай из практики) \\ Шароф Мажидович Давиров ${ }^{\bowtie}$, Пайзулла Уринбоевич Уринбоев}

Самаркандский филиал Республиканского специализированного научно-практического медицинского центра травматологии и ортопедии, Самарканд, Узбекистан

Автор, ответственный за переписку: Шароф Мажидович Давиров, sharofd1976@mail.ru

\section{Аннотация}

Введение. Лечение пациентов с открытыми оскольчатыми переломами плечевой кости с обширным дефектом костной ткани представляет задачу с высоким риском неблагоприятного исхода, так как высока вероятность развития гнойных осложнений, как следствия повреждений кожных покровов и мягких тканей, а также замещения значительного по объему участка кости. Цель. Демонстрация опыта лечения пациента с открытым оскольчатым переломом плечевой кости с обширным дефектом костной ткани путем этапного применения различных методик: чрескостной фиксации спице-стержневым аппаратом, костной пластики аутокостью из малоберцовой кости, внутренней фиксации спицами. Материалы и методы. Приводим клиническое наблюдение лечения пациента с открытым переломом плечевой кости с обширным дефектом костной ткани с использованием костно-замещающей методики с отдаленным результатом 4 года. Результаты и обсуждение. Выполнена временная чрескостная внеочаговая фиксация конечности спице-стержневым аппаратом. Проведен забор аутотрансплантата из малоберцовой кости длиной 24 см. Выполнен остеосинтез плечевой кости и пластика дефекта аутокостью с фиксацией трансплантата спицами, наложен спице-стержневой аппарат внешней фиксации. После сращения плечевой кости аппарат внешней фиксации демонтирован, удалены фиксационные спицы. Анатомическая длина сегмента восстановлена. Заключение. Комбинирование различных методик и технических средств (внешней фиксации, трансплантации аутокостью, внутренней фиксации гладкими спицами) позволило полностью восстановить поврежденную конечность, избежать осложнений и получить хороший клинический результат.

Ключевые слова: плечо, травма, открытый перелом, дефект костной ткани, аутокость, остеосинтез, аппарат внешней фиксации, комбинирование методик

Для цитирования: Давиров Ш.М., Уринбоев П.У. Лечение пациента с открытым переломом плечевой кости с обширным дефектом костной ткани с использованием костной пластики (случай из практики) // Гений ортопедии. 2022. T. 28, № 1. С. 91-96. https://doi.org/10.18019/10284427-2022-28-1-91-96

\section{Original article}

\section{Repair of open humerus fracture and extensive bone defect using bone grafting (case report) Sharof M. Davirov ${ }^{\bowtie}$, Payzulla U. Urinboev}

Samarkand branch of the Republican Specialized Scientific and Practical Medical Center for Traumatology and Orthopedics, Samarkand, Uzbekistan

Corresponding author: Sharof M. Davirov, sharofd1976@mail.ru

Abstract

Introduction Treatment of a patient with an open comminuted humerus fracture and an extensive bone defect is challenging and associated with high risk of a poor outcome, infection resulting from skin and soft tissue injury and considerable bone transport. The objective of the study is to demonstrate the experience with an open comminuted humerus fracture and an extensive bone defect treated with staged use of transosseous fixation with rod-andwire device, autologous fibula graft and internal wiring. Material and methods We report a case of an open humerus fracture and an extensive bone defect treated with a bone replacement technique and followed up to 4 years. Results and discussion The limb was temporarily fixed with external fixation device extrafocally using wires and rods. A $24 \mathrm{~cm}$ autograft was harvested from the fibula. Osteosynthesis of the humerus and autografting were produced with the graft fixed using smooth wires and external fixation was provided using wires and rods. With consolidation of the humerus achieved, the external fixation device was dismantled and transosseous wires removed. Anatomical length of the segment was restored. Conclusion Combined techniques and technical means of external fixation, autologous graft, internal fixation with smooth wires facilitated complete restoration of the injured limb avoiding complications with a good clinical outcome.

Keywords: humerus, trauma, open fracture, bone defect, autobone, osteosynthesis, external fixation device, combined techniques

For citation: Davirov Sh.M., Urinboev P.U. Repair of open humerus fracture and extensive bone defect using bone grafting (case report). Genij Ortopedii, 2022, vol. 28, no 1, pp. 91-96. https://doi.org/10.18019/1028-4427-2022-28-1-91-96

\section{ВВЕДЕНИЕ}

Лечение пациентов с открытыми оскольчатыми переломами плечевой кости с обширным дефектом костной ткани представляет задачу с высоким риском неблагоприятного исхода, так как высока вероятность развития гнойных осложнений, как следствия повреждений кожных покровов и мягких тканей, а также замещения значительного по объему участка кости. Разнообразие методов лечения затрудняет выбор оптимальных подходов в данном конкретном случае, что впоследствии приводит к развитию осложнений и неудовлетворительным результатам. Наличие наглядных примеров лечения способствует обоснованному выбору того или иного метода, позволяет транслировать успешный опыт.

На сегодняшний день основными видами фиксации переломов плечевой кости являются различные модификации накостного и интрамедуллярного остеосинтеза [1]. Причиной формирования дефектов длинных

( Давиров Ш.М., Уринбоев П.У., 2022 
костей являются переломы, кистозные образования, опухоли, ложные суставы, инфекционные поражения и состояния, связанные с необходимостью выполнения резекции кости [2]. В онкологии метастазы в костях наблюдаются при раке груди (47-85 \%), простаты (54-85 \%), щитовидной железы (38-60 \%), яичников (до 9 \%) [3]. Обширный дефект кости может быть результатом высокоэнергетической травмы, тяжелой инфекции, злокачественного новообразования и является серьезной проблемой при спасении конечности [4].

Не существует единого стандартного определения дефекта критического размера. Дефекты можно оценивать как в относительном, так и абсолютном значении в зависимости от конституционных особенностей пострадавшего. В целом, дефектом «критического размера» считается объем потерянной костной массы, который не закроется спонтанно, несмотря на хирургическую стабилизацию, и требует дальнейшего хирургического вмешательства в виде различных вариантов пластики [5].

Применение остеосинтеза различными накостными или внутрикостными фиксаторами через открытый хирургический доступ для таких пациентов часто заканчивается неблагоприятным исходом и не обеспечивает восстановления анатомической длины сегмента. Во время выполнения открытой репозиции, непосредственно после травмы, вмешательство отрицательно влияет на кровоснабжение, приводит к развитию таких осложнений как некроз мягких тканей, инфицирование, нагноение раны. Необходимость дополнительной иммобилизации в послеоперационном периоде ведет к развитию контрактур смежных суставов верхней конечности и атрофии мягких тканей. При обширных дефектах кости выполнение внутренней фиксации оставшихся отломков невозможно ввиду отсутствия необходимого объема костной ткани, а выполнение открытой репозиции непосредственно после открытой травмы чревато осложнениями. Альтернативой, обеспечивающей снижение вероятности неблагоприятного исхода лечения, является комбинирование различных методик.

Имеются данные, подтверждающие эффективность методики Б.Ш. Минасова с соавторами, которые приводят положительные результаты при замещении обширного пострезекционного дефекта кости фрагментом малоберцовой кости на микрососудистых анастомозах [6].

Уникальной особенностью дистракционного остеогенеза является способность полностью индуцировать образование новой кости в зоне дефекта. Эта процедура состоит из трех последовательных фаз: латентной фазы после остеотомии и внешней фиксации, фазы дистракции и фазы консолидации [7].
Современная травматология и ортопедия располагает огромным арсеналом методов замещения обширных посттравматических дефектов костной ткани длинных костей. В настоящее время можно выделить четыре направления: свободная пересадка костной ткани, замещение дефекта остеозамещающими и остеоиндуцирующими материалами, несвободная пересадка костной ткани по Г.А. Илизарову и комбинированные методы [8].

Относительно эффективными можно считать несвободную костную пластику по Г.А. Илизарову и реплантацию в дефект васкуляризованного или свободного аутотрансплантата [9], а также разные виды свободной костной ауто- и аллопластики [10]. В качестве импланта могут использоваться аутотрансплантаты, которые выполняют функцию биопротеза, а также искусственные имплантаты, обладающие биосовместимостью и достаточным уровнем прочности. Аутокость является остеогенным, остеокондуктивным и остеоиндуктивным пластическим материалом [11], но забор аутокости связан с дополнительной, иногда значительной, травмой и кровопотерей и лимитирован объемом доступного пластического материала.

Замещение костных дефектов по Г.А. Илизарову, по сути, является идеальной формой костной пластики, когда в проблемной зоне дозированно и направленно формируется хорошо васкуляризованный регенерат с сохранением покровных и мягких тканей, позволяющей теоретически создать в дефекте трубчатую кость любой длины и формы [9].

Костная пластика с использованием губчатой аутологичной кости считается эффективным средством в достижении костного сращения при повторных операциях и рекомендуется большинством авторов, использующих внутреннюю фиксацию. Однако это не всегда приводит к консолидации [12-13].

Замещение костного дефекта длинных костей с удлинением отломка по Г.А. Илизарову считается самым биологичным методом замещения дефектов. К недостаткам способа можно отнести длительность лечения больного, неудобство для пациента и необходимость постоянного контроля в период дистракции, который длится до 3-4 месяцев.

Поэтому предпочтительным является сочетание различных методик, обеспечивающих качественное лечение, но с меньшими затратами времени.

Целью работы является демонстрация опыта лечения пациента с открытым оскольчатым переломом плечевой кости с обширным дефектом костной ткани путем этапного применения различных методик: чрескостной фиксации спице-стержневым аппаратом, костной пластики трансплантатом из малоберцовой кости, внутрикостной фиксации.

\section{МАТЕРИАЛЫ И МЕТОДЫ}

В настоящей статье описан результат этапного лечения пациента с открытым переломом плечевой кости с обширным дефектом костной ткани с использованием костной пластики аутотрансплантатом, с применением аппарата внешней фиксации и внутренней фиксации гладкими спицами, что позволило заместить дефект с сохранением анатомической длины конечности и избежать осложнений.

Приводим клиническое наблюдение лечения пациента с открытым переломом плечевой кости с обширным 
дефектом костной ткани с использованием костно-замещающей методики, с отдаленным результатом 4 года.

Пациент С.К., 1994 г.р., получил травму в результате дорожно-транспортного происшествия 29.09.2016 года. По месту жительства больному была предложена ампутация конечности на уровне плеча. Поступил к нам 10.10.2016 года.

Пациенту проведено клиническое обследование. Диагностирована ушитая рана задней поверхности плеча с признаками воспаления, ограничение функции конечности. При подробном опросе и ревизии было установлено, что большой дефект плечевой кости обусловлен выпадением значительного по величине фрагмента через рану на задней поверхности локтевого сустава.

Пациенту проведено лучевое (рентгенография) обследование. Диагностирован двойной открытый оскольчатый перелом левой плечевой кости с обширным дефектом метадиафиза, с отломком дистального эпифиза и дефектом суставной поверхности локтевого сустава. Открытый перелом костей предплечья. Дефект плечевой кости 22 см. II тип по классификации открытых переломов Gustilio-Anderson [14] (рис. 1).

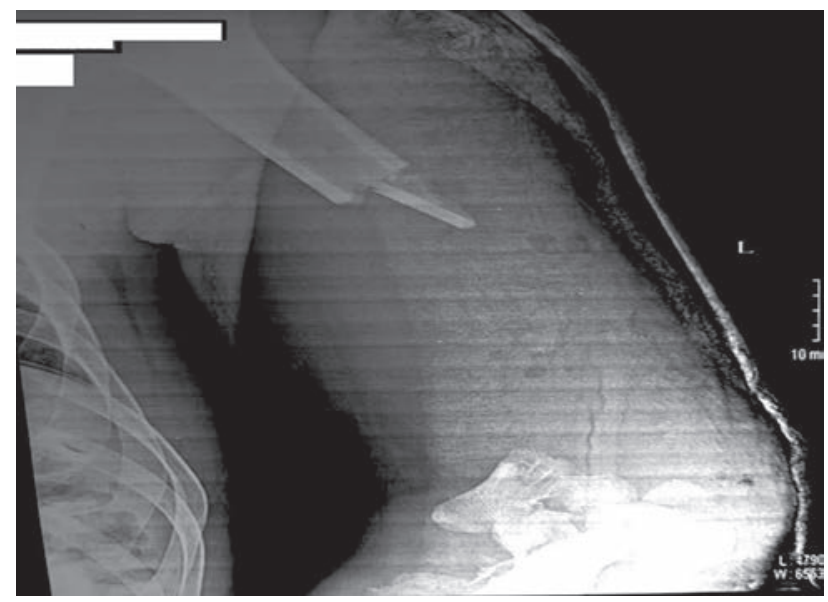

Рис. 1. Рентгенограмма левого плеча пациента С.К., 1994 г.р., при поступлении 10.10.2016 г.

На первом этапе лечения 12.10.2016 г. произведена внеочаговая чрескостная фиксация конечности спице-стержневым аппаратом внешней фиксации с сохранением длины конечности без устранения дефекта (рис. 2). Стержнями и спицами аппарата произведена малоинвазивная закрытая репозиция фрагментов плечевой кости, восстановлена нормальная длина сегмента, ликвидировано искривление по продольной оси.

При появлении признаков инфекционного процесса в ране и после выполнения бактериологических лабораторных исследований проводили антибиотикотерапию, инфекционный процесс купировали. Анализ микробного пейзажа раны показал наличие Staphylococcus aureus. Выполнена антибиотикотерапия, применяли полусинтетические пенициллины (преимущественно оксациллин), общеукрепляющее лечение, проводили ежедневную хирургическую обработку раны мягких тканей. Пациент активизирован после первого этапа операции и находился под наблюдением.

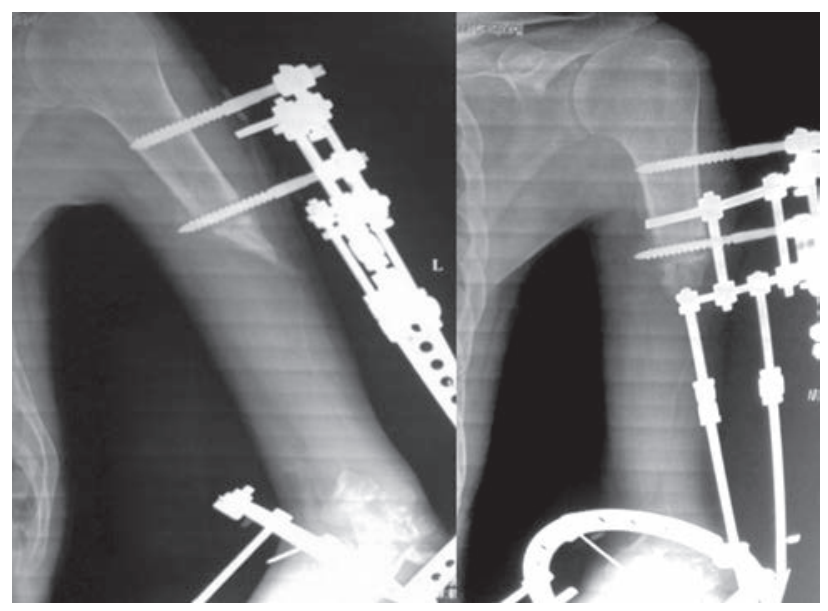

Рис. 2. Рентгенограммы левого плеча пациента С.К., 1994 г.р., после установки спице-стержневого аппарата 12.10.2016 г.

После заживления раны мягких тканей, 14.12.2016 г. провели второй этап операции. Произведен временный демонтаж спице-стержневого аппарата внешней фиксации и замещение костного дефекта плечевой кости аутотрансплантатом из малоберцовой кости длиной 24 см (рис. 3).

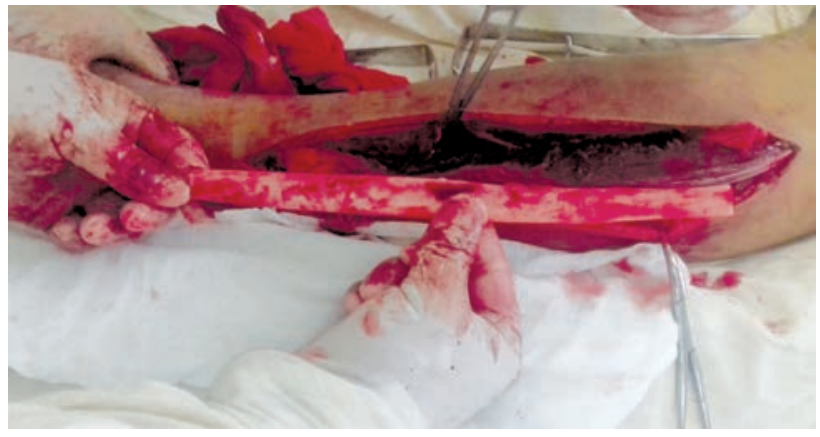

Рис. 3. Забор аутотрансплантата из малоберцовой кости длиной $24 \mathrm{cM}$

Аутокость установлена в зону дефекта плечевой кости через два миниразреза. Через первый миниразрез, выполненный со стороны дистального фрагмента плечевой кости, ввели аутокость и провели тупым путем снизу вверх до проксимального фрагмента. Затем внедрили аутокость на 2 см в костномозговой канал проксимального фрагмента. С целью внедрения и фиксации трансплантата к проксимальному фрагменту был выполнен второй миниразрез, обнажена зона расположения проксимального конца фрагмента.

После внедрения трансплантата в костномозговой канал проксимального фрагмента плечевой кости аутокость была фиксирована тремя гладкими спицами. Для фиксации дистального конца трансплантата к дистальному фрагменту плечевой кости был использован первый миниразрез, концы трансплантата и дистального фрагмента сопоставлены в стык и фиксированы пятью гладкими спицами, проведенными, в том числе, через отломок эпифиза в суставную поверхность, так как имелся дефект суставной поверхности дистального конца плечевой кости.

Осуществили наружную иммобилизацию путём повторного монтажа спице-стержневого аппарата внешней фиксации, скомпонованного из деталей аппарата Илизарова (рис. 4, 5). 

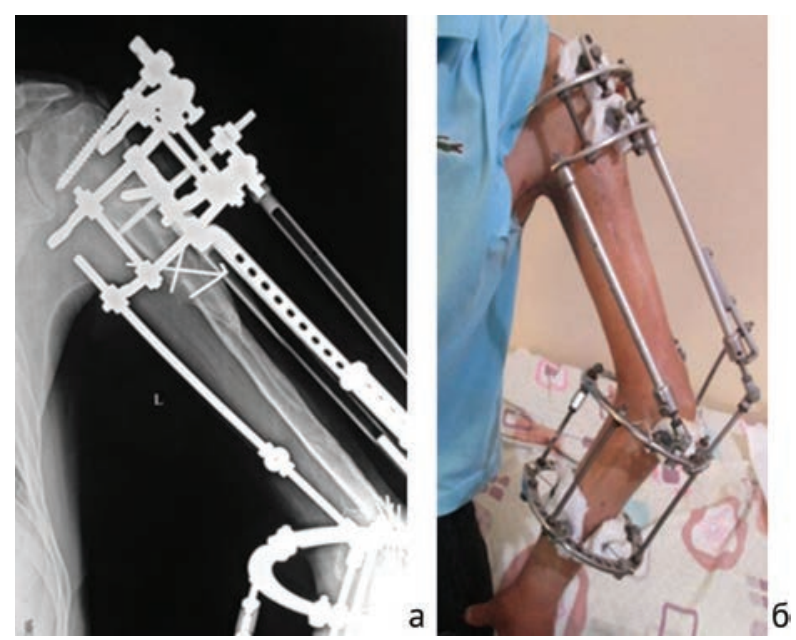

Рис. 4.: а - рентгенограмма плечевой кости после установки трансплантата и фиксации аппаратом; б - внешний вид конечности пациента после второго этапа операции

После сращения трансплантата из аутокости и костных фрагментов плечевой кости 04.04.2017 г. спице-стержневой аппарат был демонтирован, через миниразрезы выполнено удаление спиц, проведенных через зоны соединения аутокости с фрагментами плечевой кости (рис. 5).

На первом этапе, в остром периоде травмы, проведена временная чрескостная внеочаговая фиксация конечности спице-стержневым аппаратом внешней фиксации. На втором этапе проведен забор трансплан-
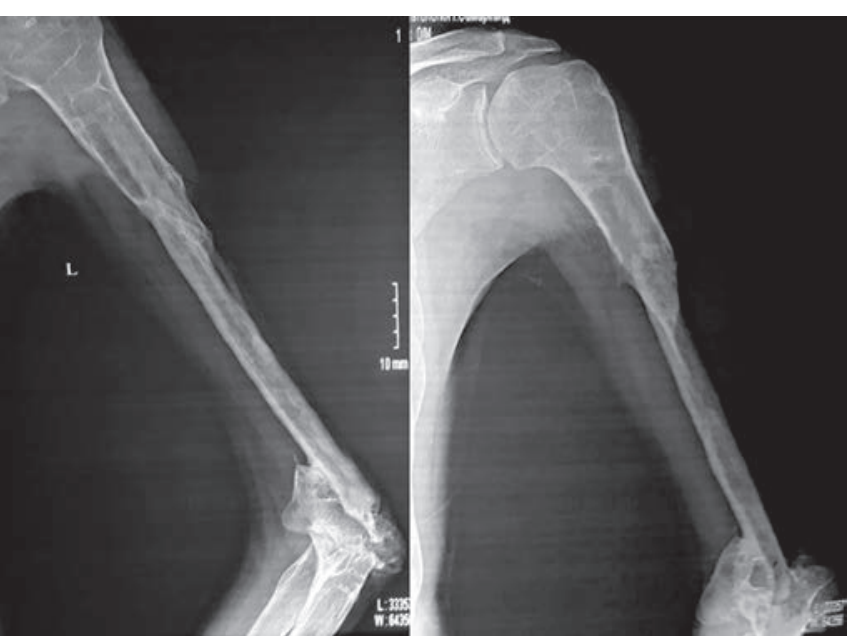

Рис. 5. Рентгенограммы левого плеча пациента после снятия аппарата и удаления спиц

тата из малоберцовой кости длиной 24 см. Выполнен остеосинтез плечевой кости и трансплантата гладкими спицами с замещением костного дефекта. Повторно наложен спице-стержневой аппарат внешней фиксации. Аппарат внешней фиксации эффективен для иммобилизации конечности, в отличие от гипсовой иммобилизации позволяет производить обработку и контролировать заживление ран [15]. После сращения аппарат внешней фиксации демонтирован и удалены внутренние спицы.

\section{РЕЗУЛЬТАТЫ}

Проведенное этапное лечение пациента с переломом плечевой кости позволило получить полное восстановление целостности сегмента. Конечность содержит естественные биологические ткани без присутствия инородных тел (рис. 5). Сформирован единый костный остов плеча, по результатам клинического обследования устойчивый к продольной, ротационной, изгибающей нагрузке. Результат лечения также оценивали по шкале «Оценка хирургии локтя», который через 24 месяца соответствовал удовлетворительной оценке (50-69 баллов) [16]. В плечевом суставе функция полная.

При контрольном осмотре через 4 года (рис. 6) 10.01.2020 г. у пациента определяется фиброзный анкилоз локтевого сустава в функционально выгодном положении. На начальном этапе лечения по месту жительства больному была предложена операция по удалению части конечности, после проведенного нами лечения конечность сохранена, развился фиброзный анкилоз локтевого сустава вследствие того, что в момент травмы была также повреждена суставная поверхность плечевой кости с формированием ее де- фекта. Пациент выполняет левой рукой все функции, работает мотористом и, несмотря на наличие анкилоза, доволен проведенным лечением.

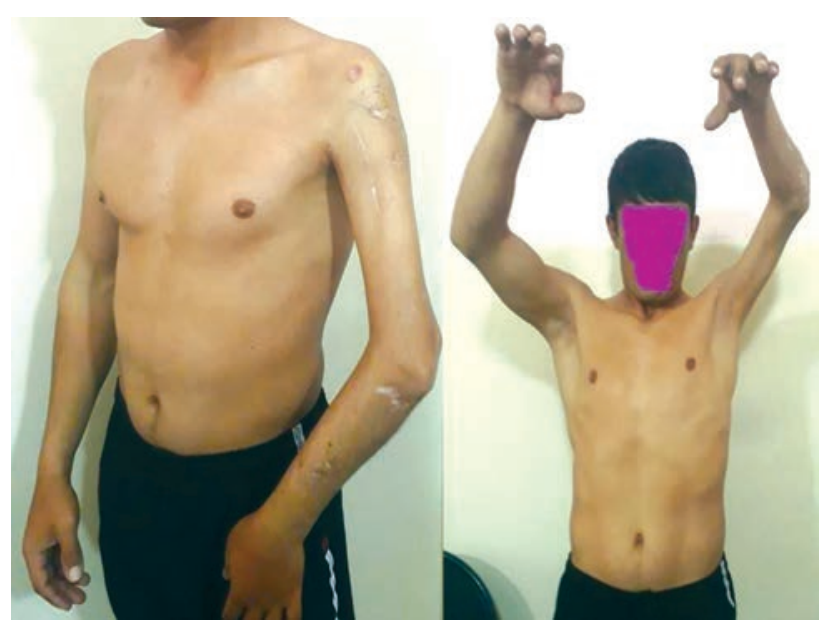

Рис. 6. Внешний вид пациента через 4 года после завершения лечения

\section{ОБСУЖДЕНИЕ}

Методом выбора при открытых переломах плечевой кости является внеочаговый или открытый остеосинтез, в зависимости от характера повреждения. Использование открытого остеосинтеза в раннем периоде травмы при обширных ранах мягких тканей с первичным бактериальным загрязнением, многооскольчатых переломах чревато возникновением осложнений в виде нагноения.

По доступным данным, при современном уровне техники, остеомиелит, как последствие открытых переломов, развивается в 5,3-75,4 \% случаев, как последствие огнестрельных переломов в 34,2-82,3 \% и как 
последствие плановых ортопедических и травматологических операций в 1,5-33,2 \% случаев [17].

По мнению А. Bagherifard, Н. Ghandhari и соавт., использование массивных аваскулярных трансплантатов сопряжено с риском повторного инфицирования, длительной структурной перестройкой, остеолизом [18]. В отличие от литературных данных, у нашего больного не наблюдалось инфекционных осложнений и остеолиза.

Длительность лечения, этапность и субъективный дискомфорт - существенные недостатки замещения дефектов по Илизарову [19]. Однако в случае нашего больного, на первичном этапе лечения больному была предложена ампутация, несмотря на длительное и этапное лечение нам удалось избежать ампутации и сохранить конечность.

Аутокость является остеогенным, остеокондуктивным и остеоиндуктивным пластическим материалом [11], но забор аутокости связан с дополнительной, иногда значительной травмой и кровопотерей и лимитом объема доступного пластического материала. По данным Mattar J.Jr., Azze R.J. и соавт., васкуляризованная костная пластика обеспечивает более высокую биомеханическую прочность, чем неваскуляризованная [20]. В нашем случае мы использовали аутокость длиной 24 см, что является массивным трансплантатом. Несмотря на использование столь массивного трансплантата, мы не наблюдали осложнений в ложе трансплантата и осложнений, связанных с приживлением аутокости.

Подобные травмы ставят перед врачом задачу использования различных способов лечения и их комбинирования для достижения успешного результата. Аппарат внешней фиксации эффективен для иммобилизации конечности, в отличие от гипсовой иммобилизации позволяет производить обработку раны и контролировать заживление ран. На основании изучения отдаленного анатомо-функционального результата можно сделать вывод, что использование малоберцовой кости с целью замещения диафизарно-метафизарного дефекта плечевой кости посттравматической этиологии целесообразно и эффективно. Однако наше сообщение основано на результатах лечения одного больного, и делать обобщающие выводы мы считаем не целесообразным.

\section{ЗАКЛЮЧЕНИЕ}

Комбинирование различных методик и технических средств внешней и внутренней фиксации позволило полностью восстановить поврежденную конечность, избежать осложнений и получить удовлетворительный клинический результат у данного пациента. Описанная костно-замещающая методика широко применяется в российских и зарубежных лечебных учреждениях.

Разнообразие методов лечения затрудняет выбор оптимальных вариантов, позволяющих избежать впоследствии развития осложнений и неудовлетвори- тельных результатов. Наличие наглядных примеров лечения способствует обоснованному выбору того или иного метода, позволяет транслировать успешный опыт.

Исход замещения большого дефекта плечевой кости путем этапного лечения с костной пластикой и использованием аппарата наружной фиксации убеждает в данной ситуации в наличии действенной альтернативы ампутации конечности при обширных дефектах плечевой кости.

\section{СПИСОК ИСТОчНИКОВ}

1. Беленький И.Г., Майоров Б.А., Ли С.Х. Оперативное лечение переломов диафиза плечевой кости. Современный взгляд на проблемы и пути их решения // Фундаментальные исследования. 2014. № 10-9. С. 1849-1857.

2. Нетылько Г.И., Румакин В.П., Конев В.А. Экспериментальное моделирование костного дефекта со склерозированной стенкой // Гений ортопедии. 2014. № 3. С. 72-76.

3. Recurrent ovarian cancer: mechanisms of development of peritoneal malignant ascities / B. Saidkulov, J. Abduraxmonov, M.N. Rahimov, F. Raufov // Eurepean Journal of Molecular \& Clinical Medicine. 2020. Vol. 7, No 2. P. 2423-2428.

4. Mauffrey C., Barlow B.T., Smith W. Management of segmental bone defects // J. Am. Acad. Orthop. Surg. 2015. Vol. 23 , No 3. P. $143-153$. DOI: $10.5435 / J A A O S-D-14-00018$.

5. Keating J.F., Simpson A.H., Robinson C.M. The management of fractures with bone loss // J. Bone Joint Surg. Br. 2005. Vol. 87, No 2. P. 142-150. DOI: 10.1302/0301-620x.87b2.15874.

6. Циркулярная резекция локтевой кости при гигантоклеточной опухоли с одномоментной пластикой васкуляризованным фрагментом малоберцовой кости / Б.Ш. Минасов, Э.М. Бикташева, М.М. Валеев, Р.Р. Якупов, Т.Б. Минасов, Т.Р. Мавлютов // Гений ортопедии. 2019. Т. 2, № 3. C. 388-392.

7. Li W., Zhu S., Hu J. Bone regeneration is promoted by orally administered bovine lactoferrin in a rabbit tibial distraction osteogenesis model // Clin. Orthop. Relat. Res. 2015. Vol. 473, No 7. P. 2383-2393. DOI: 10.1007/s11999-015-4270-5.

8. Шастов А.Л., Кононович Н.А., Горбач Е.Н. Проблема замещения посттравматических дефектов длинных костей в отечественной травматолого-ортопедической практике // Гений ортопедии. 2018. Т. 24, № 2. С. 252-257.

9. Шевцов В.И., Борзунов Д.Ю. Реабилитация пациентов с дефектами и ложными суставами длинных костей, современное состояние проблемы // Гений ортопедии. 2008. № 4. С. 48-54.

10. Лечение огнестрельных дефектов длинных костей нижних конечностей / В.К. Николенко, М.И. Бабич, А.А. Грицюк, Л.К. Брижань, М.И. Лукомский // Вестник травматологии и ортопедии им. Н.Н. Приорова. 2007. № 2. С. 64-70.

11. Finkemeier C.G. Bone-grafting and bone-graft substitues // J. Bone Joint Surg. Am. 2002. Vol. 84, No 3. P. 454-464. DOI: 10.2106/00004623200203000-00020.

12. Operative management of humeral nonunions. Factors that influence the outcome / A. Koutalos, C. Varitimidis, Z. Dialiana, K. Bargiotas, A. Koutsogiannis, K.N. Malizos // Acta. Orthop. Belg. 2015. Vol. 81, No 3. P. 501-510.

13. Free vascularized medial femoral condyle autograft for challenging upper extremity nonunions / D.B. Jones Jr., P.C. Rhee, A.T. Bishop, A.Y. Shin // Hand. Clin. 2012. Vol. 28, No. 4. P. 493-501. DOI: 10.1016/j.hcl.2012.08.005.

14. Kim P.H., Leopold S.S. In brief: Gustilo-Anderson Classification // Clin. Orthop. Relat. Res. 2019. Vol. 477, No 10. P. 2388. DOI: 10.1097/ CORR.0000000000000950.

15. Давиров Ш.М., Уринбоев П.У. Лечение пациента с открытым переломом костей предплечья и обширным дефектом костной ткани (Случай из практики) // Гений Ортопедии. 2021. Т. 27, № 1. С. 87-91. 


\section{Случай из практики}

16. Меркулов В.Н., Дергачев Д.А., Дорохин А.И. Артропластика при лечении посттравматических контрактур и анкилозов локтевого сустава у детей // Детская хирургия. 2014. Т. 18, № 4. С. 34-38.

17. Клюшин Н.М. Метод Илизарова в гнойной остеологии. Курган : [Принт-Экспресс], 2019. С. 7-9.

18. Autograft versus allograft reconstruction of acute tibial plateau fractures: a comparative study of complications and outcome / A. Bagherifard, $\mathrm{H}$. Ghandhari, M. Jabalemeli, M. Rahbar, H. Hadi, M. Moayedfar, M.M. Sajadi, A. Karimpour // Eur. J. Orthop. Surg. Traumatol. 2017. Vol. 27 , No 5. P. 665-671. DOI:10.1007./s00590-016-1863-y.

19. Gaillard J., Bourcheix L.M., Masquelet A.C. Perforators of the fibular artery and suprafascial network // Surg. Radiol. Anat. 2018. Vol. 40 , No 8. P. 927-933. DOI: 10.1007/s00276-017-1927-7.

20. Vascularized fibular graft for management of severe osteomyelitis of the upper extremity / J. Mattar Jr., R.J. Azze, M.C. Ferreria, R. Starck, A.C. Canedo // Microsurgery. 1994. Vol. 15, No 1. P. 22-27. DOI: 10.1002/micr.1920150108.

Статья поступила в редакцию 16.03.2021; одобрена после рецензирования 14.09.2021; принята к публикации 23.12.2021.

The article was submitted 16.03.2021; approved after reviewing 14.09.2021; accepted for publication 23.12.2021.

\section{Информация об авторах:}

1. Шароф Мажидович Давиров - sharofd1976@mail.ru

2. Пайзулла Уринбоевич Уринбоев - доктор медицинских наук, профессор.

\section{Information about the authors:}

1. Sharof M. Davirov - M.D., sharofd1976@mail.ru

2. Payzulla U. Urinboev - Doctor of Medical Sciences, Professor. 
Гений ортопедии. 2022. Т. 28, № 1. С. 97-103.

Genij Ortopedii. 2022. Vol. 28, no. 1. P. 97-103.

Научная статья

удК 617.576-001.46-089.844

https://doi.org/10.18019/1028-4427-2022-28-1-97-103

\title{
Восстановительное хирургическое лечение тяжелой инъекционной травмы кисти высоким давлением
}

\author{
А.М. Аристов ${ }^{2}$, С.Б. Богданов ${ }^{1,2 \varpi}$, С.Н. Куринный², А.В. Каракулев ${ }^{1,2}$, В.А. Аладьина ${ }^{1,2}$ \\ ${ }^{1}$ Кубанский государственный медицинский университет, Краснодар, Россия \\ ${ }^{2}$ Научно-исследовательский институт - Краевая клиническая больница № 1 имени профессора С.В. Очаповского, Краснодар, Россия
}

Автор, ответственный за переписку: Сергей Борисович Богданов, bogdanovsb@mail.ru

\section{Аннотация}

Введение. Инъекционная травма кисти высоким давлением, возникающая в результате попадания в кисть определенного вещества под высоким давлением, происходит, как правило, на производстве. Она встречается редко и представляет серьезную проблему ввиду крайне высокого риска осложнений. Образовавшиеся в результате этапных хирургических обработок дефекты требуют пластического закрытия свободными кожными аутотрансплантатами или несвободными кровоснабжаемыми лоскутами. Кистевая терапия является неотъемлемой частью комплекса восстановительного лечения пострадавших с данной патологией. Цель. Представить на клиническом примере методику комплексного хирургического реконструктивно-пластического лечения тяжелой инъекционной травмы кисти высоким давлением, направленной на сохранение функции поврежденной конечности. Материалы и методы. Анализ способов и результата комплексного реконструктивного хирургического лечения пациента с тяжелой инъекционной травмой кисти высоким давлением, оперированного в ГБУЗ «НИИ-ККБ № 1 им. профессора С.В. Очаповского» в 2018-2019 гг. Результаты. Непосредственным результатом хирургического лечения было полное восстановление кожных покровов при максимально возможном сохранении подлежащих глубоких анатомических структур. Последующие оперативные вмешательства были направлены на восстановление функции кисти. Заключение. Восстановительное лечение пострадавшего с инъекционной травмой кисти высоким давлением включает максимально раннюю первичную хирургическую обработку раны с широкой ревизией, максимально возможным удалением введенного вещества и нежизнеспособных тканей кисти, а также профилактику развития вторичных повреждений и инфекции в ране. Реконструкция кожного покрова осуществляется путем пластики несвободными кровоснабжаемыми лоскутами, свободными полнослойными или расщепленными кожными аутотрансплантатами. Восстановление других поврежденных функционально значимых структур возможно в отдаленном периоде после заживления ран и полного приживления аутотрансплантатов. Кистевая терапия является обязательной частью комплекса функциональной реабилитации поврежденной кисти. Ключевые слова: рана, кисть, барогидротравма, инъекция высоким давлением, лоскут, кожный аутотрансплантат, пластика, кистевая терапия

Для цитирования: Восстановительное хирургическое лечение тяжелой инъекционной травмы кисти высоким давлением / А.М. Аристов, С.Б. Богданов, С.Н. Куринный, А.В. Каракулев, В.А. Аладьина // Гений ортопедии. 2022. T. 28, № 1. С. 97-103. https://doi.org/10.18019/10284427-2022-28-1-97-103

\section{Original article}

\section{Surgical reconstruction for high-pressure injection injuries to the hand}

\section{A.M. Aristov², S.B. Bogdanov ${ }^{1,2 \bowtie}$, S.N. Kurinniy ${ }^{2}$, A.V. Karakulev ${ }^{1,2}$, V.A. Aladina ${ }^{1,2}$}

${ }^{1}$ Kuban State Medical University, Krasnodar, Russian Federation

${ }^{2}$ Research Institute - S.V. Ochapovsky Regional Clinic Hospital No. 1, Krasnodar, Russian Federation

Corresponding author: Sergey B.Bogdanov, bogdanovsb@mail.ru

Abstract

Introduction High-pressure injection injuries to the hand result from injection of substances by high-pressure industrial devices. These are rare lesions with high risk of substantial long-term morbidity. Tissue defects resulting from staged debridement require skin grafting or vascularized island flap coverage. Hand therapy is an important part of the complex rehabilitation of such patients. The objective is to present complex surgical reconstruction of severe high-pressure injection injury of the hand aimed at preserving limb function. Material and methods Methods and results of surgical reconstruction of a patient with severe high-pressure injection injury of the hand treated at the Research Institute - S.V. Ochapovsky Regional Clinic Hospital No.1 in 2018-2019. Results Short-term result of surgical treatment demonstrated complete skin restoration and maximum possible preservation of underlying deep anatomical structures of the hand. Subsequent surgical interventions were aimed at restoring the hand function. Conclusion The restorative treatment of a high-pressure injection injury of the hand includes the earliest possible primary surgical treatment of the wound with wide revision, maximum removal of the injected substance and non-viable tissues and prevention of secondary injuries and infection in the wound. Nonfree vascularized flaps, full-thickness free grafts or split-skin autografts are used for skin reconstruction. Restoration of other functionally significant structures can be considered at a long term with wounds healed and autografts completely implanted. Hand therapy is integral to the comprehensive functional rehabilitation of the high-pressure injection injuries to the hand.

Keywords: wound, hand, high-pressure injection injury, flap, skin autograft, reconstruction, hand therapy

For citation: Aristov A.M., Bogdanov S.B., Kurinniy S.N., Karakulev A.V., Aladina V.A. Surgical reconstruction for high-pressure injection injuries to the hand. Genij Ortopedii, 2022, vol. 28, no 1, pp. 97-103. https://doi.org/10.18019/1028-4427-2022-28-1-97-103

\section{ВВЕДЕНИЕ}

Барогидротравмы кисти известны с 30-х годов XX века. В медицинской литературе впервые повреждение кисти струей дизельного топлива описал С.Е. Rees [1], который сообщил о механике, получившем инъекцию в кисть дизельного топлива под высоким давлением. Несмотря на изначально благоприятно оцененное повреждение с небольшим кровотечением, некроз тканей привел к ампутации травмированного пальца. В 50-е годы прошлого века в связи с внедрением в промышленность различных форсуночных механизмов, распылителей красок и гидроусилителей повреждения кисти струей жидкости под высоким дав-

() Аристов А.М., Богданов С.Б., Куринный С.Н., Каракулев А.В., Аладьина В.А., 2022 
лением стали гораздо чаще привлекать внимание различных специалистов [2]. В зарубежной литературе подобная травма носит название «high pressure injury», «pressure gun injury», «high pressure injection». В Pocсии получил широкое распространение предложенный А.В. Конычевым термин «барогидротравма» [3]. Кисть при этом повреждается более чем в 90 \% случаев.

Несмотря на широкое промышленное распространение устройств, действующих по типу пистолетов под высоким давлением, инъекционные травмы кисти встречаются редко. В среднем это 1/600 травмированных кистей [4]. Крупные центры хирургии кисти сталкиваются за год в среднем с 1-4 инъекционными травмами [5].

В большинстве случаев местом инъекции является кисть. В основном страдает недоминантная рука [6, 7], хотя в исследовании Wieder et al. [8] 13 из 25 инъекций пришлись на доминантную кисть. Более чем в 50 \% случаев травмируется указательный палец. Второе место по частоте поражения занимает большой палец и только 10 \% приходится на ладонь.

Без адекватного лечения частота ампутаций при подобных травмах колеблется от 30 до 48 \% [9].

Часто инъекционная травма высоким давлением выглядит незначительной и вполне благоприятной в плане прогноза. Будущая проблема часто прячется за точечной раной на кисти. Клинический эффект подобного повреждения зависит от нескольких факторов, таких как давление инъекции, химическая токсичность агента, объем вещества и его температура.

Изначально давление играет основную роль. По данным литературы, при травме промышленными инжекторами оно варьирует от 40 до 800 бар. Давление в 7 бар достаточно для пенетрации кожи. При более высоком давлении непосредственный контакт устройства с кожей не требуется для инфильтрации подлежащих тканей. Инъецированная жидкость распространяется по ходу сосудисто-нервных пучков через участки с наименьшим сопротивлением [11]. Это вызывает травматическую диссекцию пальца или кисти, компрессию сосудистонервных пучков и вазоспазм, тканевую ишемию и, как следствие, приводит к тромбозу. Растяжение тканей в результате воздействия непосредственно жидкого агента, а также отек повышает гидростатическое давление, и тканевая перфузия нарушается аналогично компартмент-синдрому. Поэтому наряду с давлением важнейшее значение имеет объем вводимой в ткани жидкости. Ладонь обладает большей способностью к растяжению, чем кончик пальца. Поэтому инъекция равного объема жидкости в оба эти участка приведет к быстрейшему развитию компартмент-синдрома на пальце, чем на ладони $[12,13]$. Внутреннее распространение агента зависит от различной плотности встречаемых тканей и может продолжаться пока не встретит плотную структуру. Таким образом происходит распространение инъецированного вещества по ходу сухожильных влагалищ и сосудисто-нервных пучков.

Второй фактор - это химическое повреждение в результате воздействия инъецированной жидкости на ткани. Некоторые промышленные жидкости обладают выраженными цитолитическими свойствами, приводя к деструкции клеток, некрозу и интенсивному воспали- тельному ответу. Инъекция воды, воздуха или небольших объемов ветеринарных вакцин вызывает легкое повреждение тканей и заканчивается благоприятно даже без хирургического лечения. Краски и растворители являются более агрессивными веществами и обладают большими цитолитическими свойствами, чем вода и различные масла. Поэтому и инъекция обычно заканчивается хуже, чем других жидкостей [14]. Растворители обладают меньшей вязкостью по сравнению с красками, как следствие, более быстро распространяются по тканям. Дальнейшее различие может основываться на типе краски. Краски, имеющие в основе уайт спирит, вызывают тканевое повреждение за счет дезинтеграции клеточных мембран. В то время как масляные краски приводят к более интенсивному воспалительному эффекту. Латексные краски же оказывают меньшее, по сравнению с другими, разрушающее ткани действие.

H. Bekler считает, что одним из решающих факторов в патогенезе травмы является температура инъецированного материала [15].

Следующий фактор, играющий роль в обширном разрушении тканей - это инфекция. Она может возникнуть первично сразу после инъекции, но гораздо чаще развивается вторично. Ишемия и некроз способствуют ее возникновению. Поэтому показано применение антибиотиков широкого спектра действия.

Четвертый и единственный фактор, на который доктор и пациент могут повлиять, это время между получением травмы и началом адекватного лечения. Некоторые авторы считают его наиболее значимым прогностическим фактором $[16,17,18]$. Помимо всего прочего, риск ампутации возрастает с удлинением этого времени. Некоторые источники указывают на лимит в 10 часов, после которого риск ампутации значительно возрастает. Другие авторы не обнаруживают значительной разницы в прогнозе у больных, лечение которых началось в течение 24 часов [13]. Stark et al. [19] пришли к выводу, что у пациентов, которым декомпрессия выполнялась в течение первых 10 часов, исход лечения был лучше. Pinto et al. [20] доказали, что чем дольше время между получением травмы и началом адекватного лечения, тем выше риск ампутации. Они были вынуждены отчленить палец, когда пациент прибыл на лечение спустя 72 часа после травмы.

В ранних работах, посвященных лечению барогидротравм, рекомендовалась выжидательная или консервативная тактика, что в большинстве наблюдений приводило к ампутациям пораженных пальцев [10]. С накоплением опыта стало ясно, что только раннее оперативное удаление внедрившегося материала способно обеспечить удовлетворительный результат [1].

Сразу после травмы или при начале оказания пострадавшему медицинской помощи должна быть собрана информация о природе инъецированного вещества, чтобы исключить общую интоксикацию. При необходимости к лечению подключаются токсикологи, возможно введение специфического антидота. Обязателен контроль показателей жизнедеятельности. Общий системный ответ, кроме всего прочего, может проявиться почечной недостаточностью, аллергической реакцией или гемолизом. Наибольшая опасность интоксикации имеет 
место при инъекционной травме уайт спиритом [12]. Большинство авторов согласны, что только скорая и широкая ревизия под общей анестезией или блокадой плечевого сплетения является адекватным лечением инъекционной травмы высоким давлением [9, 17].

В исследованиях Wong et al. [21] инъекционные травмы разделены на легкие, средние и тяжелые случаи, основываясь на природе жидкости, времени начала адекватного лечения и клинической картине при поступлении. Легкие повреждения могут лечиться консервативно с применением антибиотиков широкого спектра, профилактикой столбняка, и контролем нейро-сосудистого состояния пальцев. Пострадавшие со средне-тяжелой или тяжелой травмой должны подвергнуться немедленной хирургической ревизии с декомпрессией и обширным дебридментом в комбинации с антибиотиками и профилактикой столбняка.

Наиболее рекомендованными считаются препараты третьего поколения цефалоспоринов [22].

Выдавливание жидкости или выполнение только послабляющих разрезов недостаточно для предотвращения дополнительных подкожных разрушений. Если при поступлении больного отмечается нарушение кровообращения и потеря чувствительности в пальце либо всей кисти, то с пациентом обязательно нужно обсудить возможность незамедлительной ампутации [12]. Общепризнано, что кисть является не только функционально, но и косметически важной зоной. Для восстановления целостности кожных покровов используются как полнослойные трансплантаты, так и лоскуты на питающих ножках [23, 24].

Все инъецированные вещества и некротизированные ткани должны быть удалены при обильной ирригации физиологическим раствором. Использование растворителей нежелательно, т.к. они сами по себе оказывают цитолитическое действие и вызывают дополнительное повреждение тканей. Операция выполняется под жгутом (турникет) без экссангвинации руки бинтом Эсмарха, чтобы не произвести дополнительного распространения инъецированного агента по ходу сухожильных влагалищ и сосудисто-нервных пучков [25]. Широкие разрезы и дебридмент обычно рекомендуются для максимального удаления всех не- кротизированных тканей и чужеродных субстанций. Также желательно рентгенологическое и клиническое наблюдение, чтобы точно определить, когда последующая хирургическая обработка будет необходима. Полезным дополнением для максимального удаления инородных тел и лучшего прогноза лечения является терапия раны отрицательным давлением [26, 27]. Пациенты должны быть информированы относительно сохраняющегося риска ампутации и поздних осложнений при тяжелом типе повреждения. Этапные хирургические обработки, ампутации, а также реконструкции с использованием лоскутов являются необходимыми для спасения конечности [21]. Часто возникает необходимость в нескольких дебридментах или некрэктомиях, а затем реконструкциях с использованием кожных аутотрансплантатов, островковых или же свободных лоскутов [20, 21]. Иногда более предпочтительно открытое ведение раны [20].

После операции больной должен носить ладонный сплинт. Очень важно немедленно начать физиотерапию, чтобы как можно раньше восстановить функцию кисти. В первые 3 недели пострадавшему проводится активная и пассивная мобилизация пальцев. Через 3 недели начинается интенсивная кистевая терапия и реабилитация на срок от 6 до 12 недель [4].

Позднее лечение может закончиться необратимым повреждением тканей, остающимся на всю жизнь нарушением функции кисти и даже ампутацией. Реже олеогранулемы, фиброгистиолитические опухоли, сквамозноклеточная карцинома описываются как поздние осложнения [28, 29, 30].

Таким образом, при изучении литературы мы столкнулись с достаточно редкой встречаемостью инъекционной травмы кисти высоким давлением, значительным числом возможных осложнений, а также отсутствием описания тех кровоснабжаемых лоскутов, которые применимы при лечении данной патологии.

Цель исследования. Представить на клиническом примере методику комплексного хирургического реконструктивно-пластического лечения тяжелой инъекционной травмы кисти высоким давлением, направленной на сохранение функции поврежденной конечности.

\section{МАТЕРИАЛЫ И МЕТОДЫ}

Представлен клинический случай хирургического лечения пострадавшего с инъекционной травмой кисти высоким давлением в ГБУЗ «НИИ-ККБ № 1 им. профессора С.В. Очаповского». Исследование выполнено в соответствии с Хельсинкской декларацией Всемирной медицинской ассоциации «Этические принципы прове- дения научных медицинских исследований с участием человека» с поправками 2000 г. и «Правилами клинической практики в Российской Федерации», утвержденными Приказом Минздрава РФ от 19.06.2003 г. № 266. Пациент дал добровольное информированное согласие на публикацию клинического случая в открытой печати.

\section{РЕЗУЛЬТАТЫ}

Пациент Л., 28 лет, получил травму левой кисти во время работы на станке, впрыскивающем раскаленный до $200{ }^{\circ} \mathrm{C}$ пластик в плавильную форму. Бригадой скорой медицинской помощи пострадавший был доставлен в травматологическое отделение городской больницы, где в экстренном порядке произведена первичная хирургическая обработка, включающая в себя широкое раскрытие раны, удаление застывшего пла- стика, иссечение явно нежизнеспособных тканей. На третьи сутки после травмы больной был переведен в НИИ - Краевая клиническая больница № 1 для специализированного лечения (рис. 1-2).

На следующие сутки (4-е после получения травмы) больному была выполнена этапная хирургическая обработка, включающая радикальную некрэктомию (рис. 3). Были иссечены некротизированные сухожи- 


\section{Случай из практики}

лия разгибателей и сгибателей 3, 4 пальцев, а также межкостные и червеобразные мышцы. Раневые дефекты кисти были одномоментно закрыты несвободными кровоснабжаемыми лоскутами: на тыльную поверхность был перемещен задний лоскут предплечья, не компрометирующий магистральные сосуды конечности (рис. 4 и 5), что, в свою очередь, позволило закрыть дефект ладонной поверхности кисти несвободным «лучевым» лоскутом (рис. 6 и 8).

Донорские дефекты предплечья были закрыты свободными полнослойным кожными аутотрансплантатами толщиной 1 мм, срезанными ротаторным электродерматомом с наружной поверхности левого плеча. На полученный раневой дефект была выполнена пластика расщеплённым аутотрансплантатом толщиной 0,25 мм с индексом перфорации 1:4. На область пластики уложено биологическое раневое покрытие Хитопран для сокращения сроков заживления (рис. 7-9).

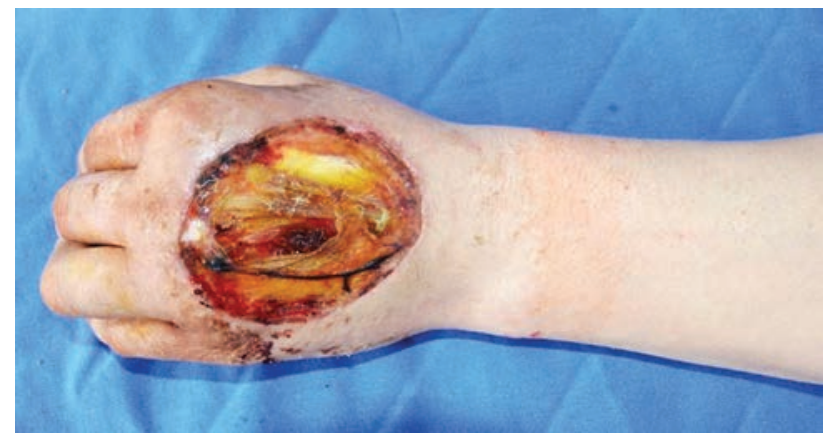

Рис. 1. Вид тыльной поверхности кисти больного при поступлении в клинику

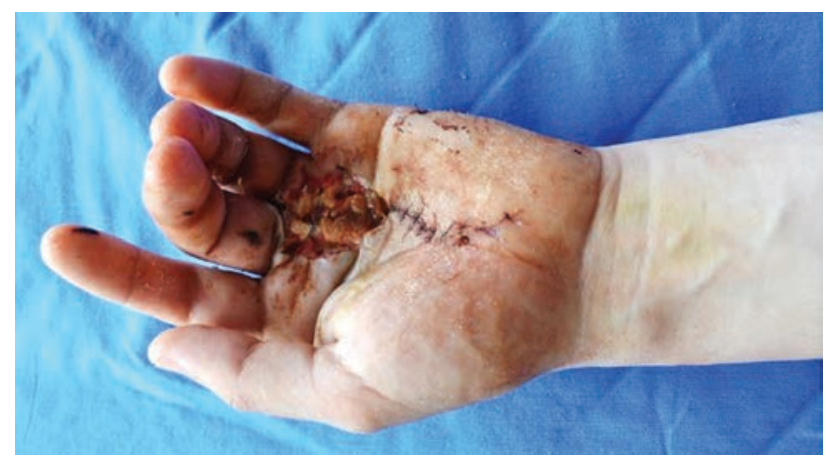

Рис. 2. Вид ладонной поверхности больного при поступлении в клинику

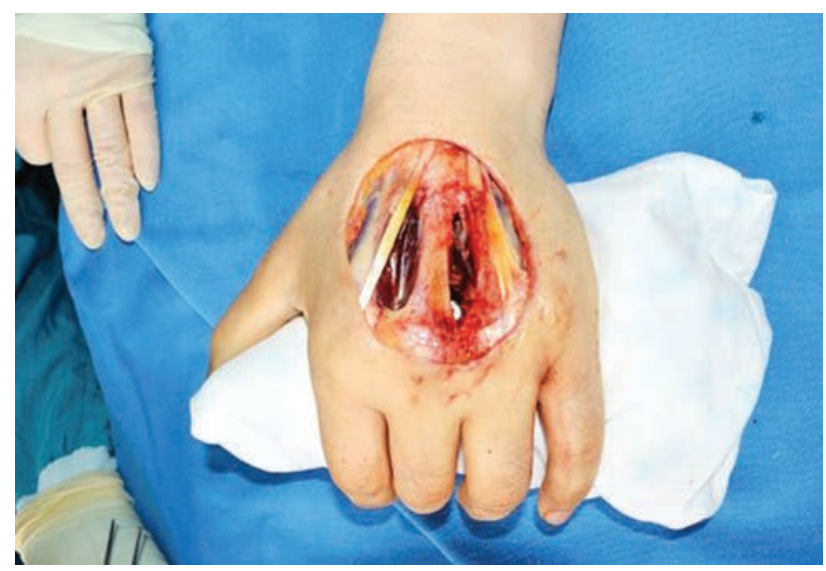

Рис. 3. Вид кисти после некрэктомии

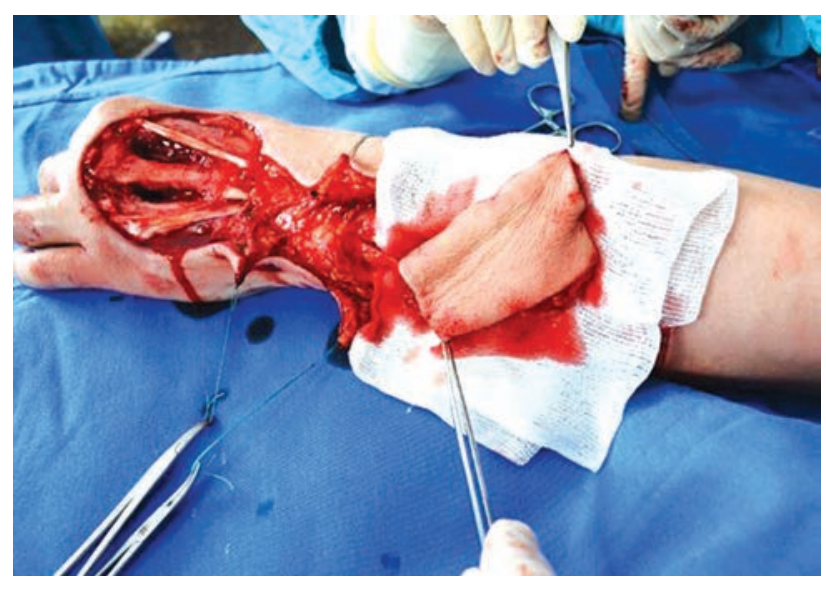

Рис. 4. На задней поверхности предплечья поднят кровоснабжаемый кожно-фасциальный лоскут

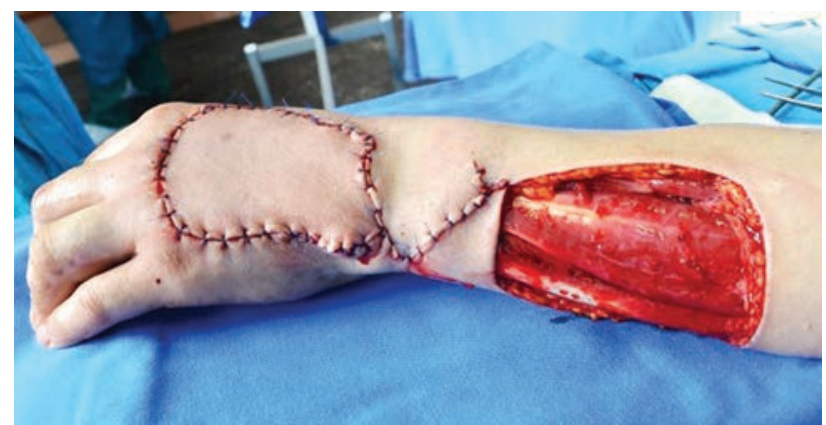

Рис. 5. Дефект тыльной поверхности кисти закрыт кровоснабжаемым лоскутом предплечья

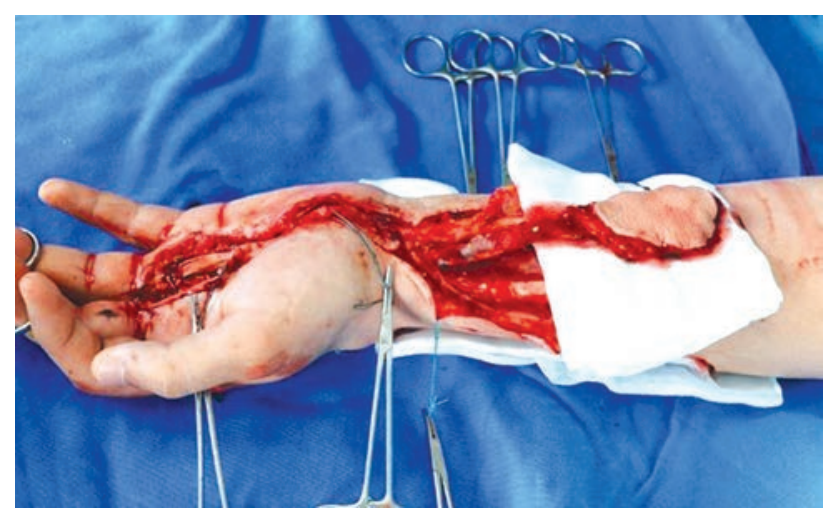

Рис. 6. На лучевом сосудистом пучке предплечья сформирован кровоснабжаемый кожно-фасциальный лоскут

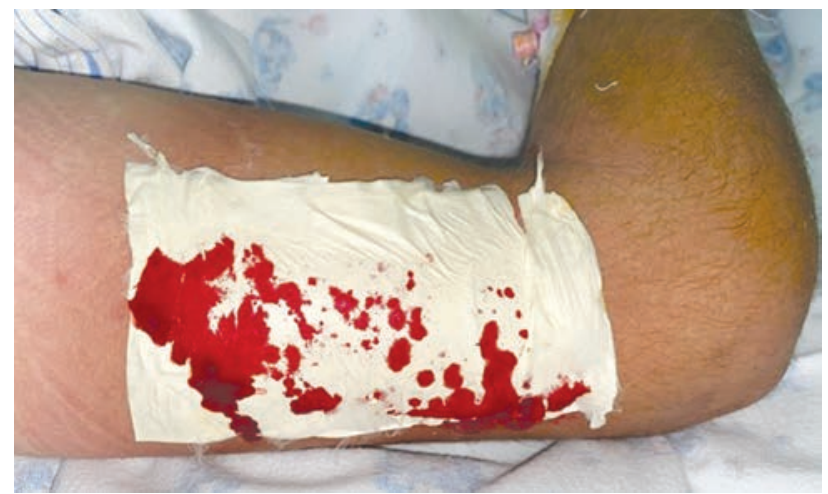

Рис. 7. Донорская рана после взятия аутотрансплантата укрыта биологическим раневым покрытием Хитопран 


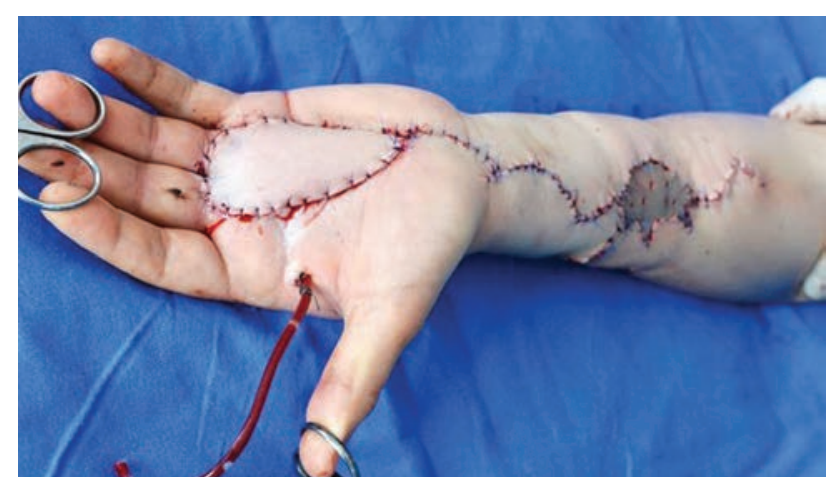

Рис. 8. Пластика дефекта ладонной поверхности кисти несвободным кровоснабжаемым «лучевым» лоскутом

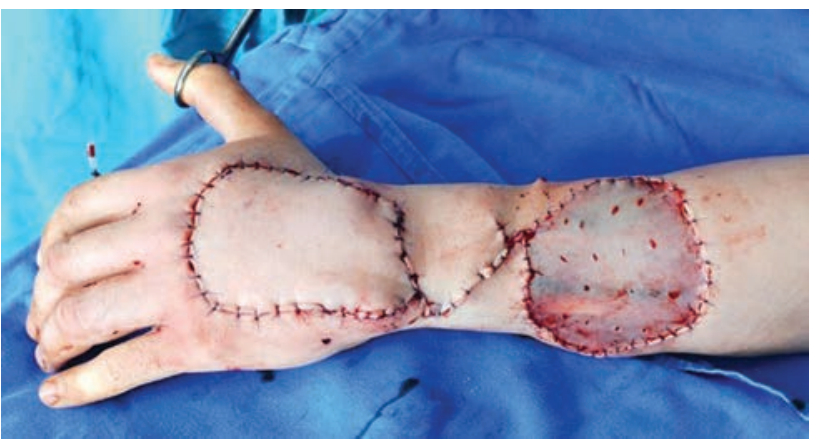

Рис. 9. Донорский дефект предплечья закрыт полнослойным кожным аутотрансплантатом

После операции конечность была иммобилизирована гипсовой лонгетой на 3 недели. Начиная с седьмых суток после операции проводили курс кистевой терапии под наблюдением специалиста, направленной на сохранение полного объема пассивных и активных движений в пальцах поврежденной кисти. Кистевая терапия проводилась на протяжении всего последующего восстановительного лечения пострадавшего, которое включало в себя пластику сухожилий разгибателей 3, 4 пальцев свободными некровоснабжаемыми аутотрансплантатами из сухожилий длинных разгибателей 4, 5 пальцев левой стопы. А также двухэтапную пластику сухожилий глубоких сгибателей 3, 4 паль- цев, состоящую последовательно из имплантации силиконовых эндопротезов и их последующей замены на свободные некровоснабжаемые аутотрансплантаты сухожилий длинных разгибателей 4,5 пальцев правой стопы. Каждое вмешательство дополнялось обязательным этапным обезжириванием прижившегося лучевого лоскута. Продолжающаяся кистевая реабилитация позволила максимально восстановить функцию кисти (рис. 10. и 11), и больной вернулся к прежнему труду.

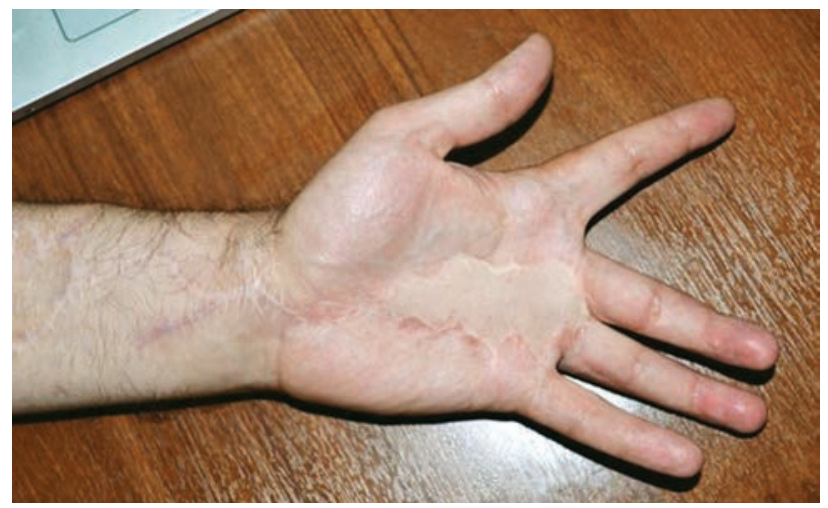

Рис. 10. Вид кисти больного через 1 год после травмы (разгибание пальцев)

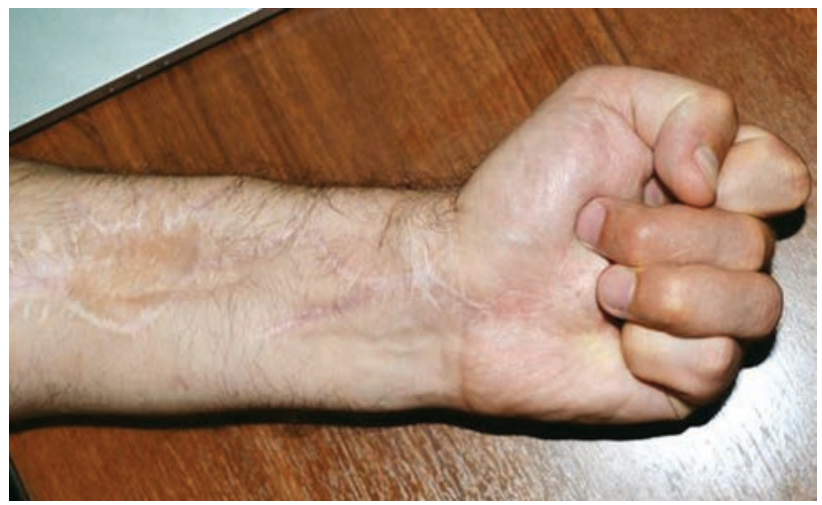

Рис. 11. Вид кисти больного через 1 год после травмы (сгибание пальцев)

\section{ДИСКУССИЯ}

Крайне редко встречающаяся в повседневной практике инъекционная травма кисти высоким давлением при несвоевременной и нерадикальной хирургической помощи может привести к тяжелым последствиям вплоть до потери пальца или всей кисти. Необходимым условием лечения является широкая ревизия раны с раскрытием всех затеков инъецированного вещества, декомпрессия сосудисто-нервных пучков. Для более полного предоперационного планирования мы используем методы визуализации, такие как компьютерная томография при поступлении больного, а в более поздние сроки - МРТ-исследование конечности. Обязательно обильное промывание раны физиологическим раствором для удаления токсических продуктов, тканевого отделяемого [27].

В доступной литературе мы не нашли четких указаний на предпочтительность использования расщеплен- ных кожных аутотрансплантатов или кровоснабжаемых лоскутов. Поэтому придерживаемся общепринятой в пластической хирургии концепции [31]: при отсутствии воспаления в ране и обнажении таких структур как нервы, сосуды, сухожилия, желательно использование кровоснабжаемых лоскутов. Причем приоритет должен принадлежать тем из них, которые не компрометируют магистральные сосуды, как, например, примененный нами тыльный лоскут предплечья. Его использование позволило поднять островковый лучевой кожно-фасциальный лоскут предплечья для реконструкции ладонной поверхности кисти без декомпенсации кровообращения в ней. Причем лоскут на лучевом сосудистом пучке нам кажется предпочтительным для восстановительной хирургии в условиях травматологического или ожогового отделения, т.к. его применение не требует специального микрохирургиче- 
ского оснащения операционной и глубокой микрохирургической подготовки оператора. Расщепленные или же полнослойные некровоснабжаемые кожные аутотрансплантаты с успехом используются для закрытия поверхностных дефектов, гранулирующих ран. В ряде случаев тонкий расщепленный кожный аутотрансплантат может быть уложен на рану функционально значимой зоны, когда сохраняется риск развития инфекционных осложнений в ней. В такой ситуации поздняя реконструкция рубцовой деформации с пластикой кровоснабжаемым лоскутом является более безопасной. Реконструкция других утраченных структур, как, например, сухожилий сгибателей и разгибателей пальцев кисти, выполняется следующими этапами после восстановления адекватного мягкотканного покрова. И может сопровождаться операциями по обезжириванию лоскута.

Также важным компонентом восстановительного лечения пострадавших с инъекционной травмой кости высоким давлением является кистевая терапия и реабилитация. В течение первых 5-7 дней кисть пациента должна быть иммобилизована сплинтом, например, гипсовой лонгетой. Затем при уменьшении отека и явлений воспаления начинается программа реабилитации, проводимая специалистом, направленная на профилактику формирования контрактур и восстановления объема пассивных и, при возможности, активных движений в пальцах кисти и кистевом суставе.

\section{ЗАКЛЮЧЕНИЕ}

Инъекционная травма кисти высоким давлением является тяжелым повреждением, требующим экстренного хирургического лечения и комплексного подхода. Оно должно включать в себя широкую ревизию раны с раскрытием всех затеков инъецированного вещества, декомпрессию сосудисто-нервных пучков, максимально возможное удаление инородных тел и явно нежизнеспособных тканей, обильное промывание раны физиологическим раствором. Рана не ушивается, ведется открыто или с использованием терапии отрицательным давлением. Пациент должен быть информирован о возможности первичной или отсроченной ампутации. Обязательно наблюдение врача анестезиолога-реаниматолога на предмет возможности резорбтивного токсического эффекта инъецированного вещества. Последующие этапные хирургические обработки направлены на удаление оставшихся затеков инъецированного вещества, нежизнеспособных тканей, профилактику развития инфекции в ране и подготовку ее к пластическому закрытию. Восстановление кожного покрова осуществляется, когда риск развития инфекции в ране минимален: она очищена от некротизированных и нежизнеспособных тканей, нет воспалительных явлений в ней. Для пластики глубоких дефектов с обнажением сосудов, нервов и сухожилий, а также таких функционально важных зон как ладонная поверхность, область суставов пальцев, предпочтительно использование не- свободных кровоснабжаемых лоскутов. В остальных случаях применяются свободные некровоснабжаемые полнослойные или же расщепленные кожные аутотрансплантаты. Реконструкция других утраченных функционально значимых структур таких как, например, сухожилия пальцев, осуществляется только после восстановления полноценного мягкотканного покрова кисти. Также важным компонентом лечения пострадавших с инъекционной травмой высоким давлением является кистевая терапия и реабилитация, направленная на профилактику развития контрактур суставов кисти, на восстановление объема пассивных и активных движений в них, на профилактику развития рубцовых сращений скользящих структур с окружающими тканями, а также на восстановление трудоспособности кисти как интегрального понятия. Все это обусловливает необходимость лечения такой категории пострадавших в региональном центре травматологии и ортопедии, где возможно участие различных медицинских специалистов: кистевые хирурги, травматологи, пластические хирурги, токсикологи, реаниматологи, гнойно-септические хирурги, реабилитологи и кистевые терапевты.

Пациент в нашем примере, получивший тяжелую инъекционную травму высоким давлением, в результате своевременного и комплексного хирургического лечения смог вернуться к обычной трудовой деятельности без значительных функциональных потерь.

\section{СПИСОК ИСТОЧНИКОВ}

1. Rees C.E. Penetration of tissue by fuel oil under high pressure from diesel engine // JAMA. 1937. Vol. 109, No 11. P. 866-867. DOI: 10.1001/ jama.1937.92780370004012c.

2. Осипенкова Т.К., Розанов В.В., Матвейчук И.В. Гидродинамическая травма. Характерные особенности и возможности идентификации // Избранные вопросы судебно-медицинской экспертизы и патологической анатомии : сб. статей. Хабаровск, 2012. С. 134-136.

3. Конычев А.В. Гнойно-воспалительные заболевания верхней конечности. СПб.: Невский диалект, 2002.352 с.

4. Verhoeven N., Hierne R. High-pressure injection injury of the hand: an often underestimated trauma: case report with study of the literature // Strategies Trauma. Limb Reconstr. 2008. Vol. 3, No 1. P. 27-33. DOI: 10.1007/s11751-008-0029-9.

5. Neal N.C., Burke F.D. High-pressure injection injuries // Injury. 1991. Vol. 22, No 6. P. 467-470. DOI: 10.1016/0020-1383(91)90131-w.

6. High-pressure water injection injuries of the hand may not be trivial / B. Bean, S. Cook, B.J. Loeffler, R.G. Gaston // Orthopedics. 2018. Vol. 41, No 2. P. 245-251. DOI: 10.3928/01477447-20180123-04.

7. High-pressure injection injuries to the hand / D. Vasilevski, M. Noorbergen, M. Depierreux, M. Lafontaine // Am. J. Emerg. Med. 2000. Vol 18, No 7. P. 820-824. DOI: 10.1053/ajem.2000.18051.

8. Long term follow-up of high-pressure injection injuries to the hand / A. Wieder, O. Lapid, Y. Plakht, A. Sagi // Plast. Reconstr. Surg. 2006. Vol. 117, No 1. P. 186-189. DOI: 10.1097/01.prs.0000185668.67855.63.

9. Hogan C.J., Ruland R.T. High-pressure injection injuries to the upper extremity: a review of the literature // J. Orthop. Trauma. 2006. Vol. 20 , No 7. P. 503-511. DOI: 10.1097/00005131-200608000-00010.

10. Матвеев Р.П., Петрушин А.Л. Повреждения кисти жидкостями высокого давления (барогидротравмы) : обзор литературы // Травматология и ортопедия России. 2009. № 3. С. 85-92.

11. Valentino M., Rapisarda V., Fenga C. Hand injuries due to high-pressure injection devices for painting in shipyards: circumstances, management, and outcome in twelve patients // Am. J. Ind. Med. 2003. Vol. 43, No 5. P. 539-542. DOI: 10.1002/ajim.10218. 
12. A 10-year review of high-pressure injection injuries to the hand / H.G. Lewis, P. Clarke, B. Kneafsey, M.D. Brennen // J. Hand Surg. Br. 1998. Vol. 23, No 4. P. 479-481. DOI: 10.1016/s0266-7681(98)80126-5.

13. Traumatisme de la main par injection sous pression: spécificité lésionnelle de l’huile industrielle / L. Obert, D. Lepage, D. Jeunet, P. Gérard, P. Garbuio, Y. Tropet // Chir. Main. 2002. Vol. 21, No 6. P. 343-349. DOI: 10.1016/s1297-3203(02)00137-3.

14. Functional outcome of high-pressure injection injuries of the hand / L. Christodoulou, E.Y. Melikyan, S. Woodbridge, F.D. Burke // J. Trauma. 2001. Vol. 50, No 4. P. 717-720. DOI: 10.1097/00005373-200104000-00020.

15. The surgical treatment and outcomes of high-pressure injection injuries of the hand / H. Bekler, A. Gokce, T. Beyzadeoglu, F. Parmaksizoglu // J. Hand Surg. Eur. Vol. 2007. Vol. 32, No 4. P. 394-399. DOI: 10.1016/J.JHSB.2007.02.003.

16. Fialkov J.A., Freiberg A. High pressure injection injuries: an overview // J. Emerg. Med. 1991. Vol. 9, No 5. P. 367-371. DOI: 10.1016/07364679(91)90381-o.

17. Gonzalez R., Kasdan M.L. High pressure injection injuries of the hand // Clin. Occup. Environ. Med. 2006. Vol. 5, No 2. P. 407-411. DOI: 10.1016/j. coem.2005.11.007.

18. Schnall S.B., Mirzayan R. High-pressure injection injuries to the hand // Hand Clin. 1999. Vol. 15, No 2. P. 245-248, VIII.

19. Stark H.H., Ashworth C.R., Boyes J.H. Paint-gun injuries of the hand // J. Bone Joint Surg. Am. 1967. Vol. 49, No 4. P. $637-647$.

20. High-pressure injection injuries of the hand: review of 25 patients managed by open wound technique / M.R. Pinto, L.D. Turkula-Pinto, W. Cooney, M.B. Wood, J. Dobyns // J. Hand Surg. Am. 1993. Vol. 18, No 1. P. 125-130. DOI: 10.1016/0363-5023(93)90256-3.

21. Wong T.C., Ip F.K., Wu W.C. High-pressure injection injuries of the hand in a Chinese population // J. Hand Surg. Br. 2005. Vol. 30, No 6. P. 588592. DOI: $10.1016 /$ j.jhsb.2005.07.009.

22. Amsdell S.L., Hammert W.C. High-pressure injection injuries in the hand: current treatment concepts // Plast. Reconstr. Surg. 2013. Vol. 132 , No 4. P. 586e-591e. DOI: 10.1097/PRS.0b013e31829f4bb4.

23. Способ пластики кожных покровов конечностей после ранней некрэктомии : пат. 2248757 Рос. Федерация МПК А 61В 17/00 / Богданов С.Б., Куриный Н.А. ; заявитель и патентообладатель Богданов С.Б., Куриный Н.А. № 2003115315/14 ; заявл. 22.05.2003 ; опубл. 27.03.2005.

24. Богданов С.Б. Виды кожных аутопластик. Атлас. Краснодар : Клуб Печати, 2018. 200 с.

25. Mizani M., Weber B. High-pressure injection injury of the hand. The potential for disastrous results // Postgrad. Med. J. 2000. Vol. 108, No 1. P. 183190. DOI: $10.3810 /$ pgm.2000.07.1161.

26. A useful option to obtain maximal foreign body removal and better prognosis in high pressure injection injuries: Negative pressure wound therapy with instillation / G. Temiz, H. Şirinoğlu, E. Güvercin, N. Yesiloğlu, M. Bozkurt, C. Eser, K. Başak // J. Plast. Reconstr. Aesthet. Surg. 2016. Vol. 69, No 4. P. 570-572. DOI: 10.1016/j.bjps.2015.11.021.

27. High pressure injection injury of the foot: a role of negative pressure wound therapy / M. Marinovic, B. Bakota, J. Spanjol, I. Sosa, N. Grzalja, G. Gulan, A. Ivancic, T. Cicvaric // Injury. 2013. Vol. 44, No Suppl. 3. P. S7-10. DOI: 10.1016/S0020-1383(13)70189-X.

28. Hayes C.W., Pan H.C. High-pressure injection injuries to the hand // South Med. J. 1982. Vol. 75, No 12. P. 1491-1498, 1516. DOI: 10.1097/00007611198212000-00012.

29. Mauzo S.H., Swaby M.G., Covinsky M.H. Tumefactive foreign body giant cell reaction following high-pressure paint injection injury: a case report and review of literature // J. Cutan. Pathol. 2017. Vol. 44, No 5. P. 474-476. DOI: 10.1111/cup.12905.

30. Saadat P., Turla S., Vadmal M. Fibrohistiocytic tumor of the hand after high-pressure paintgun injury: 2 case reports // J. Hand Surg. Am. 2005. Vol. 30, No 2. P. 404-408. DOI: 10.1016/j.jhsa.2004.08.011.

31. Пластика полнослойными кожными аутотрансплантатами ран различной этиологии / С.Б. Богданов, Р.Г. Бабичев, Д.Н. Марченко, А.В. Поляков, Ю.В. Иващенко // Инновационная медицина Кубани. 2016. № 1. С. 30-37.

Статья поступила в редакцию 14.09.2021; одобрена после рецензирования 17.11.2021; принята к публикации 23.12.2021.

The article was submitted 14.09.2021; approved after reviewing 17.11.2021; accepted for publication 23.12.2021.

Информация об авторах:

1. Андрей Михайлович Аристов - кандидат медицинских наук, ozhogovycentr@mail.ru;

2. Сергей Борисович Богданов - доктор медицинских наук, професcop, bogdanovsb@mail.ru;

3. Сергей Николаевич Куринный;

4. Антон Владимирович Каракулев - karakulev797@gmail.com;

5. Валерия Андреевна Аладьина - lerka@mail.ru.

\section{Information about the authors:}

1. Andrey M. Aristov - Candidate of Medical Sciences, ozhogovycentr@mail.ru;

2. Sergey B. Bogdanov - Doctor of Medical Sciences, Professor, bogdanovsb@mail.ru;

3. Sergey N. Kurinniy;

4. Anton V. Karakulev - karakulev797@gmail.com;

5. Valeriya A. Aladina - lerka@mail.ru. 
Гений ортопедии. 2022. Т. 28, № 1. С. 104-110.

Genij Ortopedii. 2022. Vol. 28, no. 1. P. 104-110.

Научная статья

УДК 617.578-001.19-089.844

https://doi.org/10.18019/1028-4427-2022-28-1-104-110

\section{Пересадка культи трехфалангового пальца противоположной кисти на микрососудистых анастомозах у больных с последствиями отморожений кистей и стоп (случаи из практики)}

\section{Николай Михайлович Александров ${ }^{\bowtie}$, Иван Денисович Вешаев, Дмитрий Алексеевич Купцов}

Приволжский исследовательский медицинский университет, Нижний Новгород, Россия

Автор, ответственный за переписку: Николай Михайлович Александров, aleksandrov-chetai@rambler.ru

\section{Аннотация}

Цель. Изучить возможности реконструкции пальцев кисти методом пересадки культей пальцев противоположной кисти на микрососудистых анастомозах у больных с последствиями отморожений. Материалы и методы. Анализ историй болезни и отдаленных результатов лечения двух больных с культями пальцев обеих кистей после перенесенного отморожения. Выполнена реконструкция трехфалангового и первого пальца кисти путем пересадки на микрососудистых и микроневральных анастомозах культи пальца противоположной кисти вместе с пястно-фаланговым суставом. Культи мобилизованы и пересажены на дистальном отделе локтевой артерии, венозный отток осуществлен по тыльной подкожной вене кисти. Отдаленные результаты изучены через 10 лет и 2,5 года после операции. В работе использованы клинические, рентгенологические, биомеханические и биофизические методы исследования. Результаты. Восстановлена функция двухстороннего схвата реципиентных культей кисти без функционального ущерба донорским культям. Дискриминационная чувствительность на восстановленных пальцах составляет 6 мм и 8 мм, объем активных движений в пересаженном суставе соответствует 55 и 66 градусам. Обсуждение. Пересадка культи пальца противоположной кисти на микрососудистых анастомозах имеет существенные преимущества перед классическим вариантом операции. Метод позволяет за один этап восстановить палец достаточной длины, функции, имеющий адекватное кровоснабжение и иннервацию за счет возможности пересадки короткой культи пальца кисти с пястно-фаланговым суставом. Преимуществом по сравнению с пересадкой пальца стопы является использование идентичных по функциональным свойствам и анатомическому строению структур кисти, что снижает потребность выполнения вторичных вмешательств на них. Заключение. Данный метод лечения может быть успешно применен по показаниям у больных с культями кистей после отморожения.

Ключевые слова: пересадка культи пальца кисти, реконструкция пальца кисти, последствия отморожения, микрососудистые анастомозы

Для цитирования: Александров Н.М., Вешаев И.Д., Купцов Д.А. Пересадка культи трехфалангового пальца противоположной кисти на микрососудистых анастомозах у больных с последствиями отморожений кистей и стоп (случаи из практики) // Гений ортопедии. 2022. Т. 28, № 1. C. 104-110. https://doi.org/10.18019/1028-4427-2022-28-1-104-110

Original article

\section{Opposable triphalangeal digital stump transplanted with microvascular anastomoses in patients with frostbitten hands and feet (case report) \\ Nikolai M. Aleksandrov ${ }^{\square}$, Ivan D. Veshaev, Dmitry A. Kuptsov}

Privolzhsky Research Medical University, Nizhny Novgorod, Russian Federation

Corresponding author: Nikolai Mikhailovich Aleksandrov, aleksandrov-chetai@rambler.ru

Abstract

The objective was to explore possibilities with reconstruction of opposable digital stump of the hand transplanted with microvascular anastomoses in frostbite patients. Material and methods Medical histories and long-term results of treatment of two frostbite patients with finger stumps of both hands were reviewed. The triphalangeal finger and the thumb were reconstructed by transplanting the opposable finger stump together with the metacarpophalangeal joint using microvascular and microneural anastomoses. The stumps were mobilized and transplanted to the distal ulnar artery with the venous drainage performed using the dorsal saphenous vein of the hand. Long-term results were examined at 10 years and 2.5 years of surgery. Clinical, radiological, biomechanical and biophysical investigations were produced. Results The bilateral gripping function was restored in recipient stumps without functional damage to the donor stumps. Discriminatory sensitivity of reconstructed fingers was $6 \mathrm{~mm}$ and $8 \mathrm{~mm}$, the range of active motion in the transplanted joint was 55 and 66 degrees. Discussion Opposable digital stump transplantation with microvascular anastomoses has significant advantages over the classical surgery. The technique allows for one-stage restoration of a finger to have sufficient length, function, adequate blood supply and innervation due to a short digital stump being transplanted with the metacarpophalangeal joint. The advantage over a toe transplant consists of the use of digital structures of the hand that are identical in functionality and the anatomy reducing the need for secondary interventions. Conclusion The method of management can be successfully applied for frostbite patients with hand stumps according to indications.

Keywords: finger stump transplant, finger reconstruction, frostbite, microvascular anastomosis

For citation: Aleksandrov N.M., Veshaev I.D., Kuptsov D.A. Opposable triphalangeal digital stump transplanted with microvascular anastomoses in patients with frostbitten hands and feet (case report). Genij Ortopedii, 2022, vol. 28, no 1, pp. 104-110. https://doi.org/10.18019/1028-44272022-28-1-104-110

\section{ВВЕДЕНИЕ}

На современном этапе развития хирургии одним из основных методов реконструкции пальцев кисти служит пересадка на микрососудистых анастомозах пальца стопы или его частей, которая применяется преимущественно при врожденной патологии и последствиях механической травмы [1-6]. Однако при последствиях холодовой травмы отношение хирургов к данным вме- шательствам более сдержанное, что связано с высоким риском тромбирования анастомозов и гибели трансплантата из-за закономерно развивающегося холодового эндартериита верхних и нижних конечностей [7]. Кроме того, часто у больных, перенесших отморожение, имеются также культи пальцев нижних конечностей и стоп, что значительно ограничивает потенциал метода. 
По этой причине актуальным является изучение возможностей использования донорских ресурсов противоположной кисти. По сравнению с пересадкой пальца стопы или его сегментов, пересадка комплексов тканей противоположной кисти для реконструкции пальцев применяется в единичных случаях при механических и, особенно, холодовых [8] повреждениях. Пересадка пальца полной длины противоположной кисти при отморожениях может быть выполнена редко, так как обычно имеются культи пальцев обеих кистей, в связи с чем может быть пересажена одна из культей пальца. Однако в настоящее время практически не изучены воз- можности метода, а также технические и тактические подходы к данным вмешательствам в зависимости от функционального состояния сосудов, характера дефекта и уровня культей пальцев и кисти. В литературе имеется описание единичных случаев применения метода для пересадки пальца при нехолодовых повреждениях без детализации техники операции [9-11].

Цель исследования - изучить возможности реконструкции пальцев кисти методом пересадки культей пальцев противоположной кисти на микрососудистых анастомозах у больных с последствиями отморожений кистей и стоп.

\section{МАТЕРИАЛЫ И МЕТОДЫ}

При проведении исследования были соблюдены все этические стандарты Хельсинской декларации (1975) Всемирной медицинской ассоциации с соответствующими поправками (2008). В работе использованы клинические, рентгенологические, биомеханические и биофизические методы исследования. Пересадка культи пальца противоположной кисти выполнена у двух пациентов мужского пола с культями обеих кистей после перенесенного отморожения.

Приводим клинические примеры реконструкции трехфалангового и первого пальца путем пересадки комплекса тканей противоположной кисти на микрососудистых анастомозах. Больной К., 31 год, находился в клинике по поводу культей трехфаланговых пальцев левой кисти на уровне головок, культи четвертого пальца на уровне дистальной трети основной фаланги, пятого пальца на уровне средней трети основной фаланги правой кисти, культей первых пальцев обеих стоп на уровне головок основных фаланг после отморожения, полученного два года назад (рис. 1, а, б, в). При поступлении определяются культи 2, 3, 4, 5 пястных костей левой кисти на уровне головок, которые покрыты спаянными с костью рубцами. Торцы культей 4, 5 пальцев правой кисти имеют адекватный кожный покров, дискриминационная чувствительность их составляет 4-5 мм, движения в пястно-фаланговых суставах не нарушены. Боковой схват левой кисти резко ограничен, щипковый схват отсутствует. Больному была предложена пересадка на микрососудистых анастомозах блока 2, 3 пальцев стопы в позицию 3, 4 пальцев левой кисти. От предложенного вмешательства пациент отказался, в связи с чем ему была предложена пересадка культи 4 пальца правой кисти в позицию 3 пальца левой. Выбор более длинной донорской культи был обусловлен тем, что в случае пересадки культи пятого пальца с пястно-фаланговым суставом неизбежно бы нарушилась функция мышц гипотенара, участвующих в щипковом схате и противопоставлении первого пальца остальным. Кроме того, при этом ухудшился бы также внешний вид кисти, вследствие нарушения контура лучевого карая кисти. Проведена проба Аллена, которая показала замкнутость ладонных артериальных дуг. Осуществлен волнообразной формы разрез кожи на ладонной поверхности правого предплечья с переходом на ладонь, где в проекции 4 пястной кости сформирован П-образный кожно-жировой лоскут с треугольной вершиной и с дистальным основанием. Мобилизована локтевая артерия вместе с поверхностной ладонной дугой с отходящими от нее общепальцевыми артериями третьего и четвертого межпястных промежутков. Ладонная дуга перевязана на уровне третьей пястной кости. Далее были перевязаны ладонные пальцевые артерии, отходящие к культе 5 пальца и третьему пальцу. Общепальцевые нервы в области третьего и четвертого межпястных промежутков были расщеплены до уровня проксимальной трети ладони. Для этого на ладонной поверхности общепальцевого нерва рассечен эпиневрий по ходу волокон от места деления до проксимальной трети пястных костей. Далее нервные пучки, образующие собственные пальцевые нервы, тупо отделены друг от друга от уровня деления в проксимальном направлении в пределах выполненной эпиневротомии. При этом сохраняется иннервация как донорской культи, так и соседних с ней пальцев и культей. Таким образом, в состав культи 4-го пальца были включены две общие и собственные ладонные пальцевые артерии, нервы и сухожилия сгибателей, прикрытые кожно-жировым лоскутом. На тыльной поверхности кисти также был выполнен идентичный разрез с формированием аналогичного П-образного кожно-жирового лоскута в проекции 3-ей пястной кости. Мобилизована наиболее крупная тыльная подкожная вена с образованием единого коллектора до уровня нижней трети предплечья с сохранением тыльных подкожных вен культи 4-го пальца. Выполнена поперечная остеотомия 4-ой пястной кости на уровне средней трети, отсечены тыльная и ладонная межкостные мышцы, пересечены межпястные связки. Культя пальца вместе с пястно-фаланговым суставом мобилизована на локтевой артерии и тыльной подкожной вене, сухожилиях сгибателей и разгибателей 4-го пальца, пальцевых нервах. На левой кисти обнажен торец культи 3-ей пястной кости, иссечены на нем рубцы, рана продлена на ладонь и нижнюю треть предплечья, где выделены пальцевые нервы, лучевая артерия и головная вена. Пересечены питающие сосуды на уровне нижней трети предплечья, а нервы и сухожилия сгибателей и разгибателей культи 4-го пальца - на уровне проксимальной 
трети кисти, выполнена пересадка культи 4-го пальца правой кисти вместе с фрагментом пястной кости в позицию третьего пальца левой кисти. Осуществлен остеосинтез фрагмента пястной кости, трансплантата и культи 3-ей пястной кости методом внедрения после обработки их концов цилиндрическими фрезами с дополнительной фиксацией спицей Киршнера (рис. 1, г). Выполнен шов пальцевых нервов материалом 9/0. Микрососудистые анастомозы были наложены конецв-конец между артерией трансплантата и лучевой артерией, а также мобилизованной тыльной подкожной веной кисти с головной веной шовным материалом 9/0 с использованием операционного микроскопа «Opton». Выполнен шов сухожилий сгибателей и разгибателей культи 4-го пальца с сухожилиями 3-го пальца на уровне средней трети пястных костей. Дефекты на боковых поверхностях пересаженного фрагмента 4-ой пястной кости были оставлены открытыми в расчете на отсроченное закрытие их кожными трансплантатами. Донорская рана ушита первично на ладонной и тыльной поверхности кисти и предплечье после сближения 3-ей и 5-ой пястных костей. В послеоперационном периоде проводилась инфузионная и антикоагулянтная терапия в течение 7 дней. Послеоперационное течение было гладким, кровоснабжение пересаженной культи оставалось адекватным. Пересаженный комплекс тканей и кожные трансплантаты прижились полностью. Раны в донорской и реципиентной областях зажили первичным натяжением. Признаков сосудистой недостаточности сохранившихся пальцев и их культей на донорской и реципиентной кистях не отмечалось (рис. 1, д, е, ж, з).
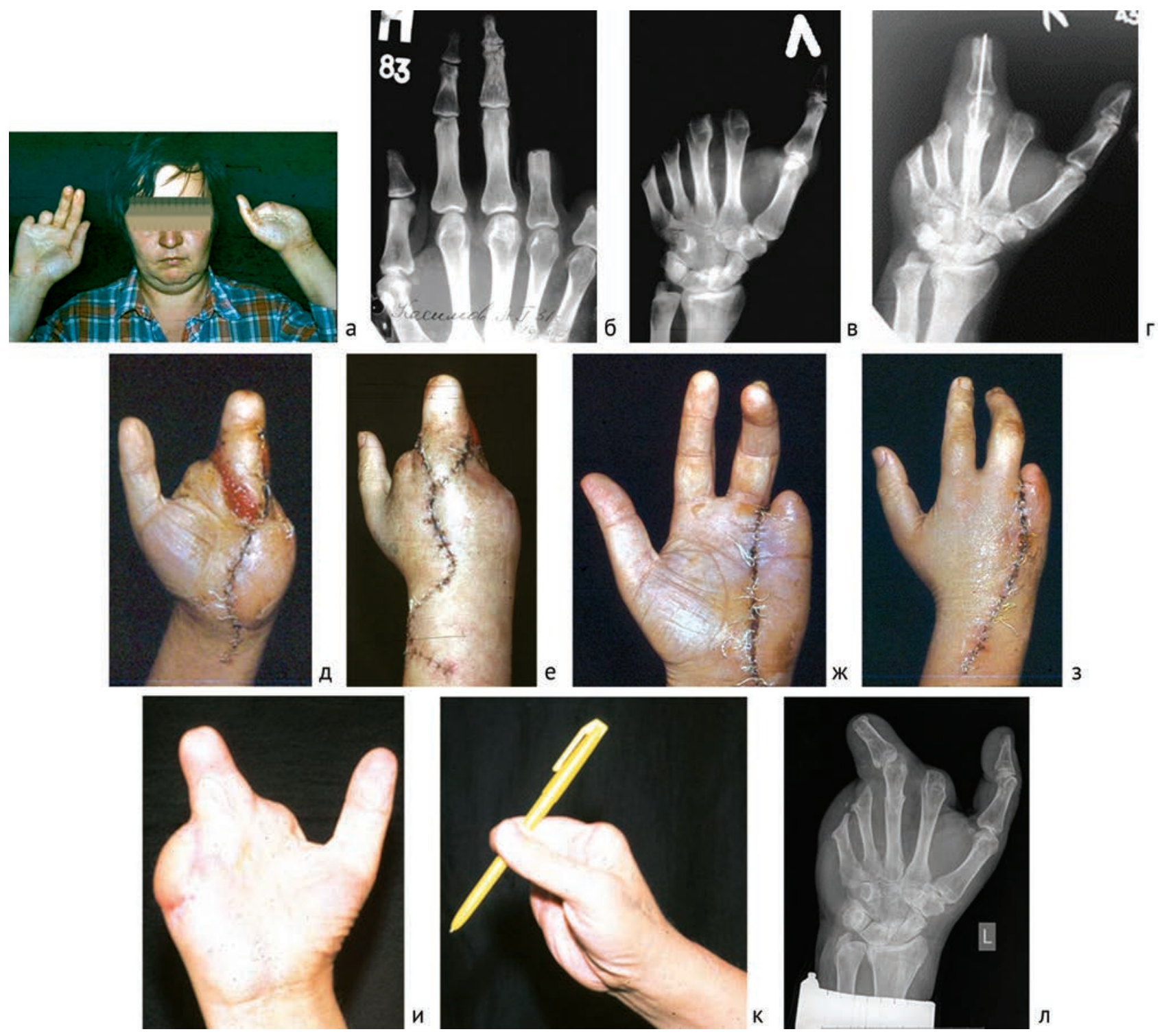

Рис. 1. Результат лечения больного К.,31 года, с культями пальцев обеих кистей: а - внешний вид кистей до операции; б - рентгенограмма донорской (правой) кисти до операции; в - рентгенограмма реципиентной (левой) кисти до операции; г -рентгенограммы кистей через две недели после операции; д - внешний вид левой кисти через две недели после пересадки культи пальца (ладонная поверхность); е - внешний вид левой кисти через две недели после пересадки культи пальца (тыльная поверхность); ж - внешний вид донорской кисти через две недели после операции (ладонная поверхность); 3 - внешний вид донорской кисти через две недели после операции (тыльная поверхность); и - внешний вид кисти и функция разгибания культи четвертого пальца правой кисти, пересаженной на культю третьей пястной кости левой кисти; к - функция щипкового схвата левой кисти; л - рентгенограмма левой кисти в отдаленные сроки после операции 
Больной К., 37 лет, поступил в клинику по поводу культей обеих кистей и первого пальца правой стопы после перенесенного отморожения. С момента травмы прошло около 2-х лет. На правой кисти имелись культи первой и второй пястных костей на уровне дистальной трети, культи третьей, четвертой, пятой пястных костей на уровне проксимальной трети (рис. 2, а). Движения культи первой пястной кости сохранены, схват кисти отсутствует из-за отсутствия локтевого края ладони. На левой кисти определялись культи второго пальца на уровне основания средней фаланги, культя третьего пальца на уровне средней трети основной фаланги, четвертого пальца на уровне дистальной трети, пятого пальца - средней трети пястной кости. Движения культей в пястно-фаланговых суставах сохранены. На торцах культей 2, 3 ,4, 5 пястных правой костей имеется грубый, малоподвижный рубец, плотно спаянный с культями и болезненный при пальпации. Аналогичные рубцы имелись на культях 4-ой и 5-ой пястных костей левой кисти. Предварительно пациенту была выполнена реконструкция локтевого края правой кисти. Первым этапом были иссечены рубцы на торцах культей 2, 3, 4, 5 пястных костей с замещением образовавшегося дефекта тканей несвободным кожно-жировым паховым лоскутом. При этом также сформированы мяг- кие ткани локтевого края кисти путем складывания кожно-жирового лоскута в дупликатуру (рис. 2, б). Паховый лоскут прижился полностью, донорская и реципиентные раны зажили первичным натяжением.

При поступлении через 2 месяца на следующий этап лечения на торцах культей 2, 3, 4, 5 пястных костей имеются адекватные, эластичные кожные покровы, а также избыточный, подвижный лоскут в области локтевого края культи, сформированный путем его складывания вдвое. На этом этапе выполнена реконструкция костной основы локтевого края кисти путем пересадки фрагмента второй плюсневой кости левой стопы с сигнальным кожно-жировым лоскутом на микрососудистых анастомозах в сочетании с интерпозиционной пластикой бессосудистым кортикально-губчатым трансплантатом, взятым из крыла подвздошной кости, на культю 4-ой пястной кости. При этом были разделены листки дупликатуры из кожно-жирового лоскута. Трансплантаты были расположены между листками дупликатуры. Кровоснабжение трансплантата восстановлено путем анастомозирования артерии питающей ножки, представленной тыльной артерией стопы, с локтевой артерией, а также медиальной подкожной вены стопы, включенной в трансплантат, с тыльной подкожной веной предплечья.
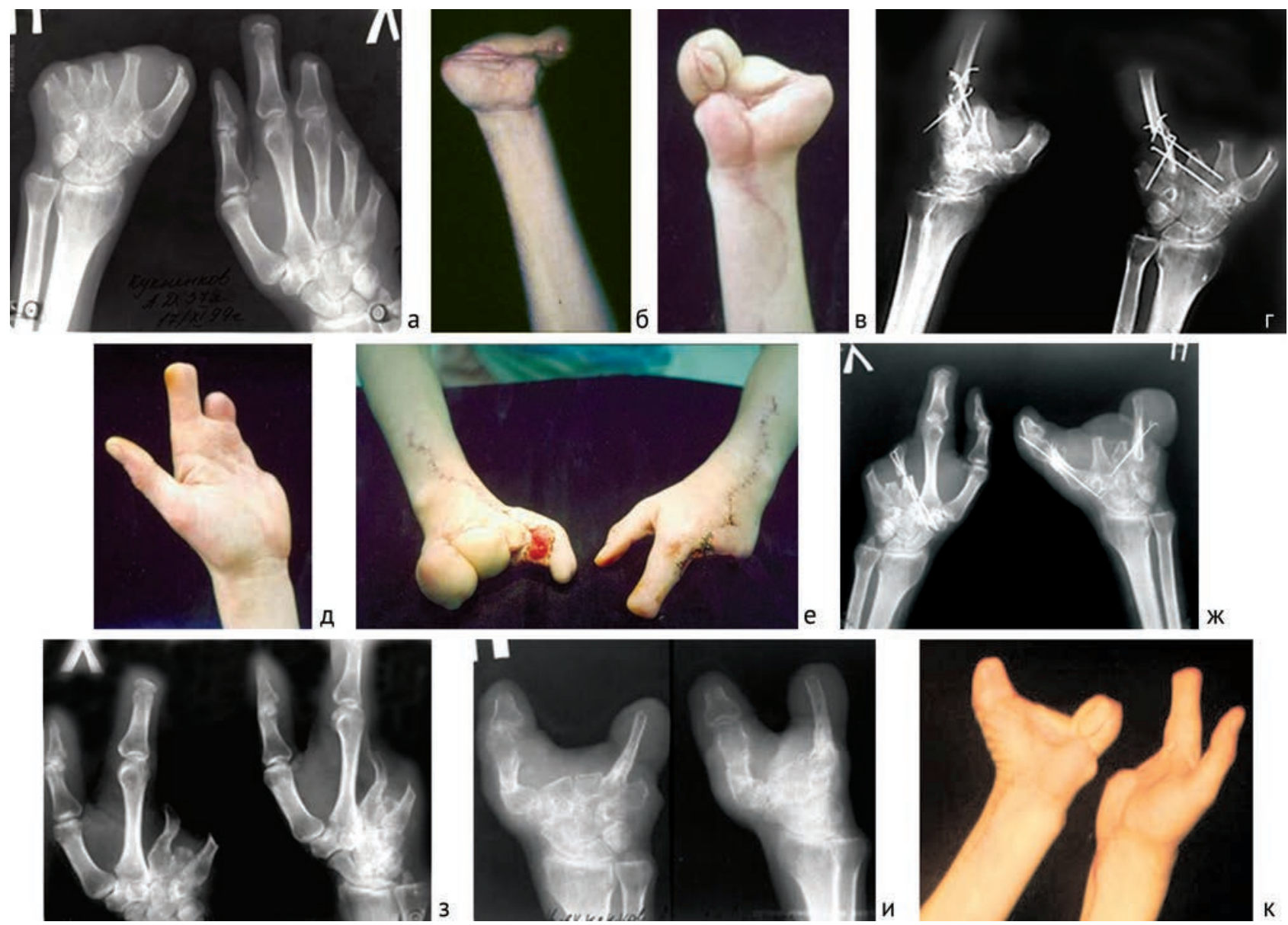

Рис. 2. Результат лечения больного К., 37 лет, с культями пальцев обеих кистей: а - рентгенограммы обеих кистей до операции; б внешний вид правой кисти после замещения рубцов и формирования мягких тканей локтевого края кисти паховым кожно-жировым лоскутом; в - внешний вид правой кисти после формирования костной основы, виден сигнальный лоскут кровоснабжаемого кожнокостного фрагмента; г - рентгенограммы правой кисти после формирования костной основы локтевого края кисти; д - внешний вид донорской кисти; е - внешний вид донорской и реципиентной культей кисти через две недели после пересадки культи 3-го пальца; ж - рентгенограммы кистей через две недели после пересадки культи пальца на правой кисти и транспозиции культи четвертой пястной кости на левой кисти; 3 - рентгенограммы левой кисти через 2,5 года после операции; и - рентгенограммы правой кисти через 2,5 года после операции; к - внешний вид обеих кистей через 2,5 года после операции 
Остеосинтез выполнен методом внедрения концов костных фрагментов после обработки цилиндрическими фрезами с дополнительной фиксацией спицами. Костные трансплантаты были укрыты сформированными на предыдущем этапе мягкими тканями, сигнальный лоскут размещен на ладонной поверхности сформированной локтевой противоупорной бранши (рис. 2, в, г). Его кровоснабжение оставалось адекватным, что свидетельствует о сохранении кровоснабжения пересаженного фрагмента второй плюсневой кости. Кожные лоскуты и костные трансплантаты прижились полностью. Через год выполнена реконструкция первого пальца правой кисти. При поступлении определяется сформированная локтевая противоупорная бранша длиной 8 см, укрытая достаточным количеством мягких тканей. В связи с наличием культи первого пальца левой стопы и пострезекционного дефекта второй плюсневой кости от пересадки комплексов тканей стопы было решено воздержаться с целью исключения нанесения дополнительного изъяна другой стопе. Было принято решение восстановить первый палец правой кисти за счет пересадки одной из культей пальца противоположной ки- сти. Проведенная проба Аллена показала замкнутость ладонных артериальных дуг. Для минимизации донорского изъяна кисти выполнена пересадка наиболее короткой из имеющихся культи 3-го пальца (рис. 2, д, е). Техника мобилизации, пересадки культи и восстановления кровотока в ней были такими же, как и в первом случае. Остеосинтез пястного фрагмента пересаженной культи с культей первой пястной кости осуществлен методом внедрения после обработки цилиндрическими фрезами с фиксацией спицей (рис. 2, ж). Рана на медиальной поверхности пересаженной культи оставлена открытой в расчете на отсроченное закрытие ее кожными трансплантатами. Для сближения краев донорской раны и обеспечения возможности ее первичного ушивания выполнена транспозиция культи 4-ой пястной кости в позицию третьей пястной кости с фиксацией фрагментов пястных костей спицей (рис. 2, ж). Пересаженная культя и расщепленные кожные трансплантаты прижились полностью. Кровоснабжение сохранившихся пальцев и культей донорской и реципиентной кистей также оставалось адекватным. Донорские и реципиентные раны зажили первичным натяжением.

\section{РЕЗУЛЬАТЫ}

Первый больной осмотрен через 10 лет после операции (рис. 1, ж, 3, и). Восстановлены функция противопоставления первого к культе третьего пальца, а также бокового схвата левой кисти, болевая и температурная чувствительность сформированного третьего пальца. Дискриминационная чувствительность пересаженной культи составляет 8 мм. Объем активных движений в пястно-фаланговом суставе пальца равен 66 градусов. Расстояние между дистальным отделом пересаженной культи и первого пальца при его отведении составляет 11 см. Рентгенологически признаков резорбции дистальных отделов культи не наблюдается. Суставная щель пересаженного сустава отчетливо прослеживается, контуры суставных концов отчетливые, имеют обычную структуру. Функция культи пятого пальца, а также второго, третьего пальцев донорской кисти не нарушена. По мнению больного, косметический вид донорской кисти после операции не изменился. Пациент активно вовлекает в повседневную работу обе кисти.

Второй больной осмотрен через 2,5 года после операции (рис. 2, 3, и, к). Длина восстановленного пальца с пястной костью составила 9 см, а сформированной локтевой противоупорной бранши - 8см, что соответствует послеоперационным данным. Первый палец занимает функционально-выгодное положение. Объем активных движений в пересаженном пястно-фаланговом суставе культи составляет 55 градусов. Восстановлен двухсторонний схват кисти. Расстояние между концами локтевой противоупорной бранши и восстановленного первого пальца при его максимальном отведении составляет 10 см. Определяется болевая и температурная чувствительность первого пальца. Донорский изъян на левой стопе незначительный, беспокойства больному не причиняет. На контрольных рентгенограммах правой кисти отмечаются полная консолидация пересаженного вместе с культей пальца фрагмента третьей пястной кости, завершенная консолидация и перестройка пересаженного бессосудистого трансплантата и фрагмента второй плюсневой кости. Пястно-фаланговый сустав первого пальца имеет обычную структуру, суставная щель отчетливая, контуры суставных концов четкие. Признаков резорбции пересаженной культи не имеется. Каких-либо ограничений функции донорской кисти не выявлено, пациент активно использует обе кисти в повседневной деятельности. Ухудшения внешнего вида донорской кисти пациент не отмечает. На рентгенограммах донорской кисти определяется полная консолидация перемещенной на проксимальный отдел третьей пястной кости культи четвертой пястной кости (рис. 2, 3, и).

\section{ОБСУЖДЕНИЕ}

Для пересадки пальца противоположной кисти может быть использована как классическая техника, так и прецизионная. Пересадка пальца противоположной кисти в классическом варианте заключается в использовании временной стебельчатой питающей ножки, содержащей пальцевые сосудисто-нервные пучки, и описана в монографии Б.В. Парина [12]. Преимуществом этого способа является возможность применения его вне зависимости от явлений эндартериита, повреждения пальцевых сосудов и отсутствие вероят- ности тромбирования сосудов. Наша клиника обладает опытом пересадки пальца противоположной кисти на временной питающей ножке у 3-х больных с последствиями механической травмы. При этом на первом этапе осуществляется остеосинтез пересаживаемого сегмента с культей восстанавливаемого пальца, донорская и реципиентная кисти фиксируются друг к другу на 4 недели до образования сосудистых связей реципиентного ложа с донорским пальцем и наступления его периферической реваскуляризации. Необходимая 
длина питающей ножки достигается за счет резекции основной фаланги донорского пальца, в связи с чем метод не применяется для пересадки пястной кости с пястно-фаланговым суставом или без него, так как в этом случае не достигаются необходимая длина пересаживаемого сегмента кисти и адекватная длина восстанавливаемого пальца. По этой причине способ применяется для реконструкции первого пальца при его культе на дистальных уровнях, обладающей подвижностью за счет функции мышц тенара. При пересечении на втором этапе питающей ножки от донорской кисти неизбежно нарушается целостность сосудистонервных пучков, вследствие чего восстановленный палец лишается чувствительности и магистрального кровообращения. Кроме того, отмечаются нарушение венозного оттока и ограничение движений в межфаланговых суставах, несмотря на восстановление сухожилий сгибателей и разгибателей. По этой причине Б.В. Парин рекомендовал пересаживать дефектный палец только для реконструкции первого пальца при сохранении чувствительности остальных трехфаланговых и никогда не пересаживал интактный палец. Таким образом, недостатками классических методов являются двухэтапность, длительное вынужденное положение конечностей, резкое ограничение движений в суставах, отсутствие чувствительности восстановленного пальца, возможность пересадки только ногтевой и средней фаланг сохранившегося трехфалангового пальца. По нашему мнению, метод может быть использован только в исключительных случаях при повреждении пальцевых сосудов и при использовании предварительной дистракции стебельчатой ножки с помощью чрескостного аппарата, обеспечивающей возможность переноса сегмента необходимой длины. Как показывают результаты пересадки культи пальца на микрососудистых анастомозах, применение микрохирургической техники позволяет за один этап восстановить пальцы достаточной длины с адекватным кровообращением и иннервацией, что совпадает с результатами пересадки при последствиях механической травмы [10]. Достаточное кровоснабжение тканей пересаженной культи обеспечивает также адекватную функцию суставов и сухожильного аппарата. В итоге достигаются полный объем движений в суставе пересаженной культи и возможность восстановления щипкового схвата и противопоставления первого пальца остальным даже при недостижимости полного восстановления анатомии пальца. По сравнению с пересадкой пальца стопы преимуществом метода является использование идентичных по строению тканей и анатомических образований в качестве донорских. В отличие от плюсне-фалангового сустава, пястно-фаланговый сустав с биомеханической точки зрения в большей степени обеспечивает функцию сгибания, тогда как в плюсне-фаланговом суставе изначально имеется дефицит сгибания и пре- обладание разгибания. По этой причине не возникает необходимости в выполнении корригирующих вмешательств на суставах восстановленного пальца, как при пересадке пальца стопы [5, 14-17]. Кроме того, можно сформировать сосудистую ножку необходимой длины с достаточным диаметром сосудов, что исключает необходимость применения их аутовенозной пластики и снижает риск тромбирования микроанастомозов. Постоянство сосудистой анатомии, большой диаметр анастомозируемых сосудов позволяет пересадить культю с высокой надежностью. Наш небольшой клинический опыт показал, что метод может быть применен для восстановления не только первого, но и одного из трехфаланговых пальцев при наличии реципиентной культи пальца на уровне основания основной фаланги и в пределах дистальной трети пястной кости в условиях отсутствия всех трехфаланговых пальцев. При наличии на донорской кисти нескольких культей трехфаланговых пальцев неизбежно встает вопрос о выборе одной из них в качестве донорского. По нашему мнению, при использовании прецизионной техники также следует пересаживать наиболее увечный палец (наличие его при отморожении отмечается крайне редко) или наиболее короткую культю, что совпадает с данными других авторов [13]. Как показывает наш опыт применения культей пальцев для реконструкции другого пальца, утрата культи практически не влияет на суммарную функцию кисти. Палец полной длины следует пересаживать только при значительном ограничении или отсутствии его функции, а также наличии перспектив на ее достаточное улучшение или восстановление, причем только для реконструкции первого пальца и локтевой противоупорной бранши. Такой подход минимизирует косметический и функциональный донорский изъян, что соответствует результатам других авторов [10, 11]. Как следует из литературных данных, после пересадки комплексов тканей стопы у 23,7\% пациентов отмечались нарушения походки [2] или имелся донорский изъян различной степени выраженности $[5,18,19]$. В то же время, вряд ли целесообразна пересадка денервированного пальца парализованной конечности, имеющего контрактуры суставов [11]. Необходимым условием выполнения операции является сохранность пальцевых сосудов донорской культи, в связи с чем перед операцией необходимо провести исследование сосудов пальцев, обеих кистей, предплечий на наличие и выраженность структурных изменений, а также пробу Аллена на донорской и реципиентной кистях. В этом плане высокоинформативным является метод ультразвуковой допплерографии [20]. Операция может быть выполнена при наличии замкнутых ладонных дуг на донорской и реципиентной кистях. В связи с риском тромбоза микроанастомозов необходимо проводить инфузионную и антикоагулянтную терапию в течение 7-10 дней.

\section{ЗАКЛЮЧЕНИЕ}

Реконструкция первого или трехфалангового пальца путем пересадки культи пальца противоположной кисти на микрососудистых анастомозах при последствиях отморожений является эффективным методом лечения и должна применяться по показаниям, с учетом характера дефектов, уровня ампутации культей кисти и состояния сосудов донорской и реципиентной областей. 


\section{СПИСОК ИСТОЧнИКОВ}

1. Quality of life in patients with toe-to-hand transplantation/A. Nakanishi, K. Kawamura, S. Omokawa, T. Shimizu, A. Iida, Y. Tanaka // J. Plast. Surg. Hand. Surg. 2018. Vol. 52, No 6. P. 359-362. DOI: 101080/2000 656X20181520123.

2. Functional donor site morbidity after vascularized toe transfer procedure: a review of the literature and biomechanical consideration for surgical site selection / M. Sosin, C.H. Lin, J. Steinberg, E.R. Hammond, P. Poysophon, M.L. Iorio, K.M. Patel // Ann. Plast. Surg. 2016. Vol. 76, No 6. P. 735742. DOI: 10.1097/SAP.0000000000000591.

3. Jones N.F., Hansen S.L., Bates S.J. Toe-to-hand transfers for congenital anomalies of the hand // Hand. Clin. 2007. Vol. 23, No 1. P. 129-136. DOI: 10.1016/j.hcl.2007.02.006.

4. Kvernmo H.D., Tsai T.M. Posttraumatic reconstruction of the hand - a retrospective review of 87 toe-to-hand transfers compared with an earlier report // J. Hand Surg. Am. 2011. Vol. 36, No 7. P. 1176-1181. DOI: 10.1016/j.jhsa.2011.04.010.

5. Waljee J.F., Chung K.C. Toe-to-hand transfer: evolving indications and relevant outcomes // J. Hand Surg. Am. 2013. Vol. 38, No 7. P. $1431-1434$. DOI: 10.1016/j.jhsa.2013.03.020.

6. Patient-reported outcome measures for toe-to-hand transfer: a prospective longitudinal study / T.Y. Tsai, C.A. Fiers, J.C. Hsiao, C.C. Hsu, Y.T. Lin, S.H. Chen, C.H. Lin, F.C. Wei, C.H. Lin // Plast. Reconstr. Surg. 2019. Vol. 143, No 4. P. 1122-1132. DOI: 10.1097/PRS. 0000000000005422.

7. The triaging and treatment of cold-induced injuries / C. Sachs, M. Lehnhardt, A. Daigeler, O. Goertz // Dtsch. Arztebl. Int. 2015. Vol. 112 , No 44. P. 741-747. DOI: 10. 3238/arztebl. 2015.0741.

8. Foucher G., Nagel D. Pinch reconstruction by hand to hand finger transfer associated with hallux transfer after a severe frostbite injury // J. Hand Surg. Br. 1999. Vol. 24, No 5. P. 617-620. DOI: 10.1054/jhsb.1999.0225.

9. Brüser P., Larkin G. Contralateral transplantation of a finger for restoration of thumb function // J. Hand Surg. Br. 1997. Vol. 22, No 3. P. 336-340. DOI: $10.1016 / \mathrm{s} 0266-76819780398-1$.

10. Jabłecki J., Kaczmarzyk J., Kaczmarzyk L. Transfer palca reki przeciwstawnej na reke bezpalcowa--ilustracja przypadku // Chir. Narzadow Ruchu Ortop. Pol. 2009. Vol. 74, No 5. P. 305-308.

11. Free transfer of a paralyzed contralateral little finger for total thumb reconstruction in an electrical burn patient: a case report and literature review / J.P. Giot, L.S. Paek, G. Mericer- Couture, E. Coeugniet, J.S. Bou-Merhi, M.A. Danino // J. Burn Care Res. 2016. Vol. 37, No 6. P. e595-e600. DOI:10.1097/BCR.0000000000000333.

12. Парин Б.В. Реконструкция пальцев руки. М.: Медгиз, 1944. 130 с.

13. Sasaki K., Nozaki M., Takeuchi M. Thumb reconstruction, after Marjolin's ulcer resection by microvascular transfer of a burn-contracted little finger: a case report of spare part surgery // Br. J. Plast. Surg. 1998. Vol. 51, No 2. P. 126-127. DOI: 10.1054/bips.1997.0095.

14. Aesthetic refinements in second toe-to-thumb transfer surgery / J. Zhao, H.Y. Tien, S. Abdullah, Z. Zhang // Plast. Reconstr. Surg. 2010. Vol. 126, No 6. P. 2052-2059. DOI: 10. 1097/PRS.0b013e3181f44994.

15. Henry S.L., Wei F.C. Thumb reconstruction with toe transfer // J. Hand Microsurg. 2010. Vol. 2, No 2. P. 72-78. DOI: 101007/s12593-010-0017-4.

16. Kumta S.M. Unfavourable results in thumb reconstruction// Indian J. Plast. Surg. 2013. Vol. 46, No 2. P. 294-302. DOI: 10.4103/0970-0358.118608.

17. Simultaneous Stiles-Bunnell tendon transfer enhances intrinsic function of second-toe transplantations / Y.T. Lin, C.Y.Y. Loh, S.H. Lien, C.H. Lin, F.C. Wei // Plast. Reconstr. Surg. 2017. Vol. 140, No 6. P. 1229-1234. DOI: 101097/PRS.0000000000003861.

18. Gait improvement and ulcer prevention with second-to-great toe transposition at the donor site: a case report / C. Yang, Y.H. Hsieh, H.H. Chen, C.H. Tsai, Y.T. Lin // Ann. Plast. Surg. 2020. Vol. 84, No 1S Suppl.1. P. S128-S131. DOI: 10.1097/SAP.0000000000002200.

19. Le V.D., Nguyen V.T., Nguyen V.T. Use of single-staged transmetatarsal trimmed great toe transfer for reconstruction of a thumb amputation at the carpometacarpal joint // J. Plast. Reconstr. Aesthet. Surg. 2021. Vol. 74, No 5. P. 1004-1012. DOI: 10.1016/j.bjps.2020.10.071.

20. Долганова Т.И., Шабалин Д.А., Шихалева Н.Г. Ультразвуковая допплерография пальцевых артерий при удлинении культей фаланг пальцев мини-фиксаторами // Травматология и Ортопедия России 2011. T. 17, № 2. C. 107-113. DOI: https://doi.org/10.21823/2311-2905-2011-0-2107-113.

Статья поступила в редакцию 15.01.2021; одобрена после рецензирования 24.03.2021; принята к публикации 23.12.2021

The article was submitted 15.01.2021; approved after reviewing 24.03.2021; accepted for publication 23.12.2021.

\section{Информация об авторах:}

1. Николай Михайлович Александров - доктор медицинских наук, aleksandrov-chetai@rambler.ru;

2. Иван Денисович Вешаев;

3. Дмитрий Алексеевич Купцов.

\section{Information about the authors:}

1. Nikolai Mikhailovich Aleksandrov - Doctor of Medical Sciences, aleksandrov-chetai@rambler.ru;

2. Ivan Denisovich Veshaev - M.D.;

3. Dmitry Alekseevich Kuptsov - M.D.

Источник финансирования отсутствует. 
Гений ортопедии. 2022. Т. 28, № 1. С. 111-115.

Genij Ortopedii. 2022. Vol. 28, no. 1. P. 111-115.

Научная статья

уДК 616.728.3:616.75-001.5-089.843

https://doi.org/10.18019/1028-4427-2022-28-1-111-115

\section{Опыт использования способа открытой лавсанопластики большеберцовой коллатеральной связки О.Н. Ямщиков ${ }^{1,2}$, С.А. Емельянов ${ }^{1,2}$, С.А. Мордовин ${ }^{1,2}$, Е.А. Колобова ${ }^{1 \bowtie}$}

1 Тамбовский государственный университет имени Г.Р. Державина, Медицинский институт, Тамбов, Россия

2 Городская клиническая больница, Котовск, Россия

Автор, ответственный за переписку: Екатерина Александровна Колобова, koloboom26@gmail.com

Аннотация

Введение. Большеберцовая коллатеральная связка (БКС) - одна из наиболее важных связок коленного сустава, первичный стабилизатор вальгусного отклонения нижней конечности. При её повреждении большинство авторов считают приоритетной тактикой консервативное лечение - длительную иммобилизацию и ограничение нагрузки на повреждённую конечность. Однако накопленный клинический опыт и большой процент осложнений после консервативного лечения данной травмы показывают необходимость применения оперативного вмешательства для восстановления целостности БКС. Цель данной публикации - продемонстрировать успешный опыт лечения пациента с разрывом большеберцовой коллатеральной связки правого коленного сустава и обосновать приоритетность выбора оперативного метода лечения данной патологии. Материалы и методы. Описание клинического случая и краткий анализ литературы по данной теме. Представлен опыт использования способа открытой лавсанопластики большеберцовой коллатеральной связки у пациентки с её разрывом в результате вывиха голени. Эффективность лечения оценивалась на основании рентгенологических методов исследования, а также при оценке функции конечности и амплитуды движения в коленном суставе. Результаты и обсуждение. Выполнена открытая лавсанопластика большеберцовой коллатеральной связки коленного сустава. Достигнуто полное восстановление функции конечности и анатомической целостности БКС. Отмечено сохранение хорошего результата после удаления металлоконструкции. Данный способ позволил исключить развитие осложнений, характерных для консервативного метода лечения: возникновение медиальной нестабильности коленного сустава и развитие деформирующего артроза, а также доказал свою эффективность по сравнению с другими оперативными способами восстановления целостности БКС. Выводы. Применение способа открытой лавсанопластики большеберцовой коллатеральной связки коленного сустава по запатентованной методике позволило полностью восстановить поврежденную конечность и сохранить ее функцию, снизить риск развития осложнений, получить хороший клинический результат.

Ключевые слова: большеберцовая коллатеральная связка, лавсанопластика, коленный сустав, травма, стабильность

Для цитирования: Опыт использования способа открытой лавсанопластики большеберцовой коллатеральной связки / О.Н. Ямщиков, С.А. Емельянов, С.А. Мордовин, Е.А. Колобова // Гений ортопедии. 2022. Т. 28, № 1. С. 111-115. https://doi.org/10.18019/1028-4427-202228-1-111-115

Original article

\section{Experience with open lavsanoplasty of the tibial collateral ligament}

\section{O.N. Yamshchikov ${ }^{1,2}$, S.A. Emelyanov ${ }^{1,2}$ S.A. Mordovin ${ }^{1,2}$, E.A. Kolobova ${ }^{1 凶}$}

${ }^{1}$ Derzhavin Tambov State University, Medical Institute, Tambov, the Russian Federation

${ }^{2}$ Kotovsk City Clinical Hospital, Kotovsk, the Russian Federation

Corresponding author: Ekaterina A. Kolobova, koloboom26@gmail.com

Abstract

Introduction The tibial collateral ligament (TCL) is one of the major ligaments of the knee and designed to counteract valgus forces. Tibial collateral ligament injury can be treated conservatively with prolonged immobilization and limited weight-bearing on the injured limb. Clinical experience and a high complication rate after conservative treatment indicate the need for surgical intervention to restore the integrity of the TCL. The purpose is to demonstrate a successful management of a patient with ruptured TCL of the right knee joint and substantiate the priority of surgical treatment in the case. Material and methods A clinical case is reported and a brief literature analysis on the topic provided. The experience with open lavsanoplasty used for a patient with rupture of the TCL resulting from dislocated tibia is presented. The effectiveness of treatment was assessed radiologically and physically for the limb functionality and ROM in the knee joint. Results and discussion Open lavsanoplasty performed for the TCL injury resulted in complete restoration of the limb function and anatomical integrity of the ligament. The good result persisted after the removal of the metal construct. The method allowed us to avoid complications being typical for conservative treatment: medial instability of the knee joint and deforming arthritis, and showed the advantages over other surgical treatments used to regain the integrity of the TCL. Conclusion Open lavsanoplasty of the TCL used as the patented technique facilitated complete recovery the injured limb, the functionality, less risk of complications providing a good clinical result.

Keywords: tibial collateral ligament, lavsanoplasty, knee injury, trauma, stability

For citation: Yamshchikov O.N., Emelyanov S.A., Mordovin S.A., Kolobova E.A. Experience with open lavsanoplasty of the tibial collateral ligament. Genij Ortopedii, 2022, vol. 28, no 1, pp.111-115. https://doi.org/10.18019/1028-4427-2022-28-1-111-115

\section{ВВЕДЕНИЕ}

Коленный сустав является одним из наиболее часто травмируемых суставов опорно-двигательного аппарата человека: по данным разных авторов, на него приходится от 35,7 до 63,2 \% повреждений всех суставов [1].

Коленный сустав образован дистальным отделом бедренной кости, проксимальным отделом больше- берцовой кости и надколенником, которые соединены сложной системой связок. Особенности анатомического строения коленного сустава делают его очень уязвимым к повреждающему воздействию различных травм, особенно часто повреждается связочный аппарат, представляющий собой внесуставные и внутрису- 
ставные связки. Коллатеральные внесуставные связки коленного сустава являются наиболее важными, так как выполняют роль стабилизаторов, и представлены большеберцовой коллатеральной связкой (lig. collaterale tibiale), которая проходит перпендикулярно фронтальной оси с медиальной стороны, и малоберцовой коллатеральной связкой (lig. collaterale fibulare) - с латеральной стороны коленного сустава [2-8].

Большеберцовая коллатеральная связка (БКС) одна из наиболее важных связок коленного сустава, первичный стабилизатор вальгусного отклонения нижней конечности. На долю повреждения БКС приходится в среднем 3 случая на 1000 человек, и чаще всего данная травма происходит при непрямом механизме - избыточном отклонении голени кнаружи и ее наружной ротации. При повреждении данной связки возникает медиальная нестабильность, заключающаяся в избыточном отклонении голени кнаружи по сравнению со здоровой конечностью [9].

Одним из наиболее частых осложнений травм БКС является возникновение медиальной нестабильности коленного сустава, которая, в конечном итоге, приводит к развитию и прогрессированию деформирующего артроза и к утрате нормального функционирования нижней конечности, что значительно ограничивает трудоспособность человека. Поэтому важным фактором в лечении повреждений данной связки является стабилизация сустава, препятствующая развитию данного осложнения [10-16]. При повреждении БКС большинство авторов считают приоритетной тактикой консервативное лечение - длительную иммобилизацию и ограничение нагрузки на повреждённую конечность. Однако накопленный клинический опыт и большой процент осложнений после консервативного лечения данной травмы показывают необходимость применения оперативного вмешательства для восстановления целостности БКС $[17,18]$.

Цель данной публикации - продемонстрировать успешный опыт лечения пациента с разрывом большеберцовой коллатеральной связки правого коленного сустава и обосновать приоритетность выбора оперативного метода лечения данной патологии.

\section{МАТЕРИАЛЫ И МЕТОДЫ}

Представляем клинический случай из собственной практики. Пациентка Н., 46 лет, 24.01.2020 г. поступила в травматологическое отделение сразу после получения бытовой травмы с жалобами на резкую боль в области коленного сустава, нарушение функции нижней конечности и её деформацию. При осмотре: нижняя конечность выпрямлена и ротирована кнаружи. В области правого коленного сустава визуально определяется отёк, выраженная деформация. По передней поверхности в области коленного сустава определяется западение мыщелков бедра, которые визуализируются по задней поверхности коленного сустава. Передне-задний размер коленного сустава увеличен. Вертикальная ось бедра смещена кзади и внутрь, ось голени отклонена вперед и кнаружи на $5-7^{\circ}$ относительно оси конечности. Активные движения в коленном суставе полностью отсутствуют. Кожные покровы голени бледные, пульсация сосудов снижена. Нарушения чувствительности в правой нижней конечности нет. При анализе рентгенограмм определяется вывих правой голени (рис. 1). Учитывая данные осмотра и дополнительных методов исследования, диагностирован закрытый травматический вывих правой голени, разрыв внутренней боковой связки правого коленного сустава. Пациентка направлена на госпитализацию в травматологический стационар. При поступлении в отделение пациентке было наложено скелетное вытяжение за правую пяточную кость, после чего следовало вправление вывиха. Из сопутствующих заболеваний выявлены хронический необструктивный бронхит (в стадии ремиссии), нарушение толерантности к глюкозе.

После проведенных лабораторных и инструментальных исследований и предоперационной подготовки пациентке Н. проведена операция: открытая лавсанопластика большеберцовой коллатеральной связки коленного сустава по Ямщикову (патент RU № 2743841) [19]. Данная операция выполнялась под спинномозговой анестезией следующим образом: через парапателлярный разрез на медиальной поверхности коленного сустава тупо и остро осуществили доступ к поврежденной связке. После ревизии места разрыва БКС обнаружено, что связка разволокнена и непригодна для сшивания. Принято решение о пластике. Для этого во внутренних мыщелках большеберцовой и бедренной кости сформировали каналы, через которые провели 2 губчатых винта с зубчатыми шайбами по направлению от медиальной плоскости к латеральной, параллельно суставной щели коленного сустава. С целью профилактики перерастяжения трансплантата и восстановления правильной кинематики сустава точная локализация отверстий для проведения винтов выбиралась по принципу минимальности изменения расстояния между бедренным и большеберцовым прикреплением БКС при всех углах сгибания голени. Винты погрузили в кость не полностью, оставляя выступающий край на 2-3 см. Через установленные винты $\mathrm{X}$-образно провели лавсановую ленту, из встречных концов которой сформировали окончательный стягивающий узел вблизи одной из шайб, после чего затянули винты до соприкосновения шайбы с костью, прижимая узел к кортикальному слою. После оценки степени стабильности сустава и прочности лавсанотрансплантата, в том числе в положении максимальной экстензии, рану ушили послойно. Проверена функция сустава. Стабильность сустава полностью восстановлена. Конечность иммобилизировали гипсовой лонгетой. На контрольных рентгенограммах спустя сутки после операции - суставные поверхности конгруэнтны, положение металлоконструкции удовлетворительное (рис. 2). 

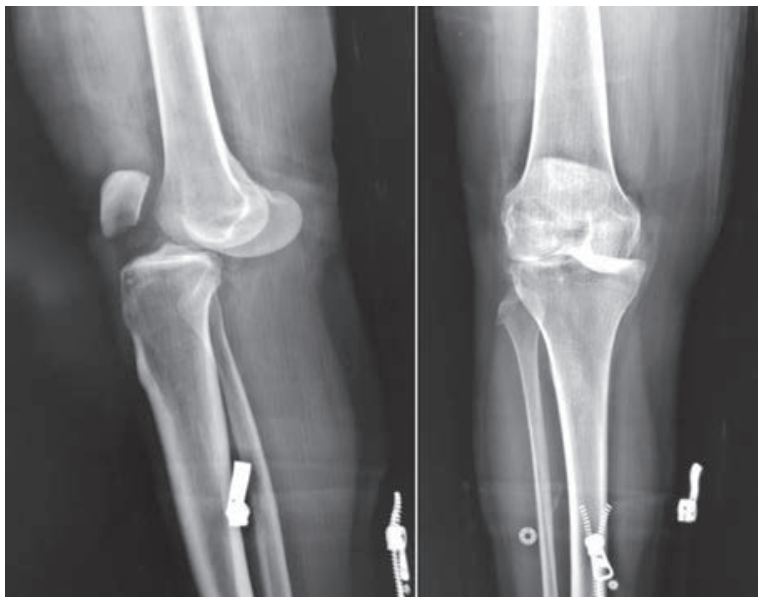

Рис. 1. Рентгенограммы правого коленного сустава в боковой и прямой проекции: вывих голени

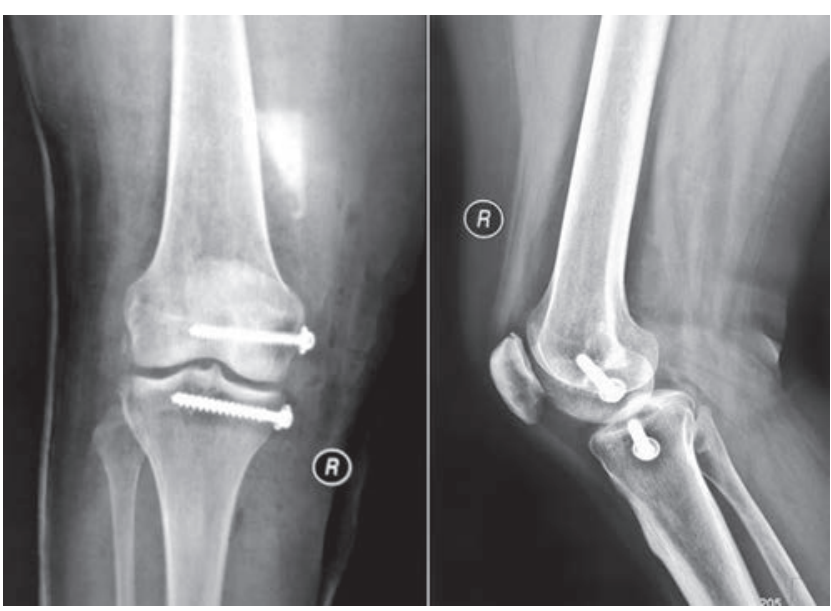

Рис. 2. Контрольная рентгенограмма правого коленного сустава в прямой и боковой проекции после лавсанопластики БКС спустя сутки с момента операции

\section{РЕЗУЛЬТАТЫ}

Послеоперационный период протекал без осложнений. Пациентка получала антибактериальную терапию с целью предупреждения инфекционных осложнений, антикоагулянты и нестероидные противовоспалительные средства для купирования болевого синдрома, выполняла ЛФК в неповреждённых суставах, изометрическое сокращение и расслабление мышц повреждённой конечности, дыхательную гимнастику.

Пациентка активизирована на 3-и сутки после операции - разрешена ходьба с помощью костылей без нагрузки на оперированную конечность. На 8-й день после операции пациентка выписана на амбулаторное лечение у травматолога по месту жительства в удовлетворительном состоянии. Даны рекомендации о дозировании нагрузки на больную конечность, сроках выполнения контрольных рентгенограмм и длительности иммобилизации гипсовой лонгетой. Рана зажила первичным натяжением. Швы сняты на 14-е сутки после операции. Период реабилитации протекал без осложнений. В послеоперационном периоде пациентка передвигалась на костылях с постепенным дозированием нагрузки на прооперированную конечность.

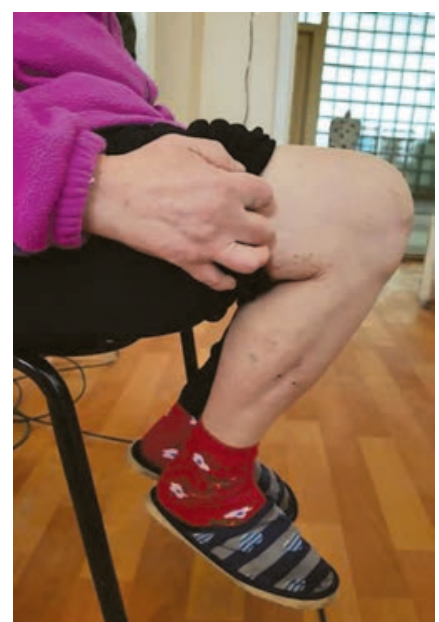

Рис. 3. Восстановление движений в повреждённом суставе (положение сгибания)

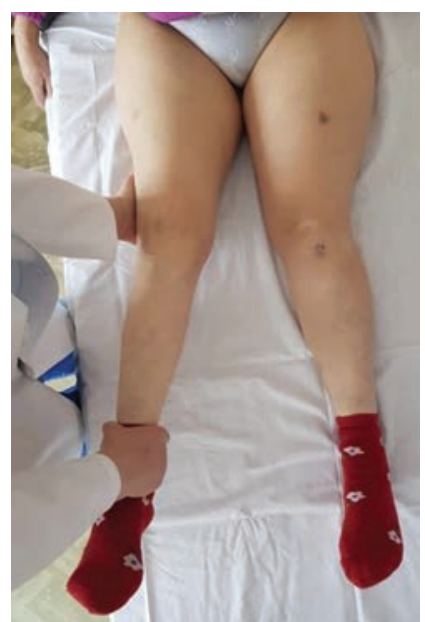

Рис. 4. Восстановление стабильности сустава после лавсанопластики БКС
На приёме через 12 месяцев с момента операции пациентка передвигалась самостоятельно без вспомогательных средств, жалобы отсутствовали. При осмотре на медиальной поверхности коленного сустава определяется послеоперационный рубец, функциональных отклонений в конечности не определяется, движения в правом коленном суставе полностью восстановлены (рис. 3), ось правой нижней конечности соответствует анатомической, стабильность сустава полностью восстановлена (рис. 4) На выполненных контрольных рентгенограммах визуализируется конгруэнтное соотношение суставных поверхностей. Пациентка госпитализирована в травматологический стационар для удаления металлоконструкции. После удаления металлоконструкции стабильность сустава сохранена, суставные поверхности на рентгенограмме конгруэнтны (рис. 5).

Проведено лечение пациентки с разрывом большеберцовой коллатеральной связки с использованием лавсанотрансплантата, фиксированного к двум губчатым винтам с зубчатыми шайбами, установленным во внутренних мыщелках большеберцовой и бедренной костей.

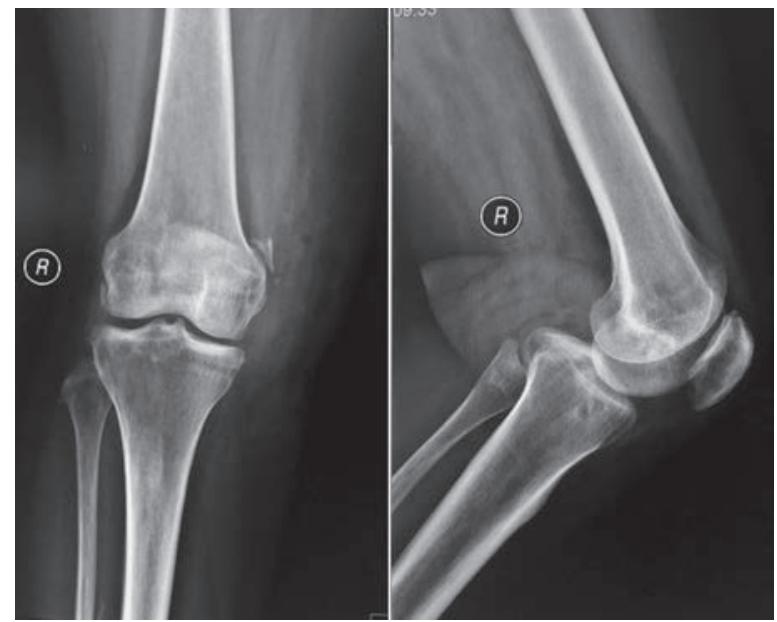

Рис. 5. Рентгенограммы правого коленного сустава в прямой и боковой проекции после удаления металлоконструкции 
После выполнения открытой лавсанопластики большеберцовой коллатеральной связки коленного сустава достигнуто полное восстановление функции конечности и анатомической целостности БКС. Функциональный результат оценивался по полному восстановлению амплитуды движения в коленном суставе при отсутствии болевого синдрома во время движения. Отмечено сохранение хорошего результата после удаления металлоконструкции.

\section{ОБСУЖДЕНИЕ}

На повреждение большеберцовой коллатеральной связки приходится в среднем 3 случая на 1000 человек. Данная травма влечёт за собой возникновение медиальной нестабильности - избыточное отклонение голени кнаружи по сравнению со здоровой конечностью [9]. Важность восстановления целостности данной связки заключается в достижении стабильности сустава, что препятствует развитию довольно частого для такой травмы осложнения - деформирующего артроза коленного сустава [10-16]. Консервативный метод лечения показывал свою эффективность на протяжении многих лет при разрыве связок коленного сустава. Тем не менее, основываясь на клиническом опыте, достигнуть более эффективного результата при подобных патологиях возможно при оперативном методе лечения, который способствует ранней вертикализации и активизации больных. Это, в свою очередь, уменьшает риск возникновения таких осложнений как развитие контрактуры сустава, мышечной гипо- и атрофии, развитие гипостатических осложнений при длительном постельном режиме и медиальной нестабильности коленного сустава с исходом в деформирующий артроз при недостаточной стабилизации сустава консервативным методом $[17,18]$.

В процессе поиска оптимального оперативного лечения повреждённой БКС разработано множество способов реконструктивных операций, в основе которых лежит применение различных пластических трансплантатов (аутотрансплантаты из близлежащих сухожилий мышц бедра, собственной связки надколенника, из широкой фасции бедра, аллотрансплантаты из синтетических материалов, в т.ч. лавсанопластика) [5].
Однако применение аутотрансплантата на практике связано с большим количеством осложнений, среди которых дополнительная травматизация сухожилий мышц бедра с развитием стойкого болевого синдрома, нарушением проприоцептивной функции аутотрансплантированных сухожилий с развитием рефлекторной симпатической дистрофии и гипотрофии мышц, низкая прочность трансплантата с возможностью его разрыва при активизации пациента [5]. Применение синтетических аллотрансплантатов по известным методикам [3] также приводит к неудовлетворительным результатам в связи с разволокнением трансплантата о режущие края металлофиксаторов в процессе активизации пациента.

Приведённый нами клинический пример демонстрирует успешное лечение разрыва БКС без развития перечисленных осложнений, что объясняется следующими преимуществами данного способа: использование синтетического трансплантата, обладающего высокой прочностью, жесткая фиксация лавсановой ленты к винтам с зубчатыми шайбами, что препятствует разволокнению трансплантата при активизации пациента. При этом использование фиксации трансплантата по описанному способу позволяет сократить сроки вынужденного положения конечности и снизить риск развития контрактур, приступить к ранней активизации, сохранив функцию конечности. Таким образом, данный способ открытой пластики повреждённой БКС с применением лавсанотрансплантата доказал свою эффективность, что позволит и дальше с успехом применять его в клинической практике.

\section{ВЫВОДЫ}

Применение способа открытой лавсанопластики большеберцовой коллатеральной связки коленного сустава по запатентованной методике позволило полно- стью восстановить поврежденную конечность и сохранить ее функцию, снизить риск развития осложнений, получить хороший клинический результат.

\section{СПИСОК ИСТОЧнИКОВ}

1. Федорова Н.С., Труфанов Г.Е., Пчелин И.Г. Результаты магнитно-резонансного обследования пострадавших с импрессионно-раскалывающими переломами мыщелков большеберцовой кости: повреждения связок и менисков коленного сустава // Вестник Российской военномедицинской академии. 2012. № 2 (38). С. 25-30.

2. Результаты моделирования повреждений связочного аппарата коленного сустава / М.Ю. Карпинский, Е.Д. Карпинская, Р.А. Щикота, А.А. Тяжелов, Л.Д. Гончарова // Травма. 2012. Т. 13, № 3. С. 165-170.

3. Миронов С.П., Орлецкий А.К., Цыкунов М.Б. Повреждения связок коленного сустава (клиника, диагностика, лечение). М. : Лесар, 1999. $228 \mathrm{c}$.

4. О компенсации стабильности коленного сустава при повреждении передней крестообразной связки / А.А. Тяжелов, И.А. Суббота, В.Г. Климовицкий, Л.Д. Гончарова, Рами Талиб Мушер // Травма. 2011. Т. 12, № 4. С. 35-39.

5. Котельников Г.П. Посттравматическая нестабильность коленного сустава. Самара : Самарский Дом печати, 1998. С. $12-113$.

6. Мамедова С.М., Мальцева Н.Л., Андреева С.Д. Анатомическая терминология : учеб. пособие : в 2 ч. Киров : Аверс, 2019.320 с.

7. Соединения свободной части нижней конечности. Система скелета. Система соединений костей. Новосибирск : Новосибирский национальный исследовательский государственный университет, 2020. С. 126-138.

8. К вопросу о КТ анатомии мягких тканей коленного сустава / Д.А. Пихута, Ю.А. Абович, О.Ю. Бронов, Ю.В. Кабанова, Т.А. Крылова // Вестник Национального медико-хирургического центра им. Н.И. Пирогова. 2016. Т. 11, № 3. С. 81-84.

9. Цыкунов М.Б. Реабилитация при повреждениях капсульно-связочных структур коленного сустава и их последствиях // Лечебная физкультура и спортивная медицина. 2016. № 2. С. 39-47 ; № 3. С. 41-46 ; № 4. С. 51-53 ; № 5. С. $42-46$.

10. Цыкунов М.Б., Буйлова Т.В., Миронов С.П. Реабилитация при повреждении капсульно-связочного аппарата коленного сустава (оперативное лечение) : клинич. рекомендации // Вестник восстановительной медицины. 2016. № 3 (73). С. 78-85. 
11. Цыкунов М.Б. Эффективность реабилитации при повреждениях большеберцовой коллатеральной и передней крестообразной связки // Вестник Ивановской медицинской академии. 2017. Т. 22, № 4. С. 27-30.

12. Комогорцев И.Е. Посттравматическая нестабильность коленного сустава (клиника и диагностика). Иркутск : НЦ РВХ ВСНЦ СО РАМН, 2003. 168 c.

13. Травматология и ортопедия : рук. для врачей : в 4 т. Т. 3 / под ред. Н.В. Корнилова, Э.Г. Грязнухина. СПб. : Гиппократ, 2006.896 с.

14. Лазишвили Г.Д. Оперативное лечение свежих повреждений связочного аппарата коленного сустава : автореф. дис. ... канд. мед. наук. М., 1993. 23 c.

15. Результаты консервативного лечения повреждений связочного аппарата коленного сустава / В.Г. Климовицкий, А.А. Тяжелов, Л.Д. Гончарова, Р.А. Щикота // Травма. 2012. Т. 13, № 1. С. 79-82.

16. Бадокин В.В. Остеоартроз коленного сустава: клиника, диагностика, лечение // Современная ревматология. 2013. № 3. С. $70-75$.

17. Бадокин В.В. Значение воспаления в развитии и течении остеоартроза // Consilium medicum. 2009. T. 11, № 9. С. 91-95.

18. Ортопедия : нац. руководство / под ред. С.П. Миронова, Г.П. Котельникова. М. : ГЭОТАР-Медиа, 2008.832 с.

19. Способ открытой лавсанопластики большеберцовой коллатеральной связки коленного сустава по Ямщикову : пат. 2743841 Рос. Федерация МПК А 61 В 17/58 / О.Н. Ямщиков, С.А. Емельянов, С.А. Мордвин, Е.А. Колобов ; заявитель и патентообладатель Тамбовский государственный университет имени Г.Р. Державина. № 2020114008 ; заявл. 03.04.2020 ; опубл. 26.02.2021.

Статья поступила в редакцию 19.04.2021; одобрена после рецензирования 12.07.2021; принята к публикации 23.12.2021.

The article was submitted 19.04.2021; approved after reviewing 12.07.2021; accepted for publication 23.12.2021.

\section{Информация об авторах:}

1. Олег Николаевич Ямщиков - доктор медицинских наук, професcop, Yamschikov.oleg@yandex.ru, https://orcid.org/0000-0001-6825-7599;

2. Сергей Александрович Емельянов - сер_а@mail.ru, https://orcid.org/0000-0002-5550-4199;

3. Сергей Алексеевич Мордовин - mordovin.s.a@rambler.ru, https://orcid.org/0000-0001-5873-3555;

4. Екатерина Александровна Колобова - koloboom26@gmail.com, https://orcid.org/0000-0002-1370-4213.

\section{Information about the authors:}

1. Oleg N. Yamshchikov - Doctor of Medical Sciences, Professor, Yamschikov.oleg@yandex.ru, https://orcid.org/0000-0001-6825-7599;

2. Sergey A. Emelyanov - cep_a@mail.ru, https://orcid.org/0000-0002-5550-4199;

3. Sergey A. Mordovin - mordovin.s.a@rambler.ru, https://orcid.org/0000-0001-5873-3555;

4. Ekaterina A. Kolobova - koloboom26@gmail.com, https://orcid.org/0000-0002-1370-4213. 
Гений ортопедии. 2022. Т. 28, № 1. С. 116-122.

Genij Ortopedii. 2022. Vol. 28, no. 1. P. 116-122.

\section{Обзорная статья}

УДК 616.71-001.5-003.93-039.73(048.8)

https://doi.org/10.18019/1028-4427-2022-28-1-116-122

\section{Современные методы медикаментозной и локальной терапии замедленной консолидации переломов (обзор литературы)}

\section{Рустем Ильгизович Садыков ${ }^{\varpi}$, Ильдар Фуатович Ахтямов}

Казанский государственный медицинский университет, Казань, Россия

Автор, ответственный за переписку: Рустем Ильгизович Садыков, rustiksadykov@mail.ru

Аннотация

Введение. Лечение пациентов с посттравматическими нарушениями костной регенерации по-прежнему является одной из сложнейших проблем травматологии и ортопедии. К ним относятся рефрактуры, ложные суставы, замедленная консолидация, несращение костей. Цель. Изучить современные методы коррекции замедленной консолидации переломов. Материалы и методы. Поиск литературных источников проводился в открытых электронных базах данных научной литературы PubMed и eLIBRARY. Глубина поиска - 10 лет. Результаты. В статье представлены методы медикаментозной и локальной терапии замедленной консолидации переломов. Отмечена эффективность использования оссеингидроксиапатитного комплекса и витамина D у пациентов для нормализации срока сращения переломов трубчатых костей. Представлены результаты исследований, показывающих, что бисфосфонаты, деносумаб и стронция ранелат снижают риск возникновения переломов, не оказывая при этом неблагоприятного влияния на их заживление. Представлены разноречивые данные по влиянию Терипаратида на ускорение сращения переломов. В данной статье мы провели анализ научной литературы применения костной пластики, костных заменителей, синтетических факторов роста, клеточной терапии, РRР-терапии при замедленной консолидации переломов. В настоящее время большой интерес представляет возможность местного применения бисфосфонатов как изолированно, так и в комбинации с другими компонентами. В статье продемонстрированы исследования локального применения бисфосфонатов (этидроната) в сочетании с ионами лантаноидов и кальцием при переломах у животных и их положительного влияния на репаративный процесс. Заключение. Актуальность медикаментозной и локальной терапии лечения пациентов с замедленной консолидацией переломов весьма высока. Несмотря на многочисленные исследования, многие вопросы остаются неразрешенными, и есть необходимость в их продолжении. Одним из перспективных направлений в лечении замедленной консолидации переломов является локальное применение бисфосфонатов.

Ключевые слова: переломы, замедленная консолидация, репаративный остеогенез, стимуляция, локальные факторы, бисфосфонаты, терипаратид

Для иитирования: Садыков Р.И., Ахтямов И.Ф. Современные методы медикаментозной и локальной терапии замедленной консолидации переломов (обзор литературы) // Гений ортопедии. 2022. T. 28, № 1. С. 116-122. https://doi.org/10.18019/1028-4427-2022-28-1-116-122

\section{Review article}

\section{Modern methods of medication and local therapy for delayed fracture consolidation (literature review)}

\section{Rustem I. Sadykov ${ }^{\bowtie}$ Ildar F. Akhtyamov}

Kazan State Medical University, Kazan, Russian Federation

Corresponding author: Rustem I.Sadykov, rustiksadykov@mail.ru

Abstract

Introduction Management of post-traumatic disorders of bone regeneration continues to be a substantial clinical challenge in orthopaedic trauma. These include refracture, nonunion, delayed consolidation. The purpose is to explore modern methods of treatment of delayed fracture consolidation. Methods The literature search was produced via open access electronic databases of scientific literature PubMed and eLIBRARY. Search depth was 10 years. Results The article presents methods of medication and local therapy for delayed fracture consolidation. The effectiveness of the use of the ossein-hydroxyapatite complex and vitamin D is reported in patients with normalized healing time of a long bone fracture. The findings showed that bisphophonates, denosumab and strontium ranelate can reduce the risk of fractures with no adverse effect on bone healing. There is controversy on the effect of Teriparatide improving fracture healing. This review will envisage the current clinical trials on bone healing augmentation based on bone grafts, bone substitutes, synthetic growth factors, cell therapy and PRP therapy. Local use of bisphosphonates administered either alone or in combination with other agents is of great interest. Bisphosphonates (etidronate) locally applied in combination with lanthanide ions and calcium for animal fractures demonstrated a positive effect on the reparative process. Conclusion The applicability of medication and local therapy is very high in the treatment of patients with delayed fracture consolidation. Despite numerous studies many questions remain unresolved, and there is a need for the investigations. The local use of bisphosphonates was shown to be promising in the management of delayed fracture consolidation.

Keywords: fracture, delayed consolidation, reparative osteogenesis, stimulation, local factors, bisphosphonate, teriparatide

For citation: Sadykov R.I.,Akhtyamov I.F. Modern methods of medication and local therapy for delayed fracture consolidation (literature review). Genij Ortopedii, 2022, vol. 28, no 1, pp. 116-122. https://doi.org/10.18019/1028-4427-2022-28-1-116-122

\section{ВВЕДЕНИЕ}

Лечение пациентов с посттравматическими нарушениями костной регенерации по-прежнему является одной из сложнейших проблем травматологии и ортопедии. К ним относятся рефрактуры, ложные суставы, замедленная консолидация, несращение костей. Актуальность проблемы определяют неуклонный рост травматизма, высокая частота несращений костей при лечении переломов, плохие отдаленные результаты лечения пациентов даже в специализи- рованных травматологических стационарах, стойкая утрата трудоспособности у населения. Замедленное сращение (консолидация) встречается в 5-12 \% случаев, а формирование ложных суставов происходит в 2-3 \% случаев по отношению к общему числу переломов костей [1]. Расстройства репаративной регенерации носят многофакторный характер. На сращение переломов оказывают влияние как общие (возраст, остеопороз, нарушение метаболических процессов,

() Садыков Р.И., Ахтямов И.Ф., 2022 
хроническая ишемия конечности) [2, 3], так и местные факторы (обширные повреждения, неадекватная репозиция и фиксация, инфицирование области повреждения).

\section{МАТЕРИАЛЫ И МЕТОДЫ}

Поиск источников проводился в открытой электронной базе данных медицинских и биологических публикаций PubMed и научной электронной библиотеке eLIBRARY за период с 2010 по 2020 г.

\section{РЕЗУЛЬТАТЫ}

Для коррекции замедленного репаративного остеогенеза используются как консервативные, так и оперативные методы [4]. К первым можно отнести медикаментозные и физиотерапевтические. Взаимодействие между лекарственными препаратами и сращением перелома, их влияние на формирование регенерата на различных стадиях процесса являются наиболее дискутабельными вопросами.

Экспериментальные данные свидетельствуют о том, что дефицит кальция и витамина D может усугубить посттравматическую потерю костной массы. Результаты исследований клинически обосновывают терапевтическую потребность в добавочном кальции и витамине $\mathrm{D}$ после перелома, особенно на фоне остеопороза $[5,6]$. Согласно российским Федеральным клиническим рекомендациям «Патологические переломы, осложняющие остеопороз» [7], необходимо использовать базисную терапию как основу консервативного лечения переломов. В качестве данной терапии с первых дней после выявления перелома, независимо от его локализации, рекомендуется ежедневное назначение препаратов кальция (с пищей и/или медикаментозно) в комбинации с колекальциферолом/альфакальцидолом [4]. В первый год после перелома в качестве препарата кальция рекомендуется использовать оссеин-гидроксиапатитный комплекс (ОГК), в котором кальций находится в виде гидроксиапатита. Ионизирование кальция в этом случае идет без скачкообразного подъема. В отличие от обычных солей кальция ОГК содержит оссеин, представленный коллагеном, остеокальцином и факторами роста: TGF-b (трансформирующий ростовой фактор бета), IGF-I (инсулиноподобный фактор роста-1), IGF-II (инсулиноподобный фактор роста-2). Наличие факторов роста способствует пролиферации и стимулированию фибробластов, хондроцитов и остеобластов, коллаген отвечает за создание ретикулофиброзного матрикса, тогда как гидроксиапатит отвечает за оссификацию и минерализацию в месте перелома и нормализацию сроков формирования костной мозоли [4]. В зарубежной литературе описан ряд сравнительных исследований оссеин-гидроксиапатитного комплекса и карбоната кальция при изучении влияния препаратов на сохранение МПК [8, 9], а в эксперименте - на формирование костной мозоли. Отмечена эффективность использования ОГК по сравнению с карбонатом кальция у женщин с сенильным остеопорозом, для нормализации срока сращения переломов трубчатых костей у пациентов с переломами на фоне остеопороза или остеопении и у пациентов, имеющих нарушения метаболизма костной ткани (замедленная консолидация после хирургического лечения псевдоартозов, осложненных регионарным остеопорозом). Срок сращения при псевдоартрозе бедренной кости сокращался в среднем на 34,3 \% по сравнению с группой контроля $(\mathrm{p}<0,05)[7]$.
Имеется обширная доказательная база того, что бисфосфонаты снижают риск возникновения переломов [10], а данные о специфике их влияния на процессы регенерации и посттравматического ремоделирования кости в литературе присутствуют разноречивые [4]. В исследовании, выполненном на собаках, выявлено, что лечение алендронатом способствует увеличению объема регенерата, но не оказывает отрицательного или благоприятного влияния на заживление перелома, прочностные качества и минерализацию кости. Однако при изучении сращения перелома у крыс с остеопорозом выявлено, что алендронат нарушал темпы заживления перелома. Авторы выявили уменьшение объема регенерата, а сам регенерат охарактеризовали как низкого качества за счет формирования в области дефекта грубоволокнистой костной ткани [11].

Лечение золедроновой кислотой у крыс на модели перелома бедренной кости способствовало активизации репаративного остеогенеза, формировались обширные экстракортикальные субпериостальные напластования, способствующие увеличению площади кости и её прочностных характеристик, однако к концу исследования их ремоделирования не было обнаружено. На замедление ремоделирования регенерата указывали и другие авторы, проводившие исследования на животных [12, 13].

Схожие результаты дали исследования непосредственно в клинической практике $[4,11]$. У пациентов с остеопорозом, перенесших перелом костей скелета, терапия алендронатом не замедляла процесса консолидации перелома. Результаты исследования HORIZON-RFT показало, что золедроновая кислота не влияла на консолидацию низкоэнергетического перелома проксимального отдела бедренной кости, даже если инфузия препарата проходила в средние сроки послеоперационного периода $[11,14]$. Ряд специалистов высказывает мнение, что назначение бисфосфонатов в ранние сроки после травмы при переломах проксимального отдела плечевой кости даже увеличивало риск несращения [7]. Влияние бисфосфонатов на консолидацию перелома дистального метаэпифиза лучевой кости также остается неясным [15]. Нельзя полностью игнорировать известные публикации о таких осложнениях при назначении бисфосфонатов как фибрилляция предсердий, атипичный перелом бедренной кости, некроз челюсти, рак пищевода [16]. Однако четкой причинной связи этих осложнений с приемом бисфосфонатов не установлено $[17,18]$.

При переломах проксимального отдела бедренной кости, осложняющих остеопороз, в качестве препарата первой линии используется деносумаб, который обеспечивает больший прирост МПК, чем бисфосфонаты [19-21], в том числе и за счет увеличения массы кортикальной кости и снижения ее порозности. В срав- 
нительном исследовании использования деносумаба и золедроновой кислоты [22] отмечено, что на фоне приема деносумаба прирост МПК оказался достоверно больше во всех исследуемых сегментах скелета - позвоночнике, шейке бедренной кости, лучевой кости. В исследовании FREEDOM [7] показано отсутствие его негативного влияния на консолидацию вневертебральных переломов, включая и перелом проксимального отдела бедренной кости. Безопасность влияния приема деносумаба показана и другими исследованиями.

Стронция ранелат - препарат с двойным механизмом действия, который способен одновременно стимулировать синтез костной ткани и подавлять ее резорбцию. В экспериментах на лабораторных крысах было показано, что прием стронция ранелата существенно повышает прочность костной мозоли, благоприятно воздействует на микроархитектонику костной мозоли, достоверно повышает соотношение объема костных трабекул к общему объему формирующейся костной ткани [23]. Эти данные были подтверждены в ходе другого экспериментального исследования, в котором у овариэктомированных крыс с закрытым переломом диафиза бедренной кости сравнивалась эффективность терапии ранелатом стронция и терипаратидом [24, 25]. При этом было установлено, что костная мозоль у животных, получавших стронция ранелат, в отличие от крыс, получавших терипаратид, оказалась намного более прочной при скручивании, хотя объем костной ткани увеличивался в обеих экспериментальных группах по сравнению с группой животных, не получавших фармакотерапии. В другом исследовании на 45 крысах [26] было показано, что в группах с применением ибандроната и стронция наблюдалось значительное увеличение количества остеобластов и значительное уменьшение количества остеокластов по сравнению с контрольной группой. Испытуемые в обеих группах имели значительно большую толщину кортикальной пластинки и площадь трабекул, чем контрольная группа. Животные же в группе с применением стронция имели значительно больше остеобластов и большую толщину кортикальной пластинки, чем животные в группе с применением ибандроната. Проспективное исследование влияния терапии стронция ранелатом в сочетании с препаратом кальция и витамином D3 и без него было проведено у 47 пациенток с переломами проксимального отдела бедренной кости на фоне системного остеопороза [27]. Было установлено, что проведенное фармакологическое лечение системного остеопороза практически не влияет на скорость сращения переломов указанной локализации [23].

K препаратам, стимулирующим процесс костеобразования, относится терипаратид [28]. В литературе присутствуют разноречивые данные о его влиянии на сращение переломов. Считается, что этот препарат может улучшить консолидацию переломов позвонков и предупреждать прогрессирование компрессии [4, 29]. На моделях крыс было показано, что интермиттирующее введение терипаратида повышает образование костной мозоли, содержание минералов и плотность кости, а также механическую прочность костной мозоли. У обезьян при остеотомии бедренной кости терипаратид ускорял естественную консолидацию перелома.
Разноречивы исследования и в клинической практике по данному препарату [4]. С одной стороны, в клиническом исследовании с участием пациентов с переломами шейки бедренной кости [30] на сроке 12 мес. терипаратид не уменьшал по сравнению с плацебо болевой синдром, не снижал риск повторных операций, не изменял сроки рентгенологического сращения перелома. С другой, при межвертельных переломах в рандомизированном сравнительном исследовании отмечено преимущество терипаратида над ризедроновой кислотой по степени снижения боли и финальным функциональным результатам. Однако при анализе рентгенограмм убедительных данных преимущества терипаратида по влиянию на консолидацию не выявлено [31]. Интересно, что дополнение комбинации витамина D и препаратов кальция терипаратидом (сравнительное исследование) выявило достоверное сокращение, по сравнению с группой, получавшей только препараты кальция и витамина D, срока консолидации межвертельных переломов [7, 32].

Назначение же терипаратида [33] сразу после перелома проксимального отдела плечевой кости не сокращало срок консолидации. В сравнительном плацебо-контролируемом исследовании [4] при переломе дистального метаэпифиза лучевой кости у женщин в постменопаузе (от 45 до 85 лет) отмечалось сокращение срока консолидации при приеме терипаратида по сравнению с плацебо.

Помимо медикаментозной терапии актуальным направлением современных исследований является возможность применения локальных факторов стимуляции репаративного остеогенеза. Эти факторы классифицируются по механизму биологического действия на остеогенные, остеокондуктивные, остеоиндуктивные.

Аутологичный костный трансплантат сочетает в себе все свойства, необходимые для биологического трансплантата: остеогенные, остеокондуктивные и остеоиндуктивные [34]. Преимущества этого трансплантата - относительно низкая стоимость, отсутствие передачи инфекций и иммунологического отторжения. Недостатками являются ограниченный объем доступного трансплантата, недостаточная структурная поддержка, болевой синдром и заболеваемость донорского участка. Аллогенные костные трансплантаты (аллотрансплантат) доступны в различных формах и размерах, таких как кортикальный, губчатый, остеохондральный и цельный костный сегмент. Основным недостатком аллотрансплантата является потеря остеогенного потенциала из-за удаления костных клеток при подготовке трансплантата.

Деминерализованный костный матрикс (DBM) представляет собой высоко переработанный аллотрансплантат, который содержит менее 5 \% кальцифицированной целлюлярной субстанции, при этом сохраняются коллагены, неколлагеновые белки и факторы роста. $\mathrm{DMB}$, из-за его более низкой структурно-механической целостности, чем аутологичный костный трансплантат, в основном применяется для заполнения дефектов кости. В литературе представлен ряд хороших результатов применения DMB для лечения переломов длинных трубчатых костей [35]. Однако клинический 
уровень доказательств, подтверждающих использование DBM в травматологической и ортопедической хирургии, ограничен и состоит, в основном, из низкокачественных и ретроспективных случаев, а итоговые оценки являются очень низкими [36].

Сульфат кальция, керамика и цемент на основе фосфата кальция, биоактивное стекло или их комбинации являются наиболее распространенными синтетическими заменителями костей. Все они обладают сходными механическими характеристиками, имеют целью имитировать остеокондуктивные свойства костного трансплантата и, в основном, используются в качестве наполнителей пустот при больших сегментарных дефектах [37].

К синтетическим факторам роста относятся костные морфогенетические белки (ВМР), факторы роста фибробластов (FGF), сосудистый эндотелиальный фактор роста (VEGF), тромбоцитарный фактор роста (PDGF) и инсулиноподобный фактор роста (IGF).

Семейство костных морфогенетических белков (BMP), главным образом ВMP-2 и ВМР-7, нашло широкое применение в области ортопедии [38].

Несколько клинических исследований показали, что BMP-2 и ВMP-7 сокращают время консолидации после хирургического лечения переломов большеберцовой кости и снижают риск возникновения новых переломов. Применение ВМР для лечения переломов, по мнению ряда авторов, оказалось благоприятной альтернативой аутологичной костной пластики. В частности, применение ВMP-2 приводило к тем же показателям консолидации (75-89 \%), что и при аутотрансплантации кости [39]. Хотя есть и другие исследования, которые показали противоречивые результаты. Н.T. Aro и соавт. показали, что заживление открытых переломов большеберцовой кости не было значительно ускорено добавлением абсорбируемой коллагеновой губки, содержащей rhBMP-2 [40]. T. Lyon и соавт. продемонстрировали у 180 пациентов с закрытыми переломами большеберцовой кости, что время до полной консолидации значительно не уменьшилось при использовании 2,0 мг/мл rhBMP-2 / СРМ по сравнению с только интрамедуллярным остеосинтезом [41]. Рекомбинантный ВMP-7 был изучен на 122 пациентах с несросшимися переломами большеберцовой кости. Хотя авторы пришли к выводу, что ВМР-7 является безопасным и эффективным средством для лечения переломов большеберцовой кости, FDA не дало разрешения на использование ВМР-7, поскольку улучшения по сравнению с аутотрансплантатом не было.

Факторы роста фибробластов (FGF) секретируются моноцитами, мезенхимальными стволовыми клетками, остеобластами и хондроцитами с ранних стадий заживления переломов на протяжении всего процесса консолидации. Н. Kawaguchi и соавт. [42] продемонстрировали в клиническом исследовании, включавшем 70 пациентов с переломами большеберцовой кости, ускорение заживления и более высокую частоту сращения переломов в группах, получавших rhFGF, по сравнению с группой, получавшей только гидрогель. Копылов В.А и соавт. показали в эксперименте на 56 крысах, что метаболиты Bacillussubtilis 804, coдержащие фактор роста фибробластов, обладают сти- мулирующим действием на репаративный остеогенез и ускоряют консолидацию переломов [43].

Фактор роста тромбоцитов (PDGF) - это сигнальная молекула, которая выделяется дегранулирующими тромбоцитами на ранних стадиях заживления переломов благодаря своей важной роли в хемотаксисе. Хотя применение rhPDGF было одобрено FDA при артродезе голеностопного сустава [44], в настоящее время не существует агентов PDGF, специально одобренных для использования при консолидации переломов [37]. Точно также было продемонстрировано, что фактор роста эндотелия сосудов обладает остеоиндуктивной функцией. Тем не менее, все доступные исследования были выполнены только на различных животных [45].

Результаты экспериментальных и клинических исследований свидетельствуют о положительном влиянии трансплантации мезенхимальных стволовых клеток (МСK) на течение репаративного процесса. Выявлено, что вследствие их остеогенной дифференцировки повышается пул остеобластов, объем новообразованной костной ткани, и сокращаются сроки восстановления целостности кости [46]. Несомненными преимуществами использования МСК является малоинвазивность процедуры получения и возможность увеличения количества в процессе культивирования.

Сложность локального введения МСК непосредственно в открытую рану заключается в том, что клетки плохо удерживаются в зоне дефекта. Одно из решений данной проблемы - применение матриц, насыщенных суспензией костного мозга. Спектр материалов, использующихся в качестве подложки, довольно широк, среди них бета-трикальцийфосфат ( $\beta$-ТКФ), минерализованный губчатый матрикс, различные металлы с покрытием из титана и др.

M. Jäger и соавт. [47] применяли МСК с подложками из коллагеновой губки или гидроксиапатита при хирургическом лечении пациентов с переломом. Через 6 месяцев у всех пациентов рентгенологически зафиксирована консолидация отломков. Сокращение сроков образования костной ткани в области перелома отмечено при использовании в качестве матрицы гидроксиапатита по сравнению с применением коллагеновой губки (6,8 против 13,6 недели). Полное восстановление кости в этих группах зафиксировано через 17,3 и 22,4 недели соответственно.

Одной из известных технологий местной стимуляции репаративного остеогенеза является PRP-терапия введение в зону перелома аутологичной, обогащенной тромбоцитами плазмы крови [48]. В проспективном исследовании применение PRP для лечения 94 несросшихся переломов длинных трубчатых костей обусловило формирование сращения через 4 месяца в $87 \%$ случаев [49]. В рандомизированном контролируемом исследовании применения PRP при остеосинтезе для лечения 29 ложных суставов большеберцовой и бедренной костей демонстрируется более высокая скорость заживления в группе PRP по сравнению с группой сравнения [50]. Но есть и противоречивые данные. В систематическом обзоре 2012 года U. Sheth и соавт., оценивая доказательства, подтверждающие использование аутологичной PRP для уменьшения боли и улуч- 
шения заживления при различных травматических повреждениях костей или мягких тканей [51], пришли к выводу, что PRP не предлагает преимущества по сравнению со стандартным лечением. На сегодняшний день надежные клинические доказательства использования обогащенной тромбоцитами плазмы для регенерации костной ткани практически отсутствуют.

В настоящее время большой интерес представляет возможность местного применения бисфосфонатов как изолированно, так и в комбинации с другими компонентами [52]. Считается, что бисфосфонаты не влияют непосредственно на формирование кости, а увеличивают баланс просто путем ингибирования ее резорбции. Однако существуют исследования, показывающие, что это может быть не совсем так. Морфологические данные об основной структурной единице предполагают возможное увеличение образования в многоклеточной единице кости, подразумевая, что может иметь место некоторое стимулирующее влияние на ее формирование. На клеточном уровне было показано, что бисфосфонаты in vitro увеличивают пролиферацию остеобластов и хрящевых клеток, а также биосинтез коллагена и остеокальцина костными клетками.

В экспериментах на животных было показано увеличение остеогенеза вокруг имплантатов при локальном использовании раствора бисфосфоната, при этом увеличение остеоинтеграции на границе «имплантат-кость» превосходило подобное явление при системном применении бисфосфонатов. Появились работы о локальном применении бисфосфонатов при цементном эндопротезировании, в которых они были смешаны с костным цементом. Однако при этом было отмечено изменение характеристик самого цемента, что снижало его усталостную прочность, в связи с чем от этой идеи пришлось отказаться. Преимущественное использование бесцементных конструкций, невозможность применения бисфосфонатов в соединении с костным цементом, а также недостаточная эффективность соединения бисфосфонатов с гидроксиапатитным покрытием подтолкнули ученых к разработке растворов бисфосфонатов для локального применения [53]. Однако выявлено, что бисфосфонаты в качестве раствора не способны удерживаться в зоне травмы продолжительно [54].

Для изучения репаративного остеогенеза у 36 кроликов была использована экспериментальная модель несквозного дефекта большеберцовой кости [55]. В этот дефект в основной группе вводили этидронат (бисфосфонат первого поколения без содержания аминогруппы, механизмом действия которого является ингибирование резорбции кости посредством индукции апоптоза остеокластов) и кальций, а с целью удержания компонентов - лантаноиды, в группе сравнения ничего не вводилось. Лантаноиды - это редкоземельные металлы, они являются эффективными катализаторами гидролитического расщепления фосфатно-эфирных связей [56]. Установлено, что лантаноидосодержащие биокомпозиционные покрытия способны улучшать трофику границы «кость-имплантат», ускоряют остеоинтеграцию и предотвращают воспалительные осложнения вследствие антитромбоцитного действия. Лантаноиды способны оказывать антимикробное действие, повышать фагоцитарную активность лейкоцитов, в результате вызывают отторжение некротических тканей, способствуют пролиферации клеток, и, как следствие, быстрое заживление раневой поверхности [57]. В результате этого исследования было показано, что дозированное применение препарата, содержащего этидронаты, ионы лантаноидов и кальций, эффективно уже на ранних сроках заживления небольших костных дефектов, выявлена достоверная выраженная разница в плотности костной ткани на ранних сроках процесса репаративной регенерации. Особенностью препарата было комплексное действие в виде снижения интенсивности воспаления; ускорения репарации; влияния на остеогенез, который в подавляющем большинстве случаев был прямым. Была показана способность препарата, содержащего этидронаты ионов лантаноидов и кальция, значительно стимулировать активность остеобластов и не оказывать при этом влияния на активность остеокластов in vitro [58].

В другом исследовании на 45 крысах [59] при оценке изменения плотности костной ткани в области перелома при интрамедуллярном остеосинтезе на фоне локального введения компонентов на основе этидронатов, ионов лантаноидов и кальция было показано, что параоссальное применение компонентов на основе этидронатов ионов лантаноидов и кальция сопровождается формированием в зоне остеотомии кортикальной пластинки с наиболее высокими показателями плотностных характеристик, а нормализация этих показателей в данной группе происходила быстрее, чем в группе с введением компонентов на основе этидронатов и кальция без содержания ионов лантаноидов. При морфологическом исследовании [60] наилучшие результаты заживления костной ткани при переломах также были получены при параоссальном введении этидроната в сочетании с лантаноидами.

В исследовании на 75 крысах [61] по данным гематологического исследования было выявлено, что компоненты, в состав которых входят лантаноид-ионы и этидронат, не оказывают отрицательного воздействия на организм крыс.

\section{ЗАКЛЮЧЕНИЕ}

Несмотря на постоянное совершенствование методов оперативного лечения переломов и применение современных материалов и технологий, основными осложнениями по-прежнему остаются замедленное сращение или несращение переломов. Проведенный анализ данных литературы свидетельствует о том, что актуальность применения медикаментозной терапии и локальных факторов, которые можно ис- пользовать для восстановления и регенерации кости, в настоящее время весьма высока. Однако, несмотря на многочисленные исследования, многие вопросы остаются неразрешенными, и есть необходимость в их продолжении. Одним из перспективных направлений в лечении замедленной консолидации переломов в настоящее время является локальное применение бисфосфонатов. 


\section{СПИСОК ИСТОЧнИКОВ}

1. Primary nonunion of intertrochanteric fractures of femur: An analysis of results of valgization and bone grafting / Ik Dhammi, Ak Jain, Ap Singh, Rehan-UI-Haq, P. Mishra, S. Jain // Indian. J. Orthop. 2011. Vol. 45, No 6. P. 514-519. DOI: 10.4103/0019-5413.87122.

2. Диагностическое значение показателей высших жирных кислот в оценке развития замедленной консолидации переломов / А.М. Мироманов, О.Б. Миронова, А.Н. Старосельников, Н.А. Мироманова // Политравма. 2020. № 2. C. 54-58. DOI: 10.24411/1819-1495-2020-10020.

3. Остеопороз в Российской Федерации: эпидемиология, медико-социальные и экономические аспекты проблемы (обзор литературы) / О.М. Лесняк, И.А. Баранова, К.Ю. Белова, Е.Н. Гладкова, Л.П. Евстигнеева, О.Б. Ершова, Т.Л. Каронова, А.Ю. Кочиш, О.А. Никитинская, И.А. Скрипникова, Н.В. Торопцова, Р.М. Арамисова // Травматология и ортопедия России. 2018. T. 24, № 1 . С. 155-168. DOI: 10.21823/23112905-2018-24-1-155-168.

4. Садыков Р.И., Ахтямов И.Ф. Современные тенденции в медикаментозной профилактике и лечении пациентов с замедленной консолидацией переломов // Opinion Leader. 2020. № 7 (36). С. 34-39.

5. Calcium and vitamin-D deficiency marginally impairs fracture healing but aggravates posttraumatic bone loss in osteoporotic mice / V. Fischer, M. Haffner-Luntzer, K. Prystaz, A. Vom Scheidt, B. Busse, T. Schinke, M. Amling, A. Ignatius // Sci. Rep. 2017. Vol. 7, No 1. P. 7223. DOI: 10.1038/ s41598-017-07511-2.

6. Роль витамина D в профилактике и лечении остеопороза - новый взгляд на известную проблему / Е.А. Пигарова, А.А. Поваляева, Л.К. Дзеранова, Л.Я. Рожинская // РМЖ «Медицинское обозрение». 2019. № 10 (II). С. 102-106.

7. Патологические переломы, осложняющие остеопороз. Клинические рекомендации : ID: KP614. 2018. C. 18-35.

8. Castelo-Branco C., Dávila Guardia J. Use of ossein-hydroxyapatite complex in the prevention of bone loss: a review // Climacteric. 2015. Vol. 18, No 1. P. 29-37. DOI: 10.3109/13697137.2014.929107.

9. Efficacy and safety of ossein-hydroxyapatite complex versus calcium carbonate to prevent bone loss / C. Castelo-Branco, M.J. Cancelo Hidalgo, S. Palacios, M. Ciria-Recasens, A. Fernández-Pareja, C. Carbonell-Abella, J. Manasanch, J. Haya-Palazuelos // Climacteric. 2020. Vol. 23 , No 3. P. 252-258. DOI: 10.1080/13697137.2019.1685488.

10. The Effect of 3 versus 6 years of zoledronic acid treatment in osteoporosis: a randomized extension to the HORIZON-Pivotal Fracture Trial (PFT)/ D.M. Black, I.R. Reid, S. Boonen, C. Bucci-Rechtweg, J.A. Cauley, F. Cosman, S.R. Cummings, T.F. Hue, K. Lippuner, P. Lakatos, P.C. Leung, Z. Man, R.L. Martinez, M. Tan, M.E. Ruzycky, G. Su, R. Eastell // J. Bone Miner. Res. 2012. Vol. 27, No 2. P. 243-254. DOI: 10.1002/jbmr.1494.

11. Дедух Н.В., Поворознюк В.В. Влияние бисфосфонатов на консолидацию переломов // Боль. Суставы. Позвоночник. 2013. 12. Matos M.A., Tannuri U., Guarniero R. The effect of zoledronate during bone healing // J. Orthop. Traumatol. 2010. Vol. 11, No 1. P. 7-12. DOI: $10.1007 / \mathrm{s} 10195-010-0083-1$.

13. Mashiba T. [Morphological analysis of bone dynamics and metabolic bone disease. Histological findings in animal fracture model - effects of osteoporosis treatment drugs on fracture healing process] // Clin. Calcium. 2011. Vol. 21, No 4. P. 551-558. (in Japanese)

14. Association between timing of zoledronic acid infusion and hip fracture healing / C. Colón-Emeric, L. Nordsletten, S. Olson, N. Major, S. Boonen, P. Haentjens, P. Mesenbrink, J. Magaziner, J. Adachi, K.W. Lyles, L. Hyldstrup, C. Bucci-Rechtweg, C. Recknor; HORIZON Recurrent Fracture Trial // Osteoporos. Int. 2011. Vol. 22, No 8. P. 2329-2336. DOI: 10.1007/s00198-010-1473-1.

15. Klinische Ergebnisse nach konservativer und operativer Therapie der distalen Radiusfraktur beim älteren Patienten : Übersicht der besten verfügbaren Evidenz / C. Bartl, D. Stengel, J. Gülke, F. Gebhard // Unfallchirurg. 2016. Vol. 119, No 9. P. 723-731. DOI: 10.1007/s00113-016-0216-y.

16. Gedmintas L., Solomon D.H., Kim S.C. Bisphosphonates and risk of subtrochanteric, femoral shaft, and atypical femur fracture: a systematic review and meta-analysis // J. Bone Miner. Res. 2013. Vol. 28, No 8. P. 1729-1737. DOI: 10.1002/jbmr.1893.

17. Poor bisphosphonate adherence for treatment of osteoporosis increases fracture risk: systematic review and meta-analysis / I. Imaz, P. Zegarra, J. González-Enríquez, B. Rubio, R. Alcazar, J.M. Amate // Osteoporos. Int. 2010. Vol. 21, No 11. P. 1943-1951. DOI: 10.1007/s00198-009-1134-4.

18. Potential risks of rare serious adverse effects related to long-term use of bisphosphonates: An overview of systematic reviews / L. Lu , L. Lu , J. Zhang , J. Li // J. Clin. Pharm. Ther. 2020. Vol. 45, No 1. P. 45-51. DOI: 10.1111/jcpt.13056.

19. Комментарии к рекомендациям EULAR/EFORT по лечению пациентов старше 50 лет с низкоэнергетическими переломами и профилактике у них повторных переломов / А.Ю. Кочиш, О.М. Лесняк, И.Г. Беленький, К.Ю. Белова, Л.П. Евстигнеева, О.Б. Ершова, А.С. Богопольская // Гений ортопедии. 2019. Т. 25, № 1. С. 6-14. DOI:10.18019/1028-4427-2019-25-1-6-14.

20. Effects of Long-Term Denosumab on Bone Histomorphometry and Mineralization in Women With Postmenopausal Osteoporosis / D.W. Dempster, J.P. Brown, A. Fahrleitner-Pammer, D. Kendler, S. Rizzo, I. Valter, R.B. Wagman, X. Yin, S.V. Yue, G. Boivin // J. Clin. Endocrinol. Metab. 2018. Vol. 103, No 7. P. 2498-2509. DOI:10.1210/jc.2017-02669.

21. Efficacy and safety of denosumab vs. bisphosphonates in postmenopausal women previously treated with oral bisphosphonates / P.D. Miller, N. Pannacciulli, J. Malouf-Sierra, A. Singer, E. Czerwiński, H.G. Bone, C. Wang, S. Huang, A. Chines, W. Lems, J.P. Brown // Osteoporos. Int. 2020. Vol. 31, No 1. P. 181-191. DOI: 10.1007/s00198-019-05233-x.

22. Comparative Safety and Effectiveness of Denosumab Versus Zoledronic Acid in Patients With Osteoporosis: A Cohort Study / N.K. Choi, D.H. Solomon, T.N. Tsacogianis, J.E. Landon, H.J. Song, S.C. Kim // J. Bone Miner. Res. 2017. Vol. 32, No 3. P. 611-617. DOI:10.1002/jbmr.3019.

23. Возможности и перспективы использования препаратов двойного действия для фармакотерапии системного остеопороза у пациентов с переломами костей / А.Ю. Кочиш, С.Н. Иванов, Д.В. Стафеев, Т.Б. Минасов // Травматология и ортопедия России. 2012. Т. 18, № 2 (64). С. 99-104.

24. Systemic treatment with strontium ranelate promotes tibial fracture healing in ovariectomized rats / Y.F. Li, E. Luo, G. Feng, S.S. Zhu, J.H. Li, J. Hu // Osteoporos. Int. 2010. Vol. 21, No 11. P. 1889-1897. DOI: 10.1007/s00198-009-1140-6.

25. Strontium ranelate enhances callus strength more than PTH 1-34 in an osteoporotic rat model of fracture healing / B. Habermann, K. Kafchitsas, G. Olender, P. Augat, A. Kurth // Calcif. Tissue Int. 2010. Vol. 86, No 1. P. 82-89. DOI: 10.1007/s00223-009-9317-8.

26. Bastian D., Martiana I.K. Сравнение влияния пероральных препаратов стронция и инъекционного ибандроната на плотность кости после овариэктомии у крыс линии Вистар // Гений ортопедии. 2020 T. 26, № 2. C. 212-215. DOI: 10.18019/1028-4427-2020-26-2-212-215.

27. Возможности фармакологической коррекции постменопаузального остеопороза у пациенток с внесуставными переломами проксимального отдела бедренной кости / А.Ю. Кочиш, А.Н. Мироненко, С.А. Ласунский, Д.В. Стафеев // Травматология и ортопедия России. 2011. T. $17, \mathrm{~N}^{\circ} 2$ (60). C. $50-56$

28. Executive summary of European guidance for the diagnosis and management of osteoporosis in postmenopausal women / J.A. Kanis, C. Cooper, R. Rizzoli, J.Y. Reginster; Scientific Advisory Board of the European Society for Clinical and Economic Aspects of Osteoporosis and Osteoarthritis (ESCEO) and the Committees of Scientific Advisors and National Societies of the International Osteoporosis Foundation (IOF) // Aging Clin. Exp. Res. 2019. Vol. 31, No 1. P. 15-17. DOI: 10.1007/s40520-018-1109-4.

29. Pharmacological Therapy of Osteoporosis: What's New? /G. Iolascon, A. Moretti, G. Toro, F. Gimigliano, S. Liguori, M. Paoletta // Clin. Interv. Aging. 2020. Vol. 15. P. 485-491. DOI: 10.2147/CIA.S242038.

30. Does Teriparatide Improve Femoral Neck Fracture Healing: Results from a Randomized Placebo-controlled Trial / M. Bhandari, L. Jin, K. See, R. Burge, N. Gilchrist, R. Witvrouw, K.D. Krohn, M.R. Warner, Q.I. Ahmad, B. Mitlak // Clin. Orthop. Relat. Res. 2016. Vol. 474, No 5. P. 12341244. DOI: $10.1007 / \mathrm{s} 11999-015-4669-z$.

31. Effects of Teriparatide Compared with Risedronate on Recovery after Pertrochanteric Hip Fracture: Results of a Randomized, Active-Controlled, Double-Blind Clinical Trial at 26 Weeks / P. Aspenberg, J. Malouf, U. Tarantino, P.A. García-Hernández, C. Corradini, S. Overgaard, J.J. Stepan, L. Borris, E. Lespessailles, F. Frihagen, K. Papavasiliou, H. Petto, J.R. Caeiro, F. Marin // J. Bone Joint Surg. Am. 2016. Vol. 98, No 22. P. 1868-1878. DOI: $10.2106 / J B J S .15 .01217$.

32. Teriparatide Improves Fracture Healing and Early Functional Recovery in Treatment of Osteoporotic Intertrochanteric Fractures / T.W. Huang, P.Y. Chuang, S.J. Lin, C.Y. Lee, K.C. Huang, H.N. Shih, M.S. Lee, R.W. Hsu, W.J. Shen // Medicine (Baltimore). 2016. Vol. 95, No 19. P. e3626. DOI: $10.1097 / M D .0000000000003626$.

33. The Effect of Teriparatide on Fracture Healing of Osteoporotic Patients: A Meta-Analysis of Randomized Controlled Trials / S. Lou, H. Lv, G. Wang, L. Zhang, M. Li, Z. Li, L. Zhang, P. Tang // Biomed. Res. Int. 2016. Vol. 2016. 6040379. DOI: 10.1155/2016/6040379. 
34. Autologous bone marrow clot as an alternative to autograft for bone defect healing / Z.X.H. Lim, B. Rai, T.C. Tan, A.K. Ramruttun, J.H. Hui, V. Nurcombe, S.H. Teoh, S.M. Cool // Bone Joint Res. 2019. Vol. 8, No 3. P. 107-117. DOI: 10.1302/2046-3758.83.BJR-2018-0096.R1.

35. Demineralized Bone Matrix Add-On For Acceleration of Bone Healing in Atypical Subtrochanteric Femoral Fracture: A Consecutive Case-Control Study / N. Kulachote, P. Sa-ngasoongsong, N. Sirisreetreerux, P. Chanplakorn, P. Fuangfa, C. Suphachatwong, W. Wajanavisit // Biomed. Res. Int. 2016. Vol. 2016. 4061539. DOI: 10.1155/2016/4061539.

36. The available evidence on demineralised bone matrix in trauma and orthopaedic surgery: A systematic review / J. van der Stok, K.A. Hartholt, D.A.L. Schoenmakers, J.J.C. Arts // Bone Joint Res. 2017. Vol. 6, No 7. P. 423-432. DOI: 10.1302/2046-3758.67.BJR-2017-0027.R1.

37. Calcei J.G., Rodeo S.A. Orthobiologics for Bone Healing // Clin. Sports Med. 2019. Vol. 38, No 1. P. 79-95. DOI: 10.1016/j.csm.2018.08.005.

38. Clinical effectiveness of Osigraft in long-bones non-unions / G.M. Calori, M. Colombo, M. Bucci, E.L. Mazza, P. Fadigati, S. Mazzola // Injury. 2015. Vol. 46, No Suppl 8. P. S55-S64. DOI: 10.1016/S0020-1383(15)30056-5.

39. Klenke F.M., Siebenrock K.A. Osteology in Orthopedics - Bone Repair, Bone Grafts and Bone Graft Substitutes // Ref. Modul. Biomed. Sci., Elsevier. 2016. P. 1-15. DOI: 10.1016/B978-0-12-801238-3.99488-1.

40. Recombinant human bone morphogenetic protein-2: a randomized trial in open tibial fractures treated with reamed nail fixation / H.T. Aro, S. Govender, A.D. Patel, P. Hernigou, A. Perera de Gregorio, G.I. Popescu, J.D. Golden, J. Christensen, A. Valentin // J. Bone Joint Surg. Am. 2011. Vol. 93, No 9. P. 801-808. DOI: 10.2106/JBJS.I.01763.

41. Efficacy and safety of recombinant human bone morphogenetic protein-2/calcium phosphate matrix for closed tibial diaphyseal fracture: a doubleblind, randomized, controlled phase-II/III trial / T. Lyon, W. Scheele, M. Bhandari, K.J. Koval, E.G. Sanchez, J. Christensen, A. Valentin, F. Huard // J. Bone Joint Surg. Am. 2013. Vol. 95, No 23. P. 2088-2096. DOI: 10.2106/JBJS.L.01545.

42. A local application of recombinant human fibroblast growth factor 2 for tibial shaft fractures: a randomized, placebo-controlled trial / H. Kawaguchi, H. Oka, S. Jingushi, T. Izumi, M. Fukunaga, K. Sato, T. Matsushita, K. Nakamura; TESK Group // J. Bone Miner. Res. 2010. Vol. 25, No 12. P. 27352743. DOI: $10.1002 / j b m r .146$.

43. Копылов В.А., Миханов В.А., Сафронов А.А. Лечение открытых переломов с помощью метаболитов Васillus subtilis 804, содержащих фактор роста фибробластов // Гений ортопедии. 2016. № 2. С. 78-83. DOI: 10.18019/1028-4427-2016-2-78-83.

44. Recombinant human platelet-derived growth factor-BB and beta-tricalcium phosphate (rhPDGF-BB/ $\beta$-TCP): an alternative to autogenous bone graft / C.W. DiGiovanni, S.S. Lin, J.F. Baumhauer, T. Daniels, A. Younger, M. Glazebrook, J. Anderson, R. Anderson, P. Evangelista, S.E. Lynch; North American Orthopedic Foot and Ankle Study Group // J. Bone Joint Surg. Am. 2013. Vol. 95, No 13. P. 1184-1192. DOI: 10.2106/JBIS.K.01422.

45. VEGFA from Early Osteoblast Lineage Cells (Osterix+) is Required in Mice for Fracture Healing / E.G. Buettmann, J.A. McKenzie, N. Migotsky, D.A. Sykes, P. Hu, S. Yoneda, M.J. Silva // J. Bone Miner. Res. 2019. Vol. 34, No 9. P. 1690-1706. DOI: 10.1002/jbmr.3755.

46. Инновационные методы оптимизации регенерации кости: мезенхимальные стволовые клетки (сообщение 2) (обзор литературы) / Н.А. Корж, П.М. Воронцов, И.В. Вишнякова, Е.М. Самойлова // Ортопедия, травматология и протезирование. 2018. № 1 (610). С. 105-116. DOI: 10.15674/0030-598720181105-116.

47. Bridging the gap: bone marrow aspiration concentrate reduces autologous bone grafting in osseous defects / M. Jäger, M. Herten, U. Fochtmann, J. Fischer, P. Hernigou, C. Zilkens, C. Hendrich, R. Krauspe // J. Orthop. Res. 2011. Vol. 29, No 2. P. 173-180. DOI: 10.1002/jor.21230.

48. Влияние A-PRP-терапии на репаративную регенерацию костной ткани при свежих переломах костей конечностей / A.Н. Блаженко, И.А. Родин, О.Н. Понкина, М.Л. Муханов, А.С. Самойлова, А.А. Веревкин, В.В. Очкась, Р.Р. Алиев // Инновационная медицина Кубани. 2019. № 3 (15). C. 32-38. DOI: 10.35401/2500-0268-2019-15-3-32-38.

49. Role of autologous platelet-rich plasma in treatment of long-bone nonunions: a prospective study / R. Malhotra, V. Kumar, B. Garg, R. Singh, V. Jain, P. Coshic, K. Chatterjee // Musculoskelet. Surg. 2015. Vol. 99, No 3. P. 243-248. DOI: 10.1007/s12306-015-0378-8.

50. Platelet-rich plasma versus exchange intramedullary nailing in treatment of long bone oligotrophic nonunions / A. Duramaz, H.T. Ursavaş, M.G. Bilgili, A. Bayrak, B. Bayram, M.C. Avkan // Eur. J. Orthop. Surg. Traumatol. 2018. Vol. 28, No 1. P. 131-137. DOI: 10.1007/s00590-017-2024-7.

51. Efficacy of autologous platelet-rich plasma use for orthopaedic indications: a meta-analysis / U. Sheth, N. Simunovic, G. Klein, F. Fu, T.A. Einhorn, E. Schemitsch, O.R. Ayeni, M. Bhandari // J. Bone Joint Surg. Am. 2012. Vol. 94, No 4. P. 298-307. DOI: 10.2106/JBJS.K.00154.

52. Перспективы локального применения антирезорбтивных препаратов при повреждениях и заболеваниях костей скелета / С.С. Родионова, М.В. Лекишвили, Е.Д. Склянчук, А.Н. Торгашин, А.Ю. Рябов, Ю.Б. Юрасова // Вестник травматологии и ортопедии им. Н.Н. Приорова. 2014. Т. 21 , № 4 . С. $83-89$.

53. Местное применение бисфосфонатов при металлоостеосинтезе. Краткий литературный обзор / М.В. Лекишвили, Е.Д. Склянчук, А.Ю. Рябов, Ю.Б. Юрасова, А.А. Очкуренко // Технологии живых систем. 2014. Т. 11, № 1. С. 46-54.

54. Изучение характера распределения солей лютеция и изменений в органах и тканях крыс после их введения / Д.А. Масленникова, С.М. Слесарев, Е.В. Слесарева, А.И. Харин, О.В. Столбовская, А.В. Хохлова, Е.С. Погодина, Д.А. Зажома, С.Н. Ворсина, Ю.В. Саенко // Ульяновский медико-биологический журнал. 2017. № 2. С. 135-143. DOI: 10.23648/UMBJ.2017.26.6228.

55. Рентгеноморфологические параллели остеорегенеративного процесса при использовании препарата на основе этиндронатов ионов лантаноидов / И.Ф. Ахтямов, Е.А. Житлова, Д.Э. Цыплаков, С.В. Бойчук, Ф.В. Шакирова, Д.А. Коробейникова // Политравма. 2017 . № 4. С. 16-22.

56. Рукк Н.С., Апрышко Г.Н., Скрябина А.Ю. Перспективность создания противоопухолевых лекарств на основе координационных соединений элементов IIIB - группы // Российский биотерапевтический журнал. 2014. Т. 13, № 2. С. 47-50.

57. Качесова Е.С., Шевченко Е.А., Успенская О.А. Новая схема комплексного лечения агрессивных форм пародонтита // Современные технологии в медицине. 2017. Т. 9, № 4. С. 209-216. DOI: 10.17691/stm2017.9.4.26

58. Комплексный подход к изучению препарата, содержащего этидронаты ионов лантаноидов и кальция, in vitro и in vivo / С.В. Бойчук, Е.А. Житлова, Ф.В. Шакирова, Д.Э. Цыплаков, И.Ф. Ахтямов, Ф.В. Девятов, Б.Р. Рамазанов, Р.Х. Закиров // Гений ортопедии. 2019. Т. 25, № 4. C. 561-568. DOI: 10.18019/1028-4427-2019-25-4-561-56.

59. Влияние компонентов на основе ионов лантаноидов и кальция на плотность костной ткани при переломе бедренной кости у животных И.Ф. Ахтямов, Ф.В. Шакирова, Д.А. Коробейникова, Хао Чжи Хань, Р.И. Садыков // Травматология и ортопедия России. 2020. Т. 26 , № 1. C. 138-146. DOI: 10.21823/2311-2905-2020-26-1-138-146.

60. Comparative Morphometric Analysis of Healing Bone Fractures under the Influence of the Preparation Based on Etidronate Without Lanthanoid Ions and in Conjuction with Them / D.E Tsyplakov, F.V. Shakirova, I.F. Akhtyamov, D.A. Korobeynikova, R.I. Sadykov // BioNanoScience. 2020. Vol. 10, No 4. P. 1143-1151. DOI: 10.1007/s12668-020-00769-3.

61. Изменения показателей крови у животных при введении в зону перелома бедренной кости компонентов на основе ионов лантаноидов и кальция в эксперименте / И.Ф. Ахтямов, Ф.В. Шакирова, Д.А. Коробейникова, Х.Ч. Хань, Е.И. Сидорук // Гений ортопедии. 2020. Т. 26, № 2. C. 228-233. DOI: $10.18019 / 1028-4427-2020-26-2-228-233$.

Статья поступила в редакцию 28.12.2020; одобрена после рецензирования 24.02.2021; принята к публикации 23.12.2021.

The article was submitted 28.12.2020; approved after reviewing 24.02.2021; accepted for publication 23.12.2021.

Информация об авторах:

1. Рустем Ильгизович Садыков - rustiksadykov@mail.ru;

2. Ильдар Фуатович Ахтямов - доктор медицинских наук, професcop, yalta60@mail.ru

\section{Information about the authors:}

1. Rustem I. Sadykov - M.D., rustiksadykov@mail.ru;

2. Ildar F. Akhtyamov - Doctor of Medical Sciences, Professor, yalta60@mail.ru 
Гений ортопедии. 2022. Т. 28, № 1. С. 123-132.

Genij Ortopedii. 2022. Vol. 28, no. 1. P. 123-132.

\title{
Обзорная статья
}

УДК 577.112:616.71-004.8-06:616.74-003.974-08(048.8)

https://doi.org/10.18019/1028-4427-2022-28-1-123-132

\section{Гетеротопическая оссификация как побочный эффект применения рекомбинантных человеческих костных морфогенетических белков}

\section{У.Ф. Мухаметов ${ }^{1}$, С.В. Люлин ${ }^{2}$, Д.Ю. Борзунов ${ }^{3}$, И.Ф. Гареев ${ }^{4 \rrbracket}$, О.А. Бейлерли ${ }^{6}$, А.А. Суфианов ${ }^{4,5}$}

\author{
${ }^{1}$ Республиканская клиническая больница им. Г.Г. Куватова, Уфа, Россия \\ 2 Медицинский центр Кармель, Челябинск, Россия \\ ${ }^{3}$ Уральский государственный медицинский университет, Екатеринбург, Россия \\ ${ }^{4}$ Федеральный центр нейрохирургии, Тюмень, Россия \\ 5 Первый Московский государственный медицинский университет им. И.М. Сеченова, Москва, Россия \\ ${ }^{6}$ Башкирский государственный медицинский университет, Уфа, Россия
}

Автор, ответственный за переписку: Ильгиз Фанилевич Гареeв, ilgiz_gareev@mail.ru

Аннотация

Введение. Гетеротопическая оссификация (ГО), также известная как оссифицирующий миозит, параостеоартопатия и гетеротопическая кальцификация, среди прочего, является часто встречающимся патологическим состоянием, которое относится к эктопическому образованию кости в мягких тканях. Хотя не до конца понятным остаётся молекулярный механизм ГО, считается, что передача сигналов костных морфогенетических белков (BMPs) играет ключевую роль в общем процессе ГО. На сегодняшний день уже активно используются в клинической практике рекомбинантный человеческий BMP-2 (rhBMP-2) и рекомбинантный человеческий BMP-7 (rhBMP-7) в восстановлении костных дефектов. Однако, несмотря на положительные стороны использования rhBMPs, имеется ряд побочных эффектов, одним из которых является ГО. Цель. В данной работе мы продемонстрируем случаи ГО после использования rhBMPs как в клинических, так и в доклинических исследованиях; попытаемся объяснить связь между сигнальными путями BMPs и процессом ГО, а также возможности предотвращения и лечения процесса ГО. Материалы и методы. Используя базы данных PubMed, Embase, базу данных Кокрановской библиотеки (Сосһrane Database) и Google Scholar, мы провели всесторонний поиск оригинальных работ, обзоров литературы, клинических случаев и метаанализов, демонстрирующих причинно-следственную связь между применением rhBMPs в терапевтических целях и ГО как осложнением. Результаты. В данной обзорной статье проанализированы возможности терапевтического применения rhBMPs в нейрохирургии и травматологии и ортопедии как в клинических, так и в доклинических исследованиях. В частности, эти исследования подтверждают, что формирование эктопической кости является одним из побочных эффектов после применения rhBMPs. Кроме того, освещены молекулярные механизмы процесса ГО, а также возможности современных методов профилактики и лечения ГО. Заключение. Согласно базе данных FDA по безопасности применения rhBMP-2 и rhBMP-7, частота нежелательных эффектов в виде ГО колеблется от 1 до 10 \%. Тем не менее, на сегодняшний день клиническое применение rhBMP-2 и rhBMP-7 оправдано, особенно когда отсутствуют альтернативные заменители костного трансплантата.

Ключевые слова: гетеротопическая оссификация, рекомбинантный, костные морфогенетические белки, механизм, лечение

Для цитирования: Гетеротопическая оссификация как побочный эффект применения рекомбинантных человеческих костных морфогенетических белков / У.Ф. Мухаметов, С.В. Люлин, Д.Ю. Борзунов, И.Ф. Гареев, О.А. Бейлерли, А.А. Суфианов // Гений ортопедии. 2022 . Т. 28 № 1. С. 123-132. https://doi.org/10.18019/1028-4427-2022-28-1-123-132

\section{Review article}

\section{Heterotopic ossification as a side effect of the use of recombinant human bone morphogenetic proteins U.F. Mukhametov ${ }^{1}$, S.V. Lyulin ${ }^{2}$, D.Yu. Borzunov ${ }^{3}$, I.F. Gareev ${ }^{4}$, O.A. Beylerli ${ }^{6}$, A.A. Sufianov ${ }^{4,5}$}

\author{
${ }^{1}$ Kuvatov Republican Clinical Hospital, Ufa, Russian Federation \\ 2 Medical Center Carmel, Chelyabinsk, Russian Federation \\ ${ }^{3}$ Ural State Medical University, Ekaterinburg, Russian Federation \\ ${ }^{4}$ Federal Center of Neurosurgery, Tyumen, Russian Federation \\ ${ }^{5}$ Sechenov First Moscow State Medical University, Moscow, Russian Federation \\ ${ }^{6}$ Bashkir State Medical University, Ufa, Russian Federation
}

Corresponding author: Ilgiz F. Gareev, ilgiz_gareev@mail.ru

Abstract

Introduction Heterotopic ossification (HO), also known as myositis ossification, paraosteoarthropathy, or heterotopic calcification, among others, is a common pathological condition that refers to ectopic bone formation in soft tissues. Although the molecular mechanism of $\mathrm{HO}$ is not fully understood, it is believed that signaling of bone morphogenetic proteins (BMPs) plays a key role in the overall process of HO. Today, recombinant human BMP-2 (rhBMP-2) and recombinant human BMP-7 (rhBMP-7) have been already actively used in clinical practice in the treatment of bone defects. However, despite the positive sides of using rhBMPs, there are a number of side effects, one of which is HO. Purpose In this study, we demonstrate cases of HO following the use of rhBMPs in both clinical and preclinical studies and make an attempt to explain the relationship between the signaling pathways of BMPs and the HO process, as well as the possibilities of preventing and treating the HO process. Materials and methods PubMed, Embase, the Cochrane Database, and Google Scholar were comprehensively searched for original articles, literature reviews, case reports, and meta-analyses demonstrating a causal relationship between therapeutic rhBMPs and HO as a complication. Results This review analyzes the potential for therapeutic use of rhBMPs in neurosurgery and traumatology and orthopedics, demonstrated by both clinical and preclinical studies. In particular, the studies confirm that ectopic bone formation is one of the side effects following administration of rhBMPs. Moreover, the molecular mechanisms of the HO process were highlighted, and the possibilities of modern methods of prevention and treatment of HO were discussed. Conclusion According to the FDA safety database for rhBMPs, the rates of adverse effects related to HO range from $1 \%$ to $10 \%$. However, to date, the clinical use of rhBMPs is justified, especially when there are no alternative substitutes for bone grafting.

Keywords: heterotopic ossification, recombinant, bone morphogenetic proteins, mechanism, treatment

For citation: Mukhametov U.F., Lyulin S.V., Borzunov D.Yu., Gareev I.F., Beylerli O.A., Sufianov A.A. Heterotopic ossification as a side effect of the use of recombinant human bone morphogenetic proteins. Genij Ortopedii, 2022, vol. 28, no 1, pp. 123-132. https://doi.org/10.18019/1028-44272022-28-1-123-132 


\section{ВВЕДЕНИЕ}

Гетеротипическая оссификация (ГО), также известная как оссифицирующий миозит, параостеоартопатия и гетеротопическая кальцификация - это образование эктопической пластинчатой кости в мягких тканях [1]. Если говорить о приобретённой ГО, то данный патологический процесс является осложнением травм центральной нервной системы (ЦНС), повреждений мягких тканей при ожогах, травмах или хирургических вмешательствах [1]. Знания о молекулярных механизмах, которые приводят к образованию ГО, и клеткахпредшественниках, участвующих в этом процессе, все еще ограничены. Различные популяции клеток-предшественников могут быть возможными предвестниками развития ГО. Исследования in vivo показывают, что клетки-предшественники могут варьировать в зависимости от подтипа ГО. Данные исследования демонстрируют, что эндотелиальные клетки (ЭК), мезенхимальные стволовые клетки (МСК) и перициты, присутствующие в поперечно-полосатой мускулатуре, сухожилиях и соединительной ткани, или даже циркулирующие стволовые клетки / клетки-предшественники могут быть источником развития ГО $[1,2]$. Также известно, что травма, которая приводит к местной воспалительной реакции, активирует определённые сигнальные пути, участвующие непосредственно в развитии ГО. К тому же, недавние исследования in vitro и in vivo доказали роль клеток иммунной системы, особенно моноцитов / макрофагов, на ранних стадиях развития ГО $[2,3]$. В частности, эти исследования подтверждают важность моноцитов / макрофагов в индукции нейрогенных и генетических форм ГО. Ак- тивированные моноциты / макрофаги экспрессируют остеоиндуктивные сигнальные факторы в ходе ГО (рис. 1). Таким образом, присутствие клеток отражает повышенную секрецию факторов роста, цитокинов / хемокинов, стимулирующих ГО, таких как интерлейкины (IL-6 и IL-10), трансформирующий фактор роста бета-1 (TGF- $\beta 1$ ), нейротрофин 3 (NT3) и костные морфогенетические белки (BMPs) (BMP-2, 4 и 7) [4, 5].

Одним из наиболее мощных остеоиндуктивных факторов роста являются многофункциональные цитокины, принадлежащие к суперсемейству TGF- $\beta$, а именно BMPs. BMPs оказывают значительное остеоиндуктивное воздействие на различные стадии процесса заживления костей после травм, такие как воспалительная реакция, ангиогенез, образование мягкой и твердой мозоли и ремоделирование кости [6]. Как было показано в доклинических и клинических исследованиях, применение рекомбинантных человеческих костных морфогенетических белков (rhBMPs) обеспечивает образование кости de novo, ускоряет время восстановления костной ткани после травм и предотвращает несращение или отсроченное сращение [7]. Например, одно из обоснований их использования при открытых переломах основано на концепции, согласно которой ускорение регенерации костной ткани и предотвращение несращений снизят частоту осложнений и уменьшат потребность в повторных хирургических вмешательствах [8]. Помимо того, что BMPs обладают остеоиндуктивными свойствами, существуют научные исследования с доказательством того, что BMPs могут стимулировать ангиогенез [7].

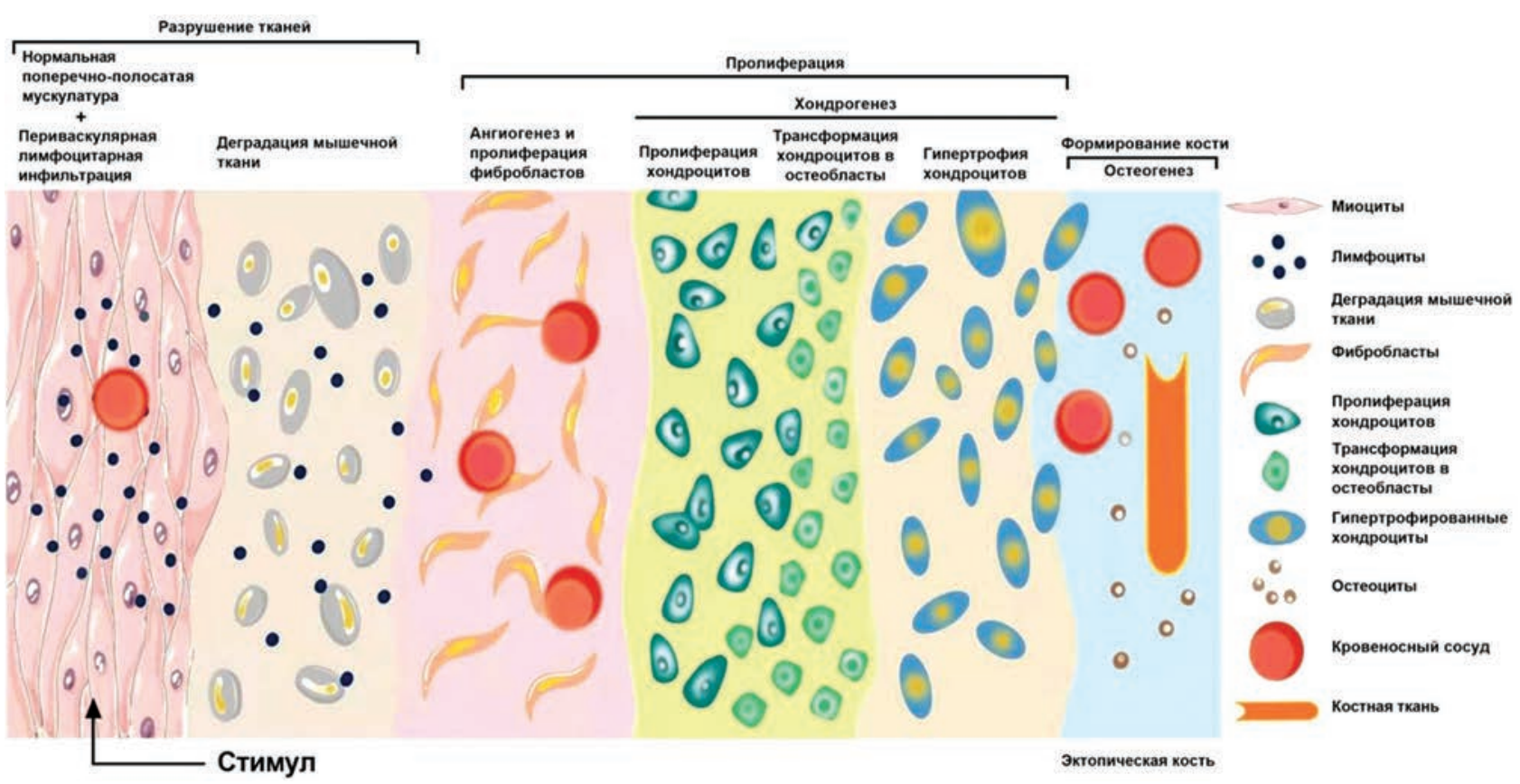

Рис. 1. Схематическое изображение стадии процесса гетеротопической оссификации (ГО). Формирование эктопической кости можно разделить на три стадии: 1) под воздействием различных стимулов или факторов происходит скопление большого количества периваскулярных лимфоцитов за счет преодоления сосудистого барьера и их миграции в раннюю область ГО в пределах поперечнополосатой мускулатуры, что сопровождается разрушением соединительнотканной структуры; 2) пролиферация клеток соединительной ткани с разрушением поперечнополосатой мускулатуры с высвобождением воспалительных медиаторов, которые, в свою очередь, стимулируют фиброплазию и ангиогенез; 3) прослеживается синтез ряда факторов роста, индуцирующих остеогенез, которые вызывают образование и дифференцировку мезенхимальных стволовых клеток (МСК) в хондроциты и остеобласты в локальном воспалительном микроокружении. Результатом этих процессов дифференциации является образование эктопической кости в области повреждения ткани (авторский рисунок) 
Однако, несмотря на значительные положительные эффекты rhBMPs, их широкое использование в практической медицине ограничено из-за ряда недостатков: быстрая деградация, высокая стоимость производства, необходимость применения в высоких дозах, остеолиз и ГО. В данной работе мы продемонстрируем слу- чаи ГО после использования rhBMPs как в клинических, так и в доклинических исследованиях. В дополнение к этому мы попытаемся объяснить связь между сигнальными путями BMPs и процессом ГО, а также возможности предотвращения возникновения ГО после применения rhBMPs.

\section{МАТЕРИАЛЫ И МЕТОДЫ}

Мы провели всесторонний поиск оригинальных работ, обзоров литературы, клинических случаев и метаанализов, демонстрирующих причинно-следственную связь между применением rhBMPs в терапевтических целях и ГО как осложнением. Базы данных, включая PubMed, Embase, базу данных Кокрановской библиотеки (Cochrane Database) и Google Scholar, были использованы для получения всех соответствующих исследований в период август-сентябрь 2021 года. Ключевые слова, включая «костные морфогенетические белки» или «рекомбинантные костные морфогенетические белки», или «факторы роста», или «семейство TGF- $\beta$ », «гетеротопическая оссификация» или «эктопическая кость», или «оссифицирующий миозит», или «патоморфология», или «осложнения» и «клинические исследования», или «доклинические исследования», или «терапия и профилактика», или «молекулярный механизм», или «побочный эффект». Кроме того, выполнялся поиск в списке литературы каждого соответствующего исследования для выявления других актуальных работ. Блок-схема систематического обзора представлена на рисунке 2.

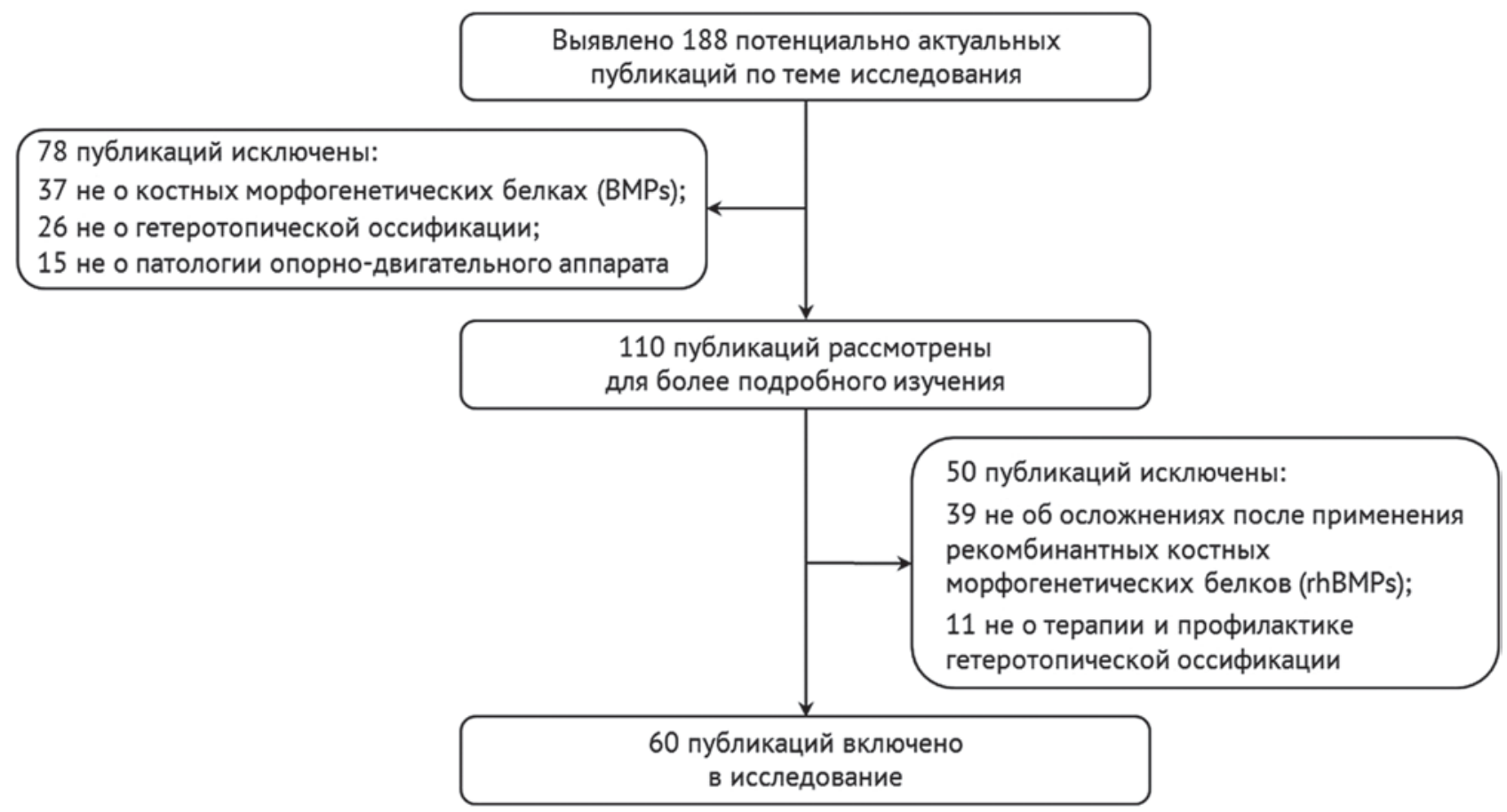

Рис. 2. Блок-схема систематического обзора

\section{РЕЗУЛЬТАТЫ И ОБСУЖДЕНИЕ}

\section{BMРs и ГО}

Местный воспалительный процесс приводит к миграции, размножению и дифференцировке множества типов клеток, включая клетки-предшественники [2]. Однако молекулярный механизм, лежащий в основе процесса различных форм ГО, до сих пор полностью не изучен. Считается, что популяция клеток-предшественников, индуктивные факторы роста и благоприятная среда могут способствовать ГО. Хорошо известно, что дифференцировке клеток-предшественников по хондрогенному пути и эндохондральному окостенению способствуют различные факторы, включая передачу сигналов BMPs и факторы транскрипции [8].
Согласно теории Kan и др., вероятно, существует один консервативный механизм, участвующий одновременно во многих типах ГО [9]. Более того, недавние данные предполагают вероятность центральной роли BMPs в патогенезе ГО, наряду с другими факторами роста и факторами транскрипции, участвующими в перекрестном взаимодействии между нижестоящими сигнальными путями BMPs [10].

BMPs является членом суперсемейства TGF- $\beta$, которые необходимы для эмбрионального развития и поддержания тканевого гомеостаза. ВМР-индуцированное костеобразование происходит не только в нормальных условиях, но и при патоло- 
гических процессах. Повышенная передача сигналов BMPs, вызванная дефектом ауторегулирующей петли, уже была подтверждена в лимфоцитах пациентов с ГО [11]. Более того, высокие уровни ВМР-2 и ВМР-7 наблюдались в сыворотке крови пациентов после травм ЦНС [12, 13]. Также экспрессия ВМР-2, 4, 7 и 9 была значительно увеличена в животных моделях ГО, вызванной повреждением спинного мозга [14]. BMP-2, 4, 7 и 9 следует рассматривать как одних из основных кандидатов BMPs в патофизиологии ГО. Лиганды BMPs передают сигнал через тетрамерный комплекс рецепторов типа I и типа II. Было идентифицировано семь рецепторов типа I (Активин-рецептор-подобная киназа 1-7 (ALK1-7)), среди которых BMPs преимущественно связывается с ALK 1, 2, 3 и 6. Как только лиганды связываются с рецепторами костного морфогенетического белка типа II (рецептор активина A типа II (ACVR2A или Act 2A) и рецептор активина 2B типа II (ACVR2B или Act 2B)), они трансфосфорилируют друг друга с активацией киназы рецепторов типа I, где в последующем активированные киназы рецепторов I типа фосфорилируют R-Smads (Smad 1, Smad 5 и Smad 8), чтобы вызвать образование комплекса со Smad 4. Впоследствии комплекс перемещается в ядро клетки, где активирует экспрессию целевого гена (рис. 3) [6, 15]. Таким образом, широко признано, что нарушение регуляции передачи сигналов BMPs ведет к ГО.

\section{2. Дозирование и носители}

Было высказано предположение, что высокие дозы вводимых rhBMPs могут привести к формированию эктопической кости [16-18]. Во всех проведенных клинических испытаниях диапазон дозирования rhBMР сильно варьирует. Считается, что ГО может быть вызвана супрафизиологическими дозами rhBMPs, которые должны использоваться у людей для эффективного лечения, чтобы преодолеть короткий период полувыведения BMPs и быстрый их клиренс in vivo ( 6-7 мин.) [19]. Например, Boraiah и др. сообщили о высоком риске образования ГО при лечении сложных переломов большеберцовой кости с использованием высоких доз rhBMP-2 [20]. Клинические дозы rhBMP-2 обычно могут варьировать от 0,1 до 0,5 мг/кг массы тела, хотя также сообщалось о применении таких высоких доз как 1 мг/кг массы тела [21]. Представленные в таблице 1 дозы применения rhBMPs в клинических исследованиях в основном составляли от 1,4 до 12 мг [16-18, 22-28]. Результаты некоторых из этих работ представляют доказательства того, что положительный результат может быть достигнут при использовании низких доз rhBMPs, и предполагают, что этим обусловлен более низкий показатель частоты осложнений ГО. Однако ограничения существующих исследований значительны и не позволяют сделать однозначных выводов о дозозависимых осложнениях в виде формирования эктопической кости при использовании rhBMPs.

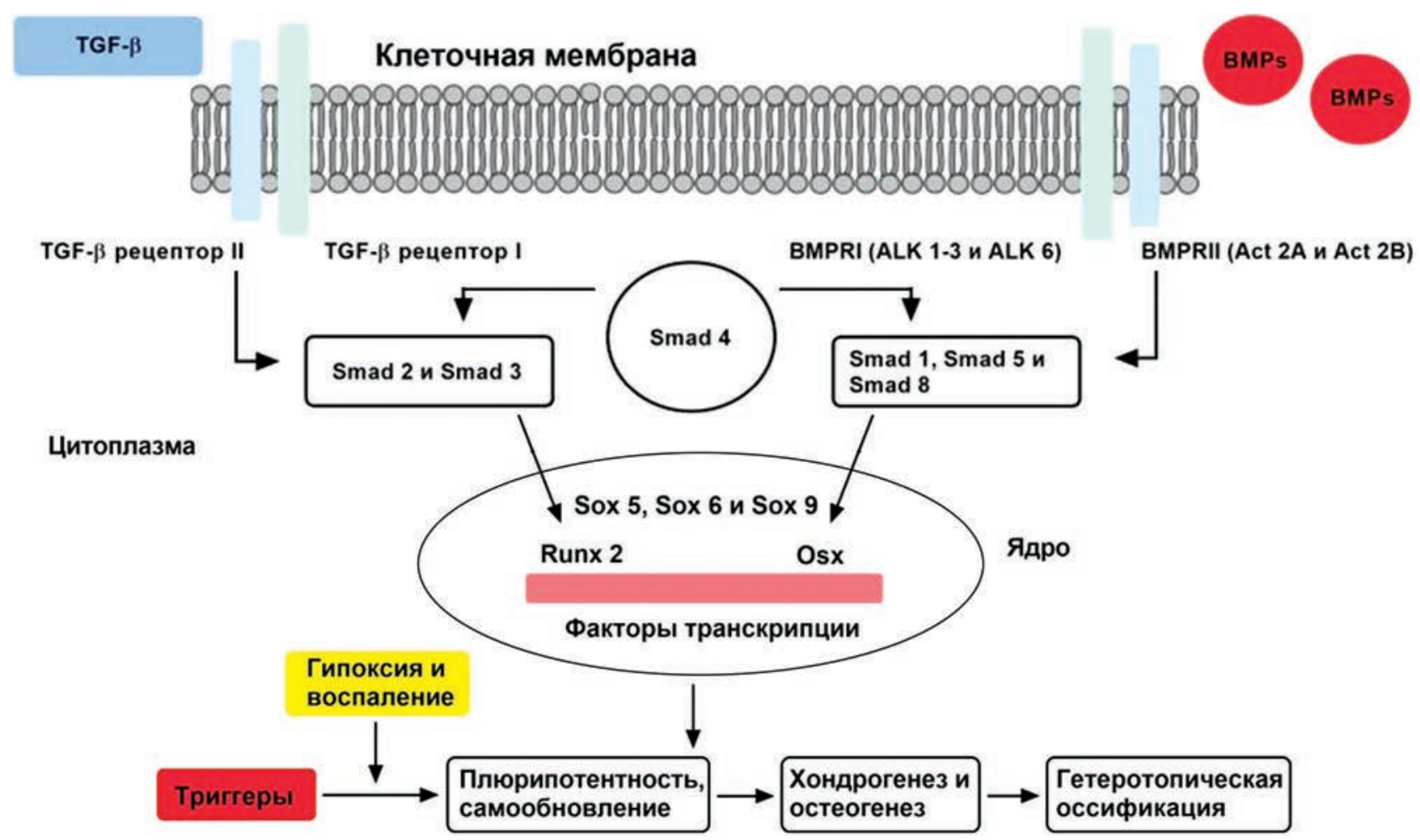

Рис. 3. Регуляция сигнального пути BMP / TGF- $\beta$ / Smad при гетеротопической оссификации. Сигнальный путь BMP / TGF- $\beta$ инициируется тетрамерным комплексом рецепторов типа I и типа II. Как только лиганды связываются с рецепторами типа II, они трансфосфорилируют друг друга и активируют киназы рецепторов типа I с последующим фосфорилированием комплекса R-Smads (Smad 1 , Smad 2, Smad 3, Smad 5 и Smad 8) co Smad 4. Комплексы перемещаются в ядро, где они привлекают факторы транскрипции для регулирования экспрессии генов-мишеней. Путь передачи сигналов BMРs участвует в общем развитии гетеротопической оссификации, включая воспаление и гипоксию. BMPs, костные морфогенетические белки; TGF- $\beta$, трансформирующий фактор роста- $\beta$; ALK, активин-рецептор-подобная киназа; Sox, SRY-бокс транскрипционный фактор; BMPR I, рецептор костного морфогенетического белка типа I; BMPR II, рецептор костного морфогенетического белка типа II; Runx 2, связанный с Runt фактор транскрипции 2; Оsх, остерикс; Act, актин (авторский рисунок) 
Таблица 1

Применение рекомбинантных костных морфогенетических белков (rhBMPs) в клинической практике с последующим развитием гетеротопической оссификации (по данным литературы)

\begin{tabular}{|c|c|c|c|c|c|c|c|c|}
\hline rhBMPs & Процедура & $\begin{array}{c}\text { Дизайн } \\
\text { исследования }\end{array}$ & $\begin{array}{c}\text { Количество } \\
\text { пациентов, n }\end{array}$ & $\begin{array}{c}\text { Дозировка, } \\
\text { мг }\end{array}$ & Носитель & $\begin{array}{c}\text { Успешность } \\
\text { процедуры, } \\
\text { n (\%) } \\
\end{array}$ & $\begin{array}{c}\text { Гетеротопическая } \\
\text { оссификация, } \mathrm{n} \\
(\%) \\
\end{array}$ & $\begin{array}{c}\text { № } \\
\text { источника }\end{array}$ \\
\hline rhBMP-2 & PLIF & $\begin{array}{l}\text { Рандомизированное } \\
\text { проспективное } \\
\text { многоцентровое } \\
\text { исследование }\end{array}$ & 34 & $4-8$ & $\begin{array}{l}\text { Абсорбируемая } \\
\text { коллагеновая } \\
\text { губка }\end{array}$ & $31(92)$ & $26(75)$ & 16 \\
\hline rhBMP-2 & TLIF и PLIF & $\begin{array}{l}\text { Проспективное } \\
\text { обсервационное } \\
\text { исследование }\end{array}$ & 23 & 4.2 & $\begin{array}{l}\text { Абсорбируемая } \\
\text { коллагеновая } \\
\text { губка }\end{array}$ & $23(100)$ & $5(21)$ & 22 \\
\hline rhBMP-2 & PLIF & $\begin{array}{l}\text { Проспективное } \\
\text { обсервационное } \\
\text { исследование }\end{array}$ & 17 & 12 & $\begin{array}{l}\text { Абсорбируемая } \\
\text { коллагеновая } \\
\text { губка }\end{array}$ & 17 (100) & $1(6)$ & 23 \\
\hline rhBMP-2 & PLIF & $\begin{array}{l}\text { Проспективное } \\
\text { обсервационное } \\
\text { исследование }\end{array}$ & 30 & 1,4 & $\begin{array}{l}\text { Абсорбируемая } \\
\text { коллагеновая } \\
\text { губка }\end{array}$ & $29(97)$ & $2(7)$ & 24 \\
\hline rhBMP-2 & TLIF & $\begin{array}{l}\text { Ретроспективное } \\
\text { когортное } \\
\text { исследование }\end{array}$ & 933 & 1,0 & $\begin{array}{l}\text { INFUSE } \\
\text { (Medtronic) }\end{array}$ & $863(92,5)$ & $125(13,5)$ & 25 \\
\hline rhBMP-2 & $\begin{array}{l}\text { Лечение дефекта } \\
\text { вертлужной } \\
\text { впадины при } \\
\text { ревизионном } \\
\text { эндопротезировании } \\
\text { тазобедренного } \\
\text { сустава }\end{array}$ & $\begin{array}{l}\text { Клинический } \\
\text { случай }\end{array}$ & 1 & 2,8 & - & $1(100)$ & $1(100)$ & 17 \\
\hline rhBMP-2 & $\begin{array}{l}\text { Остеонекроз } \\
\text { головки бедренной } \\
\text { кости }\end{array}$ & $\begin{array}{l}\text { Ретроспективное } \\
\text { когортное } \\
\text { исследование }\end{array}$ & 46 & 4 & - & $38(83,3)$ & $8(17,3)$ & 18 \\
\hline rhBMP-7 & $\begin{array}{l}\text { Лечение несращений } \\
\text { длинных трубчатых } \\
\text { костей }\end{array}$ & $\begin{array}{l}\text { Ретроспективное } \\
\text { когортное } \\
\text { исследование }\end{array}$ & 84 & 3,3 & $\begin{array}{l}\text { Бычий } \\
\text { коллаген I типа }\end{array}$ & $68(80,9)$ & $15(17,8)$ & 26 \\
\hline $\begin{array}{l}\text { rhBMР-2 и } \\
\text { rhBMP-7 }\end{array}$ & $\begin{array}{l}\text { Лечение острых } \\
\text { переломов и } \\
\text { отсроченного } \\
\text { сращения }\end{array}$ & $\begin{array}{l}\text { Серия клинических } \\
\text { случаев }\end{array}$ & 4 & $\begin{array}{c}\text { По } \\
\text { протоколу } \\
\text { продукта }\end{array}$ & Infuse и ОР-1 & $4(100)$ & $4(100)$ & 27 \\
\hline rhBMP-7 & $\begin{array}{l}\text { Лечение } \\
\text { несращения } \\
\text { дистального отдела } \\
\text { плечевой кости }\end{array}$ & $\begin{array}{l}\text { Клинический } \\
\text { случай }\end{array}$ & 1 & 3,5 & OP-1 & $1(100 \%)$ & $1(100 \%)$ & 28 \\
\hline
\end{tabular}

Аббревиатуры: PLIF - задний поясничный межтеловой спондилодез; TLIF - трансфораминальный поясничный межтеловой спондилодез; rhBMP - рекомбинантный человеческий костный морфогенетический белок; OP-1 - остеогенный белок- 11.

Текущий стандартный носитель - абсорбируемая коллагеновая губка, которая доставляет rhBMPs посредством физической абсорбции белка на материале имплантата. Тем не менее, это ограничено “взрывным” высвобождением и просачиванием белков за пределы предполагаемого места имплантации [29]. Поэтому данные супрафизиологические дозы rhBMPs обусловили возникновение осложнений в виде ГО, упомянутых ранее [22-24]. Недавно было показано, что новые носители на основе полиэлектролитных комплексов (PECs), включающих гепарин на поверхности альгинатных микрогранул, изготовленных с использованием принципа послойной самосборки полиэлектролита, доставляют rhBMP-2 контролируемым образом и значительно снижают выброс белка [30]. Например, в своей работе Wang и др. продемонстрировали, что полиэлектролитный комплекс на основе гепарина в качестве материала-носителя для rhBMP-2 продемонстрировал способность минимизировать образование ГО за счет снижения эффективной дозы в животной модели спондилодеза [31]. Результаты этого исследования показывают, что альгинатные микрогранулы, функционализированные гепарином, могут представить новую возможность для поиска эффективного носителя rhBMP-2 с меньшими осложнениями и стоимостью. С молекулярной точки зрения известно, что несколько эндогенных факторов роста, включая BMPs, существуют в компартменте внеклеточного матрикса посредством секвестрации (или прочного нековалентного закрепления) отрицательно заряженных высокосульфатированных гепариноподобных гликозаминогликанов. Таким образом сохраняется биологическая активность BMPs. Следуя этой модели хранения и регуляции, многие исследования in vitro и in vivo продемонстрировали, что ключевые молекулы гликозаминогликанов, такие как гепарин и гепарансульфат, могут использоваться для модуляции биологической активности различных экзогенных факторов роста, включая BMPs $[32,33]$.

Тем самым, минимально инвазивные методы нанесения rhBMPs, низкие их концентрации и использование современных носителей для BMPs могут снизить риск образования эктопической кости.

\section{3. Клинические исследования}

RhBMP-7 и rhBMP-2, также известные по торговым маркам как остеогенный белок-1 (OP-1) и INFUSE, одобрены Управлением по контролю за продуктами и лекарствами США (FDA) и нашли своё применение в клинической практике. Одним из побочных эффектов, связанных с использованием rhBMP-2 и rhBMP-7, является образование эктопической кости [34]. Оче- 
видно, что множество неостеобластных клеток подвергается остеогенному программированию при воздействии BMPs, включая миобласты, адипоциты и фибробласты. По оценкам, образование эктопической кости в клинических исследованиях происходит почти в шесть раз чаще, чем у контрольной группы (группа с применением аллотрансплантантов без использования rhBMPs). Оценка с помощью компьютерной томографии показала образование эктопической кости у 70,1 \% пациентов, которым вводили rhBMP-2, по сравнению с 12,9 \% пациентов, которым не вводили rhBMP-2 [35]. Например, при операциях на позвоночнике распространение rhBMPs за пределы имплантатов может происходить в эпидуральное пространство и приводить к формированию в мягких тканях эктопической кости с последующей компрессией корешков периферических нервов. При этом частота послеоперационного радикулита может составлять 14,0 \% по сравнению с 3,0 \% в контрольных группах [35]. Кроме того, производители rhBMP-2 и rhBMP-7 рекомендует соблюдать некоторые меры предосторожности при манипуляциях с продуктом rhBMP / абсорбируемая коллагеновая губка, чтобы минимизировать экстравазацию BMPs. Согласно инструкциям коммерческих продуктов кампании Medtronic по rhBMP-2 и rhBMP-7, крайне важно избегать «использования орошения или аспирации рядом с имплантатом» и «чрезмерного сдавливания смоченной губки» [34]. В таблице 1 приведены клинические исследования по использованию rhBMP-2 и rhBMP-7 при ортопедических операциях, осложнившихся ГО [1618, 22-28].

\section{4. Стандартные методы профилактики и лече-} ния ГО

Лечение ГО можно разделить на действия, направленные преимущественно на профилактику заболевания, и действия, направленные на ликвидацию уже сформировавшейся ГО. В случае профилактики обычно используют фармакологическое лечение и лучевую терапию. В фармакологической профилактике наиболее часто используются ингибиторы циклооксигеназы-2 (Сoх2) и нестероидные противовоспалительные препараты (НПВП), обе группы препаратов воздействуют на провоспалительные простагландины [36]. Традиционные НПВП, такие как аспирин, ибупрофен и индометацин, подавляют образование как физиологических, так и воспалительных простагландинов. Ингибиторы Coх2 в первую очередь подавляют воспалительные простагландины и оставляют физиологические простагландины относительно нетронутыми [36]. Предполагается, что воспалительные простагландины являются мощными регуляторами, наряду с BMPs, формирования оссификатов [2]. Ингибиторы Cox2 и НПВП, помимо воздействия на воспалительные простагландины, могут подавлять миграцию и пролиферацию индуцибельных МСК [37]. На животной модели ГО, индуцированной ВМР-деминерализованным костным матриксом, ингибиторы Cox2 и НПВП эффективно ослабляли эктопическое образование кости, ингибируя синтез воспалительных простагландинов [38]. Однако ингибиторы Cox2 и НПВП продемонстрировали минимальный эффект остановки или задержки роста эктопической кости. Большинство специалистов согласны с тем, что индометацин - лучший выбор среди НПВП не только для предотвращения ГО, но и для замедления процесса развития ГО [39]. Однако использование НПВП было ограничено из-за побочных явлений, таких как язвенная болезнь, снижение агрегации тромбоцитов и почечная недостаточность. Длительный прием НПВП увеличивает риск развития сердечнососудистых заболеваний, а также замедляет заживление переломов [40]. Ранее профилактика ГО с применением ингибиторов Сох2 и НПВП широко применялась после тотального эндопротезирования и артроскопии тазобедренного сустава, черепно-мозговых травм, травм спинного мозга и т.д. [36].

Бисфосфонаты подавляют ремоделирование костей и оказывают свое основное действие, сокращая продолжительность жизни остеокластов. Бисфосфонаты используются для лечения многочисленных заболеваний костей, при которых разрушение (резорбция) костей превышает их образование, таких как остеопороз, несовершенный остеогенез и онкология. Была доказана эффективность применения этидроната натрия в лечении ГО после травм спинного мозга. Этидронат натрия подавляет минерализацию остеоидов, связывается с фосфатом кальция и предотвращает кристаллизацию гидроксиапатита [41].

Лучевая терапия (рентгенотерапия) является еще одним эффективным методом профилактики ГО. Считается, что лучевая терапия предотвращает образование и/или прогрессирование ГО путем ингибирования дифференцировки МСК или остеопрогениторных клеток [42]. В частности, исследования in vitro продемонстрировали, что лучевая терапия подавляет передачу сигналов ВМР-2, снижает пролиферацию и дифференцировку остеобластов и способствует их апоптозу [43]. В первоначальном доклиническом исследовании взрослым крысам с имплантированным деминерализованным костным матриксом проводили облучение в периоде 2, 4, 6, 8, 10 и 12 дней после имплантации [44]. Было выявлено, что у крыс формировалась эктопическая кость через 11 дней после имплантации. При этом было отмечено, что крысы, подвергшиеся облучению через 2 и 4 дня после имплантации, имели снижение объема ГО на 60 и 24 \% соответственно. Однако, когда облучение было отложено до 8 дней после имплантации, авторы не наблюдали разницы в объеме ГО между облученными крысами и контрольной группой. В нескольких исследованиях сообщалось о положительных эффектах лучевой терапии для профилактики ГО после ЧМТ и травм спинного мозга. Например, в одном из клинических исследований фазы I/II у 33 пациентов с ГО после травмы спинного мозга, прошедших лучевую терапию, не наблюдалось дальнейшего роста эктопической кости, однако у трех пациентов подвижность суставов была незначительно нарушена [45]. При этом возможный побочный эффект, который клиницисты должны учитывать - это канцерогенез. Однако на сегодняшний день нет задокументированных случаев радиационно-индуцированных опухолей после лучевой терапии для профилактики ГО. Считается, что отсутствие опухолей связано с низкой дозировкой радиации. 
Еще одно серьезное осложнение лучевой терапии - это замедление регенерации костной ткани, а именно, несращение переломов. Согласно отчету исследования Morcos и др., нарушение восстановления переломов костей можно увидеть в 12-30 \% случаев после лучевой терапии [46].

В настоящее время хирургическая резекция является единственным эффективным методом лечения ГО. Однако рекомендуется рассматривать операцию только в том случае, если пациенты с ГО соответствуют следующим критериям: (1) значительное уменьшение диапазона движений из-за анкилоза суставов; (2) отсутствие острого воспалительного ответа; (3) наличие зрелого гетеротопического оссификата (достаточно минерализован), чтобы его можно было удалить [47, 48]. Тем не менее, при выборе срока хирургического вмешательства следует учитывать и несколько других факторов. Предыдущие исследования показали, что для снижения риска рецидива хирургическое удаление предпочтительнее после полной минерализации эктопической кости [49]. Однако за последнее десятилетие в ведении больных с ГО произошел сдвиг в сторону более ранней резекции эктопической кости, то есть хирургическое вмешательство проводится, как только пациент становится достаточно стабильным, и поражение достаточно минерализовано, чтобы сделать возможным резекцию [50]. Кроме того, недавние результаты клинических исследований свидетельствуют о том, что раннее иссечение эктопической кости может снизить риск операционных осложнений (например, периоперационный перелом) или уменьшить негативные изменения со стороны нервно-мышечного аппарата (например, атрофию мышц) [50]. Однако резекция эктопической кости связана с рядом осложнений. Например, полное удаление околосуставного оссификата является особенно проблематичным, поскольку пациенты часто остаются со стойким уменьшением диапазона движений. Как и любые другие инвазивные процедуры, резекция эктопической кости связана с потенциальной кровопотерей во время хирургического вмешательства и возможными инфекционными осложнениями в постоперационном периоде. Более того, хирургическое удаление может повредить прилегающие периферические ткани [51]. Таким образом, хирургическое вмешательство не является оптимальной терапией ГО и должно быть тщательно продумано.

5. Новые потенциальные методы профилактики

\section{и лечения ГО}

В настоящее время в разработке наиболее эффективных препаратов по профилактике и лечению ГО проводятся исследования по изучению экспрессии сигнальных молекул BMP-Smad [2]. Препараты, нацеленные на решение данной проблемы, включают, среди прочего, агонисты рецепторов ретиноевой кислоты (RAR), антагонисты BMPs и вещества, влияющие на фосфорилирование Smad. Кроме того, изучается профилактический эффект антиоксидантов и акцепторов (поглотителей) свободных радикалов.

$\mathrm{RAR}$, представленный в трех формах (RAR $\alpha, \operatorname{RAR} \beta$ и RAR $\gamma$ ), является мощным ингибитором хондрогенеза. Стимуляция этого рецептора достигается за счет использования его агонистов: неселективной активной формы витамина А и селективного агониста RAR $\gamma$, блокирующих хондрогенез in vitro [52]. Однако блокирование RAR $\alpha$ и RAR $\beta$ не влияет на процесс хондрогенеза. Агонист RAR $\gamma$ паловаротен показал свою эффективность в предотвращении начальных стадий ГО in vitro и in vivo [53]. Паловаротен значительно замедляет процесс ГО, ингибируя рост и дифференцировку клеток остеопрогениторов в хондроциты [53]. Кроме того, было обнаружено, что терапия паловаротином подавляет экспрессию SRY-бокс транскрипционного фактора 9 (Sox-9) и коллагена $2 \alpha 1$ у хондроцитов и экспрессию остеокальцина, остеопоэтина, ВМР-2, BMP-4, POU класса 5 гомебокса 1 (POU5FL) и связанного с Runt фактора транскрипции 2 (RUNX2) у остеобластов. Также было доказано, что введение агонистов RAR $\gamma$ приводит к снижению передачи сигналов BMPs за счет снижения фосфорилирования Smad 1, Smad 5, Smad 8 и, возможно, с их деструкцией в протеасомах. Этот эффект может сохраняться и навсегда ингибировать дифференцировку МСК в клетки с остеогенным потенциалом [54, 55].

Другая стратегия, направленная на путь BMP-Smad, которая может быть полезной для профилактики ГО это снижение уровня фосфора, доступного в форме аденозинтрифосфата (АТФ) или аденозиндифосфата (АДФ). Как было уже сказано, фосфорилирование Smad 1, Smad 5 и Smad 8 приводит к ингибированию дифференцировки МСК в клетки с остеогенным потенциалом [55]. Результаты исследований in vitro и in vivo на моделях ГО, где ГО была результатом ожога, показывают, что местное применение апиразы, гидролизующей АТФ и АДФ, снижает вероятность формирования эктопической кости. Более того, в группе, где использовалась апираза, не наблюдалось остеопении [56]. Кроме того, антагонисты рецептора BMPs представляют собой группу веществ, которые обладают потенциалом ингибирования образования ГО. Например, LDN-193189 (мощный ингибитор сигнальных путей BMPs, ингибирующий ALK 1, 2, 3 и 6) ингибирует экспрессию BMP-1 и эффективно снижает дифференцировку МСК в остеобласты на мышиной модели ГО [57].

Другой антагонист BMPS, Noggin (NOG), также может быть рассмотрен в качестве профилактики ГО. В одном из исследований была продемонстрирована доставка NOG в клетку с использованием вирусного вектора, где NOG эффективно подавлял экспрессию BMP-4 и, тем самым, процесс ГО [58]. Однако из-за потенциальных побочных эффектов разработанные ингибиторы BMPs до сих пор не имеют достаточного безопасного профиля действия для использования в клинических испытаниях на людях.

Недавние исследования связывают образование эктопической кости не только с воспалением, но и с ангиогенными факторами, высвобождающимися во время гипоксии тканей. Доказано, что фармакологическое ингибирование фактора, индуцируемого гипоксией 1-альфа (HIF-1 $\alpha$ ) в клетках, взятых у людей с прогрессирующей оссифицирующей фибродисплазией, снижает передачу сигналов BMPs. Также в модели ГО in vivo с активным рецептором активина А типа I 
(ACVR1) фармакологическое ингибирование HIF-1 $\alpha$ ингибирует процесс ГО. Фармакологическое ингиби- рование HIF-1 $\alpha$ с использованием $\mathrm{PX}-478$ или рапамицина также значительно замедлило процесс ГО [59, 60]

\section{ЗАКЛЮЧЕНИЕ}

BMPs обладают многообещающим потенциалом в восстановлении дефектов кости после травм благодаря их превосходной остеидуктивной способности. Однако, как и в случаях с другими факторами роста, их доставка должна быть оптимизирована с точки зрения вводимой дозы и локализации в зоне дефекта для повышения эффективности и уменьшения побочных эффектов, связанных с плейотропным действием BMPs при их присутствии в системном кровотоке. Особое беспокойство вызывают результаты недавних клинических исследований, демонстрирующие формирование эктопической кости, связанное с применением rhBMP-2 и rhBMP-7 при ортопедических операциях. Согласно базе данных по безопасности коммерческих продуктов
rhBMP-2 и rhBMP-7, частота нежелательных эффектов в виде ГО колеблется от 1 до $10 \%$. Тем не менее, на сегодняшний день клиническое применение rhBMP-2 и rhBMP-7 оправдано, особенно когда отсутствуют альтернативные заменители костного трансплантата. Несмотря на множество исследований, которые уже были выполнены за последние десятилетия, дальнейшее изучение BMPs позволит лучше оценить долгосрочные результаты, выявить новые альтернативные носители и изучить рентабельность применения rhBMP в клинической практике. Наконец, мы хотели бы подчеркнуть, что лучшее понимание процесса ГО поможет клиницистам в ее профилактике и лечении, в том числе после применения rhBMPs.

\section{СПИСОК ИСТОчНИКОВ}

1. Гареев И.Ф., Бейлерли О.А., Вахитов А.К. Гетеротопическая оссификация после травм центральной нервной системы: понимание патогенеза // Вестник травматологии и ортопедии им. Н.Н. Приорова. 2018. T. 25, № 3-4. C. 119-124. URL: https://doi.org/10.17116/vto201803041119.

2. The traumatic bone: trauma-induced heterotopic ossification / D. Dey, B.M. Wheatley, D. Cholok, S. Agarwal, P.B. Yu, B. Levi, T.A. Davis // Transl. Res. 2017. Vol. 186. P. 95-111. DOI: 10.1016/j.trsl.2017.06.004.

3. Lees-Shepard J.B., Goldhamer D.J. Stem cells and heterotopic ossification: lessons from animal models // Bone. 2018. Vol. 109. P. 178-186. DOI: 10.1016/j.bone.2018.01.029.

4. Bioinformatics Analysis of the Molecular Mechanism of Late-Stage Heterotopic Ossification / Q. Zhang, Y. Zhang, M. Yan, K. Zhu, D. Zhou, J. Tan // Biomed. Res. Int. 2020. Vol. 2020. 5097823. DOI: 10.1155/2020/5097823.

5. Potential genes and pathways associated with heterotopic ossification derived from analyses of gene expression profiles / Z. Yang, D. Liu, R. Guan, X. Li, Y. Wang, B. Sheng // J. Orthop. Surg. Res. 2021. Vol. 16, No 1. P. 499. DOI: 10.1186/s13018-021-02658-1.

6. Bone morphogenetic protein receptor signal transduction in human disease / M.C. Gomez-Puerto, P.V. Iyengar, A. García de Vinuesa, P. Ten Dijke, G. Sanchez-Duffhues // J. Pathol. 2019. Vol. 247, No 1. P. 9-20. DOI: 10.1002/path.5170.

7. Herford A.S. The use of recombinant human bone morphogenetic protein-2 (rhBMP-2) in maxillofacial trauma // Chin. J. Traumatol. 2017. Vol. 20, No 1. P. 1-3. DOI: 10.1016/j.cjtee.2016.05.004.

8. The effect of bone morphogenetic protein 2 composite materials combined with cannulated screws in treatment of acute displaced femoral neck fractures / H. Gao, D. Xing, Z. Liu, J. Zheng, Z. Xiong, M. Gong, L. Liu // Medicine (Baltimore). 2020. Vol. 99, No 6. P. e18976. DOI: 10.1097/ MD.0000000000018976.

9. Conserved signaling pathways underlying heterotopic ossification / C. Kan, L. Chen, Y. Hu, N. Ding, H. Lu, Y. Li, J.A. Kessler, L. Kan // Bone. 2018. Vol. 109. P. 43-48. DOI: 10.1016/j.bone.2017.04.014.

10. Challenges of heterotopic ossification - Molecular background and current treatment strategies / P. Łęgosz, K. Drela, Ł. Pulik, S. Sarzyńska, P. Małdyk // Clin. Exp. Pharmacol. Physiol. 2018. Vol. 45, No 12. P. 1229-1235. DOI: 10.1111/1440-1681.13025.

11. Rifas L. T-cell cytokine induction of BMP-2 regulates human mesenchymal stromal cell differentiation and mineralization // J. Cell. Biochem. 2006. Vol. 98, No 4. P. 706-714. DOI: 10.1002/jcb.20933.

12. Local expression and role of BMP-2/4 in injured spinal cord / Z.S. Cui, P. Zhao, C.X. Jia, H.J. Liu, R. Qi, J.W. Cui, J.H. Cui, Q. Peng, B. Lin, Y.J. Rao // Genet. Mol. Res. 2015. Vol. 14, No 3. P. 9109-9117. DOI: 10.4238/2015.

13. Neuroprotective effects of bone morphogenetic protein 7 (BMP7) treatment after spinal cord injury / J.P. de Rivero Vaccari, A. Marcillo, D. Nonner, W.D. Dietrich, R.W. Keane // Neurosci. Lett. 2009. Vol. 465, No 3. P. 226-229. DOI: 10.1016/j.neulet.2009.09.013.

14. Novel mouse model of spinal cord injury-induced heterotopic ossification / H. Kang, A.B. Dang, S.K. Joshi, B. Halloran, R. Nissenson, X. Zhang, J. Li, H.T. Kim, X. Liu // J. Rehabil. Res. Dev. 2014. Vol. 51, No 7. P. 1109-1118. DOI: 10.1682/JRRD.2014.01.0019.

15. Bone morphogenetic proteins in fracture repair / I. Dumic-Cule, M. Peric, L. Kucko, L Grgurevic, M. Pecina, S. Vukicevic // Int. Orthop. 2018. Vol. 42, No 11. P. 2619-2626. DOI: 10.1007/s00264-018-4153-y.

16. Posterior lumbar interbody fusion using recombinant human bone morphogenetic protein type 2 with cylindrical interbody cages / R.W. Haid Jr., C.L. Branch Jr., J.T. Alexander, J.K. Burkus // Spine J. 2004. Vol. 4, No 5. P. 527-538; discussion P. 538-539. DOI: 10.1016/j.spinee.2004.03.025.

17. Arzeno A., Wang T., Huddleston J.I. 3rd. Abundant heterotopic bone formation following use of rhBMP-2 in the treatment of acetabular bone defects during revision hip arthroplasty // Arthroplast. Today. 2018. Vol. 4, No 2. P. 162-168. DOI: 10.1016/j.artd.2017.12.004.

18. Heterotopic ossification related to the use of recombinant human BMP-2 in osteonecrosis of femoral head / L. Shi, W. Sun, F. Gao, L. Cheng, Z. Li // Medicine (Baltimore). 2017. Vol. 96, No 27. P. e7413. DOI: 10.1097/MD.0000000000007413.

19. A novel mouse model of trauma induced heterotopic ossification / X. Liu, H. Kang, M. Shahnazari, H Kim, L. Wang, O. Larm, L. Adolfsson, R. Nissenson, B. Halloran // J. Orthop. Res. 2014. Vol. 32, No 2. P. 183-188. DOI: 10.1002/jor.22500.

20. Complications of recombinant human BMP-2 for treating complex tibial plateau fractures: a preliminary report / S. Boraiah, O. Paul, D. Hawkes, M. Wickham, D.G. Lorich // Clin. Orthop. Relat. Res. 2009. Vol. 467, No 12. P. 3257-3262. DOI: 10.1007/s11999-009-1039-8.

21. Synergistic Effect of NELL-1 and an Ultra-Low Dose of BMP-2 on Spinal Fusion / L. Liu, W.M.R. Lam, M. Naidu, Z. Yang, M. Wang, X. Ren, T. Hu, R .Kumarsing, K. Ting, J.C. Goh, H.K. Wong // Tissue Eng. Part. A. 2019. Vol. 25, No 23-24. P. 1677-1689. DOI: 10.1089/ten. TEA.2019.0124.

22. Joseph V., Rampersaud Y.R. Heterotopic bone formation with the use of rhBMP2 in posterior minimal access interbody fusion: a CT analysis // Spine (Phila Pa 1976). 2007. Vol. 32, No 25. P. 2885-2890. DOI: 10.1097/BRS.0b013e31815b7596.

23. Posterior lumbar interbody fusion using rhBMP-2 / H.J. Meisel, M. Schnöring, C. Hohaus, Y. Minkus, A. Beier, T. Ganey, U. Mansmann // Eur. Spine J. 2008. Vol. 17, No 12. P. 1735-1744. DOI: 10.1007/s00586-008-0799-2.

24. Mannion R.J., Nowitzke A.M., Wood M.J. Promoting fusion in minimally invasive lumbar interbody stabilization with low-dose bone morphogenic protein-2 - but what is the cost? // Spine J. 2011. Vol. 11, No 6. P. 527-533. DOI: 10.1016/j.spinee.2010.07.005. 
25. Evaluation of Heterotopic Ossification after using Recombinant Human Bone Morphogenetic Protein-2 in Transforaminal Lumbar Interbody Fusion: A Computed Tomography Review of 996 Disc Levels / S. Niu, A.T. Anastasio, R.R. Faraj, J.M. Rhee // Global Spine J. 2020. Vol. 10, No 3. P. 280-285. DOI: 10.1177/2192568219846074.

26. Heterotopic ossification after the use of recombinant human bone morphogenetic protein-7 / M. Papanagiotou, Z.H. Dailiana, T Karachalios, S Varitimidis, M. Hantes, G. Dimakopoulos, M. Vlychou, K.N. Malizos // World J. Orthop. 2017. Vol. 8, No 1. P. 36-41. DOI: 10.5312/wjo.v8.i1.36.

27. Heterotopic ossification after the use of commercially available recombinant human bone morphogenetic proteins in four patients / T.W. Axelrad, B. Steen, D.W. Lowenberg, W.R. Creevy, T.A. Einhorn // J. Bone Joint Surg. Br. 2008. Vol. 90, No 12. P. 1617-1622. DOI: 10.1302/0301-620X.90 B12.20975.

28. Wysocki R.W., Cohen M.S. Ectopic ossification of the triceps muscle after application of bone morphogenetic protein-7 to the distal humerus for recalcitrant nonunion: a case report // J. Hand Surg. Am. 2007. Vol. 32, No 5. P. 647-650. DOI: 10.1016/j.jhsa.2007.03.001.

29. Spagnoli D., Choi C. Extraction socket grafting and buccal wall regeneration with recombinant human bone morphogenetic protein-2 and acellular collagen sponge // Atlas Oral Maxillofac. Surg. Clin. North. Am. 2013. Vol. 21, No 2. P. 175-183. DOI: 10.1016/j.cxom.2013.05.003.

30. Zhang Y., Sun T., Jiang C. Biomacromolecules as carriers in drug delivery and tissue engineering // Acta Pharm. Sin. B. 2018. Vol. 8, No 1. P. 3450. DOI: $10.1016 /$ j.apsb.2017.11.005.

31. Minimizing the Severity of rhBMP-2-induced inflammation and heterotopic ossification with a polyelectrolyte carrier incorporating heparin on microbead templates / M. Wang, S.A. Abbah, T. Hu, S.Y. Toh, R.W. Lam, J.C. Goh, H.K. Wong // Spine (Phila Pa 1976). 2013. Vol. 38, No 17. P. 1452-1458. DOI: 10.1097/BRS.0b013e31828a3504.

32. Design of hydrogels to stabilize and enhance bone morphogenetic protein activity by heparin mimetics / S. Kim, Z.K. Cui, P.J. Kim, L.Y. Jung, M. Lee // Acta Biomater. 2018. Vol. 72. P. 45-54. DOI: 10.1016/j.actbio.2018.03.034.

33. Heparan sulfate deficiency leads to hypertrophic chondrocytes by increasing bone morphogenetic protein signaling / K. Kawashima, H. Ogawa, S. Komura, T. Ishihara, Y. Yamaguchi, H. Akiyama, K. Matsumoto // Osteoarthritis Cartilage. 2020. Vol. 28, No 11. P. 1459-1470. DOI: 10.1016/j. joca.2020.08.003.

34. Lykissas M., Gkiatas I. Use of recombinant human bone morphogenetic protein-2 in spine surgery // World J. Orthop. 2017. Vol. 8, No 7. P. 531535. DOI: 10.5312/wjo.v8.i7.531.

35. Complications associated with the use of the recombinant human bone morphogenetic proteins for posterior interbody fusions of the lumbar spine / J. Chrastil, J.B. Low, P.G. Whang, A.A. Patel// Spine (Phila Pa 1976). 2013. Vol. 38, No 16. P. E1020-E1027. DOI: 10.1097/BRS.0b013e3182982f8e.

36. The prophylaxis and treatment of heterotopic ossification following lower limb arthroplasty / T.N. Board, A. Karva, R.E. Board, A.K. Gambhir, M.L. Porter // J. Bone Joint Surg. Br. 2007. Vol. 89, No 4. P. 434-440. DOI: 10.1302/0301-620X.89B4.18845.

37. COX-2 inhibitors for the prevention of heterotopic ossification after THA / G.I. Vasileiadis, I.C. Sioutis, A.F. Mavrogenis, K. Vlasis, G.C. Babis, P.J. Papagelopoulos // Orthopedics. 2011. Vol. 34, No. 6. P. 467. DOI: 10.3928/01477447-20110427-23.

38. Zhu X.T., Chen L., Lin J.H. Selective COX-2 inhibitor versus non-selective COX-2 inhibitor for the prevention of heterotopic ossification after total hip arthroplasty: A meta-analysis // Medicine (Baltimore). 2018. Vol. 97, No 31. P. e11649. DOI: 10.1097/MD.0000000000011649.

39. Wentworth K.L., Masharani U., Hsiao E.C. Therapeutic advances for blocking heterotopic ossification in fibrodysplasia ossificans progressiva // Br. J. Clin. Pharmacol. 2019. Vol. 85, No 6. P. 1180-1187. DOI: 10.1111/bcp.13823.

40. Treatment methods for post-traumatic elbow stiffness caused by heterotopic ossification / C.E. Freibott, H.C. Bäcker, S.C. Shoap, L.J. Tedesco, S.E. Galle, M.P. Rosenwasser // J. Shoulder Elbow Surg. 2020. Vol. 29, No 7. P. 1380-1386. DOI: 10.1016/j.jse.2020.02.026.

41. History of etidronate / N.B. Watts, C.H. Chesnut 3rd, H.K. Genant, S.T. Harris, R.D. Jackson, A.A. Licata, P.D. Miller, W.J. Mysiw, B. Richmond, D. Valent // Bone. 2020. Vol. 134. P. 115222. DOI: 10.1016/j.bone.2020.115222.

42. Radiotherapy for the prophylaxis of heterotopic ossification after total hip arthroplasty: A systematic review and meta-analysis of randomized controlled trails / Z.H. Hu, W. Chen, J.N. Sun, Y. Zhang, Y. Zhang, X.Y. Chen, S. Feng // Med. Dosim. 2021. Vol. 46, No 1. P. 65-73. DOI: 10.1016/j. meddos.2020.07.010.

43. Radiation-induced suppression of the Bmp2 signal transduction pathway in the pluripotent mesenchymal cell line C2C12: an in vitro model for prevention of heterotopic ossification by radiotherapy / F. Pohl, S. Hassel, A. Nohe, M. Flentje, P. Knaus, W. Sebald, O. Koelbl // Radiat. Res. 2003. Vol. 159, No 3. P. 345-350. DOI: 10.1667/0033-7587(2003)159[0345:risotb]2.0.co;2.

44. Craven P.L., Urist M.R. Osteogenesis by radioisotope labelled cell populations in implants of bone matrix under the influence of ionizing radiation // Clin. Orthop. Relat. Res. 1971. Vol. 76. P. 231-243. DOI: 10.1097/00003086-197105000-00030.

45. Sautter-Bihl M.L., Liebermeister E., Nanassy A. Radiotherapy as a local treatment option for heterotopic ossifications in patients with spinal cord injury // Spinal Cord. 2000. Vol. 38, No 1. P. 33-36. DOI: 10.1038/sj.sc.3100847.

46. Morcos M., Smith K., Tanzer M. The effect of late radiotherapy on the progression of heterotopic ossification following total hip arthroplasty // Eur. J. Orthop. Surg. Traumatol. 2018. Vol. 28, No 6. P. 1125-1131. DOI: 10.1007/s00590-018-2185-z.

47. Romero-Muñoz L.M., Barriga-Martín A., DeJuan-García J. Surgical treatment of hip ankylosis due to heterotopic ossification secondary to spinal cord injury // Rev. Esp. Cir. Ortop. Traumatol. (Engl. Ed). 2018. Vol. 62, No 6. P. 458-466. DOI: 10.1016/j.recot.2018.01.003.

48. Treatment methods for post-traumatic elbow stiffness caused by heterotopic ossification / C.E. Freibott, H.C. Bäcker, S.C. Shoap, L.J. Tedesco, S.E. Galle, M.P. Rosenwasser // J. Shoulder Elbow Surg. 2020. Vol. 29. No 7. P. 1380-1386. DOI: 10.1016/j.jse.2020.02.026.

49. A Surgical Protocol for Management of Post Traumatic Heterotopic Ossification of Elbow / D. Jayamaraju, A.S. Sarkar, S.K. Patra, S.K. Palanivelayutham, S. Rajasekaran // Indian J. Orthop. 2021. Vol. 55, No 4. P. 898-906. DOI: 10.1007/s43465-021-00381-x.

50. Heterotopic ossification on the volar surface of the distal radius in a child with fibrodysplasia ossificans progressiva: challenges in surgical excision of a rare condition / E. Sirin, E. Okay, T. Khalilov, K. Turkoz, B. Erol, C. Tetik // Hand Surg. Rehabil. 2021. Vol. 40, No 2. P. 194-197. DOI: 10.1016/j.hansur.2020.11.011.

51. Surgical resection of heterotopic bone about the elbow: an institutional experience with traumatic and neurologic etiologies / K. Baldwin, H.S. Hosalkar, D.J. Donegan, N. Rendon, M. Ramsey, M.A. Keenan // J. Hand Surg. Am. 2011. Vol. 36, No 5. P. 798-803. DOI: 10.1016/j.jhsa.2011.01.015.

52. Galdones E., Hales B.F. Retinoic acid receptor gamma-induced misregulation of chondrogenesis in the murine limb bud in vitro // Toxicol. Sci. 2008. Vol. 106, No 1. P. 223-232. DOI: 10.1093/toxsci/kfn169.

53. Palovarotene reduces heterotopic ossification in juvenile FOP mice but exhibits pronounced skeletal toxicity / J.B. Lees-Shepard, S.E. Nicholas, S.J. Stoessel, P.M. Devarakonda, M.J. Schneider, M. Yamamoto, D.J. Goldhamer // Elife. 2018. Vol. 7. P. e40814. DOI: 10.7554/eLife.40814.

54. Chondrocyte phenotype and ectopic ossification in collagenase-induced tendon degeneration/ P.P. Lui, S.C. Fu, L.S. Chan, L.K. Hung, K.M. Chan // J. Histochem. Cytochem. 2009. Vol. 57, No 2. P. 91-100. DOI: 10.1369/jhc.2008.952143.

55. Potent inhibition of heterotopic ossification by nuclear retinoic acid receptor- $\gamma$ agonists / K. Shimono, W.E. Tung, C. Macolino, A.H. Chi, J.H. Didizian, C. Mundy, R.A. Chandraratna, Y. Mishina, M. Enomoto-Iwamoto, M. Pacifici, M. Iwamoto // Nat. Med. 2011. Vol. 17, No 4. P. 454460. DOI: $10.1038 / \mathrm{nm} .2334$.

56. Liang O.D., Reginato A.M., Medici D. Apyrase as a novel therapeutic inhibitor of heterotopic ossification // Ann. Transl. Med. 2015. Vol. 3, No Suppl. 1. P. S32. DOI: 10.3978/j.issn.2305-5839.2015.03.45.

57. BMP type I receptor inhibition reduces heterotopic [corrected] ossification / P.B. Yu, D.Y. Deng, C.S. Lai, C.C. Hong, G.D. Cuny, M.L. Bouxsein, D.W. Hong, P.M. McManus, T. Katagiri, C. Sachidanandan, N. Kamiya, T. Fukuda, Y. Mishina, R.T. Peterson, K.D. Bloch // Nat. Med. 2008. Vol. 14, No 12. P. 1363-1369. DOI: 10.1038/nm.1888.

58. Retroviral delivery of Noggin inhibits the formation of heterotopic ossification induced by BMP-4, demineralized bone matrix, and trauma in an animal model / D. Hannallah, H. Peng, B. Young, A. Usas, B. Gearhart, J. Huard // J. Bone Joint Surg. Am. 2004. Vol. 86, No 1. P. 80-91. DOI: 10.2106/00004623-200401000-00013. 


\section{Обзор литературы}

59. ACVR1R206H FOP mutation alters mechanosensing and tissue stiffness during heterotopic ossification / J. Haupt, A. Stanley, C.M. McLeod, B.D. Cosgrove, A.L. Culbert, L. Wang, F. Mourkioti, R.L. Mauck, E.M. Shore // Mol. Biol. Cell. 2019. Vol. 30, No 1. P. 17-29. DOI: 10.1091/mbc. E18-05-0311.

60. Huang Y., Wang X., Lin H. The hypoxic microenvironment: a driving force for heterotopic ossification progression // Cell Commun. Signal. 2020. Vol. 18, No 1. P. 20. DOI: 10.1186/s12964-020-0509-1.

Статья поступила в редакцию 03.12.2021; одобрена после рецензирования 13.12.2021; принята к публикации 23.12.2021.

The article was submitted 03.12.2021; approved after reviewing 13.12.2021; accepted for publication 23.12.2021.

\section{Информация об авторах:}

1. Урал Фаритович Мухаметов - кандидат медицинских наук, ufa.rkbkuv@doctorrb.ru, https://orcid.org/0000-0003-3694-3302;

2. Сергей Владимирович Люлин - доктор медицинских наук, carmel74@yandex.ru, https://orcid.org/0000-0002-2549-1059;

3. Дмитрий Юрьевич Борзунов - доктор медицинских наук, borzunov@bk.ru, https://orcid.org/0000-0003-3720-5467;

4. Ильгиз Фанилевич Гареев - Ph.D., ilgiz gareev@mail.ru, https://orcid.org/0000-0002-4965-0835;

5. Озал Арзуман оглы Бейлерли - Ph.D., obeylerli@mail.ru, https://orcid.org/0000-0002-6149-5460;

6. Альберт Акрамович Суфианов - доктор медицинских наук, профессор, Sufarm@mail.ru, https://orcid.org/0000-0001-7580-0385.

\section{Information about the authors:}

1. Ural F. Mukhametov - Candidate of Medical Sciences, ufa.rkbkuv@doctorrb.ru, https://orcid.org/0000-0003-3694-3302;

2. Sergey V. Lyulin - Doctor of Medical Sciences, carmel74@yandex.ru, https://orcid.org/0000-0002-2549-1059

3. Dmitry Yu. Borzunov - Doctor of Medical Sciences, borzunov@bk.ru, https://orcid.org/0000-0003-3720-5467;

4. Ilgiz F. Gareev - M.D., Ph.D., ilgiz_gareev@mail.ru, https://orcid.org/0000-0002-4965-0835;

5. Ozal Arzuman Beylerli - M.D., Ph.D., obeylerli@mail.ru, https://orcid.org/0000-0002-6149-5460;

6. Albert A. Sufianov - Doctor of Medical Sciences, Professor, Sufarm@mail.ru, https://orcid.org/0000-0001-7580-0385.

Информация о конфликте интересов. Конфликт интересов отсутствует. 
Гений ортопедии. 2022. Т. 28, № 1. С. 133-140.

Genij Ortopedii. 2022. Vol. 28, no. 1. P. 133-140.

\section{Обзорная статья}

УДК 616.728.46/48-001.5-06-089(048.8)

https://doi.org/10.18019/1028-4427-2022-28-1-133-140

\section{Хирургическая тактика при лечении пациентов с последствиями внутрисуставных повреждений дистального отдела костей голени (обзор литературы)}

\section{О.А. Кауц, Ю.А. Барабаш $₫$, С.И. Киреев, К.А. Гражданов, П.П. Зуев, А.Л. Кесов, И.А. Норкин}

Саратовский государственный медицинский университет им. В.И. Разумовского, Саратов, Россия

Автор, ответственный за переписку: Юрий Анатольевич Барабаш, yubarabash@yandex.ru

\section{Аннотация}

Введение. Проблема лечения пациентов с последствиями внутрисуставных повреждений дистального отдела костей голени продолжает оставаться актуальной вследствие сохраняющейся высокой частоты их встречаемости, числа неудовлетворительных исходов лечения и высокой инвалидизации. Цель. Провести анализ отечественного и зарубежного опыта лечения пациентов с последствиями внутрисуставных повреждений дистального отдела костей голени, проследить современные тенденции в решении рассматриваемой проблемы. Материалы и методы. Проанализированы литературные источники по медицинским электронным базам данных (eLIBRARY, PubMed, Medline, SpringerLink) с 2000 по 2020 год. Поиск осуществлялся по ключевым словам: крузартроз, артродез, тотальная артропластика, артроскопия, дистальный отдел голени, ankle joint, total arthroplasty, endoprosthesis replacement, intra-articular distal tibial fractures. Результаты. В статье представлено современное состояние проблемы лечения неправильно сросшихся или несросшихся переломов лодыжек, контрактур и деформаций голеностопного сустава, посттравматического крузартроза. Выделены и проанализированы основные хирургические методики лечения: корригирующая остеотомия, артроскопия, дистракционная артропластика, артродез, тотальная артропластика. Оценены их преимущества и недостатки, обозначены нерешённые аспекты, устранение которых позволит приблизиться к решению этой чрезвычайно актуальной проблемы. Дискуссия. Выбор способа оперативного лечения зависит от давности травмы, состояния мягких тканей и костных структур, наличия деформации и степени выраженности крузартроза. На начальном этапе используют суставосохраняющие операции, выбирая между корригирующей остеотомией, артроскопией и дистракционной артропластикой. При терминальных стадиях крузартроза обсуждаются в основном две методики: артродезирование и тотальная артропластика. Среди преимуществ тотальной артропластики заявляется сохранение и улучшение подвижности в голеностопном суставе, короткий срок госпитализации. Сторонники артродезирования голеностопного сустава указывают на меньшее число осложнений, малозатратность. Однако большинство не видят существенных различий между методиками и рекомендуют индивидуальный подход к пациенту. Вывод. Имеется необходимость создания единого лечебного алгоритма, определения четких показаний и противопоказаний к использованию хирургических методик.

Ключевые слова: голеностопный сустав, крузартроз, артродез, тотальная артропластика, эндопротезирование, артроскопия, дистальный отдел костей голени, корригирующая остеотомия, несросшийся перелом, последствия травм

Для цитирования: Хирургическая тактика при лечении пациентов с последствиями внутрисуставных повреждений дистального отдела костей голени (обзор литературы) / О.А. Кауц, Ю.А. Барабаш, С.И. Киреев, К.А. Гражданов, П.П. Зуев, А.Л. Кесов, И.А. Норкин // Гений ортопедии. 2022. T. 28, № 1. C. 133-140. https://doi.org/10.18019/1028-4427-2022-28-1-133-140

\section{Review article}

\section{Surgical approach to the treatment of patients with sequelae of intra-articular fractures of the distal tibia (literature review)}

\section{O.A. Kauts, Yu.A. Barabash ${ }^{\bowtie}$, S.I. Kireev, K.A. Grazhdanov, P.P. Zuev, A.L. Kesov, I.A. Norkin}

Saratov State Medical University named after V.I. Razumovsky, Saratov, Russian Federation

Corresponding author: Yuri A. Barabash, yubarabash@yandex.ru

Abstract

Background Management of patients with sequelae of intra-articular fractures of the distal tibia continues to be a substantial clinical challenge in orthopaedic trauma due to the high incidence, poor outcomes and high disability rate. The objective was to review Russian and international experience in repair of intra-articular ankle fractures and explore contemporary trends in treatment strategies. Material and methods The literature search was produced using medical electronic databases of eLibrary, PubMed, Medline, SpringerLink between 2000 and 2020 and keywords: cruzarthrosis, arthrodesis, total ankle arthroplasty, arthroscopy, distal tibia, ankle joint, joint replacement, intra-articular fractures of distal tibial. Results The article presents an insight into the problem of malunited and nonunited ankle fractures, ankle contractures and deformities, post-traumatic ankle arthritis. Major surgical techniques used to address sequelae of ankle fractures include correcting osteotomy, arthroscopy, distraction arthroplasty, arthrodesis, total ankle arthroplasty with the advantages and disadvantages with each of the practices. Discussion The surgical option would depend on the time of injury, condition of soft and bone tissue, malalignment and severity of ankle arthritis. Joint saving procedures of correcting osteotomy, arthroscopy or distraction arthroplasty can be applied at early stages of the disease, and arthrodesis or total ankle arthroplasty are secured for terminal stages of ankle arthritis. Benefits of total ankle arthroplasty include preservation and improvement of ankle mobility, a short inpatient period. Ankle fusion is associated with less complication rate and low costs. Conclusion There is an obvious need for a uniform treatment algorithm with specific indications and contraindications to each surgical option.

Keywords: ankle joint, ankle arthrosis, arthrodesis, total arthroplasty, joint replacement, arthroscopy, distal tibia, correcting osteotomy, nonunited fracture, sequelae of injury

For citation: Kauts O.A., Barabash Yu.A., Kireev S.I., Grazhdanov K.A., Zuev P.P., Kesov A.L., Norkin I.A. Surgical approach to the treatment of patients with sequelae of intra-articular fractures of the distal tibia (Literature review). Genij Ortopedii, 2022, vol. 28, no 1, pp. 133-140. https:// doi.org/10.18019/1028-4427-2022-28-1-133-140

\section{ВВЕДЕНИЕ}

Лечение пациентов с последствиями внутрисуставных повреждений дистального отдела костей голени в настоящее время остается одной из нерешенных проблем травматологии и ортопедии, что обусловле- но высокой частотой внутрисуставных повреждений дистального отдела костей голени (переломы латеральной и медиальной лодыжек, переднего и заднего края большеберцовой кости), которая составляет от 71 
до 187 случаев на 100000 населения [1-3]. На данную нозологию приходится 9-20 \% от общего числа травм опорно-двигательной системы; одно из первых мест по частоте среди всех повреждений опорно-двигательной системы занимают переломы костей голени - их число достигает $60 \%$ [4].

До 70 \% пациентов с травмами области голеностопного сустава составляют лица трудоспособного возраста от 25 до 60 лет, при этом последствия внутрисуставных переломов костей дистальной части голени остаются одной из основных причин длительной нетрудоспособности и инвалидизации в 8,8-46 \% случаев [5-8].

Особенностями, определяющими сложность хирургического лечения последствий внутрисуставных повреждений дистального отдела голени, являются сопутствующая альтерация суставных поверхностей, составляющих голеностопный сустав, и хроническая нестабильность сустава, развивающаяся вследствие травмы капсульно-связочного аппарата. Анатомические особенности голеностопного сустава определяют большую, чем в других суставах нижней конечности, нагрузку на квадратный сантиметр суставной поверхности. Наряду с повреждением суставного хряща и инконгруентностью суставных поверхностей за счет неполной репозиции и нестабильности сустава, это приводит к скорому формированию остеартроза голеностопного сустава в 10-60 \% случаев. Так, например, дислокация таранной кости на 1 мм латерально ведет к инконгруентности в голеностопном суставе до $42 \%$, и значительному возрастанию нагрузки на него [9-13]. Свою негативную роль в формировании контрактуры и остеоартроза голеностопного сустава также играет выключение функции сустава из-за необоснованно длительной иммобилизации при консервативном лечении или после остеосинтеза.

Обозначенные причины обусловливают значительное количество осложнений, влияющих на окончательные исходы лечения внутрисуставных переломов дистальных отделов костей голени, вопреки использованию современных методов хирургического и консервативного лечения (стойкий болевой синдром и посттравматические отеки, неправильно сросшиеся или несросшиеся переломы лодыжек, контрактуры и деформации голеностопного сустава, посттравматический крузартроз). Данные о количественном соотношении осложнений в литературных источниках разнятся (7-68 \% при консервативном лечении; 47 \% после выполненного остеосинтеза, что связано, по-видимому, с разным по тяжести травмы исходным клиническим материалом у исследователей) [7, 14-20].

\section{МАТЕРИАЛЫ И МЕТОДЫ}

Анализ литературных источников проводился преимущественно по электронным медицинским базам данных eLIBRARY, PubMed, Medline и SpringerLink по ключевым словам: голеностопный сустав, крузартроз, артродез, тотальная артропластика, эндопротезирование, артроскопия голеностопного сустава, дистальный отдел голени, ankle joint, ankle arthrosis, total arthroplasty, endoprosthesis replacement, intra-articular ankle fractures. Предпочтение отдавалось статьям и материалам диссер- таций по рассматриваемой проблеме, опубликованным за последние 15 лет. Анализировались полнотекстовые версии статей, диссертаций и авторефератов диссертаций. Также обращались к научным работам, найденным в списках литературы уже обработанных материалов, с целью уточнения и получения дополнительных сведений о результатах хирургического лечения и реабилитации больных с последствиями внутрисуставных повреждений дистального отдела костей голени.

\section{РЕЗУЛЬТАТЫ}

Несмотря на большое количество предлагаемых хирургических методик и металлофиксаторов (как серийно выпускаемых, так и авторских), число пациентов с неудовлетворительными исходами лечения продолжает оставаться высоким, а их лечение представляется непростой задачей для многих хирургов. Первое место среди последствий переломов данной локализации занимает посттравматический крузартроз (до 60 \%). Все виды хирургических вмешательств, используемых при лечении рассматриваемой нозологии, можно разделить на суставосохраняющие (корригирующие остеотомии дистальных отделов малоберцовой и большеберцовых костей с последующим остеосинтезом, артроскопические вмешательства, дистракционная артропластика) и не сохраняющие сустав (артродез и тотальное эндопротезирование голеностопного сустава) [17, 21-24].

Среди суставосохраняющих операций основным хирургическим вмешательством, выполняемым повсеместно и не утратившим своей актуальности, является корригирующая остеотомия. Показанием для выполнения корригирующих остеотомий являются неправильно сросшиеся переломы, а также ложные суставы дистального отдела большеберцовой или малоберцовой костей с нарушением конгруэнтности в голеностопном суставе. При этой патологии, как правило, имеет ме- сто нарушение механической оси нижней конечности, что приводит к неправильному распределению и повышенной нагрузке на голеностопный сустав, дальнейшей деградации альтерированного в момент получения травмы суставного хряща, развитию крузартроза. Посредством выполнения корригирующих остеотомий удается восстановить биомеханическую ось конечности, анатомические взаимоотношения в голеностопном суставе, обеспечить разгрузку альтерированного суставного хряща. В литературе обсуждаются варианты остеотомий (клиновидные, косые, угловидные, по линии перелома и др.), а также способы фиксации отломков и различные варианты выполнения костной пластики для восполнения дефектов. Применение корригирующих остеотомий, по данным литературы, является эффективным в 75-92,5 \% случаев [25-28].

Так, И.О. Панков с соавторами в 2013 г. проанализировали исходы лечения 38 пациентов с неправильно сросшимися пронационно-эверсионными переломами дистального суставного отдела костей голени. Всем пациентам производилась корригирующая остеотомия по плоскости перелома, репозиция с восстановлением оси конечности и анатомических взаимоотношений в суставе, с последующей установкой аппарата внешней фиксации на срок 8 недель. Исходы лечения в 4 слу- 
чаях (10,5 \%) оценены как отличные, в 22 случаях (57,9\%) - хорошие, в 12 случаях (31,6 \%) - удовлетворительные; неудовлетворительных результатов выявлено не было [29].

R.J.A. Van Wensen с соавторами в 2011 г. провели аналитический поиск по нескольким базам данных и регистрам 1960-2007 гг. для выявления научных работ, описывающих выполнение корригирующих остеотомий при неправильно сросшихся переломах области голеностопного сустава, и проанализировал 15 исследований, включавших 177 пациентов. Количество отличных и хороших результатов после оперативного лечения с использованием корригирующей остеотомии составило 77,4 \% (137 человек). Исследователь делает вывод о необходимости выполнения остеотомии для предупреждения развития посттравматического артроза, однако указывает на малую эффективность такого лечения в случае уже имеющегося артроза начальной стадии, а также необходимость анализа больших групп пациентов с высоким уровнем доказательной базы [19].

С широким внедрением в практику методов эндоскопической хирургии при лечении пациентов с посттравматическим крузартозом все чаще используют артроскопию голеностопного сустава, позволяющую хирургу четко выявлять дефекты суставного хряща. Как известно, внутрисуставным переломам дистального отдела костей голени в большинстве случаев сопутствует альтерация хряща большеберцовой кости, и реже - суставной поверхности таранной кости как в момент травмы, так и вторично при развитии импиджмент-синдрома. В связи с повреждением хряща даже при полном восстановлении биомеханической оси конечности и конгруэнтности в голеностопном суставе при лечении последствий травм сохраняется высокая вероятность развития крузартроза. Артроскопия используется для лечения застарелых повреждений голеностопного сустава как самостоятельный метод лечения, а также в сочетании с другими видами оперативного вмешательства [30-32].

При артроскопическом лечении, после предварительного растяжения голеностопного сустава мануальными методами или дистракционными аппаратами, появляется возможность малоинвазивными способами устранить причины хронического болевого синдрома, ликвидировать спаечный процесс и импиджмент-синдром, провести удаление костно-хрящевых экзостозов, остеофитов, хондромных тел, альтерированного хряща, с помощью шейвера убрать имеющиеся неровности, шероховатости, сгладить суставные поверхности. Также артроскопически можно воздействовать на регенераторный процесс в хрящевой ткани, например, при лечении глубоких дефектов хряща выполняется туннелизация субхондральной кости, а также замещение дефектов при помощи специально созданных клеточных имплантов и коллагеновых матриц, индуцированных аутологичными хондроцитами. При этом тактика лечения дефектов хряща зависит от размера дефекта. Так, при наличии дефекта суставного хряща размерами менее 15 мм достаточно произвести дебридмент и туннелизацию подлежащей субхондральной кости. При превышении этого значения дополнительно рекомендуется выполнять укрытие хрящевого дефекта костнохрящевым трансплантатом или матрицей, индуцированной аутологичными хондроцитами [33-39].
А.И. Городниченко с соавторами в 2015 г. изучили роль артроскопии в диагностике и лечении последствий травм голеностопного сустава у 44 пациентов, разделенных на 2 группы: основную (27 пациентов) и контрольную (17 пациентов). У 27 пациентов основной группы, после перенесенных ранее оперативных вмешательств по поводу внутрисуставных переломов, отмечалась клиника крузартроза. У 17 пациентов контрольной группы с травмами голеностопного сустава в анамнезе отмечался хронический болевой синдром голеностопного сустава. В основной группе была выполнена артроскопия в 2 этапа: сначала диагностическая, а затем лечебная. Пациентам второй группы артроскопия не выполнялась, а проводилось лечение нестероидными противовоспалительными препаратами, физиотерапия и внутрисуставное введение глюкокортикостероидных гормонов. Отдаленные результаты лечения пациентов основной группы показали возврат к безболезненности при бытовой физической активности в $100 \%$ случаев, полное восстановление функции голеностопного сустава отмечено у 74 \% (20) пациентов. В контрольной группе возвращение к безболезненности при бытовой физической активности было отмечено лишь у 17,6 \% (3) пациентов; полного восстановления функции сустава не наблюдалось. Авторы сделали вывод о том, что при посттравматических повреждениях голеностопного сустава артроскопия высокоинформативна, позволяет эффективно устранять весь спектр внутрисуставных проблем и улучшать качество жизни пациентов [40]. Другие исследователи также сообщают о высоком проценте хороших результатов (до 96 \%) при артроскопическом лечении деформирующего артроза голеностопного сустава, но с оговоркой на то, что у пациента при клиническом обследовании обнаруживаются начальные стадии крузартроза (не тяжелее II стадии), имеются полностью восстановленные анатомические взаимоотношения в суставе и неизмененная ось нижней конечности [41-42].

Одной из суставосохраняющих методик является дистракционная артропластика (артродиастаз). В основе данной методики лечения лежит стремление повысить репаративную активность и добиться восстановления суставного хряща. Это достигается путём длительной (по разным данным от 6 недель до 3-4 месяцев) разгрузки хряща голеностопного сустава при дозированной дистракции в аппарате внешней фиксации. В качестве дистракционного аппарата наиболее удобен аппарат Илизарова, так как его компоновка позволяет производить дистракцию сустава более равномерно, в отличие от монолатеральных аппаратов внешней фиксации. Важным условием для достижения успеха является обеспечение нормальных биомеханических взаимоотношений в суставе. По данным разных авторов, эффективность данного метода составляет от 55 до 91 \%, а его применение позволяет отдалить или вовсе избежать артродезирования сустава при остеоартрозе 1-2 стадии [43-45]. Имеются сообщения о комбинированном использовании дистракционной артропластики аппаратом Илизарова и лечебнодиагностической артроскопии [46].

Среди не сохраняющих голеностопный сустав оперативных вмешательств при последствиях внутрисуставных повреждений дистального отдела костей голени артродезирование голеностопного сустава в течение многих десятилетий признается травматологами-ортопедами «золотым стандартом» лечения. Показаниями к 
артродезу, помимо поздних стадий крузартроза, также являются выраженная комбинированная контрактура в голеностопном суставе, неправильно сросшиеся переломы и псевдоартрозы, возникшие в результате внутрисуставных повреждений, стойкое нарушение опороспособности стопы вследствие не устраненного повреждения связочного аппарата. Суть операции во всех случаях сводится к замыканию голеностопного сустава путем создания костного анкилоза в функционально выгодном положении, что обеспечивает стопе опороспособность и избавляет от хронического болевого синдрома, значительно улучшая качество жизни пациентов. Существует много методов артродезирования, однако не один из них полностью не удовлетворяет хирургов.

Артродезы подразделяются на компрессионные и некомпрессионные. При компрессионном артродезе костного анкилоза достигают посредством использования чрескостной фиксации в аппаратах (Илизарова, Волкова-Оганесяна, Гришина), поддерживая необходимую величину компрессии [47-49]. Ю.А. Плаксейчук с соавторами в 2012 г. на большом клиническом материале (286 пациентов с артрозом голеностопного и подтаранного суставов III-IV стадии) проанализировали исходы артродеза с использованием аппарата Илизарова и костной пластики. 36 пациентам артродез выполнен по авторской методике (основная группа). В результате в основной группе костный блок достигнут у всех пациентов, а в группе сравнения у 97,2 \%, что делает компрессионный артродез в аппарате внешней фиксации эффективным в лечении остеоартроза; метод позволяет устранить болевой синдром и восстановить опороспособность конечности [47]. В ряде работ описывается возможность добиться артродезирования голеностопного сустава при помощи аппарата Илизарова «закрыто» при наличии у пациента артрозоартрита и инфекционных изменений в суставе [50]. При использовании некомпрессионного артродеза после обработки суставных поверхностей и установки костей в нужном положении производится фиксация погружными металлофиксаторами: накостной пластиной, интрамедуллярным стержнем, винтами, авторскими конструкциями [51-53].

Д.В. Павлов с соавторами в 2015 г. обобщили сведения о лечении 53 пациентов после артродезирования голеностопного сустава различными методиками: 22 пациентам устанавливали канюлированные винты, 24 ретроградные интрамедуллярные стержни HAN, 4 проводили трансартикулярную фиксацию тремя спицами, 6 - аппаратом внешней фиксации Илизарова. Операции выполнялись открыто с резекцией суставных поверхностей и использованием остеотомий. Наилучших результатов удалось добиться при использовании винтов (костного анкилоза достигали в 68 \% случаев) и аппарата внешней фиксации (67 \%); худших - при использовании спиц (25 \%). При применении интрамедуллярных стержней анкилоза достигли у 62 \% пациентов, однако в этой группе число осложнений (фиброзные анкилозы, нагноения и ампутации) было выше и составило 38 \%, что авторы связывают с недостаточной первичной компрессией и нарушением кровообращения таранной кости из-за прохождения через нее массивного стержня [54]. Некоторые авторы отдают предпочтение накостным пластинам в качестве аппарата фиксации в связи с их большей надежностью в формировании костного анкилоза, простотой использования и дешевизной [55].
В пользу использования при артродезе интрамедуллярной фиксации при сопутствующем вовлечении в дегенеративный процесс подтаранного сустава высказываются многие исследователи. Например, К.С. Михайлов с соавторами в 2016 г. проанализировали исходы лечения 63 пациентов после двухсуставного артродеза ретроградным блокируемым стержнем. Артродез признали состоявшимся у 94 \% пациентов, причем констатировано значимое $(\mathrm{p}<0,01)$ улучшение всех клинико-функциональных показателей по визуальной аналоговой шкале, шкале клинической оценки заболеваний стоп и голеностопного сустава Американской ассоциации ортопедов стопы и голеностопного сустава (AOFAS), а также биомеханики стоп при ходьбе [56].

C развитием артроскопической техники появляются сообщения о возможности ее применения и при посттравматических крузартрозах III-IV стадий. Так, Л.К. Брижань с соавторами в 2017 г. опубликовали результаты лечения крузартроза III-IV стадий путем разработанного малоинвазивного артроскопического артродеза голеностопного сустава. При этом артроскопический артродез позиционируется как альтернатива классическому артродезу в связи с высоким риском инфекционных осложнений последнего. В I группе пациентов с посттравматическим деформирующим артрозом голеностопного сустава III-IV стадий (102 пациента) выполнен артродез голеностопного сустава с фиксацией ретроградным интрамедуллярным стержнем HAN (46 из них по традиционной методике открыто). Во II группе (56 пациентов) после предварительной аппаратной дистракции артроскопически шейвером выполняли дебридмент суставного хряща большеберцовой и таранной костей до появления кровоточащих участков, убирали синовиальные разрастания, внутрисуставные тела, при необходимости пересекали лодыжки. Затем производили фиксацию интрамедуллярным стержнем, как и в I группе. В результате удалось на $26 \%$ уменьшить число послеоперационных осложнений, на 40 \% сократить сроки пребывания в стационаре и на $20 \%$ - период нетрудоспособности, в 100 \% случаев добиться состоятельного анкилоза [57]. Об успешном применении артроскопического артродезирования при крузартрозе III-IV стадий пишут и другие исследователи, указывая сроком формирования артродеза 8,5 недель $[58,59]$.

Следует отметить, что нет консенсуса между хирургами в отношении обработки суставных поверхностей голеностопного сустава при выполнении артродеза и необходимости использования костных трансплантатов. Одни хирурги полностью удаляют хрящ до появления кровоточивости подлежащей кости, другие не видят в этом необходимости, а главную роль отводят жесткой фиксации сустава. Нет единого мнения и о способах фиксации. Ряд авторов считает достаточным введение нескольких канюлированных винтов, другие наиболее эффективным признают фиксацию накостной пластиной и винтами, третьи - интрамедуллярным стержнем, четвертые - аппаратом Илизарова [60]. К несомненным плюсам методики артродезирования следует отнести относительную легкость выполнения хирургического вмешательства.

Однако следует отметить, что в мире имеется тенденция к постепенному снижению числа выполняемых артродезов, что связано с довольно большим количеством послеоперационных осложнений, возникающих, по некоторым данным, в 60 \% случаев. Кроме того, известно, 
что артродез оказывает негативное воздействие на биомеханнику стопы, приводит к формированию остеоартроза других ее суставов и появлению болевого синдрома, вследствие чего доля в лечении крузартроза современных методик - тотального эндопротезирования и артроскопии голеностопного сустава - возрастает [61, 62].

Тотальная артропластика голеностопного сустава является высокотехнологичным и трудоемким оперативным вмешательством, но в этом методе имеется еще много спорных и нерешенных вопросов. Существуют довольно строгие показания к выполнению артропластики, которые учитывают возраст и индекс массы тела пациента, выраженность болевого синдрома, необходимость присутствия не менее 70 \% объема движений в суставе и отсутствие деформации заднего отдела стопы. Этим критериям соответствует не более 20 \% пациентов с последствиями травм голеностопного сустава. Оптимальный возраст пациентов для эндопротезирования изменился с течением времени, сейчас доказано, что для молодых пациентов оно также актуально, как и для пациентов пожилого возраста [63, 64].

В настоящее время в мире предпочтение отдается несвязанным моделям эндопротезов, применение которых позволяет добиться уменьшения и более равномерного распределения нагрузки на кость в местах фиксации компонентов эндопротеза, что приводит к более редкому возникновению нестабильности и увеличивает срок выживаемости эндопротеза. Тотальные эндопротезы голеностопного сустава также делятся на эндопротезы цементной и бесцементной фиксации, а в зависимости от числа компонентов, входящих в их состав - на двухкомпонентные и трехкомпонентные.

В мире постоянно происходит совершенствование моделей эндопротезов, навигации и инструментария для их имплантации, открываются перспективы использования КТ-моделирования и 3D-печати как самих эндопротезов, так и резекторных блоков. В настоящее время считается, что наилучшие результаты достигаются использованием эндопротезов бесцементной фиксации, состоящих из трех компонентов. Их пятилетняя выживаемость, по некоторым данным, составляет 72,7-98 \%, а десятилетняя - $80 \%[56,66]$.

Оценка исходов тотальной артропластики голеностопного сустава производится по результатам клинико-рентгенологического обследования пациентов, биомеханического исследования изменений статикодинамических показателей нижних конечностей с использованием различных вариантов шкал и опросников [67-69]. Так, Д.В. Павлов с соавторами в 2012 г. оценили статико-динамическую функцию нижних конечностей у 18 пациентов после эндопротезирования. Через 6 месяцев была констатирована адаптация нижней конечности к нагрузкам с увеличением максимальной силы толчка, коэффициента ритмичности и перераспределением опоры на оперированную конечность; к 12 месяцам восстановление биомеханических показателей с выравниванием их между здоровой и оперированной конечностью продолжается, достигая нормы через 24 месяца [67]. К.С. Михайлов с соавторами в 2018 г. оценили исходы эндопротезирования у 71 больного и пришли к выводу о том, что тотальная артропластика голеностопного сустава обеспечивает хорошие или удовлетворительные результаты у подавляющего большинства пациентов: 100 \% по визуально-аналоговой шкале и 96 \% по шкале Американской ассоциации ортопедов стопы и голеностопного сустава (AOFAS) через 2 года; 100 \% по обеим шкалам через 3 года; 92,3 \% через 5 лет и 85,7 \% через 7 лет [68].

Несмотря на свои преимущества (восстановление нормальной биомеханики сегмента и сохранение хоть и ограниченного объема движений (порядка $25^{\circ}$ ) в голеностопном суставе в ближайший период), тотальная артропластика имеет явные недостатки, которыми являются осложнения, возникающие, как правило, в отдаленные сроки после операции. К наиболее частым осложнениям относится нестабильность компонентов эндопротеза, чаще тибиального, стрессовый перелом лодыжек, частота которого может достигать $20 \%$, гнойно-воспалительные осложнения. Реже наблюдаются образование оссификатов, экзостозов лодыжек, мешающих ходьбе, локальный остеопороз [68, 70]. Количество ревизионных оперативных вмешательств после эндопротезирования достигает 24 \% [71].

Задачи, стоящие перед учеными в плане создания «идеальной» модели эндопротеза для артропластики, могут быть решены только при максимальном учете сложностей, связанных с анатомо-функциональным строением голеностопного сустава, его биомеханики, многообразия функций, приходящимися на него огромными нагрузками статического и динамического характера.

\section{ДиСКУССИЯ}

Хирургическая реабилитация пациентов с последствиями внутрисуставных переломов дистального отдела костей голени направлена на купирование болевого синдрома, восстановление опороспособности конечности и, при наличии такой возможности, сохранение функции голеностопного сустава. Выбор способа оперативного лечения зависит от давности травмы, состояния мягких тканей и костных структур, наличия деформации в области сустава и степени выраженности крузартроза. На начальном этапе лечения последствий внутрисуставных переломов рассматриваемой локализации большинство исследователей отдают предпочтение суставосохраняющим операциям, выбирая ту или иную методику. Так, ряд авторов при наличии посттравматической деформации или несросшегося перелома рекомендуют выполнение корригирующей остеотомии, что позволяет восстановить взаимоотношения в суставе, биомеханическую ось конечности и добиться хорошего результата лечения [72, 73]. Другие авторы в своих работах доказывают, что без учёта состояния суставного хряща, который повреждается в большинстве случаев, лечение недостаточно эффективно, так как приводит к развитию посттравматического артроза. Избежать этого они предлагают, используя артроскопические вмешательства [40, 41]. Некоторые авторы считают более эффективным методом лечения и предупреждения развития артроза дистракционную артропластику, указывая на возможность хряща к регенерации, при устранении на определённое время механического воздействия на последний [46].

При более тяжёлых стадиях крузартроза (III-IV) обсуждаются в основном две методики: артродезиро- 
вание и тотальная артропластика. Одни авторы отдают предпочтение тотальной артропластике, заявляя, что, помимо облегчения боли, ее главным положительным моментом является сохранение и улучшение подвижности в голеностопном суставе, что обеспечивает физиологическую походку, особенно на неровных поверхностях, лестницах, наклонах, а также более короткий срок госпитализации пациентов [74, 75]. Другие исследователи приходят к выводу о том, что артродезирование голеностопного сустава лучше, потому что дает меньше осложнений, менее затратно и реже требует гемотрансфузии, чем эндопротезирование, причем артродезирование возможно и при неудачах тотальной артропластики $[76,77]$. Подавляющее же большинство исследователей не выявляют существенных различий между этими методами в ближайшем послеоперационном периоде. Для выбора хирургического метода рекомендуют использовать индивидуальный подход к конкретному пациенту и его клинической ситуации [78].

Несмотря на некоторые успехи, непрекращающееся развитие и совершенствование хирургических техно- логий в травматологии и ортопедии, проблема лечения пациентов с последствиями внутрисуставных повреждений дистального отдела костей голени не стала менее актуальна, о чем свидетельствуют сохраняющаяся частота патологии, по-прежнему большое количество осложнений и неудовлетворительных исходов лечения и крайне высокий процент выхода на инвалидность.

Сегодня у травматологов-ортопедов нет однозначного ответа на вопрос об оптимальном методе лечения последствий травм области голеностопного сустава, показания и противопоказания к ним требуют уточнения и конкретизации. В литературе не затронуты или недостаточно освещены такие важные, по нашему мнению, для выбора тактики лечения аспекты, как изменения минеральной плотности костной ткани дистального отдела большеберцовой и таранной костей вследствие длительно существующего патологического процесса, отсутствия опоры на конечность и нарушения репаративного остеогенеза, а также вопросы биомеханики и необходимость коррекции деформаций вышележащих отделов нижней конечности.

\section{ЗАКЛЮЧЕНИЕ}

Проблема лечения больных с последствиями внутрисуставных повреждений дистального отдела костей голени не стала с годами менее актуальной в связи с остающейся высокой её частотой и распространённостью, высоким процентом неудовлетворительных исходов и инвалидизации.
Создание единого лечебного алгоритма, определение четких показаний и противопоказаний к использованию различных методик хирургического вмешательства, учитывающих все возможные аспекты этой многогранной проблемы, позволит хирургам избежать ошибок при выборе тактики и улучшить исходы лечения пациентов.

\section{СПИСОК ИСТОЧнИКОВ}

1. Elsoe R., Ostgaard S.E., Larsen P. Population-based epidemiology of 9767 ankle fractures // Foot Ankle Surg. 2018. Vol. 24 , No 1. P. 34-39. DOI: $10.1016 /$ j.fas.2016.11.002.

2. Epidemiology of adult ankle fractures in Sweden between 1987 and 2004: a population-based study of 91,410 Swedish inpatients / C. Thur, G. Edgren, K. Jansson, P. Wretenberg // Acta Orthop. 2012. No 83. P. 276-281. DOI: 10.3109/17453674.2012.672091.

3. Epidemiology of ankle fractures in Rochester, Minnesota / P.J. Daly, R.H. Fitzgerald, L.J. Melton Jr., D.M. Ilstrup // Foot and Ankle Surgery 2017. Vol. 24, No 1. P. 34-39. DOI: 10.1016/j.fas.2016.11.002.

4. Восстановление формы и функции голеностопного сустава / О.В. Оганесян, С.В. Иванников, А.В. Коршунов. М.: БИНОМ: Лаборатория знаний, Медицина, 2003. 120 с.

5. Кувин М.С. Эффективность лечения переломов костей голеностопного сустава при различных видах открытой фиксации: автореф. дис. ... канд. мед. наук. Иркутск, 2002. 22с.

6. Куров М.А., Голубев В.Г. Современные представления о патогенезе хронической нестабильности голеностопного сустава. Обзор литературы. Кремлевская медицина. Клинический вестник. 2018. № 4. С. 98-106.

7. Артродез в системе реконструктивного лечения пациентов с последствиями повреждений голеностопного сустава / Т.Н. Омельченко, А.П. Лябах, А.А. Бурьянов, С.В. Хомич, И.А. Лазарев // Вісник ортопедії, травматології та протезування. 2016. № 1 (88). С. $48-53$.

8. Juto H., Nilsson H., Morberg P. Epidemiology of Adult Ankle Fractures: 1756 cases identified in Norrbotten County during 2009-2013 and classified according to AO/OTA // BMC Musculoskelet Disord. 2018. No 19. Art. No 441. DOI: 10.1186/s12891-018-2326-x.

9. Гайко Г.В., Бруско А.Т., Лимар Э.В. Остеоартроз - новий підхід до його профілактики // Вісник ортопедіi, травматологіі та протезувания. 2005. No 2. Р. 5-11.

10. Ким Л.И., Дьячкова Г.В. Комплексная диагностика повреждений голеностопного сустава // Гений ортопедии. 2013. №4. С. 20-24.

11. Leontaritis N., Hinojosa L., Panchbhavi V.K. Arthroscopically detected intra-articular lesions associated with acute ankle fractures // J Bone Joint Surg Am. 2009. Vol. 91, No 2. P. 333-339. DOI: 10.2106/JBJS.H.00584.

12. Магнитно-резонансная томография в оценке повреждения связок голеностопного сустава при застарелых его повреждениях / Т.М. Исакова, Г.В. Дьячкова, С.В. Гюльназарова, М.В. Налесник, К.А. Дьячков // Гений ортопедии. 2009. №1. С. 65-69.

13. Fractures of the Ankle Joint Investigation and Treatment Options / H. Goost, M.D. Wimmer, A. Barg, K. Kabir, V. Valderrabano, C. Burger // Dtsch Arztebl Int. 2014. Vol. 111, No 21. P. 377-88. DOI: 10.3238/arztebl.2014.0377.

14. Современное представление вопроса лечения больных с повреждением голеностопного сустава (обзор литературы) / А.Б. Слободской, В.Д. Балаян, М.Х. Язбек, О.Н. Ямщиков // Вестник Тамбовского университета. Серия: Естественные и технические науки. 2016. Т. 21. № 1. С. 176-181.

15. Хорошков С.Н. Лечение повреждений голеностопного сустава и их последствий (клинико-экспериментальное исследование): автореф. дис. ... докт. мед. наук. М., 2006. 48 с.

16. Сравнительный анализ результатов лечения пострадавших с переломами дистального метаэпифиза большеберцовой кости типов В и С / В.В. Хоминец, А.Л. Кудяшев, А.Л. Печкуров, А.О. Федотов, С.О. Наниев // Травматология и ортопедия России. 2017. Т. 23. № 3. С. 69-79.

17. Череватый Н.И., Соломин Л.Н. Лечение пациентов с последствиями переломов лодыжек (обзор мировой литературы) // Аста Віотеdica Scientifica. 2019. T. 4, №6. С. 77-88.

18. Сысенко Ю.М., Бунов Д.В. Лечение больных со сложными переломами голеностопного сустава методом чрескостного остеосинтеза по Илизарову // Гений ортопедии. 2003. №3. С. 29-32.

19. Reconstructive osteotomy of fibular malunion: review of the literature / R. J. A. Van Wensen, M. P. J. van den Bekerom, R.K. Marti, R.J. van Heerwaarde // Strat Traum Limb Recon. 2011. No. 6. P. 51-57. DOI: 10.1007/s11751-011-0107-2.

20. Long-term outcome after 1822 operatively treated ankle fractures: A systematic review of the literature / S.A.S. Stufkens, M.P.J. van den Bekerom, G.M.M.J. Kerkhoffs, B.Hintermann, C.N. van Dijk // Injury. 2011. Vol. 42, No 2. P. 119-127. DOI: 10.1016/j.injury.2010.04.006. 
21. Михайлов К.С. Совершенствование хирургического лечения больных с деформирующим артрозом голеностопного сустава: автореф. дис. ... канд. мед. наук. Санкт-Петербург, 2016. 24c.

22. Оперативное лечение посттравматического крузартроза III-IV стадии / Р.О. Горбатов, Д.В. Павлов, Н.Н. Рукина, О.В. Воробьева, А.Н. Кузнецов // Вестник Волгоградского государственного медицинского университета. 2016. № 2 (58). С. 94-96.

23. Morash J., Walton D. M., Glazebrook M. Ankle Arthrodesis Versus Total Ankle Arthroplasty // Foot Ankle Clin. 2017. Vol. 22 , No 2. P. $251-266$. DOI: 10.1016/j.fcl.2017.01.013.

24. Реутов А.И., Давыдов О.Д., Устюжанинова Е.В. Особенности ортоградного стояния у больных с посттравматическим остеоартрозом голеностопного и таранно-пяточного суставов // Гений ортопедии. 2013. №4. С. 48-52.

25. Wynes J., Kaikis A.C. Current advancements in ankle arthrodiastasis // Clin Podiatr Med Surg. 2018. Vol. 35, No 4. P. 467-479. DOI: 10.1016/j. cpm.2018.05.006.

26. Способ пластики костного дефекта эпиметафиза большеберцовой кости: патент RU 2309691 C1. A61B 17/56 / Малышев Е.Е., Варварин О.П., Королев С.Б., Ваганов Б.В.; патентообладатель ФГУ «Нижегородский научно-исследовательский институт травматологии и ортопедии Федерального агентства по здравоохранению и социальному развитию». № 2006104086/14; заявл. 10.02.2006; опубл. 10.11.2007, Бюлл. № 31 .

27. Rammelt S., Marti R.K., Zwipp H. Joint-preserving osteotomy of malunited ankle and pilon fractures // Der Unfallchirurg. 2013. Vol. 116, No. 9. P. 789-796. DOI: 10.1007/s00113-013-2385-2.

28. Malleolar osteotomy - osteotomy as approach / A. Barg, G. Pagenstert, A. Leumann, V. Valderrabano // Der Orthopäde. 2013. Vol. 42, No 5. P. 309321. DOI: $10.1007 / \mathrm{s} 00132-012-2007-7$.

29. Хирургическое лечение неправильно сросшихся пронационно-эверсионных переломов дистального отдела костей голени / И.О. Панков, Р.3. Салихов, В.Р. Нагматуллин, А.Л. Емелин, И.А. Валитов // Современные проблемы науки и образования. 2013. № 2. Ст. 58.

30. Хирургическая профилактика посттравматического крузартроза I-II стадий у пациентов после переломов лодыжек / Крюков Е.В., Брижань Л.К., Давыдов Д.В., Юрмина Н.С., Керимов А.А., Сливков К.А., Шеянова Е.Ю. // Военно-медицинский журнал. 2017. Т. 338. № 10. С. 37-42.

31. Гильфанов С.И., Семенов А.И., Степанова А.И. Роль артроскопии в лечении посттравматического импиджмент синдрома голеностопного сустава // Кремлевская медицина. Клинический вестник. 2017. № 4-2. С. 91-95.

32. Schoettle P.B., Imhoff A.B. Die osteochondrale Autograft-Transplantation (OATS) // Am. Talus. Operat. Orthop. Traumatol. 2000. No 10. P. 113-129.

33. Малоинвазивная артроскопическая стабилизация застарелых повреждений связок голеностопного сустава / А.А. Очкуренко, А.Г. Ширмазанян, А.М. Мацакян, А.В. Горохводацкий // Вестник Смоленской государственной медицинской академии. 2017. Т. 16. № 4. С. 185-161.

34. Штробель М. Руководство по артроскопической хирургии. В 2-х томах. М.: Изд-во Панфилова, 2011. 344 с.

35. Matrix-induced autologous chondrocyte implantation of talus articular defects / E. Giza, M. Sullivan, D. Ocel, G. Lundeen, M.E. Mitchell, L. Veris, J. Walton // Foot Ankle Int. 2010. Vol. 31, No 9. P. 747-753. DOI: 10.3113/FAI.2010.0747.

36. Thomas B., Yeo J.M., Slater G.L. Chronic pain after ankle fracture: an arthroscopic assessment case series // Foot Ankle Int. 2005. Vol. 26 , No 12. P. 1012-1016. DOI: 10.1177/107110070502601202

37. Merian M., Easley M. Diagnosis and treatment of osteochondral lesions of the talus // Der Orthopäde. 2008. Vol. 37, No 3. P. 204-211. DOI: 10.1007/ s00132-008-1219-3.

38. Hepple S., Guha A. The role of ankle arthroscopy in acute ankle injuries of the athlete // Foot Ankle Clin. 2013. Vol. 18 , No 2. P. $185-194$. DOI: $10.1016 / \mathrm{j} . \mathrm{fcl} .2013 .02 .001$.

39. Murawski C.D., Kennedy J.G. Operative treatment of osteochondral lesions of the talus // J Bone Joint Surg Am. 2013. Vol. 95, No 11. P. 1045-1054. DOI: 10.2106/JBJS.L.00773.

40. Городниченко А.И., Семенов А.И., Минаев А.Н. Артроскопия в диагностике и лечении посттравматического деформирующего артроза голеностопного сустава // Кремлевская медицина. Клинический вестник. 2015. №3. С. 71-74.

41. Омельченко Т.Н., Бурьянов А.А., Хомич С.В. Артроскопия в системе реконструктивно-восстановительного лечения больных с поражениями голеностопного сустава (информационно-аналитическое исследование) // Вісник ортопедії, травматології та протезування. 2015. № 2 (85). C. 69-75.

42. The treatment of severe posttraumatic arthritis of the ankle joint / S. Giannini, R. Buda, C. Faldini, F. Vannini, M. Romagnoli, G. Grandi, R. Bevoni // J Bone Joint Surg Am. 2007. 89(Suppl 3). P. 15-28. DOI: 10.2106/JBJS.G.00544.

43. Ankle distraction arthroplasty / M. Bernstein, J. Reidler, A. Fragomen, S.R. Rozbruch // J Am Acad Orthop Surgeons. 2017. Vol. 25 , No. 2. P. 89-99. DOI: 10.5435/jaaos-d-14-00077.

44. Functional analysis of distraction arthroplasty in the treatment of ankle osteoarthritis / H. Zhao, W. Qu, Y. Li, X. Liang, N. Ning, Y. Zhang, D. Hu // J. Orthop. Surg. Res. 2017. Vol. 12, No 1. Art. No. 18. DOI: 10.1186/s13018-017-0519-x.

45. Intermediate-term follow-up after ankle distraction for treatment of end-stage osteoarthritis / M.P. Nguyen, D.R. Pedersen, Y. Gao, C.L. Saltzman, A. Amendola // J Bone Joint Surg Am. 2015. Vol. 97, No. 7. P. 590-596. DOI: 10.2106/jbjs.n.00901

46. Леончук С.С., Островских Л.А., Сазонова Н.В. Дистракционная артропластика голеностопного сустава с использованием аппарата Илизарова и артроскопической техники: первый клинический опыт // Гений ортопедии. 2021. T. 27. № 1. C. 92-96. DOI: 10.18019/1028-44272021-27-1-92-96)

47. Плаксейчук Ю.А., Салихов Р.З., Соловьев В.В. Хирургическое лечение больных с артрозом голеностопного сустава // Казанский медицинский журнал. 2012. Т. 93, № 1. С. 38-43. DOI: 10.17816/KMJ2142.

48. Outcome of transfibular ankle arthrodesis with Ilizarov apparatus / T. Onodera, T. Majima, Y. Kasahara, D. Takahashi, S. Yamazaki, R. Ando, A. Minami // Foot Ankle Int. 2012. Vol. 33, No 11. P. 964-968. DOI: 10.3113/fai.2012.0964.

49. Khanfour A.A. Versatility of Ilizarov technique in difficult cases of ankle arthrodesis and review of literature // Foot Ankle Surg. 2013. Vol. 19, No 1. P. 42-47. DOI: $10.1016 /$ j.fas.2012.10.001

50. Closed arthrodesis in infected neuropathic ankles using ilizarov ring fixation / Y. Alammar, A. Sudnitsyn, A. Neretin, S. Leonchuk, N.M. Kliushin // Bone Joint. 2020. Vol. 102-B, No. 4. P. 470-477. DOI: 10.1302/0301-620X.102B4.BJJ-2019-1158.R1.

51. Артродезирование голеностопного сустава с использованием трех спонгиозных винтов / В.В. Хоминец, С.В. Михайлов, Д.А. Шакун, С.Е. Жумагазиев, А.В. Комаров // Травматология и ортопедия России. 2018. Т. 24, № 2. C. 117-126. DOI: 10.21823/2311-2905-2018-24-2-117-126.

52. Мацакян А.М., Процко В.Г., Ширмазанян А.Г. Артродез голеностопного сустава штифтом с блокированием при выраженной варусной деформации стопы // Современная наука: актуальные проблемы теории и практики. Серия: Естественные и технические науки. 2017. № 9. С. 65-71.

53. Omelchenko T.M., Buryanov O.A., Lyabakh A.P. Arthrodesis of ankle joint. Biomechanical aspects and algorithm of choice of methods of fixation // Ортопедия, травматология и протезирование. 2018. Т. 613, № 4. С. 64-70.

54. Персонифицированная реабилитация больных после артродеза голеностопного сустава / Р.О. Горбатов, Д.В. Павлов, О.П. Мотякина, Н.Н. Рукина, А.Н. Кузнецов, В.В. Борзиков // Кафедра травматологии и ортопедии. 2016. № 4 (20). С. 44-47.

55. A Biomechanical Comparison of Internal Fixation Techniques for Ankle Arthrodesis / C. Clifford, S. Berg, K. McCann, B. Hutchinson // J. Foot Ankle Surg. 2015. Vol. 54, No 2. P. 188-191. DOI: 10.1053/j.jfas.2014.06.002.

56. Динамика изменений клинико-функциональных показателей у пациентов после артродезирования голеностопного и подтаранного суставов интрамедуллярным блокируемым стержнем / К.С. Михайлов, В.Г. Емельянов, Р.М. Тихилов, А.Ю. Кочиш, Е.П. Сорокин // Актуальные проблемы травматологии и ортопедии. Сборник научных статей, посвященный 110-летию РНИИТО им. Р.Р. Вредена. Санкт-Петербург, 2016, С. 196-202.

57. Современный подход к профилактике инфекционных осложнений при артродезе голеностопного сустава / Л.К. Брижань, В.В. Хоминец, Д.В. Давыдов, Ю.М. Стойко, Н.С. Юрмина, Сливков К.А., Керимов А.А., Кузьмин П.Д. // Вестник Национального медико-хирургического 
Центра им. Н.И. Пирогова. 2017. Т. 12, № 4, часть 2. С. 67-71.

58. Малотравматичный метод артродезирования голеностопного сустава / Г.М. Кавалерский, С.В. Архипов, А.Р. Дрогни, А.В. Лычагин // Пироговская научно-практическая конференция. Вестник РГМУ. 2005. № 3. С. 42.

59. Мацакян А.М., Бутаев Б.Г., Процко В.Г. Артроскопический артродез голеностопного сустава // Современная наука: актуальные проблемы теории и практики. Серия: Естественные и технические науки. 2016. № 8. С. 99-102.

60. Sport and physical activity after ankle arthrodesis with Ilizarov fixation and internal fixation / P. Morasiewicz, M. Dejnek, M. Kulej, S.Ł. Dragan, G. Konieczny, A.Krawczyk, W. Urbański, W. Orzechowski, S.F. Dragan, Ł. Pawik // Adv Clin Exp Med. 2019. Vol. 28, No. 5. P. 609-614. DOI:10.17219/acem/80258.

61. Thomas R., Daniels T.R., Parker K. Gait analysis and functional outcomes following ankle arthrodesis for isolated ankle arthritis // J Bone Joint Surg Am. 2006. Vol. 88, No 3. P. 526-535. DOI: 10.2106/JBJS.E.00521.

62. Outcome of unilateral ankle arthrodesis and total anklereplacement in terms of bilateral gait mechanics / S. Chopra, H. Rouhani, M. Assal, K. Aminian, X. Crevoisier // J Orthop Res. 2014. Vol. 32, No 3. P. 377-384. DOI: 10.1002/jor.22520.

63. Obesity is associated with increased complications after operative management of end-stage ankle arthritis / B.C. Werner, M.T. Burrus, A.M. Looney, J.S. Park, V. Perumal, M.T. Cooper // Foot Ankle Int. 2015. Vol. 36, No 8. P. 863-870. DOI: 10.1177/1071100715576569.

64. Choice of surgical treatment for patients with arthrosis of the ankle joint/ V.G. Emelyanov, A. Yu. Kochish, A.A. Bulatov, K.S. Mikhailov // Foot and Ankle Online Journal. 2018. Vol. 11. № 1. Ст. №3.

65. Histological analysis of early osteolysis in total ankle arthroplasty / O.N. Schipper, S.L. Haddad, P. Pytel, Y. Zhou // Foot Ankle Int. 2017. Vol. 38. No. 4. P. 351-359. DOI: 10.1177/1071100716682333.

66. Total ankle arthroplasty versus ankle arthrodesis for the treatment of end-stage ankle arthritis: a meta-analysis of comparative studies / H.J. Kim, D.H. Suh, J.H. Yang, J.W. Lee, H.J. Kim, H.S Ahn, S.W. Han, G.W. Choi // Int Orthop. 2017. Vol. 41. No. 1. P. 101-109. DOI: 10.1007/s00264016-3303-3.

67. Patient-reported outcomes before and after primary and revision total ankle arthroplasty / J.R. Lachman, J.A. Ramos, S.B. Adams, J.A. Nunley 2 ${ }^{\text {nd }}$, M.E. Easley, J.K. DeOrio // Foot Ankle Int. 2019. Vol. 40. No. 1. P. 34-41. DOI: 10.1177/1071100718794956.

68. Результаты эндопротезирования голеностопного сустава третьим поколением моделей эндопротезов / К.С. Михайлов, А.А. Булатов, Д.Г. Плиев, Е.П. Сорокин, М.С. Гуацаев // Кафедра травматологии и ортопедии. 2018. T. 31, № 1. C. 40-45. DOI: 10.17238/issn22262016.2018.1.40-45

69. Эндопротезирование и артродез голеностопного сустава. Сравнение результатов лечения / Д.Л. Мирошников, О.В. Сабодашевский, А.А. Афаунов, И.И. Замятин, Х.Х. Матар, Ю.В. Напах // Инновационная медицина Кубани. 2018. № 2 (10). С. 29-36.

70. Secondary arthrodesis after total ankle arthroplasty / C.E. Gross, J.S. Lewis, S.B. Adams, M. Easley, J.K. DeOrio, J.A. Nunley $2^{\text {nd }}$. // Foot Ankle Int. 2016. Vol. 37. No. 7. P. 709-14. DOI: 10.1177/1071100716641729.

71. Клюшин Н. М., Ермаков А. М. Двухэтапное артродезирование голеностопного сустава при лечении перипротезной инфекции // Гений ортопедии. 2020. Т. 26, №1. С. 99-102.

72. Weber D., Weber M. Corrective osteotomies for malunited malleolar fractures // Foot Ankle Clinics. 2016. Vol. 21, No. 1. P. 37-48. DOI: 10.1016/j. fcl.2015.09.003.

73. Liu G.T. Ankle Fractures. In Complications in Foot and Ankle Surgery: Management Strategies / New York, J. Springer, 2017. P. 385-407.

74. Jastifer J., Coughlin M.J., Hirose C. Performance of total ankle arthroplasty and ankle arthrodesis on uneven surfaces, stairs, and inclines: a prospective study // Foot Ankle Int. 2015. Vol. 36, No 1. P. 11-17. DOI: 10.1177/1071100714549190.

75. Total ankle arthroplasty versus ankle arthrodesis: a comparative analysis of arc of movement and functional outcomes / D.I. Pedowitz, J.M. Kane, G.M. Smith, H.L. Saffel, C. Comer, S.M. Raikin // Bone Joint J. 2016. Vol. 98-B, No 5. P. 634-640. DOI: 10.1302/0301-620X.98B5.36887.

76. Time trends and risk factors for perioperative complications in total ankle arthroplasty: retrospective analysis using a national database in Japan / T. Matsumoto, H. Yasunaga, H. Matsui, K. Fushimi, N. Izawa, T. Yasui, Y. Kadono, S. Tanaka // BMC Musculoskelet Disord. 2016. Vol. 17, No 1. Art. No 450. DOI: 10.1186/s12891-016-1299-x.

77. Complications and results of the arthrodesis after total ankle arthroplasty failure: a retrospective monocentric study of 12 cases / F. Egrise, J. Parot, C Bauer., F. Galliot, M. Kirsch, D. Mainard // Eur J Orthop Surg Traumatol. 2020. Vol. 30, No 2. P. 373-381. DOI: 10.1007/s00590-019-02561.

78. Total ankle arthroplasty versus ankle arthrodesis-a comparison of outcomes over the last decade / C.D. Lawton, B.A. Butler, R.G. Dekker $2^{\text {nd }}$, A. Prescott, A.R. Kadakia // J Orthop Surg Res. 2017. Vol. 12, No 1. Art. No 76. DOI: 10.1186/s13018-017-0576-1.

Статья поступила в редакцию 02.02.2021; одобрена после рецензирования 14.04.2021; принята к публикации 23.12.2021.

The article was submitted 02.02.2021; approved after reviewing 14.04.2021; accepted for publication 23.12.2021.

\section{Информация об авторах:}

1. Олег Андреевич Кауц - кандидат медицинских наук;

2. Юрий Анатольевич Барабаш - доктор медицинских наук, професcop, yubarabash@yandex.ru;

3. Сергей Иванович Киреев - доктор медицинских наук;

4. Константин Александрович Гражданов - кандидат медицинских наук;

5. Павел Павлович Зуев - кандидат медицинских наук;

6. Андрей Леонидович Кесов;

7. Игорь Алексеевич Норкин - доктор медицинских наук, профессор.

\section{Information about the authors:}

1. Oleg A. Kauts - Candidate of Medical Sciences;

2. Yuri A. Barabash - Doctor of Medical Sciences, Professor, yubarabash@yandex.ru;

3. Sergey I. Kireev - Doctor of Medical Sciences;

4. Konstantin A. Grazhdanov - Candidate of Medical Sciences;

5. Pavel P. Zuev - Candidate of Medical Sciences;

6. Andrey L. Kesov - M.D.;

7. Igor A. Norkin - Doctor of Medical Sciences, Professor.

Конфликт интересов: работа выполнена в рамках государственного задания по теме «Разработка персонализированного подхода к выбору тактики хирургической реабилитации пациентов с последствиями внутрисуставных повреждений дистального отдела костей голени», научный руководитель - д.м.н., профессор, начальник отдела инновационных проектов в травматологии и ортопедии НИИТОН СГМУ И.А. Норкин. 
Гений ортопедии. 2022. Т. 28, № 1. С. 141-149.

Genij Ortopedii. 2022. Vol. 28, no. 1. P. 141-149.

\title{
Обзорная статья
}

удК [616.718.56/.66+616.75]-001.5-089(048.8)

https://doi.org/10.18019/1028-4427-2022-28-1-141-149

\section{Повреждение дистального межбериового синдесмоза, пути улучшения результатов лечения (обзор литературы)}

\section{Д.А. Никифоров ${ }^{1 \bowtie}$, М.А. Панин ${ }^{2,3}$, В.Г. Процко ${ }^{2,4}$, Р.Д. Боргут ${ }^{2,5}$, Р.Н. Алиев ${ }^{2,6}$}

\author{
1 Клиника ЗАО МЦК, Москва, Россия \\ 2 Российский университет дружбы народов, Москва, Россия \\ ${ }^{3}$ Городская клиническая больница № 17, Москва, Россия \\ ${ }^{4}$ Городская клиническая больница № 7, Москва, Россия \\ ${ }^{5}$ Клиника К + 31, Москва, Россия \\ ${ }^{6}$ Городская клиническая больница № 31, Москва, Россия
}

Автор, ответственный за переписку: Дмитрий Александрович Никифоров, nikiforovmd@gmail.com

\section{Аннотация}

Введение. Лечение пациентов с повреждениями дистального межберцового синдесмоза (ДМБС) до настоящего времени остаётся одной из самых дискутабельных тем в хирургии стопы и голеностопного сустава. Переломы лодыжек с повреждением дистального межберцового синдесмоза сопровождаются значительно худшими результатами. Однозначного мнения об алгоритме диагностики и лечения таких повреждений до настоящего времени не существует. Цель. Путём анализа современной мировой литературы обобщить данные относительно методов диагностики и лечения повреждений дистального межберцового синдесмоза, как изолированных, так и в комплексе с переломами лодыжек. Материалы и методы. При подготовке обзора были использованы электронные базы данных elibrary, PubMed, ResearchGate. Глубина поиска составила 30 лет. После предварительного сбора информации все низкорелевантные источники были исключены. Предпочтение отдавалось исследованиям типа мета-анализ, рандомизированным контролируемым исследованиям, систематическим обзорам, кадаверным биомеханическим исследованиям. Результаты. Для фиксации ДМБС могут использоваться винты и шовные пуговицы, выполняться остеосинтез переломов Волькмана, Шапута и Вагстаффа, которые являются чрескостными повреждениями ДМБС. Для рентгенологической оценки качества устранения смещения может использоваться рентгенография, МСКТ, МРТ и артроскопия. Частичные повреждения ДМБС, если они выявлены своевременно, могут лечиться консервативно, с переходом к хирургической стабилизации при наличии признаков сохраняющейся нестабильности. Обсуждение. Большинство исследований указывает на крайне низкое диагностическое значение обычной рентгенографии в диагностике повреждений ДМБС. Исследователи рекомендуют проводить билатеральную МСКТ, а в случаях частичных изолированных повреждений - МРТ голеностопного сустава. В случае сопутствующих повреждений малоберцовой вырезки большеберцовой кости многие авторы рекомендуют восстановление её целостности до принятия решения о транссиндесмозной фиксации. Открытое устранение смешения в ДМБС сопровождается меньшим риском мальпозиции и мальредукции малоберцовой кости. Для транссиндесмозной фиксации предпочтительнее использовать шовные пуговицы. Удаление позиционных винтов не влияет на функциональный результат лечения. В случае повреждения ДМБС на фоне нейропатии используется более стабильный остеосинтез. Ключевые слова: межберцовый синдесмоз, разрыв дистального межберцового синдесмоза, трёхлодыжечный перелом, позиционный винт, шовная пуговица, перелом заднего края, треугольник Фолькмана

Для иитирования: Повреждение дистального межберцового синдесмоза, пути улучшения результатов лечения (обзор литературы) / Д.А. Никифоров, М.А. Панин, В.Г.Процко, Р.Д. Боргут,Р.Н.Алиев // Гений ортопедии. 2022.Т. 28, № 1. С. 141-149. https://doi.org/10.18019/10284427-2022-28-1-141-149

\section{Review article}

\section{Injury to the distal tibiofibular syndesmosis, ways to improve treatment results (literature review)}

$$
\text { D.A. Nikiforov }{ }^{1 \bowtie} \text {, M.A. Panin }{ }^{2,3} \text {, V.G. Protsko }{ }^{2,4} \text {, R.D. Borgut }{ }^{2,5}, \text { R.N. Aliev }{ }^{2,6}
$$

\section{${ }^{1}$ Clinic CJSC MCK, Moscow, Russian Federation}

2 Peoples' Friendship University of Russia, Moscow, Russian Federation

${ }^{3}$ City Clinical Hospital No. 17, Moscow, Russian Federation

${ }^{4}$ City Clinical Hospital No. 7, Moscow, Russian Federation

${ }^{5}$ Clinical K + 31, Moscow, Russian Federation

${ }^{6}$ City Clinical Hospital No. 31, Moscow, Russian Federation

\section{Corresponding author: Dmitry A. Nikiforov, nikiforovmd@gmail.com}

\section{Abstract}

Introduction Treatment of patients with distal tibiofibular syndesmosis (DTFS) ruptures remains controversial. Ankle fractures accompanied by syndesmosis rupture are associated with worse outcomes. There is no diagnosis and treatment algorithm for such injuries to date. The objective was to summarize the data on diagnosis and treatment of syndesmotic injury alone and in combination with ankle fractures through world literature review. Material and methods A systematic literature search was undertaken using elibrary, PubMed, ResearchGate databases with articles dated 1990 and later. The search depth was 30 years. With preliminary information collected low-relevant articles were excluded. Meta-analysis studies, randomized controlled trials, systematic reviews, cadaveric biomechanical studies were reviewed. Results Screws and suture buttons can be used to fix DTFS, and Volkmann, Shaput and Wagstaff fractures being transosseous injuries to DTFS can be repaired with osteosynthesis. Imaging evaluation of reduction can be produced with radiography, MSCT, MRI and arthroscopy. Partial injuries to the DTFS, if timely detected, can be treated conservatively with transition to surgical stabilization if signs of instability persist. Discussion Conventional radiography has very low diagnostic value for DTFS injury. Bilateral MSCT is recommended for assessment of a syndesmotic injury and MRI of the ankle joint is practical for partial isolated injuries. Concomitant injuries of the fibular notch of the tibia are recommended to address first prior to transsyndesmotic fixation. Open reduction of displaced DTFS is accompanied by a lower risk of fibular malposition and malreduction. Suture buttons are practical for transsyndesmotic fixation. Removal of positional screws does not affect the functional result of treatment. More stable osteosynthesis would be needed for DTFS injury in neuropathy.

Keywords: tibio-fibular syndesmosis, distal tibio-ibular syndesmosis rupture, trimalleolar fracture, positional screw, suture button, posterior malleolus fracture, Folkmann triangle

For citation: Nikiforov D.A. Panin M.A. Protsko V.G. Borgut R.D. Aliev R.N. Injury to the distal tibiofibular syndesmosis, ways to improve treatment results (literature review). Genij Ortopedii, 2022, vol. 28, no 1, pp. 141-149. https://doi.org/10.18019/1028-4427-2022-28-1-141-149 


\section{ВВЕДЕНИЕ}

Около 1 \% всей взрослой человеческой популяции страдает от артроза голеностопного сустава. На посттравматические артрозы приходится 78 \% артрозов голеностопного сустава, подавляющая часть из которых развивается именно после трехлодыжечных переломов [1, 2].

К основным причинам развития посттравматического артроза голеностопного сустава относят непосредственное повреждение суставного хряща в момент травмы, хроническое увеличение контактной нагрузки из-за нарушения конгруэнтности и увеличение пиковых нагрузок из-за нестабильности сустава [3-6]. Восстановление нормальной анатомии необходимо для восстановления конгруэнтности, а фиксация синдесмоза - для решения проблемы нестабильности. При этом необходимо понимать, что осевая нагрузка в нейтральном положении не в полной мере отражает степень изменения пиковых нагрузок на суставной хрящ в условиях нестабильности. Так, в кадаверном исследовании было показано, что осевая нагрузка в $300 \mathrm{~N}$ при наличии 3 мм ступеньки 50 \% площади на суставной поверхности голеностопного сустава увеличивала пиковые нагрузки только на $50 \%$, а при приложении силы в $20 \mathrm{~N}$ в передне-заднем направлении (имитация ходьбы) пиковые нагрузки возрастали на 800 \% [7]. При оценке долгосрочных результатов лечения переломов лодыжек ведущее значение имеет адекватное устранение смещения на уровне ДМБС и стабильность фиксации [8]. При этом частота ошибок устранения смещения в ДМБС по данным послеоперационных МСКТ составляет от 16 до $52 \%$ случаев [8, 9, 10]. Количество ошибок и осложнений может определяться типом перелома лодыжек (В или С по АО классификации), наличием перелома задней лодыжки, переломовывиха, используемой хирургической техники (наружный доступ и закрытое устранение, заднелатеральный доступ и открытое устранение), типом примененных фиксаторов (один или два трёхкортикальных и четырёхкортикальных винта или одна - две пуговицы) $[11,12]$.

В существующих исследованиях, посвящённых проблеме повреждения ДМБС, предлагается несколько путей улучшения результатов лечения данной категории больных. Это адекватная диагностика, прежде всего использование МСКТ при любом подозрении на повреждение ДМБС, и восстановление нормальной анатомии малоберцовой вырезки во всех случаях, когда это представляется возможным, а также использование пуговчатых фиксаторов, снижающих риск как мальредукции, так и поломки металлофиксаторов, а, следовательно, утраты репозиции.

Четкие критерии мальредукции, так же как и группы сравнения, крайне важны для адекватной оценки результатов лечения. Так, одни и те же рентгенограммы или данные МСКТ могут быть трактованы рентгенологами по-разному, в зависимости от того, какие критерии оценки ими используются как нормальные. В настоящее время стандартом послеоперационной оценки корректности репозиции и стабильности фиксации ДМБС становится билатеральная МСКТ.

Цель - путём анализа современной мировой литературы обобщить данные относительно методов диагностики и лечения повреждений дистального межберцового синдесмоза, как изолированных, так и в комплексе с переломами лодыжек.

\section{МАТЕРИАЛЫ И МЕТОДЫ}

Нами был произведён систематический анализ литературных источников в базах данных elibrary, PubMed, ResearchGate. Глубина поиска составила 30 лет. Предпочтение отдавалось исследованиям типа: рандомизированное контролируемое исследование, систематические обзоры, кадаверные биомеханические исследования, экспериментальные исследования, серии случаев, когортные исследования.

Для поиска использовались следующие ключевые запросы: distal syndesmosis rupture, posterior malleolus, trimalleolar fracture, syndesmosis screw, syndesmosis fixation, syndesmosis malreduction, posttraumatic arthritis of the ankle, syndesmosys sprain, anatomy of distal tibiofibular syndesmosis, suture button, + randomized trial, + cohort trial, + diagnosis, + management.

Нами было проанализировано 168 статей, из которых были исключены исследования, датированные до 1990 года, исследования типа «серия случаев», включающие менее 10 пациентов, когортные исследования с периодом наблюдения менее 1 года, исследования, включающие исключительно консервативный подход к лечению.
В результате в нашей работе мы представили анализ 2-х рандомизированных исследований, посвящённых сравнению шовной пуговицы и позиционного винта, 14ти когортных исследований, посвящённых сравнению различных вариантов фиксации разрывов ДМБС винтами, их функциональных результатов, необходимости остеосинтеза переломов заднего края и удаления позиционных винтов. Также нами были проанализированы 4 ретроспективных исследования, посвящённых оценке взаимосвязи функционального результата с остаточной нестабильностью и мальпозицией, 9 исследований, посвящённых рентгенодиагностике, МСКТ-диагностике, МРТ-диагностике, артроскопической диагностике повреждений ДМБС, а также 3 биомеханических исследования межберцового синдесмоза, 4 экспериментальных исследования, оценивающих влияние нестабильности и ступени на суставной поверхности на заживление и ремоделирование хрящевой ткани и риск развития артроза в животной модели, и одно эпидемиологическое исследование, посвящённое рискам развития посттравматического артроза голеностопного сустава.

\section{РЕЗУЛЬТАТЫ}

\section{Анатомия}

Большеберцовая и малоберцовая кости надёжно соединены между собой элементами дистального межберцового синдесмоза. Он состоит из 4-х основных элементов: передней и задней нижних межберцовых связок, межкостной связки и в более проксимальной части - межкостной мембраны. Такое строение межберцового синдесмоза обеспечивает высокую степень стабильности и 
одновременно позволяет малоберцовой кости двигаться в вырезке большеберцовой кости в передне-заднем направлении и ротировать кнаружи, при этом суммарная амплитуда движения не превышает 2 мм. Несмотря на малую амплитуду, возможность такого движения крайне важна, так как таранная кость, хоть и имеет полуцилиндрическую форму, но её передняя часть более широкая чем задняя, и при тыльном сгибании в голеностопном суставе малоберцовая кость должна освобождать как раз те самые 2 мм, для того, чтобы это движение было возможно.

К повреждениям синдесмоза можно отнести как разрывы всех или нескольких из перечисленных связочных элементов, так и переломы, включающие в себя точки их прикрепления - перелом задней лодыжки или перелом Volkman, а также перелом Chaput и перелом Vagstaffe (рис. 1).

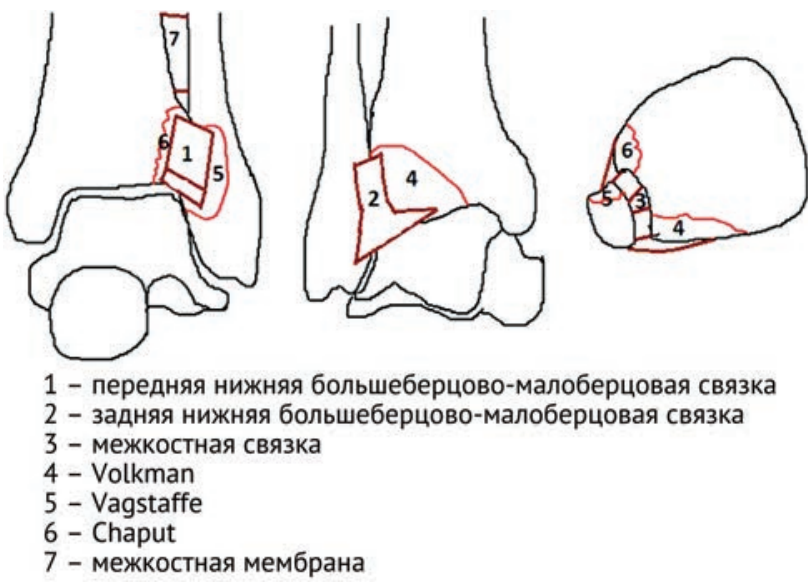

Рис. 1. Костные и связочные структуры, образующие дистальный межберцовый синдесмоз

\section{Биомеханика}

В норме ДМБС обеспечивает высокую степень стабильности голеностопного сустава, обеспечивая при этом значительную амплитуду сгибания и разгибания. Таранная кость в аксиальной плоскости имеет конусовидную форму, при тыльном сгибании малоберцовая кость смещается кзади, проксимально и ротируется кнаружи, создавая пространство для её более широкой части.

Подвижность малоберцовой кости на уровне ДМБС оценивалась в исследовании А. Beumer и соавт. Полученные данные авторы предложили рассматривать как вариант физиологической нормы для движений в ДМБС. Приложение 7,5 Nm наружной ротации к стопе в положении нейтрального сгибания приводило к наружной ротации малоберцовой кости от 2 до 5 градусов, медиальной трансляции от 0 до 2,5 мм и смещения кзади от 1 до 3,1 мм (рис. 2) [13].

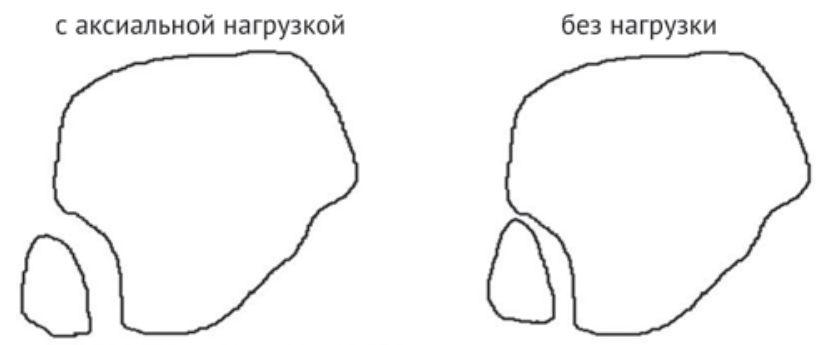

в норме под нагрузкой происходит наружная ротация и трансляция малоберцовой кости кнаружи и кзади

Рис. 2. Амплитуда движений малоберцовой кости на уровне ДМБС
K неправильной позиции ДМБС могут привести различные группы факторов: укорочение малоберцовой кости при неадекватной репозиции, ротация малоберцовой кости, передняя и задняя трансляция, избыточная компрессия. Кроме того, возможно нарушение структуры самой малоберцовой вырезки при смещении заднего или переднего её края (треугольник Volkman или фрагмент Chaput). При закрытом устранении смещения в ДМБС крайне важным является технически правильная установка остроконечных репозиционных щипцов, наиболее корректная позиция это уровень синдесмоза на малоберцовой кости на её латеральном крае, на большеберцовой - посередине её передне-задней длины в боковой проекции. Установка репозиционных щипцов в другой проекции приводит к трансляции малоберцовой кости кпереди или кзади соответственно [14]. Восстановление нормальной анатомии малоберцовой кости облегчает устранение трансляции и ротации, но такой риск сохраняется и остаётся высоким при закрытом устранении смещения в ДМБС.

Диагностика

Европейская ассоциация спортивной травматологии, хирургии коленного сустава и артроскопии (ESSKA-AFAS) в 2017 году рекомендовала использовать в качестве клинических диагностических критериев повреждения ДМБС боль при пальпации в проекции передней нижней большеберцово-малоберцовой связки (ПНБМС), задней нижней большеберцово-малоберцовой связки (ЗНБМС), тест трансляции малоберцовой кости и тест Cotton [15].

Многие авторы указывали на сложности в диагностике повреждения синдесмоза и переломов заднего края при выполнении стандартных рентгенограмм в прямой и боковой проекции. Это связано с большим разнообразием анатомических вариантов малоберцовой вырезки большеберцовой кости, которые различаются по своей глубине от 8 до 0 мм и имеют, соответственно, либо плоскую, либо полукруглую форму в поперечном сечении (рис. 3) [16, 17].

типы строения малоберцовой вырезки большеберцовой кости и их вид на МСКТ и на проекции Mortise
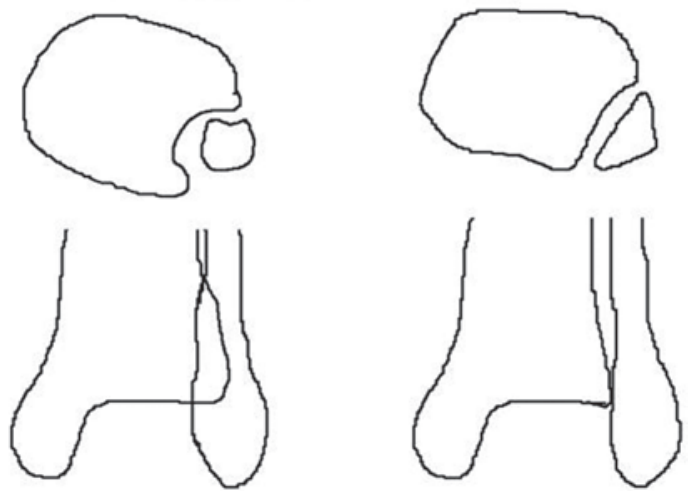

Рис. 3. Анатомические варианты строения ДМБС и их рентгенологические особенности (схема)

Данная особенность предопределяет трудности при рентгенологической оценке устранения смещения в ДМБС [18-21]. Кроме повреждения ДМБС в комплексе с переломом лодыжек также можно встретить 
его повреждения без костной травмы на уровне голеностопного сустава. Частичные повреждения ДМБС пропускаются рентгенологами на стандартных рентгенограммах в подавляющем большинстве случаев. Частота повреждений ДМБС при травме латерального связочного комплекса голеностопного сустава может достигать 11 \% [22]. По этой причине в диагностике повреждений дистального межберцового синдесмоза особое значение имеет МСКТ [19, 21]. При рентгенографии можно обнаружить только расхождение синдесмоза более 3 мм, в то же время МСКТ достоверно указывает на расхождение на 1 мм. Однако при частичных и динамических повреждениях синдесмоза и этой диагностической чувствительности может быть недостаточно. Например, при изолированном разрыве только ПНБМС расхождение может появляться только при наружной ротации стопы относительно фиксированной голени. В такой ситуации на помощь приходят такие методы как МРТ и диагностическая артроскопия голеностопного сустава, которые позволяют выявить частичные повреждения ДМБС и динамическую нестабильность [23, 24, 25, 26].

Классификация повреждений ДМБС, методы лечения

Необходимо разделить повреждения ДМБС в комплексе с переломами лодыжек и изолированные связочные повреждения. Van Dijk CN и соавт. в 2016 году пересмотрели классификацию изолированных разрывов ДМБС и разделили их по времени от момента травмы на свежие (до 6 недель), подострые (от 6 недель до 6 месяцев) и застарелые (после 6 месяцев). Свежие повреждения были разделены на стабильные и нестабильные. К стабильным могут быть отнесены изолированные повреждения ПНБМС, реже ЗБМБС, иногда с вовлечением межкостной связки (МКС). Нестабильные повреждения ДМБС включают латентные - динамические, которые чаще включают также повреждение МКС и дельтовидной связи (ДС), а также явные, с повреждением всех элементов ДМБС и дельтовидной связки. Подострые повреждения также принято делить на восстановимые и невосстановимые, а хронические дополнительно подразделяются в зависимости от наличия остеоартроза голеностопного сустава [27].

Частичные, то есть стабильные повреждения ДМБС, в свежих случаях лечатся консервативно. T.L. Miller и соавт. предлагают следующий протокол лечения свежих частичных изолированных повреждений ДМБС: первые 2 недели - покой, лёд, возвышенное положение, иммобилизация в шарнирном ортезе, без осевой нагрузки [28]. На второй фазе, со 2-ой по 6-ю неделю, разрешается осевая нагрузка в функциональном брейсе, тренировка мышечной выносливости, силы, восстановление полной амплитуды движений. В третьей фазе проводится тренировка мышечного баланса и проприорецепции. Пациенты возвращаются к нормальной жизни уже через 8 недель от момента получения травмы, однако следует продолжить наблюдение до 6 месяцев, для исключения остаточной нестабильности, гетеротопической оссификации и формирования гипертрофического рубца в области ПНБМС [27].

В случае полного повреждения ДМБС хирургическое лечение обязательно. Оно может быть выполнено с использованием транссиндесмозных винтов, динамической фиксации шовными пуговицами, прямого восстановления за счёт остеосинтеза отрывных костных фрагментов или сшивания связок с аугментацией или без нее.

Фиксация при помощи винтов является наиболее распространённой. Существуют различные варианты фиксации ДМБС. Может быть использован 1 или 2 винта диаметром 3,5 или 4,5 мм, проходящие через 3 или 4 кортикала. В исследовании Monga и соавт. к 2008 году 97 \% хирургов использовали для фиксации межберцового синдесмоза только винты. При этом 58 \% устанавливали трёхкортикальные винты, а 33 \% четырёхкортикальные [29].

Логично предположить, что жёсткость, то есть устойчивость к поломке металлоконструкции и устойчивость к расхождению синдесмоза, будет возрастать соответственно с увеличением количества винтов, их диаметра и количества пройденных кортикалов. Но биомеханические исследования не обнаружили подобной взаимосвязи. Так, в исследовании Thompson не было обнаружено статистически значимой разницы при сравнении стабильности фиксации 3,5 и 4,5 мм трёхкортикальными винтами [30]. При этом производилась нагрузка на смоделированный перелом типа С по Веберу, фиксированный 3,5 и 4,5 мм винтами. Позднее Markolf и соавт. провели более широкое исследование, включающее использование 3,5 и 4,5 мм винтов с трёхкортикальной и четырёхкортикальной позицией. В своём биомеханическом кадаверном исследовании, датированном 2013 годом, авторы также не обнаружили статистически значимой разницы между 3,5 и 4,5 мм винтами, а также трёхкортикальной и четырёхкортикальной фиксацией [31]. При этом они обнаружили, что максимальная нагрузка на позиционный винт возникает при одновременной осевой нагрузке и наружной ротации стопы, в связи с этим авторами рекомендовано ограничивать такой тип нагрузки во время реабилитации пациентов с подобным типом повреждений.

C точки зрения возможности движений в голеностопном суставе после фиксации позиционным винтом можно предположить обратную зависимость, так как один трёхкортикальный винт при движениях в голеностопном суставе будет быстрее расшатываться и освобождать возможность для движений малоберцовой кости, чем два винта, или винт большего диаметра, или четырёхкортикальный винт.

Так, в исследовании А.С. Peek и соавт. рекомендуется использование одного трёхкортикального 4,5 мм винта, удаление которого не рекомендуется. По мнению авторов, такая тактика будет сопровождаться меньшим риском поломки, миграции, вторичного смещения, инфекционных осложнений, а также меньшим риском получить избыточно жёсткую конструкцию по сравнению с другими вариантами комбинаций винтов [32]. Однако убедительное статистическое подтверждение для данного алгоритма отсутствует. Исследование литературы, посвящённой синдесмозным винтам, затруднительно с точки зрения доказательности, так как на клинический и функциональный результат влияет множество факторов помимо диаметра, количества и длины винтов. 
В исследовании Мanjoо и соавт. 2010 года, включившего 106 пациентов, которым был установлен позиционный винт, было обнаружено, что OMAS-score (Olerud-Molander Ankle Score) был значительно выше в группе пациентов, где были сломанные, расшатанные или удалённые позиционные винты $(85 \pm 3)$, чем в группе с интактными позиционными винтами (70 \pm 6) [33]. При этом во второй группе было обнаружено сужение свободного тибио-фибулярного пространства в среднем на 1 мм в сравнении с первой группой. Это указывает на тот факт, что при установке позиционного винта происходит избыточная компрессия синдесмоза, и, если она не устраняется (путём удаления винта или при поломке / расшатывании металлоконструкции), можно ожидать значимо худшего функционального результата. Так, в исследовании 2013 года Gardner и coавт. пришли к выводу, что в случае использования двух 4,5 мм четырёхкортикальных винтов их удаление необходимо, так как они обеспечивают крайне жёсткую фиксацию и могут стойко ограничивать амплитуду движений в том случае, если они не удалены [34].

В подавляющем большинстве исследований винты устанавливаются на 2-3 см выше линии сустава под углом 20-30 градусов спереди назад. Удаление винтов никак не влияет на функциональный результат лечения в случае использования трёхкортикальных винтов [35, 36].

Следует отметить, что использование одного винта, вне зависимости от его диаметра и количества кортикалов, сопровождается статистически однородными результатами. Единственный вариант фиксации, который обладает значимо отличающейся жёсткостью и требует рутинного удаления имплантов в срок от 8 до 16 недель, это использование 2-х четырёхкортикальных винтов 4,5 мм.

Другим крайне дискутабельным моментом является принципиальная необходимость в использовании транссиндесмозной фиксации. Многие авторы сходятся во мнении, что при наличии перелома заднего края или перелома переднего края малоберцовой вырезки, его остеосинтез позволяет избежать транссиндесмозной фиксации и, следовательно, всех возможных связанных с ней осложнений.

Использование любых видов транссиндесмозной фиксации и наложение костной цапки само по себе является фактором риска мальпозиции и мальредукции. Так, в исследовании J. Franke, в которое вошли 252 пациента с переломами лодыжек и разрывом ДМБС, при выполнении послеоперационной МСКТ у 82 из них (39 \%) были обнаружены ошибки репозиции, при этом 64 (25 \%) были связаны с мальпозицией малоберцовой кости в вырезке большеберцовой [37].

В 2017 году M.A. Miller и соавторы опубликовали исследование, проведённое в University of Mississippi Medical Center, Jackson, MS, USA, в котором оценивалось 198 переломов лодыжек с повреждением заднего края. 151 пациент был прооперирован по стандартной методике в положении на спине из латерального доступа, при этом в 27,2 \% случаев потребовалась установка позиционного винта в связи с интраоперационно выявленной нестабильностью ДМБС при тесте Коттона и наружной ротации. 47 пациентов были проопери- рованы из постеролатерального доступа в положении на животе. Всем был выполнен остеосинтез заднего края, необходимость в установке позиционного винта возникла только в 1 случае (2,1 \%). Таким образом, по данным авторов, при операции в позиции на животе и остеосинтезе заднего края необходимость в транссиндесмозной фиксации была в 13 раз ниже [38]. M.A. Miller и Bartonijek и соавт. рекомендуют избегать транссиндесмозной фиксации во всех случаях, когда это технически возможно. То есть тогда, когда есть чрескостные повреждения (перелом Volkman, перелом Chaput или перелом Vagstaffe).

В исследовании 2015 года Bartonijek и соавт. также указывают на то, что остеосинтез перелома заднего края, включающего заднюю стенку малоберцовой вырезки, из постеролатерального доступа в 95 \% случаев восстанавливает стабильность синдесмоза и устраняет необходимость использования транссиндесмозной фиксации [39].

Согласно исследованию М.J. Gardner, остеосинтез костных элементов синдесмоза восстанавливает нормальную анатомию малоберцовой вырезки и стабилизирует синдесмоз в большей степени, чем позиционные винты [40].

Другая группа исследователей в большей степени полагается на совершенствование транссиндесмозной фиксации, чем на попытки избежать её. Так, Y. Shimozono и C. Colcuc указывают на значительно более хорошие результаты при использовании транссиндесмозной фиксации. Использование для транссиндесмозной фиксации шовных пуговиц, по их мнению, позволяет ускорить реабилитацию за счёт более ранней осевой нагрузки и движений в голеностопе, а также помогает избежать проблем с поломкой импланта и утратой репозиции $[41,42]$.

Пуговчатые фиксаторы показали себя с лучшей стороны для решения всех вышеуказанных проблем, однако не стоит забывать, что самым главным хирург-ассоциированным фактором в лечении разрывов ДМБС всё равно остаётся точность репозиции перелома малоберцовый кости и точность редукции синдесмоза.

Особняком стоит проблема разрыва ДМБС у пациентов с сахарным диабетом. Отсутствие защитной протективной чувствительности у пациентов с сахарным диабетом (и в более редких случаях с другими видами периферической нейропатии) может привести к серьезным последствиям, поломке и миграции металлофиксаторов, утрате репозиции, развитию артропатии Шарко, инфекции и даже утрате конечности. По этой причине у данной категории больных применяется иной алгоритм лечения. Используется максимально мощный фиксатор, который позволяют защитить мягкие ткани, а также значительно расширяются показания к первичному артродезу. Для фиксации синдесмоза используется множество (3-4) четырёхкортикальных винтов увеличенного диаметра или минимум 2 шовные пуговицы через пластину. Использование постеролатерального доступа снижает риск инфекции, некроза краёв раны и её расхождения. Также разумной альтернативой в подобной ситуации становится первичный остеосинтез с использованием аппарата Илизарова. В том случае, если перелом произо- 
шёл на фоне артропатии Шарко, целесообразно проведение первичного артродеза в аппарате Илизарова или панартродез штифтом с блокированием [43].

Оценка интраоперационной редукции ДМБС

Интраоперационная оценка редукции ДМБС является сложной задачей. Как показали многие исследователи, для этого недостаточно просто выполнить рентгенографию в прямой проекции или с внутренней ротацией $15^{\circ}$, так как результат может быть обманчив. Высокая частота мальпозиций в сагиттальной плоскости и ротационно делает необходимым интраоперационную оценку позиции малоберцовой кости в данной плоскости в сравнении с контралатеральной стороной [44].

Для оценки позиции малоберцовой кости относительно большеберцовой в сагиттальной плоскости можно использовать истинные боковые рентгенограммы. Для адекватной оценки нужно выполнять рентгенограммы с контралатеральной стороны.

Также большое практическое значение имеет правило измерения передне-заднего большеберцово-малоберцового отношения, предложенное в 2013 году S. Grenier. Данный метод крайне актуален для интраоперационного контроля позиции малоберцовой кости. На истинных боковых рентгенограммах нужно отметить передний край большеберцовой кости и точку пересечения переднего края малоберцовой кости с границей метафиза. Если продолжить эту линию до заднего кортикала большеберцовой кости в истинной боковой проекции, точка пересечения переднего края малоберцовой кости с линией метафиза должна делить эту линию пополам (рис. 4) [45].

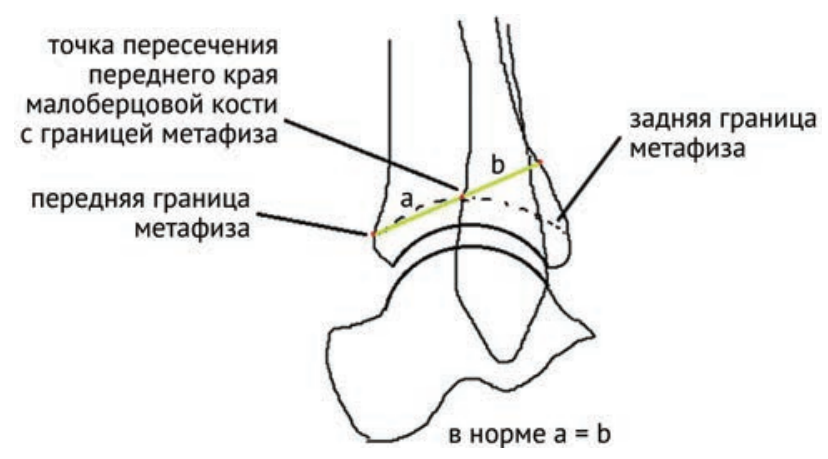

Рис. 4. Использование рентгенографии в боковой проекции для оценки правильности редукции ДМБС в сагиттальной плоскости (схема)

Обязателен контроль контралатеральной стороны как в прямой, так и в боковой проекции, а также МСКТ-контроль после операции [40].

Многие исследователи отмечают, что открытая редукция ДМБС под визуальным контролем и остеосинтез сопутствующих чрескостных повреждений значительно снижают риск мальпозиции $[9,35,40]$.

\section{ОБСУЖДЕНИЕ}

Одной из основных причин неудовлетворительных результатов лечения разрывов ДМБС, в том числе в симптомокоплексе с переломами лодыжек, является неадекватное устранение смещения - мальпозиция малоберцовой кости. Основным способом уменьшения риска ятрогенных мальредукций и, как следствие, плохих функциональных результатов, являются адекватная предоперационная диагностика и планирование (МСКТ), открытое устранение смещения ДМБС, остеосинтез сопутствующих чрескостных повреждений, отказ от необоснованной транссиндесмозной фиксации, использование шовных пуговиц. Дистальный межберцовый синдесмоз имеет крайне вариабельное анатомическое строение, что затрудняет рентгенодиагностику данного типа повреждений, интраоперационный рентгеноконтроль и послеоперационную оценку качества устранения смещения в ДМБС.

В исследовании Н. Claude Sagi и соавт. была проведена ретроспективная оценка результатов лечения 68 пациентов с переломами лодыжек с повреждением дистального межберцового синдесмоза при двухлетнем периоде наблюдения. У всех пациентов выполняласьпослеоперационная МСКТ, функциональный результат оценивался по шкале Olerud-Molander Ankle Score (OMAC) и по шкале Short Form Musculoskeletal Assessment (SFMA). Примечательно, что из 68 рассмотренных клинических случаев при МСКТ после операции в 27 (39,7 \%) наблюдалась мальредукция синдесмоза. При этом по стандартным рентгенограммам нельзя было её заподозрить ни в одном случае.

В 64 \% случаев мальредукция была связана с трансляцией малоберцовой кости (рис. 5), в 28 \% случаев с ротацией, оставшиеся 8 \% были связаны с не- адекватной репозицией перелома малоберцовой кости. При этом частота данного ятрогенного осложнения была 44 \% в группе закрытого устранения смещения и фиксации и значимо ниже - 15 \% - в группе открытой фиксации синдесмоза.

разрыв дистального межберцового синдесмоза

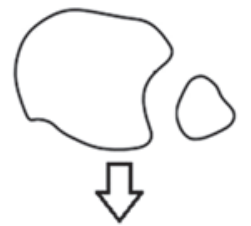

фиксация ДМС винтом

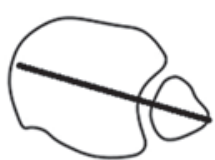

правильный угол

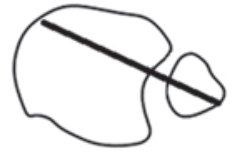

винт под небольшим углом спереди назад

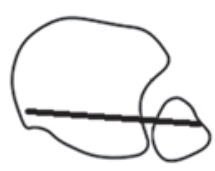

винт под небольшим углом сзади наперед
Рис. 5. Варианты мальредукции малоберцовой кости на уровне ДМБС вследствие установки позиционного винта под неправильным углом

Функциональный результат лечения через 2 года после операции значительно отличался в группе с мальредукцией синдесмоза. При оценке по шкале SFMA в группе с анатомичной репозицией был получен результат $12 \pm 10,6$, а в группе с мальредукцией $27 \pm 23,3$ (различия статистически достоверны). При оценке результатов лечения по шкале OlerudMolander также была получена статистически значимая разница в результатах; в группе анатомичной репозиции $72,7 \pm 22,5$, тогда как в группе мальредукции $46,3 \pm 28,5$ [47]. Таким образом, открытое устранение 
смещения ДМБС приводило к уменьшению риска мальредукции и улучшению функциональных результатов [47].

Проблема мальредукции синдесмоза во время наложения костной цапки и установки позиционного винта широко известна. A.N. Miller и соавт. в 2013 году посвятили ей отдельное кадаверное исследование. Они предположили, что наложение костной цапки в условиях разрыва ДМБС при недостаточной визуализации может резко увеличить риск смещения малоберцовой кости кпереди или кзади, а также ротационно, при этом дальнейшая установка позиционного винта может усугубить имеющееся смещение. Для проверки своей гипотезы авторы использовали 14 кадаверных голеней, все элементы синдесмоза пересекались, после чего устанавливалась костная цапка под углом 0, 15, 30 градусов относительно сагиттальной оси, после чего происходила установка позиционного винта под углом 15 и 30 градусов с точкой входа либо латерально, либо задне-латерально. На каждом этапе выполнялась МСКТ. Примечательно, что авторы не смогли добиться адекватного устранения смещения в ДМБС ни в одной из указанных позиций. Согласно распространённому среди травматологов мнению, костную цапку, так же как и позиционный винт, следует устанавливать под углом кпереди (15-30), однако в данном исследовании было показано, что такая позиция во всех случаях разрыва ДМБС приводит к наружной ротации малоберцовой кости и избыточной компрессии синдесмоза, с различной степенью передней трансляции малоберцовой кости. Установка же цапки и винта под углом $0^{\circ}$ приводит к трансляции малоберцовой кости кзади, но в меньшей степени сопровождается нарушением её ротации и избыточной компрессией.
При статистической оценке полученных данных оказалось, что наилучшей позицией, сопровождаемой наименьшими нарушениями взаимоотношений в ДМБС, является $0^{\circ}$. Ограничением данного исследования является моделирование изолированного связочного повреждения ДМБС. Можно предположить, что при наличии интраинцизурных переломов большеберцовой кости синдесмозный винт будет вызывать трансляцию малоберцовой кости в сторону перелома из-за недостатка опоры. Таким образом, данное исследование выявило отсутствие технической возможности адекватно устранить смещение в ДМБС при помощи костной цапки. По этой причине авторы рекомендовали во всех случаях использовать открытую технику устранения смещения в ДМБС для уменьшения риска мальредукции [48].

Так как же не пропустить повреждение ДМБС и как его правильно лечить? Правило большого пальца - если есть малейшее подозрение на повреждение ДМБС - делай МСКТ. Вне зависимости от выбора дальнейшей тактики это позволит избежать грубых ошибок - таких как пропущенный разрыв ДМБС или перелом Volkman, а также перелом Chaput и перелом Vagstaffe. Второе правило - сначала восстанови костные структуры, затем решай, нужна ли фиксация ДМБС, после остеосинтеза всех трёх лодыжек при трёхлодыжечных переломах в большинстве случаев фиксация ДМБС не требуется. Третье правило - используй контралатеральную конечность для контроля. Четвёртое правило - лучше визуализировать синдесмоз хотя бы с одной стороны. Пятое - не надо ставить винт на всякий случай, если нет признаков нестабильности при рентгеноскопии. И шестое - шовные пуговицы более предпочтительны, чем винты.

\section{ВЫВОдЫ}

Повреждения дистального межберцового синдесмоза по-прежнему остаются одной из наиболее дискутабельных тем применительно к травмам голеностопного сустава. Это связано как с трудностями диагностики, так и с трудностями стабильной и анатомически верной фиксации, разнообразными подходами к остеосинтезу переломов заднего края большеберцовой кости, тактикой при частичных и динамически нестабильных повреждениях, а также важной роли повреждения синдесмоза в дальнейшем развитии посттравматического артроза голеностопного сустава.

Тем не менее, становится возможным определить несколько важных трендов в развитии ортопедической мысли применительно к повреждениям ДМБС. Bo-первых, это анатомичное восстановление incisura fibularis во всех случаях, когда имеется повреждение образующих ее костей - чаще это перелом Volkman, реже перелом Chaput и перелом Vagstaffe. Bo-вторых, желательно проводить открытую редукцию ДМБС с ревизией содержимого incisura fibularis, так как не редки случаи интерпозиции межкостной связки с небольшими костными фрагментами, затрудняющими репозицию, или же просто ошибки репозиции при наложении костной цапки. Использование гибких типов фиксации, таких как пуговицы Tight Rope, ускоряют реабилитацию и снижают риск потери редукции с течением времени в случаях изолированных лигаментарных повреждений ДМБС. В случае повреждения ДМБС на фоне периферической нейропатии (при длительном СД или других причинах) требуется намного более жёсткая и даже грубая фиксация и более продолжительный период времени без полной осевой нагрузки в сравнении с обычными повреждениями ДМБС.

Окончательная тактика по отношению к фиксации ДМБС в комплексе трёхлодыжечных переломов до настоящего времени не определена, однако можно отметить тренд на расширение показаний к использованию постеролатерального доступа, анатомичной репозиции и стабильной фиксации всех типов интраинцизурных переломов вне зависимости от размера фрагмента и уход от рутинной фиксации заднего края спереди назад, а также предпочтительное использование эластичных методов фиксации, таких как шовные пуговицы. В настоящее время отсутствуют рандомизированные исследования, сравнивающие использование транссиндесмозной фиксации и остеосинтеза заднего края при трёхлодыжечных переломах, но имеющиеся когортные исследования указывают на их равноценность. 


\section{СПИСОК ИСТОЧНИКОВ}

1. Felson D.T. The epidemiology of osteoarthritis: Prevalence and risk factors // Osteoarthritis Disorders / Kuettner K.E., Goldberg V.M., editors. Rosemont (IL): American Academy of Orthopedic Surgeons. 1995. P. 229-237.

2. Randomized Trial Comparing Suture Button with Single Syndesmotic Screw for Syndesmosis Injury / M.R. Andersen, F. Frihagen, J.C. Hellund, J.E. Madsen, W. Figved // J. Bone Joint Surg. Am. 2018. Vol. 100, No 1. P. 2-12. DOI: 10.2106/JBJS.16.01011.

3. The extent of matrix damage and chondrocyte death in mechanically traumatized articular cartilage explants depends on rate of loading / B.J. Ewers, D. Dvoracek-Driksna, M.W. Orth, R.C. Haut // J. Orthop. Res. 2001. Vol. 19, No 5. P. 779-784. DOI: 10.1016/S0736-0266(01)00006-7.

4. Osteoarthrotic changes after acute transarticular load. An animal model / R.C. Thompson Jr., T.R. Oegema Jr., J.L. Lewis, L. Wallace // J. Bone Joint Surg. Am. 1991. Vol. 73, No 7. P. 990-1001.

5. Healing and remodeling of articular incongruities in a rabbit fracture model / A. Llinas, H.A. McKellop, G.J. Marshall, F. Sharpe, M. Kirchen, A. Sarmiento // J. Bone Joint Surg. Am. 1993. Vol. 75, No 10. P. 1508-1523. DOI: 10.2106/00004623-199310000-00012.

6. Cartilage changes caused by a coronal surface stepoff in a rabbit model / G. Lovász, A. Llinás, P.D. Benya, S.H. Park, A. Sarmiento, J.V. Luck Jr. // Clin. Orthop. Relat. Res. 1998. No 354. P. 224-234. DOI: 10.1097/00003086-199809000-00027.

7. Incongruity versus instability in the etiology of posttraumatic arthritis / T.O. McKinley, M.J. Rudert, D.C. Koos, T.D. Brown // Clin. Orthop. Relat. Res. 2004. No 423. P. 44-51. DOI: 10.1097/01.blo.0000131639.89143.26.

8. Weening B., Bhandari M. Predictors of functional outcome following transsyndesmotic screw fixation of ankle fractures // J. Orthop. Trauma. 2005. Vol. 19, No 2. P. 102-108. DOI: 10.1097/00005131-200502000-00006.

9. Direct visualization for syndesmotic stabilization of ankle fractures / A.N. Miller, E.A. Carroll, R.J. Parker, S. Boraiah, D.L. Helfet, D.G. Lorich // Foot Ankle Int. 2009. Vol. 30, No 5. P. 419-426. DOI: 10.3113/FAI-2009-0419.

10. Sagi H.C., Shah A.R., Sanders R.W. The functional consequence of syndesmotic joint malreduction at a minimum 2-year follow-up // J. Orthop. Trauma. 2012. Vol. 26, No 7. P. 439-443. DOI: 10.1097/BOT.0b013e31822a526a.

11. Randomised Trial Comparing Suture Button, with Single Syndesmotic Screw for Syndesmosis Injury / M.R. Andersen, F. Frihagen, J.C. Hellund, J.E. Madsen, W. Figved // J. Bone Joint Surg. Am. 2018. Vol. 100, No 1. P. 2-12. DOI: 10.2106/JBJS.16.01011.

12. A prospective randomized multicenter trial comparing clinical outcomes of patients treated surgically with a static or dynamic implant for acute ankle syndesmosis rupture / M. Laflamme, E.L. Belzile, L. Bédard, M.P. van den Bekerom, M. Glazebrook, S. Pelet // J. Orthop. Trauma. 2015. Vol. 29, No 5. P. 216-223. DOI: 10.1097/BOT.0000000000000245.

13. Management of syndesmotic injuries of the ankle / J. de Las-Heras Romero, A.M.L. Alvarez, F.M. Sanchez, A.P. Garcia, P.A.G. Porcel, R.V. Sarabia, M.H. Torralba // EFORT Open Rev. 2017. Vol. 2, No 9. P. 403-409. DOI: 10.1302/2058-5241.2.160084.

14. Van den Bekerom M.P., Haverkamp D., Kloen P. Biomechanical and clinical evaluation of posterior malleolar fractures. A systematic review of the literature // J. Trauma. 2009. Vol. 66, No 1. P. 279-284. DOI: 10.1097/TA.0b013e318187eb16.

15. Classification and diagnosis of acute isolated syndesmotic injuries: ESSKA-AFAS consensus and guidelines / C.N. van Dijk, U.G. Longo, M. Loppini, P. Florio, L. Maltese, M. Ciuffreda, V. Denaro // Knee Surg. Sports Traumatol. Arthrosc. 2016. Vol. 24, No 4. P. 1200-1216. DOI: 10.1007/s00167-015-3942-8.

16. Radiographic evaluation of the normal distal tibiofibular syndesmosis / A.S. Shah, A.R. Kadakia, G.J. Tan, M.S. Karadsheh, T.D. Wolter, B. Sabb // Foot Ankle Int. 2012. Vol. 33, No 10. P. 870-876. DOI: 10.3113/FAI.2012.0870.

17. Lui T.H., Ip K., Chow H.T. Comparison of radiologic and arthroscopic diagnoses of distal tibiofibular syndesmosis disruption in acute ankle fracture // Arthroscopy. 2005. Vol. 21, No 11. P. 1370. DOI: 10.1016/j.arthro.2005.08.016.

18. Harper M.C. An anatomic and radiographic investigation of the tibiofibular clear space // Foot Ankle Int. 1993. Vol. 14 , No 8. P. 455-458. DOI: $10.1177 / 107110079301400805$.

19. Ostrum R.F., De Meo P., Subramanian R. A critical analysis of the anterior-posterior radiographic anatomy of the ankle syndesmosis // Foot Ankle Int. 1995. Vol. 16, No 3. P. 128-131. DOI: 10.1177/107110079501600304.

20. Radiographic and CT evaluation of tibiofibular syndesmotic diastasis: a cadaver study / N.A. Ebraheim, J. Lu, H. Yang, A.O. Mekhail, R.A. Yeasting // Foot Ankle Int. 1997. Vol. 18, No 11. P. 693-698. DOI: 10.1177/107110079701801103.

21. The fibular incisure of the tibia on CT scan: a cadaver study / N.A. Ebraheim, J. Lu, H. Yang, J. Rollins // Foot Ankle Int. 1998. Vol. 19, No 5. P. 318321. DOI: $10.1177 / 107110079801900509$.

22. Syndesmosis sprains of the ankle / W.J. Hopkinson, P. St. Pierre, J.B. Ryan, J.H. Wheeler // Foot Ankle Int. 1990. Vol. 10, No 6. P. 325-330. DOI: $10.1177 / 107110079001000607$.

23. Injury of the tibiofibular syndesmosis: value of MR imaging for diagnosis / K. Oae, M. Takao, K. Naito, Y. Uchio, T. Kono, J. Ishida, M. Ochi // Radiology. 2003. Vol. 227, No 1. P. 155-161. DOI: 10.1148/radiol.2271011865.

24. Diagnosis of a tear of the tibiofibular syndesmosis. The role of arthroscopy of the ankle / M. Takao, M. Ochi, K. Oae, K. Naito, Y. Uchio // J. Bone Joint Surg. Br. 2003. Vol. 85, No 3. P. 324-329. DOI: 10.1302/0301-620x.85b3.13174.

25. Computed tomography of normal distal tibiofibular syndesmosis / H. Elgafy, H.B. Semaan, B. Blessinger, A. Wassef, N.A. Ebraheim // Skeletal Radiol. 2010. Vol. 39, No 6. P. 559-564. DOI: 10.1007/s00256-009-0809-4.

26. Kinematics of the distal tibiofibular syndesmosis: radiostereometry in 11 normal ankles / A. Beumer, E.R. Valstar, E.H. Garling, R. Niesing, J. Ranstam, R. Löfvenberg, B.A. Swierstra // Acta Orthop. Scand. 2003. Vol. 74, No 3. P. 337-343. DOI: 10.1080/00016470310014283.

27. Amendola A., Williams G., Foster D. Evidence-based approach to treatment of acute traumatic syndesmosis (high ankle) sprains // Sports Med. Arthrosc. Rev. 2006. Vol. 14, No 4. P. 232-236. DOI: 10.1097/01.jsa.0000212329.32969.b8.

28. Removal of Hardware after Syndesmotic Screw Fixation: A Systematic Literature Review / K.C. Walley, K.J. Hofmann, B.T. Velasco, J.Y. Kwon // Foot Ankle Spec. 2017. Vol. 10, No 3. P. 252-257. DOI: 10.1177/1938640016685153.

29. Stabilization of the syndesmosis in the Maisonneuve fracture - a biomechanical study comparing 2-hole locking plate and quadricortical screw fixation / R. Gardner, T. Yousri, F. Holmes, D. Clark, P. Pollintine, A.W. Miles, M. Jackson // J. Orthop. Trauma. 2013. Vol. 27, No 4. P. 212-216. DOI: 10.1097/BOT.0b013e31825cfac2.

30. Markolf K.L., Jackson S.R., McAllister D.R. Syndesmosis fixation using dual $3.5 \mathrm{~mm}$ and $4.5 \mathrm{~mm}$ screws with tricortical and quadricortical purchase: a biomechanical study // Foot Ankle Int. 2013. Vol. 34, No 5. P. 734-739. DOI: 10.1177/1071100713478923.

31. Functional and radiographic results of patients with syndesmotic screw fixation: implications for screw removal / A. Manjoo, D.W. Sanders, C. Tieszer, M.D. MacLeod // J. Orthop. Trauma. 2010. Vol. 24, No 1. P. 2-6. DOI: 10.1097/BOT.0b013e3181a9f7a5.

32. Miller T.L., Skalak T. Evaluation and treatment recommendations for acute injuries to the ankle syndesmosis without associated fracture // Sports Med. 2014. Vol. 44, No 2. P. 179-188. DOI: 10.1007/s40279-013-0106-1.

33. Peek A.C., Fitzgerald C.E., Charalambides C. Syndesmosis screws: how many, what diameter, where and should they be removed? A literature review // Injury. 2014. Vol. 45, No 8. P. 1262-1267. DOI: 10.1016/j.injury.2014.05.003.

34. Thompson M.C., Gesink D.S. Biomechanical comparison of syndesmosis fixation with 3.5- and 4.5-mm stainless steel screws // Foot Ankle Int. 2000. Vol. 21, No 9. P. 736-741. DOI: 10.1177/107110070002100904.

35. Should syndesmotic screws be removed after surgical fixation of unstable ankle fractures? A systematic review / S.A. Dingemans, S. Rammelt, T.O. White, J.C. Goslings, T. Schepers // Bone Joint J. 2016. Vol. 98-B, No 11. P. 1497-1504. DOI: 10.1302/0301-620X.98B11.BJJ-2016-0202.R1.

36. Stability of the Syndesmosis after Posterior Malleolar Fracture Fixation / M.A. Miller, T.C. McDonald, M.L. Graves, C.A. Spitler, G.V. Russell, L.C. Jones, W. Replogle, J.A. Wise, J. Hydrick, P.F. Bergin. // Foot Ankle Int. 2018. Vol. 39, No 1. P. 99-104. DOI: 10.1177/1071100717735839.

37. Manway J.M., Blazek C.D., Burns P.R. Special Considerations in the Management of Diabetic Ankle Fractures // Curr. Rev. Musculoskelet. Med. 2018. Vol. 11, No 3. P. 445-455. DOI: 10.1007/s12178-018-9508-x. 
38. Posterior malleolar fractures of the ankle / J. Bartoníček, S. Rammelt, M. Tuček O. Naňka // Eur. J. Trauma Emerg. Surg. 2015. Vol. 41 , No 6. DOI: $10.1007 / \mathrm{s} 00068-015-0560-6$.

39. Technical Considerations in the Treatment of Syndesmotic Injuries Associated with Ankle Fractures / M.J. Gardner, M.L. Graves, T.F. Higgins, S.E. Nork // J. Am. Acad. Orthop. Surg. 2015. Vol. 23, No 8. P. 510-518. DOI: 10.5435/JAAOS-D-14-00233.

40. Suture Button versus Syndesmotic Screw for Syndesmosis Injuries: A Meta-analysis of Randomized Controlled Trials / Y. Shimozono, E.T. Hurley, C.L. Myerson, C.D. Murawski, J.G. Kennedy // Am. J. Sports Med. 2019. Vol. 47, No 11. P. 2764-2771. DOI: 10.1177/0363546518804804.

41. Lower complication rate and faster return to sports in patients with acute syndesmotic rupture treated with a new knotless suture button device C. Colcuc, M. Blank, T. Stein, F. Raimann, S. Weber-Spickschen, S. Fischer, R. Hoffmann // Knee Surg. Sports Traumatol. Arthrosc. 2018. Vol. 26, No 10. P. 3156-3164. DOI: 10.1007/s00167-017-4820-3.

42. Intraoperative three-dimensional imaging in the treatment of acute unstable syndesmotic injuries / J. Franke, J. von Recum, A.J. Suda, P.A. Grützner, K. Wendl // J. Bone Joint Surg. Am. 2012. Vol. 94, No 15. P. 1386-1390. DOI: 10.2106/JBJS.K.01122.

43. APTF: anteroposterior tibiofibular ratio, a new reliable measure to assess syndesmotic reduction / S. Grenier, B. Benoit, D.M. Rouleau, S. Leduc, G.Y. Laflamme, A. Liew // J. Orthop. Trauma. 2013. Vol. 27, No 4. P. 207-211. DOI: 10.1097/BOT.0b013e31826623cc.

44. Sagi H.C., Shah A.R., Sanders R.W. The functional consequence of syndesmotic joint malreduction at a minimum 2-year follow-up // J. Orthop. Trauma. 2012. Vol. 26, No 7. P. 439-443. DOI: 10.1097/BOT.0b013e31822a526a.

45. Instability of the tibio-fibular syndesmosis: have we been pulling in the wrong direction? / J.J. Candal-Couto, D. Burrow, S. Bromage, P.J. Briggs // Injury. 2004. Vol. 35, No 8. P. 814-818. DOI: 10.1016/j.injury.2003.10.013.

46. Iatrogenic syndesmosis malreduction via clamp and screw placement / A.N. Miller, D.P. Barei, J.M. Iaquinto, W.R. Ledoux, D.M. Beingessner // J. Orthop. Trauma. 2013. Vol. 27, No 2. P. 100-106. DOI: 10.1097/BOT.0b013e31825197cb.

47. Management of distal tibio-fibular syndesmotic injuries: a snapshot of current practice / P. Monga, A. Kumar, A. Simons, V. Panikker // Acta Orthop. Belg. 2008. Vol. 74, No 3. P. 365-369.

Статья поступила в редакцию 28.10.2021; одобрена после рецензирования 29.11.2021; принята к публикации 23.12.2021.

The article was submitted 28.10.2021; approved after reviewing 29.11.2021; accepted for publication 23.12.2021.

\section{Информация об авторах:}

1. Дмитрий Александрович Никифоров - nikiforovmd@gmail.com;

2. Михаил Александрович Панин - кандидат медицинских наук, panin-mihail@yandex.ru, SPIN-код: 5834-3500;

3. Виктор Геннадьевич Процко - доктор медицинских наук;

4. Рами Джамалевич Боргут - кандидат медицинских наук;

5. Расул Николаевич Алиев - кандидат медицинских наук.

\section{Information about the authors:}

1. Dmitry A. Nikiforov - nikiforovmd@gmail.com;

2. Mikhail A. Panin - Candidate of Medical Sciences, panin-mihail@yandex.ru, SPIN code: 5834-3500;

3. Victor G. Protsko - Doctor of Medical Sciences;

4. Rami D. Borgut - Candidate of Medical Sciences;

5. Rasul N. Aliyev - Candidate of Medical Sciences. 
Гений ортопедии. 2022. Т. 28, № 1. С. 150-157.

Genij Ortopedii. 2022. Vol. 28, no. 1. P. 150-157.

Обзорная статья

удК 617.586-001-089.844(048.8)

https://doi.org/10.18019/1028-4427-2022-28-1-150-157

\section{Реконструкция мягких тканей при обширных раневых дефектах стопы лоскутами с осевым типом кровоснабжения (обзор литературы)}

\section{Б.Ш. Минасов, Э.М. Бикташева, М.М. Валеев ${ }^{\varpi}$, Р.Р. Якупов, Т.Б. Минасов, Т.Р. Мавлютов}

Башкирский государственный медицинский университет, Уфа, Россия

Автор, ответственный за переписку: Марат Мазгарович Валеев, valeevmm@rambler.ru

Аннотация

Введение. Стопа несет на себе нагрузку всего тела при ходьбе, особенно подошвенная ее часть испытывает колоссальную нагрузку. Особенностью кожных покровов опорных зон является то, что эластические волокна мягких тканей подошвы стопы фиксируют кожу к глубокой фасции и костному скелету и в результате минимизации подвижности опорных тканей увеличивается устойчивость давления без нарушения кровообращения в зонах повышенной нагрузки. В связи с этим повышаются требования к пластическим свойствам выбранного материала для реконструкции мягких тканей стопы. Цель. Обзор различных методов и способов хирургического лечения при обширных дефектах мягких тканей стопы с использованием лоскутов с осевым типом кровоснабжения. Материалы и методы. Поиск материалов проводился на протяжении 2015-2020 гг. в нижеперечисленных источниках получения информации: eLibrary.ru; библиографические базы (Scopus,; Web of Science); электронная библиотека диссертаций Российской государственной библиотеки (http://diss.rsl.ru) и сайты диссертационных советов. Представлен обзор 72 публикаций отечественных и зарубежных авторов, в которых освещена данная тема. Глубина отбора источников составила 16 лет, начиная с 2004 года. В последние 5 лет опубликованы данные 45 исследований. Проведен анализ литературы, посвященной хирургическому лечению при обширных дефектах мягких тканей стопы с использованием сложносоставных лоскутов с осевым типом кровоснабжения. Результаты. На основе анализа публикаций из различных источников представлены недостатки и достоинства различных способов и методов реконструктивно-пластических операций, описаны различные подходы и критерии выбора методов хирургической реконструкции мягких тканей. Заключение. При лечении пациентов с обширными дефектами мягких тканей стопы на современном этапе развития реконструктивно-пластической хирургии наиболее приемлемыми способами и методами восстановления утраченных кожных покровов являются доктрины, основанные на микрохирургических технологиях аутотрансплантации комплексов тканей с осевым типом кровоснабжения.

Ключевые слова: пластическая хирургия, реконструктивная хирургия, микрохирургия, кожная пластика, стопа, дефект мягких тканей

Для цитирования: Реконструкция мягких тканей при обширных раневых дефектах стопы лоскутами с осевым типом кровоснабжения (обзор литературы) / Б.Ш. Минасов, Э.М. Бикташева, М.М. Валеев, Р.Р. Якупов, Т.Б. Минасов, Т.Р. Мавлютов // Гений ортопедии. 2022 . Т. 28, № 1. C. 150-157. https://doi.org/10.18019/1028-4427-2022-28-1-150-157

\section{Review article}

\section{Soft tissues reconstruction in the patients with extensive wound defects of the foot using flaps with axial type of circulation (literature review)}

\section{B.Sh. Minasov, E.M. Biktasheva, M.M. Valeev ${ }^{\bowtie}$, R.R. Yakupov, T.B. Minasov, T.R. Mavlyutov}

Bashkir State Medical University, Ufa, Russian Federation

Corresponding author: Marat M.Valeev, valeevmm@rambler.ru

Abstract

Introduction The foot bears the load of the entire body while walking and particularly the plantar part of it resists a tremendous weight-bearing. A peculiarity of the skin cover of the supporting zones is that the elastic fibers of the soft tissues of the plantar foot fix the skin to the deep fascia and the bone skeleton, resulting in minimizing of the supportive tissue mobility and increasing pressure stability without circulation disorder in areas of increased weight-bearing. Therefore, the requirements to the plastic properties of the selected material for the reconstruction of the soft tissues of the foot increase. Purpose is to review the various methods and techniques of surgical treatment for extensive soft tissue defects of the foot using flaps with an axial type of circulation. Material and methods The search of materials was performed from 2015 through 2020 in the following sources of information: eLibrary.ru; bibliographic bases (Scopus,; Web of Science); electronic library of dissertations of the Russian State Library (http://diss.rsl.ru) and sites of Dissertation Boards. The review of 72 publications of national and foreign authors related to this topic is presented. The depth of source selection was 16 years, starting from 2004. In the last 5 years, 45 studies data have been published. The literature related to surgical treatment of extensive defects in the foot soft tissues using complex flaps with an axial type of circulation supply was analyzed. Results Basing on the analysis of publications from various sources, the disadvantages and advantages of various methods and techniques of reconstructive plastic surgery are presented and various approaches and criteria for choosing the techniques of surgical soft tissues reconstruction are described. Conclusion In the treatment of patients with extensive soft tissue defects of the foot at the current stage of the reconstructive plastic surgery development, the doctrines based on microsurgical technologies of autografts of tissue complexes with an axial type of circulation became the most acceptable ways and techniques for lost skin restoration.

Keywords: plastic surgery, reconstructive surgery, microsurgery, skin grafting, foot, soft tissue defect

For citation: Minasov B.Sh., Biktasheva E.M., Valeev M.M., Yakupov R.R., Minasov T.B., Mavlyutov T.R. Soft tissues reconstruction in the patients with extensive wound defects of the foot using flaps with axial type of circulation. Genij Ortopedii, 2022, vol. 28, no 1, pp. 150-157. https://doi. org/10.18019/1028-4427-2022-28-1-150-157

\section{ВВЕДЕНИЕ}

Бурное развитие современной медицины при оказании квалифицированной помощи после травм опорно-двигательной системы требует разработки определенных доктрин, основной целью которых является скорейшее восстановление после полученных повреж- дений. Необходимость разработки концепций и доктрин обусловлена массовым характером такого рода повреждений и прогрессивным развитием реконструктивной хирургии. Реализацию таких доктрин обеспечивают современные хирургические технологии. 
Завышенные ожидания диктуют необходимость систематизации не только хирургических реконструктивнопластических технологий, но и социальной, бытовой и профессиональной реабилитации, стимулируя развитие новых концепций и доктрин. Современная клиническая практика обостряет проблему оказания практической помощи пациентам с обширными раневыми дефектами мягких тканей, особенно в функционально активных зонах (области суставов, опорных областях и т.д.) [1-28].

В настоящее время до конца не разработаны оптимальные доктрины при реконструкции мягких тканей подобных зон. Особенностью кожных покровов опорных зон является то, что эластические волокна мягких тканей подошвы стопы и ладони кисти фиксируют кожу к глубокой фасции и костному скелету и в результате минимизации подвижности кожных покровов увеличивается устойчивость опорности без нарушения кровообращения. В этом смысле мягкотканные компоненты обладают неадекватностью, но функциональностью, а их перерождения не происходит. Разрушения тканей в результате травм опорно-двигательной системы имеют тенденцию к увеличению в результате усугубления дорожного и бытового травматизма, утяжеления природных и техногенных катастроф. Данную проблему можно отнести к государственной проблеме и здравоохранения в целом, в частности, вследствие того, что качественное и количественное увеличение травматизма непосредственно влияет на критерии здоровья населения, особенно трудоспособного возраста. Проблема усугубляется еще тем, что наблюдается динамика роста сочетанных и множественных повреждений, которые влекут за собой грубые, порой необратимые, дефекты основных сегментов скелета [1, 5, 10-18, 29, 30].

Цель. Обзор различных методов и способов хирургического лечения при обширных дефектах мягких тканей стопы с использованием лоскутов с осевым типом кровоснабжения.

\section{МАТЕРИАЛЫ И МЕТОДЫ}

Поиск материалов проводился на протяжении 2015-2020 гг. в нижеперечисленных источниках получения информации: eLibrary.ru; библиографические базы (Scopus,; Web of Science); электронная библиотека диссертаций Российской государственной библиотеки (http://diss.rsl.ru) и сайты диссертационных советов. При этом использовались термины: пластическая хирургия, реконструктивная хирургия, микрохирургия, кожная пластика, стопа, дефект мягких тканей. Представлен обзор 72 публикаций отечественных и зарубежных авторов, в которых освещена данная тема.
Глубина отбора источников составила 16 лет, начиная с 2004 года. За последние 5 лет опубликовано 45 исследований. Публикации, в которых освещены результаты хирургического лечения пациентов с обширными дефектами мягких тканей стопы с использованием различных способов и методов кожной пластики лоскутами с осевым типом кровоснабжения, являлись критериями включения в анализ. Критерии исключения - статьи, хотя и посвященные исследуемой проблеме, но не содержащие описание хирургических аспектов лечения.

\section{РЕЗУЛЬТАТЫ}

К одному из трудноразрешимых проявлений разрушения мягких тканей сегментов конечностей относятся обширные травматические раневые поверхности кожных покровов дистальных отделов конечностей, особенно стоп. Трудность решения этой проблемы обусловлена рядом факторов: утяжелением степени травматизации сегментов конечностей опорно-двигательной системы, имеющей тенденцию к увеличению; специфичностью кровоснабжения различных отделов стопы; особенностью строения мягких тканей опорной поверхности стопы; специфичностью архитектоники в виде несмещаемости кожи стопы и дефицитом мягких тканей; взаиморасположением в небольшом пространстве большого количества анатомических структур, находящихся в тесной функциональной взаимосвязи. Все вышеперечисленные факторы затрудняют закрытие обширных дефектов мягких тканей, особенно в случаях сочетанных повреждений с обнажением костей, суставов, сосудов и нервов с возможным развитием инфекционных костных осложнений. В связи с тем, что нагрузка всего тела приходится на стопу, возникает огромная нагрузка на ее подошвенную часть, увеличивающаяся при ходьбе в виде трения, поэтому свойства используемого пластического материала должны обладать большим потенциалом механической прочности. С учетом вышеизложенных особенностей подбора пластического материала, традиционные методы и способы реконструкции мягких тканей в последние годы утратили свою популярность ввиду низкой функциональной эффективности. Поэтому на сегодняшний день известную популярность снискали методы замещения обширных дефектов покровных тканей комплексами тканей с осевым типом кровоснабжения [6, 10, 14, 15, 19-26, 30, 31, 32].

Существуют следующие виды хирургических подходов при реконструкции мягких тканей различных сегментов конечностей, в том числе стопы. Одним из простых приемов является перемещение геометрических лоскутов в различных направлениях и комбинациях, преследующих цель сближения краев раневого дефекта. В последние годы многие авторы начали широко использовать метод дермотензии экспандерами с целью создания запаса кожи, которая также направлена на сближение краев раны. Данная методика не всегда эффективна на стопе ввиду особенностей рельефа последней. Расщепленные и полнослойные кожные лоскуты особенно незаменимы при закрытии обширных ран с термическими повреждениями конечностей и туловища, преследующие цель немедленного замещения утраченного кожного покрова. Общеизвестно, что кожные лоскуты, не имеющие автономного кровоснабжения, не обладают достаточной степенью эластичности ввиду неизбежной ретракции в отдаленном послеоперационном периоде и поэтому не могут способствовать 
полноценной реконструкции мягких тканей стопы, особенно на подошвенной поверхности. Известные не одно столетие выкроенные кожно-жировые лоскуты по итальянской и индийской методикам можно отнести к самым ранним способам закрытия обширных дефектов мягких тканей конечностей. Частые погрешности в планировании границ подобных аутотрансплантатов обусловлены тем, что формирование соотношения ширины к длине лоскута проводится без анатомического анализа проекции осевых, питающих данный участок сосудов. Первые зачатки осевого типа кровообращения кожного аутотрансплантата можно заметить в круглом стебельчатом кожно-жировом лоскуте, разработанном В.П. Филатовым, который можно отнести к прообразу современных комплексов тканей с осевым типом кровоснабжения. Данный лоскут позволяет формировать необходимое количество пластического материала. К следующему достоинству лоскута относится достаточная степень кровоснабжения за счет наличия двух питающих ножек, обеспечивающих адекватное кровенаполнение аутотрансплантата. Лоскуты на питающей ножке («итальянская» пластика, «филатовский стебель»), кроме длительного процесса лечения, нередких некрозов и трофических нарушений, доставляют пациентам неудобства, связанные с длительным вынужденным положением тела [24, 26-29, 33-36].

В последние годы многими авторами широко используются лоскуты с регионарным типом кровоснабжения без пересечения сосудистой ножки. Популярность данных лоскутов обусловлена неоспоримым преимуществом, которое заключается в возможности использования значительных по площади комплексов тканей на одной сосудистой ножке. К следующему преимуществу можно отнести простоту выделения данных лоскутов без обязательного использования микрохирургического инструментария. История подобных лоскутов начитается с предложения S. Esser (1817) выделять кровоснабжаемые комплексы тканей с учетом анатомического сосудистого строения архитектоники кожи и подлежащих тканей. Данное начинание продолжил C. Manchot, который в 1889 году издал атлас анатомического строения 36 зон на теле человека с осевым и регионарным типом кровоснабжения. Первое упоминание о применении островкового кожно-мышечного лоскута на основе торакодорзальных сосудов с целью реконструкции мягких тканей при обширном дефекте грудной клетки после радикальной мастэктомии принадлежит Tanzini (1896). По мнению J.B. McCrow, D.G. Dibbell (1977), основной принцип использования васкуляризированных кожно-мышечных лоскутов заключается в том, что данный комплекс рассматривается как единый орган на общем питающем сосудистом пучке. В результате проведенных исследований многих авторов, в частности J. Hoopers (1976), В. Myers и W. Donovan (1977), доказано, что выживаемость лоскутов на несвободной сосудистой ножке прямо пропорциональна калибру и скорости кровотока питающих сосудов, т.е. зависит от величины кровотока. При этом можно игнорировать некорректное геометрическое соотношение ширины и длины выкраиваемых лоскутов. Массовое применение мышечных и кожно-мышечных лоскутов с доминантной сосудистой реваскуляризацией в несвободном варианте при реконструкции мягких тканей различных сегментов конечностей началось после публикаций V.Y. Bakamjian (1969), Б.С. Логосова и Э.Г. Курбанова (1970) [1, 6, 8, 29, 30, 37-45].

Коренное изменение основных принципов и доктрин хирургических приемов при реконструкции обширных дефектов мягких тканей, особенно сочетающихся с тяжелыми травмами костного скелета, произошло после широкого применения комплексов тканей на основе концепции о доминирующей роли перегородочно-кожных артерий в кровоснабжении. Данная концепция позволила разработать новые технологии замещения дефектов мягких тканей, даже обширных по площади, позволяющие нивелировать недостатки существующих традиционных методов и способов реконструкции мягких тканей на основе использования методик реконструктивно-пластической хирургии. Доказано, что при травме любого сегмента конечности нарушается регионарное кровоснабжение, в частности стопы. Кровоснабжаемые лоскуты наряду с покровной функцией при этих состояниях благодаря автономному кровоснабжению улучшают васкуляризацию ишемизированной стопы. Практически полное исключение образования плотного рубца между аутотрансплантатом и подлежащими анатомическими образованиями делает незаменимым использование в качестве пластического материала васкуляризированных лоскутов при реконструкции мягких тканей подошвенной поверхности стопы, испытывающих колоссальную механическую нагрузку и подвергающихся значительному смещению при ходьбе. Также имеется возможность реиннервации свободных васкуляризированных лоскутов за счет наложения периневрального шва нерва аутотрансплантата с сенсорным нервом проблемной зоны сегмента $[6,10,28,29,33,41,42,44,46-52]$.

В современной реконструктивно-пластической микрохирургии существует два способа использования аутотрансплантатов с осевым типом кровоснабжения. Первый способ - это перенос лоскута с донорской области в свободном виде, т.е. с пересечением питающей сосудистой ножки с последующей реваскуляризацией путем наложения микрохирургических сосудистых анастомозов. Второй вариант использования подобных лоскутов заключается в реверсии аутотрансплантата на питающих сосудах. Для первого способа реваскуляризации лоскута необходимо наличие микрохирургического инструментария и увеличительной оптики и подготовленной хирургической бригады [34, 37, 38, 40].

Как правило, травматические повреждения стопы с обширным разрушением мягких тканей сопровождаются переломом костного скелета сегмента. При подобных сочетанных повреждениях встает вопрос о последовательности проведения восстановления костной основы и реконструкции мягкотканных структур стопы. Последовательность и сроки выполнения восстановительных и реконструктивных операций с использованием тех или иных способов и методов кожной пластики и остеосинтеза костных отломков в современной литературе активно дискутируется. Также возникает проблема закрытия дефектов мягких 
тканей в плане использования традиционных методов и способов кожно-пластических операций после «созревания» раневого дефекта или васкуляризированной кожной пластики, как в свободном, так и несвободном исполнении.

Одни авторы являются активными сторонниками реконструкции мягких тканей кровоснабжаемыми лоскутами в свободном виде с использованием микрососудистых анастомозов, мотивируя свою позицию тем, что свободная пересадка кровоснабжаемых лоскутов снижает риск развития инфекционных осложнений костной ткани и минимизирует возможность развития пороков сращения костных отломков по сравнению с несвободной васкуляризированной кожной пластикой

Другая группа авторов не находит большой разницы между видами реваскуляризации комплексов тканей по частоте и распространенности инфекционных осложнений и сроков сращения костных отломков [1, 3, 14, 35, 53-60].

Следующая группа авторов придерживается мнения, что обширные разрушения мягких тканей при высокоэнергетических травмах в остром периоде являются противопоказанием для использования в качестве пластического материала комплексы тканей с осевым типом кровоснабжения в любом виде реваскуляризации. В то же время, некоторые авторы придерживаются более активной тактики, отдают приоритет васкуляризированным тканям для закрытия обширных дефектов мягких тканей, в том числе и стопы.

По данным различных авторов, в практической деятельности даже опытнейших микрохирургов, использующих современное микрохирургическое оборудование, непроходимость микрососудистых анастомозов в виде тромбоза с учетом локализации и степени повреждения встречается в 5-18 \% случаев. В связи с этим, многими хирургами ведется поиск наиболее безопасных способов применения васкуляризированных комплексов тканей, особенно при закрытии обширных дефектов кожных покровов дистальных отделов нижней конечности, в частности стоп, с предпочтением использования островковых кровоснабжаемых лоскутов. Подобные аутотрансплантаты более просты в отношении хирургического исполнения, а их использование практически лишено риска развития сосудистых тромбозов по сравнению со свободными лоскутами на микрососудистых анастомозах [1, 3, 6, 8, 15, 19, 22, 25, 37, 43, 45].

В доступной современной литературе имеются различные публикации, порой противоречивые, о сроках реконструкции мягких тканей при обширных дефектах, в частности дистальных отделов нижней конечности. Одни авторы предлагают раннюю активную хирургическую тактику, другие, наоборот, более осторожную, иногда запоздалую тактику. К последним относится М.В. Kim, который на основе анализа лечения пациентов с дефектами мягких тканей голени, пришел к выводу, что при закрытии ран кожными швами или различными методиками вакуумного лечения резко снижается доля реконструктивно-пластических операций с применением микрохирургической техники. Число осложнений лечения в виде остеомиелита, несращений костных отломков и глубокой ишемии дистального отдела конечности, по утверждению автора, не снизилось. Рекомендации к снижению доли использования кровоснабжаемых лоскутов при закрытии обширных дефектов мягких тканей при сочетанных повреждениях дистальных отделов нижней конечности предлагают В.Б. Бондарев с соавторами в пользу первичного укорочения травмированного отдела конечности и аутопластики расщепленным кожным аутотрансплантатом после подготовки раневого дефекта вакуумным лечением. Данное утверждение исключает безальтернативность закрытия обширных дефектов мягких тканей микрохирургическими способами $[7,10,16,21,24,36,50]$.

На основе анализа современной отечественной литературы можно заключить, что в последние годы имеет место значительное увеличение доли ранней реконструкции мягких тканей дистальных отделов нижних конечностей, в том числе стоп, кожной пластикой с применением микрохирургической техники. Так, Л.А. Родоманова и А.Ю. Кочиш, анализируя результаты лечения двух групп из 594 пациентов, пришли к выводу о целесообразности выполнения ранней реконструкции мягких тканей микрохирургическим способом до момента развития грубой рубцовой ткани. Данная тактика позволяет минимизировать инвалидизацию, сроки лечения и долю многоэтапного оперативного пособия. А.А. Богов с соавторами придерживаются тактики первичной радикальной хирургической обработки области травматического разрушения мягких тканей, утверждая, что раневой дефект мягких тканей независимо от размеров, локализации и сочетанности, необходимо заместить в кротчайшие сроки после травмы. Комплексные исследования, проведенные в РНИИТО им. Р.Р. Вредена, позволили сделать вывод, что сроки до шести недель от момента травмы являются оптимальными для пластического закрытия дефектов мягких тканей конечностей. При этом предпочтительно использовать только кровоснабжаемые комплексы тканей как в свободном, так и несвободном виде [2, 6, 10, 23, 36, 45, 60-65].

На сегодняшний день развития реконструктивнопластической хирургии методом выбора того или иного вида кожной пластики при замещении обширных раневых дефектов мягких тканей конечностей, особенно в функционально активных зонах, по мнению большинства авторов, могут быть хирургические доктрины с использованием комплексов тканей с осевым типом кровоснабжения. Использование кровоснабжаемых комплексов тканей при ранней активной хирургической тактике при обширных разрушениях мягких тканей конечностей обеспечивает профилактику инфекционных осложнений, значительно оптимизирует репаративные процессы, защищает подлежащие анатомические образования от дальнейшего вовлечения в инфекционный процесс. Следующим позитивным положением следует считать то, что одномоментное восстановление всех поврежденных анатомических образований в зоне повреждения, в том числе и глубжележащих тканей (костная ткань, периферические нервы и магистральные артерии, сухожилия), позволяет значительно сократить сроки восстановления функциональных возможностей травмированной конечности, 
используя раннее функциональное реабилитационное лечение [1, 5, 6, 8, 15, 17, 41, 44, 53, 58].

В отношении использования комплексов тканей с осевым типом кровоснабжения на сосудистой ножке в островковом варианте или в свободном виде на микрососудистых анастомозах также имеются различные мнения.

Сторонниками расширения показаний к использованию в ранние сроки после получения травмы свободных лоскутов с наложением микрососудистых анастомозов являются Липатов К.В. с соавторами, объясняя свои убеждения тем, что применение в качестве пластического материала для закрытия обширных раневых дефектов островковых комплексов тканей увеличивает случаи развития инфекционных осложнений и несращения костных отломков $[2,6,10,31,32,36$, 52, 66-69].

\section{ОБСУЖДЕНИЕ}

В результате анализа обсуждаемой проблемы сделан вывод, что закрывать обширные дефекты мягких тканей стопы предпочтительно сложносоставными лоскутами с автономным кровоснабжением. Решение использования подобных лоскутов в свободном или несвободном варианте принимается в зависимости от давности травмы, степени, площади и сочетанности повреждений, а также подготовленности операционной бригады в плане микрохирургических технологий $[1,3,6,8,10,12,15,17,21,29,34,44,53,58,68]$.

В ходе ретроспективного анализа представленных исследований оценили эффективность использования различных видов лоскутов с осевым типом кровоснабжения. Кожно-фасциальные лоскуты более предпочтительны при обширных дефектах без явлений явного инфицирования раневой поверхности, вовлечения в процесс глубжележащих анатомических структур. Кожно-мышечные лоскуты рекомендуются при обнажении костной ткани, суставов, сухожилий и сосудисто-нервных пучков. Инфекционный процесс в области обширного дефекта мягких тканей является, по нашему мнению, не противопоказанием к использованию кровоснабжаемых кожно-мышечных лоскутов, а, наоборот, показанием к операции, т.к. использование данного лоскута позволяет купировать гнойный процесс за счет подключения дополнительного кровоснабжения патологической области $[1,4,9,15,16,24,27$, 29, 31, 36].

При определении сроков проведения реконструктивных операций после травматического разрушения мягких тканей стопы большинство исследователей склонно к более раннему оперативному вмешательству, предупреждающую развитие рубцовых деформаций и контрактур суставов. Данная тактика лечения обосновывается результатами собственных наблюдений. Вполне понятно, что от сроков реконструкции мягких тканей зависит и начало раннего реабилитационного лечения. Более того, в случаях развития инфекцион- ных осложнений в мягких тканях и костном скелете, данная тактика лечения наиболее целесообразна и позволяет исключить переход процесса в хроническую форму [2, 5, 8, 13, 16, 28, 29, 31, 36, 61].

По данным большинства авторов, в отношении реваскуляризации комплекса тканей приемлема следующая тактика. Лоскуты с осевым типом кровоснабжения без пересечения сосудистой ножки просты в исполнении, питающие аутотрансплантат сосуды практически не подвергаются тромбозу. Поэтому подобные комплексы тканей широко используются многими авторами $[1,3,5,10,19,22,34,38,68]$.

В свою очередь, ограниченные размеры подобных аутотрансплантатов не позволяют использовать их для закрытия значительных по площади дефектов мягких тканей стопы. В таких случаях многие авторы рекомендуют использовать микрохирургические технологии, а именно, свободные сложносоставные комплексы тканей, преимуществом которых является возможность получать необходимые большие по площади и различной конфигурации лоскуты. Для проведения операций по реваскуляризации аутотрансплантата с помощью микрохирургических анастомозов необходима соответствующая увеличительная аппаратура, специфический инструментарий и, главное, квалифицированная операционная бригада, на подготовку которой потребуются годы. Свободная микрохирургическая пересадка лоскутов отдаленных участков тела показана при значительных по площади дефектах мягких тканей, когда невозможно прибегнуть к использованию ограниченных по площади «островковых» лоскутов [2, 4, $6,12,15,17,23,31,32,40,41,53,54]$.

В то же время, показания к операциям с использованием комплексов тканей с осевым типом кровоснабжения должны быть определены достаточно четко, так как чрезмерное использование реконструктивных хирургических вмешательств подобного рода может быть неоправданным риском для пациента.

\section{ЗАКЛЮЧЕНИЕ}

Таким образом, актуальность проблемы замещения мягких тканей стопы обусловлена значительным количеством научных сообщений, содержащих всесторонний анализ различных хирургических подходов с использованием современных технологий реконструктивно-пластической хирургии. Традиционные способы свободной кожной пластики расщепленными или полнослойными аутотрансплантатами требуют наличия хорошо кровоснабженной гранулирующей раневой поверхности, подготовка которой занимает значительное время. Это положение усугу- бляет развитие контрактуры суставов травмированного сегмента, особенно при локализации обширного дефекта мягких тканей в функционально активных зонах, и обнажения глубжележащих анатомических структур (костных отломков, периферических нервов, сухожилий, капсулы суставов и т.д.). При этом способе кожной пластики вновь образованная кожа имеет низкую механическую прочность, что практически полностью исключает использование данной методики при локализации повреждения на опорной области стопы $[2,5,10,16,24,32,36,51,64]$. 
На основании вышеизложенного можно констатировать, что при лечении пациентов с обширными дефектами мягких тканей стопы на современном этапе развития реконструктивно-пластической хирургии наиболее приемлемыми способами и методами восстановления утраченных кожных покровов являются доктрины, основанные на микрохирургических технологиях аутотрансплантации комплексов тканей с осевым типом кровоснабжения. Остаются до конца нерешенными вопросы о сроках и способах пластики вышеуказанными лоскутами с учетом локализации раневого дефекта, сочетанности повреж- дений и собственных ресурсов травмированной стопы. Решение проблемы социальной, бытовой и профессиональной реабилитации пациентов с обширными травматическими дефектами мягких тканей стопы возможно путем дальнейших изысканий с разработкой оптимальной хирургической доктрины, включающей определение показаний и противопоказаний к различным методам и способам реконструктивно-пластических операций, сроков и объема проведения хирургических вмешательств и научно обоснованных реабилитационных мероприятий на основе положений доказательной медицины.

\section{СПИСОК ИСТОЧнИКОВ}

1. Бикташева Э.М., Минасов Б.Ш., Валеев М.М. Современные хирургические технологии при обширных дефектах и рубцовых деформациях мягких тканей проксимального отдела стопы с использованием функциональных лоскутов // Медицинский вестник Башкортостана. 2015. T. 10 , № 1 . C. $39-44$.

2. Hallock G.G. Soft Tissue Coverage after Revisional Foot and Ankle Surgery // Clin. Podiatr. Med. Surg. 2017. Vol. 34, No 3. P. 389-398. DOI: 10/1016/j.cpm.2017.02.009.

3. Богов А.А., Ибрагимова Л.Я., Муллин Р.И. Применение васкуляризированной кожной пластики медиальным лоскутом стопы для замещения дефекта мягких тканей стопы // Практическая медицина. 2012. № 8. С. 86-88.

4. Валеев М.М. Использование аутовитальных лоскутов у больных с дефектом мягких тканей конечностей // Здравоохранение Башкортостана. 2004. № 6. С. 67-80.

5. Богданов С.Б., Бабичев Р.Г. Новые подходы к хирургическому лечению ожогов тыльной поверхности кистей и стоп // Вопросы реконструктивной и пластической хирургии. 2016. Т. 19, № 2 (57). С. 5-10.

6. Возможности современных методов реконструктивно-пластической хирургии в лечении больных с обширными посттравматическими дефектами тканей конечностей / Р.М. Тихилов, А.Ю. Кочиш, Л.А. Родоманова, Д.И. Кутянов, А.О. Афанасьев // Травматология и ортопедия России. 2011. № 2. С. 164-170.

7. As'adi K., Salehi S.H., Shoar S. Early Reconstruction of Distal Leg and Foot in Acute High-Voltage Electrical Burn: Does Location of Pedicle in the Zone of Injury Affect the Outcome of Distally Based Sural Flap? // Ann. Plast. Surg. 2017. Vol. 78, No 1. P. 41-45. DOI: 10.1097/ SAP.0000000000000719.

8. Кутянов Д.И., Родоманова Л.А. Современные принципы и тенденции использования осевых кровоснабжаемых лоскутов в реконструктивной хирургии конечностей // Травматология и ортопедия России. 2015. № 1 (75). С. 106-115.

9. Beidas O.E., Tan B.K., Petersen J.D. The rotational advancement of medial plantar flap for coverage of foot defect: a case report // Microsurgery. 2012. Vol. 32, No 4. P. 322-325. DOI: 10.1002/micr.21956.

10. Васкуляризированная кожная пластика осевыми лоскутами в хирургическом лечении больных с сочетанными повреждениями голени и стопы. Обзор литературы / А.А. Богов, Л.Я. Ибрагимова, Р.И. Муллин, И.Г. Ханнанова, Р.Ф. Масгутов // Современные проблемы науки и образования. 2013. № 1. С. 28.

11. The Distally Based Sural Flap for the Reconstruction of Ankle and Foot Defects in Pediatric Patients / H. Zheng, J. Liu, X. Dai, A.F. Schilling // Ann. Plast. Surg. 2016. Vol. 77, No 1. P. 97-101. DOI: 10.1097/SAP.0000000000000341.

12. Davenport C., Dubin A. Tadalafil therapy and severe chronic foot wound resolution// Int. Wound J. 2015. Vol. 12, No 6. P. 733-736. DOI: 10.1111/ iwj.12378.

13. Clinical application of venous nutrition flap pedicled by medial plantar artery of the hallux on the medical aspect of the foot / L. Jian, L. Cheng, Z. Heping, L. Hua, Z. Tianhao, W. Zhijiang, W. Huajun // Zhonghua Zheng Xing Wai Ke Za Zhi [Zhonghua Zhengxing Waike Zazhi = Chinese Journal of Plastic Surgery]. 2015. Vol. 31, No 3. Р. 179-182.

14. Использование методов биомеханики в оценке состояния и коррекции патологии опорно-двигательной системы (обзор) / Н.А. Ромакина, А.С. Федонников, С.И. Киреев, Н.Х. Бахтеев, И.А. Норкин // Саратовский научно-медицинский журнал. 2015. Т. 11, № 3. С. $310-316$.

15. Бикташева Э.М., Минасов Б.Ш., Валеев М.М. Микрохирургические технологии при лечении больных с обширными дефектами мягких тканей проксимальных отделов стопы // Практическая медицина. 2015. № 6 (91). С. 90-93.

16. Бондарев В.Б., Каленский В.О., Иванов П.А. Особенности повреждений заднего отдела стопы у пациентов с сочетанной травмой // Неотложная медицинская помощь. 2016. № 2. С. 20-24.

17. Возможности микрохирургической аутотрансплантации при лечении обширных ран и дефектов тканей у детей / В.В. Рыбченок, А.В. Александров, В.В. Волков, А.А. Смолянкин // Анналы пластической, реконструктивной и эстетической хирургии. 2015 . № 1. С. 77.

18. Mahmoud W.H. Foot and Ankle Reconstruction Using the Distally Based Sural Artery Flap versus the Medial Plantar Flap: A Comparative Study // J. Foot Ankle Surg. 2017. Vol. 56, No 3. P. 514-518. DOI: 10.1053/j.jfas.2017.01.019.

19. Верега Г.М., Фегю Л.Г. Некоторые особенности использования островкового медиального подошвенного лоскута // Вопросы реконструктивной и пластической хирургии. 2010. Т. 11, № 2. С. 10-17.

20. Haddock N.T., Wapner K., Levin L.S. Vascular bone transfer options in the foot and ankle: a retrospective review and update on strategies // Plast. Reconstr. Surg. 2013. Vol. 132, No 3. P. 685-693. DOI: 10.1097/PRS.0b013e31829acedd.

21. Distally based adipofascial flaps covering soft-tissue defects of the dorsal foot and ankle in children / M.B. Kim, Y.H. Lee, J.H. Kim, J.E. Lee, W.C. Shin, G.H. Baek // Ann. Plast. Surg. 2014. Vol. 73, No 5. P. 568-577. DOI: 10.1097/SAP.0b013e318276d127.

22. Минасов Б.Ш., Бикташева Э.М., Валеев М.М. Новый способ несвободной пересадки осевого медиального лоскута стопы // Травматология и ортопедии России. 2015. № 1. С. 90-94.

23. Кутянов Д.И., Родоманова Л.А. Использование технологий реконструктивно-пластической микрохирургии при лечении пациентов с патологией области голеностопного сустава // Травматология и ортопедия России. 2013. № 2. С. 39-46.

24. Коростелев М.Ю., Шихалева Н.Г. Современное состояние проблемы лечения пациентов с обширными отслойками покровных мягких тканей // Гений ортопедии. 2017. Т. 23, № 1. С.88-94.

25. Оганесян А.Р. Комплексные аутотрансплантаты при реконструкции дефектов мягких тканей и нижних конечностей // Анналы пластической, реконструктивной и эстетической хирургии. 2015. № 1. С. 67.

26. Vascular considerations in foot and ankle free tissue transfer: Analysis of 231 free flaps / E.H. Cho, R.M. Garcia, I. Pien, M. Kuchibhatla, H. Levinson, D. Erdmann, L.S. Levin, S.T. Hollenbeck // Microsurgery. 2016. Vol. 36, No 4. P. 276-283. DOI: 10.1002/micr.22406.

27. Lin T.S., Quing R. Long-Term Results of a One-Stage Secondary Debulking Procedure after Flap Reconstruction of the Foot // Plast. Reconstr. Surg. 2016. Vol. 138, No 4. P. 923-930. DOI: 10.1097/PRS.0000000000002510.

28. Островский Н.В., Белянина И.Б. Современные подходы к профилактике и лечению рубцов в реконструктивно-пластической хирургии // 
Анналы пластической, реконструктивной и эстетической хирургии. 2016. № 1. С. 95-96.

29. Реконструкция мягких тканей стопы сложносоставными лоскутами / Б.Ш. Минасов, М.М. Валеев, Р.Ф. Газизов, Э.М. Валеева // Травматология и ортопедия России. 2007. № 3. С. 18-21.

30. Реконструктивно-пластические операции при лечении больных с дефектами покровных тканей / В.М. Шаповалов, Н.Г. Губочкин, В.М. Гайдуков, Н.П. Лукичёва, Н.И. Мясников // Гений ортопедии. 2014. № 4. С. 58-62.

31. Пластическое закрытие обширного дефекта мягких тканей подошвы стопы / А.В. Панов, С.Г. Шаповалов, А.С. Плешков, П.В. Локтионов // Анналы пластической, реконструктивной и эстетической хирургии. 2015. № 1. С. 67-68.

32. Use of lateral calcaneal flap for coverage of hindfoot defects: an anatomical appraisal / P. Zygouris, A. Michalinos, V. Protogerou, E. Kotsiomitis, A. Mazarakis, I. Dimovelis, T. Troupis // Plast. Surg. Int. 2015. Vol. 2015. P. 212757. DOI: 10.1155/2015/212757.

33. Free and pedicled flaps for reconstruction of the weightbearing sole of the foot: a comparative analysis of functional results / V. Struckmann, C. Hirche, F. Struckmann, L. Kolios, M. Lehnhardt, U. Kneser, A. Daigeler // J. Foot Ankle Surg. 2014. Vol. 53, No 6. P. 727-734. DOI: 10.1053/j. jfas.2014.06.009.

34. Применение медиального подошвенного лоскута в хирургическом лечении дефектов покровных тканей пяточной области / У.А. Курбанов, А.А. Давлатов, С.М. Джанобилова, М. Носири // Вестник Авиценны. 2010. № 2. С. 9-17.

35. Hong, J.P., Park S.W., Choi D.H. Reply: The thin gluteal artery perforator free flap to resurface the posterior aspect of the leg and foot // Plast. Reconstr. Surg. 2015. Vol. 135, No 4. P. 794e. DOI: 10.1097/PRS.0000000000001072.

36. Липатов К.В., Комарова Е.А. Особенности кожно-пластических реконструкций у больных со стрептококковой некротизирующей инфекцией мягких тканей // Анналы пластической, реконструктивной и эстетической хирургии. 2015. № 4. С. 51-57.

37. Способ ротации медиального кожно-фасциального лоскута стопы при пластике дефектов мягких тканей стопы : пат. 2357696 Рос. Федерация : МПК А61В 17/56 / Минасов Б.Ш., Валеев М.М., Частиченко С.А., Газизов Р.Ф., Валеева Э.М. ; патентообладатель ГОУ ВПО «Башкирский государственный медицинский университет Федерального агентства по здравоохранению и социальному развитию». № 2008104735/14; заявл. 28.01.2008 ; опубл. 10.06.2009, Бюл. № 16.

38. Шведовченко И.В., Фомин Н.Ф., Аристов А.М. Потенциальные возможности подошвенной области стопы как донорской зоны в реконструктивно-пластической хирургии нижних конечностей (клинико-анатомическое исследование) // Травматология и ортопедия России. 2007. № 3. C. $12-17$.

39. Perforator-based chimaeric thoracodorsal flap for foot reconstruction / J. Rausky, J.P. Binder, S. Mazouz-Dorval, C. Hamou, M. Revol // J. Plast. Reconstr. Aesthet. Surg. 2013. Vol. 66, No 12. P. 1798-1800. DOI: 10.1016/j.bjps.2013.04.064.

40. Leclère F.M., Casoli V. Reconstruction of a traumatic plantar foot defect with a novel free flap: The medial triceps brachii free flap // J. Cosmet. Laser Ther. 2015. Vol. 17, No 5. P. 286-289. DOI: 10.3109/14764172.2015.1022188.

41. The use of fabricated chimeric flap for reconstruction of extensive foot defects / B. Song, J. Chen, Y. Han, Y. Hu, Y. Su, Y. Li, J. Zhang, S. Guo // Microsurgery. 2016. Vol. 36, No 4. P. 303-309. DOI: 10.1002/micr.22399.

42. Anatomical Footprint of the Tibialis Anterior Tendon: Surgical Implications for Foot and Ankle Reconstructions / M. Willegger, N. Seyidova, R. Schuh, R. Windhager, L. Hirtler // Biomed. Res. Int. 2017. Vol. 2017. P. 9542125. DOI: 10.1155/2017/9542125.

43. Modified free radial forearm fascia flap reconstruction of lower extremity and foot wounds: optimal contour and minimal donor-site morbidity / M.A. Medina 3rd, H.M. Salinas, K.R. Eberlin, D.N. Driscoll, J.Y. Kwon, W.G. Austen Jr., C.L. Cetrulo Jr. // J. Reconstr. Microsurg. 2014. Vol. 30, No 8. P. 515-522. DOI: 10.1055/s-0034-1383499.

44. Санников А.Б. Реконструктивно-восстановительная хирургия конечностей с использованием кожно-фасциальных островковых лоскутов с осевым кровоснабжением // Анналы пластической, реконструктивной и эстетической хирургии. 2015. № 1. С. 77-78.

45. Repair of soft tissue defect in hand or foot with lobulated medial sural artery perforator flap / Z. Fengjing, Y. Jianmin, Z. Xingqun, M. Liang, Z. Longchun, X. Yibo, W. Peng, Z. Zhen // Zhonghua Zheng Xing Wai Ke Za Zhi. 2015. Vol. 31, No 6. P. 418-421.

46. Gomez M.M., Casal D. Reconstruction of large defect of foot with extensive bone loss exclusively using a latissimus dorsi muscle free flap: a potential new indication for this flap // J. Foot Ankle Surg. 2012. Vol. 51, No 2. P. 215-217. DOI: 10.1053/j.jfas.2011.07.008.

47. Free partial latissimus dorsi myocutaneous flap for coverage of severe achilles contracture in children / L. Zhu, J. Wei, S. Daluvoy, S.T. Hollenbeck, D. Chuan, H. Xu, J. Dong // J. Plast. Reconstr. Aesthet. Surg. 2013. Vol. 66, No 1. P. 113-119. DOI: 10.1016/j.bjps.2012.08.010.

48. Parajuli N.P., Shrestha D., Panse N. Distally based sural faciocutaneous and fascial (adipofascial) flap for reconstruction of distal leg, ankle and foot defects // Kathmandu Univers. Med. J. (KUMJ). 2014. Vol. 12, No. 46. P. 126-131. DOI: 10.3126/kumj.v12i2.13659.

49. Microvascular reconstruction of complex foot defects, a new anatomo-functional classification / F. Santanelli di Pompeo, P. Pugliese, M. Sorotos, C. Rubino, G. Paolini // Injury. 2015. Vol. 46, No 8. P. 1656-1663. DOI: 10.1016/j.injury.2015.05.002.

50. The adipofascial dorsalis pedis perforator turn-over flap for reconstruction of a distal defect of the foot/ R. Horta, R. Valença-Filipe, R. Nascimento, D. Monteiro, A. Silva // Microsurgery. 2015. Vol. 35, No 4. P. 333-334. DOI: 10.1002/micr.22343.

51. Каплун В.А., Копысова В.А., Мартель И.И. Методы хирургического лечения больных с повреждениями голеностопного сустава // Вестник травматологии и ортопедии им. Н.Н. Приорова. 2013. № 1. С. 27-33.

52. An algorithmic approach for managing orthopaedic surgical wounds of the foot and ankle / E.H. Cho, R. Garcia, I. Pien, S. Thomas, L.S. Levin, S.T. Hollenbeck // Clin. Orthop. Relat. Res. 2014. Vol. 472, No 6. P. 1921-1929. DOI: 10.1007/s11999-014-3536-7.

53. Минасов Б.Ш., Бикташева Э.М., Валеев М.М. Пластика лоскутами с осевым типом кровоснабжения при обширных дефектах мягких тканей заднего отдела стопы. Уфа, 2019. 132 с.

54. Родоманова Л.А.,. Кочиш А.Ю. Реконструктивные микрохирургические операции при травмах конечностей: руководство для врачей. СПб., 2012. 116 с.

55. Barve D.J., Gupta A. The extended distally based sural neurocutaneous flap for foot and ankle reconstruction: a retrospective review of 10 years of experience // Ann. Plast. Surg. 2015. Vol. 74, No 6. P. 743. DOI: 10.1097/SAP.0000000000000476.

56. Scaglioni, M.F., Kuo Y.R., Chen Y.C. Reconstruction of distal hand and foot defects with the free proximal peroneal artery perforator flap // Microsurgery. 2016. Vol. 36, No 3. P. 183-190. DOI: 10.1002/micr.22364.

57. An alternative method to free flap for distal leg and foot defects due to electrical burn injury: distally based cross-leg sural flap / C. Eser, E. Kesiktas, E. Gencel, E.E. Aslaner, M. Yavuz // Ulus. Travma Acil. Cerrahi Derg. 2016. Vol. 22, No 1. P. 46-51. DOI: 10.5505/tjtes.2015.35306.

58. Posterior interosseous artery perforator-free flap: treating intermediate-size hand and foot defects / C.S. Yoon, H.J. Noh, G. Malzone, H.S. Suh, D.H. Choi, J.P. Hong // J. Plast. Reconstr. Aesthet. Surg. 2014. Vol. 67, No 6. P. 808-814. DOI: 10.1016/j.bjps.2014.03.007.

59. Афоничев К.А., Никитин М.С., Купцова О.А. Лечение послеожоговой вторичной деформации стопы // Ортопедия, травматология и восстановительная хирургия детского возраста. 2015. Т. 3, № 2. С. 52-55.

60. Атипичные способы реваскуляризации кровоснабжаемых комплексов тканей в реципиентной зоне / Л.А. Родоманова, Г.В. Медведев, А.О. Афанасьев, Е.С. Цыбуль // Анналы пластической, реконструктивной и эстетической хирургии. 2018. № 1. С. $100-101$.

61. Микусев И.Е., Микусев Г.И., Хабибуллин Р.Ф. Диагностика типа закрытой травматической отслойки кожи // Практическая медицина. 2015. T. 1 , № 4. C. $129-131$.

62. Reconstruction of foot and ankle defects with a superthin innervated anterolateral thigh perforator flap / S. Xie, X. Deng, Y. Chen, D. Song, K. Li // J. Plast. Surg. Hand Surg. 2016. Vol. 50, No 6. P. 367-374. DOI: 10.1080/2000656X.2016.1184158.

63. Bista N., Shrestha K.M., Bhattachan C.L. The reverse sural fasciocutaneous flap for the coverage of soft tissue defect of lower extremities (distal $1 / 3$ leg and foot) // Nepal Med. Coll. J. 2013. Vol. 15, No 1. P. 56-61.

64. Scaglioni M.F., Rittirsch D., Giovanoli P. Reconstruction of the Heel, Middle Foot Sole, and Plantar Forefoot with the Medial Plantar Artery Perforator Flap: Clinical experience with 28 cases // Plast. Reconstr. Surg. 2018. Vol. 141, No 1. P. 200-208. DOI: 10.1097/PRS.0000000000003975. 
65. Cross-leg repair of large soft-tissue defects in distal sites of the feet by distally based neuro-fasciocutaneous flaps with perforating vessels / Z.Q. Wang, Y.L. Cao, Y.F. Huang, D.O. Liu, X.F. Li // Genet. Mol. Res. 2014. Vol. 13, No 3. P. 5484-5491. DOI: 10.4238/2014.July.25.1.

66. Adipofascial fold-down flaps based on the posterior tibial artery perforator to cover the medial foot and ankle defects / K.J. Lee, S.H. Lee, M.B. Kim, Y.H. Lee // J. Plast. Reconstr. Aesthet. Surg. 2016. Vol. 69, No 12. P. e229-e237. DOI: 10.1016/j.bjps.2016.08.019.

67. Chimeric flap and free-style puzzle flap for extended coverage of the foot and ankle / B. Chaput, H. Eburdery, J. Laguerre, A. Spiecker, C. Herlin, J.L. Grolleau // Plast. Reconstr. Surg. 2015. Vol. 135, No 4. P. 797e-799e. DOI: 10.1097/PRS.0000000000001048.

68. Применение васкуляризированной кожной пластики задним фасциально-жировым лоскутом голени на ретроградном кровотоке для замещения дефекта мягких тканей нижней трети голени и стопы / Л.Я. Гизатулина, А.А. Богов, Р.И. Муллин, Я.Х. Ибрагимов // Практическая медицина. 2017. № 8. С. 53-55.

69. Acartürk T.O., Tunc S., Acar F. Versatility of the Perforator-Based Adipose, Adipofascial, and Fasciocutaneous Flaps in Reconstruction of Distal Leg and Foot Defects // J. Foot Ankle Surg. 2016. Vol. 55, No 2. P. 362-367. DOI: 10.1053/j.jfas.2014.12.020.

Статья поступила в редакцию 11.04.2020; одобрена после рецензирования 25.01.2021; принята к публикации 23.12.2021.

The article was submitted 11.04.2020; approved after reviewing 25.01.2021; accepted for publication 23.12.2021.

\section{Информация об авторах:}

1. Булат Шамильевич Минасов - доктор медицинских наук, професcop, B.minasov@ya.ru;

2. Элина Маратовна Бикташева - кандидат медицинских наук, dr.elinabiktasheva@yandex.ru;

3. Марат Мазгарович Валеев - доктор медицинских наук, valeevmm@rambler.ru;

4. Расуль Радикович Якупов - доктор медицинских наук, rasulr@mail.ru;

5. Тимур Булатович Минасов - доктор медицинских наук, m004@yandex.ru;

6. Тагир Рыфатович Мавлютов - доктор медицинских наук, mavlutovtagir@mail.ru.

\section{Information about authors:}

1. Bulat Shamilevich Minasov - Doctor of Medical Sciences, Professor, B.minasov@ya.ru;

2. Elina Maratovna Biktasheva - Candidate of Medical Sciences, dr.elinabiktasheva@yandex.ru;

3. Marat Mazgarovich Valeev - Doctor of Medical Sciences, valeevmm@rambler.ru;

4. Rasul Radikovich Yakupov - Doctor of Medical Sciences, rasulr@mail.ru;

5. Timur Bulatovich Minasov - Doctor of Medical Sciences, m004@yandex.ru;

6. Tagir Ryfatovich Mavlyutov - Doctor of Medicine, mavlutovtagir@mail.ru.

Конфликт интересов: не заявлен.

Источник финансирования: исследование проведено без спонсорской поддержки. 


\section{Указатель статей научно-теоретического и практического журнала «Гений Ортопедии» за 2021 2., T. 27, №№ 1-6}

\section{Index of articles from the scientific-theoretical and practical journal "Orthopaedic Genius" 2021, T. 27, no. 1-6}

Abdul Basith cм. Римашевский Д.В. № 5/628

Ahmed A.-S. A.-A. cm. Hosny G.A. № 3/351

Alberghina F. cM. Andreacchio A. № 4/406, 431

Alomar K. cm. Müller F. № 4/446

Andreacchio A., Alberghina F., Canavese F. Применение эластичных стабильных интрамедуллярных стержней для лечения переломов длинных костей у пациентов с незрелым скелетом № 4/406

Andreacchio A., Alberghina F., Monforte S., Dimeglio A.,

Canavese F. Косолапость: современная концепция лечения № 4/431 Bari M.M., Shahidul I., Tanvir A., Shayan A.M., Bari R. Обзор вариантов лечения детей с фиброзной дисплазией большеберцовой кости методом Илизарова № 3/357

Bari R. cm. Bari M.M. № 3/357

Bryan Gervais de Liyis, John Nolan, Made Agus Maharjana Внеклеточные везикулы рецептора 1 фактора роста фибробластов как новый метод лечения остеоартрита № 6/693

Canavese F. cM. Andreacchio A. № 4/406, 431

Cao Loi B. cm. Nguyen Nam H. № 6/686

Chaudhary I.M. cM. Chaudhary M.M. № 3/361

Chaudhary M.M., Chaudhary I.M. Лечение запущенной косолапо-

сти методами Илизарова и Понсети № 3/361

Chen J. cM. Tan W. № $1 / 55$

Chen W. cm. Tian L. № 3/322

Chen W., Hua Q., Zhao J., Qu L. Открытие и клиническое значение «Двойного эффекта открытой створки» при выполнении техники поперечного перемещения фрагмента большеберцовой кости по Илизарову № 3/372

Chen W., Qu L. Открытие и клиническое значение второго общебиологического принципа Илизарова («Харбинский феномен» костного транспорта) № 3/296

Dimeglio A. cM. Andreacchio A. № 4/431

Duong Chinh D. cM. Nguyen Nam H. № 6/686

Feng J. cM. Li K. № 3/319

Guo B. cM. Qin S. № 3/291

Hadar A.K. cm. Ismiarto Y.D. № 6/746

He G., Zhou X., Shi Y., Wang D., Yu J., Xing H., Yin H., Zhang J.

Liu H., Wang B., Jia Y., Zhang Y. Мониторинговая ценность ультразвукового исследования при сращении в зоне контакта после перемещения фрагмента большеберцовой кости с помощью аккордеонного маневра № 3/374

Horn J. Обзор лечения идиопатического увеличения антеверсии бедренной кости у детей и подростков № $4 / 450$

Hosny G.A., Ahmed A.-S. A.-A. Неизбежна ли артропластика после реконструкции по Илизарову нестабильных тазобедренных суставов у подростков и молодых людей? Долгосрочная оценка 136 случаев № $3 / 351$

Hua Q. cM. Chen W. № 3/372

Ismiarto Y.D., Ramdan A., Sudjana D.P.P., Rahim A.H., Hadar A.K. Сравнительная диагностическая ценность методов GeneXpert MTB/ RIF, IS6110-ПЦР и посева для диагностики туберкулеза позвоночника № 6/746

Jia Y. cm. He G. № 3/374

John Nolan cM. Bryan Gervais de Liyis № 6/693

Journeau P. cM. Lascombes P. № 4/413

Journeau P. cM. Müller F. № 4/446

Kirienko A., Malagoli E., Lucchesi G. Метод Илизарова в лечении нейрогенных деформаций стопы № 3/383

Lascombes P., Journeau P., Popkov D.A. Применение эластичных стержней при диафизарных переломах у детей. Пять вопросов и ответов № $4 / 413$

Lascombes P., Mainard-Simard L. Хондромы и множественный энхондромато3 № 4/441

Lascombes P., Popkov D.A., Leonchuk S.S. Реконструктивная хирургия при рецидиве косолапости № 4/435

Le Anh T. cm. Nguyen Nam H. № 6/686

Leonchuk S.S. CM. Lascombes P. № 4/435

Li F. cM. Li K. № 3/319

Li H. CM. Li K. № 3/319

Li K., Rong S., Zheng C., Teng Y., Li H., Liu L., Zhen K., Shen X.

Feng J., Li F. Результаты использования внешнего мини-фиксатора Илизарова при переломах Монтеджиа у детей № 3/319

Liu H. cm. He G. № 3/374

Liu L. CM. Li K. № 3/319

Lucchesi G. cM. Kirienko A. № 3/383

Made Agus Maharjana cM. Bryan Gervais de Liyis № 6/693

Mainard-Simard L. cM. Lascombes P. № 4/441

Malagoli E. cM. Kirienko A. № 3/383

Monforte S. cM. Andreacchio A. № 4/431

Müller F., Alomar K., Journeau P. Скелетно-мышечные аномалии у детей с мукополисахаридозами № $4 / 446$

Nguyen Le H. cM. Nguyen Nam H. № 6/686

Nguyen Nam H., Nguyen Le H., Vu Khoa V., Duong Chinh D. Cao Loi B., Le Anh T. Клинические характеристики и факторы, влияющие на время ожидания операции и продолжительность госпитализации пожилых пациентов с переломами проксимального отдела бедра№ 6/686

Oshmianska N. cM. Tan W. № $1 / 55$

Popkov D.A. cm. Lascombes P. № 4/413, 435

Qin S. cM. Zang J. № 3/331

Oin S., Zang J., Guo B. Технология Илизарова и китайская философия (к 100-летию со дня рождения профессора Илизарова)№ 3/291 Qu L. CM. Chen W. № 3/296, 372

Qu L. cM. Tian L. № $3 / 322$

Rahim A.H. cM. Ismiarto Y.D. № 6/746

Ramdan A. cM. Ismiarto Y.D. № 6/746

Ran R. cM. Tan W. № $1 / 55$

Rong S. cM. Li K. № 3/319

Shahidul I. cM. Bari M.M. № 3/357

Shayan A.M. cM. Bari M.M. № 3/357

Shen X. cM. Li K. № 3/319

Shi Y. cm. He G. № 3/374

Sudjana D.P.P. cM. Ismiarto Y.D. № 6/746

Tan W., Chen J., Ran R., Zheng W., Oshmianska N. Опыт артроскопической хирургии при тофусной подагре: показания, результаты и осложнения № $1 / 55$

Tanvir A. cM. Bari M.M. № 3/357

Teng Y. cM. Li K. № 3/319

Tian L., Chen W., Qu L.Технические особенности внешнего минификсатора Илизарова для лечения переломов фаланг № 3/322

Vu Khoa V. cм. Nguyen Nam H. № 6/686

Wang B. cM. He G. № 3/374

Wang D. cM. He G. № 3/374

Xing H. cm. He G. № 3/374

Yin H. cm. He G. № 3/374

Yu J. cм. He G. № 3/374

Zaalan Wessam см. Римашевский Д.В. № 5/628

Zang J. cM. Qin S. № 3/291

Zang J., Qin S. Аналитический обзор 35075 случаев хирургиче-

ского лечения деформаций конечностей и причины установления инвалидности № 3/331

Zhang J. cM. He G. № 3/374

Zhang Y. cM. He G. № 3/374

Zhao J. cM. Chen W. № 3/372

Zhen K. cM. Li K. № 3/319

Zheng C. CM. Li K. № 3/319

Zheng W. cM. Tan W. № $1 / 55$

Zhou X. см. He G. № 3/374

Абакиров М.Д. см. Панин М.А. № $1 / 43$

Абакиров М.Д., Аль-Баварид О.А., Панин М.А., Нурмухаметов P.М., Мамырбаев С.Т., Аленизи А.А. Результаты трансфораминального эндоскопического удаления грыжи диска пояснично-крестцового отдела позвоночника, дополненного нуклеопластикой № 2/243 Абдуллаев К.Ф. см. Каплунов О.А. № 6/808

Абдуллах А.М. см. Нуриахметов А.Н. № $1 / 80$

Абуладзе Л.Р. см. Петряйкин А.В. № 6/800

Айдаров В.И. см. Ахтямов И.Ф. № 1/121

Аксельров М.А. см. Скрябин Е.Г. № 6/700

Аксенов А.Ю. см. Долганова Т.И. № 6/827

Аладьина В.А. см. Богданов С.Б. № 2/163

Алейник Д.Я. см. Мусихина И.В. № $1 / 32$

Александров Н.М., Вешуткин В.Д., Жуков А.Е., Вешаев И.Д.,

Купцов Д.А., Углёв О.И. Факторы прочности лучевой кости после формирования краевого дефекта № 2/187

Алексеева А.В. см. Чирков Н.Н. № 3/337

Аленизи А.А. см. Абакиров М.Д. № 2/243

Алиев А.Г., Амбросенков А.В., Бояров А.А., Жабин Г.И., Федюнина С.Ю., Тихилов Р.М., Шубняков И.И. Структура ревизионного эндопротезирования локтевого сустава № 5/532

Алиев А.Г., Риахи А., Середа А.П., Вебер Е.В., Шубняков И.И., Тихилов P.М. Влияние пандемии Covid-19 на госпитализацию пациентов после артропластики коленного и тазобедренного суставов № $5 / 570$

Алиев Б.Г. см. Ткаченко А.Н. № 5/527

Аль-Баварид О.А. см. Абакиров М.Д. № 2/243

Амбросенков А.В. см. Алиев А.Г. № 5/532

Антонов Н.И. см. Рябых С.О. № 6/773

Антропова И.П. см. Ершов А.С. № 5/514

Аранович А.М. см. Коробейников А.А. № 4/418

Аранович А.М. см. Менщикова Т.И. № 3/366 
Аранович А.М. см. Попков Д.А. № 4/461, 487 Арсениевич В.Б. см. Мизюров С.А. № 6/821 Артемьев А.А., Брижань Л.К., Давыдов Д.В., Бытдаев 3.М., Кашуб А.М., Шипулин А.А., Гулулян Г.Г. Место эстетической хирургии нижних конечностей в современной ортопедии № $1 / 59$ Артюх В.А., Божкова С.А., Тихилов Р.М., Ярмилко А.В., Муравьева Ю.В. Факторы риска летального исхода после хирургического лечения больных хронической перипротезной инфекцией тазобедренного сустава № $5 / 555$

Артюх В.А. см. Афанасьев А.В. № 2/232

Архипкин С.В. см. Шнякин П.Г. № 6/727

Афанасьев А.А. см. Волошин В.П. № 2/227

Афанасьев А.В., Божкова С.А., Артюх В.А., Лабутин Д.В., Ливенцов В.Н., Кочиш А.А. Применение синтетических заменителей костной ткани при одноэтапном лечении пациентов с хроническим остеомиелитом № 2/232

Афанасьев А.П. см. Рязанцев М.С. № 2/237

Афиногенов Г.Е. см. Линник С.А. № $5 / 548$

Афиногенова А.Г. см. Линник С.А.. № 5/548

Афоничев К.А. см. Никитюк И.Е. № 2/254

Ахмад Е.С. см. Петряйкин А.В. № 6/800

Ахтямов И.Ф. см. Волченко Д.В. № $1 / 38$

Ахтямов И.Ф. см. Нуриахметов А.Н. № 1/80

Ахтямов И.Ф. см. Римашевский Д.В. № 5/628

Ахтямов И.Ф., Айдаров В.И., Хасанов Э.Р. Современные методь восстановительного лечения пациентов после артроскопической реконструктивной пластики передней крестообразной связки коленного сустава: обзор литературы № $1 / 121$

Ахтямов И.Ф., Гильмутдинов И.Ш., Хасанов Э.Р. Новый вариант пластики тибиального плато большеберцовой кости при эндопротезировании коленного сустава № 5/592

Бажанов С.П. см. Шульга А.Е. № 6/709

Базаров А.Ю., Сергеев К.С., Лебедев И.А., Паськов Р.В.,

Цветкова А.К. Периоперационные факторы риска осложнений и рецидивов при гематогенном остеомиелите позвоночника: анализ моноцентровой когорты № 6/750

Байимбетов Г.Д., Ходжанов И.Ю. Новые подходы к лечению детей с посттравматическими контрактурами локтевого сустава № 5/578 Байимбетов Г.Дж. см. Ходжанов И.Ю. № $1 / 15$

Балаклеец С.В. см. Семенкин О.М. № $1 / 24$

Бальжинимаев Д.Б. см. Михайлов И.Н. № 6/789

Балюра Г.Г. см. Голубев И.О. № 2/182

Басов С.В. см. Иванян С.Т. № 5/587

Бердюгина O.В. Анализ вероятности возникновения периимплантной инфекции и ее последствия при внешней транспедикулярной фиксации позвоночника № 6/732

Березин П.А. см. Брагина С.В. № 5/636

Блаженко А.Н. см. Богданов С.Б. № 2/163

Блаженко А.Н. см. Черевцов В.Н. № $2 / 214$

Богданов С.Б. см. Черевцов В.Н. № 2/214

Богданов С.Б., Забунян Г.А., Марченко Д.Н., Блаженко А.Н., Каракулев А.В., Аладьина В.А. Демонстрация возможностей реконструктивных оперативных вмешательств по укрытию открытых костей лицевого скелета и свода черепа по поводу дефектов различной этиологии № $2 / 163$

Богданова М.А. см. Семенкин О.М. № $1 / 24$

Божкова С.А. см. Артюх В.А. № 5/555

Божкова С.A. см. Афанасьев А.В. № 2/232

Божкова С.А. см. Пантелеев А.Н. № 5/562

Бойко А.В. см. Панин М.А. № $1 / 43$

Борзунов Д.Ю. см. Ступина Т.А. № 2/249

Ботов А.В. см. Шнякин П.Г. № 6/727

Бояров А.А. см. Алиев А.Г. № 5/532

Брагина С.В., Москалёв В.П., Петрушин А.Л., Березин П.А.

Проблема периоперационного прогнозирования гнойных ослож-

нений эндопротезирования тазобедренного и коленного суставов.

Часть I. № 5/636

Братийчук А.Н. см. Семенкин О.М. № $1 / 24$

Брижань Л.К. см. Артемьев А.А. № 1/59

Буксеев А.Н. см. Скрябин Е.Г. № 6/700

Бунов В.С. см. Тепленький М.П. № 3/345

Бурцев А.В. см. Губин А.В. № 2/146

Бурцев А.В. см. Ермаков А.М. № 5/540

Бушуев О.М. см. Голубев И.О. № 2/182

Бытдаев 3.М. см. Артемьев А.А. № 1/59

Бялик B.Е. см. Нурмухаметов М.P. № 2/220

Бялик Е.И. см. Нурмухаметов М.Р. № 2/220

Варсегова Т.Н. см. Кубрак Н.В. № 6/782

Вебер Е.В. см. Алиев А.Г. № 5/570

Величко М.Н. см. Волченко Д.В. № 1/38

Верхотуров В.В. см. Михайлов И.Н. № 6/789

Верхотурова Е.В. см. Михайлов И.Н. № 6/789

Ветрилэ М.С. см. Губин А.В. № 2/146

Вешаев И.Д. см. Александров Н.М. № 2/187

Вешуткин В.Д. см. Александров Н.М. № 2/187

Виссарионов С.В. см. Никитюк И.Е. № 6/758
Вишневский А.А. Сравнение основных факторов риска формирования сепсиса у пациентов с неспецифическим остеомиелитом позвоночника и туберкулезным спондилитом № 6/740

Владзимирский А.В. см. Петряйкин А.В. № 6/800

Владимиров А.А. см. Фищенко Я.В. № 2/209

Власов М.В. см. Мусихина И.В. № $1 / 32$

Волков Е.Е. см. Панин М.А. № $1 / 43$

Волков Е.Е., Голощапов А.П., Мустафин Р.Н., Ностаева С.Э.

Исследование аллельных вариантов генов VDR и PAI у пациентов с асептическим некрозом головки бедренной кости № 2/260

Волокитина Е.А. см. Ершов А.С. № 5/514

Волошин В.П. см. Шевырев К.В. № 2/265

Волошин В.П., Галкин А.Г., Ошкуков С.А., Санкаранараянан А.С.,

Степанов Е.В., Афанасьев А.А. Аддитивные технологии у пациентов с обширными дефектами костей нижних конечностей № 2/227

Волченко Д.В., Ахтямов И.Ф., Терсков А.Ю., Созонов О.А.,

Величко М.Н., Удалов Ю.Д., Семенов М.С., Шпиз Е.Я., Леп-

сверидзе Л.Т. Краткосрочные результаты тотального эндопротези-

рования тазобедренного сустава у пациентов с анкилозирующим

спондилоартритом (первичное сообщение) № 1/38

Вороков А.А. см. Линник С.А. № 5/548

Вороков А.А. см. Ткаченко А.Н. № 5/527

Галкин А.Г. см. Волошин В.П. № $2 / 227$

Гарипов И.И. см. Долганова Т.И. № 6/827

Гвоздев Н.С. см. Попков Д.А. № 4/461, 475

Гильмутдинов И.Ш. см. Ахтямов И.Ф. № 5/592

Голощапов А.П. см. Волков Е.Е. № 2/260

Голубев И.О., Саруханян А.P., Меркулов М.В., Бушуев О.М.,

Ширяева Г.Н., Кутепов И.А., Максимов А.А., Капырина М.В.

Балюра Г.Г. Эффективность кровоснабжаемой и обычной костной

пластики в достижении сращения при ложных суставах плечевой

кости № 2/182

Гордиенко И.И., Сакович А.В., Цап Н.А., Марфицын А.В., Кутепов С.М. Лечебная тактика при переломах ключицы у детей № 1/13 Гординская Н.А. см. Мусихина И.В. № 1/32

Гречаный С.В., Гуренич А.Д., Наумов Д.Г., Мушкин А.Ю. От-

ношение к болезни в семьях детей с деформациями позвоночника № $6 / 767$

Грицук Н.О. см. Иванян С.Т. № 5/587

Губин А.В. см. Жалмагамбетов К.Л. № 1/97

Губин А.В. см. Попков Д.А. № 4/461

Губин А.В. см. Рябых С.О. № 4/468

Губин А.В., Хан Н.В., Рябых С.О., Овчинников Е.Н., Бурцев А.В.,

Ветрилэ М.С., Пуляткина И.В., Соломянник И.А. «ЗДТ»-концепт как модель интеграции травматолого-ортопедической службы в приоритетные направления развития и национальные проекты Российской Федерации № 2/146

Гулулян Г.Г. см. Артемьев А.А. № 1/59

Гуренич А.Д. см. Гречаный С.В. № 6/767

Гюльназарова С.В. см. Кутепов С.М. № 3/307

Давиров Ш.М., Уринбоев П.У. Лечение пациента с открытым

переломом костей предплечья и обширным дефектом костной ткани (случай из практики) № $1 / 87$

Давыдов Д.В. см. Артемьев А.А. № 1/59

Дарвин Е.О. см. Карасев А.Г. № 3/313

Демкин С.А. см. Каплунов О.А. № 6/808

Дзюба Г.Г. см. Одарченко Д.И. № 2/270

Долганова Т.И. см. Рахматулина А.А. № 3/325

Долганова Т.И., Аксенов А.Ю., Рябых С.О., Гарипов И.И. Методы и критерии оценки динамического сагиттального баланса тела (несистематизированный обзор) № 6/827

Дороганов С.О. см. Котельников Г.П. № 5/645

Дорофеев Ю.Л. см. Ткаченко А.Н. № 5/527

Дубров В.Э. см. Щербаков И.М. № 5/502

Дулаев А.К. см. Заяц В.В. № $1 / 48$

Дыдыкин А.В. см. Заяц В.В. № $1 / 48$

Дьячков А.Н. см. Лукин С.Ю. № $1 / 6$

Дьячков К.А. см. Рябых С.О. № 6/773

Дьячкова Г.В. Много лет спустя. Илизаров (к 100-летию со дня

рождения) № 3/286

Дюрягина О.В. см. Рябых С.О. № 6/773

Дюрягина О.В. см. Ступина Т.А. № 2/249

Евстигнеева Л.П. см. Ершов А.С. № 5/514

Еманов А.А. см. Ступина Т.А. № 6/795

Ермаков А.М., Силантьева Т.А., Науменко 3.С., Клюшин Н.М., Малкова Т.А., Бурцев А.В. Комплексный подход и значение гистологического исследования в диагностике перипротезного остеомиелита у 29 пациентов на этапе ревизионного эндопротезирования инфицированного тазобедренного сустава № 5/540

Ерофеев С.А. см. Одарченко Д.И. № 2/270

Ершов А.С., Антропова И.П., Волокитина Е.А., Евстигнеева Л.П. Гематологические особенности у больных ревматоидным артритом при эндопротезировании тазобедренного сустава № 5/514

Жабин Г.И. см. Алиев А.Г. № 5/532

Жалмагамбетов К.Л., Рябых С.О., Жданов А.С., Губин А.В. При-

менение транспедикулярной спинальной системы и блок-решетки 
при оперативном лечении посттравматической деформации таза: случай из практики и краткий анализ литературы № 1/97

Жданов А.С. см. Жалмагамбетов К.Л. № 1/97

Жданов А.С. см. Карасев А.Г. № 3/313

Жуков А.Е. см. Александров Н.М. № 2/187

Забунян Г.А. см. Богданов С.Б. № $2 / 163$

Загородний Н.В. см. Панин М.А. № $1 / 43$

Загородний Н.В. см. Торгашин А.Н. № 2/153

Загородний Н.В., Колесник А.И., Лазарев А.Ф., Солод Э.И.,

Очкуренко А.А., Соломянник И.А., Овчаренко А.В., Солодилов И.М., Иванов Д.А., Иванов М.А., Суриков В.В. Хирургические доступы при лечении пациентов со свежими переломами вертлужной впадины № $5 / 610$

Зарецков А.В. см. Мизюров С.А. № 6/821

Зарецков В.В. см. Мизюров С.А. № 6/821

Зарецков В.В. см. Шульга А.Е. № 6/709

Зарипов А.Р. см. Рязанцев М.С. № 2/237

Заяц В.В., Дулаев А.К., Дыдыкин А.В., Ульянченко И.Н. Клиническая эффективность анатомической пластики передней крестообразной связки коленного сустава № $1 / 48$

Зверева К.П., Островский В.В., Марков Д.А., Сертакова А.В., Решетников А.Н. Анализ выживаемости сохраняемого феморального компонента эндопротеза тазобедренного сустава при изолированном ацетабулярном ревизионном вмешательстве № 5/521

Зиновьев М.П. см. Римашевский Д.В. № 5/628

Злобина Ю.С. см. Щербаков И.М. № 5/502

Зотов П.Б. см. Скрябин Е.Г. № 6/700

Зюзин Д.А. см. Шербаков И.М. № 5/502

Иванов В.В. см. Котельников Г.П. № $5 / 645$

Иванов Д.А. см. Загородний Н.В. № 5/610

Иванов Д.В., Кириллова И.В., Коссович Л.Ю., Лихачев С.В., Полиенко А.В., Харламов А.В., Шульга А.Е. Сравнительный анализ мобильного приложения для измерения параметров сагиттального баланса «СпиноМетр» с системой surgimap: апробация межэкспертной надежности № $1 / 74$

Иванов М.А. см. Загородний Н.В. № 5/610

Иванова О.Ф. см. Котельников Г.П. № 5/645

Иванян С.Т., Басов С.В., Грицук Н.О., Пронин В.А., Тихонен-

ко С.Н. Двухэтапное лечение глубокой перипротезной инфекции

тазобедренного сустава, осложненной забрюшинным дефектом

мочевого пузыря № 5/587

Измалков С.Н. см. Семенкин О.М. № 1/ 24

Ильин Д.О. см. Рязанцев М.С. № 2/237

Каземирский А.В. см. Пантелеев А.Н. № 5/562

Казьмин А.И. см. Переверзев В.С. № 6/813

Каплунов К.О. см. Каплунов О.А. № 6/808

Каплунов О.А., Демкин С.А., Абдуллаев К.Ф., Каплунов К.О.,

Малякина А.А. Застарелое повреждение мышщ надплечья и

вращательной манжеты плеча: клинический кейс миофасциальной

транспозиции № 6/808

Капырина М.В. см. Голубев И.О. № 2/182

Карагезов Г. см. Линник С.А. № $5 / 548$

Каракулев А.В. см. Богданов С.Б. № 2/163

Карасев А.Г., Жданов А.С., Дарвин Е.О., Карасева Т.Ю., Сутягин И.В., Лушников А.В. Анализ отдаленных результатов оперативного лечения пациентов с переломами проксимального отдела большеберцовой кости аппаратом Илизарова № 3/313

Карасева Т.Ю. см. Карасев А.Г. № 3/313

Кашуб А.М. см. Артемьев А.А. № 1/59

Квиникадзе Г.Э. см. Линник С.А. № 5/548

Кетов М.С. см. Черевцов В.Н. № $2 / 214$

Ким Ю.Д., Шитиков Д.С., Князев Н.А., Лихолатов Н.Э., Ша-

фиев О.А. Современные методики лечения пациентов с закрытым переломом надколенника № 5/597

Кириенко А.П. см. Шевцов В.И. № 3/299

Кириллова И.В. см. Иванов Д.В. № $1 / 74$

Киселева А.Н. см. Петряйкин А.В. № 6/800

Клеменов А.В. Возможности применения обратной ходьбы при

патологии коленного сустава (обзор литературы) № 1/128

Климов О.В. см. Коростелев М.Ю. № 2/169

Клюшин Н.М. см. Ермаков А.М. № 5/540

Клюшин Н.М. см. Линник С.А. № 5/548

Клюшин Н.М. см. Рахматулина А.А. № 3/325

Князев Н.А. см. Ким Ю.Д. № 5/597

Князев Н.А. см. Семенкин О.М. № 1/ 24

Кожевников В.В. см. Попков Д.А. № $4 / 475$

Колесник А.И. см. Загородний Н.В. № $5 / 610$

Колесов С.В. см. Переверзев В.С. № 6/813

Корнеенков А.А. см. Ткаченко А.Н. № 5/527

Коробейников А.А., Аранович А.М., Попков Д.А. Метод Илиза-

рова при лечении детей с околосуставными переломами № 4/418

Королев А.В. см. Рязанцев М.С. № 2/237

Коростелев М.Ю., Шихалева Н.Г., Климов О.В. К вопросу о

классификации травматических отслоек покровных тканей № 2/169

Корыткин А.А. см. Пронских А.А. № 5/620

Косимов А.А. см. Ходжанов И.Ю. № 2/199
Коссович Л.Ю. см. Иванов Д.В. № 1/74

Котельников Г.П., Иванов В.В., Николаенко А.Н., Иванова О.Ф.,

Дороганов С.О. Эндопротезирование голеностопного сустава № 5/645

Кочиш А.А. см. Афанасьев А.В. № $2 / 232$

Кравцов Д.В. см. Линник С.А. № $5 / 548$

Кравчук Л.Д. см. Фищенко Я.В. № 2/209

Краснов В.В. см. Кубрак Н.В. № 6/782

Кубасов В.А. см. Никитюк И.Е. № 2/254

Кубрак Н.В., Варсегова Т.Н., Краснов В.В., Рябых С.О. Резуль-

таты применения противоспаечного геля после моделирования

контузионного повреждения спинного мозга у крыс № 6/782

Кузнецов В.П. см. Ступина Т.А. № 6/795

Кузнецов Н.К. см. Одарченко Д.И. № 2/270

Кулеш П.Н., Соломин Л.Н. Изменения взаимоотношений рефе-

рентных линий при коррекции формы ног в соответствии с желаниями пациента № 3/390

Кулеш П.Н., Соломин Л.Н. Комментарий к статье «Место эстетической хирургии нижних конечностей в современной ортопедии» № $5 / 584$

Купцов Д.А. см. Александров Н.М. № 2/187

Курмангулов А.А. см. Скрябин Е.Г. № 6/700

Кустуров В.И., Кустурова А.В. Фиксация таза при повреждении

заднего полукольца у пострадавших с политравмой № 6/678

Кустурова А.В. см. Кустуров В.И. № 6/678

Кутепов И.А. см. Голубев И.О. № 2/182

Кутепов С.М. см. Гордиенко И.И. № 1/13

Кутепов С.М., Гюльназарова С.В. К истории изучения и развития метода чрескостного остеосинтеза на Среднем Урале № 3/307

Лабутин Д.В. см. Афанасьев А.В. № 2/232

Лазарев А.Ф. см. Загородний Н.В. № 5/610

Лебедев И.А. см. Базаров А.Ю. № 6/750

Лебедев М.Ю. см. Мусихина И.В. № 1/32

Леончук Д.С. см. Рахматулина А.А. № 3/325

Леончук С.С., Островских Л.А., Сазонова Н.В. Дистракционная артропластика голеностопного сустава с использованием аппарата

Илизарова и артроскопической техники: первый клинический опыт № $1 / 92$

Лепсверидзе Л.Т. см. Волченко Д.В. № 1/38

Ливенцов В.Н. см. Афанасьев А.В. № 2/232

Линник С.А., Афиногенов Г.Е., Афиногенова А.Г., Квиникадзе Г.Э., Кравцов Д.В., Клюшин Н.М., Мадай Д.Ю., Хайдаров В.М., Карагезов Г., Вороков А.А. Выбор спейсера на первом этапе лечения поздней глубокой перипротезной инфекции тазобедренного сустава № $5 / 548$

Лихачев С.В. см. Иванов Д.В. № $1 / 74$

Лихачев С.В. см. Мизюров С.А. № 6/821

Лихачев С.В. см. Шульга А.Е. № 6/709

Лихолатов Н.Э. см. Ким Ю.Д. № 5/597

Логвинов А.Н. см. Рязанцев М.С. № 2/237

Лукин С.Ю., Солдатов Ю.П., Дьячков А.Н. Результаты лечения больных с множественной и сочетанной травмой с применением малоинвазивных технологий остеосинтеза и электромагнитных

волн терагерцевого диапазона № $1 / 6$

Лунева С.Н. см. Рахматулина А.А. № 3/325

Лушин А.В. см. Чирков Н.Н. № 3/337

Лушников А.В. см. Карасев А.Г. № 3/313

Любчак В.В. см. Цыбин А.В. № 5/508

Люлин С.В. см. Рахматулина А.А. № 3/325

Магнитская Н.Е. см. Рязанцев М.С. № 2/237

Мадай Д.Ю. см. Линник С.А. № 5/548

Мазалов А.В. см. Черевцов В.Н. № 2/214

Макаров М.A. см. Нурмухаметов М.P. № 2/220

Максимов А.А. см. Голубев И.О. № 2/182

Малкова Т.А. см. Ермаков А.М. № 5/540

Малыгин Р.В. сM. Цыбин А.В. № $5 / 508$

Малякина А.А. см. Каплунов О.А. № 6/808

Мамырбаев С.Т. см. Абакиров М.Д. № 2/243

Мансуров Д.Ш. см. Ткаченко А.Н. № 5/527

Марков Д.А. см. Зверева К.П. № 5/521

Мартыненко Д.В. см. Шевырев К.В. № 2/265

Марфицын А.В. см. Гордиенко И.И. № 1/13

Марченко Д.Н. см. Богданов С.Б. № 2/163

Менщикова Т.И., Аранович А.М. Удлинение голеней у больных ахондроплазией 6-9 лет как первый этап коррекции роста № 3/366

Меньщикова Т.И. см. Рахматулина А.А. № 3/325

Меркулов М.В. см. Голубев И.О. № 2/182

Мизюров С.А., Островский В.В., Зарецков В.В., Арсениевич В.Б., Лихачев С.В., Зарецков А.В., Папаев А.В. Баллонная кифопластика в хирургическом лечении агрессивных гемангиом позвоночника (обзор литературы) № 6/821

Милёхина И.Е. см. Шнякин П.Г. № 6/727

Мингазов Э.Р. см. Попков Д.А. № 4/461

Митина Т.А. см. Шевырев К.В. № 2/265

Михайлов И.Н., Пусева М.Э., Бальжинимаев Д.Б., Семенов А.В.,

Верхотуров В.В., Верхотурова Е.В. Сравнительное определение

механической прочности моделей трансплантатов из половины 
сухожилия длинной малоберцовой мышцы и сухожилия полусухожильной мышщы (экспериментальное исследование) № 6/789

Молдакулов Ж.М. см. Римашевский Д.В. № 5/628

Морозов С.П. см. Петряйкин А.В. № 6/800

Москалёв В.П. см. Брагина С.В. № $5 / 636$

Моховиков Д.С. см. Ступина Т.А. № 2/249

Муравьева Ю.В. см. Артюх В.А. № 5/555

Мурсалов А.К. см. Торгашин А.Н. № 2/153

Мусихина И.В., Языкова А.Б., Власов М.В., Гординская Н.А.

Лебедев М.Ю., Алейник Д.Я., Тенилин Н.А. Врожденный иммунитет и метаболизм костной и хрящевой ткани у детей с врожденным вывихом бедра - пилотное исследование № $1 / 32$

Мустафин Р.Н. см. Волков Е.Е. № 2/260

Мушкин А.Ю. см. Гречаный С.В. № 6/767

Накоскина Н.В. см. Рахматулина А.А. № 3/325

Науменко 3.С. см. Ермаков А.M. № 5/540

Наумов Д.Г. см. Гречаный С.В. № 6/767

Некролог: Михиал Моисеевич Щудло (1934-2021) № 6/834

Некролог: Профессор Свешников Анатолий Андреевич

(3.11.1936 - 21.01. 2021) № 1/132

Нестеренко В.А. см. Нурмухаметов М.P. № 2/220

Нестерова Ю.В. см. Попков Д.А. № $4 / 487$

Низовцова Л.А. см. Петряйкин А.В. № 6/800

Никитин М.С. см. Никитюк И.Е. № 2/254

Никитюк И.Е., Афоничев К.А., Никитин М.С., Петраш В.В.,

Кубасов В.А. Выживаемость изолированных кожных эксплантатов

при дистанционном взаимодействии со слоистыми периодическими структурами № 2/254

Никитюк И.Е., Виссарионов С.В. Особенности опорной функции стоп у детей с тяжелыми формами идиопатического сколиоза до и после хирургического лечения № 6/758

Николаев Н.С. см. Чирков Н.Н. № 3/337

Николаенко А.Н. см. Котельников Г.П. № 5/645

Новаков В.Б., Новакова О.Н., Чурносов М.И. Факторы риска

и молекулярные основы этиопатогенеза остеоартроза коленного

сустава (обзор литературы) № $1 / 112$

Новакова О.Н. см. Новаков В.Б. № $1 / 112$

Новиков К.И. см. Шевцов В.И. № 3/299

Ностаева С.Э. см. Волков Е.Е. № 2/260

Нуриахметов А.Н., Ахтямов И.Ф., Цыплаков Д.Э., Абдуллах А.М.,

Нуриахметова Т.Ю. Дозозависимое влияние бетаметазона на су-

ставной хрящ (экспериментальное исследование) № 1/80

Нуриахметова Т.Ю. см. Нуриахметов А.Н. № 1/80

Нурмухаметов М.Р., Макаров М.А., Бялик Е.И., Хренников Я.Б.,

Бялик В.Е., Нестеренко В.А. Применение техники аутологичного

индуцированного матрицей хондрогенеза в лечении пациентов с

остеоартритом первого плюснефалангового сустава № 2/220

Нурмухаметов Р.М. см. Абакиров М.Д. № 2/243

Овчаренко А.В. см. Загородний Н.В. № 5/610

Овчинников Е.Н. см. Губин А.В. № $2 / 146$

Овчинников Е.Н. см. Ступина Т.А. № 6/795

Одарченко Д.И., Дзюба Г.Г., Ерофеев С.А., Кузнецов Н.К.

Проблемы диагностики и лечения асептического некроза головки

бедренной кости в современной травматологии и ортопедии (обзор литературы) № $2 / 270$

Олейников Е.В. см. Тепленький М.П. № 3/345

Островский В.В. см. Зверева К.П. № 5/521

Островский В.В. см. Мизюров С.А. № 6/821

Островский В.В. см. Шульга А.Е. № 6/709

Островских Л.А. см. Леончук С.С. № $1 / 92$

Очирова П.В. см. Рябых С.О. № 4/453, 468

Очкуренко А.А. см. Загородний Н.В. № 5/610

Ошкуков С.А. см. Волошин В.П. № 2/227

Ошкуков С.А. см. Шевырев К.В. № 2/265

Павлов В.В. см. Пронских А.А. № 5/620

Павлов В.В. см. Чындын-оол Э.С. № $5 / 658$

Павлова Д.Д., Шарков С.М., Петров М.А. Техники шва мениска

коленного сустава у детей и показания к их применению № 4/424

Панин М.А. см. Абакиров М.Д. № 2/243

Панин М.А., Загородний Н.В., Бойко А.В., Самоходская Л.М., Абакиров М.Д., Волков Е.Е. Значение полиморфизмов генов факторов VII и XIII системы свертываемости крови в патогенезе нетравматического асептического некроза головки бедренной кости № $1 / 43$

Пантелеев А.А. см. Переверзев В.С. № 6/813

Пантелеев А.Н., Божкова С.А., Преображенский П.М., Каземир-

ский А.В. Возможности выявления латентной ППИ при ревизион-

ном эндопротезировании коленного сустава № 5/562

Папаев А.В. см. Мизюров С.А. № 6/821

Паськов Р.В. см. Базаров А.Ю. № 6/750

Переверзев В.С., Казьмин А.И., Сажнев М.Л., Пантелеев А.А.,

Колесов С.В. Искусственный интеллект для прогнозирования

различных состояний в вертебрологии: систематический обзор № $6 / 813$

Петраш В.В. см. Никитюк И.Е. № 2/254

Петров М.А. см. Павлова Д.Д. № 4/424
Петрушин А.Л. см. Брагина С.В. № 5/636

Петряйкин А.В., Сергунова К.А., Низовцова Л.А., Соловьев А.В., Петряйкин Ф.А., Ахмад Е.С., Семенов Д.С., Абуладзе Л.Р.,

Яссин Л.Р., Киселева А.Н., Владзимирский А.В., Морозов С.П.

Внедрение асинхронной количественной компьютерной томогра-

фии в работу амбулаторного учреждения № 6/800

Петряйкин Ф.А. см. Петряйкин А.В. № 6/800

Полиенко А.В. см. Иванов Д.В. № $1 / 74$

Попков Д.А. см. Коробейников А.А. № 4/418

Попков Д.А. см. Рябых С.О. № 4/453

Попков Д.А., Мингазов Э.Р., Губин А.В., Гвоздев Н.С., Арано-

вич А.М., Семенов А.Л. Несовершенный остеогенез: роль и место ортопедической хирургии нижних конечностей № 4/461

Попков Д.А., Нестерова Ю.В., Аранович А.М. Результаты ис-

следования мнения родителей детей с ахондроплазией о роли воз-

оритида в лечении заболевания № $4 / 487$

Попков Д.А., Чибиров Г.М., Кожевников В.В., Гвоздев Н.С.

Многоуровневые ортопедические вмешательства у детей со спастическим параличом № 4/475

Попков Д.А., Чибиров Г.М., Томов А.Д. Реконструктивные вмешательства при вывихе бедра у детей с церебральным параличом № $4 / 481$

Правила для авторов научно-теоретического и практического

журнала «Гений Ортопедии» № 1/133; № 2/277; № 3/398; № 4/493;

№ 5/669; № 6/835

Преображенский П.М. см. Пантелеев А.Н. № 5/562

Пронин В.А. см. Иванян С.Т. № 5/587

Пронских А.А., Харитонов К.Н., Корыткин А.А., Романова С.В.,

Павлов В.В. Тотальное эндопротезирование у пациентов с послед-

ствиями переломов вертлужной впадины № $5 / 620$

Пуляткина И.В. см. Губин А.В. № 2/146

Пусева М.Э. см. Михайлов И.Н. № 6/789

Рахимов А.М. см. Ходжанов И.Ю. № 2/199

Рахматулина А.А., Лунева С.Н., Накоскина Н.В., Клюшин Н.М.,

Люлин С.В., Долганова Т.И., Меньщикова Т.И., Леончук Д.С.

Содержание некоторых сосудистых факторов роста в сыворотке

крови больных с гнойными осложнениями высокоэнергетической

травмы № 3/325

Резник А.В. см. Рябых С.О. № 6/773

Решетников А.Н. см. Зверева К.П. № 5/521

Риахи А. см. Алиев А.Г. № 5/570

Римашевский Д.В., Ахтямов И.Ф., Федуличев П.Н., Zaalan Wessam,

Устазов К.A., Abdul Basith, Молдакулов Ж.М., Зиновьев М.П.

Патогенетические особенности лечения хронического остеомиелита № $5 / 628$

Родионова С.С. см. Торгашин А.Н. № 2/153

Рой И.В. см. Фищенко Я.В. № 2/209

Романова С.В. см. Пронских А.А. № 5/620

Руденко П.Г. см. Шнякин П.Г. № 6/72

Рябых С.О. см. Губин А.В. № 2/146

Рябых С.О. см. Долганова Т.И. № 6/827

Рябых С.О. см. Жалмагамбетов К.Л. № 1/97

Рябых С.О. см. Кубрак Н.В. № 6/782

Рябых С.О. см. Филатов Е.Ю. № 6717

Рябых С.О. см. Щурова Е.Н. № 1/68

Рябых С.О., Губин А.В., Савин Д.М., Филатов Е.Ю., Очирова П.В.,

Рябых Т.В., Сергеенко О.М. Деформации позвоночника у детей с церебральным параличом: естественное течение и методы коррекции № 4/468

Рябых С.О., Попков Д.А., Щурова Е.Н., Очирова П.В., Рябых Т.В.

Несовершенный остеогенез: современные аспекты этиологии, патогенеза, классификации (систематический обзор) № 4/453

Рябых С.О., Силантьева Т.А., Дюрягина О.В., Дьячков К.А.,

Стогов М.В., Антонов Н.И., Тушина Н.В., Резник А.В. Разработка

пористых титановых имплантатов для межтелового спондилодеза № 6/773

Рябых Т.В. см. Рябых С.О. № 4/453, 468

Рязанцев М.С., Магнитская Н.Е., Зарипов А.Р., Логвинов А.Н.,

Ильин Д.О., Афанасьев А.П., Фролов А.В., Королев А.В. Антропометрические данные и площадь поперечного сечения сухожилий полусухожильной и нежной мышц по данным МРТ как предикторы диаметра графта для пластики передней крестообразной связки

№ $2 / 237$

Савин Д.М. см. Рябых С.О. № 4/468

Савин Д.М. см. Филатов Е.Ю. № 6717

Сажнев М.Л. см. Переверзев В.С. № 6/813

Сазонова Н.В. см. Леончук С.С. № $1 / 92$

Сакович А.В. см. Гордиенко И.И. № $1 / 13$

Салохиддинов Ф.Б. Оценка результатов лечения пациентов с переломами проксимального конца бедренной кости разработанным стержневым аппаратом в сравнении с различными видами остеосинтеза № 2/175

Самохин А.Г. см. Чындын-оол Э.С. № 5/658

Самоходская Л.М. см. Панин М.А. № $1 / 43$

Санкаранараянан А.С. см. Волошин В.П. № 2/227

Сапрыкина К.А. см. Щербаков И.М. № 5/502 
Саруханян А.Р. см. Голубев И.О. № 2/182

Семенкин О.М., Измалков С.Н., Братийчук А.Н., Солопихина Э.Б. Балаклеец С.В., Богданова М.А., Князев Н.А. Результаты оперативного лечения пациентов с синдромом запястного канала в зависимости от степени выраженности заболевания № $1 / 24$

Семенов А.В. см. Михайлов И.Н. № 6/789

Семенов А.Л. см. Попков Д.А. № 4/461

Семенов Д.С. см. Петряйкин А.В. № 6/800

Семенов М.С. см. Волченко Д.В. № $1 / 38$

Сергеев К.С. см. Базаров А.Ю. № 6/750

Сергеенко О.М. см. Рябых С.О. № 4/468

Сергунова К.А. см. Петряйкин А.В. № 6/800

Середа А.П. см. Алиев А.Г. № 5/570

Сертакова А.В. см. Зверева К.П. № 5/521

Сивков В.С. см. Цыбин А.В. № 5/508

Силантьева T.A. см. Ермаков А.M. № 5/540

Силантьева Т.А. см. Рябых С.О. № 6/773

Скрябин Е.Г., Буксеев А.Н., Зотов П.Б., Аксельров М.А., Кур-

мангулов А.А. Неосложненные переломы шейных позвонков у

детей и подростков № 6/700

Смолькин А.А. см. Шульга А.Е. № 6/709

Созонов О.А. см. Волченко Д.В. № $1 / 38$

Солдатов Ю.П. см. Лукин С.Ю. № $1 / 6$

Солдатов Ю.П. см. Ходжанов И.Ю. № $1 / 15$

Соловьев А.В. см. Петряйкин А.В. № 6/800

Солод Э.И. см. Загородний Н.В. № 5/610

Солодилов И.М. см. Загородний Н.В. № 5/610

Соломин Л.Н. см. Кулеш П.Н. № 3/390; № 5/584

Соломин Л.Н. см. Череватый Н.И. № 1/104

Соломянник И.А. см. Губин А.В. № 2/146

Соломянник И.А. см. Загородний Н.В. № 5/610

Солопихина Э.Б. см. Семенкин О.М. № $1 / 24$

Степанов Е.В. см. Волошин В.П. № 2/227

Степанов Е.В. см. Шевырев К.В. № 2/265

Стогов М.В. см. Рябых С.О. № 6/773

Ступина Т.А., Дюрягина О.В., Моховиков Д.С., Ступина Ю.А., Борзунов Д.Ю. Гистоморфометрические изменения синовиальной оболочки коленного сустава при комбинированном применении несвободной костной пластики по Илизарову и технологии Masquelet (экспериментальное исследование) № 2/249

Ступина Т.А., Еманов А.А., Кузнецов В.П., Овчинников Е.Н. Оценка риска развития остеоартроза коленного сустава при протезировании голени (пилотное экспериментально-морфологическое исследование) № 6/795

Ступина Ю.А. см. Ступина Т.А. № 2/249

Суриков В.В. см. Загородний Н.В. № 5/610

Сутягин И.В. см. Карасев А.Г. № 3/313

Тенилин Н.А. см. Мусихина И.В. № $1 / 32$

Тепленький М.П., Олейников Е.В., Бунов В.С. Технология закрытого вправления вывиха бедра по Г.А. Илизарову при лечении детей с врожденной дисплазией тазобедренного сустава № 3/345

Терсков А.Ю. см. Волченко Д.В. № 1/38

Тихилов Р.М. см. Алиев А.Г. № 5/532, 570

Тихилов P.М. см. Артюх В.А. № 5/555

Тихоненко С.Н. см. Иванян С.Т. № 5/587

Ткаченко А.Н., Корнеенков А.А., Дорофеев Ю.Л., Мансуров Д.Ш., Хромов А.А., Хайдаров В.М., Вороков А.А., Алиев Б.Г. Оценка динамики качества жизни методами анализа выживаемости у пациентов, перенесших артропластику тазобедренного сустава № 5/527 Томов А.Д. см. Попков Д.А. № 4/481

Торгашин А.Н., Мурсалов А.К., Родионова С.С., Загородний Н.В. Особенности лечения асептического некроза таранной кости. Проект клинических рекомендаций № $2 / 153$

Трифонова Е.В. см. Шевырев К.В. № 2/265

Тушина Н.В. см. Рябых С.О. № 6/773

Углёв О.И. см. Александров Н.М. № 2/187

Удалов Ю.Д. см. Волченко Д.В. № 1/38

Указатель статей научно-теоретического и практического журнала

«Гений Ортопедии» за 2020 г., Т. 26, №№ 1-4 № 1/136

Ульянченко И.Н. см. Заяц В.В. № $1 / 48$

Уринбоев П.У. см. Давиров Ш.М. № 1/87

Устазов К.А. см. Римашевский Д.В. № 5/628

Федуличев П.Н. см. Римашевский Д.В. № 5/628

Федюнина С.Ю. см. Алиев А.Г. № 5/532

Филатов Е.Ю. см. Рябых С.О. № 4/468

Филатов Е.Ю., Рябых С.О., Савин Д.М. Алгоритм лечения врож-

денных аномалий позвоночника № 6/717

Филимонова Г.Н. см. Шурова Е.Н. № $1 / 68$

Фищенко Я.В., Владимиров А.А., Рой И.В., Кравчук Л.Д.,

Чернобай С.П. Лечение коксалгии у пациентов с дегенеративным остеоартрозом тазобедренного сустава 3-4 стадии № 2/209

Фролов А.В. см. Рязанцев М.С. № 2/237

Хайдаров В.М. см. Линник С.А. № $5 / 548$

Хайдаров В.М. см. Ткаченко А.Н. № 5/527
Хан Н.В. см. Губин А.В. № 2/146

Харитонов К.Н. см. Пронских А.А. № 5/620

Харламов А.В. см. Иванов Д.В. № 1/74

Хасанов Э.Р. см. Ахтямов И.Ф. № 1/121; № 5/592

Ходжанов И.Ю. см. Байимбетов Г.Д. № $5 / 578$

Ходжанов И.Ю., Рахимов А.М., Косимов А.А. Сравнительный

анализ результатов хирургического лечения несросшихся перело-

мов и ложных суставов костей предплечья № 2/199

Ходжанов И.Ю., Солдатов Ю.П., Байимбетов Г.Дж., Эдилов У.А.

Наш опыт лечения застарелых вывихов головки лучевой кости у детей№ $1 / 15$

Хренников Я.Б. см. Нурмухаметов М.Р. № 2/220

Хромов А.А. см. Ткаченко А.Н. № 5/527

Цап Н.А. см. Гордиенко И.И. № $1 / 13$

Цветкова А.К. см. Базаров А.Ю. № 6/750

Цыбин А.В., Любчак В.В., Сивков В.С., Шильников В.А.,

Малыгин Р.В., Шубняков М.И. Обоснование использования оригинальной классификации посттравматических деформаций вертлужной впадины при первичном эндопротезировании тазобедренного суставав№ $5 / 508$

Цыплаков Д.Э. см. Нуриахметов А.Н. № 1/80

Череватый Н.И., Соломин Л.Н. Накостный остеосинтез при лечении взрослых пациентов с переломами дистального отдела бедренной кости: история, настоящее, перспективы (обзор мировой литературы) № $1 / 104$

Черевцов В.Н., Блаженко А.Н., Богданов С.Б., Мазалов А.В.,

Кетов М.С. Объективизация показаний к хирургическому восстановлению плантарной пластинки с помощью УЗИ при лечении многоплоскостной статической деформации стопы, сопровождающейся молоткообразной деформацией «малых пальцев» № 2/214

Чернобай С.П. см. Фищенко Я.В. № 2/209

Чибиров Г.М. см. Попков Д.А. № 4/475, 481

Чирков Н.Н., Николаев Н.С., Алексеева А.В., Яковлев В.Н., Лушин А.В. Эффективность современных методик оперативного лечения передней рецидивирующей нестабильности плечевого сустава в зависимости от анатомо-функциональных изменений № 3/337

Чурносов М.И. см. Новаков В.Б. № $1 / 112$

Чындын-оол Э.С., Павлов В.В., Самохин А.Г. Разгибательно-отводящая контрактура тазобедренных суставов как следствие фиброза ягодичных мышц № $5 / 658$

Шавырин Д.А. см. Шевырев К.В. № 2/265

Шарков С.М. см. Павлова Д.Д. № 4/424

Шафиев О.А. см. Ким Ю.Д. № 5/597

Шевцов В.И., Кириенко А.П., Шихалева Н.Г., Новиков К.И.

История мини-фиксатора Илизарова, этапы становления хирургии

кисти в Центре Илизарова № 3/299

Шевырев К.В., Волошин В.П., Шавырин Д.А., Митина Т.А.

Трифонова Е.В., Мартыненко Д.В., Ошкуков С.А., Степанов Е.В.

Результат лечения пациентки с поражением бедренных костей мно-

жественной миеломой (случай из практики) № 2/265

Шелупаев А.А. см. Щербаков И.М. № 5/502

Шильников В.А. см. Цыбин А.В. № 5/508

Шипулин А.А. см. Артемьев А.А. № 1/59

Ширяева Г.Н. см. Голубев И.О. № 2/182

Шитиков Д.С. см. Ким Ю.Д. № 5/597

Шихалева Н.Г. см. Коростелев М.Ю. № 2/169

Шихалева Н.Г. см. Шевцов В.И. № 3/299

Шкода А.С. см. Щербаков И.М. № 5/502

Шнякин П.Г., Ботов А.В., Милёхина И.Е., Руденко П.Г., Ар-

хипкин С.В. Проблема жировой дегенерации параспинальной

мускулатуры у пациентов после операций по поводу дегенеративно-

го стеноза № 6/727

Шпиз Е.Я. см. Волченко Д.В. № 1/38

Шубняков И.И. см. Алиев А.Г. № 5/532, 570

Шубняков М.И. см. Цыбин А.В. № 5/508

Шульга А.Е. см. Иванов Д.В. № $1 / 74$

Шульга А.Е., Зарецков В.В., Островский В.В., Бажанов С.П.,

Лихачев С.В., Смолькин А.А. Особенности сагиттального баланса пациентов при посттравматических деформациях грудного и поясничного отделов позвоночника № 6/709

Щербаков И.М., Дубров В.Э., Шкода А.С., Злобина Ю.С., Шелупаев А.А., Сапрыкина К.А., Зюзин Д.А. Лечение чрезвертельных переломов у пожилых пациентов - насколько важна динамическая фиксация? № 5/502

Щурова Е.Н. см. Рябых С.О. № 4/453

Щурова Е.Н., Филимонова Г.Н., Рябых С.О. Влияние величины деформации в грудном отделе позвоночника на морфологическую картину параспинальных мышц у больных с идиопатическим сколиозом тяжелой степени № $1 / 68$

Эдилов У.А. см. Ходжанов И.Ю. № $1 / 15$

Языкова А.Б. см. Мусихина И.В. № $1 / 32$

Яковлев В.Н. см. Чирков Н.Н. № 3/337

Ярмилко А.В. см. Артюх В.А. № 5/555

Яссин Л.Р. см. Петряйкин А.В. № 6/800 


\section{Правила для авторов научно-теоретического и практического журнала «Гений Ортопедии»}

\section{Instructions for authors of the scientific-theoretical and practical journal «Orthopaedic Genius»}

При направлении статьи в редакцию рекомендуется руководствоваться следующими правилами, составленными с учетом «Единых требований к рукописям, предоставляемым в биомедицинские журналы» (Uniform Requirements for Manuscripts Submitted to Biomedical Journals), разработанных Международным комитетом редакторов медицинских журналов (International Committee of Medical Journal Editors).

$\S 1$. Публикуемое исследование должно быть проведено в соответствии с этическими и юридическими нормами. Рукописи, подаваемые для публикации, должны содержать заявление о том, что исследования на людях были одобрены соответствующим комитетом по этике и проводились в соответствии с этическими стандартами, изложенными в Хельсинской декларации. В рубрике «Материалы и методы» должно быть указано о получении информированного согласия лиц, включенных в исследование. Детали, способствующие персонификации пациентов, должны быть исключены. Экспериментальные исследования на животных должны соответствовать международным и национальным нормативным актам обращения с лабораторными животными.

§2. Исследователи должны гарантировать, что их публикации являются честными, ясными, точными, полными и взвешенными, они должны не допускать выборочного или двусмысленного изложения фактов, вводящего в заблуждение читателей. Публикуемое исследование должно быть качественно и тщательно выполненным.

§3. Подаваемая работа должна содержать оригинальный материал, не являться плагиатом и не быть опубликованной ранее. Работа не может быть направлена одновременно в несколько изданий.

§4. Новые результаты должны быть представлены в контексте предыдущих исследований. Работы других ученых должны быть подобающим образом отражены. Авторы не должны копировать из других публикаций ссылки на работы, с которыми они сами не ознакомились.

§5. Исследователи должны описывать методологию выполнения работы четко и однозначно, чтобы их результаты могли быть подтверждены другими. Исследователи должны публиковать все значимые результаты исследований, которые важны для понимания. Исследователи должны использовать соответствующие методы анализа и представления данных. При статистической обработке данных необходимо указывать использованные методы (пакет статистического анализа). Единицы измерения должны соответствовать Международной системе единиц СИ, термины - международным номенклатурам, названия болезней - международной классификации болезней.

§6. Авторы должны представлять детальное и достоверное изложение результатов исследования в разделе «Результаты» и интерпретировать свое мнение в сравнении с результатами других исследований - в разделе «Дискуссия». Выводы из существующих исследований должны быть полными, сбалансированными и включать сведения вне зависимости от того, поддерживают они гипотезы и толкования автора публикации или нет.

§7. Авторы должны уведомлять редколлегию в случае обнаружения ошибки в поданной, принятой для публикации или уже опубликованной работе. Авторы должны сотрудничать с редакторами при необходимости правки или сокращения работы.

§8. Авторство исследовательской работы должно точно отражать вклад отдельных людей в её выполнение и описание. Ответственность за правильное определение авторства полностью лежит на самих авторах, действующих в соответствии с правилами, принятыми в их учреждении. Авторы несут коллективную ответственность за свою работу и содержание публикации. Все авторы должны дать согласие на внесение в список авторов и одобрить направленную на публикацию рукопись. Ответственный автор выступает контактным лицом между редколлегией и другими авторами.

§9. Следует раскрывать источники финансирования и связанные с ними возможные конфликты интересов.

Виды научных публикаций и требования к объему

- Оригинальные статьи. Список литературы - не более 30 названий.

- Случаи из практики - описание отдельных клинических наблюдений, представляющих большой практический интерес.

- Новые технологии - описание новых методов, способов и устройств.

- Обзоры литературы по отдельным медицинским проблемам, анализ научных публикаций преимущественно за последние 5-лет. Список литературы - не более 60 источников.

- Лекциии.

- Статьи по истории медицины.

- Материалы в помощь практическому врачу.

- Материалы съездов, конференций.

- Отчеты о работе диссертационных советов, протоколы заседаний общества травматологов-ортопедов и ассоциации.

- Информационные сообщения, рецензии, дискуссии, поздравления юбиляров принимаются по заказу редакции. 


\section{Структура оригинальных статей}

1. Заглавие научной статьи:

- название статьи на русском языке;

- инициалы и фамилии авторов на русском языке;

- название статьи на английском языке;

- инициалы и фамилии авторов в романском алфавите (латиница).

Требования к заглавиям:

- заглавия статей должны быть информативными;

- в заглавиях статей можно использовать только общепринятые сокращения;

- в заглавиях статей на английском языке не должно быть никаких транслитераций с русского языка, кроме непереводимых названий собственных имен, приборов и др. объектов, имеющих собственные названия.

2. Фамилии и инициалы авторов с указанием аффилиации авторов (полное официальное название организации и ведомства) на русском и английском языках.

3. Структура аннотации на русском и английском языках в стандарте IMRAD:

- введение (краткая история вопроса, цели и задачи) - Introduction;

- методы - Methods;

- результаты - Results;

- дискуссия - Discussion;

- ключевые слова - Keywords.

Требования к аннотациям:

- информативность (не содержать общих слов);

- оригинальность;

- содержательность (отражать основное содержание статьи и результаты исследований);

- структурированность;

- компактность (200-250 слов).

Приветствуется структура аннотации, повторяющая структуру статьи.

В тексте аннотации на английском языке следует применять терминологию, характерную для иностранных специ альных текстов. Необходимо использовать активный, а не пассивный залог. Сокращения и условные обозначения, кроме общепринятых, применяют в исключительных случаях. В аннотации не должно быть ссылок на литературу.

4. В сведениях об авторах необходимо указывать фамилию, имя и отчество (полностью), должность, ученое звание, ученую степень, Email, а также определить автора, ответственного за переписку с редакцией. Эти данные размещаются после аннотации.

5. Структура статьи:

- ВВЕДЕНИЕ;

- МАТЕРИАЛЫ И МЕТОДЫ;

- РЕЗУЛЬТАТЫ;

- ДИСКУССИЯ;

- ЗАКЛЮЧЕНИЕ/ВЫВОДЫ;

- СПИСОК ИСТОЧНИКОВ.

Во ВВЕДЕНИИ описывают состояние изучаемой проблемы на основе опубликованных по данной теме работ, ее актуальность и значимость, доказывают необходимость проведения исследования. В конце данного раздела указывают цель исследования или гипотезу, проверяемую исследованием или наблюдением.

В раздел «МАТЕРИАЛЫ И МЕТОДЫ» включают только информацию, которая была доступна на момент составления протокола исследования. Всю информацию, полученную во время исследования, описывают в разделе «РЕЗУЛЬТАТЫ»

Четко описывают принципы, в соответствии с которыми проводился отбор участников клинического исследования или эксперимента (пациенты или лабораторные животные, включая контрольные группы), указывая при этом критерии соответствия и исключения.

В данном разделе отражают следующие моменты: тип исследования; способ отбора участников исследования; методика проведения измерений; этические принципы; способы представления и обработки данных.

Обязательно следует описать используемые статистические методы. Желательно представить количественную оценку данных и указать соответствующие параметры, отражающие ошибку измерения либо вероятностный характер результатов (например, доверительные интервалы). Если для обработки данных применяется пакет статистических программ, следует указывать его название и версию.

Сокращения и аббревиатуры расшифровывают при первом их использовании в тексте и в дальнейшем используют в неизменном виде. 
При описании лекарственных средств указывают название действующего вещества, а не торговое (коммерческое) название. Названия использованных аппаратуры, оборудования, реактивов и т.д. приводятся с указанием фирм и стран изготовителя. Если в статье приводят клинические наблюдения, полные фамилии больных и номера историй болезни не указывают.

Материал раздела «РЕЗУЛЬТАТЫ ИССЛЕДОВАНИЯ» излагают в логической последовательности. Графики используют как альтернативу таблицам, исключая дублирование данных в графиках, таблицах и тексте. При обобщении данных представляют числовые результаты не только в виде производных (например, процентов), но и в виде абсолютных значений, на основании которых были рассчитаны эти производные.

В разделе «ОБСУЖДЕНИЕ», который является обязательным для всех статей, проводят детальный анализ, интерпретацию полученных результатов и сопоставление их с данными отечественной и зарубежной литературы. Вместо перечисления предыдущих исследований объясняют, почему полученные результаты отличаются от результатов, полученных другими авторами, или совпадают с ними. Акцентируют внимание на новых и важных аспектах исследования и выводах, следующих из них, в контексте современной доказательной базы. Описывают имеющиеся ограничения и недостатки данного исследования, особенно если они оказали существенное влияние на полученные результаты или их интерпретацию, а также преимущества проведенного исследования по сравнению с аналогичными исследованиями других авторов, указывают возможность применения полученных результатов в будущих исследованиях и клинической практике.

ВЫВОДЫ сопоставляют с целями исследования, избегая неквалифицированных заявлений и выводов, неподтвержденных фактами.

\section{Оформление статей}

При написании и оформлении научных статей в журнал «Гений ортопедии» необходимо придерживаться следующих правил:

- Файл статьи должен быть представлен в одном из общепринятых форматов

- Иллюстрации должны быть четкими, контрастными. Число иллюстраций не должно превышать 5 простых (размером не более $10 \times 12 \mathrm{~cm}$ ) или 3 комбинированных (размером не более $13 \times 18$ см каждая). В тексте необходимы ссылки на рисунки (фото, диаграмма, схема, рентгеновский снимок, график и пр.). Подписи к рисункам должны быть размещены под рисунком. В подписях к микрофотографиям необходимо указывать увеличение и метод окраски. Иллюстрации должны быть также сохранены в отдельных файлах в формате *.tiff с разрешением не менее $\mathbf{3 0 0} \mathbf{d p i}$.

- Таблицы должны иметь название и номер. Цифры, приведенные в таблице, не должны повторяться в тексте статьи. В тексте необходима ссылка на таблицу в круглых скобках. Все аббревиатуры, употребляемые в таблице, должны быть расшифрованы в примечании к таблице. В примечании к таблице также должна быть указана статистическая вариабельность данных.

- При ссылке в тесте на отечественных и иностранных авторов вначале указывают инициалы, затем фамилию. Иностранных авторов печатают в оригинальном написании на латинице. В квадратных скобках после фамилии цитируемого автора ставят номер источника, соответствующий списку литературы.

- В библиографии (пристатейном списке литературы) каждый источник следует помещать с новой строки под порядковым номером.

- В списке все работы перечисляются в порядке цитирования, а не в алфавитном порядке.

- В библиографическом описании каждого источника должны быть представлены все авторы. Недопустимо сокращать название статьи. Название англоязычных журналов следует приводить в соответствии с каталогом названий базы данных MedLine. Если журнал не индексируется в MedLine, необходимо указывать его полное название.

- Русскоязычные источники необходимо оформлять в соответствии с правилами ГОСТ Р 7.0.5-2008.

- В список литературы не включаются неопубликованные работы (диссертации, отчеты НИР), тезисы конференций и симпозиумов. Возможна ссылка на материалы съездов, всероссийских и международных форумов, которые находятся в свободном доступе в сети Internet.

- Допускается не более 10 \% ссылок на собственные работы автора (самоцитирование автора) и не более 10 \% ссылок на публикации журнала "Гений ортопедии" (самоцитирование журнала).

\section{Подача статей}

- Статья может быть подана на сайте журнала http:/ilizarov-journal.com или отправлена почтой.

- Электронный вариант статьи, сопроводительные документы (в оцифрованном виде), лист с подписями авторов (в оцифрованном виде) следует присылать по электронной почте на Email: genius@ilizarov.ru.

Автор, ставя свою подпись под статьей, передает свои права на издание.

Редакция журнала оставляет за собой право не принимать рукописи, которые не отвечают вышеуказанным требованиям. 
Главный редактор А. В. Бурцев

Компьютерная верстка М. А. Беляева

Перевод Т. А. Малкова, И. А. Саранских, Н. Г. Альфонсова

Информационная поддержка сайта журнала О. Б. Борзунова, Е. А. Дворянцева

Журнал зарегистрирован Федеральной службой по надзору в сфере связи, информационных технологий и массовых коммуникаций ПИ № ФС77-68207 от 30 декабря 2016 года

Территория распространения: Российская Федерация, зарубежные страны

Подписано в печать 18.02.2022. Дата выхода 03.03.2022

Формат $60 \times 841 / 8$. Усл. печ. л. 19,3

Тираж 75 экз. Заказ № 59378. Свободная цена

Адрес издателя, редакции журнала «Гений ортопедии» 640014, Россия, г. Курган, ул. М. Ульяновой, 6 http://ilizarov-journal.com

Отпечатано в Типографии «Эталон». 198097, г. Санкт-Петербург, ул. Трефолева, 2 литера БН, помещение 3-Н, офис 1 

ilizarov-journal.com 